0-01-1 血栓回収療法後のarterial spin labelingにおける hyperperfusionについての検討

○山崎 直也 ${ }^{1} 、 土$ 井尻遼介 ${ }^{1} 、$ 小田 桃世 ${ }^{2} 、$ 横沢 路子 ${ }^{3}$ 、高橋 賢 1 、 菅原 孝行 ${ }^{3}$ 高橋 弘明 1 、村 尚人 3 、菊池 貴彦

岩手県立中央病院脳神経内科、岩手県立中央病院リハビリテーション科、

岩手県立中央病院 脳神経外科

【目的】急性期脳梗塞後のMRI画像に扔ける Arterial spin labeling (ASL)の意義 については一定の見解が得られていない。ASLでのhyperperfusionは再灌流後に 高頻度で出現すること、出血性合併症に先行することが報告されているが、血检 回収療法後のASL所見については報告が少ない。血栓回収療法後のASLの所見 について検討した。【方法】2019年4月1日から10月31日までに当院で内澒動脈閉塞 症、中大脳動脈閉塞症に伴う急性期脳梗塞例に対して血栓回收療法を施行し、術 後7日以内にMRI拡散强調像（DWI）とASLを撮像した19例を対象とした。MRI 装置は1.5T (GE Healthcare) を用いてpsuedo-Continuous ASLでlabelingを行 い、 post labeling delayは2025 msとした。ASLでMRI DWI高信号を呈した領域 またはその周囲の領域と対側のCerebral blood flow（CBF）を視覚的に比較し、 hyperperfusionの有無を定性的に評佂した。結果】19例中9例でhyperperfusion (HP) と診断した。Hyperperfusion 群 (HP群) と非HP群と比較したところ、HP群 で来院時NIHSSが高い倾向 ( 24 vs $20, \mathrm{p}=0.067$ )、来院時の頭部CTでのASPECTS が低い傾向（7.6 vs 9.3, $\mathrm{p}=0.066$ )、来院時収縮期血圧が高い傾向（167 vs 145 $\mathrm{p}=0.063$ ) 認め、血栓回收療法でのTICI 3 が多かった $(7 \mathrm{vs} 2, \mathrm{p}=0.023)$ 【結論】血 栓回收療法後にASLを用いることでhyperperfusionを予測し術後の内科治療の参 考になる可能性がある。

\section{0-01-3 僻地・離島における脳卒中診療の実態に関する研究}

\author{
○益子 貴史、三浦久美子、阿南 悠平、松䓟 構佑、小澤 忠翤、 \\ 嶋㠃 晴雄、小出 玲爾、田中 亮太、藤本茂 \\ 自治医科大学内科学講座神経内科学部門
}

【目的】地域への脳卒中医療の均てん化に扔いて、限られた医療資源の適切な活用 は重要であるが、地域医瘵の最前線である僻地・離島における脑卒中診療の実態 はよくわかっていない。本研究では本学の卒業生が卒後僻地浐袮に従事すること に着目し、卒業生連絡網を利用して僻地・離島に㧍ける脳卒中診療の現状を明ら かにすることを目的とした。[方法】本学全卒業生に対して調査票を郵送し、所属 医療機関の種類、年間新規脳卒中患者数、検查機器状況、抗血栓䔁採用状況、市 民啓発プログラムについて調查した。【結果]僻地・離島の診療所あるいは病院に 勤務していると回答した 236 件を解析した。標榜科は脳神経内科あるいは脳神経 外科が10名、その他内科が189名であった。診療所に146名、病院に90名が勤務し ていた。年間の新規急性期脳卒中患者数中央值は診療所2 例、病院25例であった。 CTあるいはMRI検查は1116施設 $(49 \%)$ 、到部血管エコーは174施設 $(74 \%)$ が可能と 回答し、PT-INR測定は165施設 $(70 \%)$ が卯日可能、6施設が測定不可能と回答した。 抗血栓薬の採用率では、アスピリン $97 \%$ 、クロピドグレル $96 \%$ 、シロスタゾール 88\%、ワルファリン $96 \%$ であったが、DOACはダビガトラン $55 \%$ 、リバロキサバン $70 \% 、$ アピキサバン $64 \%$ 、エドキサバン $69 \%$ であった。脳卒中に関する市民㤵登プ ログラムを有していたのは24施設(10\%)であったが、219施設 (93\%)が市民啓発の 必要性があると回答した。【結論了僻地・離島においても画像・超音波機器は比較 的普及しており、血栓溶解療法の開始など脑卒中急性期初期診療を担う地盤は坦 間見えた。一方、用量調整不要なDOACの普及は十分といえず、専門病院で精查 決定された最適な慢性期治療が継続されない可能性がある。僻地・離島における 脳卒中䛦療を担っているのは脎卒中診療のニーズに理解を示した非脳神経内科医 であり、神経専門医が僻地の医師と連携して情報・技術を共有し支援する意義は 大きい。

\section{0-01-5 一側後脊骾動脈症候群の臨床像および画像所見の検討}

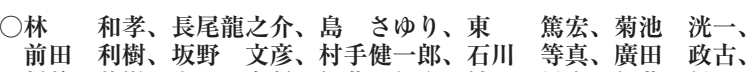
新美 芳樹、水谷 泰彰、加藤 邦尚、植田 晃広、伊藤 信二、 武藤多津郎、渡辺 宏久

藤田医科大学医学部 脳神経内科学

【目的】後脊䯣動脈症候群は疼痛を伴い、深部感喾優位の感営障害や錐体路障害て 突然発症する稀な症候群で、両側性の発症が多いとされている。今回我々は一眼

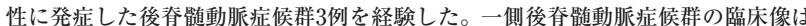
いまだ明らかとなっていない面も多く、3例の解析を行い診断・治療に有用な臨床 および画像的特徴を検討する。【方法】2018年〜2019年に当院一入院した一側後食 跑動脈症候群の3例 (37藏、71歳、83歳のいずれも男性) について血管危険因子を含 めた患者背景、神経学的所見および画像所見とその経時的変化について检討した。 【結果】初診時には画像的所見がはっきりしない症例や、突然の片麻疩であること から脳梗塞と疑われた症例もあった。また例の特徽として以下の3点が挙げられ た。1) 突然の片側麻痻を発症し数時間から数日で症状は最悪点に到達した。2) 梗

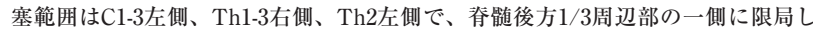
ていた。3) 1例にリポプロテイン (a) の軽度上昇を認めた以外には明らかな血管危 険因子を認めず、膠原病・血管炎などの自己抗体も陰性であった。[結論]今回の3 症例は30-80歳代と幅広く、明らかな血管危険因子が少なく、梗塞範囲は春噵後方

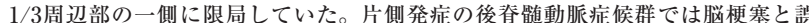
診されることもあり、急性発症と特微的な感覚障害, 経過と画像所見の推移に着 目することが重要であることが示唆された。
0-01-2 健常者におけるWillis動脈輪の形態と経時変化および それに関連する因子

○䍏田陽子、明地雄司、武井 聡子、松本清香、千崎 健佑、 三浦 史郎、越智 博文、伊賀瀬道也、大八木保政

愛媛大学大学院医学系研究科 脑神経内科・老年医学講座

【目的】Willis動脈輪は脳循環の側副血行路として重要であり、その形態は個体差 が大きいことが知られている。MRAを用いたWillis動脈輪の检討は少数ながら存 在するが、経時変化に関する検討は極めて少ない。今回は、ドック受診者を対象 としてWillis動脈輪の形態の差違と経時変化、およびその関連因子について検討 する。【方法】当院の抗加齢ドックを受診した943例（平均年齢65.3）を対象とした。 3D-TOF MRAを用いて、前大脳動脈 $\mathrm{Al}$ ( $\mathrm{Al}$ )、前交通動脈 (A-com)、後大䑈動脈 P1 (P1)、後交通動脈 (P-com)の描出の有無を調べた。さらに複数回受䛦歴のある 153名に抢いて、動脈硬化の危除因子を中心に、血管描出の経時変化に影響する 因子を、t検定およびFisher検定を用いて検討した。(結果】今回の血管描出率はA1 右913例 (96.8\%)、左935例例 (99.2\%)、A-com849例 (90.3\%)、P-com右597例 (63.3\%)、 左602例 (63.9\%)、P1右909例 (96.5\%)、左922例 (98.2\%)であった。血管描出率は、 いずれの血管も加输とともに低下傾向を認めた。複数回受診例（平均受診回数 3.1 回、平均観察期間 4.5 年) では、21例 (13.6\%) に血管描出の変化を認め、非描出化が 11例 $(7.1 \%)$ で、逆に描出化が10例 (6.5\%) であった。血管変化の影響因子として、 主幹動脈の $50 \%$ 以上の狭窄を有する症例で血管描出を多く認めた( 狭窄あり群 $2 / 7$ 例 vs.狄窄なし群 $6 / 146$ 例、 $\mathrm{p}=0.0442$ )。[結論]今回の解析では、脳血管障害患者対 象の既報と比較して血管描出率が高く、健常高齢者の血行動態と考元られた。㑡 副血行路は加齢に伴って描出されにくい傾向であったが、今回は半数で非描出か ら描出への変化も認めており、主幹動脈狭窄による腮血流低下に対して側副血行 路が発達した可能性が考えられた。

\section{0-01-4 当院における潜因性脳梗塞に対するICMでの発作性 心房細動の検出率と手術成績・注意点}

齊藤 智成 1,2 、大久保誠二 1 、沼尾紳一郎 ${ }^{1,2} 、$ 阿部 新 1 、小村 和美 $^{2}$ ${ }^{1} \mathrm{NTT}$ 東日本関東病院 腷血管内科、 ${ }^{2}$ 日本医科大学 腮神経内科

背景：脳梗塞の原因が同定できない潜因性脑梗塞（ESUS）について、多くが発作 性心房細動（Paf）ではないかとも考えられているが、まだ明らかでない。当院で はESUSの診断となった患者に積極的にICM植え込み術を行っており、そのPaf 検出率と手術成績・注意点について報告する。方法：当院に脑梗塞として入院歴 のある患者において、脳塞栓症が疑われた患者を対象とし、頝動脈エコー、経胸 壁心エコー、ホル夕ー心電図、下肢静脈エコー、経食道心エコー、造影CT、血 管造影検查、血液学検查などを施行し、明らかな塞栓源が同定できなかった患者 にICM植え込み術の同意が得られた19例を検討した。ICMとしては、全例Reveal LINQ®を用いた。平均年龄66.9歳、男15例 $(78.9 \%$ )、主幹動脈閉塞例は5 例 (26.3\%) 、

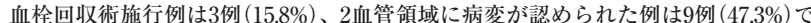
あった。結果：Pafの検出率は $26.3 \% て ゙$ 既報告と同等以上であった。 ICM植え込み からPaf同定までの日数は、平均 58.2 日であった。全例脳神経内科医が施行し、合 併症は認めなかった。1例、術後に乳癌检診にてマンモグラフィーが施行困難と なった症例があり、症例によっては植え込及位置に注意する必要性が示唆された。 結語：ICM植え込み術は、神経内科医により安全に施行可能であるが、植光込み 位置に注意が必要なこともある。Pafが検出された患者に抽いて、検出されなかっ た症例との比較梌討も行い報告する。

\section{0-01-6 進行性症状経過を呈したbranch atheromatous diseaselに対するurokinase静注療法の検討}

\section{○周藤 豊、吉田健太郎、徳田 直希、福田 弘毅}

松江赤十字病院 脳神経内科

【はじめに|Branch atheromatous disease (BAD) は症状進行により治療にしばし ば難渋する。当院では進行性の経過を呈したBADに対Lurokinase (UK) 静注療法 を施行しており、その効果を检討した。対象と方法]2015年4月から2019年3月に 当科入院した急性期脳梗塞1190例のうち、主幹動脈狭窄がなく穿通枝領域の $15 \mathrm{~mm}$

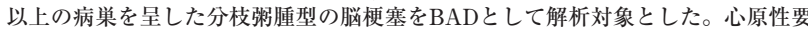
素を有する症例、 $\mathrm{ADL}$ が非自立(登症前 $\mathrm{mRS} \geq 4$ ) 症例は検計から除外した。148例 のBAD 症例をみとめ、argatroban・edaravone (堅機能障害にて未使用6例あり). 抗血小板薬による初期治療でも進行性の経過を呈した症例に対しUK 24 万単位/ day静注を1-3日間併用した。UK投与とその用法用量は当院倫理委員会の承認に基 づいて実施した。進行の定義をNIHSS 1点以上の增悪とし、通常治療群（UK未使 用) 79例、UK有效群 (UK投与後進行停止) 38例、UK無效群 (UK投与後も進行) 18 例の3群に分頪し、UK有効群の特徽について他群と比較検討した。結果】UK投与 にて38例 $/ 56$ 例 (67.9\%) で投与後の症状進行停止をみとめ、テント上のBADでょり 進行停止がみとめられた $(73.8 \%)$ 。UK有効群ではUK無効群と比較してUK投与後 の脳梗塞体皘が少なく $(\mathrm{P}<0.05)$ 、退院時 $\mathrm{mRS} \leqq 3$ 割合が高かった $(\mathrm{P}<0.05)$ 。UK 有効群では通常治療群と比較してUK投与後の腷梗塞体積、退院時 $\mathrm{mRS} \leqq 3$ の割合 に有意差を久とめなかったUK投与に上る症状進行停止に容与した要因として UK使用後の脳梗塞体皘に有意な傾向が夕とめられた。対象症例においてUK併用 による出血性合併症はみとめなかった。はとめ】BADで進行性の症状経過を呈す る症例に対し、UK追加投与の有効性が考光られる。 


\section{0-01-7 脳梗塞急性期における栄養障害と嚥下障害}

千葉 哲矢 ${ }^{1,2}$ 、福間 一樹 ${ }^{1}$ 、馬明 克成 ${ }^{3} 、$ 田川 直樹 ${ }^{1,2}$ 、

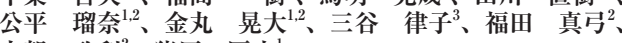
古賀 政利、猪原 匡史

国立循環器病研究センター 脳神経内科、

国立循環器病研究センター 脳血管内科、

3 国立循環器病研究センター 看護部

【目的】脳梗塞急性期に拈ける入院時の栄養障害と転退院時の菲下障害との関連性 を調查することを目的とした。【方法】2012年〜2019年に当院に入院した $20 \sim 79$ 藏 の急性期脳梗塞患者を選択した。除外基準は発症前に経口掑取不能または車椅子 ベッド上生活であった患者、栄盖指数及び栄盖方法の情報が収集不可能な者と した。人院時の栄養状態を geriatric nutritional risk index (GNRI) を用いて評佂 した。GNRI<92群（栄美障害あり）とGNRI $\geq 92$ 群に分けて、背景因子と転退院時

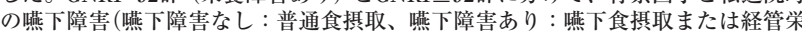
盖と定義) を調查した。[結果] 2332 例を登録。年齢平均值67.4藏、男性1613例 $(69 \%)$ 。 GNRI $<92$ 群は157例（7\%）。GNRI<92群は、GNRI $\geq 92$ 群と比較して、飲酒習慣、 高血圧症・脂質異常症・糖尿病の合併、心原性脳塞栓症の割合が高く、発症前 mRS 0-2が少なく、入院時NIHSSが高く、いずれも有意差を認めた。転退院時の 嚾下障害は212例 (9\%)で認められ、GNRI<92群で有意に多かった $(21 \%$ vs $8 \%$, P $<0.001$ )。多重ロジスティック回帰分析 (年齢・性別・飲酒・高血圧症・脂質異常症 糖尿病・脳血管障害の既往・発症前 $\mathrm{mRSO}-2 \cdot$ 入院時NIHSS - 脳卒中病型で調節) では、入院時GNRI<92は転退院時の壦下障害と有意な関連を示した（調節後オッ ズ比 2.13, 95\% CI 1.29-3.54, P值 0.003)。【結論】脳梗塞急性期において、入院時の GNRI低值が㗪下障害の合併や遷延の指標になることが示唆された。発表時には GNRIの経時的変化との関連を含めて報告する。

\section{0-01-9 発症時間不明の脑梗塞患者におけるDWI/FLAIRミス マッチに基づく血栓溶解療法の検討}

保浦明日香、一條 真彦、砂生奈那美、㝨毛 翔吾、鈴木 正史、 渡邊 稳之、網野 猛志、鎌田 智幸 武藏野赤十字病院 神経内科

【背景と目的】2019年3月に、静注血栓溶解療法適正治療指針第三版において、発症 特間が不明な場合でも頭部MRI DWIの虚血性変化がFLAIR画像で明膫でない埸 合 (以下DWI/FLAIRミスマッチ) には発症4.5時間以内の可能性が高く、このよう な症例に血栓溶解療法を行うことを考虑しても良いと改訂された。当院において 発症時間が不明だが、DWI/FLAIRミスマッチが陽性であることに基づいて血栓 溶解療法を行った症例の成績と安全性を検討した。【方法】2019年3月1日から2019 年11月11日までに、当院を受診し、血栓溶解療法を施行した腷梗塞患者を対象と した。脳梗塞の発症時間が不明、頭部MRIでのDWI/FLAIRミスマッチ陽性と判 断し血栓溶解瘵法を施行した群 (以下DWI/FLAIRミスマッチ群) と、脳梗塞の発 症から4.5時間以内に血栓溶解療法を施行した群を対象とし、臨床情報、画像情報 を収集し後ろ向きに解析した。[結果】 30 例が選択基準に合致し、DWI/FLAIRミ スマッチ群は8例であった。両群間で来院時NIHSSや背景因子に有意差は認めな かった。脳梗塞(発症から24時間後のNIHSS、7日後のNIHSSは両群間で差はなく、 早期症状改善 (発症 7 日目のNIHSSが来院時上り8占以上改善、あるいはNIHSS または 1 人改善)も両群間で有意差を認めなかった $(4 / 8$ vs. $8 / 22, P=0.68)$ 。而群 で死亡例、症候性頭蓋内出血も認められなかった。[結論]発症時間不明の脳梗塞 患者においても、頭部MRIでのDWI/FLAIRミスマッチが陽性である症例では、 血栓溶解療法を安全に施行し、有効な転帰を得られる可能性がある。

0-02-1 Frequent subclinical cranial nerve involvement in IgG4 anti-NF155 antibody-positive CIDP

\footnotetext{
Hidenori Ogata ${ }^{1}, \mathrm{Xu}$ Zhang ${ }^{1}$, Saeko Inamizu ${ }^{1}$, Ryo Yamasaki ${ }^{1}$, Takuya Matsushita ${ }^{1}$, Noriko Isobe ${ }^{2}$, Jun-ichi Kira

${ }^{1}$ Department of Neurology, Neurological Institute, Graduate School of Medical Sciences, Kyushu University, Japan, ${ }^{2}$ Department of Neurological
Therapeutics, Neurological Institute, Graduate School of Medical Sciences, Kyushu University
}

Background: Cranial nerve involvement in IgG4 anti-neurofascin 155 (NF155) antibody-positive chronic inflammatory demyelinating polyneuropathy (CIDP) remains to be elucidated. Aims: To clarify involvements of trigeminal an facial nerves in IgG4 anti-NF155 antibody-positive CIDP by neuroimaging and electrophysiological methods. Methods: Ten IgG4 anti-NF155 antibody-positive CIDP patients followed-up in our clinic since 2012 ( 8 males and 2 females; mean age at onset, 34 years; disease duration, 5-210 months until brain MRI) were enrolled. All patients definitely met EFNS/PNS electrodiagnostic criteria for CIDP. All patient were examined by coronal and axial T2-weighted brain MRI for hypertrophy of the first branch of trigeminal nerve while 8 were also studied by blink reflex. An normal upper limit of R1 in blink reflex was set as 13 ms. Results: Facial sensory disturbance and weakness were found in 3 and 1 patients, respectively. All 8 patients examined by blink reflex showed absent or delayed R1 (13.4 to $30.9 \mathrm{~ms}$ ) Hypertrophy of the first branch of trigeminal nerve was detected in 3 patients. The disease duration was significantly longer in patients with trigeminal nerve hypertrophy than those without. One patient had diplopia due to compression of left superior rectus muscle by the massively enlarged supraorbital nerve. Conclusions: Subclinical involvement of trigeminal and/or facial nerves frequently occurs in IgG4 anti-NF155 antibody-positive CIDP. Coronal cranial MRI and blink reflex are useful to detect such subclinical cranial nerve lesions in this condition.

\section{0-01-8 延檤外側梗塞における顔面神経皮質核路の走行}

神林 隆道、今野 正裕、田中 園子、立山 佳鿆、濱田 雄一、 山本 淳平、松倉 清司、古川 裕一、神谷 久雄、千葉 隆司、 北國 圭一、畑中 裕己、園生 雅弘

帝京大学病院 神経内科

【目的】顔面神経皮質核路の走行経路については，少なくとも一部の線維は延揈ま で下行したのちにループを形成しながら交叉し，延喠背外側を上行して反対側の 顔面神経核に至る経路が推定されているが，神経解剖学の教科書などにも記載さ れていないことも多く，未だ不明な点もある. 本検討では，延噵外側梗塞を対象 とし, 顔面神経皮質核路の走行経路について検討した。【方法】2009年1月から2019 年11月までに当科に入院した急性期脳梗塞患者のうち，延随外側に限局した梗塞 巣を認めた連続31例を対象とした，病変局在はMRI拡散強調像にて同定し，延䯠 外側梗塞を上下方向には上部，中部，下部に分類し、水平方向には腹側型，沉腹 側型, 背側型, 広範囲型, 前外側型に分類した。中枢性顔面神経麻痺合併群と非 合併群において上下, 水平方向の病変局在, おょび臨床症候を統計学的に解析し た.【結果】延檤外側に限局した脳梗塞31例中，中枢性顔面神経麻瘦合併が7例，末 梢性顔面神経麻瘏合併が2例，非合併例 22 例であり，中枢性，末梢性いずれも病 変と同側の麻瘦であった。頭尾側で病変部位を分類すると，上部延䯑道5例中 2 例が 末梢性 (中枢性は 0 例), 中部延䯣 15 例中 6 例が中枢性, 中部〜下部延檤 4 例中 1 例が 中枢性顔面神経麻痺を合併した。下部延随病変7例では顔面神経麻痺合併例はな かった。軸位断での病変部位で分類すると, 中枢性顔面神経麻痺合併群の方が腹 側型の病変部位を含む例が有意に多かった $(\mathrm{P}<.001)$.さらに, 背側型, 前外側 型では中枢性顔面神経麻痺を呈した例は認めなかった。臨床症候の比較では，中 枢性顔面神経麻痺合併群のほうが非合併群に比較し嚥下障害 $(\mathrm{P}<0.05)$, 吃逆 $(\mathrm{P}$ <.001）を呈する頻度が有意に高かった.【結論】顔面神経皮質核路は，上下方向に おいては少なくとも延䯑道中部レベルまで下行し，ループを形成し交叉したのちに 延䯣背外側の中でも特に腹側かつ内側を上行し顔面神経核へ至ると考えられた。

\section{0-01-10 心房細動アブレーション後の微小脳塞栓と認知機能の 前向き研究}

加藤奈津子 ${ }^{1,2}$ 、村賀香名子 ${ }^{1,8}$ 、平田 佳寛 ${ }^{1}$ 、新堂 晃大 ${ }^{1}$

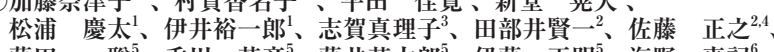
藤田 聡、香川 芳彦 ${ }^{5}$ 藤井英太郎、伊藤 正明 ${ }^{5}$ 、海野 真記 ${ }^{6}$ 、 前田 正幸 6 、冨本 秀和 ${ }^{1,2,3}$

重大学医学部 神経病態内科学、 2 三重大学医学部 認知症医療学講座、 重大学医学部付属病院 基幹型認知症疾患医療センター、 ${ }^{4}$ 三重大学医

学部付属病院 認知症センター、 ${ }^{5}$ 三重大学医学部 循環器・腎藏内科学、

三重大学 放射線診断科、 ${ }^{7}$ 三重大学医学部 先進画像診断学講座、

日本医科大学 脳神経内科

(目的)心房細動は認知症の危険因子であり、認知症と皮質微小梗塞 (cortical microinfarction, CMI)、脳微小

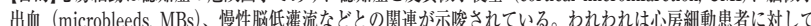
アブレーションを行い、認知機能への影響を調べた。【方法】当院循環器内科で平成29年8月〜平成30年 8 月にア ブレーションを行った持続性心房細動患者 41 名, 発作性心房緗動患者33名 (男性53名,女性21名, 年齢 32-86歳, 平 均 $68.3 \pm 10$ 歳)に対し、術直後 $(1-3$ 日) と6か月後に腷MRI 高次脳機能検查 (MMSE, RCPM, RBMT物語の記憶 Necker立方体模写, Mie Constructional Apraxia Scale (MCAS), TMT-A/-B, 語想起を施行した。腷MRIは、 DWI,3D-FLAIR 3D-double inversion recovery (3D-DIR),3D-TIWI, susceptibility-weighted imaging (SWI) を撮像した「結果了術直後の脳MRI DIRでは62例に微小塞栓を認め、慢性期には21例で病変が遗残していた。 SWIでは術直後に49例にMBsを認め、6か月後には新たに10例で出現した。病変の個数に関しては、術直後に DIRで337個の微小塞栓を認め、局在は皮質に多く、慢性期には33個が遗残していた。SWIで術直後に156個認 めたMBsは6か月後に80個增加し、うち63個が術直後の微小塞栓の局在に完全に一致した MMSE (66例で施 行) は術直後 $27.9 \pm 2.4$ 点, 6 加後 $28.5 \pm 2.0$ 点 $(p=0.04)$ と改善した。またRBMT, MCAS, TMT-Aが有意に改善 Lた。機能はejection fraction (EF) とbrain natriuretic peptide (BNP) か改善L、MMSEの変化とEFの変 化との間に正の相関を認めた( $\mathrm{r}=0.36 、 p=0.02)$ 「考察】アプレーション後に生じた微小塞栓は約9割の患者で消 失するが、多くがMBsに移行する。また、認知機能は全般的に改善する。心房䋖動患者では腷血流が低下す ることが報告されており、アブレーションによる脑灌流の正常化が認知機能改善の主な理由と考えられる。

\section{0-02-2 Two subtypes of anti-neurofascin 155/contactin-1} antibody-negative CIDP by CSF cytokine profiling

$\bigcirc$ Xu Zhang ${ }^{1}$, Hidenori Ogata ${ }^{1}$, Ryo Yamasaki ${ }^{1}$, Kenichi Kaida ${ }^{2}$

Motoi Kuwahara ${ }^{3}$, Susumu Kusunoki ${ }^{3}$, Takuya Matsushita ${ }^{1}$,

Noriko Isobe ${ }^{4}$, Jun-ichi Kira ${ }^{1}$

${ }^{1}$ Department of Neurology, Neurological Institute, Graduate School of Medical Sciences, Kyushu University, Japan, ${ }^{2}$ Department of Neurology, Anti-Aging and Vascular Medicine, National Defense Medical College, Department of Neurology, School of Medicine, Kindai University, Department of Neurological Therapeutics, Neurological Institute, Graduate School of Medical Sciences, Kyushu University

Background: Antibodies to nodal proteins such as neurofascin 155 (NF155) and contactin-1 (CNTN1) are found in subsets of chronic inflammatory demyelinating polyneuropathy (CIDP) patients. We reported that anti-NF155 antibody-positive $\left(\mathrm{NF155^{+ } )}\right.$ CIDP shows unique CSF cytokine profile, such as increase of Th2 and Thl cytokines/downstream chemokines and marked decrease of IL-lb and ILlra. However, these antibody-negative (NF155/CNTN1) CIDP remains heterogeneous. Aim: To clarify subtypes of NF155/CNTNl CIDP by CSF cytokine profiling. Methods: We measured 28 CSF cytokines in $36 \mathrm{NF} 155$ /CNTNl CIDP (23 pre- and 13 post-treatment states) and $35 \mathrm{NF}^{\circ} 55^{+} \mathrm{CIDP}$ patients, and 28 patients with non-inflammatory neurological diseases (NIND) by a multiplexed fluorescent immunoassay. Results: Dual cluster analysis of all CSF cytokines revealed two subgroups in $\mathrm{NF1} 55 / \mathrm{CNTNl}$ CIDP. When NF155/CNTNl CIDP patients were classified into low and norma IL-1 $\beta$ subgroups by median value $(1.06 \mathrm{pg} / \mathrm{ml})$, the low IL-1 $\beta$ subgroup showed significantly higher frequency of typical CIDP ( $89 \%$ vs. $44 \%, \mathrm{p}=0.0063)$ and greater CSF protein levels $(134 \pm 85$ vs. 50 $\pm 20 \mathrm{mg} / \mathrm{dl}, \mathrm{p}<0.0001)$ than the normal IL-lb subgroup. Moreover, the low IL-1 $\beta$ subgroup showed higher CXCL10/IP-10 $(\mathrm{p}=0.052)$ and IFN- $\gamma \quad(\mathrm{p}=0.0057)$ but lower IL-1ra levels $(\mathrm{p}<0.001)$ than NIND patients while the normal IL-1b suboroup showed only marginal increase of CXCL10/IP-10 ( $\mathrm{p}=0.0444)$ than NIND patients. Conclusion: Among NF155/CNTN1 CIDP, there is a unique subgroup showing increase of Thl cytokines/chemokines but marked decrease of IL-1 $\beta$ and IL-lra in CSF. 
0-02-3 Investigation on the site of action of immunoglobulin as an immune-modulator

Masahiro Iijima ${ }^{1,2}$, Yuki Fukami ${ }^{2}$, Ryoji Nishi $^{2}$, Haruki Koike ${ }^{2}$, Masataka Hamachi ${ }^{3}$, Koji Murakami ${ }^{3}$, Hitoshi Nakagawa ${ }^{3}$, Masahisa Katsuno

${ }^{1}$ Division of Advanced Medicine, Nagoya University, Japan, ${ }^{2}$ Department of Division of Advanced Medicine, Nagoya University, Japan, ${ }^{2}$ Department
Neurology, Nagoya University Graduate School of Medicine, Japan, ${ }^{3}$ Japan Neurology, Nagoya University
Blood Products Organization

[Objective] The efficacy of high-dose Immunoglobulin (Ig) has been established for immune-mediated neuropathies, including CIDP. However, the portion as an immune-regulator is unknown. Therefore, we aimed to compare the difference between complete-Ig and Fc-fragments in a spontaneous autoimmune polyneuropathy mice model. [Methods] Twenty NOD B7-2 knockout siblings were divided into complete- $\operatorname{IgG}(\mathrm{n}=10)$, IgG-derived $\mathrm{Fc}$-fragment $(\mathrm{n}=5)$, and saline control $(n=5)$ and intraperitoneally admitted from 19 weeks of age. The fluctuation of body weight and each index of the cat-walk system were evaluated. Besides, pathological findings of autopsied sciatic nerves at 27 weeks of age were analyzed. [Results] Body weight was well-maintained in complete$\mathrm{Ig}$ and $\mathrm{Fc}$-fragment groups from the initial to intermittent phase (complete-Ig: $-0.9 \pm 1.8 \mathrm{~g}$, Fc-fragment: $0.9 \pm 3.0 \mathrm{~g}$ in 24 weeks of age), while severe body weight loss was shown in control. $(-6.1 \pm 2.8 \mathrm{~g})$. Besides, the efficacy was superior in the Fc-fragment than in the complete-Ig. However, it had converged to decrease as the same to control. From the pathological findings of autopsied sciatic nerves, high-grade inflammatory cells diffusely infiltrated into the control nerve bundles, while the infiltration of inflammatory cells is diminished or localized in the complete-Ig and Fc. [Conclusions] Complete Ig, as well as Fc-fragment, could suppress the specific immune response. The superiority of Fc-fragment was also suggested and encouraged as novel therapeutics for autoimmune neuritis.

\section{0-02-5 Diversity in clinical phenotype of patients with} neuronal intranuclear inclusion disease

Tomoko Okamoto ${ }^{1}$, Tasuku Ishihara ${ }^{1}$, Yuji Saitoh ${ }^{1}$

Toshiyuki Yamamoto', Tadashi Tsukamoto, Wakiro Sato ${ }^{2}$,

Yuko Saito $^{3}$, Noriko Sato ${ }^{4}$, Takashi Yamamura ${ }^{2}$, Yuji Takahashi ${ }^{1}$

Department of Neurology, National Center Hospital, National Center of Neurology and Psychiatry, Japan, ${ }^{2}$ Department of Immunology, National Institute of Neuroscience, National Center of Neurology and Psychiatry, ${ }^{3}$ Department of Laboratory Medicine, National Center Hospital, National Center of Neurology and Psychiatry, ${ }^{4}$ Department of Radiology, National Center Hospital, National Center of Neurology and Psychiatry

Objective: To investigate the clinical features of patients with neuronal intranuclear inclusion disease (NIID). Methods: We retrospectively studied the clinical course, electrophysiological features, and brain MRI in 12 cases of NIID diagnosed by skin biopsy at our hospital. Results: In the 12 NIID cases (5 men, 7 women), the age of onset was 31-68 years, and the period from onset of symptoms to diagnosis was 1-17 years. Brain MRI images showed cerebral and cerebella atrophy in all cases. In 10 cases, a distinct high-intensity signal in the corticomedullary junction was seen in diffusion-weighted brain MRI. FLAIR images showed high-intensity, extensive, and diffuse signal in the cerebral white matter, medial cerebellar hemisphere beside the vermis (paravermal area), and middle cerebellar peduncle in 9, 8, and 7 cases, respectively. Nerve conduction study showed reduced velocity and amplitude of motor and sensory nerves in 11 cases. The two cases that did not show the characteristic MRI findings and had peripheral neuropathy (PN) as the main finding were initially diagnosed as chronic inflammatory demyelinating polyneuropathy (CIDP). In one of the patients, due to a lack of immunotherapy response and presence of stroke-like episodes and miosis, a sural nerve or skin biopsy was performed and NIID was diagnosed. Conclusions: Although MRI findings are important for the diagnosis of NIID, a few cases do not exhibit them. In some cases, the main findings show peripheral neuropathy resembling CIDP, suggesting that NIID is one of the most important differential diagnoses of PN.

0-02-7 Induction therapy for POEMS syndrome: A comparison study of thalidomide, lenalidomide and bortezomib

Tomoki Suichi, Sonoko Misawa, Yukari Sekiguchi,

Kazumoto Shibuya, Atsuko Tsuneyama, Yo-ichi Suzuki,

Keigo Nakamura, Hiroki Kano, Satoshi Kuwabara Department of Neurology, Graduate School of Medicine, Chiba University,
Japan

【目的】POEMS症候群は形質細胞異常を基盤に、多発ニューロパチー等の多彩な症状 を呈する疾患である。骨檤腫治療楽の有効性が報告されているが、それぞれの治療法 の比較は不十分である。本研究の目的は、POEMS症候群における、サリドマイド・デ キサメタゾン $(\mathrm{Td})$ 療法、レナリドミド・デキサメタゾン $(\mathrm{Rd})$ 療法、ボルテゾミブ・デ キサメタゾン $(\mathrm{Bd})$ 療法を比較検討することである。【方法】当施設において、Td、Rd、 Bd療法のいずれかにより寛解導入療法を施行した、初発または再発POEMS症候群連 続症例を対象とした。初回治療で寛解導入できなかった例は、次治療に移行した。力 ルテ調查により、患者背景、寛解達成率、有害事象を評価した。寛解は血清VEGF値 の正常化 $(<1000 \mathrm{pg} / \mathrm{mL})$ と定義した。【結果】72例が79回の寛解導入療法を受けた（Td 療法56回、Rd療法7回、Bd療法16回)。血清VEGF減少率の平均值は、 $\mathrm{Td} 、 \mathrm{Rd} 、 \mathrm{Bd}$ 療 法のそれぞれで $46.9 \% 、 69.5 \% 、 71.6 \%$ 、寛解達成率は $50 \% 、 71 \% 、 81 \%$ あった。寛解 導入までの中央值期間はそれぞれ、5.0力月、0.9カ月、1.5力月で、Td療法と比較して Bd療法で有意に短かった $(\mathrm{P}<0.001)$ 。初回Td療法で寛解導入できなかった例において、

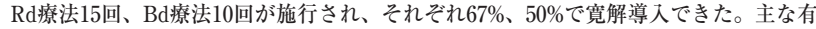
害事象として、Td療法で便秘 $(75 \%) 、$ 洞性徐脈 $(43 \%) 、 R d$ 療法で血球減少 $(18 \%)$ 、蒋 疹(18\%)、Bd療法でニューロパチー $(21 \%) 、$ 便秘 $(17 \%)$ が生じた。結論】POEMS症候 群に対する寛解導入療法として、Td、Rd、Bd療法それぞれの特性を示した。Td療法 は骨䯣抑制が少ないが、寛解導入までの期間が長い。Rd、Bd療法は寛解導入までの 期間が短く、Td療法不応例にも奏功する可能性があるため、带急性増悪例、難治例に おける選択肢になりうる。一方、Rd療法は末梢血幹細胞採取への影響が懸念されるた め、若年例への適応が限られる。病勢、患者背景を考虑した治療選択が重要である。
0-02-4 Brachial plexus involvements in patients with ALS and CIDP: MR neurography study

OTomomasa Ishikawa ${ }^{1}$, Akihiro Ueda ${ }^{1}$, Sayuri Shima ${ }^{1}$, Ryunosuke Nagao ${ }^{1}$, Kenichiro Murate ${ }^{1}$, Toshiki Maeda ${ }^{1}$, Koichi Kikuchi ${ }^{1}$, Yoshiki Niimi ${ }^{1}$, Yasuaki Mizutani ${ }^{1}$, Atsuhiro Higashi ${ }^{1}$, Kazutaka Hayashi ${ }^{1}$, Fumihiko Bannno ${ }^{1}$, Kunihisa Kato ${ }^{1}$, Seiko Hirota, Shindi Itou ${ }^{1}$, Kazuhiro Murayama ${ }^{3}$, Hiroshi Toyama ${ }^{3}$, Tatsuro Mutoh ${ }^{2}$, Hirohisa Watanabe ${ }^{1}$ Department of Neurology, Fujita Health University School of Medicine, Japan, ${ }^{2}$ Fujita Health University Chubu Centrair International Airport Clinic Department of Radiology, Fujita Health University School of Medicine

[Purpose] We aimed to investigate the diffusion character of brachial plexus and to evaluate the quantitive diagnostic value of diffusion-weighted whole-body imaging with background body signal suppression (DWIBS) in patients with chronic inflammatory demyelinating polyneuropathy (CIDP) and amyotrophic lateral sclerosis (ALS). [Methods] We enrolled 16 patients with definite CIDP, 20 patients with probable/definite ALS, and 14 healthy control participants at our hospital. We obtained an axial whole-body maximum intensity projection MR image from DWIBS using a 3.0-T Ingenia MRI scanner. The volume of the plexus and nerve roots was quantified using the AZE VirtualPlace ${ }^{\mathrm{TM}}$ software. We corrected the actual volume of each plexus with the body surface area Results. DWIBS visualized the brachial plexus in all participants. The brachial plexus volume/body surface area ratio ranged from 6.2 to $49.5 \mathrm{ml} / \mathrm{m}^{2}$ in the CIDP group, 3.3 to $9.1 \mathrm{ml} / \mathrm{m}^{2}$ in the ALS group and, 6.3 to $13.9 \mathrm{ml} / \mathrm{m}^{2}$ in the healthy control group. Patients with CIDP showed a significant increase in the volume/body surface area ratio compared to the healthy control participants $(\mathrm{p}=0.0083)$. On the contrary, ALS patients showed a significant decrease in the volume/body surface area ratio compared to healthy subjects $(p=0.0001)$. Significant differences in the volume/body surface area ratio existed between patients with CIDP and those with ALS $(\mathrm{p}<0.0001)$. [Conclusion] DWIBS will provide useful information about the involvement of brachial plexus in patients with CIDP and ALS.

\section{0-02-6 Neuroprotective activities of exendin-4 toward} dorsal root ganglion neurons and Schwann cells

Kazunori Sango, Shizuka Takaku, Naoko Niimi, Hideji Yako Diabetic Neuropathy Project, Tokyo Metropolitan Institute of Medical Science, Japan

[Objective] Besides its insulinotropic actions on pancreatic $\beta$ cells, the localization of glucagon-like peptide-1 receptor (GLP-1R) at the nervous system suggests neuroprotective properties of GLP-1. Exendin-4 (Ex-4), a GLP-1R agonist, has exerted neuroprotective actions following axonal injury and in a variety of neurodegenerative disorders; however, the underlying mechanisms remain unclear. [Methods] The bioactivities of Ex-4 on cultured adult rat dorsal root ganglion (DRG) neurons, immortalized adult rat Schwann cells IFRS1, and DRG neuron-IFRS1 coculture system were invetigated. Thirty 3-monthold femal Wistar rats were used for the primary culture of DRG neurons. [Results] Ex-4 dose-dependently $(1 \mathrm{nM}<10 \mathrm{nM}<100 \mathrm{nM})$ promoted neurite outgrowth and survival of DRG neurons, survival/proliferation and migration of IFRS1 Schwann cells, and movement of IFRS1 cells toward the neurites emerging from DRG neurons in the coculture. By western blotting, treatmen with $100 \mathrm{nM} \mathrm{Ex}-4$ induced phosphorylation of a serine/threonine kinase AKT at 1 day of coculture, and up-regulated the expression of myelin protein zero and peripheral myelin protein 22 at 21 days of coculture. [Conclusions] These findings suggest that Ex-4 acts on both DRG neurons and IFRS1 Schwann cells to accelerate myelin formation through phosphatidyl inositol-3'-phosphatekinase/AKT signaling pathway, and imply its efficacy for axonal regeneration and remyelination following peripheral nerve injury, as well as prevention and amelioration of diabetic and other peripheral neuropathies.

\section{0-02-8 Clinical characteristics of GBS with pain as an initial symptom}

Naohiro Sakamoto, Hiroshi Takazaki, Yuichiro Furuya,

Taro Matsui, Keishi Yamazaki, Yu Hongo, Katsunori Ikewaki, Kenichi Kaida

Department of Neurology, Anti-aging and Vascular medicine, Division of Internal Medicine, National Defense Medical College, Japan

【目的】疼痛はギラン・バレー症候群 (以下GBS) の半数以上にみられ, 誤診の要因 となり, 患者のQOLにも影響する。本研究では疼痛を呈するGBSの疫学的・臨 床的特徵を, 疼痛を初発とした例に焦点を当て明らかにする.【方法】2017年から 2019年の間に当院で抗糖脂質抗体を測定したGBS例のうち, Brightonの診断基準1 〜3を満たす例を抽出し，疼痛を呈した症例の特徴を後方視的に疫学的，臨床的に 解析した.【結果】Brightonの診断基準1〜3を満たす58例中9例（15.5\%）に経過を通 じて疼痛がみられ，8例(13.8\%)が疼痛を初発とした(初発群)。初発群8例の疼痛部 位は腰背部が 3 例, 肩甲骨間 (上背部) 1 例, 四肢 3 例, 関節 1 例であった。最初に整 形外科を受診した割合は疼痛を初発としなかった (非初発群) 50例中3例 $(6 \%)$, 初 発群 4 例 $(50 \%)$ であった $(\mathrm{p}$ 値 $<0.05)$. 脳春髄液検查の蛋白濃度は初発群で非初発群 に比し有意に高かった (初発群54.23 \pm 32.66 , 非初発群 $166.25 \pm 157.10, \mathrm{p}$ 值<0.05). 抗糖脂質抗体は初発群で有意に低頻度であった $(\mathrm{p}$ 值 $<0.05)$. 神経伝導検查所見に ついては脱䯣型を呈した例が初発群で 4 例 $(50 \%)$, 非初発群 17 例 (34\%) であったが, 有意差はみられなかった。治療に関しては初発群 $(87.5 \%)$, 非初発群 $(88 \%)$ とも経 静脈的免疫グロブリン療法を行っていた.【結論】本邦のGBSでは疼痛を初発症状 とする例は欧米に比し少ない。初発群の脳脊㕼液蛋白高值は神経根病変の強さを 示している可能性があるが, MRI検査を含めた今後の検討が必要である. 疼痛初 発例は脳神経内科受診が遅れる可能性が高いことに注意すべきである。 


\section{0-03-1ウェアラブルデバイスを用いたパーキンソン病におけ る睡眠障害の評価}

○鈴木 将史、中村 友彦、原田祐三子、上田 雅道、勝野 雅央 名古屋大学大学院医学系研究科 神経内科学

【目的】パーキンソン病（PD）は突発的睡眠、日中過眠、中途覚醒など様々な睡眠 障害を示すことが知られている。PDの睡眠障害の評䛧としてはPD sleep scale (PDSS) やEpworth sleepiness scale (ESS) などの質問紙法が用いられることが多 い。質問紙法以外の手法としては、加速度センサーを用いることによりPDの睡眠 時間や中途㥯醒の頻度を評価した報告があるが、十分な検討はなされていない。 今回、我々はウェアラブルデバイスから得られる心拍変動と活動状沉より睡眠時 間や中途鸴醒の評㑛を行い、PDの睡眠障害について検討を行ったので報告する。 【方法】PD17例（62.4 \pm 9.5 歳、罹病期間 $6.3 \pm 3.8$ 年）とコントロール16例（64.3 13.0 歲）に対して、ウェアラブルデバイスPOLAR V800 HR（CPolar Electro）を用い て、心拍変動拈よび活動状態のデー夕を取得した。夜間、安静卧位で心拍数が持 続して低下している時間を睡眠時間と仮定し、睡眠時間中に心拍数が持続的に上 昇した回数を中途営醒回数とした。PDとコントロールにおける睡眠時間、中途覚 醒回数の比較や、PDSS・ESSとの関連について换討を行った。[結果]PDとコント ロールにおいて睡眠時間には有意差を認めなかったが（PD; 7.0 1.9時間 vs. コン トロール: $6.6 \pm 1.6$ 時間, $p=0.464) 、 \mathrm{PD}$ ではコントロールと比較し中途営醒回数が 有意に上昇していた $(2.3 \pm 1.3$ 回 vs. $0.9 \pm 0.8$ 回, $p<0.001)$ 。PDでは睡眠時間が短く なるほどPDSSやESSのスコアが悪化する傾向にあり (PDSS; $r=0.39, p=0.120$, ESS $r=-0.39, p=0.121$ )、年齢で補正した場合には睡眠時間とPDSSに有意な相関を認め た $(r=0.51, p=0.035)$ 。[結論】ウェアラブルデバイスから得られる心拍変動や活動状 態のデー夕に基づく睡眠時間や中途覚醒回数は、PDの睡眠障害の指標の一つとし

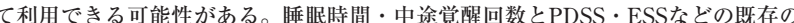
睡眠障害の指標との関連については、症例数を增やしさらなる検討が必要である。

\section{0-03-3 パーキンソン病における流涎と運動障害重症度および DATスキャン所見の関係の検討}

○水戸 泰紀、矢口 裕章、田島 康敬 市立札幌病院 脳神経内科

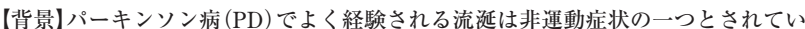
る. 一方で甠液分泌量はPDで低下することが報告されており、流涎が生じる原因 としては口㛊の運動量低下にともなう㕰液の嚾下障害が指摘されている.【目的】 未治療のPDの流涎と運動障害重症度㧍よびドパミントランスポーター (DAT) ス キャン所見との関係を検討し、流涎に対する運動障害およびドパミン神経変性の 関与度を考察した【対象・方法】ヤール重症度 3 以下で発症5年以内の未治療PD35 例 (男14例、女 21 例 : 平均年龄 $71.9 \pm 7.2$ 歳、ヤール重症度 $2.2 \pm 0.7$ ) を対象とし全例 の流诞の有無を評侹し、Unified Parkinson's Disease Rating Scale (UPDRS) を 用いた運動障害重症度およびDATスキャンの線条体取り达火率（SBR）との関倸 を検討した.【結果]未治療のPDにおいて流涎のある群は無い群と比べてUPDRS motor score、Akinetic-rigid scoreおよび棝下障害scoreは高值でSBRは低值であっ

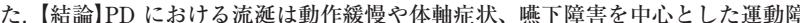
害の重症度およびドパミン神経の変性と関係している可能性が示唆された。

\section{O-03-2 Tilt台を用いたパーキンソン病における起立性低血圧 の分類と評価}

○黑野 裕子、鳥飼 裕子、阔村 正哉、原 済生会神奈川県病院 神経内科

【目的】パーキンソン病例に施行したhead-up till検查 (HUT) で、起立性低血圧 $(\mathrm{OH})$ を有した症例を、回復良好型 $\mathrm{OH} \cdot$ 回復不良型 $\mathrm{OH} \cdot$ delayed $\mathrm{OH}$ に分類し、各々の OHにおけるノルアドレナリン (NAd) 值を評侕した。また、パーキンソン病の病 期におけるOHタイプ別の割合を調べた。【方法】HUT検查は安静卧位10分後に倾 斜角70度で施行した。梌查の1時間前にNAd採血のためのルートを確保し、安静 卧位後7分頃と tilt-up後7分頃に採血を行った。 tilt-up後にNAd值が前值の1.5倍以 上になっていた場合、反応良好とした。対象はパーキンソン病でHUTを施行した 連続153例のうち $\mathrm{OH}$ 呈した 77 例。OHはtilt-up後3分以内の収縮期血圧 $20 \mathrm{mmHg}$ 以上の低下と定義した。 $\mathrm{OH}$ さらに回復良好型 $\mathrm{OH}$ (起立後 $3-4$ 分以内に回復)、 回復不飠型 $\mathrm{OH}$ (tilt-upの間、血压が低い状能が持繹する) d d layed $\mathrm{OH}$ (起立後 3分以降に血圧低下）に分類。回復不良型OHについては mild (収縮期血圧20-30低 下)、moderate (同30-50低下)、 severe（同50低下）に分類した。結果】パーキン ソン病期の進行とともに、回復良好型 $\mathrm{OH}$ や mid $\mathrm{OH}$ の割合は減少し、moderate、 severe $\mathrm{OH}$ が増加した NAdの安静時の值は回復良好型OHで最も高く $(510 \mathrm{pg}$ )

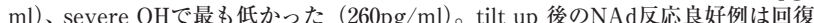
良好型OHで最も多く $(71 \%) 、$ severe $\mathrm{OH}$ で最も少なかった $(22 \%)$ 。結論]病状の 進行とともに重度の $\mathrm{OH}$ が增えた。また、 $\mathrm{OH} か ゙$ 重度になるほど安静時NAd值が低 く、tilt up 後の反応性にそしかった。単にOHがあるというだけでなく、そのOH のタイプを知ることで、より深く病態を理解できる可能性がある。

\section{0-03-4末治療早期パーキンソン病におけるDAT QUANTと 血圧循環調節障害との関連}

\footnotetext{
○北川 友通 ${ }^{1}$ 中中原 淳夫 ${ }^{1}$ 、梅原 淳 ${ }^{2}$ 岡 尚省 ${ }^{1}$

${ }^{1}$ 東京慈恵会医科大学附属第三病院 神経内科、

東京慈恵会医科大学附属病院 神経内科
}

【目的】パーキンソン病 (PD) 患者においてDAT QUANTの集積パターンが血圧循 環調節障害と関連するか否かを検討した.【対象】2014年1月から2019年10月の期間 に当院に入院した未治療早期PD患者 129 例を対象とした.【方法】DAT QUANTの 尾状核 (caud) と線条体 (stria) のstriatal uptake ratio (SUR) の左右平均值をそれ ぞれCaud，Striaとし，線条体に対する尾状核のSUR比Caud/Striaを算出した。血 圧循環調節障害の評価として Head up tilt試験での血厈低下が $30 \mathrm{mmHg}$ 以上の 患者を起立性低血圧 $(\mathrm{OH})$ 陽性群, $30 \mathrm{mmHg}$ 未満を $\mathrm{OH}$ 陰性群。経口ブドウ糖負荷 試験での血圧低下が $30 \mathrm{mmHg}$ 以上の患者を食事性低血圧 (PPH) 陽性群, $30 \mathrm{mmHg}$ 未満をPPH除性群.24時間血圧測定でnon-dipperの患者を夜間血圧低下不良群， dipperを夜間血圧低下良好群として分類した。OH，PPH，夜間血圧低下により それぞれ分類した陽性群，㓌性群および不良群，主好群の2群間のCaud/Striaに ついてMann-WhitneyのU検定で解析した.【結果】対象の中央值は, 年齢は76歳, 性別は男性が $40.3 \%$, 罹病期間は18ヶ月, Hoehn \& Yahrは2, UPDRS part III は19 点, MMSEは27点, FABは15点であった。OH陽性群は67例 $(52 \%)$, PPH陽性群 は54例 $(42 \%)$ ，夜間血圧低下不良群は61例 $(47 \%)$ であった，夜間血圧低下におい て，血圧低下不良群は血圧低下良好群に比べてCaud/Striaが有意に $(\mathrm{p}=0.046)$ 低值

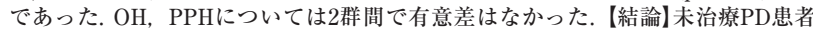
において, 夜間血圧低下が不良な例はDAT QUANTでの被殼に対する尾状核の SUR比が低值であった。 
0-03-5 前屈型頸部ジストニアにおける深部椎前筋治療の有効性

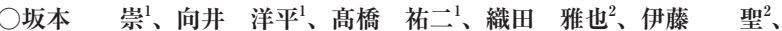
高松 直子 $3^{3}$ 和泉 唯信 $3^{3}$ 桜沢伸太郎 4 、小原琢磨、猪野 裕通 ${ }^{4}$ $1{ }^{1}$ 国立精神・神経医療研究センター病院 脳神経内科、

至次神経内科クリニック 花の里、 ${ }^{3}$ 德島大学腧神経内科、 ${ }^{4}$ 三愛病院

【目的】我々はParkinson病の首下がりの治療として斜角筋群の緊張光進緩和の有 用性を報告したが、それには反応しない患者にも遭遇する。こうした患者では概 して下顎が胸壁に密着するほどに前屈が高度で、その矯正のための装具装着も困 難である。他に前屈の原因筋となり得るのはより深部の椎前筋（頭長筋、頚長筋） だが、アプローチが困難なため治療が蹄躇されてきていた。今回、治療抵抗性の 前屈型頚部ジストニアにおける深部椎前筇を対象とした治療について検討する。 【方法】対象は高度の顠部前屈をきたした女性患者4名。28歳の歌舞伎症候群 1 名

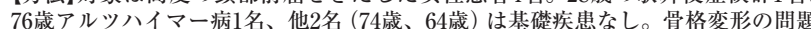
は除外され、頙部伸筋群の筋力低下はない。さらに斜角筋群へのボッリヌス治療・ リドカイン治療では十分な改善はみられていなかった。[結果]全例座位・立位て 深部椎前筋の安静時筋放電が強く、1回のリドカイン注射で缅部前屈は平均 $88.7 \%$ 改善した。これは斜角筋へのリドカイン注射時の平均改善率 $26.6 \%$ よも有意に 高かった。結果、全例でフイラデルフイアカラーを装着するに十分な究䍀を磼保 することができた。椎前筋は文字通り頸椎の前面を体軘に沿って縦走する筋であ る。前屈曲率半径が最大となる部位で、僧帽筋前縁から椎体に向けて針を刺入す る。その際、事前に概況をMRI,CTで把握するとともに、超音波で隣接する血管 を礁認しながら針を進めることで安全性が担保される。また、超音波による目視 と同時の注射が困難な場合でも、一度刺入経路を確認していれば、ガイドなしで も安全から確寒に施注できた。両側各25Uのボッリ又又注射後、フイラデルフィ アカラーを併用し、1か月後の評洒での改善率は $64.5 \%$ であった。【結論】難治性の 前屈型频部ジストニアにおいては深部椎前筋の影響を確認して同部の筋緊張緩和 を図ることが有効である。

\section{0-03-7 一次性ジストニアの発症年齢の男女差の検討}

松本 真一、小泉 英貴

大阪脳神経外科病院 脳神経内科

【はじめに】一次性ジストニア発症の修飾因子として、女性ホルモンの関与が議 論されている。目的】一次性ジストニアの発症年齢の男女差を検討した。【方法】 2011年6月から2019年 5 月までに受診した新規患者7515例のうち、発症年齢が碓 認できた一次性局所性ジストニア (のうち遗伝異常を伴わない) 眼瞼㽷攣373例、 䅡部ジストニア468例、上肢ジストニア198例、疾患コントロールとして片側顔面

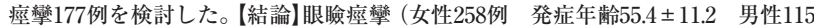
例 発症年龄 $530 \pm 10.1)$ は有意に女性の発症が葿かった $(p=0.03)$ このうち女性 81 名が50墄まで177名が51歳以上、男性43名が50歳まで72名が51歳以上の発症て 51 墄以上の女性の発症が有意に多くはなかった。頝部ジストニア（女性183名 発 症年齢 $43.1 \pm 14.7$ 男性 285 名 発症年齢 $40.5 \pm 13.2$ ） は有意に女性の発症が逑か。 た $(p=0.002)$ 。このうち女性 113 名が50歳まで70名が51歳以上、男性219名が50歳 まで66多が51歲以上の発症で51歲以上の女性の発症が有意に多かった（ $p=0.0004$ オッズ比 $=2.06$ )。上肢ジストニア (女性 62 名 発症年龄 $34.7 \pm 16.1$ 男性 136 名

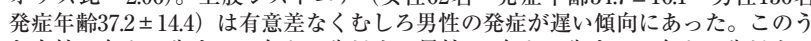
ち女性49名が50藏まで13名が51藏以上、男性108名が50歳まで28名が51藏以上の 発症で有意差を認めなかった。片側颜面痓彎 (女性126名 発症年齢 $53.8 \pm 12.0$ 男 性51例 $53.3 \pm 13.6 ）$ は有意差を認めなかった。このうち女性49名が50歳まで77名 が51歳以上、男性20名か550歳まで31名が51歳以上の発症で有意差を認めなかった。 ジストニアの発症年齢と男女差について文献的考察を加え報告する。

\section{0-03-9 CBS-CBD7例におけるペランパネル内服効果と治療 前脳血流シンチ $(E C D)$ の関連の検討}

\footnotetext{
城戸美和子 ${ }^{1}$ 、妹尾 洋 ${ }^{1}$ 、藤原 善寿 ${ }^{1}$ 、城間加奈子 ${ }^{1}$ 、中地 亮 ${ }^{1}$, 渡嘉敷 崇1 、諏訪園秀吾1,2

1独立行政法人国立病院機構沖縄病院 脳神経内科、

独立行政法人国立病院機構沖縄病院脳・神経・筋疾患研究センター

【目的】我々は第47回日本臨床神経生理学会 (2017年11月)にて、大脳皮質基底核変 性症（以下「本症」）1例においてペランパネル内服にて筋トーヌスと関節可動域改 善を認め、これに伴う治療前後てでの上肢SEPの振幅変化を報告した。本報告て は、本症7例におけるペランパネル内服効果と治療前脳血流シンチ (ECD) の関連 を報告する。【方法】本症と臨床的に診断した7症例にペランパネル $1 \sim 2 \mathrm{mg} /$ 日を内 服投与し、筋トーヌスや関節可動域の改善を認めた群と認めなかった群について、 ECD-SPECTにおける3D-SRTを用いた局所脳血流量推定值（以下rCBF）を後方視 的に比較検討した。【結果】ペランパネル投与によって筋トーヌスと関節可動域の 改善を認めたのは4例であった。効果を認めなかった 3 例中 2 例では、治療前の中 心前回や中心傍回のrCBFが健側と比較して患側で増加していた。治療効果を臨 床的に確認できた 4 症例はともに健側に比較して患側のrCBF低下が治療前に認め られた。【結論】治療前のECD-SPECTで、中心前回や中心傍回での集積に左右差が 忍められ患側がより低下している本症症例では、ペランパネル投与により筋卜ー
} ヌスや関節可動域を短期的に改善できる可能性がある。

\section{0-03-6ジストニアにおけるドパミン産生機能の画像的検討}

池澤 淳 ${ }^{1,5}$ 、横地 房子 $^{1}$ 、沖山 亮一 ${ }^{1}$ 、熊田 聡子 $^{2}$ 、 戸島 麻耶 ${ }^{1} 、$ 上山 勉、花川隆、松田 博史 ${ }^{4}$ 、田中 章景、 5 中田 安浩 ${ }^{3} 、$ 磯崎 英治

都立神経病院 脳神経内科、

都立神経病院 神経小児科、 ${ }^{3}$ 都立神経病院 神経放射線科、

国立精神・神経医療研究センター 脳病態統合イメージングセンター、

横浜市立大学 神経内科学・脳卒中医学

【目的】ジストニアは運動過剩症であり、基底核ループにおいてパーキンソン病と逆の機序、 直接路の光進・間接路の低下で説明される。しかし、ドパミン合成経路の酵素異常症であ るDYT5 (DYT-GCH1、瀬川病)、ドパミン受容体拮抗薬の長期投与が原因である遅発性シ ストニアなど、一部のジストニアはドパミン系の機能低下により発症する。さらに、ジス トニアにおける病理学的検討で黒質神経細胞脱落が報告(Iacono D et al. 2015)され、DYT5 以外でもドパミン産生機能低下が示唆される。本研究では神経メラニン画像、ドパミント ランスポータースペクト ${ }^{123}$ I FP-CIT SPECT, DAT SPECT) を用いてジストニアにおける ドパミン産生機能を検討する。【方法】対象:ジストニア群18例（平均 $40 \pm 2.6$ 歳、M/F $12 / 6$ 、 全身性/分節性 16/2、一次性/二次性 14/4)。対照として初期パーキンソン病 (PD) 群 18 例 (52 \pm 12 歲、 M/F 12/6)、健常者群27例 $(39 \pm 18$ 歳 M/F 15/12)。方法：(1) 袖経メラニン画像 により黑質メラニンの高信号域面積 (NRC) を検討した。(2) さらにジストニア群17例、PD 群8例でDAT SPECTを行い、健常者データベース（Matsuda H, 2018）とSpecific Binding Ratio（SBR）を比較した。【結果】(1) NRC值：ジストニア群平均 $31 \pm 4.2 、 P D$ 群 $28 \pm 3.8$ 、健 常者群 $43 \pm 3.8$ であった。NRCはFahn-Marsden Dystonia Rating Scale (FMDRS) と逆相関 した $(\mathrm{r}=-0.48, \mathrm{p}<0.05) 。(2) \mathrm{SBR}$ 值: ジストニア群 $5.1 \pm 0.2 、 \mathrm{PD}$ 群 $2.8 \pm 0.2$ 、健常予測值 9.2 あ゙っ た。ジストニア群においてSBRはFMDRSと逆相関した $(\mathrm{r}=-0.53, \mathrm{p}<0.05)$ 。神経メラニン画 像によるNRCではジストニア群とPD群は同程度であったが、DAT SPECTによるSBRでは PD群のほうが低值であった。結論】ジストニア症状への黑質線条体系の関与が示唆される。 また、ジストニアにおける黒質の異常の様相はパーキンソン病とは異なると考えられる。

\section{O-03-8ＭRガイド下集束超音波による片側視床または淡蒼球 破壊術の有害事象の検討}

伊藤 恒 ${ }^{1}$ 、山本 一徹 ${ }^{2}$ 、福武 滋 ${ }^{1}$ 、小渡 貴司 ${ }^{1}$ 、龟井 徹正 ${ }^{1}$

${ }^{1}$ 湘南藤沢德洲会病院 神経内科、 ${ }^{2}$ 東京女子医科大学 脳神経外科

【目的】MRガイド下集束超音波（MRgFUS）による片側視床または淡蒼球破壊 術の有害事象を検討する。【方法】当グループの共同倫理委員会の承認を得て, MRgFUSによる片側視床破壊術を行った本態性振戦11例と振戦優位型パーキンソ ン病の10例，および，片側淡蒼球破壊術を行ったジスキネジアを呈するパーキン ソン病の3例について 超音波照射中・治療から6か月後までの有害事象について 検討した.【結果】視床破壊術を行った21例では, 照射中に頭痛 $(15$ 例 $)$ ・浮遊感 $(5$ 例 $)$ ・嘔気湢吐 $(3$ 例 $)$ が, 治療直後に感覚障害 $(5$ 例 $)$ ・歩行の不安定性 $(4$ 例 $) \cdot$ 運動 緩慢と歩行障害 (小刻久歩行・玄くみ足歩行) (3例) ・ 眼瞼浮腫 $(2$ 例 $) \cdot$ 失調性片麻 疩（1例）が，それぞれ認められた。運動緩慢と歩行障害を認めた全例がパーキン ソン病だった、淡苓球破壊術を行った3例では照射中に頭痛（3例）が，治療直後に 眼瞼浮腫 (2例) が，それぞれ認められた。治療後に認められた有害事象はいずれ も6か月以内に消失し, 遅発性の有害事象は認められなかった.【結論】照射中に は頭痛が高頻度に認められた。 また, 治療直後に認められた運動緩慢・小刻み歩行・ すくみ足歩行はパーキンソン病症例に対して視床破壊術を行った際に特有の有害 事象である可能性があり，多数例での検討が必要である。

\section{O-03-10 MAO-B阻害薬の新規の処方状況 : 2019 年度の変化}

川嶋 将司、大喜多賢治、松川 則之 名古屋市立大学 脳神経内科

【目的】2019年6月1日よりラサギリンの長期処方が可能となり、パーキンソン病に 選択できるMAO-B阻害薬は2殽に增えた。しかし、現時点ではMAO-B阻害薬の 使い分けについての明確なエビデンスがない。そこで、ラサギリンの長期処方解 禁の前後でMAO-B阻害薬の処方状況が変わっているのかを調查するため、セレ ギリンとラサギリンの各々の新規処方を受けた患者について、後方視的検討をお こなった。【方法】対象は、指定の期間に当院でMAO-B阻害薬を新たに処方された パーキンソン病患者である。2018年12月1日〜2019年5月31日を期間A、2019年6月

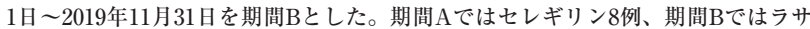
ギリン32例とセレギリン2例の新規処方があった。各期間において、患者プロファ イル、薬剤の投与量、MAO-B阻害薬の切り替えの有無、継続率などを比較検討 した。【結果】罹病期間に有意差があり、ラサギリンは罹病期間が長い患者にも処 方される傾向がみられた。ラサギリン長期処方の開始の後、セレギリンからラサ ギリンへの変更が12例、ラサギリンの中止後にセレギリンへの変更が1例あった。 投与量は、当院ではラサギリンは $1 \mathrm{mg}$ 錠のみの採用につき、投与量は全例 $1 \mathrm{mg}$ あった。一方、セレギリンの投与量は3.8+-1.9mgであった。結論】MAO-B阻害薬 の新規処方は、ラサギリンの長期処方の解禁から6か月間に約 4 倍に増えていた。 1日1回の内服で済む服楽コンプライアンスの利点から、ラサギリンは最大投与 量の $1 \mathrm{mg}$ でも高い継続率を有していた。一方、セレギリンはジスキネジアの悪化 などの副作用の発現が少なかった。2019年は、パーキンソン病の治療において、 MAO-B阻害楽の処方状況が大きく変化した年といえる。長期効果の検証について は、さらなる前方視的研究が課題である。 
0-04-1 Ataxic phenotype with altered Cav3.1 channel property in a mouse model for spinocerebellar ataxia 42

OShunta Hashiguchi ${ }^{1},{ }^{2}$ Hiroshi Doi ${ }^{1}$, Misako Kunii ${ }^{1}$,

Yukihiro Nakamura ${ }^{2}$, Misa Shimuta ${ }^{2}$, Etsuko Suzuki ${ }^{2}$, Masaki Okubo ${ }^{1}$ Shun Kubota ${ }^{1}$, Mikiko Tada ${ }^{1}$, Shigeru Koyano ${ }^{3}$, Hideyuki Takeuchi ${ }^{1}$, Taro Ishikawa ${ }^{2}$, Fumiaki Tanaka

${ }^{1}$ Department of Neurology and Stroke Medicine, Yokohama City University Graduate School of Medicine, Japan, ${ }_{3}^{2}$ Department of Pharmacology, The Jikei University School of Medicine, ${ }^{3}$ Department of Neurology, Yokohama Minami Kyosai Hospital

Objective: Spinocerebellar ataxia 42 (SCA42) is a neurodegenerative disorder recently reported to be caused by c.5144G $>$ A (p.Arg1715His) mutation in CACNA1G, which encodes the T-type voltage-gated calcium channel $\mathrm{Ca}_{\mathbf{y}} 3.1$. The aim of this study is to determine whether the mutation directly causes abnormal neuronal function, ataxic symptoms and neurodegeneration in mouse model. Methods: Knock-in mice harboring c.5168G $>\mathrm{A}$ (p.Arg1723His) mutation in Cacnalg, corresponding to the mutation identified in the SCA42 patients were generated, and behavioral, pathological and electrophysiological studies wer performed in the knock-in mice. Results: Both heterozygous and homozygous mice developed an ataxic phenotype from the age of 11-20 weeks and showed Purkinje cell loss at 50 weeks old. Electrophysiological analysis of Purkinje cells using acute cerebellar slices from knock-in mice showed that the mutation altered the voltage dependence of $\mathrm{Ca}_{\mathrm{y}} 3.1$ channel activation and reduced the rebound action potentials after hyperpolarization, although it did not affect the basic properties of synaptic transmission onto Purkinje cells. Further, we revealed that the resonance of membrane potential of neurons in the inferior olivary nucleus was decreased in knock-in mice, which indicated that the mutation affects climbing fiber signaling to Purkinje cells. Conclusions: Using the animal model of SCA42, we showed that the missense mutation of $\mathrm{Ca}_{\mathrm{v}} 3.1$ directly caused progressive ataxia, Purkinje cell degeneration, and the electrophysiological abnormalities at an early stage preceding the neurodegeneration.

\section{0-04-3 Clinical and laboratory Features of Elderly-Onset} Temporal Lobe Epilepsy:comprehensive data analysis

Hirofumi Takeyama ${ }^{1}$, Riki Matsumoto ${ }^{2,3}$, Maya Tojima ${ }^{2}$,

Masayuki Honda, Atsushi Shima ${ }^{2}$, Mitsuhiro Sakamoto
Kozue Hayashi ${ }^{2}$, Kiyohide Usami

${ }^{1}$ Department of Respiratory Care and Sleep Control Medicine, Kyoto

University, Japan, ${ }^{2}$ Department of Neurology, Kyoto University, ${ }^{3}$ Division

of Neurology, Kobe University Graduate School of Medicine, ${ }^{4}$ Department

of Clinical Laboratory, Kyoto University, ${ }^{5}$ Department of Neurology,

Rakuwakai Otowa Hospital, ${ }^{6}$ Department of Epilepsy, Movement Disorders

and Physiology, Kyoto University

$<0$ bjective $>$ To clarify the clinical features of elderly onset, temporal lobe epilepsy (TLE) $<$ Method > TLE patients with elderly onset (over 60 year old) who clinically needed to be admitted to our hospital for diagnosis between 2000 and 2019 were recruited. The symptoms, EEG, Wechsler memory scale-revised (WMS-R), MRI volumetry, FDG-PET, anti-neuronal autoantibody were retrospectively analyzed.<Result> 47 patients were included [male 28 (59.6\%), age 61 - 82 The most common seizure semiology was complex partial seizure without generalized seisures $(72.3$ $\%$ ). Most patients (59.6\%) showed good response for antiepileptic drugs. WMS-R results showed that the general memory, verbal memory, and delayed recall were all impaired. EEG showed bilateral or unilateral temporal epileptiform discharge in $31.9 \%$ and $48.9 \%$ patients, respectively. Antineuronal antibody was positive in 8 out of 19 patients (42.1\%). Brain MRI volumetry revealed that the enlargement of the amygdala was most frequently observed as the volume< change (lef amygdala enlargement: $56.4 \%$ of patients. right amygdala enlargement: $43.6 \%$ of patients), and 35.9 $\%$ of patients manifested bilateral amygdala enlargement FDG.PET analysis revealed the increased regional glucose metabolism in the bilateral amygdala in the patients with bilateral amygdala enlargement.<Conclusion>In our cohort of elderly onset TLE patients, the frequently observed bilateral abnormality in the EEG, MRI, FDG-PET and the positive results of the antineuronal autoantibody were seen in $42.1 \%$ of the patients and it suggested the autoimmune etiology.

\section{0-04-5 Characteristics of the intercortical epileptic} network: a cortico-cortical evoked potential study

Masaya Togo ${ }^{1}$, Riki Matsumoto ${ }^{2}$, Nobutaka Mukae ${ }^{3}$, Katsuya Kobayashi ${ }^{4}$, Kiyohide Usami ${ }^{5}$, Akihiro Shimotake ${ }^{1}$, Takuro Nakae ${ }^{6}$, Takayuki Kikuchi ${ }^{7}$, Kazumichi Yoshida ${ }^{7}$, Masao Matsuhashi ${ }^{5}$, Takeharu Kunieda Susumu Miyamoto ${ }^{7}$, Ryosuke Takahashi ${ }^{1}$, Akio Ikeda ${ }^{5}$ Kyoto University Graduate School of Medicine, Department of Neurology, Japan, ${ }^{2}$ Kobe University Graduate School of Medicine, Division of Neurology, ${ }^{3}$ Kyushu University Graduate School of Medica Sciences, Department of Neurosurgery, ${ }^{~ E p i l e p s y ~ C e n t e r, ~ C l e v e l a n d ~ C l i n i c, ~}{ }^{3}$ Koto University Graduate School of Medicine, Department of Epilepsy, Movement disorder and physiology, ${ }^{6}$ Shiga General Hospital, Department of Neurosurgery, Kyoto University Graduate School of Medicine, Department of Neurosurgery, ${ }^{8}$ Ehime University Graduate School of Medicine, Department of Neurosurgery

[ObjectivelThe modification of epileptic activities on brain connectivity remains a matter of debate. Although some studies showed seizure onset zone (SOZ) evoked higher response amplitude in corticocortical evoked potential (CCEP), the study on global characteristics of seizure networks is sparse. Therefore, we focused on the intercortical effective connectivity involving SOZ using CCEP with subdural grid electrodes. [MethodslSubjects were 11 patients with drug-resistant focal epilepsy wh underwent subdural grids implantation for presurgical evaluation. Single-pulse electrical stimuli (1 $\mathrm{Hz}$, pulse width $0.3 \mathrm{msec}, 6-12 \mathrm{~mA}$ ) were delivered to the whole neighboring pairs of electrodes (1162 electrodes). We extracted the responses with a 7 -score of more than 6 and a peak latency of less than 50 ms. We calculated an adjacency matrix, illustrated networks and then analyzed the normalized inbound outbound connectivity in each electrode. [Results]The SOZ did not show the significant differences in the number of both inbound/outbound connections compared to the non-SOZ. With regards to the strength of connectivity (the sum of CCEP amplitudes), the SOZ showed significantly higher strength of inboun connectivity compared to the non-SOZ. The strength of outbound connectivity was not significantly higher in the SOZ. IConclusionlThe present findings suggested that epileptic activity does not affect the global intercortical network structures, but modulates the strength of the inbound connectivity. These network characteristics could be a physiologic surrogate marker for identifying SOZ.

\section{0-04-2 RELATIONSHIP BETWEEN CORTICAL EXCITABILITY AND COGNITIVE DYSFUNCTION IN ALS}

Mana Higashihara ${ }^{1,2}$, Parvathi Menon ${ }^{1}$, Mehdi A.j. Van Den Bos ${ }^{1}$, Nimeshan Geevasinga ${ }^{1}$, Matthew C. Kiernan ${ }^{3}$, Steve Vucic

${ }^{1}$ Westmead Clinical School, University of Sydney, Australia, ${ }^{2}$ Department of Neurology, Tokyo Metropolitan Geriatric Medical Center, Japan, ${ }^{3}$ Brain and Mind Centre, University of Sydney

Objective: Cortical hyperexcitability has been established an important pathophysiological mechanism underlying the development of amyotrophic lateral sclerosis (ALS), while ALS specific cognitive dysfunction has been acknowledged. We investigated the relationship between cortical hyperexcitability and cognitive dysfunction in sporadic ALS patients. Methods: In total, 43 sporadic ALS patients ( 25 males, $62.3 \pm 10.4$ years) were underwent cortical excitability and neuropsychological assessment lusing the Edinburgh Cognitive and Behavioural ALS Screen (ECAS)]. Results: Cognitive dysfunction, as reflected by the ECAS total score, was evident in $35 \%$ ALS patients. Interestingly, language dysfunction was most frequent (26\%), followed by executive dysfunction (16\%) and impaired letter fluency (14\%). Cortical hyperexcitability was heralded by a reduction of short-interval intracortical inhibition $(\mathrm{SICI})[\mathrm{P}<0.01]$ and cortical silent period duration $[\mathrm{P}$ $<0.01]$, as well as an increase in short-interval intracortical facilitation (SICF) $[\mathrm{P}<0.001]$ and MEP amplitude $[\mathrm{P}<0.05]$. Interestingly, the increase in SICF was more pronounced in patients with an abnormal ECAS total [P $<0.01]$ and ALS specific scores $[\mathrm{P}<0.001]$, while SICI reduction was greater in patients with abnormal language $[\mathrm{P}<0.05]$ and fluency $[\mathrm{P}<0.05]$ scores. Conclusions: The present study established that cortical hyperexcitability was more prominent in those patients that exhibited cognitive difficulties.

0-04-4 Neural processes during picture naming are lateralized and category-biased in occipitotemporal areas

Kiyohide Usami ${ }^{1,2}$, Riki Matsumoto ${ }^{3}$, Anna Korzeniewska ${ }^{2}$

Akihiro Shimotake ${ }^{4}$, Takuro Nakae ${ }^{5}$, Masao Matsuhashi ${ }^{1}$

Takayuki Kikuchi $^{6}$, Kazumichi Yoshida ${ }^{6}$, Takeharu Kunieda ${ }^{7}$

Ryosuke Takahashi, ${ }^{4}$ Nathan Crone ${ }^{2}$, Matthew Lambon Ralph ${ }^{8}$, Akio Ikeda

${ }^{1}$ Department of Epilepsy, Movement Disorders and Physiology, Kyoto University Graduate School of Medicine, Japan, ${ }^{2}$ Department of Neurology, Johns Hopkins University School of Medicine, USA, ${ }^{3}$ Division of Neurology, Kobe University Graduate School of Medicine ${ }^{4}$ Medicine, USA, Division of Neurology, Kobe University Graduate School of Medicine, of Neurosurgery, Shiga General Hospital, ${ }^{6}$ Department of Neurosurgery, Kyoto University of Neurosurgery, Shiga General Hospital, ${ }^{6}$ Department of Neurosurgery, Kyoto University School of Medicine, ${ }^{8}$ MRC Cognition and Brain Sciences Unit, University of Cambridge

[Objective] Occipitotemporal areas are reportedly involved in the processing of visual information Despite the semiological relevance, it remains veiled whether activation of these areas is lateralized and how the difference of the picture categories affects the process. We attempted to reveal whether the two categories consisting living/non-living things induce different patterns 0 information propagation. [Methods] The electrocorticograms (ECoG) during visual naming task were recorded in the language-dominant side of five epilepsy patients and in the non-dominant side of three patients (IRB\#C533). Induced high-gamma activities (HGA: 80-150 Hz), which are proxies of neuronal firings, were calculated in each patient. The channels that showed the upper $10 \%$ of large HGA were chosen for further analysis. In occipitotemporal areas, HGA and their propagations revealed by event-related causality (ERC) were analyzed. [Results] HGA were not statistically different in both sides $(\phi=0.14)$. However, ERC revealed more propagation of HGA at around $200 \mathrm{~ms}$ after visual stimuli within occipitotemporal areas in the non-dominant side than in the dominant side $(p<0.05)$. In the dominant side, non-living things elicited more propagation within the areas than living things did $(p<0.05)$. [Conclusion] The neural processes during picture naming are lateralized and category-biased in occipito-temporal areas.

\section{0-04-6 Eye-hand coordination in reaching task in SCA compared with Parkinson disease}

Satomi Inomata-terada ${ }^{1}$, Shin-ichi Tokushige ${ }^{2}$, Shun-ichi Matsuda ${ }^{3}$ Yuji Takahashi ${ }^{7}$, Ayumi Uchibori ${ }^{2}$, Yaeko Ichikawa ${ }^{2}$, Atsurou Chiba ${ }^{2}$, Masashi Hamada ${ }^{4}$, Yoshikazu Ugawa ${ }^{1,5}$, Shoji Tsuji ${ }^{4,6}$, Yasuo Terao ${ }^{1}$ ${ }^{1}$ Department of Medical Physiology, Kyorin University, Japan, ${ }^{2}$ Departmen of Neurology, Kyorin University, ${ }^{3}$ Department of Neurology, NTT Medical Center Tokyo, ${ }^{4}$ Department of Neurology, The University of Tokyo, ${ }^{5}$ Department of Neurodegeneration, Fukushima Medical University,
Department of Molecular Neurology, International University of Health ${ }^{6}$ Department of Molecular Neurology, International University of Health and Welfare, ${ }^{7}$ Department of Neurology, National Center of Neurology and Pshchiatry

[Objectives] Eye and hand movements are known to be closely linked in daily actions (eye-hand coordination, and the cerebellum plays a pivotal role not only in controlling movements of both effectors but also in their coordination. To clarify the role of the cerebellum in eye-hand coordination, we studied eye and finger movements in hereditary spinocerebellar degeneration (SCA) during reaching tasks, and compared it with normal controls (NC) and Parkinson disease (PD), with a system that can record the trajectories of eye and hand movements simultaneously. [Methods] Subjects were 12 SCA (SCA6 or 31) patients with pure cerebellar symptoms and 31 age-matched NC and 3 PD patients. Subjects performed visually guided reaching tasks. A video-based eye tracker recorded eye movements, while a touch panel recorded the trajectory of the finger during the task. [Results] In most trials, the eyes preceded the finger movements to the target. In SCA, the distance between final position of eye and target and between final position of finger and target are significantly larger than in NC. In PD patients these distances tended to be larger than in NC, but the difference was not significant. There was a significant correlation between the final positions of gaze and the accuracy of the finger in al groups (NC: $r=0.65, p=0.001 ; \mathrm{SCA} r=0.53, \mathrm{p}=0.001$; PD 0.57, $\mathrm{p}<0.001$ ), but the correlation was weaker in SCA and PD than in NC. And the correlation was weaker in SCA than in PD. [Conclusion] Disturbance of eye-hand coordination system in SCA may be different from that in PD. 


\section{0-04-7 Neurofeedback facilitation of imagery-related SMA activation improves gait in PD}

$\bigcirc$ Masahito Mihara ${ }^{1}$, Hironori Otomune $\mathrm{e}^{2,3}$, Yuta Kajiyama ${ }^{3}$,

Hiroaki Fujimoto ${ }^{2}$, Noriaki Hattori ${ }^{3,4}$, Ichiro Miyai ${ }^{2}, K_{0 z o}$ Hanayama $^{5}$, Yoshihide Sunada ${ }^{1}$, Hideki Mochizuki ${ }^{3}$

${ }^{1}$ Department of Neurology, Kawasaki Medical School, Japan,

${ }^{2}$ Neurorehabilitation Research Institute, Morinomiya Hospital, ${ }^{3}$ Department of Neurology, Osaka University, ${ }^{4}$ Division of Clinical Neuroengineering, Osaka University Global Center for Medical Engineering and Informatics,

${ }^{5}$ Department of Rehabilitation Medicine, Kawasaki Medical School

[Objective] To investigate the efficacy of the supplementary motor area (SMA) facilitation using functional near infrared spectroscopy mediated neurofeedback system (fNIRS NFB) on gait impairment in PD. [Methods] Clinically established PD ( $\mathrm{N}=19,8$ males, age: $75.6 \pm 5.6$ y.o.) with written informed consent have participated. Subjects are randomly allocated to REAL and SHAM groups. In addition to the usual inpatient rehabilitation, patients participated 6 sessions of neurofeedback training with gait related motor imagery. As a feedback, their own SMA activity was provided in REAL group but irrelevant signals were provided in SHAM group. Clinical measures including motor symptom, Hoehn-Yahr stage, and cognitive status are assessed. Gait and balance measures including Timed Upand-go test (TUG), Berg Balance Scale (BBS), and Gait speed are also assessed before, immediately after, and 2 weeks after the end of intervention. [Resultsl Baseline clinical characteristics were comparable between two groups. After controlling the possible confound factors, there was significant interaction between group and TUG time $\left(\mathrm{F}_{2,24}=3.42\right.$ $\mathrm{p}<0.05)$, and group and gait speed $\left(\mathrm{F}_{2.24}=5.802, \mathrm{p}<0.01\right)$. Although TUG time and gait speed improved significantly at the end of intervention in the REAL group $\left(t_{0}=-3.05, p<0.05\right.$, and $t_{9}=3.42, p<0.01$, respectively), these effects were not sustained. There was no adverse effect associated with fNIRS-NFB [Conclusions] Our pilot RCT revealed the safety and beneficial effect of fNIRS-NFB on gait disturbance in PD, but its clinical efficacy did not last long.

\section{0-04-9 Clinical characteristics in patients with nonlesional late-onset epilepsy}

Naoto Nagino ${ }^{1}$, Satoru Miyao ${ }^{2}$, Hidetoshi Nakamoto ${ }^{2}$, Satoko Fukuchi ${ }^{1}$, Susumu Itoh ${ }^{3}$, Yuichi Kubota ${ }^{1,4}$, Hirokazu Oguni ${ }^{1}$

${ }^{1}$ Stroke \& Epilepsy Center, TMG Asaka Medical Center, Japan, ${ }^{2}$ Departmen of Neurosurgery, TMG Asaka Medical Center, ${ }^{3}$ Department of Pediatrics, Tokyo Women's Medical University, ${ }^{4}$ Department of Neurosurgery, Tokyo Women's Medical University Medical Centre East

Introduction: Incidence and prevalence of epilepsy increase with age Several identified etiologies were reported as a cause late-onset epilepsy. However, approximately $50 \%$ of the etiologies of late-onset epilepsy were unknown. Especially, no conclusions were identified in nonlesional cases. We retrospectively evaluated in a total of 80 patients with nonlesional late-onset epilesy (NLLOE). The aim of this study is to evaluate the characteristics in a cohort of patients with NLLOE. Methods: A total of 80 patients affected by diagnosed NLLOE after the age of 65 years were retrospectively analyzed through medical record at our epilepsy center. We described seizure type electroencephalography (EEG) characteristics, imaging findings, and comorbid medical conditions. Results: The most frequent seizure types were focal impaired awareness seizure $(76 \%)$ as well as focal to bilateral tonic clonic seizures $(38 \%)$ and focal awareness seizure $(21 \%)$. Interictal EEG revealed epileptiform discharges (EDs) from temporal region in 73\% EDs. Periventricular hyper-intensity was common findings on imaging. Prevalence of dementia was $38 \%$ among our patients. Conclusions: Clinical manifestation of the majority of patients with NLLOE were similar to that of patients with temporal lobe epilepsy. There was a higher prevalence of dementia in ou patients, which merits further investigation. Our findings may help to clarify the pathophysiology of NLLOE.

\section{0-05-1 Exome analysis in 137 autopsied sporadic ALS} cases

Tomohiko Ishihara ${ }^{1}$, Yuya Hatano ${ }^{1}$, Akio Yokoseki ${ }^{2}$, Mari Tada ${ }^{3}$,

Takashi Nakajima ${ }^{4}$, Ryoko Koike ${ }^{5}$, Akiyoshi Kakita ${ }^{3}$

Osamu Onodera

${ }^{1}$ Department of Neurology, Brain Research Institute, Niigata University, Japan, ${ }^{2}$ Center for Inter-Organ Communication Research, Niigata Universit Graduate School of Medical and Dental Sciences, Niigata University,

Department of Pathology, Brain Research Institute, Niigata University,

${ }^{4}$ Department of Neurology, National Hospital Organization Niigata National Hospital, ${ }^{5}$ Department of Neurology, National Hospital Organization Nishiniigata Chuo Hospital

[Objective] Most amyotrophic lateral sclerosis (ALS) are sporadic ALS (SALS) and familial ALS (FALS) is about $10 \%$. More than 30 causative genes are known in ALS. These mutations are often identified not only in FALS but also in SALS, and are important for elucidating the ALS pathophysiology. We conducted an exome analysis in autopsied SALS cases in our institute to create the genetic data list corresponding to clinical and pathological features. [Methods] We analyzed the 137 autopsied SALS cases by exome sequence using DNA extracted from the central nervous tissue. We analyzed 39 ALS-related genes (Chia R, et al. Lancet Neurol, 2018). The detected rare variants (allele frequency $<0.001$ ) were classified into probable, possible or unknown significant pathogenic mutations by the allele frequency and existence of previous reports (Dols-Lcardo 0 , et al JNNP, 2018). [Results] We found the 32 cases having the rare variant in ALS candidate genes. In these, 4 and 5 cases had probable or possible mutations, and they showed short survival duration than without rare variant cases (average: 23.4 vs 41.9 months). In addition, other 9 cases had in del / fs mutations in the gene $\mathrm{X}$, which were classified as unknown significant because of their allele frequency. However, the cases having gene $\mathrm{X}$ mutation had significant poor prognosis (average: 13.9 months). [Conclusion] Exome analysis of 137 SALS cases identified causative gene mutations in 9 cases. And we found the gene $\mathrm{X}$ mutations as a prognostic factor candidate in ALS.
0-04-8 Severe sleep apnea syndrome diagnosed at a neurology department --- present status and problems

Hidehiro Shibayama, Shohei Harase, Kei Yamakami, Shun Akaike, Kazue Tajima, Ryoko Takeuchi, Fumiaki Katada, Susumu Sato,

Toshio Fukutake

Department of Neurology, Kameda Medical Center, Japan

[Background and Objective] The advent of convenient monitoring system for sleep urges us neurologists to pay much attention to sleep in our practice. So, we launched into grasping the present status for sleep apnea syndrome (SAS) to improve future management of this potentially treatable condition which sometimes triggers consciousness disturbance with convulsion. TMethods Medical records of those patients who have taken full or simple polysomnography from May 2008 to October 2019 were retrospectively reviewed. Severe SAS was defined as those who have $>30.0$ apnea-hypopnea index or respiratory disturbance index. [Results] Five hundred fifteen sleep examination (full 25, simple 490) have been done on 477 patients (male 291, female 186), of which $125(26.2 \%)$ were diagnosed as severe SAS (male 91, female 34). Obstructive apnea pattern predominated over central apnea pattern (109 vs. 16). Their body mass index was $27.1 \pm 5.3$ and Epworth Sleepness Scale was $7.0 \pm 4.6$. Twenty-eight patients $(22.5 \%)$ had progressive neurodegenerative (Alzheimer disease, Parkinson disease etc.) or neuromuscular (muscular distrophy etc.) diseases. As for treatment, continuous positive airway pressure or bilevel positive airway pressure were proposed for 73 patients $(58.4 \%)$, but only $37(50.7 \%)$ are maintaning their use. [Conclusions] Severe SAS is frequently encountered in neurological practice including in patients with progressive neurological disorders. We shoud be cautious to its presence. Improvement of repiratory assistant apparatus is further wanted considering its insufficient long-term tolerance.

\section{0-04-10 Walking ability Improvement using Hybrid Assistive} Limb $^{\circledR}$ for Amyotrophic lateral sclerosis patients

Kiyoko Murata ${ }^{1}$, Tatsuki Sugisawa ${ }^{2}$, Hirotaka Fukuda ${ }^{2}$, Masayuki Uchi', Ryuichi Okamoto ${ }^{1}$, Hiromi Konaka ${ }^{1}$, Junya Ebina ${ }^{1}$, Harumi Morioka ${ }^{1}$, Maya Kyuzen ${ }^{1}$, Masahiro Sawada ${ }^{1}$, Sayori Hanashiro ${ }^{1}$

Masaru Yanagihashi ${ }^{1}$, Kiyokazu Kawabe ${ }^{1}$, Satoru Ebihara ${ }^{2}$, Osamu Kano

Department of Neurology, Toho University Faculty of Medicine, Japan,

Department of Rehabilitation, Toho University Faculty of Medicine

Background: Hybrid assistive limb (HAL ${ }^{\circledR}$ CYBERDYNE Inc.) is a wearable cyborgtype robot that interactively provides motion according to the wearer's voluntary drive. $\mathrm{HAL}^{\otimes}$ for medical use (lower limb type) received approval to be manufactured and sold as a medical device by the Ministry of Health, Labour and Welfare, and covered costs by public medical insurance in Japan. However, little is known about the efficacy of HAL for Amyotrophic lateral sclerosis (ALS) patients. Objectives:To assess the effect of HAL training on the walking ability in ALS patients. Methods: Eleven patients underwent $\mathrm{HAL}^{\circledR}$ training (mean age $60.0 \pm 10.9$ ) at least 9 days during $4-5$ weeks. Walking ability ( 2 min walk and $10 \mathrm{~m}$ walk), muscle strength and ALS functional Rating Scale-Revised (ALSFRS-R), Forced vital capacity (\%FVC) were major outcome. Walking ability were conducted by physical therapists trained to perform standardized assessment procedures The outcome measures were evaluated before and after $\mathrm{HAL}^{\circledR}$ training. Results:Two of 11 ALS patients were evaluated under non-invasive ventilation. The mean 2 min walk before training was $94.0 \pm 28.6 \mathrm{~m}$, and was significantly increased up to $108.3 \pm 33.0 \mathrm{~m}$ $(\mathrm{p}=0.003)$. In addition, $10 \mathrm{~m}$ walk test improved in both speed $(\mathrm{p}=0.01)$ and cadence ( $p=0.01$ ), however, step length did not change. There was no difference in muscl strength, ALSFRS-R, and \%FVC during observational period. Conclusions:Although this study is a single-arm trial, our findings showed that $\mathrm{HAL}^{\circledR}$ training ameliorated the walking ability and might lead to slower disease progression in ALS patients.

\section{0-05-2 withdrawn}




\section{0-05-3 CCR2-positive macrophages infiltrated into the peripheral nerves protect motor neuron disease}

$\bigcirc$ Wataru Shiraishi, Ryo Yamasaki, Yu Hashimoto, Yuko Kobayakawa, Jun-ichi Kira

Department of Neurology, neurological Institute, Graduate School of Medicine, Kyushu University, Japan

Aim: We reported intrathecal upregulation of MCP-1/CCL2 was associated with disease severity in amyotrophic lateral sclerosis (ALS). We aimed to clarify the Methods: We generated transgenic "Red-Green" $S O D 1^{\mathrm{G} 93 \mathrm{~A}}$ mice, which express CCR2-RFP and CX3CR1-GFP heterozygously. We also established SODI ${ }^{\mathrm{G} 93 \mathrm{~A}}$, $C C R 2^{\mathrm{RFP} / \mathrm{RFP}}$ mice, which possess a CCR2-deficient phenotype. We compared the clinical course and pathology between CCR2-positive $\left(C C R 2^{R F P / W T}\right)$ and -deficient mSOD1-Tg mice. Results: In mSOD1-Tg mice, mSOD1 protein was deposited earlier in the sciatic nerve than in the spinal cord. Before the onset of clinical symptoms, $\mathrm{CCR} 2^{+}$macrophages phagocytizing mSOD1 infiltrated much earlier in the sciatic nerve than in the lumbar cord. CCR2-deficient mSOD-Tg mice showed an earlier onset of disease, and more severe $\mathrm{NeuN}^{+}$spinal anterior horn cell loss and axonal derangement in the sciatic nerve than CCR2-positive mSOD1-Tg mice $(p<0.05)$. CCR2-deficient mSOD1-Tg mice showed a marked increase of deposited mSOD1 in the sciatic nerve compared with CCR2-positive mice together with decreased infiltration of $\mathrm{CCR} 2^{+}$macrophages which phagocytized mSOD1 and expressed Arg-1 but not iNOS. CCL2 production by Schwann cells was unaltered by genotype. Conclusion: These findings suggest that $\mathrm{CCR} 2^{+}$macrophages recruited into the peripheral nerves from blood exert neuroprotective functions in mSOD1 ALS, and that clearance of mSOD1 protein by these cells from the peripheral nerves is the hitherto-underestimated host's protective mechanism.

0-05-5 withdrawn roles of $\mathrm{CCR} 2^{+}$macrophages recruited from blood to the neural tissues in ALS.

0-05-4 Nusinersen improves muscle fatigue: a preliminary repetitive nerve stimulation study in adult SMA

$\bigcirc$ Takeshi Araki, Kenji Sekiguchi, Yoshikatsu Noda,

Shunsuke Watanabe, Kohei Morimoto, Riki Matsumoto

Division of Neurology, Kobe University Graduate School of Medicine, Japan

Objective: Intrathecal nusinersen improves motor function for infants and children with spinal muscular atrophy (SMA), but its effect on adults with SMA remains elusive. We aimed to clarify the effect of nusinersen on adult SMA patients by means of quantitative myasthenia gravis (QMG) score and repetitive nerve stimulation (RNS). Methods: We recruited three adult patients with SMA who were admitted to our hospital for the treamtment with nusinersen. We evaluated patients clinically by QMG scores (Pinch: pinch strengths, Arm: arm elevation time, Head: head lift time) and electrophysiologically by $3-\mathrm{Hz}$ RNS. Efficacy of nusinersen was evaluated by comparing clinical and electrophysiological findings before and one month after nusinersen treatment. Results: Clinically, pinch, arm, and head QMG scores all improved after nusinersen injection compared to pre-injection (mean: Pinch: 9.1 to 12.7 P; Arm: 35.8 to $52.7 \mathrm{sec}$; Head: 78.5 to $138 \mathrm{sec}$ ). Electrophysiologically, amplitude and area decrement improved for both axillary (amplitude decrement from $26.9 \%$ to $21.5 \%$; area decrement from $31.4 \%$ to $26.3 \%$ ) and accessory (amplitude decrement from $18.2 \%$ to $13.1 \%$; area decrement from $22.3 \%$ to $14.8 \%)$ nerve RNS. Conclusions: For adult SMA patients, nusinersen injection lead to short-term improvement of motor functions including muscle fatigability, suggesting its effect at the neuromuscular junction. Long follow-up evaluation is necessary to elucidate the long-term efficacy of nusinersen.

\section{0-05-6}

\section{The involvement of hypoxia stress in amyotrophic} lateral sclerosis: in vivo imaging of HIF-1a

Emi Nomura ${ }^{1}$, Yasuyuki Ohta ${ }^{1}$, Koh Tadokoro ${ }^{1}$ Tian Feng ${ }^{1}$, Xia Liu ${ }^{1}$ Xiaowen Shi', Namiko Matsumoto ${ }^{1}$, Ryo Sasaki ${ }^{1}$, Keiichiro Tsunoda', Mami Takemoto ${ }^{1}$, Nozomi Hishikawa ${ }^{1}$, Toru Yamashita ${ }^{1}$,

Takahiro Kuchimaru', Shinae Kondoh', Koji Abe

${ }^{1}$ Department of Neurology, Graduate School of Medicine, Dentistry and

Pharmaceutical Sciences, Okayama University, Japan, ${ }^{2}$ School of Life Science and Technology, Tokyo Institute of Technology, ${ }^{3}$ Center for Molecular Medicine, Jichi Medical University

Purpose: To investigate the involvement of hypoxia stress in amyotrophic lateral sclerosis (ALS) by in vivo hypoxia inducible factor-la (HIF-la) imaging, and assess the therapeutic effects of dimethyloxalylglycine (DMOG), HIF-la stabilizer, in ALS model mice. Methods: We investigated the hypoxic stress in G93A-human $\mathrm{Cu} / \mathrm{Zn}$ superoxide dismutase transgenic mice by in vivo HIF-la imaging, and treated the mice with DMOG. Results: In vivo HIF-1a imaging analysis showed an enhanced hypoxic stress in both the spinal cord and muscles of lower limbs of ALS mice. HIF-la expression decreased as the disease progressed until end stage. DMOG treatment significantly ameliorated the decrease of HIF-la expression, the degeneration of both spinal motor neurons and myofibers in lower limbs, gliosis and apoptosis in the spinal cord. This was accompanied by prolonged survival. Conclusions: The present study suggests that in vivo HIF-la imaging is useful for evaluating hypoxic stress in ALS, and that the enhancement of HIF-1a is a therapeutic target for ALS patients.

\section{0-05-8 The Edinburgh Cognitive and Behavioural ALS Screen (ECAS) for Japanese ALS and FTD Patients}

\section{0-05-7 Prognosis and clinical features of ALS patients in Japan}

ONaoki Atsuta ${ }^{1}$, Naoki Hayashi ${ }^{1}$, Ryoichi Nakamura ${ }^{1}$, Masahisa Katsuno ${ }^{1}$

Yuishin Izumi ${ }^{2}$, Kazuaki Kanai ${ }^{3}$, Akira Taniguchi ${ }^{4}$, Mitsuya Morita ${ }^{5}$, Osamu Kano ${ }^{6}$, Kazumoto Shibuya 7 , Satoshi Kuwabara ${ }^{7}$, Naoki Suzuki ${ }^{8}$, Masashi Aoki ${ }^{8}$, Masaya Oda ${ }^{9}$ Yasuyuki Ohta ${ }^{10}$, Koji Abe ${ }^{10}$, Nobutaka Hattori ${ }^{3}$, Ryuji Kaji ${ }^{2}$, Gen Sobue ${ }^{1}, J_{C A C A S}{ }^{1,2,3,}$ ${ }^{1}$ Nagoya University, Japan, ${ }^{2}$ Tokushima University, ${ }^{3}$ Juntendo University, ${ }^{4}$ Mie University, ${ }^{5}$ Jichi Medical University, ${ }^{6}$ Toho University, Chiba University, ${ }^{8}$ Tohoku University, ${ }^{9}$ Mifukai Vihara Hananosato Hospital, ${ }^{10}$ Okayama University

Background The prognosis and clinical phenotypes in ALS patients have been reported to be variable among different ethnic populations. It is important to clarify the clinical characteristics of ALS patients in each region and country. Objectives The aim of this study is to describe the clinical features of Japanese ALS patients and to clarify the heterogeneity of prognosis according to the phenotypes. Methods We constructed a multicenter registration and follow-up system. The ALS patients were classified by motor phenotypes in the early phase of disease. We analyzed the phenotypes of the registered patients and performed survival analysis according to the phenotypes. Results From Jan 2006 to Sep 2018, 1519 ALS patients were registered in the registry. The male to female ratio was 1.43 , and the mean age at onset was 61.8 years. The median times from onset to death or starting tracheostomy invasive ventilation (TIV) of the patients were as follows: the total patients, $3.75(95 \% \mathrm{CI}: 3.51-4.00)$ years; the upper-limb dominant type $(\mathrm{N}=569$, $37.5 \%), 4.00$ (3.58-4.42) years; the lower-limb dominant type ( $\mathrm{N}=398,26.2 \%), 4.24(3.63$ $4.85)$ years; the bulbar type ( $\mathrm{N}=348,22.9 \%), 3.00(2.71-3.28)$ years; the flail arm type ( $\mathrm{N}=76$, $5.0 \%), 4.75(4.05-5.45)$ years; the respiratory onset type $(\mathrm{N}=30,2.0 \%), 2.09$ (1.81-2.37) years There was a significant difference among the groups $(\mathrm{p}<0.001)$. Discussion The prognoses of Japanese ALS patients were generally better than the reports from Europe and worse than the reports from China. The reason for the difference remains to be elucidated.
Y Yasuhiro Watanabe ${ }^{1}$, Mieko Ogino ${ }^{2}$, Hiroo Ichikawa ${ }^{3}$,

Kenji Nakashima ${ }^{4}$, Ritsuko Hanajima

${ }^{1}$ Division of Neurology, Department of Brain and Neurosciences, Faculty of Medicine, Tottori University, Japan, ${ }^{2}$ International University of Health and Welfare, School of Medicine, Office of Medical Education, ${ }^{3}$ Department of Neurology, Showa University Fujigaoka Hospital, ${ }^{4}$ Department of Neurology, Neurology, Showa University Fujigaoka Hospital, ${ }^{4}$ Depa
National Hospital Organization, Matsue Medical Center

[Objective] Amyotrophic lateral sclerosis (ALS) is the most common form of motor neuron disease. ALS patients frequently present non-motor symptoms resembling frontotemporal dementia (FTD), including cognitive impairments and behavioural abnormalities. An easy screening tool for detecting these non-motor symptoms is needed, and ideally the screener would not be influenced by a patient's motor deficits. The Edinburgh Cognitive and Behavioural ALS Screen (ECAS) was developed to meet these demands. The present study aimed to evaluate the newly established Japanese version of the ECAS. [Methods] Twenty-eight control subjects and 35 ALS patients participated in this study: 3 patients from the ALS group also fulfilled the criteria for the behavioural variant of FTD. All participants were administered the ECAS. The ALS patients were also subjected to the Montreal Cognitive Assessment (MoCA), and respiratory function testing. Demographic and disease characteristics were also recorded. [Results] The ALS patients underperformed on the ECAS compared to control subjects. Significant differences were noted in executive function $(r=0.48, p<$ $0.0001)$, language $(r=0.38, p<0.01)$, ALS-specific functions $(r=0.49, p<0.0001)$, and ECAS total score $(r=0.40, p<0.01)$. Cognitive impairments were observed in $34.4 \%$ of the ECAS is useful for assessing multiple cognitive functions in ALS. Frontal Assessment Battery (FAB), ALS functional rating scale-revised (ALSFRS-R), of all ALS patients. [Conclusions] Similar to the original version, the Japanese version 
0-05-9 Clinical characteristics and pathophysiology of a rare muscle atrophy in superficial siderosis

$\bigcirc$ Ryo Iwase, Nobuo Sanjo, Taro Ishiguro, Takanori Yokota Department of Neurology and Neurological Science, Tokyo Medical and Dental University, Japan

[Objective] Superficial siderosis (SS) is a rare disease with about 100 cases identified throughout Japan. Few patients with SS primarily develop proximal upper limb atrophy that mimics motor neuron disease. Herein, we describe the uncharacterized features and pathophysiology of SS. [Methods] We retrospectively reviewed the clinical symptoms, radiological, and electrophysiological studies of patients with SS admitted to our hospital from September 2011-2019. We comparatively studied patients with SS with (SSA group) and without (SS group) proximal upper limb atrophy. [Result]The SS group had 22 patients (8 women). The mean age at onset of SS symptoms was 56.7 years, whereas that in the SS-A group was 63.0. $(\mathrm{p}=0.39)$. The SS-A group had 3 patients (all men). The mean age at onset of muscle weakness in the SS-A group was 47.0 years. The SS-A group showed atrophy predominantly in the deltoid and biceps muscles and in the cervical C5-6 level. Needle electromyography showed chronic denervation of the atrophied muscles. Fibrillation potentials and positive sharp waves on the needle electromyogram, and accumulation of contrast media in the epidural space on computed tomography (CT) myelography were identified at the C5-7 vertebral level in one patient in the SS-A group. [Conclusion] The prevalence of SS-A was about 10 patients in Japan. The accumulation of contrast media probably indicating that the structural compartment outside the delaminated dura matter developed a check valve-like structure, resulting in increased epidural pressure and subsequent spinal cord compression.

\section{0-06-2 Epi-RODの臨床像 : てんかん重積状態に合併する臟器障害}

\section{$\bigcirc$ 梁 成勲 ${ }^{1}$ 、永山 富子 ${ }^{1}$ 、永山 正雄 ${ }^{1,2}$}

国際医療福祉大学熱海病院 脳神経内科、脳卒中・神経センター、

国際医療福祉大学大学院医学研究科脳神経内科学

【背景】てんかん重積状態（status epilepticus: SE）は、呼吸不全、循環不全等の臓 器障害を合併しうる。SEに伴う臓器障害はlife threateningであり、転㷌に影響 する。【目的】SEに合併する臓器障害を明確にし、臟器障害が転帰に及ほす影響を 検討する。【方法】2006年5月から2019年3月の当科入院連続1821例からSEを抽出し た。我々は、SE（痤攣性あるいは非婳攣性）による致死的あるいは高度機能障害 を呈する各種臟器機能障害をてんかん関連臟器機能障害 (epilepsy-related organ dysfunction [Epi-ROD]) と提唱した。Epi-RODの臨床像、頻度、死亡率を評価した。 【結果】対象症例は83例 (全入院例の $4.6 \% 、 74 \pm 18$ 歳、男性53例、女性 30 例)、SEの 病型は全身痤攣重積状態 (generalized convulsive status epilepticus: GCSE) 23例 (27.7\%)、非㽿攣性てんかん重積状態（nonconvulsive status epilepticus: NCSE） 44例 (48.1\%)、再者混在 (GCSE/NCSE) 16例 (19.2\%)。SE83例中33例 (39.8\%) か Epi-RODを有した。Epi-RODを有するSEの病型は、GCSE 9例（39.1\%)、NCSE 16 例 $(36.1 \%)$ 、両者混在 (GCSE/NCSE) 8例 $(50.0 \%)$ であった。臟器障害の内訳 は、腎機能障害10例、心血管障害9例、肝機能障害8例、呼吸障害6例の順であっ た。Epi-RODを有するSE群がEpi-RODを有しないSE群と比較し有意に転帰不良 であった $(54.5 \%$ vs $18.0 \%$; $<0.001)$ 【結論】Epi-RODはGCSE例のみならずNCSE 例でも高頻度にみられる致死的な病態である。明らかな㾏攣発作が無くとも、原 因不明の急性臓器機能障害例ではSE (㽷攣性あるいは非㾏攣性) を鑑別診断に加 えることが重要である。

\section{0-06-4＼cjkstart高齢てんかん患者における酵素誘導型抗てんかん薬の 脂質代謝への影響}

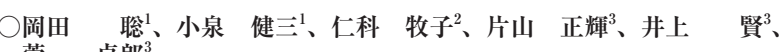
菅 貞郎 ${ }^{3}$

${ }^{1}$ 東京歯科大学市川総合病院 神経内科、 ${ }^{2}$ 東京歯科大学市川総合病院 内科、

東京歯科大学市川総合病院 脳神経外科
}

【目的】急速に進行する高齢化社会において、高齢てんかん患者の増加が推測さ れている。酵素誘導型抗てんかん薬 (EIAED) の脂質代謝への影響は良く知られ ているが高齢者での詳細な報告はなく、EIAED投与による血清脂質值が正常域 から異常域に変動するリスクの詳細な報告もない。高齢てんかん患者における EIAED投与の血清脂質值への経時的な影響と、各脂質值が正常值から異常值に 変動するリスクを検討した。【方法】成人てんかん患者（EIAED投与群235例、非醭 素誘導型抗てんかん薬 (非EIAED) 投与群213例) を65歳未満、65-75歳、75歳以上 に分類した。薬剤投与前、投与約 3 月月後、約6か月後の血清脂質（TC, TG, HDL LDL, non-HDL）值を後方視的に混合モデルを用いて解析し、各脂質值が正常值か ら異常值に変動するリスクをロジスティック回㷌分析で検討した。結果】EIAED 投与群を referenceとした場合、非EIAED投与群での脂質值 $(1 / 100$ 值) の最小 2 乗 平均差、95\% CI、p值は、65-75歳患者のLDL, non-HDLでそれぞれ、-0.23 (-0.36 $-0.10), \mathrm{p}=0.001,-0.22(-0.33,-0.19), \mathrm{p}<0.001$ だった。75歳以上では、TC, LDL, nonHDLでそれぞれ、-0.18 $(-0.27,-0.09) \mathrm{p}<0.001,-0.08(-0.15,-0.01) \mathrm{p}=0.038,-0.17(-0.26$ $-0.07) \mathrm{p}<0.001$ だった 65 歲以上の患者群でEIAED投与のTC, LDL, non-HDLが異 常高值へ変動するリスク (OR, 95\% CI) はそれぞれ78.1 (4.76-1280.13), 17.59 (3.92 78.95), 4.89 (1.76-13.54)であった。【結論】高齢者においてもEIAED投与は血清脂質 值に有意に影響した。EIAED投与は血清脂質值の平均值を上昇させるだけでなく、 正常值から異常值への変動に有意なリスクであることが示された。

\section{0-06-1 側頭葉てんかんでは左海馬CA1 の相対的容積の減少} が長期記憶の健忘を加速させる

○向野 隆彦 ${ }^{1} 、$ 上原 平 ${ }^{1,2}$ 、岡留 敏樹 ${ }^{1} 、$ 横山 淳 ${ }^{1}$ 荒川 友美 ${ }^{3} 、$ 九州大学大学院医学研究院神経内科学、

九州大学大学院医学研究院臨床神経生理学

${ }^{3}$ 九州大学病院リハビリテーション部、 ${ }^{4}$ 九州大学病院検查部、 ${ }^{5}$ 福岡山王病院 リハビリテーションセンター、福岡山王病院てんかん・すいみんセンター、

九州大学大学院医学研究院保健学部門検查技術科学分野

【目的】近年、側頭葉てんかん患者 (TLE) においてaccelerated long-term forgetting (ALF) の 報告が増えている。私たちはTLEではどのような要因がALFへ影響を及ほしているかを明ら かにすることを目的とした。【法】てんかんセンター2 施設に通院するTLE拉よび健常者を対 象とした。参加者に睡眠脳波、各種神経心理検查、気分障害に対する質問票、頭部MRI検查を 施行した。さらにALFを評洒するために作成した言語性記憶課題 (物語課題)を用いて10分後、 1週後の忘却率を調べた。画像解析にはFreeSurferを用いた。IQ 2群間の忘却率を重回帰分析で比較した。また、TLE群において、忘却率を目的変数とし、年齢、 IQ、羅病期間、旧世代抗てんかん薬の使用 (old medication: OM)、発作間欠期てんかん性放電 (interictal epileptiform discharge: IED)、海馬容積もしくはCA1の相対的容積を説明変数とし て、複数のモデルを作成し、重回帰分析を行なった。【結果】TLE 78名、健常者31名が参加し、 それぞれ64名、30名が解析対象となった。性別、年齢の調整後、ALFを反映する 1週後忘却率 はTLEで有意に高かった $(\mathrm{p}=0.04)$ 。TLE群における重回帰分析では、Modell (説明変数:年齢、 IQ、罹病期間、OM、IED、左海馬容皘）で、10分後忘却率は左海馬容皘、1週後忘却率はOM に有意に関連を認めた $(\mathrm{p}=0.04 、 0.02)$ 。 Model 2 (説明変数 : 年齢、IQ、罪病期間、OM、IED、 左 $\mathrm{CA} 1$ 相対的容積)では、 1 週後忘却率と $0 \mathrm{M}$ 、左 $\mathrm{CA} 1$ 相対的容積に有意に関連を認めた $(\mathrm{p}=0.01$ 、 0.005)。睡眠ステージ2を5分以上記録できた50例のサブグループでは、1週後忘却率はノンレム 睡眠時のIEDの頻度とも有意に関連していた $(\mathrm{p}=0.03)$ 【結論】TLEでは、ALFには左海馬CAl の相対的容積、旧世代抗てんかん薬の使用、ノンレム睡眠時のIEDの頻度が寄与している。

\section{0-06-3 取り下げ演題}

\section{0-06-5 高齢てんかん重積状態例の退院時の生活自立度低下と 関連する因子の検討}

傳 和眞 ${ }^{1}$ 、今井 啓輔 ${ }^{1}$ 徳田 直輝 ${ }^{1}$ 、山本 敦史 ${ }^{1}$ 、猪奥 徹也 ${ }^{1}$ 、 上田 倰大 ${ }^{1}$ 、濱中 正嗣

京都第一赤十字病院 脳神経・脳卒中科、 ${ }^{2}$ 京都第二赤十字病院 脳神経内科

【目的】高齢てんかん重積状態 (SE) 例の退院時の生活自立度低下と関連する因子を明 らかにする【方法】2014年4月から2019年3月の間にてんかん発作で救急搬送後に当科 入院となった 65 歳以上の高齢患者のうち, 搬入時にSEを呈していた連続例を対象. 退院時の生活自立度低下を余儀なくされる広範囲脳卒中や低酸素脳症に伴う急性症 候性発作例は除外した，対象を脸卒中の概括予後評価尺度であるmodified Rankin Scale が発症前と比較し退院時に一段階以上悪化した群 (W群) と悪化しなかった群 (N群)に分け, 両群で背景因子と発作型, 病因, 初療内容, 入院後経過を比較した.【結 果】対象 71 例中, W群 22 例 $(31 \%), \mathrm{N}$ 群 49 例であった。背景因W群/N群にて, 年齢中 央値82.5/73歳, 初回発作 $19(86 \%) / 27(55 \%)$ 例, 発症前mRS平均值2.4/2.1, 電解質 異常11 (50\%)/19 (39\%) 例であり，W群で後期高龄者例と初発例が多かった，全例が 焦点発作で，両側へのけいれん波及18 $(82 \%) / 29(59 \%)$ 例，焦点意識隇損発作持続4 $(18 \%) / 20(41 \%)$ 例であり，W群で両側へのけいれん波及例が多かった。病因として は認知症 $8(36 \%) / 8(16 \%)$ 例, 過去の脳卒中 $4(18 \%) / 23(47 \%)$ 例, その他 $2(9 \%) / 2(4 \%)$, 急性症候性発作あるいは不明 $8(25 \%) / 17(35 \%)$ 例であり、W群で認知症が多かった 初療内容としては，ジアゼパム (DZP) 単剤2 $(9 \%) / 1(2 \%)$ 例, 非ベンゾジアゼピン 系の抗てんかん薬 (non-BZP AED) 単剂1 (5\%)/3 (6\%), DZP + non-BZP AED14 $(64 \%) / 41(84 \%)$ 例，DZP + non-BZP AED+静脈麻酔薬6 (27\%)/2 (4\%) 例，抗てん かん薬非使用 $0 / 2(4 \%)$ 例であり，W群で静脈麻醉薬使用例が多かった．入院中の感 染症合併 $20(91 \%) / 22(45 \%)$ 例, 入院日数中央值 $34.5 / 13$ 日, 自宅退院4 $(18 \%) / 46(94 \%)$ 例であり，W群で感染症合併が多かった【結語】高齢SE例の退院時生活自立度低下 と関連する因子は初発，両側のけいれん波及，認知症，静脈麻醉薬使用，感染症合 併であった。高齢SE例の診療時にはこれらの因子に留意すべきである。 
0-06-6 臨床てんかん患者で、細胞外K濃度の変動状態が発作 発現に関与する可能性

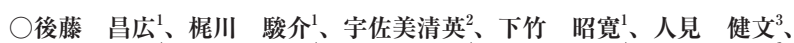
山尾 幸広 ${ }^{4} 、$ 菊池 隆幸、吉田 和道 ${ }^{4} 、$ 宮本 享、松橋 眞生 ${ }^{2} 、$ 大野 行弘 ${ }^{5}$ 高橋 良輔、池田 昭夫 ${ }^{2}$

${ }^{1}$ 京都大学大学院医学研究科臨床神経学、京都大学大学院医学研究科 てん 汃・運動異常生理学講座、 ${ }^{3}$ 京都大学大学院医学研究科臨床病態検查学、

"京都大学大学院医学研究科脳神経外科、 ${ }^{5}$ 大阪薬科大学楽学部

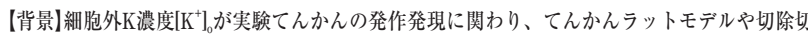

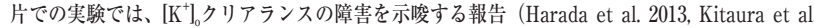
2018)や、短時間の[K+] 上昇が発作を誘発することが報告 (Librizzi et al. 2017) されている。【目 的慢性の臨床てんかんでは、緗胞外下漲度の変動状態を支持する状況は全く検討されていない。 難治部分てんかん術前の侵襲的胋波記録で発作開始状態を細胞外K港度の関連から検討した。 【方法】成人女性の難治性左侧頭葉てんかんにおける定位的深部胘波記録 (SEEG) で、海馬頭部 の電極で繰り返し検出された反復脱分極波形は、約0.5 Hzで反復する高振幅 $(1100-2400 \mu \mathrm{V})$ て

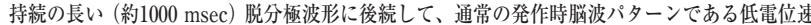
波活動(LVFA: low voltage fast activity)をきたした。 LVFAが発現する状況を、直前の反復脱

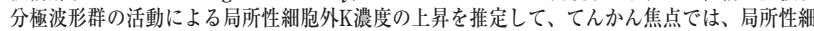
胞外K瀇度の緩衝機構から逸脱することがVFAの発現に関連することを仮説とした。解析に は、1）先行発作終了からの時間と、2)LVFAの直前の反復眖分極波形群の振幅の時間皘分値の 相関を㭲討した。記㳟中、抗てんかん薬の調整を行ったため、抗てんかん薬濃度が安定してい ると思われる梌查8日目の登作時のLVFAについて解析を行った。結果了海馬哣部のLVFAは56 回検出され、解析々適しない7回を除いた49回について解析を行った。先行発作からの時間間陑 直前の反復脱分極波形群の振幅の時間積分值は負の相関を示した。結論1先行発作からの時間 間陑が長いほど、直前の反復脱分極波形群は仼度の関与でLVFAは㺃起された。発作間欠期に、 発作発現間值に達する要因が徐々に蓄皘する可能性が示唆され、その候補として、実験てんか んで示峻された焦点における紐胞外K緩㣫機構の破綻によるK蓄積が挙げられる。

0-06-8 新規抗てんかん薬出現に伴うてんかん治療変容の検討

○三枝 隆博、吉田 弘樹、和泉 賢明、藤田 理奈、北川 理、 奥田 真也、松井 大

大津赤十字病院 脳神経内科

[目的]てんかん治療に拉いて、過去約10年で上市された新規抗てんかん薬の出現 による治癔拱択肢の增加で起きた処方内容の変化について検討することを目的と した。[方法12008年4月から 2019 年3月まで、当院脳神経内科でてんかんに対して 処方された代表的抗てんかん薬13種[フェニトイン (PHT)、フェノバルビタール

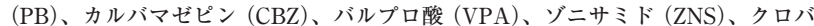
ザム (CLB)、クロナゼパム (CZP)、トピラマート (TPM)、ガパペンチン (GBP) ラモトリギン(LTG)、レベチラセタム (LEV)、ラコサミド(LCM)、ペランパネル (PER)]の処方状沉の推移を調べ特徴について梌討した。[結果]2008年度では対象 患者総数220名であったが、2018年度では468名と増加した。内訳はPHT:16名 (2008 年総数の $6 \%$ ) から 22 名 $(2018$ 年総数の $3 \%$ 、以下同様) と変化、以下PB: 5 名 $(2 \%)$ から 14名 (2\%)、CBZ:64名 (24\%) から134名(19\%)、VPA:137名(51\%)から151名(21\%)、 ZNS:20名 (8\%) から47名 (7\%)、CLB:6名(2\%)から30名 (4\%)、CZP:9名(3\%)から 22 名 $(3 \%)$ 、TPM:0名 $(0 \%)$ から14名 $(2 \%) 、 G B P: 11$ 名 (4\%) から16名 $(2 \%)$ ＬTG:0名 (0\%)加 32 名(4\%)、LEV:0名(0\%)から181名(25\%)、LCM:0名(0\%)から37名(5\%)、 PER:0名 (0\%) から 23 名 (3\%) であった。使用薬郕数は平均 1.22 から1.55に增加し、2 種以上の多剂使用例も 2008 年の 220 名中 30 名 $(155 \%$ ） から 2018 年の 468 名中 157 名 (33.5\%) に增加した。年代別では2008年では25 34歳 (30名、14\%) と65 74歳(43名、 $20 \%$ )、2018年では $35 \sim 44$ 歳 $(78$ 名、17\%) と75 84歳 (69名、15\%) と二峰性を示した。 [結諭]11年の経過で、加療対象患者数は倍増しており、また多剂併用症例も増加 した。高齢発症てんかんを含め、てんかんの病態について周知されたため新規の てんかんと診断される症例が増加したことや、難治症例のみならず作用占を念顽 に置いた合理的多剂療法を指向するケースが増加したことが反映された可能性な どが示唆される。

\section{0-06-10 脳梗塞後早期けいれん発作の再発と転帰}

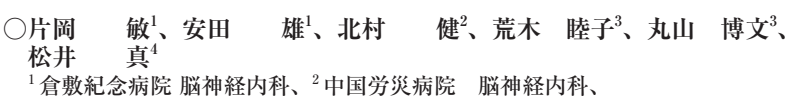

${ }^{3}$ 広島大学大学院 脳神経内科、 ${ }^{4}$ 金沢医科大学 脳神経内科

目的 : 脳梗塞後早期けいれん発作について抗てんかん薬による治療開始後の発作 再発の検討。対象・方法: 脳梗塞発症後1週間以内に生じた早期発症けいれん発作 23例（男18例、女5例、平均年齢 72.8 歳）に対して発症直後から抗てんかん薬で治 療を開始し、その後のけいれん発作型、再発時期とけいれん重積状態の頻度につ いて確認した。脑梗塞早期けいれん発作例での治療開始後の観察期間は平均 19.6 か月間で、入院から通院中のけいれん発作症状の盬床的特徴（発作型、再発時期、 頻度）を調べた。結果：脳梗塞発症後1週以内の早期けいれん発作は脑梗塞発症後 12時間以内の出現は10例、12 48時間は11例で48時間から 2 週に出現したのは2 2例 であった。発作型は局所性発作 +2 次性全般化が14例、全般発作のみ確認されたの が 4 例、局所性発作 4 例、発作型不明1例であった。脳梗塞発症後1 1 週以内の早期け いれん重皘状態は16例(69.5\%)に認めた。早期けいれん発作例の再発は8例 (34.8\%) に認め、再発がなかったのは15例 $(65.2 \%)$ であった。発作再発例での再発時期は2 週以降から 23 かのの間に認め中央值は4か月であった。その中で4か月以内の発作 再発は3例 $(37.5 \%)$ で、4 の発作型では2次性强直間代性発作は4例、全般性発作は2例、局所性発作は2例で、 けいれん重積状態の再発は2例に認めた。発作再発例中3例 $(37.5 \%)$ が2回の再発を 生じ、5例(62.5\%)が3回以上の再発を生じた。結論：胹梗塞後早期けいれん発作の 多くは発症後24〜48時間に出現しけいれん重積状態を伴う。早期けいれん発作て も発作再発は約 $35 \%$ に生じ、その中で牯月以降の邆発性の発作再発は $60 \%$ 以上に 認められた。早期けいれん発作も複数回の再発があり、迤発性にけいれん発作の 再発を生じることから長期の治療と管理が必要である。

\section{O-06-7 成人発症焦点性てんかんにおける発作後SPECT}

福間 一樹、田中 智貴 ${ }^{1} 、$ 高屋 成利 ${ }^{2}$ 池田 宗平 ${ }^{1,3} 、$

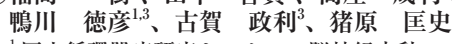

${ }^{1}$ 国立循環器病研究センター 脑神経内科、

千里リハビリテーション病院 脳神経内科、

国立循環器病研究センター 脳血管内科

【目的】我々は、脳卒中後てんかんに执いて発作後過鹳流が出現し遷延することを 明らかにしている。脳卒中を原因としない成人発症焦点性てんかんにおける発作 後灌流変化は十分に検討されていないため、調查することを目的とした。【方法】 2013 年から 2018 年に入院LSPECTを 2 回 (発作後と発作間欠期) に撮影した成人発 症焦点性てんかんのうち、腷卒中非合併焦点性てんかん（外傷・腫黈・感染症が原 因の者も除外）と脳卒中後てんかんを登録した。発作後SPECTの灌流変化を発作 間欠期SPECTとの差分解析（閾值2SD）を行うことで正確に㭘出した。患者背景、 てんかん性脳波異常(棘波/鋭波または周期性放電)、発作後SPECTの灌流変化 (発 作後過灌流および低灌流)を2群間で比較した。【結果】対象患者は69例 (年齢中央値 75歳、範囲38藏 96歳、男性40例)。脑卒中非合併焦点性てんかん19例と脳卒中 後てんかん50例（天幕上の媨梗塞23例、脑出血24例、くも膜下出血3例）を比較検 討した。非脳卒中合併焦占性てんかん群は、脳卒中後てんかん群と比較して、高 血圧症・心房細動既往が有意に少なく、認知症既往・非けいれん性発作が有意に 多かった。年齢、性別、焦点起始两側強直間代発作、てんかん性胘波異常の有無 は両群で差を認めなかった。発作後過灌流は、脳卒中後てんかん群（50例中43例、 $86 \%$ ）と比較して、非脳卒中合併焦点性てんかん群（19例中 3 例、16\%）で陽性率か 有意に低かった $(\mathrm{P}<0.01)$ 。発作後低灌流は、非脳卒中合併焦点性てんかん群の2 例の久に認められた。結論成人発症焦点性てんかんにおける発作後灌流変化の パターンは病因によって異なる。脑卒中後てんかんでは発作後過灌流の出現率が 高く、脳卒中など器質性病変のない焦点性てんかんでは発作後過灌流の出現率が 低く、発作後低灌流を認めることがある。

\section{O-06-9 取り下げ演題}

\section{0-07-1 䯣液GFAP-lgG抗体陽性䯣膜脳咨/䯣膜脳脊髄炎の臨 床像の検討}

○工藤 玩哉、木村 暁夫、東田 和博、山田 恵、林 祐一、

下畑 享良

岐皁大学医学部付属病院 脳神経内科

【目的】近年、海外より髄液GFAP-IgG抗体が陽性となり、ステロイド治療が奏功 する䯣膜脳炎/䯣膜脳春髄炎が報告されたが、本邦では同疾患の報告例は少ない。 本邦例の同定と臨床的特徴を明らかにすることを目的として、抗体陽性患者の検 索と臨床像の検討を行った。【方法】炎症性中枢神経疾患255例（自己免疫性111例、 感染性61例、原因不明83例）と非炎症性神経疾患35例の合計290例を対象として、 cell-based assayと免疫組織学的手法により䯣液抗GFAP-IgG抗体を検索した。そ の後、抗体陽性患者の臨床像を後方視的に検討した[結果】䯣膜脳炎/揈膜脳春䯣炎 を呈した23例の淢液で、抗GFAP-IgG抗体を検出した。年齢の中央值は56歳、男 女比は14：9であった。3例で腫瘍を合併し、2例が卵巣奇形腫、1例が甲状腺滤胞 腺腫であった。卵巣奇形腫を合併した1例で抗NMDAR抗体が陽性であった。主な 神経学的所見として、意識障害 $(75 \%)$ 、㕼膜刺激徴候 $(63 \%)$ 、振戦/ミオクローヌ 又 $(63 \%)$ 、自律神経症状 $(63 \%)$ 、腱反射克進 $(58 \%)$ 、四肢体幹失調 $(50 \%)$ 、認知機 能障害 (46\%) を認めた。喵液一般検查では、単核球優位の細胞增多 (中央值 $102 / \mu$ L) と蛋白量の増加 (中央值 $189 \mathrm{mg} / \mathrm{dL}$ ) を認めた。頭部MRIにて、本疾患に特徴と される脳室周囲に放射状に拡がる線状造影病変を18例中10例（56\%）に認めた。春 髄MRIでは、16例中7例 (44\%) で3椎体以上の脊髄長大病変を認めた。1例を除く全 例でステロイド治療が行われ、modified Rankin Scaleの中央值は入院時の5から， 最終観察時の1に改善した。再発例は認めなかった。【結論】㖪液GFAP-IgG抗体陽 性患者の臨床像を多数例で検討した。不随意運動や自律神経症状、特徵的な頭部

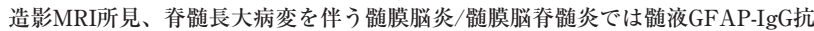
体の検索を行う必要がある。 
0-07-2 抗代謝型グルタミン酸受容体 1 型抗体陽性小脳失調 症の臨床像の検討

\author{
○村 暁夫 ${ }^{1}$ 、吉倉 延亮、竹腰 顕 $^{1}$ 、林 祐一 ${ }^{1}$ 、山下 翔子 $^{2}$ 、 \\ 安井 敬三 ${ }^{3}$ 、下畑 享良 \\ ${ }^{1}$ 岐阜大学大学院医学系研究科脳神経内科学分野、 \\ 2 近畿大学医学部 脳神経内科、 ${ }^{3}$ 名古屋第二赤十字病院 脳神経内科
}

【目的】抗代謝型グルタミン酸受容体1型（metabotropic glutamate receptor 1: mGluR1) 抗体陽性小脳失調症の臨床像を明らかにする【方法】mGluR1を強制発 現させたCOS 7 細胞を用いたcell-based assayにより、138名の孤発性小脳失調症 （带急性小脳失調症、特発性小脳性運動失調症）患者を対象として、血清中の抗 mGluR1抗体を検索した。その後、抗体陽性患者の臨床像を検討した【結果】3名の 患者で抗mGluR1抗体を検出した。年齢は、51-74歳、男 : 女 $=2: 1$ 、初発症状はい ずれも歩行障害で、発症から入院までの日数は7-90日であった。経過中に全例で 体幹失調、左右差のある四肢運動失調、失調性構音障害を認めた。眼球運動障害、 嚥下障害、味覚障害、四肢腱反射充進、右下肢のミオキミア様不随意運動をそれ ぞれ1例ずつに認めた。鹃迹液検査では、細胞数 $5-7$ 個 $/ \mathrm{mm}^{3}$, 蛋白量 $22-60 \mathrm{mg} / \mathrm{dL}$ と正 常もしくは軽度の増加を示した。初回の頭部MRIは、全例正常であり、脳血流シ ンチでは2例が正常、1例で右小脳の血流低下が疑われた。全例でステロイドパル スおよび血槳交換療法が施行され、1例でIVIgとリツキシマブが追加された。3例 ともに治療により症状の改善が得られた。1例が再発を繰り返し、後療法として プレドニゾロンとアザチオプリンの内服を行っているが、発症57カ月後のMRIで、 小脳萎縮を認めた。3例とも腫瘍の合併は認めなかった【結論】抗mGluR1抗体陽性 小脳失調症は、歩行障害で発症し亜急性の経過で四肢・体幹失調と構音障害を呈

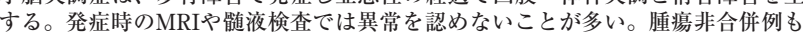
多く、ステロイドパルス、IVIg、血槳交換などの免疫療法が奏功する。経過は単 相性と再発性があり、後者では長期にわたる免疫療法を必要とする。上記臨床症 状を有する孤発性小脳失調症では抗mGluR1抗体の測定が必要である。

\section{0-07-4 急性脳炎症候群例の予後不良と関連する因子の検討}

\author{
○山本 敦史 ${ }^{1}$ 、今井 啓輔 ${ }^{1}$ 、徳田 直輝 ${ }^{1}$ 、傳 和眞 ${ }^{1}$ 、猪奥 徹也 ${ }^{1}$ 、 \\ 上田 凌大 ${ }^{1}$ 、濱中 正嗣 ${ }^{2}$ 崔 聡 $^{3}$ 、毛受 奏子 ${ }^{3}$ 長 正訓 $^{4}$ \\ ${ }^{1}$ 京都第一赤十字病院 脳神経・脳卒中科、 ${ }^{2}$ 京都第二赤十字病院 脳神経内科、 \\ 京都府立医科大学 脳神経内科、 ${ }^{4}$ 済生会滋賀県病院 脳神経内科
}

【目的】急性脳炎症候群 (AES) 例の予後不良と関連する因子を明らかにする【方法】 対象は 2010 年 4 月から 2019 年 8 月までに緊急入院した 16 歳以上のAES連続100例。 AESの定義は，急性発症し24時間以上持続する，他臓器疾患によらない広範囲の 脳機能障害を呈した急性脳炎・脳症例とした，脳卒中例や外傷例，明らかな髄膜 炎例やてんかん例は除外した，対象を退院時のGlasgow Outcome Scaleが1-3の予 後不良群 ( $\mathrm{P}$ 群) と, 4-5 予後良好群 ( G 群) に分け, 両群で初発症状, 初診時検查 所見, 免疫療法, 最終診断分類を比較した【結果】P群/G群は $46 / 54$ 例, 年齢中央值 69 (16-95)/51.5 (16-84) 歳, 男性25 (54\%)/25 (46\%) 例とP群で高齢者が多かった 初発症状はP群/G群にて $37.5^{\circ} \mathrm{C}$ 以上の発熱30 (65\%)/33 (61\%) 例, 痤攣21 $(46 \%) / 16$ (30\%)例，精神症状23 (50\%)/29 (54\%)例であり，P群で虐攣が多い傾向にあった。 初診時検查所見は，頭部MRI-DWI/FLAIR高信号31 $(67 \%) / 39(72 \%)$ 例，㖪液細 胞数增多 $(\geqq 6 / \mu \mathrm{L}) 18(39 \%) / 23(43 \%)$ 例, 髄液蛋白上昇 $(\geqq 50 \mathrm{mg} / \mathrm{dl}) 24(52 \%) / 30$ $(56 \%)$ 例, 脳波異常 (梀徐波複合/PSD/PLEDS) $11(24 \%) / 4(7 \%)$ 例であり, P群 で脳波異常が有意に多くみられた $(p<0.05)$. 免疫療法実施はステロイドパルスが $38(83 \%) / 40(74 \%)$ 例，IVIgが10 (22\%)/4 (7\%) 例，血獎交換が11 $(24 \%) / 5(9 \%)$ 例であり，いずれもP群で多かった。抗てんかん薬使用は $29(63 \%) / 25(46 \%)$ 例で ありP群で多かった。最終診断分類は自己免疫性6 $(13 \%) / 14(26 \%)$ 例，傍感染性 $10(22 \%) / 17(31 \%)$ 例， その他 (代謝性/楽剤性/PRES等) $7(15 \%) / 7(13 \%)$ 例，原 因不明 $23(50 \%) / 16(30 \%)$ 例であり，P群にて自己免疫性がやや少なく，原因不明 が有意に多かった $(p<0.05)$ 【結論】AES例での予後不良関連因子は，痤䛓と脳波異 常, 免疫療法施行, 原因不明であった。 AES例に痓攣や脳波異常がみられた際には, 予後不良となる危険性を念頭に置きながら診療にあたるべきである。

0-07-6 取り下げ演題
0-07-3 亜急性小脳性運動失調症における免疫病態のスクリー ニング方法の確立と有用性の検証

○吉倉 延亮、木村 暁夫、竹腰 顕、下畑 享良 岐皁大学大学院医学系研究科脳神経内科学分野

【目的】亜急性小脳性運動失調症における免疫病態のスクリーニング方法を確立 し，その有用性を後方視的に検証することが目的である.【方法】患者血清を使用 し, ラット小脳涷結切片を用いた免疫組織染色を行った。抗小脳抗体の有無と染 色性によって陰性群, 細胞内抗体群, 細胞膜表面抗体群に分類した. 抗体陽性例 では既知の抗体検索を行った. 3群間で, 臨床・画像所見, 治療内容, 治療反応 性，予後を比較した【【結果】対象59例の年齢は66 19 歳，女性は28例 $(47 \%)$ で, 免疫組織染色の結果，陰性群 22 例 (37\%), 細胞内抗体群 26 例 (44\%), 細胞膜表面 抗体群11例 (19\%) に分類された，有意差を認めた項目は，陰性群にめまいが多く $(27 \%, 4 \%, 0 \%, p=0.020)$, 細胞膜表面抗体群では体幹失調 $(73 \%, 85 \%, 100 \%, p=$ $0.049)$, 血液浄化療法の施行 $(6 \%, 0 \%, 27 \%, p=0.029)$, 治療後改善例が多く $(67 \%$, $19 \%, 78 \%, p=0.007)$, 細胞内抗体群では治療後不変例が多い $(33 \%, 69 \%, 0 \%, p=$ 0.003）という点であった．細胞内抗体群では腫湟の併存例の割合，および1年後の modified Rankin Scaleの平均值が高い傾向があったそその他の症候や，小脳萎縮 の有無、ステロイドパルス療法およびIVI $\mathrm{g}$ 療法の施行には有意差はなかった。既 知の抗体は細胞内抗体群の 2 例 $\left(Y_{0}, \mathrm{Ma} 2\right)$, おょび細胞膜表面抗体群の 4 例 (mGluR1 3例, VGCC 1例) で認められた.【結論】本研究は, 抗体陽性群ではめまいを合併す る頻度が低いこと，また細胞内抗体群と細胞膜表面抗体群の比較では，症候に明 らかな相違はないものの, 後者では血液浄化療法が多く施行され, 治療後の改善 例が多いことを示した．ラット小脑涷結切片を用いた抗小脳抗体のスクリーニン グは，予後の推定と治療方針の決定にきわめて有用であると考えられた.

\section{0-07-5 当科で経験した抗MOG抗体陽性関連疾患 6 例の臨床的検討}

○佐竹 紅音、森嶋 悠人、諏訪 裕美、栗田 尚史、深尾 統子、 名取 高広、土屋 舞、羽田 貴礼、一瀬佑太、高 紀信、 長坂 高村、新藤 和雅、瀧山 嘉久 山梨大学病院 神経内科

【目的】myelin oligodendrocyte glycoprotein (MOG) は檤鞘の最外層に局在する脳 タンパクであり、近年MOGに対する自己抗体が様々な中枢神経脱髄疾患で検出さ れることが報告され、抗MOG抗体陽性関連疾患として研究が進められている。抗 MOG抗体陽性関連疾患については多彩な臨床症状・経過・検查所見が報告されて いる。当科にて診断・治療を行った抗MOG抗体陽性関連疾患6例の臨床的特徵、 血液・髄液所見、画像所見等について検討を行ったため報告する。【対象・方法】当 科で診断を行った抗MOG抗体陽性の6例 (男性2例、女性4例、発症年齢17-65歳) に 関して、臨床経過、検查所見、画像所見、治療について後方視的に検討した。【結果】 初発症状は視神経炎が2例、春䯣炎 1 例、脳炎 3 例であった。先行感染は2例で認めた。 血清抗MOG抗体は 128-4,096倍を示した。また、抗AQP-4抗体は1例40U/ml以上 で陽性であった。髄液検查では細胞数は2-27個/ $\mu 1$ 、全例単核球優位であり、2例 で暍迹液蛋白の増多を認めた $(26-86 \mathrm{mg} / \mathrm{dl})$ 。 oligoclonal band (OCB) は4例で陽性、 myelin basic proteinは4例で陽性IgG index上昇は 2例で認めた。MRI検査におい て、大脳病変 6 例、視神経炎 2 例、脳幹病変 4 例、脊䯣病変 2 例を認めた。脊髄病変 に関してはいずれもnon-longitudinally extensive transverse myelitis (NETM)で あった。治療は全例にIVMP施行後にPSLの内服を行った。1例に関しては効果不 十分であり、血液浄化療法を併用した。【結論】脊㖪病変に関してはlongitudinally extensive transverse myelitis (LETM) が多いとされているが当科の2症例はいず れもNETMであり、NETMであっても抗MOG抗体陽性関連疾患を考慮する必要 がある。

O-07-7 抗MOG抗体関連疾患自験 4 例の臨床的検討 -10 年 間フォローアップしえた症例を含めて

○陳佑佳、黒川 幸子、安田 高志、徳岡健太郎、野川茂 東海大学医学部付属八王子病院 神経内科

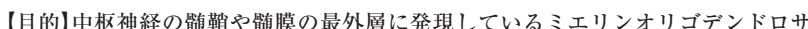
イト糖蛋白 (MOG) は、近年、中枢神経の炎症性脱䯣疾患の原因抗原として注目さ れており、抗MOG抗体関連疾患が提唱されている。しかし、抗MOG抗体陽性例 は種々の病型を呈し、その再発頻度や治療方針については、未だ確立されていな い。【方法】2017年10月から2019年1月に当院に入院した抗MOG抗体陽性患者4例(年 齢27.3歳 \pm 8.5 、男:女 $=3: 1$ ) の臨床的特徵をまとめ、その臨床像や治療について検討 した。【結果】罹患歴は、2009年から2019年に渡った。発症病型としては、大脳皮 質脳炎による痤攣 $(n=3)$ 、㵦液細胞增多・頭痛 (無菌性㖪膜炎) $(n=2)$ 、大脳白質 病変 $(n=2)$ 、視神経炎 $(n=1)$ の順に多かった。4 例中 3 例に再発がみられ、その うち 2 例は同様の症状での再発であったが、約 10 年間フォローアップしえた 1 例 では、無菌性檤膜炎・㽷攣（皮質脳炎）・視神経炎などの多彩な病型で再発した。 治療は3例でステロイドの内服を行い、いずれも反応性は良好であった。しかし、 1例ではステロイド中止後に再発を繰り返し、1例ではステロイド減量中に再発し た。また、同時に抗NMDA受容体抗体が陽性で、精神症状を認めた 1 例では、ス テロイドに加え、他院で免疫抑制薬が追加され加療された。[結論]抗MOG抗体陽

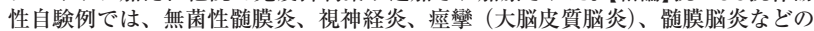
多彩な臨床像を呈したが、その他にも、ADEM・CIS・MS・TDLなどの発症病型 が報告されている。また、本疾患は比較的ステロイド反応性が良好で、予後が良 いとする意見もあるが、精神症状に難渋したり、約 10 年にわたり、視神経炎を含 む再発を繰り返した症例もあり、ステロイド減量・中止には慎重を期す必要があ ると思われた。 


\section{0-07-8 腫瘍様脱髄病変をきたした抗MOG抗体陽性症例の放 射線画像的特徵と治療反応性の検討}

○森 崇博 ${ }^{1}$ 三條 伸夫 ${ }^{1}$ 、西田陽一郎 ${ }^{1}$ 、高橋 利幸 ${ }^{2}$ 、横田 隆徳 ${ }^{1}$ ${ }^{1}$ 東京医科歯科大学脳神経病態学分野、 ${ }^{2}$ 東北大学神経内科

【目的】病変径が $20 \mathrm{~mm}$ 以上の腫瘍様脱䯣病変 (tumefactive demyelinating lesion : TDL)をきたす中枢神経炎症性疾患は、tumefactive demyelinating disease (TDD) と呼ばれており、その中で抗myelin oligodendrocyte glycoprotein (MOG) 抗体が 陽性となる報告がなされている。また、従来ステロイド治療効果が良好と考えら

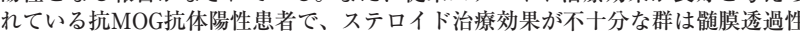
と関連がある報告もある。TDD患者で抗MOG抗体陽性患者と陰性患者とを比較 し、放射線画像的特徵と治療反応性について検討した。【方法】2006年から2019年 の間に当院に外来通院もしくは入院し脳MRIでTDDと考えられた症例で、血清と 䯣液中の抗MOG抗体を cell-based assay法で測定し、抗MOG抗体陽性例と陰性例 での画像的特徴と治療反応性を後乃向きに調べた。結果】TDD5症例のうち1例で 抗MOG抗体が血清㭘体と䯣液検体ともに陽性となった。抗MOG抗体陽性患者は 脳MRIで初回に左後頭葉、2回目に左放線冠に腫瘍様病変を認め、造影効果も伴 い最大病変径は $45 \mathrm{~mm}$ であった。䯣膜透過性の指標のQAlb は0.0055で、治療はス テロイドに加えて血漿交換療法を行った。抗MOG抗体陰性患者の最大病変径の平 均は $29 \mathrm{~mm}$ で、4例中 3 例でステロイド治療のみであった。治療前後でのEDSSは抗

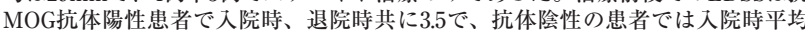
4.625、退院時平均2であった。抗MOG抗体陽性患者では再発が9年後に1度あり 抗体陰性患者では再発は1例で、残り3例は現在まで症候性再発は認めていない 【結論】抗MOG抗体陽性TDD患者は抗体陰性患者と比較し画像的特徵や治療反庥 性が異なる可能性が示唆され、既報では抗MOG抗体陽性患者の難治例では㕼膜透 過性が上昇しているという報告があるが䯣膜透過性の上昇を示さない難治例もお り、ステロイド治療抵抗性の患者では早期から血槳交換療法など強力な免疫療法 も考慮すべきである。

\section{O-07-10 自己免疫性脳炎の全国調査：VGKC複合体抗体関連脳 症の解析}

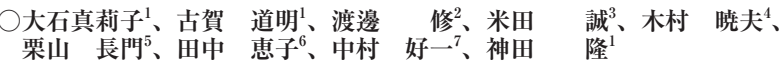
${ }^{1}$ 山口大学大学院医学系研究科臨床神経学、蔍児島市立病院脳神経内科、 福井県立大学看護福祉学部、 ${ }^{4}$ 岐皁大学大学院医学系研究科脳神経内科学、 京都府立医科大学 大学院医学研究科 地域保健医療疫学、 ${ }^{6}$ 新潟大学脳研究所 細胞神経生物学分野、 ${ }^{7}$ 自治医科大学公衆衛生学

【目的】全国調查に基づき, 本邦での自己免疫性脳炎・脳症の実態把握と, 診断基準と標準的治療 法の確立を目的とした。第60回学術大会でNMDAR䐉炎の結果を報告し, 今回はVGKC複合体抗 体関連脳症の結果について報告する.【方法】自己免疫機序が考えられる脳炎・脳症」を対象とし て，諸施設で2013年10月から 2016 年9月までの3年間に経験した症例数を調查し，一次調查で返 答のあった277施設、計878症例に対し二次調查を実施した、【結果】198施設より返答があった(回 収率71.8\%)。疾患の内訳ではNMDAR脳炎 (CBA法での抗体測定結果に基づく)が最も多く(280 症例, $47.9 \%)$, VGKC複合体抗体関連脑症は63症例 $(10.8 \%)$ であった. VGKC複合体抗体関連腷症 に関して，発症時年齢は平均年龄53歳で男女比は約6:4であった.VGKC複合体抗体関連腷症例 の中で, LGII抗体が $32 \% て ゙ ， C a s p r 2$ 抗体が3\%で検出されていた，脳波異常が72\%で，脳MRIて の異常は $90 \%$ の症例でみられた(NMDAR脳炎ではそれぞれ $85 \%, 40 \%)$. ピーク時の平均 $\mathrm{mRS} は 3.4$ で，退院時までに1.3まで回復していた(同 47,18$)$ ，初期治療を道入した医療機関での入院期間 は平均 2 ヶ 月であり(同 3.7 ケ月), 退院時には約 $70 \%$ の症例で後遺症が残り，その多くが認知機能 障害, てんかんであった. いずれの脳症でも, 初期治療として大部分の症例に対しmPSLパルス 療法が施行され，回復不十分の場合にIVIgや血漿浄化療法が追加されていた，【結論】本邦での V GKC 複合体抗体陽性細症は既報告と同様に中年の男性に多くみられた。一方で，海外の報告て は4 6割程度とされる脸MRIでの異常が9割の症例でみられたことが特徽的であった. NMDAR 脳炎に比べVGKC複合体抗体陽性脎症は入院時に軽症で，入院期間もより短い傾向にあることが 明らかとなった，NMDAR脳炎とVGKC複合体抗体関連脳症はいずれも免疫治療により mRS 1 程度の良好な転帰となる可能性が高く, 積極的な免疫治療を行う必要がある。

\section{0-08-2 Slipped-CAG DNA binding small molecule} induces trinucleotide repeat contractions in vivo

Masayuki Nakamori ${ }^{1}$, Gagan Panigrahi ${ }^{2}$, Stella Lanni ${ }^{2}$,

Hideki Hayakawa ${ }^{1}$, Terence Gall-duncan ${ }^{2}$, Evan Eichler ${ }^{4}$

Adam Shlien ${ }^{2}$, Kazuhiko Nakatani ${ }^{3}$, Hideki Mochizuki ${ }^{1}$

Christopher Pearson

${ }^{1}$ Department of Neurology, Osaka University Graduate School of Medicine, Japan, ${ }^{2}$ Program of Genetics \& Genome Biology, The Hospital for Sick Children, ${ }^{3}$ Department of Regulatory Bioorganic Chemistry, The Institute of Scientific and Industrial Research, Osaka University, ${ }^{4}$ Department of Genome Sciences, University of Washington

[Introduction] In trinucleotide repeat expansion disorders (TRED), the expanded repeats continue to expand in tissues by aberrant repair of mutagenic slipped-DNA structures. Since ongoing repeat expansions contribute to disease onset progression and severity, inducing repeat contractions could potentially reverse disease onset progression and severity in TRED. [Methods] We developed a small molecule Naphthyridine-Azaquinolone (NA) that specifically binds to slipped-CAG DNAs. We evaluated the effects of NA on repair of slipped-DNAs, replication of repeats. and repeat instability in Huntington Disease (HD) cells and model mice. [Results NA arrested repair of slipped-out CAG repeats, but not slipped-CTGs, or base-base mismatches. It did not block replication, transcription, or translation across expanded repeats. NA induced contractions of the expanded repeat in HD cells, having no effect on non-expanded repeats, and did not appear to induce mutations in the rest of the genome. The effect was independent of proliferation/replication, yet dependent upon transcription through the repeat. Intrastriatal injections of NA into HD mice induced contractions of the expanded repeat in vulnerable cells and reduced mutant HTT protein aggregates, a biomarker of HD pathogenesis and severity. [Conclusions] Repea structure-specific DNA ligands have a potential to contract expanded repeats in TRED.
0-07-9 多発性硬化症における抗KIR4.1 抗体の陽性率に関す るシステマティックレビュー

○村美知恵 ${ }^{1}$ 中中根 俊成、檤口 理 ${ }^{2}$ 松尾 秀德 ${ }^{2}$ 熊本大学大学院 生命科学研究部神経内科学分野、

長崎川棚医療センター臨床研究部

【目的】2012年Srivastavaらによって多発性硬化症（MS）患者の46.9\%で抗KIR4.1抗 体が陽性であることが報告された。その後複数の検証結果が報告されている。本 研究ではMS患者における抗KIR4.1抗体の陽性頻度についてシステマティックレ ビューを行い、㭘查としての有用性を明らかにすることを研究目的とする。【方法】 PubMed上で2019年10月までの文献を検索し、二名の検者で文献を選択した。文 献には自験例の結果も組み入れた。各文献での対象国、測定方法、抗KIR4.1抗体 のMS患者、その他の神経免疫疾患、コントロール群での陽性率に関して比較検討 した。【結果】11の文献を選択した。対象国は、ドイッ、フランス、USA、イスラ エル、日本、イタリア、中国、スペインであった。測定方法は7文献ではELISA 法のみ、1文献ではcell based assay (CBA) 法のみ、1文献ではELISA法に加え免 疫沈降法,1文献ではELISA法に加え免疫蛍光法であった。自験では、ELISA法、 CBA、ルシフェラーゼ免疫沈降法にて測定した。3文献（ドイツ2、イスラエル 1 ) のみでコントロール群と比較してMS患者で有意に高い抗KIR4.1抗体陽性頻度を 認めたが、自験例を含む8文献では有意差は認めず、陽性頻度も低かった。結論】 MS患者における抗KIR4.1抗体陽性率は初報告の文献ほど高くない可能性が示唆 された。要因として測定方法の違いや人種差が考えられた。今後同一サンプルを 国際的な枠組みで、報告されている全ての抗体測定法での比較検討が必要と思わ れる。

0-08-1 Systemic injection of a peptide drug ameliorates the dystrophic phenotype in DMD model mice

Yoshihide Sunada ${ }^{1}$, Shun-ichi Shirakawa ${ }^{1}$, Hiroki Hagiwara ${ }^{2}$,

Yutaka Ohsawa ${ }^{1}$

Kawasaki Medical School, Department of Neurology, Japan, ${ }^{2}$ Teikyo

University of Science, Medical Science

[Background] Myostatin, a muscle-specific TGF- $\beta$, negatively regulates skeletal muscle mass. The N-terminal prodomain noncovalently binds and suppresses the C-terminal mature ligand. We previously identified a 29-amino acid inhibitory core (IC) which selectively suppresses activation of myostatin Intramuscular injection of the IC peptide alleviated muscle atrophy and the absolute force in LGMD1C model mice. However, intravenous injection failed to show any therapeutic effects. [Objective] To develop peptide drugs that exert therapeutic effects when administered systemically. [Methods] To overcome instability of peptides in the blood we applied the staple technology to peptide drug discovery. After screening of the optimal positions where staple should be placed, we produced 49 different stapled peptides and performed the inhibition activity assay. Out of 6 peptides with inhibitory activity, the best optimized stapled peptide, SP23 was finally obtained. The therapeutic effects was evaluated by intravenous injection into model mice of DMD, $D B A / 2$ $m d x$, which show the most severe phenotype $(\mathrm{n}=5)$. [Results] Intravenous injection of 20 nmole SP23 increased body weight, EDL muscle/ body weight ratio, grip strength and muscle specific force significantly $(p<0.05)$. Muscle histopathology showed restoration of dystrophic changes with less fibrosis and fatty infiltration. [ConclusionslWe have produced a modified peptide drug with significant therapeutic effects in the muscular dystrophy model mice by intravenous systemic administration.

\section{0-08-3 Development of BBB-penetrating heteroduplex oligonucleotides (HDO)}

Takanori Yokota ${ }^{1}$, Tetsuya Nagata ${ }^{1}$, Chrissa Dwyer ${ }^{1,2}$, Kie Yoshida ${ }^{1}$,

Kotaro Yoshioka ${ }^{1}$, Punit Seth ${ }^{2}$, Frank Rigo ${ }^{2}$, Frank Bennett ${ }^{2}$

${ }^{1}$ Tokyo Medical and Dental University, Japan, ${ }^{2}$ Ionis Pharmaceurticals

[Objective] Developing a convenient method to efficiently regulate endogenous gene expression in the central nervous system (CNS) is a major step for treating neurological diseases. Here we design the sophisticate molecular technology which can penetrate BBB of antisense oligonucleotide (ASO) and achieve marked inhibition of endogenous gene in CNS. [Methods] We recently developed a new "DNA/RNA heteroduplex oligonucleotide" (HDO) technology that achieves highly efficient gene silencing in vivo. HDO is composed of a gapmer ASO, duplexed with a complementary RNA (cRNA) conjugated to delivery ligands (Nat Communs 2016, Sci Rep 2018, 2019, Nucleic Acid Res 2019), and its patent has been approved in US, EU, AU and Japan. Using HDO technology, we made screening of more than 100 ligands to cross BBB, and optimize molecular structure of HDO and chemical modification. [Results] The optimized HDO can distributed throughout the brain and spinal cord, and suppressed target gene expression including key genes for the dideases with dementia by $70-90 \%$ by subcutaneously and intravenously administrations. This suppression was observed in all major cell types in the CNS and was most prominent in microglial cells as well as neurons. This enabels us to regulate neuroinflammation in neurodegenerative diseases. Its suppression effect in CNS lasted for more than 2 months by a single injection and was linearly accumulated by multiple injections. [Conclusions] HDO potentially represents a breakthrough technology and offers a novel concept for delivering therapeutic oligonucleotides to CNS. 
0-08-4 Treatment for FAP with overhanging heteroduplex oligonucleotides by transferrin-mediated delivery

Kotaro Yoshioka, Taiki Kunieda, Yutaro Asami, Kie Tanaka,

Wenying Piao, Hiroya Kuwahara, Kazutaka Nishina,

Tetsuya Nagata, Takanori Yokota

Department of Neurology and Neurological Science, Tokyo Medical and Dental University, Japan

Objective: Two nucleic acid medicines, patisiran and inotersen, were approved by FDA for treatment of FAP. However, efficient delivery of therapeutic oligonucleotides to target tissues, especially without delivery-molecules, remains challenging. In the present study, we have developed a new class of doublestranded antisense oligonucleotide (ASO), overhanging duplex oligonucleotide (ODO), to achieve efficient and safe therapy by lowering TTR for FAP. Materials and Methods: We administered intravenously the single-stranded ASO or ODO into wild-type or FAP model mice $(n=4)$ and evaluated silencing efficacy and side-effects in liver and kidney. Next, we performed pharmacological study and analyses of carrier-molecules in blood and cellular uptake mechanism of ODO using LC-MS/MS and receptor-knockdown by siRNAs. Results: ODO achieved a four-fold increase in the target mRNA silencing as well as decrease in hepatic and renal toxicities, compared to the parent ASO. Next, PK study indicated that ODO improves cellular uptake from blood surprisingly. Moreover, ODO has additional binding molecules in serum, one of which was found to be transferrin Finally, the knockdown study of transferrin-receptor (TfR) demonstrated that TfR is associated with efficient cellular uptake of ODO to liver. Conclusion: We demonstrate that the enhanced in vivo potency of ODO is associated with the delivery mechanism mediated by transferrin. Our ODO technology opens a new field of therapeutic oligonucleotides without an additional delivery-molecule.

\section{0-08-6 Reduction of mRNA aggregation in myotonic dystrophy by CRISPR interference}

Fumiaki Saito ${ }^{1}$, Miki Ikeda ${ }^{1}$, Hiroki Hagiwara ${ }^{2}$, Naomichi Sasaki ${ }^{2}$

Toshihiro Masaki ${ }^{2}$, Kiichiro Matsumura ${ }^{1}$, Masahiro Sonoo ${ }^{1}$

${ }^{1}$ Teikyo University, Department of Neurology, Japan, ${ }^{2}$ Teikyo University of

Science, Department of Medical Science

[Objective] Myotonic dystrophy type 1 (DM1) is the most common adult-onset muscular dystrophy and caused by expansion of the CTG repeat in DMPK gene. In the previous annual meetings of this society, we showed that the expanded CTG repeat is excised by CRISPR/Cas9 genome editing and it leads to dramatic reduction of RNA foci, i.e. aggregation of the expanded mRNA. To apply this innovative technology for the therapeutic purpose, we have to ultimately prevent undesired damages to the genome. For the purpose, we examined CRISPR interference strategy to suppress the transcription of the DMPK gene and tested if the aggregation of mRNA is reduced by this procedure. [Methods] We designed several guide RNAs in the vicinity of DMPK transcription start site (TSS). The guide RNAs were co-expressed with dCas9-KRAB fusion protein in HEK293 cells or fibroblasts derived from DM1 patients. The expression of DMPK mRNA was determined by quantitative RT-PCR and the aggregation of mRNA was evaluated by RNA-FISH assay. [Results] We showed that one guide RNA designed at 184 bases downstream of TSS reduces the transcription of DMPK gene. Using this guide RNA for CRISPR interference, we demonstrated that the aggregation of expanded DMPK mRNA is significantly reduced. [Conclusion] Compared to genome editing using the conventional CRISPR/Cas9, CRISPR interference is considered to be safe because it does not induce double strand brakes of the genome. Novel and safe therapeutic strategy for DM1 using CRISPR interference is expected to be developed in the future.

\section{0-08-8 Decrease of differentiation- and regeneration-related genes in dystrophin-deficient cardiomyocytes}

Daigo Miyazaki ${ }^{1,2}$, Mitsuto Sato ${ }^{1,5}$, Naoko Shiba ${ }^{3}$, Yuji Shiba ${ }^{3,5}$,

Yusuke Echigoya ${ }^{4}$, Toshifumi Yokota ${ }^{4}$, Yoshitaka Mizobe ${ }^{5}$,

Yoshitsugu Aoki ${ }^{5}$, Shinichi Takeda ${ }^{5}$, Akinori Nakamura ${ }^{1,6}$,

${ }^{1}$ Department of Medicine (Neurology and Rheumatology), Shinshu

University School of Medicine, Japan, ${ }^{2}$ Intractable Disease Care Center,

Shinshu University Hospital, Japan, ${ }^{3}$ Institute for Biomedical Sciences,

Shinshu University, ${ }^{4}$ Department of Medical Genetics, School of Human

Development, Faculty of Medicine and Dentistry, University of Alberta,

${ }^{5}$ Department of Molecular Therapy, National Institute of Neuroscience,

National Center of Neurology and Psychiatry (NCNP), ${ }^{6}$ Department of

Neurology, National Hospital Organization Matsumoto Medical Center

[0bjective] Heart failure is a major cause of death in Duchenne muscular dystrophy (DMD). We previously generated iPSC-derived cardiomyocytes from a DMD patient with an exon 46-55 deletion in DMD (DMD-PSSC.CMs) and revealed that several differentiation- and regeneration-related genes were decreased in DMD.PSC.CMs. This study aimed to evaluate whether these genes were ameliorated after exon 45 skipping and examine the changes in cell function after gene knock-down using small interfering RNA (siRNA) gene targeting. [Methodsl We treated exon-46-55-deleted DMD-iPSC-CMs with phosphorodiamidate morpholino oligomers (PMOs) specific for exon 45. The changes in gene expression were examined by qPCR 3 weeks after exon 45 skipping. Additionally, we treated HEK293 cells with siRNA targeting several differentiation- and regeneration-related genes for evaluation of alterations in signal transduction by $\mathrm{q}_{\mathrm{PCR}}$ and western blot analysis. [Results] Among several differentiationand regeneration-related genes, TMSBAX and IGF2 expression were ameliorated along with the restoration of truncated dystrophin expression in DMD.PSC.CMs by exon 45 skipping. Using siRNA targeting TMSB4X and IGF2, gene expression was down-regulated by $85-90 \%$ in HEK293 cells. Although no changes in PI3K/Akt-signal transduction were seen after gene knock-down, we identified a significant association between TMSB4X and IGF2 as TMSB4X knock-down led to the down-regulation of IGF2. [Conclusion] TMSBAX may be a regulatory factor of IGF2 and associate with the pathomechanisms of dystrophin-deficient cardiomyopathy.

0-08-5 withdrawn

\section{0-08-7 withdrawn}

0-08-9 A Japanese family of primary familial brain calcification with paroxysmal kinesigenic dyskinesia

$\bigcirc$ Akihiko Mitsutake ${ }^{1,2}$, Takashi Matsukawa ${ }^{2,3}$, Tatsuya Sato ${ }^{1}$,

Junko Katsumata ${ }^{1}$, Tomonari Seki ${ }^{1}$, Risa Maekawa

Takuto Hideyama ${ }^{1}$, Masaki Tanaka ${ }^{2,3}$, Hiroyuki Ishiura ${ }^{2}$,

Tatsushi Toda ${ }^{2}$, Shoji Tsuji ${ }^{3,4}$, Yasushi Shiio ${ }^{1}$

${ }^{1}$ Department of Neurology, Tokyo Teishin Hospital, Japan, ${ }^{2}$ Department of Neurology, The University of Tokyo Hospital, Japan, ${ }^{3}$ Department of Molecular Neurology, Graduate School of Medicine, The University of Tokyo, ${ }_{4}^{4}$ Institute of Medical Genomics, International University of Health and Welfare

[Objective] Primary familial brain calcification (PFBC), traditionally described as Fahr's disease, is reportedly complicated by paroxysmal kinesigenic dyskinesia (PKD). We aimed to elucidate the genetic cause of PFBC complicated by PKD. [Methods] We performed whole-exome sequencing (WES) of familial cases of PFBC complicated by PKD. [Results] Patient 1 is a 16-year-old Japanese girl presenting with a two-year history of paroxysmal stiffness of bilateral upper extremities. Neurological examination was normal between the attacks. Brain CT revealed bilateral calcification in the globus pallidus. Patient 2 is a 43-year-old Japanese man, and is the father of patient 1. In his teens, he had stiffness in his bilateral upper extremities during the exercise. His symptoms spontaneously disappeared in his 20 's. Brain CT showed bilateral calcification in the globus pallidus and dentate nucleus. WES suggested the deletion of exon 1 of SLC20A2. On the other hand, there were no disease-causing variants in genes associated with paroxysmal movement disorder including PRRT2. [Conclusion] Exonic deletion of SLC2OA2 was considered to be the cause of PFBC in our cases. To date, ten cases of PKD with PFBC have been reported, and no genetic causes of PKD have not been found in those cases. Our cases add to the increasing evidence that PKD can be associated with PFBC, although the coincidental presence of PFBC and PKD cannot be completely excluded. 
0-08-10 Frequencies of genetic cerebral small vessel disease in adult-onset leukoencephalopathy

Masahiro Uemura ${ }^{1}$, Hiroaki Nozaki ${ }^{2}$, Naoko Sakai ${ }^{1}$, Shoichiro Ando ${ }^{1}$ Masato Kanazawa', Hajime Kondo ${ }^{3}$, Akira Iwanaga,

Hiroyuki Murota $^{4}$, Takeshi Ikeuchi ${ }^{5}$, Ikuko Mizuta ${ }^{6}$, Toshiki Mizuno ${ }^{6}$, Osamu Onodera

${ }^{1}$ Department of Neurology, Brain Research Institute, Niigata University, Japan, ${ }^{2}$ Department of Medical Technology, Health Sciences Faculty of Medicine, Niigata University, ${ }^{3}$ Department of Neurology, Anjo Kose Hospital, ${ }^{4}$ Department of Dermatology. Nagasaki University Hospital, ${ }^{5}$ Department of Molecular Genetics, Brain Research Institute, Niigata
University, ${ }^{6}$ Department of Neurology, Kyoto Prefectural University of University,

[Objectivel Genetic cerebral small vessel disease ( $\mathrm{gCSVD}$ ) is one of the cause of adult-onset leukoencephalopathy. Cerebral autosomal dominant arteriopathy with subcortical infarcts and leukoencephalopathy (CADASIL) is the most frequent $\mathrm{gCSVD}$, however, the frequency of the other $\mathrm{gCSVD}$ were remained unknown. The purpose of this study is to clarify the frequency of gCSVD among patients with adult-onset leukoencephalopathy. [Methods We included one hundred Japanese patients who satisfied the following conditions: 1) positive neurological symptoms/signs and 2) severe confluent white matter lesions on magnetic resonance imaging. First, genetic tests for CADASIL, high-temperature requirement A serine peptidase 1 (HTRA1) and retinovasculopathy with cerebral leukoencephalopathy (RVCL) were performed by Sanger method. Second, we performed whole exome sequencing for the remaining undiagnosed samples to investigate the other gCSVD. [Results] We identified the following gCSVD: twenty-five patients with CADASIL,10 patients with HTRA1-related CSVD, 3 patients with pseudoxanthoma elasticum (PXE), 1 patient with RVCL, and 1 patient with a mutation in COL4A1. gCSVDs other than CADASIL or HTRA1-related CSVD were identified patients with the age at onset $\leqq 40$ years-old irrespective of family history or the age at onset $\leqq 55$ years-old with family history. [Conclusions] Except for CADASIL and HTRA1-related CSVD, frequency of the other gCSVD were quite rare. Younger age onset or positive family history are important clinical features to identify such rare gCSVD.

\section{0-09-2 免疫チェックポイント阻害薬による神経筋合併症}

野田 智子 1 、蔭山 遙1 三浦 美紀 1 、田村 拓也 ${ }^{1}$ 、伊藤 宏樹 ${ }^{1}$ 福島 曜、寺島 常郎 ${ }^{2} 、$ 伊藤 克樹、野田 成哉 3 、村上あゆ香 4 勝野 雅央、檤口 理、松尾 秀德 ${ }^{5}$ 、鈴木 重明 $^{6}$

一宮市立市民病院 脳神経内科、2 - 宮市立市民病院呼吸器内科

江南厚生病院 呼吸器内科、 ${ }^{4}$ 名古屋大学医学部 神経内科、

5 長崎川棚医療センター 臨床研究部、6 慶応義熟大学 神経内科

【目的】免疫チェックポイント阻害薬による治療が広く行われるようになり、免疫関連有害

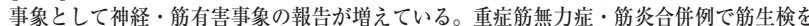
実施した報告はまだ少なく、自験例の特徽について梌討した。【方法・対象】当院にて肺癌 に対してペムブロリズマブ投与後に重症疑無力症・筋炎を発症した3例について検討を行っ た。[結果]年齡は77-79藏で男性1名、女性2名。初発症状は眼瞼下垂、筋痛で、ペムブロリ ズマブ投与後14-48日で発症し、経過中に四肢筋力低下、構音障害、嚾下障害が進行した。 重症筋無力症関連自己抗体は、1例は抗AChR抗体・抗 榢性で、他の2例は乞れでれれ抗Kv1.4抗体、抗LRP4 抗体が陽性であった。筋生梌では筋線

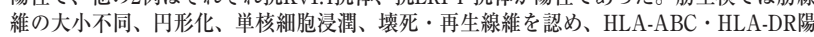
性線維やCD4陽性T緗胞、CD8陽性T細胞も観察された。また筋線維膜、いくつかの筋外 䩪の毛細血管が非特異的に補体C5b-9で染色された。CKは6230-10333U/1まで著明に上早 したが、ステロイド治療開始後13-42日で正常化した。重症筋無力症クリーゼとなり人工

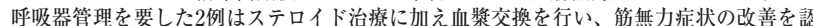
めた。1例は人工呼吸器を離脱し独歩で第2 209 病日に自宅退院、1例は人工呼吸器装着のま ま第165病日に自宅退院となった。人工呼吸器管理を行わなかった1例は第49病日に癌性り ンパ管症で死しした。独步で自宅退院した1例は、肺癌再発を来たし化学療法を行ってい るが、抗AChR抗体陽性は持続して戈り、PSL少量内服継続にて神経症状の悪化は見られ ていない。結論 3 例ともCK上昇に加光筋生検で炎症性機序を認內、重症筋無力症関連抗

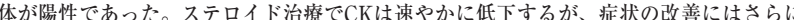
時間を要する。クリーセ発症例には人工呼吸器管理下で血槳交換を行うことが重要である。

\section{0-09-4 重症筋無力症患者の予後因子としての血清中可溶性 PD-L1 濃度}

○岩佐 和夫 ${ }^{1}$ 吉川 弘明 2 、山田 正仁 $^{1}$

金沢大学大学院 脳老化・神経病態学 (脳神経内科学)

金沢大学保健管理センター

目的：重症筋無力症 (MG) 患者の骨格筋では、PD-L1 (programmed death ligand-1)の発現が元進しており、病態への関与が考えられている。一方、骨格筋に おいてPD-L1の発現が克進していても骨格筋と免疫担当細胞との接触がなければ PD-L1による免疫制御機能が十分に働かない可能性が指摘されている。恵性腫愓 予後と血清中の可溶性PD-L1（s PD-L1）との関連を調べた研究では、s PD-L1の源 度が高いほど予後が悪くなることが報告されており、s PD-L1が腄愓免疫に影響を 与えていることが示唆されている。この研究ではMGにおける S PD-L1濃度を測定 し、MGの病態における S PD-L1の関与について検討した。対象・方法：MG21例、 正常対象22例の血清を用いた。 MGは男性8例、女性13例、平均年齢46.7 202.2 歳 $114-79$ 歲)であった。sPD-L1の測定はELISAキットを用いて測定した。s PD-L1值とMG の病態の関連を評価するため、s PD-L1值と発症年龄、MGFA分頪、QMGスコア MG-ADLスケール、抗アセチルコチン受容体抗体価との関連について調べた。結果

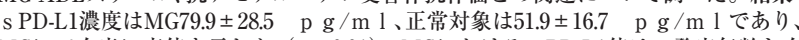
MGにて有意に高值を示した（ p < $0.01 ） 。 M G に$ 打ける s PD-L1值は、発症年齢と有 意な正の相関を示し $(\mathrm{R}=0.45 、 \mathrm{p}=0.039)$ 、退院時 $\mathrm{QMG}$ スコアとは負の相関を示し た $\mathrm{R}=-0.49 、 \mathrm{p}=0.044)$ 。一方、MGFA分頪、入院時QMG スコア、MG-ADLスケール 抗アセチルコチン受容体抗体俩との関連は認められなかった。入院時のQMGスコ アが14以上の症例について入院時と退院時のQMGの差とsPD-L1值と関連を検討し たところ、これらに強い正の相関が認められた $(\mathrm{R}=0.89 、 \mathrm{p}=0.001)$ 。結論：MGに おける血清 S PD-LL湛度を測定した。MGでは、正常対象と比べ有意に s PD-L1浱度 が高く、その浱度は発症年齢と相関を認めた。 QMGスコアの高いMGでの検討では、 s PD-L1濃度が高い症例ほどMG症状の改善が期待できる可能性が示された。

\section{O-09-1 全身型重症筋無力症における補体と補体調整因子の動態}

○小澤由希子 ${ }^{1}$ 鵜沢 顕之 ${ }^{1} 、$ 安田 真人 ${ }^{1}$ 小島 雄太 ${ }^{1}$ 織田 史子 ${ }^{1}$ 、 川口直樹, ${ }^{1,2}$ 桑原聡

${ }^{1}$ 千葉大学大学院医学研究院 脳神経内科学、 ${ }^{2}$ 脳神経内科千葉

【目的】重症筋無力症 (MG) は神経筋接合部 (NMJ) の抗体介在性自己免疫疾患で、 85-90\%で抗アセチルコリン受容体 (AChR) 抗体が検出される。抗AChR抗体はIgG サブクラスがIgG1またはIgG3であるため古典的経路を中心とした補体介在性のシ ナプス後膜の破壊が生じるとされている。今回、抗AChR抗体陽性全身型MGの補 体と補体調整因子を測定し、臨床症状や予後との関連について検討した。【方法】 免疫治療未介入の抗AChR抗体陽性全身型MG患者 44 名と対照群として非免疫性神 経疾患患者20名の血清で補体 $(\mathrm{C} 3, \mathrm{C} 4, \mathrm{SC} 5 \mathrm{~b} 9)$ と補体調整因子[Vitronectin (VTN) Clusterin (CLU), Properdin〕を測定した。結果】C3はMG群と対照群で有意差はな かったが治療開始 $1 \cdot 2$ 年後のMGADLと正の相関を認めた（1年後: $\mathrm{r}=0.37 \mathrm{p}=0.03,2$ 年後; $\mathrm{r}=0.42, \mathrm{p}=0.04)$ 。C 4 はMG群と対照群で有意差はなく、踇床症状や予後とも相 関は認めなかった。 sC5b9はMG群で高い傾向 $(\mathrm{p}=0.09)$ にあり、1年後のMGADL とも正の相関の傾向 $(\mathrm{r}=0.30, \mathrm{p}=0.08)$ を認めた。VTNはMG群で高値 $(\mathrm{p}=0.0006)$ て あり、1年後のMGADLとも正の相関 $(\mathrm{r}=0.37, \mathrm{p}=0.03)$ を認めた。CLUはMG群と 対昭群で有意差はなかったがMGADLと負の相関傾向（r=-0.30, =0.05）にあった。 ProperdinはMG群で有意に低值 $(\mathrm{p}=0.03)$ でありMGの重症度が高いほど低い傾向 $(\mathrm{r}=-0.26, \mathrm{p}=0.09)$ にあった。考察·結論】今回C3·C4は対照群と有意差を認めなかっ たが、既報でも血清中の総量が多いためNMJでの局所反応を反映しにくいという 報告がある。C5b7 結合LMAC形成を抑制するVTNはMG群で高く、sC5b9の上 昇と同粎にMG病態におけるMAC形成光進を反映しているものと考えられた。副 経路でC5分解を促進するProperdinは古典経路活性の代償として下がっている可 能性があり、重症度と相関していたことから病勢の客観的な指標になりうる。全 身型MGにおいて補体、補体調整因子は病態と関与しており、バイオマーカーと なる可能性がある。

\section{0-09-3 胸腺腫関連重症筋無力症における胸腺摘除術前と術後 短期・長期経過一予後との関連一}

伊崎 祥子、山元 正臣、橋本 ばく、山鹿 哲郎、杉本 恒平、 宮内 敦生、古谷真由美、田中賞、石塚慶太、鈴木 理人、 成川 真也、原渉、田島 孝士、吉田 典史、王子 聡 傳法 倫久、深浦 彦彰、野村 恭-

埼玉医科大学総合医療センター 神経内科

【目的】胸腺腫関連性重症筋無力症（thymoma-associated myasthenia gravis TAMG）は, 非胸腺腫合併MGと比較して重症化しやすく, 胸腺摘除術後にMG症 状が増悪する症例が多いが，胸腺摘除後の長期間にわたる臨床経過を追った報告 はない. 我々はTAMGの胸腺摘除術前と術後短期・長期経過を追い, 治療法と 予後との関連を検討した。【方法】対象はTAMG連続10例と胸腺異常を伴わない 全身型MG連続25例で，後方視的に治療法や経過を比較した、【結果】TAMG10 例の初発時年齢は58 (42-75) 歳, 全例が浸潤型胸腺腫で拡大胸腺摘除術を行っ た。初診時から手術まで要した期間は1.4 (0.6-15.4) ケ月, 術後から現時点まで 48.5 (39-69) ケ月の経過を追った。 10例の現在のMGFA postintervention status は薬理学的寛解 (PR) 3例, 軽微症状 (MM) 6例, 改善 (I) 1例だった.このうち MM or better with < prednisolone (PSL) $5 \mathrm{mg}$ /日を達成しているのは6例 $(60 \%)$ で, 術前・術後早期から積極的にPSLや免疫抑制剤などの経口免疫療法や血液浄 化療法 (PP) ・免疫グロブリン静注療法 (IVIg) を組み合わせて治療を行なってい た. 一方, 対照25例の初発時年齢は51 (19-87) 歳で, 初診時から50ケ月の時点で のMGFA postintervention statusは, PR 12例，MM 11例，I 2例であった。この うち $>5 \mathrm{mg}$ /日を達成しているのは 22 例 $(88 \%)$ であった.【結論】TAMG胸腺摘除術 後の長期経過において 9例がMM or better statusに详しており一般的なTAMG の治療経過と比較すると良い経過で, 対照群と比較して遜色ない経過であった。 診断後早期から積極的に経口免疫療法やPP・IVIgを組み合わせて治療を行うこと で長期的に安定した経過を得られる可能性が示唆された

\section{0-09-5 PD-1 阻害薬投与後に重症筋無力症・筋咨・心筋炎を 発症した 55 歳女性例}

\author{
宗＼cjkstart勇人、池口亮太郎、鈴木 美紀、小林 正樹、吉澤 浩志、 \\ 飯嶋 睦、清水 優子、北川一夫 \\ 東京女子医科大学病院 脳神経内科
}

[目的]PD-1阻害薬は、切除不能な腫場の治療に用いられている免疫チェックポイン 卜阻害薬であり、ここ数年重症筋無力症 (MG) を含む神経筋疾患の副作用が注目さ れている。今回我々はNivolumab開始後にMG ・ 壊死性筋炎・心筋炎を発症した症 例を経験した。本研究は自験例をもとに文献的レビューを行い、PD-1阻害薬による MGの特微を明らかにすることを目的とする。方法了症例は55歲女性、X-6年に胸腺 腫を摘出した際に抗AChR抗体陽性を指摘された (無症候)。X年3月に視野障害を

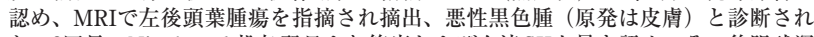
た。2回目のNivolumab投与翌日より筋痛拉よび血清CK上昇を認め、その後眼球運 動障害、眼臉下垂、球症状、四肢筋力低下が出現した。抗AChR抗体が陽性であり 筋生椧所見から壊死性筋炎合併の重症筋無力症と診断した。不整脈や心筋逸脱醉素 の上昇、左室壁運動低下などあり心筋炎も合併した。IVIgを開始するも呼吸状態は 悪化、人工呼吸瞼管理となった。症状は遷延 LIVIg、ステロイドパルス、血槳交換 を繰り返し緩徐に改善した。本例と同様にPD-1阻害薬関連重症筋無力症を発症した 既報告例について、文献的レビューを行いその特徴について検討した。結果]検索 した限り50例のPD-1阻害薬関連重症筋無力症の報告例があり、心筋炎を合併したの は5例、筋炎・心箅炎を合併したのは2例であった8例はMGの既往があり、3例は MGの発症はないものの抗AChR抗体が陽性であった。48例中44例 (92\%) がPD-1阻 害薬の投与 3 回以内にMGを発症していた。人工呼吸器管理を行ったのは48例中 17 例 (35\%) であった。[結論】PD-1阻害薬関連MGに壊死性筋炎、心筋炎を合併すること は稀であり、貴重な症例と考元報告した。MGはPD-1阻害薬の早期合併症の一つて あり、抗AChR抗体陽性およびMGの既往はPD-1阻害薬関連MGの危険因子である可 能性があるため、治療開始前にスクリーニングを行うべきと考える。 
0-09-6 過剩自己貪食を伴うX 連鎖性ミオパチー (XMEA) の 全国実態調査

\author{
杉江 和馬 ${ }^{1}$ 、小牧 宏文 ${ }^{2}$ 倉重 毅志 ${ }^{3}$ 、大熊 彩 ${ }^{4}$ 江浦 信之 ${ }^{1}$ \\ 塩田智 1 井口直颜、松井健、阿部達哉、形岡 博史 1 、

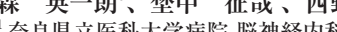 \\ 国立精神・神経医療研究センター病院 小览神経科、 ${ }^{3}$ 国立病院機構 吳医 \\ 療センター・中国がんセンター 脳神経内科、 ${ }^{4}$ 国立病院機構 箱根病院 神 \\ 経筋・難病医療センター 神経内科、 ${ }^{5}$ 奈良県立医科大学 未来基礎医学、 \\ ${ }^{6}$ 国立精神・神経医療研究センター神経研究所 疾病研究第一部
}

【目的】過剩自己領食を伴うX 連鎖性ミオパチー(X-linked myopathy with excessive autophagy: XMEA) はライゾ゙ームvacuolar ATPaseアセンブリ因子であるVMA21の原発性欠損によりオートファジー機能 異常をきたし、ミオパチーを呈するX連鎖性劣性遺伝の超希少疾患である。Danon病と病理学的には類似 し、筋䩗脱の性質を有する特異な自己会食空胞 (AVSF) を特徴とする。今回、XMEAの自然歴を明らか にするため全国実態調查を実施した。(方法】 全国の2,617の)関連学会専門施設に調查を行い、XMEA患者 の実態を解析した。情報提供された症例の瀶床症状に加え、遗伝子解析結果吊筋病理所見についても検討 した。結果】 合計1,409施設から回答を得て(回收率 54\%)、XMEA患者4家系12例(全例男性)を見出した。 発症は生下時から10歳代までばらつきを認めた。全例で緩徐進行性の四肢近位筋優位の筋力低下を呈した。 現在2家系3例が生存している。死亡 9 例の死因は呼吸不全または肺炎で、6例が乳児期に、3例が40歳代に 死亡した。明らかな心筋症を呈した症例はなかったが、3例で心肥大を認めた。生榆筋では筋線維内に多 数のAVSFを認め、電影的解析では空胞壁は二重膜構造を示した。一部の筋線維表面ではC5b-9の沈着を

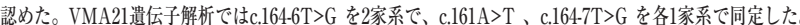
c.164-6T $>G$ 変異を見出した2家系は、過去に私たちが先天性自己貪食空胞性ミオパチー (CAVM)、乳児型 自己会食空胞性ミオパチー (IAVM) として報告した症例であった。結論] XMEAは原発性のライソゾー 么機能障害による極めて稀な骨格筋疾患である。Danon病と同様の筋病理所見を呈するが、XMEAでは 心筋症は認めないことで籃別できる。また、CAVMとIAVMは重症のXMEAのアレル病と考えられた。 本研究結果により、XMEAの重症度も発症年齢も臨床的により幅が広いことが示唆された。

\section{0-09-8 免疫チェックポイント阻害薬誘発筋炎 2 症例の診断 マーカーの検索}

\author{
原敦、関口 兼司、山口星一郎、小牧 遼平、未廣 大知、 \\ 森本 耕平、野田 佳克、千原 典夫、松本 理器 \\ 神戸大学大学院医学研究科 脳神経内科学
}

【目的】免疫チェックポイント阻害薬（immune checkpoint inhibitors: ICIs）誘発 筋炎では心筋・眼筋・横隔膜といった一般的な炎症性筋疾患と異なる部位の障害 が報告されており、特に横隔膜の障害は予後に影響する。ICI誘発筋炎と炎病 性筋疾患を比較し、診断マーカー候補を明らかにする。【方法】当院で経験した ICIs誘発筋炎の2症例と炎症性筋疾患例の臨床像・検查所見を比較する。【結果】 症例1は75藏男性。淡明型袩細胞癌に対してnivolmabを2回投与後14日目に両下 肢筋力低下、呼吸不全、嚾下障害が現れた。症例2は73歳男性。督孟癌に対して pembrolizumabを 2 回投与後 3 日目に複視、眼瞼下垂、複視、嗄声、䠐下障害、呼 吸不全、四肢筋力低下が現れた。2例ともにCK高使 $(6808-4841 \mathrm{IU} / 1) 、$ 抗AchR抗 体・抗Musk抗体は陰性で、低頻度反復刺激試験でdecrementはなく、針筋電龱て

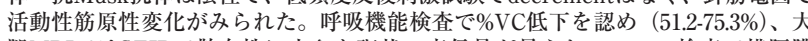
腿MRIではSTIRで散在性に小さな斑状の高信号が見られ、エコー検查で横隔膜 の可動性がモしかった。症例1は筋生検で壞死性ミオパチーが示唆され、CT・I コー検查で横隔膜の萎縮があったIVIgとステロイド大量療法で加療し、症例1 は呼吸不全、症例 2 嚾下障害・嗄声が残存した。両例とも治療開始 1 个月以内に CKは正常化したが、症例1は\%VC低下と横隔膜の萎縮・可動性のそしさが残存し た。筋生検と抗体検查で壞死性ミオパチーと診断した炎症性筋疾患症6例におい ては、大腿MRIのSTIRでびまん性の高信号域を認め、横隔膜の萎縮はなかった。結 詥IICIs誘発筋炎は横隔朕が障害され得る。検查結果では炎症性筋疾患と比較し筋 MRI (STIR) で特微的な散在性の小さな玟状信号変化とエコー椧查やCTによる横 隔膜の萎縮・可動性低下が見られ、診断マーカー侯補と考えられた。

\section{0-09-10 後頝部圧痛、複視、めまいを呈し筋膜リリースにて改 善する症候群}

\section{○井野邊純一 \\ 井野辺病院 神経内科}

目的】後䅡部圧痛、複視、めまいを呈し筋膜リリースにて改善する症候群の存在 を明らかにする。[方法]症例は7例。男 1 例女6例。年龄は 40 から 80 歳（平均年齢68 歳)。全例めまいを訴え外来を受診。全例に後碩部に圧痛あり。めまいは非回転 性6例、回転性1例で体動時に生じた。全例両下肢の脱力感や下肢の重たい感じを 訴えていた。7例中4例で複視を認め全方向性であった。頚部の圧痛部位の筋肉を エコーにて同定しその筋膜や筋肉内に生理食塩水（生食）と麻醉液の混合物（生食

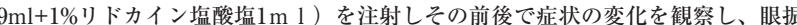
計にて眼球運動検查、重心動摇計にて平衡機能検查を施行した。結果了後䁰部の 圧痛部位はエコーにて上頭斜笛、下頭斜筋などの後頭下筋群、頭半蝀筋と推定さ れた。その筋膜リリースや筋内への生食+リドカイン塩酸塩注射を行った。注射 直後から全例後顏部の圧痛、めまい、雨下肢脱力感、複視の改善を認めた。眼球 軍動はsaccadic eye movement (SEM)を認め、注射後にSEMの改善を認めた。重 心動摇計にてロンベルグ率の改善を認めた。[結論]後澒部の圧痛、めまい、複視、 両下肢脱力感を訴える症例の中にSEMを認め後颈部の筋膜リリースにて改善する 症候群が存在する。後頙部に眼球運動と関係する筋肉やファシアが存在する可能 性が示唆された。

\section{0-09-7 成人筋ジストロフィー患者の嚥下障害とその自覚}

○山本 敏之、森 まどか、大矢 寧、高橋 祐二

国立精神・神経医療研究センター病院 脑神経内科

【目的】筋強直性ジストロフィー (DM1)，デュシェンヌ型筋ジストロフィー (DMD), 顔面肩甲上腕型筋ジストロフィー (FSHD)の成人患者を対象に嚾下障害 の合併頻度とその自覚について検討した. [方法]遗伝子検查で診断した 20 歳以上 のDM1 126 人 (女 50 人, 男 76 人, 平均年齢 $43.2 \pm 13.7$ 歳) DMD 44 人 (男 44 人 平均年齢 $267 \pm 49$ 歲), FSHD 35 人(女 22 人 男 13 人 平均年龄 $492 \pm 174$ 歲) を対象とした。すすへての対象は日常の食事を経口掑取していた。ず゙ての対象に 日本語版嚾下障害問診票 (SDQ) を回答させた後, 䓵下造影検查を実施した。䓰下 造影検查では液体バリウムの嚾下から, 誤㗪, 喉頭蓋谷の残留, 梨状陥凹の残留 のいずれかを認めた場合，「雚下障害」と判定した．SDQの総点と嚾下造影検査の 結果を比較した，統計は $\chi$ 二乗検定を行い, 有意水準 $\mathrm{p}<0.05$ を有意とした。な挍,

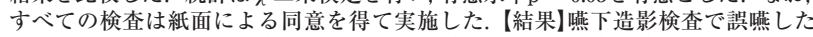
患者は，DM1 36人 (28.6\%)，DMD 4人 (9.0\%)，FSHD 2人 (5.7\%) であった。喉頭 蓋谷と梨状窝のいずれか，もしくは両方に残留を認めたのはDM1 107人 (84.9\%), DMD 35人 (79.5\%)，FSHD 12人 (34.3\%)であった. SDQの平均総点は, DM1 9点, DMD 9点,FSHD 8点であった. SDQで棝下障害を判定する場合, DM1は8点を 判别点すると感度 0.41 , 特異度 0.52 で有意差なし，DMDは6点を判別点すると感 度 0.66 , 特異度 0.56 で有意差なし, FSHDは8 点を判別点とすると感度 0.75 , 特異度 0.78 で有意差があった $(\mathrm{p}<0.01)$. もっとも自覚の多い症状は, す心゙ての疾患で飲 み込んだ後，口の中，㐘ぐきと頪の間，舌の裏に食べ物が残ったり，上頡部分に 食べ物が貼りついたりすることがありますか?」であった.【結論成人筋ジストロ

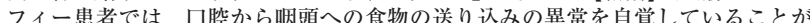
多かった. FSHDではSDQから嚾下障害の合併を評価できることを示した。

\section{0-09-9 筋ジストロフィーと移行医療}

○森 まどか ${ }^{1}$ 、七字 美延 ${ }^{2}$ 、水野 勝広 ${ }^{3}$ 、高橋 祐二 ${ }^{1}$

${ }^{1}$ 国立精神・神経医療研究センター 病院 脳神経内科、 ${ }^{2}$ 東京女子医科大学 小 児科、 ${ }^{3}$ 国立精神・神経医療研究センター 病院 身体リハビリテーション科

背景）小児発症重症神経筋疾患の予後改善に伴い小児科から脳神経内科への移行 が必要な症例が増加している。担当科・担当施設の変更は患者家族の当惑や情報 伝達の不備を招来する可能性がある。安全で満足度の高い移行を模索する。目的） 当院と提携している大学病院小児科で移行プロジェクトを計画し、安全で満足度 の高い患者移行を検討した。方法）患者移行プロジェクトとして1 一定の併診期 間、(2)移行時に脳神経内科での評佂入院を計画、(3)入院時に小览科・脳神経内科 担当医および担当他職種と患者家族によるカンファランスを施行、とし 2013 年 12 月より行った。候補者は重症神経筋疾患患者で、身体障害や呼吸・心筋障害の継 続診療が必要な15歳以上の患者とし、プロジェクトについて説明、希望者に施行 した。移行前後でアンケートを行い満足度を評価した。結果) 14名、平均年齢17.6 土3.3歲 (15-27歲)、男性 13 人、女性 1人、病型はデュシェン又型7名、福山型5名 エメリー・ドレフュス型1名、ベッカー型筋1名だった。移行前のアンケートでは 所在地や情報伝達への不安、当院の専門医療への期待がよせられた。1-2年の外来 併診を行った後に入院・移行カンファランスを行い、経過・現状・今後の治療方 針や生活設計の共有を行った。移行後のアンケートでは短い併診期間へ不満、合 同カンファランスへの満足度の高さが目立った。移行後の経過観察期間は平均 3.2 年 $(0-6)$ 、移行後の心保謢治療導入 2 名、呼吸器導入 3 名、胃瘦造設 2 名、心機能低 下 2 名、心不全発症 2 名、死亡 5 名〔突然死 1 名、急性膵炎 1 , 心不全 2 , 呼吸不全 1 〕 であった。結論）移行患者の重症化に対して受け入れ側の準備が重要である。十 分な準備期間と計画的な入院・移行カンファランスを行うことで満足度の高い移 行を行える。かかる労力を支える社会制度の整備が必要である。

\section{0-10-1 Molecular epidemiology of spinocerebellar degeneration based on J-CAT}

Yuka Hama ${ }^{1}$, Hidetoshi Date ${ }^{1}$, Yuji Takahashi ${ }^{1}$, Hidehiro Mizusawa ${ }^{1}$ J-CAT (Japan Consortium of Ataxias)

${ }^{1}$ Department of Neurology, National Center Hospital, National Center of Neurology and Psychiatry, Japan, ${ }^{2}$ J-CAT (Japan Consortium of Ataxias)

Objective We aim to elucidate the molecular epidemiology of degenerative ataxias in Japan based on a nation-wide web-based registry, J-CAT. Methods By November 2019, 1278 patients have been registered in J-CAT from al over Japan. PCR fragment analysis and repeat-primed PCR were performed for SCA1, SCA2, MJD/SCA3, SCA6, SCA7, SCA8, SCA12, SCA17, SCA31, SCA36, DRPLA, and HD in 761 patients. Whole exome sequencing (WES) was conducted in 136 patients whose initial mutational analysis was negative, prioritized for those with familial history (102 patients) or early onset (at or under 30 years old) with negative familial history (34 patients). Results Molecular diagnosis was established in 366 patients (48\%). The overall rate of positive genetic testing was $58 \%$ in subjects with positive $\mathrm{FH}$ and $17 \%$ in negative. The breakdown of number was 111 SCA31, 103 SCA6, 69 MJD/ SCA3, 23 DRPLA, 15 SCAR8, 14 SCA2, 11 SCA1, 6 SCA8, 4 HD, 2 EA2, 2 SCA5, 1 SCA19, 1 SCA36, 1 SCA43, 1 SCA46, 1 SCAR10 and 1 SCAN2 patient. WES revealed positive results in $6(18 \%)$ out of 34 patients with early onset and negative FH. Mean age of onset and mean SARA score of these 6 patients was $9 \pm 7$ years and $15 \pm 13$, respectively. They had intellectual disability, peripheral neuropathy, or pyramidal sign as well. Conclusions J-CAT has elucidated the current molecular epidemiology of degenerative ataxias in Japan. A substantial number of patients with positive $\mathrm{FH}$ remained undiagnosed, prompting the search for intronic mutations or novel causative genes. WES for early onset SCD should be considered even when FH is negative. 
0-10-2 Power-law and lognormal components of gait rhythm represent the quantity of ataxia in SCD patients

$\bigcirc$ Ryoji Goto ${ }^{1}$, Koichiro Oba ${ }^{2}$, Kyoko Todoroki ${ }^{2}$, Junichiro Yoshida ${ }^{2}$, Kyota Bando ${ }^{2}$, Daisuke Nishida', Katsuhiro Mizuno ${ }^{2}$,

Hidehiro Mizusawa ${ }^{1}$, Yuji Takahashi

${ }^{1}$ Department of Neurology, National Center of Neurology and Psychiatry,
Japan, ${ }^{2}$ Department of Physical Rehabilitation, National Center of Neurology Japan, ${ }^{2}$ Departm
and Psychiatry

[Objective] Rehabilitation is an effective measure for SCD patients. However, it is often difficult to assess its effect, since existing scales are discrete and not sensitive enough to detect subtle changes. We aimed to estimate the quantity of ataxia by analyzing their gait rhythm. [Methods] We recruited 9 patients with SCD. Four were SCA31 patients, two were SCA6, and the others had pure cerebellar ataxia whose genetic causes haven't yet identified. They walked a 350 -meter path independently $(n=8)$ or with a walker $(n=1)$ at the most comfortable speed. We measured step times using pressure sensors, calculated the ratios of adjacent times, and analyzed their distribution. We defined SARA gait/ posture subscore as a sum of item 1 to 3 , and SARA kinetic as that of item 5 to 8 , then studied their correlations with the distribution. [Results] The distribution was expressed as a sum of power-law and lognormal ones. The index of the former might tend to correlate with SARA kinetic subscore $(r=-0.458, p=0.25)$, while the dispersion of the latter might correlate with SARA gait/posture subscore $(\mathrm{r}=0.589, \mathrm{p}=0.12)$. We discovered the correlation between the ratio of coefficients of both distributions and that of SARA kinetic to gait/posture $(r=0.762, p=0.03)$ [Conclusions] We quantified the variability of ataxic gait as a linear combination of power-law and lognormal distributions. The former indicates the scale-free characteristics of the distribution. It is hypothesized that each component might reflect the distinct property of cerebellar systems controlling gait rhythm.

\section{0-10-4 Impaired adaptive motor learning is correlated with} brain gray matter atrophy in SCD: A VBM study

Kyota Bando ${ }^{1}$, Takeru Honda ${ }^{2}$, Yuji Takahashi ${ }^{1}$, Katsuhiro Mizuno ${ }^{1}$, Hidehiro Mizusawa ${ }^{1}$, Takashi Hanakawa ${ }^{3}$

${ }^{1}$ National center of neurology and psychiatry, Japan, ${ }^{2}$ Tokyo metropolitan institute of medical science, ${ }^{3}$ Department of Integrated Neuroanatomy and Neuroimaging Kyoto University Graduate School of Medicine

【目的】春䯣小脳変性症 (Spinocerebellar Degeneration: SCD)のプリズム順応学習能力 指標 (Adaptability Index: AI) 低下に関わる脳萎縮部位をVoxel-based morphometry （VBM）解析を用いて明らかにする.【方法】倫理承認に基づく同意を得た 23 名のSCD 群（SCA3, SCA6, SCA31）と健常コントロール群（21名）を対象とした横断研究を実 施した.3T MRIを用いて三次元撮像T1 強調MRIを取得した.リーチングタスクのプ リズム順応課題によりAIを算出した.VBM解析にはSPM12を用いた.各被験者のMRI 画像を白質・灰白質・脳脊䯑道液に分割した.DARTEL (diffeomorphic anatomica registration through exponentiated liealgebra) toolboxを用いて本研究で用いるテン プレートを作成した次にMNI (Montreal Neurological Institute) テンプレートを用 いて空間的標準化を行った.最後に $8 \mathrm{~mm}$ ガウシアンフィルターにて平滑化を行った.統 計解析として,SCD群と健常コントロール群の脳灰白質容積の違いについて,性別と全 脳容積を共変量とする共分散分析を実施したまたた,SCD群におけるAIと脳灰白質容皘 との関倸性について,重回帰分析を用いて解析を行った.Family-wise error多重比較補 正後のp <.05を有意水準とした.【結果]健常コントロール群と比較し,SCD群はAIが低 值であり，小脳の広範な領域において灰白質容積が低下していることが示された.SCD 群において,AIと小脳外側半球および下頭頂葉の灰白質容積の間に相関を認めた.[結 論】AIは,萎縮の著明であった小脳外側に加えて下頭頂葉灰白質の容積と関係している ことを初めて示したこれらの脳部位はプリズム順応課題時に活動することが知られ ている. AIが特定の小脳萎縮の臨床バイオマーカーとして有用であると思われる.小脳 は多くの脳部位と解剖学的機能的に連結をしているが今後、下頭頂䒜灰白質の異常 と小脳萎縮との関係を解明するために神経ネットワーク解析を進める予定である

\section{0-10-6 Clinical and Genetic study of SPG46 in Japan}

OKishin Koh ${ }^{1}$, Hiroyuki Ishiura ${ }^{2}$, Takashi Kimura ${ }^{3}$, Kiyotaka Nakamagoe ${ }^{4}$, Keiko Nakamura ${ }^{5}$, Yuta Ichinose ${ }^{1}$ Hiroo Yoshikawa ${ }^{3}$, Yoshihide Sunada ${ }^{6}$, Akira Tamaoka $^{4}$,

Masahito Yamada ${ }^{5}$, Shoji Tsuji ${ }^{7}$, Yoshihisa Takiyama ${ }^{1}, J^{1}$ SPAC $^{8}$ ${ }^{1}$ Department of Neurology, University of Yamanashi, Japan, ${ }^{2}$ Department of Neurology, The University of Tokyo, ${ }^{3}$ Department of Neurology, Hyogo College of Medicine, ${ }^{4}$ Department of Neurology, Division of Clinical Medicine, Faculty of Medicine, University of Tsukuba, ${ }^{5}$ Department of Neurology and Neurobiology of Aging, Kanazawa University Graduate School of Medical Sciences, ${ }^{6}$ Department of Neurology, Kawasaki Medical School, ${ }^{7}$ Department of Molecular neurology, The University of Tokyo, Japan Spastic Paraplegia Research Consortium

目的 本邦の遗伝性丞性対麻㽻 (HSP) 家系においてGBA2遺伝子変異によるSPG46症例の隍 床・遗伝学的特徴を検討した。方法 JASPACで遗伝子解析を行った常染色体劣性遗伝性 HSP (AR-HSP) のうち GBA2遗伝子変異を持つ症例の臨床像を検討した。結果 JASPAC で遗伝子解析を行ったAR-HSP 210家系のうち GBA2遗伝子変異を有する4家系を見出した $(1.9 \%) 。 4$ 家系はすべて近親婚のある家系であり、それぞれc.1195C > T, c.1122_1123delTC, c.1625C > T, c.1838A $>\mathrm{G}$ の変異をホモ接合性に有していた。これらはすべてこれまでに原 因遗伝子変異として報告のない新規の変異であった。フレームシフト変異が1つ、ナン センス変異が1つ、ミスセンス変異が2つ (SIFTでdamaging、PROVEANでdeleterious Polyphen2でprobably damaging、CADD scoreが28.6と28.7) であり、原因遗伝子変異であ ると考えられた。臨床像については、発症年齢は15-35歳と若年であった。神経学的には全 例に認知機能低下、構音障害、小脳失調を認めた。また一部の症例では、感覚障害、排尿障害、 手指の変形、凹足変形を認めた。頭部MRIでは3例に脳梁の菲薄化、2例に小脳萎縮を認め た。また統合失調症、てんかんの合併をそれぞれ1例に認めた。結論 本邦においてSPG46 を4家系見出した。今回見出した4つの変異はすべて新規の変異であった。SPG46の頻度は 本邦AR-HSPの中ではSPG15と並び3番目であり、認知機能低下、小脳失調、脳梁の菲薄化、 手指の変形を伴う若年性HSPにおいては鑑別の一つとして重要な疾患であると考えられた。
0-10-3 Endothelial cells regulates cognitive function through communication with hippocampal neurons

Feng Han, Ya-ping Lu, Ying-mei Lu

College of Pharmacy, Nanjing Medical University, China

Objective: The proper interactions between blood vessels and neurons are critical for maintaining the strength of neural circuits and cognitive function. However, whether vascular cells can directly regulate neural circuits through intercellular signaling in the central nervous system remains largely unknown. Methods: We used the mice of the selective knockout of semaphorin $3 \mathrm{G}$ in endothelial cells. Extracellular field recordings and Whole cell recordings combining with optogenetics were used to determine the mechanisms that underlie synaptic plasticity and transmission. Y-maze task and contextualdependent memory were examined. Results: In this study, we used a database mining strategy with three inclusion criteria to find a critical gene Sema3G. We showed that knockout of Sema3G specifically in ECs impairs hippocampal dependent memory in mice. Furthermore, we uncovered a Sema3G/Nrp2/ Plexin A4 signaling cascade that activates intracellular Racl to promote excitatory glutamatergic synapse density and synaptic function. Conclusion: These results provide the first evidence that, in the central nervous system, Sema3G, a vascular endothelium derived synaptic organizer, plays a critical role in regulating synaptic plasticity and hippocampal dependent memory. Our findings highlight the role of vascular endothelial cells in regulating cognitive function through intercellular communication with neurons in the hippocampus.

\section{0-10-5 Very early diagnosis of synucleinopathy: beyond the multidisciplinary approach}

Ryuji Sakakibara, Fuyuki Tateno, Yosuke Aiba,

Tomoyuki Uchiyama, Tatsuya Yamamoto, Hiroyoshi Suzuki, Katsuyoshi Matsuoka

Neurology, Internal Medicine, Sakura Medical Center, Toho University, Japan

【目的】神経変性疾患の早期診断は脳神経内科医にとってのチャレンジと思われ る。我々は消化器内科・泌尿器科と共同して、神経変性疾患（特にシヌクレイノ パチー)の早期診断を試みた。対象と方法】研究1多系統萎縮症MSA121名の前向 き/後ろ向き研究: 組み入れ期間 5 年、観察期間 $6.5 \pm 4.0$ 年。全例にウロダイナミク ス・括約筋筋電図・脳MRIを施行。研究2.レヴィー小体病LBD450名の前向き研究: 組み入れ期間 5 年、観察期間 $5.5 \pm 3.0$ 年。全例に脳DATscan・心筋MIBGシンチク ラフィー・脳MRIを施行。【結果】研究1.MSA121名中18.2\%が膀胱症状のみで発症 し(頻尿プラス多量の残尿)、28年 (1-7年) 後運動症状が出現した。研究2LBD450 名中 $4.2 \%$ が消化管症状とREM睡眠行動障害 (一部起立性低血圧) のみで発症し、こ のうち $39 \%$ で観察期間中運動症状・認知症が出現した。【まと】 MSAの膀胱初発 型は、仙䯑道を中心とする部位の病変を表すと考えられ、LBDの消化管初発型は、 腸管壁内神経叢の病変を表すと考えられる。これらシヌクレイノパチー（MSAと LBD)の早期診断およびヶアは、内科および各診療科の協力が不可欠と思われる。

\section{0-10-7 Clinical significance of cerebrospinal fluid 5-HIAA in multiple system atrophy}

Ryunosuke Nagao, Kazutaka Hayashi, Kunihisa Kato, Fumihiko Banno, Koichi Kikuchi, Atsuhiro Higashi, Kenichiro Murate, Seiko Hirota, Tomomasa Ishikawa, Yoshiki Niimi, Yasuaki Mizutani, Sayuri Shima, Akihiro Ueda, Shinji Ito, Tatsuro Mutoh, Hirohisa Watanabe Department of Neurology, Fujita Health University School of Medicine, Japan

【背景】多系統萎縮症（MSA）で突然死を認めた症例では、延䯣のセロトニン神経 細胞脱落が高度であることが報告されている。また延䯣のセロトニン神経細胞 は、呼吸、循環、排尿など臨床的にMSAの予後に影響を及ぼす臨床症状と関連す ることが知られている。目的】MSAに打ける蹃液5-HIAA值と臨床症状との関係 を明らかにする。【方法】対象は当施設に入院し、能迹5-HIAAを測定したprobable もしくはpossible MSA 26例（MSA-C 19例、MSA-P 7例、男性16名、女性10名、 平均年齢63.1歳、平均罹病期間25.3か月)。䯣液5-HIAAの中央值で26例を 2 群に分 け、発症年齢、罹病期間、臨床病型、ADL、臨床的な自律神経不全の重症度を 後方視的に評価した【結果】MSA症例における蹎液中の5-HIAAは $22 \mathrm{ng} / \mathrm{ml} ら$ $35.9 \mathrm{ng} / \mathrm{ml}$ であり、26例中 25 例が $30 \mathrm{ng} / \mathrm{ml}$ 未満で、 26 例中 22 例が $20 \mathrm{ng} / \mathrm{ml}$ 未満であっ た。中央值は $13.7 \mathrm{ng} / \mathrm{ml}$ 、゙央值以上群（MSA-C 11例、MSA-P 2例）と以下群 (MSA-C 8例、MSA-P 5例) の2群に分けて臨床指標を比較したところ、以下群で は、12例がprobableであり、残尿、失禁、尿閉、高度の起立性低血圧のいずれか もしくは複数を有していた。また、1例のpossibleも喘鳴を伴っていた。以上群で は、 possibleが10例、probable 2例で、全体に自律神経不全が軽微であった。【結論】 MSAにおける䯕液5-HIAAは、自律神経不全の重症度と関係している可能性があ る。今後、予後との関連や詳細な自律神経検查との関係解明が課題である。 
0-10-8 Clinical study of sporadic spinocerebellar degeneration using J-CAT

OShinji Oda, Yuji Saitoh, Yuji Takahashi, Hidehiro Mizusawa, Japan Consortium of Ataxias

Department of Neurology, National Center Hospital, National Center of Neurology and Psychiatry, Japan

[Purpose]A wide variety of disease types including sporadic spinocerebellar degeneration (SSCD) are registered in Japan Consortium of Ataxias (J-CAT). We analyzed the information of SSCD patients in J-CAT in reference to diagnostic criteria of idiopathic cerebellar ataxia (IDCA) published in 2018. [Method] Until October 2019, 1069 patients were enrolled in J-CAT, of whom 399 (37.3\%) were SSCD patients with negative family history. Of these, we examined 233 patients who were with slow onset, slowly progressive course and underwent genetic testing. [Result] Of these, $48(21.5 \%)$ patients were genetically diagnosed (SCA6:24, SCA31:13, DRPLA:5, MJD/SCA3:3, SCA8:2, SCA1:1). In the remaining 185 patients, 48 patients had cerebellar atrophy, zero score on autonomic items in UMSARS, and no MRI findings suggestive of MSA. Of these, 16 patients met diagnostic criteria for IDCA: age at onset above 30 and disease duration below 5 years.Their mean age at onset, disease duration, and SARA score were 51.2, 13.1, and 14.2, respectively. None of the autoantibodies (anti GAD65/TPO/gliadin/ mGluRl antibody) were measured. In 137 undiagnosed patients, the mean age at the onset, disease duration, and UMSARS score were 49.5, 7.3, and 25.8, respectively. [Conclusion] J-CAT system is useful for extracting patients with suspected IDCA. Insufficient exclusion of autoimmune cerebellar ataxia is the issue to be addressed. SSCD patients who don't meet diagnostic criteria for IDCA may include MSA in early stage, and prospective studies on this cohort may be useful to refine the diagnostic criteria for MSA.

\section{0-11-2 パーキンソン病における黒質線条体ドパミン神経障害 の局在と心臟交感神経障害の関連}

梅原 淳 1 茂木 晴彦 1 高橋 麻葵、幕 昂大 ${ }^{1}$ 白石 朋敬 ${ }^{1}$

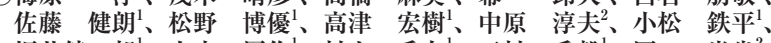

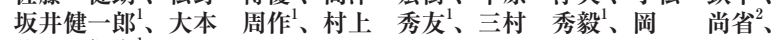
井口 保之 ${ }^{1}$

${ }^{1}$ 東京慈恵会医科大学附属病院 神経内科、

2 東京慈恵会医科大学附属第三病院 神経内科

[目的]筋metaiodobenzylguanidine (MIBG) シンチグラフィーにて評価される心臓交感神経 障害が強いパーキンソン病患者は、弱い患者に比べ将来的に運動機能や認知機能が低下しやす いと報告されている。このことは、被殼・尾状核の各々の部位へ投射する黒質線条体ドパミン 神経の変性と心筋MIBGシンチグラフィーの取り込み率に関連があることを示唆する。我々は Dopamine transporter（DAT）scanで得られた被殼および尾状核のDAT密度をDaTQUANT を用いて定量值化し、心筋MIBGシンチグラフィーの取り込み率との関連を評価した。[方法］ 認知機能正常な 82 名の早期未治療パーキンソン病患者を対象とした。認知機能はMini-Mental Status Examination (MMSE) およびFrontal Assessment Battery (FAB)にて評価した。運動 機能と関連性が高い被殸後部の線条体撖取率 (specific uptake ratio: SUR)、および認知機能 と関連性が高い被殼前部と尾状核のSURと心筋MIBGシンチグラフィーで得られた心縦隔比 (heart to mediastinum ratio: $\mathrm{H} / \mathrm{M}$ ) の後期像 (delayed) との相関を評価した。結果患者背景 は年齢71 \pm 10 (平均 $\pm S D)$ 歳、女性 $44(53.6 \%)$ 人、罹病期間は $1.4 \pm 1.2$ 年、Unified Parkinson's Disease Rating Scale (UPDRS) motor score 21 \pm 10 、MMSE $28 \pm 1 、$ FAB 15 \pm 2 であった。年 齢・性別・罪病期間を考虑した重回帰分析にてDelayed H/MはUPDRS motor score、MMSE、 FABのいずれとも有意な関連を認めなかった。一方で、Delayed $\mathrm{H} / \mathrm{M}$ は左右いずれの被殼後 部、被喨前部、尾状核のSURと正の相関を認めた (全て、 $\mathrm{p}<0.001)$ 。各々の相関は年齢、性別、 罹病期間、UPDRS motor scoreを考慮した重回帰分析にても保たれていた。[結論]パーキン ソン病に扔ける心筋MIBGシンチグラフィーの取り込み率は、被殼後部や被殼前部・尾状核の SURと強く関連しており、将来的な運動機能低下や認知機能低下を予測する因子となりうる。

\section{O-11-4 レビー小体型認知症およびパーキンソン病における核 医学画像の比較}

○浅原 有揮、宮川 晋治、鈴木 正彦

東京慈恵会医科大学暮飾医療センター神経内科

【目的】レビー小体型認知症 (DLB) とパーキンソン病 (PD) は臨床症状が共通する ものが多く，発症初期にはどちらの疾患か断定することが困難な症例も存在する しかし, DLBとPDで予後や治療方法が異なり,鑑別方法が確立されることが望ま しい. 本研究では当院のDLBおよびPD患者の核医学画像を比較し, 鑑別の一助と なる可能性のある所見を抽出することを目的とした. 【方法対象は当院に2015年 11月から2019年8月までに診断目的に入院した患者で，DLB診断基準（2017年）ま たはPD診断基準（2015年）を満たし， ${ }^{123} \mathrm{I}$-FP-CIT SPECTとMIBG心筋シンチグラ フィの两方を施行した症例とした。, 入院する一年以上前に画像を撮影していた症 例は，発症前に検查している可能性を考虑して除外した. ${ }^{123}$ I-FP-CIT SPECTで はspecific binding ratio (SBR) の左右平均, 左右差の絶対値, asymmetry index を後方視的に比較した. MIBG心筇シンチグラフィでは早期像, 後期像の心緶隔比, washout rateを同様に比較した。また，有意差の得られた変数を用いてreceiver operating characteristic (ROC) 曲線による解析を行った。尚, 本研究は当院の 倫理委員会の承認を得て施行した.【結果】DLB患者20例およびPD患者43例の画像

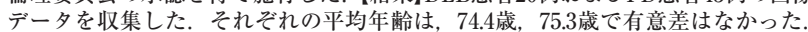
画像データのうち，両群間で有意差が得られたのはSBRの左右平均 $(\mathrm{p}=0.0158)$ お よび左右差の絶対值（ $\mathrm{p}=0.0335 ） の$ みであったそれぞれのarea under the curve

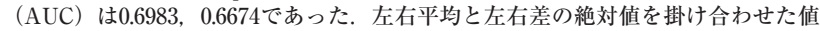
のAUCも算出したところ0.7215であった.【結論】レビー小体型認知症およびパー キンソン病の鑑別に拈いてSBRの左右平均と左右差の絶対值に加え, その両者を 掛け合わせた值が有用な可能性がある。

\section{0-11-1 パーキンソン病の一次視覚野の血流低下には舌状回の} 血流低下が関連する

○前田 利樹 ${ }^{1}$ 林 和孝 ${ }^{1}$ 、坂野 文彦、加藤 帮常 ${ }^{1}$ 、東 篤宏 ${ }^{1}$ 、 菊池 淡一 1 、長尾龍之介 ${ }^{1}$ 、村手健一郎 ${ }^{1}$ 、石川 等真 ${ }^{1}$ 、廣田 政克 ${ }^{1}$ 、

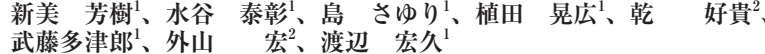

${ }^{1}$ 藤田医科大学 医学部 脳神経内科学、 ${ }^{2}$ 藤田医科大学 医学部放射線医学

【目的】゚ーキンソン病 $(\mathrm{PD})$ では一次視喾野の血流低下が起こるが病理学的変化 が無いことも報告されており、その機序は明らかとなっていない。一つの要因 として、他領域の病変からのリモートエフエクトが関与している可能性を考膚 しその関連性を梌討する【方法ICalneの診断基淮がdefiniteからL-dopa内服が有 効でMIBG心筋ジチグラフィーで集積低下を認めた当院通院中のPD症例のう ち、2016年から2018年にかけて媨血流SPECTを撮影した 34 症例 (男 17 , 女 17 ; 年 齢 $74.4 \pm 8.4$ 歳; 䍜病期間 $47.3 \pm 35.5$ 月) について検討した。全症例は同機種 (GCA9300R囚、Canon)で摄影し、核種には ${ }^{123} \mathrm{I}$-IMP SPECTを用い、Brodmannのマップ から得られたStereotactic Extraction Estimation (SEE) 解析のZスコアに着目し、

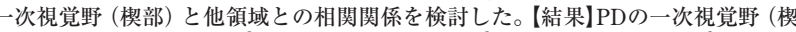
部)は、左では、舌状回 $\left(\mathrm{R}^{2}=0.638\right)$ 、上頭頂小葉 $\left(\mathrm{R}^{2}=0.428\right)$ 、中後頭回 $\left(\mathrm{R}^{2}=0.340\right)$ 、 上後頭回 $\left(\mathrm{R}^{2}=0.318\right)$ 、楔前部 $\left(\mathrm{R}^{2}=0.289\right)$ と有意な相関を認め、重回㷌分析では $\mathrm{R}^{2}=0.839$ で、舌状回（t=5.61）、中後頭回（ $\left.\mathrm{t}=2,73\right)$ 、枴前部 $(\mathrm{t}=2,38)$ が有意で、舌 状回の影響が最も大きかった。右では、舌状回 $\left(\mathrm{R}^{2}=0.638\right)$ 、上頭頂小葉 $\left(\mathrm{R}^{2}=0.169\right)$ 、 中後頭回 $\left(R^{2}=0.291\right)$ 、上後頭回 $\left(R^{2}=0.549\right)$ 、潔前部 $\left(R^{2}=0.155\right)$ と有意な相関を

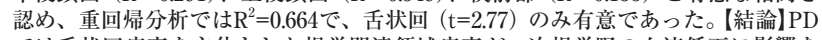
では舌状回病変を主体とした視鸴関連領域病変が一次視鸴野の血流低下に影響を 及ほしている可能性がある。

\section{0-11-3 パーキンソン病における脳血流低下様式の特徵}

坂野 文彦、林和孝 1 加藤邦尚 ${ }^{1} 、$ 東 篤宏 1 、菊池 淡二 1 、 長尾龍之介、前田 利樹、村手健一郎 ${ }^{1}$ 、廣田 政古 ${ }^{1}$ 、石川 等真 ${ }^{1}$ 、 新美 芳樹 ${ }^{1}$ 、水谷 泰彰 ${ }^{1} 、$ 島さゅり ${ }^{1}$ 、植田 晃広 ${ }^{1}$ 、乾 好貴 ${ }^{2} 、$ 伊藤 信二 ${ }^{1}$ 、武藤多津郎 ${ }^{1}$ 、外山宏 ${ }^{2} 、$ 渡辺 宏久 ${ }^{1}$

${ }^{1}$ 藤田医科大学医学部 脳神経内科学、 ${ }^{2}$ 藤田医科大学医学部 放射線医学

【目的】パーキンソン病（PD）における全脳の血流の低下様式を㭲討する。【方法】 対象は、MDSの診断基準を満たしたPD 33例（平均撮像年齢74.5歳、平均䍜病期 間 3.9年、Hoehn \& Yahr重症度 2.9)。全例で'123I-MIBG心筋シンチグラフィの集皘 低下を確認した。脑血流SPECTは ${ }^{123}$ IIMP (IMP-SPECT) を用い、Canonの頭部專 用機9300Rで撮像した。3D-SSP解析後、Stereotactic Extraction Estimation を用 いてBrodmannの領域每にZスコアを算出した。各領域のZスコアと、領域間のZ スコアの相関関係を調べた。【結果】PDにおけるZスコアは、0.547 (右紡鏵状回) か ら1.52 (右横㑯頭回) であり、全領域において健常群上りも軙度低下していた。 スコアが1を超える領域は、前頭葉では下前頭回、前方・後方带状回、側頭葉では、 横側頭回、上側頭回、頭頂葉では縁上回、㯲前部、角回、舌状回、後頭葉では㮩 部であった。Brodmann map の60領域間のZスコアの相関では、高い相関 $(r>0.50$, $\mathrm{p}<0.05)$ は、例えば下前頭回では中前頭回と带状回、前方带状回では眼窝回、直回、 上前頭回、带状回など、近接する領域と認め、遠隔領域とは認めなかった。多重 比較でも同㥞であった。【結論]PDでは一次視觉野を除き、情報を統合する連合野 を中心とした全般性の血流低下を認めた。一方、領野間の血流低下様式の検討で は、葉を超えた有意な相関は無かった。今後、病理所見や経時的SPECT所見と比 較し、その意義を検討する必要がある。

\section{0-11-5 取り下げ演題}


0-11-6 DAT SPECT3 次元フラクタル解析とパーキンソン病 /症候群の認知機能

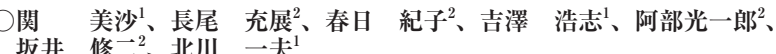

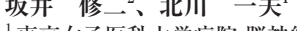 \\ 東京女子医科大学 面像診断学・核医学講座
}

【目的】ドパミントランスポーター (DAT)SPECTの視覚評佂は通常 2 次元から主 観的な評伯に留まっている。我々は臟器内の核種が浱度依存性に分布する不均一 さを数值化する3次元フラクタル解析で得たフラクタル次元 (Fractal Dimension FD) から視覚評洒の定量化を図り、さらにパーキンソン病/症候群 ( $\mathrm{PD} / \mathrm{PS})$ の認 知機能との関連を検討した。【方法】2014年1月～2016年12月に DAT SPECT (DAT scan）を施行し、視覚評佂からSBR< 4 からPD/PSと考えられた例で、MMSEで 認知機能を評価した31例を対象とした。また、同時期に視喾評佂とSBR值から正 常と判断した14例を対照群とした。この計44例についてDAT SPECT画像から ソフトウェアSymbia (SIEMENS社) を用いてフラクタル解析を実施した。結果】 $\mathrm{PD} / \mathrm{PS}$ 群31例は、年齢71 12 歳、男性 16 例 $(51.6 \%) 、 \mathrm{MMSE} 26.1 \pm 4.3$ 点だった。 臨床䛦断はPD17例、DLB7例、PSP1例、MSA1例、CBS2例、VaP2例で2例は不明 だった。PD/PS群のうち認知機能低下例は13例でDLBが7例と最も多かった。FD はPD/PS群 (右 $2.91 \pm 0.75$, 左 $2.86 \pm 0.81$ )、対照群 (右 $1.99 \pm 0.57$, 左 $1.85 \pm 0.21$ ) とPD/ PS群で高值だった。また、PD/PS 群では認知機能低下群 (右 $2.33 \pm 0.39$, 左 $2.26 \pm$ 0.51 ) 認知機能正常群 (右 $3.33 \pm 0.66$, 左 $3.29 \pm 0.71$ ) と認知機能正常例で有意に高做 を示した。【結論】FDは診断や、認知機能障害の予測に有用な客観的指標となりう る。

\section{0-11-8 レボドパ・カルビドパ配合経腸用液の長期投与におけ る有効性と安全性の検討}

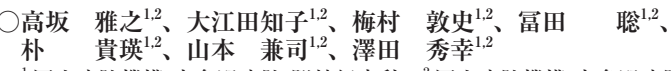

${ }^{1}$ 国立病院機構 宇多野病院 脳神経内科、 ${ }^{2}$ 国立病院機構 宇多野病院 臨床研究部

【目的】レボドパ・カルビドパ配合経腸用液（LCIG）療法は、進行期パーキンソン 病（PD）のウェアリング・オフ現象、非運動症状を改善することが報告されてい る。本研究では、ウェアリング・オフ現象、運動症状、非運動症状に対するLCIG の長期投与の有効性と安全性を検討した。【方法】対象は、LCIG療法を新規導入し たPD患者15例（男性10例、女性5例）。導入前と導入後 $2 、 4 、 24 、 52 、 104$ 週の各 時点におけるオフ時間とオン時間 (症状日誌)、UPDRS 3、Non-Motor Symptom assessment scale for Parkinson's Disease (NMSS)、レボドパ1日投与量の経時 的変化を評価した。また、合併症の発生頻度を検証した。【結果】LCIG療法導入時 の平均年齢は $59.4 \pm 9.9$ 歳 $($ 平均 $\pm \mathrm{SD})$ 、罹病期間は $10.9 \pm 4.3$ 年であった。 LCIG療 法導入前の 1 日あたりのオフ時間は $4.9 \pm 2.7$ 時間、日常生活に支障のあるジスキネ ジア (TSD) のないオン時間は $10.5 \pm 2.4$ 時間、TSDのあるオン時間は $0.5 \pm 0.8$ 時間、 UPDRS 3 は $16.3 \pm 6.5$ 点、NMSSは $81.3 \pm 37.2$ 点であった。導入 2 週後にはいずれの 指標にも改善がみられ、その効果は104週後まで持続した。104週後のオフ時間は $0.6 \pm 0.5$ 時間、TSDのないオン時間は $12.9 \pm 3.4$ 時間、TSDのあるオン時間は $0.7 \pm 1.4$ 時間、UPDRS 3 は $13.7 \pm 5.4$ 点、NMSSは $6.5 \pm 4.5$ 点であった。レボドパ1日投与量 は導入前 $992 \pm 337 \mathrm{mg} /$ 日、104週後 $958 \pm 280 \mathrm{mg}$ /日であった。一方、合併症として カテーテル関連合併症が最も多く、その頻度は 0.9 /人年であった。結論】LCIG療 法導入後104週までオフ時間の短縮、運動症状、非運動症状の改善効果が確認さ れた。レボドパ1日投与量はわずかに減少傾向であった。合併症はカテーテル関 連合併症が最多であった。

\section{0-11-10 パーキンソン病におけるレボドパ/カルビドパ配合経 腸用液療法の効果と今後の課題}

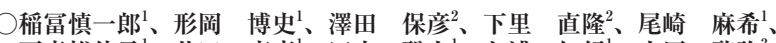
西森裕佳子 ${ }^{1}$ 、井口 直彦、田中 聡人 1 、七浦 仁紀 1 、小原 啓弥 ${ }^{3}$ 江浦 信之 ${ }^{1} 、$ 松井 健、眞野 智生、桐山 敬生、吉治 仁志、 杉江 和馬 ${ }^{1}$

${ }^{1}$ 奈良県立医科大学 脳神経内科、 ${ }^{2}$ 奈良県立医科大学 内科学第三講座、
}

南奈良総合医療センター 脳神経内科

【目的】奈良県におけるパーキンソン病(PD)のレボドパ/カルビドパ配合経腸用液 (LCIG) 撚 法の効果と課題を検討する。(方法】対象はPD 9例（男性3例、女性6例、年齢67-78歳、罡患 期間6-20年)とした。オフ時Hoen\& Yahr StageはIV とV (6、3例)であり、ジスキネジア (dys)、 幻覚、軽度認知を有したのはそれぞれ $5 、 1 、 1$ 例であった。 LCIG療法後、短期と長期の効 果と継続困難となった原因を検討した。【結果】LCIG療法後（持続投与量1.0-3.3ml/hr）、7例 で運動症状が改善し、䫫部姿勢異常や腹部症状、痛み、喉頭の締め付け感にも改善をみと めた。経鼻小腸チューブ（NJチューブ）に上る試用のみでLCIG療法を終了した理由は、䦭 眼失行とジストニアの出現 (1例)、顕著なFreezingがあり霧視が出現 (1例)、withdrawal syndrome (1例)、デバイスの重量や介謢の問題 (2例) であった。経胃瘦的空腸チューブ (PEG-Jチューブ) を留置した5例（観察期間：最長32ヶ月)では、2例が良好な経過であり国 内旅行等を行えるまで改善した。1例ではdysと頙部後屈が悪化し誤䓵性肺炎となり、LCIG 療法を中断し淡苓球内節電気刺激を行う予定となった。気分障害のある1例は器質的原因が 同定できない嘔気で中止となった。チューブトラブルが4回あり、キンク2回、胃への逆流 1 回、脱落 1 回であった。また胃瘦造設中に激しいdysが出現してSpO2が低下し、胃瘦造設 を延期した例があった。結論】LCIG療法はPD症状を改善するが、顕著なFreezingに効果 は認めなかった。導入前、気分障害を有する例には慎重な検討を要する。特に地方では介 護者が少なく家族環境を十二分に加味する必要があり、高齢者にはデバイスの重量が問題 となる。道入にあたり withdrawal syndromeを考えアゴニストは㖾減する必要がある。内 服治療に難治性である腹部症状や顕部姿勢異常、痛みを軽滅できる可能性がある。
0-11-7 多系統萎縮症におけるMIBG心筋シンチグラフィーと 臨床的因子との関連についての検討

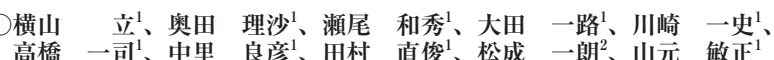
${ }^{1}$ 埼玉医科大学病院 脳神経内科、 ${ }^{2}$ 埼玉医科大学病院 核医学診療科

【目的】多系統萎縮症 (MSA) のMIBG心筋シンチグラフィーの成績と、Parkinson's disease (PD) およびMSAの臨床的因子との関連について検討し、本症の心臓交感 神経の病態について検討する。【対象・方法】対象は多系統委縮症 (MSA) 23例 (年 齢69.5 \pm 9.4 歳; mean \pm SD、罹病期間 $30.4 \pm 18.5$ 力月) と Parkinson's disease (PD) 30 例（年齢72.6 \pm 6.4 歳、罹病期間 $28.2 \pm 24.9$ 力月）にMIBG心筋シンチグラフィー を施行し，早期像，後期像の $\mathrm{H} / \mathrm{M}$ と洗い出し率（WR）を比較した。次にMSA をMSA-P13例、MSA-C10例の 2 群に分け、同様の検討を実施した。【結果】 1 . MSA とPDの比較 : 早期像と後期像のH/Mは、PDではMSAに比較し低下し (各々 $\mathrm{p}<0.001) 、 W R は P D は M S A よ り$ 高值であった $(\mathrm{p}<0.001)$ 。2. MSA-P、MSA-Cと PDの比較 : 早期像と後期像のH/Mは、PDはMSA-PとMSA-Cに比較し低下（全て $\mathrm{p}<0.001$ )、MSA-PはMSA-Cに比較し共に低下していた（各々 $\mathrm{p}<0.05 ） 。 W R は P D$ ではMSA-PとMSA-Cに比べ高く $(\mathrm{p}<0.05 、 \mathrm{p}<0.001) 、$ MSA-PはMSA-Cに比較し 高值であった $(\mathrm{p}<0.005)$ 。 PDでは後期像のH/Mは早期像に比較し低值であるが、 MSA-Pでは後期像が早期像より高值であった。3.MSA23例のうち、早期像のH/ Mがカットオフ值2.2以下であったのは6例で、全てMSA-Pであった。4. MSAー Pの早期像の取り込み低下群と正常群の 2 群間では、罹病期間に差は認められな かった。4.MSA-Pの中で4例は経時的にMIBG心筇シンチグラフィーを施行され ていたが、早期像、後期像ともに経時的に取り込み低下はなかった。【結論】1. MSAはPDに比較し、心臓の交感神経機能は保たれる。2. MSA-Pでは心臟の交 感神経機能は低下するが、その程度はPDに比較すると軽度である。3. MSAに みられる心臓交感神経機能低下はMSAの進行に関係はなく、機序としては、節前 交感神経変性によるtranssynaptic degenarationな機序が示唆された。

\section{0-11-9パーキンソン病患者 23 例における 52 週間レボドパ- カルビドパ経腸用ゲルの検討}

○志村 秀樹 ${ }^{1}$ 栗田 尚栄 ${ }^{1} 、$ 森 聡生 ${ }^{1} 、$ 渡邊 雅男、服部 信孝 ${ }^{2} 、$ 卜部 貴夫

順天堂大学医学部附属浦安病院 脳神経内科、

順天堂大学医学部附属順天堂医院 脳神経内科

【目的】進行期パーキンソン病患者 23 例における52週間のレボドパ-カルビドパ経晹 用ゲル療法の効果を検討した。方法】対象患者は男性 9例, 女性 10 例。平均年齢 は $68.92 \pm 2.71$ 。ホーエン・ヤール重症度分類はオン $3.08 \pm 0.36$, オフ時 $4.2 \pm 0.88$ 。 罹病期間は $9.78 \pm 4.82$ 年。経胃瘦空腸チューブからのレボドパーカルビドパ経 腸用 ゲル (LCIG) 療法導入前後においてオフ時間, 生活に支障を来たすジスキネジアを 伴 うオン時 間, 生活に支障を来たすジスキネジアの無いオン時間について評価 した。導入前は入院後 3 日間の平 均, 導入後は 52 週間後の 3 日間の平均で評価し た。【結 果】1日当たりの平均オフ時間はLCIG投与前 $6.54 \pm 1.64$ 時間, LCIG投与後 $2.08 \pm 2.42$ 時間。生活に支 障を来たすジスキネジアを伴うオン時間はLCIG投与前 $3.09 \pm 1.89$ 時 間, LCIG投与後 $0.6 \pm 0.75$ 時間。生活に支障を来たすジスキネジアの 無いオン時間LC IG投与前 $8.36 \pm 1.92$ 時間, LCIG投与後 $15.34 \pm 2.52$ 。1日当たりの 平均オフ時間, 生 活に支障を来たすジスキネジアを伴うオン時間は有意に短縮 $(\mathrm{p}<0.001)$ 。生 活に 支障を来たすジスキネジアの無いオン時間は有意に延長した $(\mathrm{p}<0.001)$ 【結論】LCIG療法52週間継続投与時においても既存のパーキンソン病 治療薬では改善が認められなかったウェリングオフ症状改善に有効であった。

0-12-1 Clinical trial of the effect of vestibular stimulation on balance disorders with Alzheimer's disease

Kiyotaka Nakamagoe ${ }^{1}$, Shiori Yamada ${ }^{1}$, Rio Kawakami,

Takami Maeno ${ }^{2}$, Tadachika Koganezawa ${ }^{3}$, Akira Tamaoka ${ }^{1}$ Department of Neurology, Division of Clinical Medicine, Faculty of Medicine, University of Tsukuba, Japan, ${ }^{2}$ Department of Primary Care and Medical Education, Division of Clinical Medicine, Faculty of Medicine, University of Tsukuba, Department of Physiology, Division of Biomedical

Objective: We showed that vestibular dysfunction derived from cerebral disorders contributes to balance disorders in a previous study on Alzheimer's disease (AD) (JAD 2015). No previous clinical study had attempted to prevent the progression of balance disorders in dementia patients through vestibular stimulation using an air caloric device. The purpose of this pilot study was to delay the progression of balance disorders by inducing vestibular compensation, specifically by utilizing the effect of vestibular stimulation to activate the cerebrum. Methods: Fifteen individuals were randomized and classified in a stimulation group or a non-stimulation group. Eight AD patients underwent vestibular stimulation every 2 weeks for 6 months in the stimulation group. Seven AD patients participated in the non-stimulation group (the control group). Both groups were subsequently evaluated using an MMSE, stepping test, caloric test, and smooth-pursuit eye movement test just before starting the study and 6 months later. Results: In the stepping test, the rate of decline tended to be larger in the non-stimulation group than in the stimulation group $(\eta 2=0.58)$. Moreover, the stimulation group's rate of decline in MMSE scores decreased more than did that of the non-stimulation group ( $\mathrm{p}=0.015, \eta^{2}=0.41$ ). Aside from the MMSE scores, the various tests showed no significant differences between the two groups. Conclusions: Repeated vestibular stimulation might delay the progression of functional impairment of the cerebrum and help patients retain greater balance and higher function. 
0-12-2 Neuronavigated transcranial magnetic stimulation for prodromal dementia with major depression

Hanna Lu, Sandra Chan, Sukling Ma, Vincent Mok, Lin Shi,
Defeng Wang, Linda Lam

The Chinese University of Hong Kong, Hong Kong SAR, China

Objective: This study aims to assess the safety and clinical efficacy of MRIguided repetitive transcranial magnetic stimulation (rTMS) in major neurocognitive disorder (NCD) patients with depression. Methods: We conducted a randomized, single blind, sham-controlled clinical trial (Registration ID: ChiCTR-IOR-16008191). Seniors diagnosed with DSM-5 major NCD comorbid treatment-resistant depression were randomly allocated to two groups for a 3-week intervention of either active rTMS $(10 \mathrm{~Hz})$ or sham rTMS. Individual structural MRI image was used to localize the stimulation targets (left dorsolateral prefrontal cortex, DLPFC) and guide the coil position during treatment. Depressive symptoms and cognitive function were evaluated at the baseline, $3^{\text {rd }}$ week, $6^{\text {th }}$ week and $12^{\text {th }}$ week. Results: The dropout rate of this trial was $13.3 \%(8 / 60)$. The demographics and baseline profile were comparable between two groups. Cornell Scale for Depression in Dementia (CSDD) was used to assess the severity of depressive symptoms and Montreal cognitive assessment (MoCA) was used to assess the cognitive function. After the intervention ( $3^{\text {rd }}$ week), both active rTMS and sham rTMS groups showed enhanced depressive symptoms and cognition. Compared to sham rTMS, active rTMS group had more mood enhancement $(\mathrm{p}=0.03)$ and cognitive gains $(p=0.02)$. Conclusion: Neuronavigated rTMS over left DLPFC showed significant and moderate effects on depressive symptoms and global cognition in prodromal dementia patients, which could last for 2 months. It should be noted the significant placebo effect in rTMS intervention.

\section{0-12-4 Clinical characteristics and CSF biomarkers in cerebral amyloid angiopathy-related inflammation}

Masaki Ikeda, Horoo Kasahara, Kouki Makioka, Kazuaki Nagashima, Yukio Fujita, Yoshio Ikeda

Department of Neurology, Gunma University Graduate School of Medicine, Japan

[Objective] Cerebral amyloid angiopathy-related inflammation (CAA-RI) occurs in association with vasculitis of small- and medium-sized leptomeningeal and cortical arteries. CAA-RI has been reported to present lobar cerebral microbleeds (CMBs), cortical superficial siderosis (cSS) and lobar cerebral hemorrhage (LCH) as cerebral amyloid angiopathy (CAA). [Methodsl Diagnostic criteria for CAA-RI was used the patients for Chung (2011) and modified by Auriel (2016). We examined distributions and the number of CMBs, cSS and LCH in 9 CAA-RI patients detecting MRI T2 WI. We measured CSF levels of A $\beta 1-42$, phosphorylated tau 181 (P-Tau) and total tau (T-Tau). We also compared the CSF levels of A $\beta 1-42$, P-Tau and T-Tau amongst age matched Alzheimer's disease $(\mathrm{AD})$ patients and non-dementia (ND) subjects. [Results] In 9 CAA RI patients, male dominancy was $33.3 \%$, age at onset was $70.0 \pm 9.7$ years-old. In them, 8 patients $(88.9 \%)$ showed lobar CMBs, 2 patients showed cSS $(22.2 \%)$ and none in LCH. CSF A $\beta 1-42$ levels of CAA-RI and AD were significantly lower than those of ND $(\mathrm{p}<0.0001$, respectively). CSF P-Tau levels of AD were significantly higher than those of CAA-RI and ND $(\mathrm{p}<0.0001$, respectively), while CSF P-Tau levels of CAA-RI were similar levels as ND without significant difference. CSF T-Tau levels of CAA-RI and AD were significantly higher than those of ND $(\mathrm{p}<0.0104, \mathrm{p}<0.0001$, respectively $)$. IConclusionsl In CAA-RI patients CSF T-tau is significantly higher than those of ND, but P-Tau is similar levels as those of ND, which CAA-RI might exist different vascular dysfunction from AD.

\section{0-12-6 Fully automated immunoassay system to measure plasma biomarkers for Alzheimer's disease}

OKazuto Yamashita ${ }^{1}$, Shunsuke Watanabe ${ }^{1}$, Takuya Iino, Takehiro Hasegawa, Masahiro Miura ${ }^{1}$, Toshihiro Watanabe ${ }^{1}$, Shigeki Iwanaga ${ }^{1}$, Amane Harada David Verbel ${ }^{2}$, Shobha Dhadda ${ }^{2}$, Hiroyuki Amino ${ }^{3}$, Mitsuhiro Ino,

Akihiko Koyama ${ }^{2}$, Takehiko Miyagawa, Tomokazu Yoshida

${ }^{1}$ Sysmex Corporation, Japan, ${ }^{2}$ Eisai Inc., ${ }^{3}$ Eisai Co. Ltd.

[Objective] To detect the clinical feature of Alzheimer's disease (AD), the deposition of amyloid beta (A $\beta)$ in the brain, amyloid PET and CSF test are often used. Currently, we developed fully automated plasma $\mathrm{A} \beta_{140}$ and $\mathrm{A} \beta_{142}$ immunoassay system (HISCL ${ }^{\mathrm{TM}}$ series). To assess the performance of our assay for the prediction of the deposition of A $\beta$ in brain using paired CSF and plasma samples or plasma samples from the Eisai Elenbecestat Phase 3 program. [Methods] Samples were commercially available paired CSF and plasma samples, or plasma samples with PET information from clinical trial subjects in screening with a clinical diagnosis of $\mathrm{MCI}$ and mild $\mathrm{AD}$ who underwent amyloid PET to confirm amyloid status. Amyloid status was determined by visual read of amyloid PET scan. To evaluate the overall performance, receiver operating characteristic (ROC) analysis was performed using logistic regression and calculated the area under the curve (AUC). The plasma A $\beta_{142}$ A $\beta_{1-40}$ ratio, as well as a model incorporating subject age and APOE4 status, were also evaluated in separate analyses. [Results] Plasma $\mathrm{A} \beta_{1-42} / \mathrm{A} \beta_{1-40}$ ratio measured by our system predicted Amyloid PET positivity with an AUC of 0.74 Including age and APOE4 status, in addition to the plasma $\mathrm{A} \beta_{1-42} / \mathrm{A} \beta_{1-40}$ ratio as predictors, the model increased the overall performance to an AUC of 0.82 [Conclusions] We have observed plasma $\mathrm{A} \beta_{1-42} / \mathrm{A} \beta_{1-40}$ ratio measured by our fully automated immunoassay system can predict $\mathrm{A} \beta$ deposition in the brain This result indicates our system could be a screening method for amyloid PET.
0-12-3 withdrawn

\section{0-12-5 Cerebrospinal fluid and plasma biomarkers in neurodegenerative diseases}

Takeshi Kawarabayashi ${ }^{1,2}$, Yusuke Seino ${ }^{3}$, Takumi Nakamura ${ }^{2}$ Masamitsu Takatama ${ }^{1}$, Mikio Shoji ${ }^{1}$

${ }^{1}$ Department of Neurology, Geriatrics Research Institute and Hospital, Japan, Department of Neurology, Gunma University Hospital, Japan, ${ }^{3}$ Department of Neurology, Hirosaki National Hospital

[Objective] Cerebrospinal fluid (CSF) amyloid- $\beta$ (A $\beta$ ) 42 and tau are biomarkers for Alzheimer's disease (AD); however, the effects of other neurodegenerative processes on these biomarkers remain unclear. We measured biomarkers in CSF and plasma using matched samples from various neurodegenerative diseases to expand our basic knowledge on these biomarkers and their practical applications. Next, we developed novel ELISA assays for tau (t-tau), and tau phosphorylated at threonine 181 (p181tau). [Methods] A $\beta 40, \mathrm{~A} \beta 42$, t-tau, p181tau, and $\alpha$ -synuclein were measured using a total of $213 \mathrm{CSF}$ and 183 plasma samples including cognitively unimpaired subjects, patients with AD dementia (ADD), mild cognitive impairment (MCI), non-AD dementias, and other neurological diseases. T-tau and pl81tau by novel ELISAs were measured using $72 \mathrm{CSF}$ samples from patients with ADD and various neurodegenerative diseases. [Results] Significantly decreased A $\beta 42$ levels and an increased A $\beta 40 / 42$ ratio were found in CSF in ADD/MCI. T-tau levels were increased in ADD/MCI, encephalopathy, and MSA, and p181tau levels were increased in ADD/MCI. There was no merit in measuring a-synuclein in CSF or plasma as a biomarker for PD and MSA. Our t-tau and p181tau assay system showed good correlations with widely used ELISA systems for t-tau and p181tau, and showed that serum and hemoglobin contamination in CSF samples did not decrease sensitivity. [Conclusions] CSF A $\beta 40, \mathrm{~A} \beta 42$, p181tau, and t-tau were identified as biomarkers for AD. Our ELISAs were reliable assays for CSF t-tau and p181tau similar to commonly used ELISAs.

\section{0-12-7 Graph theoretical analysis of structural brain network of Alzheimer's disease patients}

OHiroyuki Maruoka ${ }^{1}$, Takaaki Hattori ${ }^{1}$, Satoshi Orimo ${ }^{2}$,

Takanori Yokota

${ }^{1}$ Department of neurology and neurological science, Tokyo medical and dental university, Japan, ${ }^{2}$ Department of nuerology, Kanto central hospital

Objective : Alzheimer's disease (AD) accumulates amyloid- $\beta$ and tau protein in brain, resulting in morphological changes in certain areas of brain. We aimed to identify the alteration of structural networks in AD patients by using graph theoretical analysis for 3 dimensional-T1 weighted image (3DT1). Method : 3DT1 brain MRI images were acquired from 41 control (CN) subjects and 127 AD patients. 3DT1 MRI images were analyzed by using the "Freesurfer v6.0.0". All brain cortices were parcellated into 68 region of interest (ROI). Five morphometric features (surface area, gray matter volume, cortical thickness, mean curvature, folding index) were extracted for each ROI and used as feature vectors. Pearson's correlation coefficients were calculated for each feature vector pair, and a correlation matrix was created. The correlation matrix was binarized by using a threshold, and then an individual network was constructed. The correlation coefficients were compared between groups. Graph theoretical measures were also evaluated. Result: Mean of all correlation coefficients was significantly increased in $\mathrm{AD}$ group than $\mathrm{CN}$ group. The correlation coefficients between left entorhinal cortex and other ROIs were increased in AD group. Among graph theoretical measures, assortativity was decreased in the AD group than $\mathrm{CN}$ group. Conclusion : Our results suggest that certain structural networks are degenerated over AD progression. Assortativity, an index of resilience, may be associated with degeneration and compensatory process of AD. 
0-12-8 Impaired dopamine release response in the NAcc is in the center of "binge-like eating" mechanism

$\bigcirc$ Yusuke Fujioka ${ }^{1}$, Kaori Kawai ${ }^{1}$, Kuniyuki Endo ${ }^{1}$, Minaka Ishibashi ${ }^{2}$, Satoshi Yokoi ${ }^{1}$, Nobuyuki Iwade ${ }^{1}$, Masahisa Katsuno,

Hirohisa Watanabe ${ }^{3}$, Shinsuke Ishigaki $i^{1,2,4}$, Gen Sobue ${ }^{2.3}$

${ }^{1}$ Department of Neurology, Nagoya University Graduate School of Medicine, Japan, ${ }^{2}$ Research Division of Dementia and Neurodegenerative Disease. Nagoya University Graduate School of Medicine, ${ }^{3}$ Department of Neurology,
Naterative Fujita Health University, ${ }^{4}$ Brain and Mind Research Center, Nagoya University, ${ }^{5}$ Aichi Medical University

[Background and Aim] "Binge-like eating" is caused by various stresses or disease conditions including some neurodegenerative diseases such as FTLD as well as psychiatric disorders. Despite those clinical etiology, the precise mechanism of "binge-like eating" has yet to be clarified. In animal models, it has been usually assessed by body weight increase, daily consumption of food, and preference to a certain palatable food or opioid. However, these methods are complicated and not enough sensitive to detect subtle abnormalities. Herein, we aimed to clarify the mechanism of "binge-like eating" by establishing a real-time monitoring system of eating behaviors. [Method and Result] We prepared two binge-like eating models, the mice pretreated with intermittent high-fat-diet and the mice under single-housing stress. The real-time monitoring system revealed binge pattern behaviors in both model mice prior to an increase in body weight or daily intake. Microdialysis revealed impaired dopamine (DA) release response to feeding at the nucleus accumbens (NAcc) shell. Interestingly, the abnormal eating behaviors of both models were recovered by administration of DA to NAc shell. Moreover, the specific inactivation of DA neurons in VTA projecting to NAcc shell by DREADD recapitulated binge patterns. [Conclusion] Impaired dopamine release response in the NAcc is in the center of "binge-like eating" mechanism. Our real-time monitoring system is a promising tool to detect subtle abnormalities and it can be a biomarker for various neurological and psychiatric disorders and stress conditions.

\section{0-12-10 Evaluation of 20 years of CJD surveillance in Hokkaido, the northern-island of Japan}

OShinsuke Hamada ${ }^{1}$, Ichiro Yabe ${ }^{2}$, Ikuko Iwata ${ }^{2}$, Katsuya Satoh ${ }^{3}$, Tetsuyuki Kitamoto ${ }^{4}$, Hidehiro Mizusawa ${ }^{5}$, Fumio Moriwaka ${ }^{1}$, Hidenao Sasaki ${ }^{2}$

${ }^{1}$ Hokuyukai Neurological Hospital, Japan, ${ }^{2}$ Department of Neurology, Faculty of Medicine and Graduate School of Medicine, Hokkaido University, ${ }^{3}$ Department of Locomotive Rehabilitation Sciences . Nagasaki University Graduate School of Medicine, ${ }^{4}$ Division of CJD Science and Technology, Department of Prion Research , Center for Translational and Advanced Animal Research on Human Diseases, Tohoku University School of Medicine, ${ }^{5}$ National Center of Neurology and Psychiatry

[Objective] We report the incidence of human prion diseases in Hokkaido, the northernisland of Japan. This is the first study to report such a comprehensive verification. [Methods We analysed the epidemiological data and clinical features of cases with prion diseases that had been registered by the Creutzfeldt-Jakob Disease (CJD) Surveillance Committee Japan. [Results] We conducted a surveillance survey of 332 cases (1999-2018) and confirmed CJD in 241. Of these, 187, 38, 14 and 2 cases were of sporadic CJD, genetic CJD, dura matter graft-associated CJD, and unclassified CJD, respectively. The incidence rate of CJD (new cases/1,000,000/year) in Hokkaido 2.24 (average of 1999-2018) is higher than the national incidence rate of 0.85 (average of 1999-2008). It also showed an increase rates over time (1999$2003: 1.23,2004-2008: 2.30,2009-2013: 2.53$ and 2014-2018 $: 2.90$ ). [Conclusion] The increasing incidence rates of CJD in Hokkaido are disclosed and the establishment of a surveillance cooperation system and increased awareness of the diseases may have contributed the diagnostic range of CJD. In the present study, we confirmed a familial case of 5-octapeptide repeat insertion presenting dementia and parkinsonism, that is similar to frontotemporal dementia with extremely gradual progress. This work contributes to the prevention of onset risk factors and infections for CJD in Hokkaido, as well as diagnosis of dementia.

\section{0-13-2 Observational study on nusinersen \pm cybernic treatment} with $\mathrm{HAL}^{\circledR}$ for gait function in patients with $\mathrm{SMA}$

Takashi Nakajima ${ }^{1}$, Toshio Saito ${ }^{2}$, Nakabayashi Taiki ${ }^{3}$,

Kazuki Kodera ${ }^{3}$, Kota Utsumi ${ }^{1}$, Takeshi Kanayama ${ }^{1}$, Haruka Urabe ${ }^{1}$ ${ }^{1}$ Department of Neurology, National Hospital Organization Niigata National Hospital, Japan, ${ }^{2}$ Department of Neurology, National Hospital Organization Osaka Toneyama Medical Center, ${ }^{3}$ Department of Paediatrics, National Hospital Organization Niigata National Hospital

[Objective] We assess whether ambulatory function of patients with spinal muscular atrophy (SMA) is enhanced by combining nusinersen, a splicing modifier of SMN2 gene expression, with cybernic treatment using a cyborg-type robot, Hybrid Assistive Limb ${ }^{\circledR}\left(\mathrm{HAL}^{\circledR}\right)$. [Methods] In this ongoing, multicentre observational study (JMA-IIA00400), patients with late-onset SMA (Type II III, or IV; >40 months after onset) receiving nusinersen are assigned to $\mathrm{HAL}^{2}$ (Group 1) or standard rehabilitation (Group 2), depending on $\mathrm{HAL}^{\circledR}$ availability at the clinical sites. The primary endpoint is the change in the 2-minute walk tes (2MWT) at 15 months after baseline. Other endpoints include maximum walking speed, 6-minute walk test, Hammersmith Functional Motor Scale Expanded (HFMSE), Revised Upper Limb Module, Functional Independence Measure, and Patient Reported Outcomes (PedsQL, Decision Regret Scale) at 15 months. [Results] 10 patients (Type II/III, n=4/6, 7-65 years old) have been enrolled; 5 patients in each group. Currently, the observational period has been 10-24 months. The current data showed improvement of 2MWT and $\triangle$ HFMSE $\geqq 3$ in all cases in Group 1 when comparing before and after using $\mathrm{HAL}^{\circledR}$, while the scores displayed heterogeneous changes in Group 2. [Conclusions] We will analyze 12 patients with late-onset SMA who are receiving nusinersen in the observational study. In the real-world clinical environment, we are trying to confirm whether the treatment effect of nusinersen on physical function can be enhanced by cybernic treatment.
0-12-9 Positive association between cognitive function and cerebrospinal fluid orexin A levels in AD

Soichiro Shimizu ${ }^{1}$, Yuta Inagawa ${ }^{1}$, Naoto Takenoshita ${ }^{1}$,

Daisuke Hirose ${ }^{1}$, Kentaro Hirao $^{1}$, Hidekazu Kanetaka ${ }^{1}$,

Takashi Kanbayashi ${ }^{2}$, Hirofumi Sakurai ${ }^{1}$, Haruo Hanyu

${ }^{1}$ Tokyo Medical University, Geriatric Medicine, Japan, ${ }^{2}$ International

Institute for Integrative Sleep Medicine (WPI-IIIS), University of Tsukuba

[Objective] Recently, many studies have investigated the association between orexin A and Alzheimer disease (AD). However, it remains to be determined whether the observed changes in orexin A levels are associated with pathological changes underlying $\mathrm{AD}$, or cognitive function. In particular, a direct association between cerebrospinal fluid (CSF) orexin A levels and cognitive function has not been reported to date. The aim of this study was to identify whether there is a direct association between the orexinergic system and cognitive function in $\mathrm{AD}$. [Methods] For this study, we included 22 patients with AD and 25 control subjects who underwent general physical, neurological, and psychiatric examinations, neuroimaging, and CSF collection by lumbar puncture were enrolled. Correlations between CSF orexin A levels and CSF AD biomarker levels (i.e., levels of phosphorylated tau [p-taul, $\mathrm{A} \beta_{42}$, and $\mathrm{A} \beta_{42} / \mathrm{A} \beta_{40}$ ) were assessed to confirm the results of previous studies. Moreover, the correlation between CSF orexin A levels and Mini Mental State Examination (MMSE) and Japanese version of the Montreal Cognitive Assessment (MoCA-J) scores were analyzed. [Results] There was a significant positive correlation between CSF orexin-A levels and cognitive function in $\mathrm{AD}$ patients.[Conclusions] This is the first study to our knowledge demonstrating an association between cognitive function and CSF orexin A levels in $\mathrm{AD}$. Our results suggest the possibility that orexinergic system overexpression is not always a negative factor for cognitive function In AD.

0-13-1 withdrawn

\section{0-13-3 Genetic analysis of adult leukoencephalopathies}

OHiroshi Doi ${ }^{1}$, Masaki Okubo ${ }^{1}$, Misako Kunii ${ }^{1}$, Hitaru Kishida ${ }^{2}$, Keita Takahashi ${ }^{1}$ Atsuko Katsumoto ${ }^{1}$, Mikiko Tada ${ }^{1}$, Atsushi Fujita ${ }^{3}$, Satomi Mitsuhashi ${ }^{3}$ Satoko Miyatake ${ }^{3}$, Yasuhiro Ito ${ }^{4}$, Naohisa Ueda ${ }^{2}$, Shigeru Koyano ${ }^{1,5}$, Hideyuki Takeuchi ${ }^{1}$, Naomichi Matsumoto ${ }^{3}$, Fumiaki Tanaka ${ }^{1}$ ${ }^{1}$ Department of Neurology and Stroke Medicine, Yokohama City University School of Medicine, Japan, ${ }^{2}$ Department of Neurology, Yokohama City University Medical Center, ${ }^{3}$ Department of Human Genetics, Yokohama Memorial Hospital, ${ }^{5}$ Department of Neurology, Yokohama Minami Kyosa Hospital

[Background] Leukoencephalopathies comprise a broad spectrum of disorders, but the genetic background of adult leukoencephalopathies has rarely been assessed. [Methods] We analyzed 110 Japanese patients with genetically unresolved adult leukoencephalopathy using custom-designed gene panel (CDGP), whole-exome sequencing (WES) and repeat-primed PCR (RP-PCR) for detecting GGC expansion in NOTCH2NLC, which was recently identified as the cause of neuronal intranuclear inclusion disease (NIID). As for CDGP and WES, the patients with "likely pathogenic and "pathogenic" variants were picked up according to American College of Medical Genetics (ACMG) guidelines. The patients were widely recruited from the neurology department of our hospital and its affiliated facilities. Only index cases were examined in the pedigree. Patients with apparent acquired diseases/conditions were excluded. [Results] As the results of CDGP and WES, we found 11 patients with "likely pathogenic" / "pathogenic" NOTCH3 variants as the major cause of adult leukoencephalopathy detectable by short-read sequencing. In addition, "likely pathogenic" / "pathogenic" CSF1R, EIF2B2, POLR3A, L2HGDH and TUBB4 variants were found independently in one patient. Employing RP-PCR, we found 12 patients with GGC expansion in NOTCH2NLC, the most frequent cause of adult leukoencephalopathy in our cohort. [Conclusion] NIID and CADASIL are two major causes of Japanese adult non-acquired leukoencephalopathy. 


\section{0-13-4 a Novel Mutation in a New Area of TRPV4 Gene in a CMT2C Family}

Hui Wang, Lingchao Meng, Jianwen Deng, He Lv, Wei Zhang, Zhaoxia Wang, Yun Yuan

Peking University First Hospital, China

Objective:To report a family of CMT type $2 \mathrm{C}$ caused by mutation of a new area of TRPV4 gene. Methods:We performed clinical evaluation, electrophysiology, nerve ultrasound, nerve root MR of the proband. Genetic analysis was performed in the family members. Results: The affected member of the family exhibited motor and sensory axonal neuropathy. The proband showed abnormal gait and poor running activity with muscle atrophy in thenar and interosseus muscles and mild pes cavus. Distal muscle weakness and hypaesthesia appeared in upper and lower extremities. Electrophysiology examination showed mild decrease in left and right median nerve conduction with declined $\mathrm{F}$ wave. More severe clinical manifestation and electrophysiology results were displayed in his mother. However, no vocal cord paresis or diaphragm involvement or short stature was discovered in any member of the family. A novel p.P838_P844del mutation in the TRPV4 gene was identified in the family. Nerve pathology indicated active axonal peripheral neuropathy. This mutation was in the last exon. There is no functional domain in this area of the protein. Conclusions: Mutations in different regions in TRPV4 gene may lead to variable phenotypes. It is likely that beyond the ANK domains, transmembrane domains and areas of interaction with calmodulin and ITPR3, there is certain functional regions in the $\mathrm{C}$-terminal of the protein.

\section{0-13-6 withdrawn}

0-13-8 withdrawn

\section{0-13-5 Hetereoduplex oligonucleotides technology improves therapeutic index for CNS diseases}

$\bigcirc$ Chunyan Jia, Kotaro Yoshioka, Su Su Lei Mon, Kie Tanaka, Tetsuya Nagata, Takanori Yokota

Department of Neurology and Neurological Science, Tokyo Medical and Dental University, Japan

Objective: ASOs (antisense oligonucleotides) with direct injection into CSF space have been developed for treatment of intractable CNS diseases. Recently, one of ASOs, nusinersen, was approved by PMDA for spinal muscular atrophy. However, CNS toxicities of ASOs are one of main obstacles for generally clinical application. We have developed brand-new technology of ASOs, hetereoduplex oligonucleotides (HDOs) which are double-stranded nucleic acids. In the present study, we applied this HDO technology to ASO-treatments with intracerebroventricular (ICV) administration to diminish CNS toxicities without reducing activities of ASOs Materials and Methods: We designed various HDOs using ASOs which silence target RNAs highly but have severe and lethal CNS toxicity, with a variety of modifications in the complementary strands. We then injected these HDOs and the parent single-stranded ASOs into wild type mice $(n=4)$ via ICV route to assess silencing efficacy and severity of acute CNS toxicity from phenotypic behaviors of mice using Roche tolerability scoring system (RTSS). Results: RTSS scores of Mice treated with HDOs significantly reduced to less than one-third of those with the parent ASOs. Moreover, we revealed optimal structures of HDOs which enabled almost no toxicity and equal or greater efficacy of silencing the target RNAs to compare with the parent ASOs. Conclusion: HDO-technology achieved dramatic improvements of CNS toxicities of the single-stranded ASOs without losing those potencies and consequently provides promising future in nucleic acid therapy for CNS disease.

\section{0-13-7 Clinical and molecular genetic studies on a} Filipino Family with a Peculiar Muscle Disease

OKristine Joyce L. Porto ${ }^{1,2}$, Sheryl Zamora ${ }^{3}$, Marvin Zamora ${ }^{3}$,

Jun Mitsui ${ }^{1}$, Hiroyuki Ishiura ${ }^{1}$, Tatsushi Toda ${ }^{1}$, Shoji Tsuji, ${ }^{1,4}$

${ }^{1}$ Department of Molecular Neurology, The University of Tokyo, Japan, ${ }^{2}$ St.

Luke's Medical Center, Philippines, ${ }^{3}$ Premiere Medical Center, Philippines,

International University of Health and Welfare

Objective: To present a peculiar case of muscle disease in a Filipino family Method: Case-series Results: The proband is a 48y.o, Filipino male, from a non-consanguineous marriage, presenting at $17 \mathrm{y} .0$ with progressive proximal weakness. At 46y.o, he experienced difficulty of breathing, necessitating BiPAP all day, but non-compliance led to multiple ICU admissions. The examination was pertinent for proximal extremity weakness with scapular winging and absent gag reflex; facial and extraocular muscles were spared. His CK level was normal. Further investigation revealed affected family members with an unusual form of weakness that persisted through 4 generations. The pattern of inheritance seemed to be autosomal dominant; but we couldn't exclude X-linked inheritance with confidence. Fourteen were affected; 9 were alive. There is highly variable proximal extremity weakness. The mean onset was 36y.o (18$74 \mathrm{y} .0$ ). Four of the 9 surviving affected individuals were males (mean 50y.o), and mean onset was 20y.o. The females (mean 69y.o) had a later onset (mean 51 y.o). The proband died at 49 y.o, before any muscle biopsy was done, due to severe respiratory failure. We did mutational analysis for the following genes: LMNA, EMD, FHL-1, and GAA and no pathogenic mutation was seen. CNV analysis aCGH revealed no pathology. The WES results of the proband showed no pathogenic mutation in all genes causing myopathy. Conclusion: We report an unsual case of myopathy in a Filipino family. Further genetic analysis like linkage analysis and whole genome sequence analysis should be performed.

\section{0-13-9 A family of autosomal recessive amyotrophic lateral sclerosis with CFAP410 variant}

Takashi Kurashige ${ }^{1}$, Hiroyuki Morino ${ }^{2}$, Yukiko Matsuda ${ }^{2}$, Tomoya Mukai, ${ }^{3}$ Tomomi Murao ${ }^{1}$, Megumi Toko $^{4}$, Kodai Kume ${ }^{2}$, Ryosuke Ohsawa ${ }^{2}$, Tsuyoshi Torii ${ }^{1}$, Hiroshi Tokinobu ${ }^{3}$ Hirofumi Maruyama ${ }^{4}$, Hideshi Kawakami ${ }^{2}$

${ }^{1}$ National Hospital Organization Kure Medical Center and Chugoku Cancer Center, Japan, ${ }^{2}$ Department of Epidemiology, Hiroshima University Research Institute of Radiation Biology and Medicine, ${ }^{3}$ Department of Neurology, Hiroshima Prefectural Hospital, ${ }^{4}$ Department of Clinical Neuroscience and Therapeutics, Hiroshima University Graduate School of Biomedical and Health Sciences

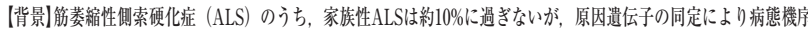
の解明が進んでいる。これまでにALS1 23・ALSFTD1〜6の他にも多くの疾患感受性遗伝子があり，その1つ

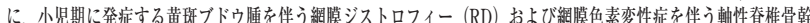
端異形成症 (SMDAX) の原因遗伝子であるCFAP410 (Cilia- and flagella-associated protein 410) がある.しかし， CFAP410を原因遗伝子とする遗伝性ALSの報告はこれまでにない。(目的·方法劣性遗伝性ALSO原因遗伝子を 同定するために遺伝学的解析を行った，対象となる家系は雨親が血族結婚のALS姉妹例で，発症者2名を含む同胞 3名に高密度SNPタイピングを行い，Homozygosity Fingerprintingによって同柤染色体領域を解析したままた発 症者2名にエクソームシーケンスを行い，BWAにてマッピングしGATKなどのソフトウェアを用いてvariantをコー ルした. [結果】Homozygosity Fingerprintingでは1番，12番，15番，21番に同相染色体領域を認めた。エクリー ムシーケンスから得られたvariantにフイルタリングを行った結果，発症者2名に共通するホモ接合性のvariantが 53個得られ，同祖染色体領域に存在する遗伝子変異としてCFAP410の) leucine-rich repeat C-terminal domainに (c.319T>C, p.Y107H) を認めた. 臨床的には発症者2名ともAwaji criteriaのprobableに該当するUMN/LMN徎候を 有しており，さらに，運動症状に先行して網獏色素変性症を呈していたことが特微的であった，非発症同胞には神 経学的・眼科的・整形外科的な異常所見は一切認めな⿰力口た。【考察]CFAP410のvariantをへテ口接合性に有寸る

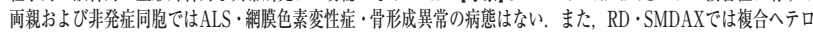
接合でvariantを有することから，CFAP410はホモ接合性で劣珄遗云性のALS原因遺伝子となっていると考えた。 
0-13-10 Search for new candidate genes for ALS by textmining and exome analysis of autopsy cases

OYuya Hatano', Tomohiko Ishihara ${ }^{1}$, Akio Yokoseki', Mari Tada ${ }^{3}$, Akiyoshi Kakita ${ }^{3}$, Shujiro Okuda ${ }^{4}$, Osamu Onodera

${ }^{1}$ Department of Neurology, Brain Research Institute, Niigata University, Japan, ${ }^{2}$ Center for Inter-Organ Communication Research, Niigata University Graduate School of Medical and Dental Sciences, Niigata University. ${ }_{3}^{3}$ raduate School of Medical and Dental Sciences, Niigata University, Department of Pathology, Brain Research Institute, Niigata University, and Dental Sciences, Niigata University

[Objective] More than 30 causal genes have been identified in amyotrophic lateral sclerosis (ALS), and many of them are RNA binding proteins (RBP). Recently, a new method for searching disease related gene using the text mining method has been reported (Bakkar N, et al. Acta Neuropathol. 2018). To clarify the usefulness of this method, we conducted a new ALS causal gene search using the similar method. [Methods] We used the two text mining method, Word2vec and fastText, which quantified semantic relationships of words. We analyzed 163948 abstracts of RBP-related papers published from 2000 to 2019 by word2vec and fastText. We ranked 1164 RBP according to the similarity of 11 RBP genes known to cause ALS, and the top 10 genes in the word2vec or fastText ranking data were selected as ALS candidate genes. We confirmed whether 137 consecutive sporadic ALS cases in our institute had mutation of these genes by exome analysis. [Results] Sixteen genes were found a ALS candidate genes. In 11 out of 137 ALS cases, we found nonsynonymous rare variants (minor allele frequency $<0.001$ ) in 7 of the 16 ALS candidate genes. Furthermore, we found that cases with these rare variants had shorter survival time than those without rare variants of these and ALS known causative genes ( $\mathrm{p}=0.03$ ) (median survival time : 19 vs 28 months). [Conclusion] New pathogenic gene search using text mining is expected to develop as a new method. Future studies should evaluate whether genetic mutations are truly a causative factor, by analysis in familial ALS cases, pathological and biochemical analysis.

\section{0-14-2 ALS診断におけるRNS漸減応答とNCS APB/ADM比 の有用性に関する検討}

杉本 太路1、黑川 勝己 2 石川 若芸、林 正裕、峰 奈保子 ${ }^{1}$ 内藤 裕之主、野村 栄一! 兄脇 健盛

1 広島市立広島市民病院 脳神経内科、

川崎医科大学総合医療センター脳神経内科

【目的】筋萎縮性側索硬化症 (ALS) 診断で反復刺激試験 (RNS) の潄減応答 (decrement)

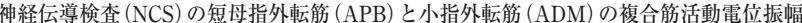
比（APB/ADM比）低下は知られているが、両者を組以合わせた場合の検討報告はあま り行われていない。ALS診断に伴う両検查の有用性を後方視的に换討した。【方法】対象 は2017年7月から 2019年10月までに当院でALSと診断した連絸例でRNS穾施例とした。 Updated Awaji診断基準に加え進行性筋萎綰症（PMA）を含むこととし、経過からALS に矛盾しない症例を解析対象とした。 RNS対象筋はAPB、ADM、前頭筋 (Fro)、僧帽筋 (Trap)、三角筋（Del）で少なくとも1筋は䒠施したDecrement10\%以上、APB/ADN 比 0.6 未满をそれぞれ陽性 $(+)$ とした。[結果]連続44例のうちRNS未実施1例、他院骖断 3 例を除外した41例を解析対象とした。Updated Awaji基準でdefinite 4例、probable 17 例、probable laboratory-supported 2例、possible 13例、PMA 5例であった。発症時 年齢69 12 歳、初発症状領域別でupper-limbを含む（include U) 19例、それ以外22例 (bulbar 6例、lower-limb14例、その他例)、罪病期問はRNS䒠施時平均 $398 \pm 414$ 日、初 診からALS診断までは96さ211日であった。初診から骖断までの日数に初発症状別で有 意差はなかった。いずれかの管でdecrement+であった症例は24例（59\%）で、部位別で はAPB6例 (16\%)、ADM4例 (10\%)、Fro0例 (0\%)、Trap14例 (34\%)、Del20例 (51\%)であっ た。 NCSは34例で害施LAPB/ADM比+症例は16例(47\%)であった。 decrement十あるい はAPB/ADM比+の症例は全体で28例 $(68 \%$ )、初発症状による分類別でinclude U 17 例 $(89 \%)$ 、それ以外1例(50\%)であり有意であった $(p<0.01)$ [結論]初発症状でupper-limb 症状を含むALS患者では診断に伴いdecrement+あるいはAPB/ADM比+の少なくとも どちらか一方を認める場合が多く、两検查の所見は参考所見として相互補完しうる

\section{0-14-4 ALSにおける正中神経刺激体性感覚誘発電位の N20-P25 増高は病態に関連した現象か?}

\author{
○清水 俊夫、木田 耕太、木村 英紀、森島 亮、川添 僚也、 \\ 原田 龍平、磯崎 英治 \\ 都立神経病院 脳神経内科
}

[背景]筋萎縮性側索硬化症 (ALS) に㧍いては，病初期に正中神経刺激体性感営誘 発電位 (SEP) の早期頭頂葉成分であるN20-P25の振幅が增大し, 生命予後と関連 していることが報告された。一次感覚野の興奮性增大は, ALSの病態と関連し て抢り，初期の神経変性を反映している可能性がある。【目的】N20-P25の増高が， ALSに特徽的な現象かどうかを梌討するため, 各神経疾患（袖経変性疾患，盼骬 性疾患, neuropathy, myelopathy, myopathy, てんかん等) におけるN20-P25の 增高 (giant SEP) の頻度を検討し，その臨床的意義について考察する。[方法]当院 て2010年1月～12月にSEP検查をした連続370例，2010年〜2015年に検查を行った ALS 140例，および健常者124例を対象とした。正中神経刺激SEPは，手首にて 動間值上刺激を刺激強度とし, 記塗電極は第5䅡椎棘突起挹上び対側頭皮 $\mathrm{CP}$, 基 潐電極はFzに置き５Hz，250回刺激して加算平均した。疾患ごとにN20-P25振幅 N13-P20の中枢伝導時間を健常対照群と比較した (Student's t-test)。[結果]進行性 ミオクローヌスてんかん1例では巨大なN20-P25を示した。疾患群としてはALSO 久が有意な $20-\mathrm{P} 25$ の振幅增大を示した $(\mathrm{p}<0.0001)$ 。逆に呼吸器装着下の進行期 ALS, ジストニア疾患，中枢脱榷性疾患，myelopathy，neuropathyでは有意な 減少を示した。枢伝道時間は准行期ALSの及有音な延長を呈した（ $\mathrm{p}=0.0286) 。$ 【結論病初期ALSにおけるN20-P25の振幅増大は疾患の病態に関連した現象であ り,ALS初期病変による感覚野の興古性增大を示している。また進行期ALSの振 幅の低下は, 疾患の進行に伴う中枢感営路の変性を反映している可能性がある。

\section{0-14-1 筋萎縮性側索硬化症の閾値追跡経頭蓋 2 連発磁気刺激 検査による上位運動ニューロン評価}

○渉谷 和幹、鈴木 陽一、三澤 園子、水地 智基、常山 篤子、

千葉大学病院 脑神経内科

【目的】筋菱縮症側索硬化症 (ALS) における上位運動ニューロン障害の評価は、神 経診察以外にはない。閥值追跡経頭蓋 2 連発磁気刺激検查 (TT-TMS) は、運動皮 質興曾性を詳細に評価できる検查手法であり、ALSにおける上位運動ニューロン 障害の代替的評価手法として注目されている。しかしTT-TMS検查所見と、䠦 床・生理学的所見との関倸を詳細に検討した報告はない。【方法】ALS患者30名に TT-TMSを実施し、健常者（NC）26名の結果と比較した。年齢、性別、䍜病期 間、初発症状、上位運動ニューロン微侯の程度 (UMNスコア)、機能評価スケー ル (ALSFRS-R)、複合筋活動電位 (CMAP) 振幅と、TT-TMS所見との関係を検討 した。【結果】患者背景は、平均年齢69歳、平均䍜病期間19か月、男性13名、球発 症10名であった。TT-TMSによるALS診断において有用とされるaveraged short interval intracortical inhibition (SICI) (1-7ms)は、ALSで有意に低下していた $<0.01$ )。ALS患者に扔いて、年齢、性別、䍜病期間、初発症状、UMNスコア、 ALSFRS-R、CMAP振幅と averaged SICI (1-7ms) との間に、有意な相関関倸や差 異は認められなかった。上位運動ニューロン街候を検出しなかった例において も、 averaged SICI (1-7ms) の低下を認めた。【結論】TT-TMSは日本人ALSにおい ても、上位運動ニューロン機能障害の検出に有用な可能性がある。SICIと上位運 動ニューロン徵候に相関が認められなかった原因として、運動皮質興奮性と錐体 路の障害が並行しない可能性や、下位運動ニューロン障害により上位運動ニュー ロン街候がマスクされている可能性が考えられた。今後症例数を增やし、さらな る検討が必要と考える。

\section{0-14-3 筋萎縮性側索硬化症患者への栄養療法 -新たな予測 式に基づく介入の有効性について-}

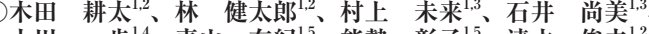 \\ 小川 一歩 ${ }^{1,4}$ 、青山 有紀 ${ }^{1,5}$ 、能勢 彰子 ${ }^{1,5}$ 、清水 俊夫 犬 $^{1,2}$ \\ 都立神経病院 栄羑サポートチーム、2 都立神経病院 脳神経内科、 \\ 都立神経病院 看護科、“都立多摩総合医療センター 薬剂科、 \\ 都立神経病院 栄養科
}

【背景】筋萎縮性側索硬化症(ALS)において病初期の体重減少は独立した予後予測因子であ る. 従来のRMR-HB (Harris-Benedictの基硕代謝量) x活動係数 $\mathrm{x}$ ストレス係数での必要エ ネルギー量予測では, 実際の必要エネルギー量との乘離があり, 体重隇少が持続する症例 が散見された，そこでALS患者の実際のエネルギー代謝について二重標識水を用いて計測 し，それを元に算出した必要エネルギー量の予測式TEE $(\mathrm{kcal} / \mathrm{d})=(1.67 \times \mathrm{RMR}-\mathrm{HB})+$ (11.8 x ALSFRS) -680が示された (Shimuzu, et al. ALSFTD, 2018). 目的にの予測式 （Shimizuの式）を用いた予測必要エネルギー量に基づいた介入前後の栄養摂取量の変化に ついて検討する.【方法】平成 30 年度に当院栄養サポートチーム (NST) が介入し, Shimizu の式を用いて必要エネルギー量を算出したALS患者26例のうち気管切開後, 終日非侵襲的 陽圧人工呼吸, 緩和ヶアへ移行した患者を除いた19例を対象とした。介入時の摂取エネル ギー量がShimizuの式を用いた予測必要エネルギー量より低かった群 (低エネルギー群) と 高かった群 (高エネルギー群)の二群について各々介入時体重, 介入時摄取エネルギー量, 退院時摄取エネルギー量, 退院時と介入時摂取エネルギー量の差について比較した。さう に従来の予測式に基づいて介入を行った平成 29 年度を対照とした.【結果】介入時搷取エネ ルギー量, 退院時掑取エネルギー量は低エネルギー群で有意に低值であったが, 低エネル ギー群の退院時㠌取エネルギー量は, 介入と比較して有意に増加していた $(\mathrm{p}=0.0243)$. 方，高エネルギー群では介入による有意な変化はなかった $(\mathrm{p}=0.3860)$ ，なお，29年度は 両群ともに介入前後での摂取エネルギー量に変化が見られなかった、結論】ALS患者の実 際のエネルギー代謝に基づいて求められたShimizuの式は, ALS患者の必要エネルギー量 を予測し，栄養掑取が不良な患者の摂取エネルギー量を改善させる上で有効である。

\section{0-14-5 臨床経過よりGlobular glial tauopathyを疑った 3 症例の検討}

○茂木 晴彦、大本 周作 ${ }^{1} 、$ 向井 泰司 ${ }^{2}$ 、幕 昂大 ${ }^{1}$ 高橋 麻葵 1 秋山 志穂 ${ }^{1}$ 高津 宏樹 ${ }^{1} 、$ 佐藤 健朗 ${ }^{1}$ 、小松 鉄平 ${ }^{1}$ 、坂井健一郎 ${ }^{1}$ 、 梅原淳 ${ }^{1}$ 至村 秀毅、村上 秀友 ${ }^{1}$ 、井口 保之 ${ }^{1}$

東京慈恵会医科大学附属病院 神経内科、

東京慈恵会医科大学附属柏病院 神経内科

【目的】Globular glial tauopathy（GGT）は, グリア細胞内封入体（GGI）を特徴とした 4-repeat tauopathyであり，GGIの出現部位によりType I (前頭側頭葉), Type II (運動野 錐体路)，Type III ( I と II の混在)に分類される。前頭側頭葉型認知症 (FTD) と運動ニュー ロン疾患 $(\mathrm{MND})$ を両端とする臨床スペクトラムとの対応が指摘されている. 当院GGT疑 い例と既報告を比較し，GGTの臨床像を考察する.【方法】2012年1月から2019年11月まで の入院症例から臨床上GGTを疑った3例を抽出した.【結果】症例1 : 78歳女性, 3年前から 右上肢遠位優位の丞性麻疩が進行，頭部MRIで左中心前回の萎縮及びT2W1で皮質下の 高信号, ${ }^{123}$ I-IMP SPECTで同部位の血流低下を認めた 上位運動ニューロン障害のみで, 原発性側索硬化症 (PLS) との鑑別を要したが，画像所見からGGT Type II 疑った，症例 $2: 65$ 歳男性, 6 年の経過で右側優位の痓性不全対麻疩, 軽度認知障害が進行. 頭部画像で 左前頭葉から側頭葉，中心前回優位の萎縮と $\mathrm{T} 2 \mathrm{~W} 1$ で皮質下高信号，同部位の血流低下を 認めた FTLD-MNDを鑑別に挙げたが経過中に下位運動ニューロン障害は認めなかった 臨床的にGGT Type IIIを疑った。症例 $3: 80$ 歳男性. 7 年前に歩行障害から䅡椎症性春噵症 を指摘，6年前に手術をしたが症状の改善なく以後増悪した３年前にパーキンソニズムを 指摘されたがレボドパ反応性はなかった. 2 年前から両手に杖を持たないと歩行困難となっ た．認知機能低下は無く，上肢は左優位，下肢は対称性の痓縮と鉛管様固縮を認めた。頭 部画像では右側優位，両側中心前回に限局した萎縮とT2W1で皮質下高信号があり，右中 心前回の血流は低下していた，DAT SPECTで線条体集積低下はなかった．PLSを鑑別に 挙げたが，固縮がある点が非典型的で画像所見と併せGGT Type II を疑った【結論IFTD PPLS/ALSを疑う場合でも，非典型例の場合はGGTを鑑別に挙げることが重要である. 
○勝木 歩

【目的】筋萎縮性側索硬化症 (ALS) ではALS/FTDという概念も提唱されているよ うに、認知機能低下をきたす一群が存在する。その一方でALS患者の中には明白 例も存在する。今回我々は2015年以降に当施設で経験した明らかな認知症を有さ ないALS症例に関して脳血流SPECT画像につき検討した。【方法】2015年1月から 2019年3月の期間に当院にて難病指定を受けたALS患者20例 (男性7例、女性13例)、 平均年龄67.9 \pm 6.2.歳である。全例に対し脳血流SPECT画像を撮影した。SPECT 画像は 3 DSSPにて解析した。またBrodmann areaでの血流低下を分析した。【結 果ISPCET施行20例中18例（90.0\%）にて前頭葉の血流低下を認めた。また20例中 17例（85.0\%）下て側㰯葉の血流低下を喼めた。後頭葉の血流低下は概して保たれ ていた。3DSSP では前頭葉、側頭葉、大脳边縁系での血流低下が頙著であった。 Broadmann area 47, 45, 44, 38, 20での血流低下が最も顕著であった【結論】前頭 葉、㧍よび側頭葉前方での血流低下はALSで高頻度に認められた。前頭葉血流低 下はALSの診断の一助ともなりうるものと考えられた。
0-14-6 筋萎縮性側索硬化症の脳血流パターン

福井大学医学部附属病院 脳神経内科 な認知機能低下を示さないのにSPECT画像で前頭葉〜側頭葉の血流低下を示す

0-14-7 筋萎縮性側索硬化症剖検例のリン酸化TDP-43 病理の 拡がりと臨床経過との関連性

○石田 千穂 ${ }^{1}$ 、駒井 清暢、高橋 和也 ${ }^{1}$ 、本崎 裕子 ${ }^{1}$ 、坂井 健二 ${ }^{2}$ 、

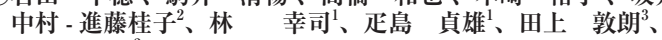

山田 正仁

NHO 医王病院 脳神経内科

金沢大学大学院 脳老化·神経病態学 (脳神経内科学) 、

NHO 医王病院 呼吸器内科

【目的】筋萎縮性側索硬化症（ALS）剖検例におけるリン酸化TDP-43（p-TDP43） 病理の㕬がりと，臨床経過，予後との関連性を検討する.【方法】2008年 1 月 〜2017年12月の連続剖检例のうち, pTDP-43病理を有するALSと診断され， Brettschneiderが提唱したstaging (BS)によりpTDP-43病理（BS1運動系限局一 BS4広範囲)の評価がなされた44例について, 診療・剖検記録からBSと臨床症状・ 経過を抽出し後方視的に検討した.【結果】各BS症例数と全経過 (平均上标準偏差)

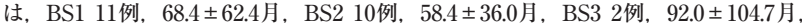
BS4 21例，70.0 555.3月であった。初発症状は，BS1は9例が上肢，BS2は下肢5例， 上肢3例，BS4は上肢9例，球麻痻7例、呼吸3例であった.BS4のみ9例で認知症あ りと臨床骖断されており，BS2 2例とBS4 8例でTotally locked-in stateに至ってい た. 発症から呼吸不全（気管切開，非侵襲的呼吸器終日装着，死亡のいずれかの うち最短) までの期間 (平均士㯲準偏差) は, BS1 43.5 \pm 17.0 月, BS2 $32.1 \pm 19.4$ 月,

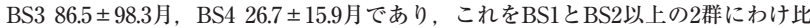
較すると、BS1が有意に長かった $(\phi<0.05)$.【結論】過去の症例の蓄皘、检討より p-TDP43陽性所見を含むALS病理の進展が，経過年数のみによるものではないこ とは知られているが, 今回, BSを用いた半定量的評価方法から, p-TDP43病理の 出現部位選択性と瀶床症状・予後が関連している可能性が示唆された。

\section{0-14-9 MRI SWI法によるALSの一次運動野画像評価の上位 運動ニューロン徵候としての有用性}

安井 昌彰、坂本 健、村上 圭秀、堀 昂平、江守誠司、 小上修平、萬翔子、高橋麻衣子、中山 宜昭、阪田麻友美、 高真守、石口宏、伊東 秀文

和歌山県立医科大学病院 脳神経内科

【目的】筋萎縮性側索硬化症（ALS）患者の一次運動野をMRI Susceptibilityweighted imaging (SWI) を用いて評佂しSWIの結果を上位運動ニューロン得 候として組み込むことにより診断にどのような影響を与えるかを明らかにする。 【方法】対象はALS患者23人 (男16人、女7人、平均年齢65.6歳) で、ALSの診断は改 訂El Escorial基準に従い診断し、上位運動ニューロンスコア(UMN score)の)経年 変化と診断グレードを確認した。MRI画像は 3 テスラ（SIEMENS社）の機器を用

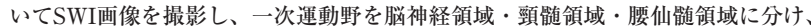
臨床症状を知らない3名の神経内科専門医の合議により、Three-point scoring
(TPS) を用いて確認を行った。結果]ALS患者は23例中22例でMRI SWIで一次運 動野に低信号域を認めた。経過中に低信号域がより鮮明化する例はあったが、消 退する例はなかった。TPSを脳神経領域・领邻領域・腰仙葡領域の各上位運動 ニューロン微候として診断の評㑛に加えると、初診時の診断グレードが23例中9 例変化した【結詥]ALS患者では多くの症例がMRI SWIで一次運動野に低信号域 を認めた。また、診断当初の上位運動神経症状が芝しい時期においてもSWIでー 次運動野に低信号域を認めており、経過中に低信号域が消退する例もなく、診断 の一助になる可能性が示唆された。

\section{0-15-1 内頸動眽狭窄症例の粥腫性状と頭蓋内主幹動脈狭窄 バイオマーカーの関連について検討}

\author{
加藤 昌昭 ${ }^{1}$ 、鈴木 直輝 ${ }^{1,2}$ 、井泉瑠美子 ${ }^{1,2}$ 、曽我 天馬 ${ }^{1,2} 、$ \\ 川内 裕子 ${ }^{2}$ 青木 正志 $^{2}$ \\ 将道会総合南東北病院 脳神経内科、 ${ }^{2}$ 東北大学病院 脳神経内科
}

【目的】筋萎縮性側索硬化症 (ALS) は疾患進行に伴い外来通院が困難となり、在宅 療養、訪問診療を中心とした診療となる。かし、その後も症状進行に伴い呼吸 苦、全身の苦痛が出現し緩和医療が必要となり、介護負担、家族、本人の不安も 増大し、最終末期に在宅療養困難となって入院対応が必要となる例も少なからず 存在する。当院は急性期病棟と、地域包括病棟をもつ一般病院で、神経難病病棟、 長期療養病床は有していないが、ALS終末期入院対応を行った症例に関して解析 し、現状と問題点を示す。【方法】2015年4月から2019年4月までの4年間に当院受診 したALS患者について後方視的に転機と診療状況、緩和医療、入院日数他につい て検討した。【結果】上記期間に当院受診したALS患者は計81例、うち期間内死亡 例37例であった。死亡例の内訳として、当院入院での死亡例 18 例 $(49 \%)$ 、当院救 急外来にて死亡確認 2 例 (5\%)、在宅(訪問診療) での死亡 10 例 $(30 \%) 、$ 他の医療機関、 不明 6 例 $(16 \%)$ であった。当院入院患者の平均入院回数 2.1 回 (1 7回)、平均入院 期間 23.8 日 $(0 \sim 99$ 日) であった。当院入院死亡例では、気管切開人工呼吸管理 $1 / 18$

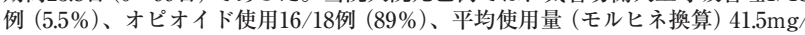
日であった。【考察】当院受診ALS終末期患者の約半数が入院で最期を迎えた。昨 今在宅、訪問診療体制で最期を迎える患者が増加しているが、最終末期になった 際に在宅介護、療養が困難となり当院に紹介受診、入院となる例が多く、ある一 定の入院必要例があることがわかった。終末期入院対応の問題占として、入院の 長期化と、長期化に伴う患者本人、家族の精神的疲弊、気分の落ち込みが強くな る点がある。入院時点で入院終末期対応とは決めずに、短期間であっても退院、 自宅への外出外泊を企画すること、医師、看護師、リハビリテーションスタッフ、 他、多職種が連携した緩和ケアを行うことが重要である。

\footnotetext{
飯島 直樹、小倉 英、清水 高弘、萩原 悠太、星野 俊、 荒賀＼cjkstart崇、長谷川泰弘 聖マリアンナ医科大学病院 脳神経内科
}

【目的】頭蓋内動脈硬化症 (ICAD) と頭蓋外動脈硬化症 (ECAD) の両者を合併する 症例は、脳血管障害再発率が高く、死亡率も高いとされている。頸動脈潞腫病変 の不安定性とICADの程度とは関連する可能性が高いが、充分な検討は行われて いない。本研究の目的は、頸動脈狭窄症例を対象として頸動脈潞腫性状をBlackBlood (B-B)法MRI (Time of Flight法)、超音波造影剂による頸動脈エコー検查に より評価し、更に動脈硬化関連バイオマーカーを測定してICADの関連因子を明 らかにすることにある。【方法】頸動脈エコー検查で動脈硬化性頸動脈狭窄 (>50\%、 Area法) を認めた 50 例 (男42例、平均年齢 $73.7 \pm 9.5$ 才、脳梗塞既往例 19 例) を対象 とした。全例に超音波造影剤（ペルフルブタン）を用いた頸動脈エコー検查、B-B 法MRI、脳MRAを行った。MRAで頭蓋内主幹動脈に $50 \%$ 以上の狭窄を有するも のをICAD (+) とし、頸動脈距腫性状と動脈硬化に関連するバイオマーカー（酸化 LDL, LOX-1, MPO, PTX3, MMP-9, h-CRP) との関連を多変量ロジスティック回帰 分析により検討した。【結果】ICAD (+) は50例中15例 (30\%)に見られ、いずれも中 大脳動脈狭窄であった。高度須動脈狭窄 (peak flow velocity[PSV] $>200 \mathrm{~cm} / \mathrm{sec}$ ) は16例、潰場性プラークは7例、頸動脈潞腫のペルフルブタン造影効果は14例に認 められた。頸動脈B-B法MRIでは、脂質コアが $60 \%$ 、强腫内出血は $16 \%$ の症例に見 られた。単変量解析の結果、高血圧, 脳梗塞既往, 総コレステロール値, PSV200 以上, MMP-9值, 高感度CRP值, 脂質コア $(+)$ においてICAD との関連が示され $(\mathrm{p}<0.2)$ 、多変量ロジスティック回帰分析の結果、血清MMP-9值が有意な因子 として残った (OR 1.23, 95\%CI 1.02-1.50,P=0.03)。【結論】本研究では、MRI、頸動 脈エコーで得られる粥腫性状を反映する諸因子とICAD と関連は示されなかった。 ICADの進行においてMMP-9高值に関連する機序を考虑する価值がある。 


\section{0-15-2 急性期脳梗塞患者における左心耳血流速度と潜因性脑 卒中の関連}

$\begin{array}{rlllll}\text { ○徳永 } & \text { 敬介、矢坂 } & \text { 正弘、森田 } & \text { 隆雄、吉野 } & \text { 文隆、橋本 } & \text { 剛、 } \\ \text { 友寄 } & \text { 龍太、大橋 } & \text { 一慶、友原 } & \text { 沙織、和田 } & \text { 晋一、森 } & \text { 興太、 } \\ \text { 船水 } & \text { 章央、陣内 } & \text { 重郎、桑城 } & \text { 貴弘、岡田 } & \text { 靖 } & \end{array}$

九州医療センター 脳血管・神経内科

【目的】左心耳機能と潜因性脳卒中の関連を検討した先行研究はほとんどない. 左 心耳機能を評価するための指標の1つに経食道心エコー図検査における左心耳血 流速度がある. 本研究の目的は脳梗塞患者における左心耳血流速度と潜因性脳卒 中の関連を明らかにすることである.【方法】2001年1月から2019年9月までの間に 当センターに入院した発症7日以内の心房細動を有さない急性期脳梗塞患者を連 続的に登録した。 入院中に経食道心エコー図検查を施行しなかった患者は除外し た. 左心耳血流速度は経食道心エコー図検查における左心耳最高流出血流速度と 定義した. 左心耳血流速度の四分位に従って対象を 4 群に分類し, 臨床的特徴を 比較した．左心耳血流速度と潜因性脳卒中の関連をロジスティック回帰モデルを 用いて検討した【結果】本研究に登録された連続4,492例から入院中に経食道心工 コー図検查を施行しなかった 3,412 例 $(76 \%)$ を除外し，残った 1,080 例 (平均年齢67 \pm 12 歳, 女性 379 例) を解析した。左心耳血流速度の四分位が上昇するに従い，潜 因性脳卒中の割合は段階的に低下していた $(\mathrm{P}=0.017)$. 第1四分位と比較し，第 4 四分位における潜因性脳卒中の多変量調整オッズ比は有意に低かった（多変量調 整オッズ比 $0.55, \quad 95 \%$ 信頼区間 $0.37-0.83, \quad \mathrm{P}=0.004)$ 。連続変数としての左心耳血流 速度は潜因性脳卒中と負の関連を示した $(10 \mathrm{~cm} / \mathrm{s}$ 毎の多変量調整オッズ比 0.90 95\%信頼区間0.86-0.94, $\mathrm{P}<0.001$ ).【結論】心房細動を有さない急性期脳梗塞患者に おいて左心耳血流速度の低下は潜因性脳卒中と独立して関連していた。この研究 結果は潜因性脳卒中が心房細動に依らない左心耳機能不全による血栓塞栓症を含 むことを示している.

\section{0-15-4 卵円孔開存の関与があり得る潜因性脑梗塞の解析}

\author{
三村 秀毅、田邊 真希、佐藤 健朗、高津 宏樹、小松 鉄平、 \\ 坂井健一郎、梅原淳、大本 周作、村上 秀友、井口保之 \\ 東京慈恵会医科大学附属病院 脳神経内科
}

【目的】近年脳梗塞再発予防効果が示されている経皮的卵円孔開存閉鎖術の適応と なる卵円孔開存を伴う潜因性脳梗塞の臨床的特徴について後方視的に解析する。 【方法】当院に入院し、頭部MRIで症候性病巣が確認できた脳梗塞患者を対象とし た。対象患者のうち、単一穿通枝領域脳梗塞 (ラクナ梗塞、BADなど)、アテロー 厶血栓性脳梗塞、心原性脳塞栓症、大動脈原性脳塞栓症の確診例、特殊な原因の 脳梗塞 (動脈解離、悪性腫場関連など) を除外し、原因不明な潜因性脳梗塞 (CS) を 抽出した。CS患者の臨床背景、右左シャント疾患（卵円孔開存、心房中隔欠損、 肺動静脈瘦）の合併頻度を解析した。【結果】2012年10月から2019年9月に入院した 対象患者1,374例 (女性389例、平均年齢68歳)のうち、単一穿通枝領域脳梗塞377例、 アテローム血栓性脳梗塞229例、心原性脳塞栓症286例、大動脈原性脳塞栓症44例、 特殊な原因の脳梗塞126例、その他（複数の原因、検査不充分） 72 例を除いた 240 例 (17\%、女性83例、平均年齢66歳) がCS患者であった。CS患者240例のうち、100 例 $(42 \%)$ が右左シャント疾患を有しており (卵円孔開存65例、心房中隔欠損 1 例、 肺動静脈瘦1例、経頭蓋超音波のみ(経食道心臓超音波未施行) 33例) 、奇異性脳塞 栓症確診例は21例であった。経皮的卵円孔開存閉鎖術の適応となる60歳未満の症 例は30例 (CS患者 240 例の $13 \%$ 、全対象1,374例の $2 \%$ )であった。【結論】CS患者のう ち経皮的卵円孔開存閉鎖術の適応基準を満たす症例は $13 \%$ あるる。

\section{0-15-6 植込み型心電図記録計を施行した潜因性脳梗塞例の中 間解析結果}

○土井尻遼介 ${ }^{1}$ 、木村 尚人 ${ }^{3}$ 、山崎 直也 ${ }^{1}$ 、小田 桃世 ${ }^{2} 、$ 高橋 賢 1 、 高橋 弘明 ${ }^{1}$ 、遠藤 秀晃 4 、菊池 貴彦 ${ }^{1}$

1 岩手県立中央病院 脳神経内科、2 岩手県立中央病院 リハビリテーション科、 岩手県立中央病院 脳神経外科、4 岩手県立中央病院 循環器内科

【背景】日本で潜因性脳梗塞 (CS) に対する植込み型心電図記録計 (ICM) が適応とな り約3年が経過した。当院ではCS例に対するICMを脳神経内科で植込み、モニタ リングを行っている。【目的】当院でCSと診断されICMを施行した症例での中間成 績、脳神経内科医がモニタリングする上での現状の課題を検討する。【方法】2016 年12月〜2019年10月までにICMを扱入した88例を対象とした。CSの診断には診 断の手引きに沿って経食道心エコーまたは大動脈CT、下肢静脈エコー、長時間 心電図モニタリング、ホルター心電図を行い、心原性や他の確定された原因を除 外した。ICMでPAFが検出された場合適宜不整脈専門医へ波形確認を依頼した。 使用したICMのデバイスはReveal LINQ® 74 例 $(84 \%) 、 C o n f i r m ~ R x ® 14$ 例 $(16 \%)$ であった。【結果】全症例の背景因子は年齢69（58-76）歳、男性52名 (59\%) であっ た。追跡期間281 (91-511) 日のうちPAFは21例 (27\%) で、植込みからPAF検出ま で44 (12-240) 日であった。PAFが検出された症例は全例抗凝固療法へ変更し、そ のうち 6 例 $(28 \%)$ にカテーテルアブレーションを施行した。脳梗塞急性期入院中に 植込みした症例は77例 $(87 \%)$ であり、発症からICM植込みまで13 (9-20) 日であっ た。PAFが検出されICMを抜去した症例は 4 例 $(4 \%)$ であった。ICMによる自動解 析されたPAFが擬陽性であったのは7例 $(7 \%)$ であり、原因となった不整脈は二段 脈、発作性上室性期外収縮、T波の増高が主な原因であった。【結語】ICMを用い たPAF検出率は 1 年以内に $27 \%$ に認められ、適切な脳梗塞再発予防㭗の変更に寄与 できた。ICMはPAFを自動検出する機能があるが擬陽性の可能性もあり、目視で の波形確認が重要である。
0-15-3 ESUS症例における心磁図を用いた左房機能評価方法の開発

○池之内 初 ${ }^{1}$ 鶁田 和夫 ${ }^{1}$ 、福間 一樹 ${ }^{1}$ 、吉本 武史 ${ }^{1} 、$ 服部 頼都、 豊田一則 ${ }^{2}$ 古賀 政利 ${ }^{2}$ 猪原 匡史

${ }^{1}$ 国立循環器病研究センター 脳神経内科、

国立循環器病研究センター 脳血管内科

目的：心磁図は心臟内の磁場強度を測定することにより、非侵襲的かつ簡便に 心伝導障害を評価することができる。塞栓源不明脳塞栓症 (Embolic Stroke of Undetermnied Source: ESUS) 症例において、発作性心房細動と関連する既知の左 房負荷を反映する因子と、心磁図のP波の磁場強度との関連性を検討した。方法： 2018年10月〜2019年10月の期間にESUSの診断で当科へ入院し、発症3r月以内に 心磁図を施行した症例を対象とした。心磁図におけるP波の左房・右房成分の磁場 強度をそれぞれ計測し、左房負荷と関連のあるBNP (Brain natriuretic peptide)、 12誘導心電図における $\mathrm{PTFV}_{1}\left(\mathrm{P}\right.$ terminal force in $\left.\mathrm{V}_{1}\right) 、 24$ 時間ホルター心電図に おけるPAC (Premature atrial contraction)、経胸壁心エコーにおけるLVEF (left ventricular ejection fraction)、LAD (left atrium diameter) との関連性を一般化線 形モデルを用いて評価した。結果:ESUSに対して心磁図を施行した20例 (男性11例、 平均 $71 \pm 9$ 歳）を対象とした。各因子の平均值は、BNP76 $\pm 84 \mathrm{pg} / \mathrm{ml} 、 \mathrm{PTFV}_{1} 2.1 \pm$ $1.2 \mu \mathrm{V} ・ \mathrm{~s} 、 \mathrm{PACl} 2 \pm 29 \% 、 \mathrm{LVEF} 62 \pm 5 \% 、 \mathrm{LAD} 37 \pm 5 \mathrm{~mm}$ であった。P波の右房成 分、左房成分の磁場強度はそれぞれ $2.5 \pm 1.3 \mathrm{pT} 、 1.4 \pm 0.9 \mathrm{pT}$ であった。P波の左房成 分は、BNP $(\beta=0.64, \mathrm{p}<0.01)$ 、 LVEF $(\beta=-0.47, \mathrm{p}=0.03)$ と有意な相関を認め、木 ルター心電図に拈けるPACの割合 $(\beta=0.43, \mathrm{p}=0.05) 、 12$ 誘導心電図におけるPTFV $(\beta=0.41, \mathrm{p}=0.07)$ と相関の傾向を示したが、LADとは相関を認めなかった $(\beta=0.33$, $\mathrm{p}=0.14)$ 。また、P波の右房成分の磁場強度とこれら所見の間にも有意な相関を認め なかった。結論：ESUS症例において、心磁図検査におけるP波の左房成分の磁場強 度は、BNPと正の相関を、LVEFと負の相関を示し、PAC、PTFV 傾向を示した。心磁図によるP波の左房成分の磁場強度の計測により、ESUS症例に おいて発作性心房細動と関連する左房負荷を定量的に評価できる可能性がある。

0-15-5 withdrawn

\section{O-15-7 脳梗塞におけるAIでの画像解析も考慮した適切な治 療選択を可能とするロジックの開発}

\footnotetext{
柴田宗一郎 ${ }^{1}$ 、櫻井 謙三 ${ }^{2}$ 、飯島 直樹 ${ }^{1}$ 、小林 泰之 ${ }^{3}$ 、長谷川泰弘 ${ }^{1}$ ${ }^{1}$ 聖マリアンナ医科大学病院 脳神経内科、 ${ }^{2}$ 川崎市立多摩病院 神経内科、 ${ }^{3}$ 聖 マリアンナ医科大学大学院医学研究科/医療情報処理技術応用研究分野
}

【目的】脳卒中医療の均露化を図る上で、脳卒中非専門医が初期対応せざるを得な い地域でも安全かつ有効な脳卒中初療を可能とする方策を確立する必要がある。 一般にMRI等の検查により脳梗塞である事は非専門医でも容易に診断可能である が、病型診断を行うことは容易ではない。一方、近年人工知能 $(\mathrm{AI})$ の開発もすす み、一定の画像自動読影が可能となり、病型診断を行う一助となっている。本研 究では初療時の様々な情報から、病型診断を行う判定ロジックを開発することに ある。【方法】2018年8月から2019年9月までに当院脳神経内科に急性期脳梗塞で入 院した 200 例を対象に、病歴、既往歴、内服歴、来院時の身体所見、検查所見お よび退院時の最終臨床亜病型を調査した。CT画像はCT自動読影機器を利用し、 CT-ASPECTを自動計測した。初療時の情報から最終病型に対する治療を導き出 せるようフローチャートを作成し、その判定ロジックの検証を試みた。結果】AI による画像読影にて脳梗塞と診断した後、 tPA静注症例や動脈解離、その他特殊 な脳梗塞6例を除外、その後心房細動やDダイマー、年龄、NIHSS scoreをもとに 抗凝固療法適応症例を選択し、次に、BNPやDダイマーおよび高血圧の既往なと から抗血小板療法が望ましい症例を選択、どれにも当てはまらない症例は来院ま での時間を加味することでそれぞれの治療指針をある程度示すことができた。そ

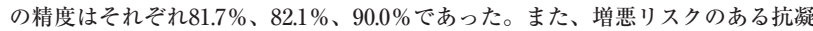
固療法適応症例には、初期増悪およびAIによるCT解析などによって抗血小板楽 併用症例を選択した。結論】身体所見や血液検查所見のみでは病型診断は不十分 であったが、CT画像のAI読影を利用することで、初療時の情報から病型診断の 精度が格段に改善された。治療方針決定の安全性、適切性を担保する判定ロジッ ク開発において、AI診断の追加は有用と思われ、更なる検討の価值がある。 
0-15-8 高血圧性脳出血における遠隔微小DWI高信号病変に 関連する因子

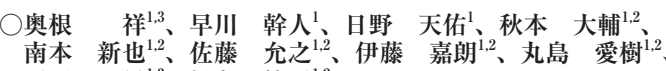

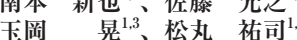

筑波大学病院 脳卒中科、筑波大学医学医療系 脳神経外科、 筑波大学医学医療系 脑神経内科

【目的】迋陑微小DWI高信号病変 (R-DWILs;Remote diffusion-weighted imaging lesions) は，脳出血患者において，血腫から離れた位置にみられる微小なDWI高信号病変で，そ の機序や病態は明らかになっていない，一般的に無症状とされるが，予後に影響すると の報告もある，我々は，R-DWIsが関連する因子を明らか纪するため，高血压性脳出血 患者における頻度，背景因子，検查結果，治療内容に関し梌討した. 【方法]2017年4月 から2019年3月までに当院の脑卒中科に入院した高血圧性腷出血患者を後方視的に検討 した. 入院時に頭部C下検查が施行され, 20 日以内に脳MRIが行われた 60 名の患者に対し, 年齢, 性別, 高血圧, 糖尿病, 心房細動, 透析, 抗血小板薬あるいは抗凝固薬の使用, 来院時の収縮期血圧（SBP），入院時血糖优，入院時クレアチニン値，eGFRと一週間以 内に行われた摇血検查で確認されたクレアチニン値，eGFRとの変動值、入院時の好中 球・リン八゚球比, HbAlc, 出血部位と血腄量, ラクナ梗塞の存在, 白質病変, 微小出血, 手術加療の有無, Nicardipine使用期間と最大点滴速度 $(\gamma)$, 他の楽剂の併用, 収縮期 血圧が140mmHgを下回るまでの時間，24時間の収縮期血压の最低值を単変量および多 変量解析を使用して検討した，R-DWILsは，血腄から少なくとも20 mm離れたDWI高 信号病変として定義した【結果】登録された60人の患者のうち，18人（30\%）にR-DWI が観察された。单変量解析では遠隔微小DWI高信号病変に関連する因子はeGFR変動值 $(\mathrm{p}=0.031)$, 好中球・リンパ球比 $(\mathrm{p}=0.013)$ ，白質病変 $(\mathrm{p}=0.005)$, 微小出血 $(\mathrm{p}=0.039)$ であっ た. 多変量解析では, 白質病変 $(\mathrm{p}=0.054)$ が関連する傾向が見られた. R-DWILsと転㫶 には関係性はみられなかった、結論】高血圧性腷出血の約3分の1がR-DWILsを呈した。 白質病変はR-DWILsの発生に関与する可能性があり，今後の症例集積が重要である。

\section{O-15-10 一過性全健忘連続 79 例における頭部拡散MRI所見の特徵}

\author{
加藤 邦尚、廣田 政古、新美 芳樹、林 和孝、坂野文彦、 \\ 東篤宏、菊池 洸一、長尾龍之介、前田 利樹、村手健一郎、 \\ 石川 等真、水谷 泰彰、島さゆり、植田晃広、伊藤信二、 \\ 武藤多津郎、渡辺 宏久 \\ 藤田保健衛生大学病院 脑神経内科
}

【目的】一過性全健忘（TGA: Transient Global Amnesia）は突然に発症する前向性 健忘と逆行性健忘を呈する症候群で、中年以降で発症率が高い。最近、急性期の 脳MRI拡散胎調画像 (DWI) 高信号がぬられることが報告され、その画像的特徽か ら、静脈性虚血により虚血に弱い海馬CA1領域の一過性の障害を抢こす可能性か 推定されている。しかし、その病態は未だ解明されていない。今回我々は当病院 における連続症例の横断的評価を行い、TGAのMRI急性期DWI所見について多数 例での検討を行った。【方法】2008年1月から2019年7月に当病院を受診し、Hodges の診断基淮をみたL、MRIを行ったTGA連緬71例を対象に、DWI所見について後 方視的に検討した。【結果]71例中、24時間以内の撮像が59例、24〜48時間の撮像 が7例、3〜7日目の撮像が5例であった。24時間以内に撮像した59例中11例（18.6\%） でDWI高信号を認めた。海馬病変に左右差はなく、1例では両㑡に高信号を認めた。 被凯、側頭葉外傊皮質、頭頂葉皮質、視床に高信号を認める症例もあった。24 48時間の間に撮像された7例中5例で海馬領域に高信号を認めた（1例で両側性）。3 〜 7日の間に撮像された5例中1例で両側海馬、1例で白啠に高信号を認めた。24時 間以内に異常のなかった48例中5例で2回目の摄像で海馬領域に高信号を認めた。 【結論】TGAでは、既報告と同様に海馬領域でDWI高信号を示す例が多いものの、 特に、その他の領域でも高信号を呈することがあり、静脈虚血以外の機序が考元 られた。

\section{O-16-2 多発性硬化症における脳萎縮パターンの解析}

藤盛 寿一 1 、藤原 一男 ${ }^{2,3}$ 、中島 一郎 ${ }^{1}$

${ }^{1}$ 東北医科薬科大学 老年神経内科学、 ${ }^{2}$ 福島県立医科大学医学部 多発性硬化 症治療学講座, 一般財団法人脳神経疾患研究所 多発性硬化症・視神経春䯣炎 センター、 ${ }^{3}$ 東北大学医学部 多発性硬化症治療学講座

【目的】多発性硬化症 (Multiple sclerosis: MS) では全脳のみならず様々な脳領域の 萎縮が認められ，それらが身体機能障害や高次脳機能障害に関連することが報告 されている.しかし，全脳および局所脳がどのようなパターンで萎縮していくの かについて検討した報告はない. 今回我々はMSの脳萎縮パターンを明らかにす ることを目的としてMRI画像データを用いたクラスター解析を行った.【方法】75 例のMS症例および21例の健常者を対象として高分解度のT1強調MRI画像を撮像 LFreeSurferによる脳容皘解析を行うことで，一例につき全56領域の兴容皘を湘 定した． 得られた脳容積データを用いてクラスター解析および主成分解析を行い， MS症例を類似した脳容積パターンを示すクラスターに分類した。臨床的特徴お よび脳容積をクラスター間で比較し検討を行った.【結果】MS症例は3つのクラス ター（クラスター $1,2,3)$ に分類された。 クラスター間で身体機能障害度に違い を認め, クラスター $3,2,1$ の順に強い障害を認めた。認知機能障害の目立つ症 例もクラスター 3 に分類された。全脳および視床，脳梁などを含めたテント上の 局所脳容積はクラスター 3 で最も強い減少を示し, 次いでクラスター 2 で減少し たが, クラスター 1 と健常者の間には有意差を認めなかった。一方で腹側間脳お よびT1白質低信号の脳容皘のみが健常者，クラスター $1,2,3$ の 4 群間で有意に 異なっていた。しかし小脳皮質と脳幹の脳容積はクラスター 3 と 1 の間で異なる ものの, クラスター 1 と 2 およびクラスター 2 と 3 の間では有意差を認めず, ク ラスター間で容積の差が目立たなかった.【結論】MSの脳萎縮は 3 つのパターンに 分類され，臨床的重症度を反映することが明らかとなった。また腹側間脳の萎縮 が軽症MSでも認められ，MSの脳萎縮進展を考える上で重要な所見であると考え られた。

\section{0-15-9 急性期脳梗塞における画像診断の現状: 2 次全国アン ケート調查}

古賀 政利 ${ }^{1}$ 井上 学 ${ }^{1,2}$ 、岡田 敬史 ${ }^{1}$ 、田中 寛大 ${ }^{2}$ 塩澤 真之 ${ }^{1}$ 園田 和隆 ${ }^{3}$ 池之内 初 ${ }^{1}$ 、福田 哲也 ${ }^{4}$ 、佐藤 徹 ${ }^{5}$ 、猪原 匡史、 工藤 與亮、板橋亮、山上 宏 ${ }^{8}$ 、豊田 一則 ${ }^{1}$

${ }^{1}$ 国立循環器病研究センター 脳血管内科、 ${ }^{2}$ 国立循環器病研究センター 脳卒中集中治療科、 福岡県济生会福岡総合病院 脳神経内科、 ${ }^{4}$ 国立循環器病研究センター 放射線部、 5 国立循環器病研究センター 脳神経外科、 ${ }^{6}$ 国立循環器病研究センター 脳神経内科、

北海道大学大学院 医学研究院 放射線科学分野 画像診断学教室、 ${ }^{8}$ 岩手医科大学 内科学 講座 神経内科・老年化分野、 ${ }^{9}$ 国立病院機構大阪医療センター 脳卒中内科

【目的】2018年に全国アンケート調査 (1次調查、2018年8月送付)を行い、CTとMRI両方で急性期脳梗 塞の診断を行っている施設が多く、発症6時間以降の脳梗塞に対する脳灌流画像評価が $12 \%$ と普及し ていないことが明らかになった。2次調查で画像診断の詳細とrt-PA静注療法のタイミングを含む診 療の流れ明らかにする。【方法】1 次調查で2次調查に協力できると回答した 360 施設（日本神経学会認 定施設、日本脳卒中学会認定研修教育病院、日本脳神経外科学会専門医所属病院）を対象とした。急 性期脳梗塞に対して行っている治療内容で、再灌流療法なし(治療なし)施設、rt-PAの々施行(rt-PA) 施設、またはrt-PAと血管内治療両方施行 (EVT) 施設に分類した。発症6時間以内と発症 6 24時間に わけて、脳梗塞疑い患者に対して行っている画像診断とrt-PAの施行順番などをWEBアンケートで質 問した (2018年11 月送付)。【結果】239施設 (66\%) から有効回答があった。治療なし施設 $(\mathrm{n}=26)$; 発症 6時間以内では、単純CTのみ評価施設4\%、DWI/MRA 35\%、DWI/MRA/MRP 12\%、CTとMRI両方 50\%であった。発症6〜24時間で脳灌流画像(MRPまたはCTP) 評価は27\%であった。 rt-PA施設 $(\mathrm{n}=48)$ ： 発症6時間以内ではrt-PA施行前に単純CTのみ $4 \%$,DWI/MRA 38\%、CTとMRI両方58\%であった。 発症6 24時間で脑灌流画像評価は15\%であった。EVT施設 $(n=165)$; 発症6時間以内でrt-PA施行前 に単純CTのみ評価18\%、DWI/(MRA) 15\%、単純CT/CTA 13\%、CTとMRI 両方 $45 \%$ であった。発 症6〜24時間で脳灌流画像評俩は31\%であった。結論]最低限の画像診断で再灌流療法までの時間短 縮に務めることが推奨されている発症6時間以内にCTとMRI両方で評価している施設が多いことが明 らかになった。1次調查時より発症6時間以降の脳灌流画像評価施設が増えていた。

\section{O-16-1＼cjkstart酢酸PETを用いた視神経脊髄炎におけるアストロサイ トイメージング}

甲田 亨 ${ }^{1}$ 、奥野 龍禎 ${ }^{1} 、$ 加藤 弘樹 ${ }^{2} 、$ 木下 允 $^{1}$ 、清水 幹人 ${ }^{1} 、$ 別府 祥平 ${ }^{1}$ 、石倉 照之 ${ }^{1}$ 、村田 尚 ${ }^{1}$ 、畑澤 順 $^{2}$ 、中过 裕司 ${ }^{3}$ 、 望月 秀樹 ${ }^{1}$

大阪大学 神経内科、 ${ }^{2}$ 大阪大学 核医学講座、 ${ }^{3}$ 富山大学 神経内科

【目的】視神経盗喠炎 (NMOsd) は抗アクアポリン (AQP) 4 抗体の発見により多発 性硬化症（MS）と区別されるようになった。オゴデンドロサイトの障害が主で あるMSに対し、NMOでは抗AQP 4 抗体によるアストロサイト障害が主と考え られている。我々はこれまで酢酸が中枢神経でアストロサイト特異的に代謝され ることに注目しMS患者に対して酢酸PETを用いて、MS脳での酢酸代謝の著明な 充進を見出した。今回、我々はNMOsdに対して酢酸PETを用いて生体脳におけ るアストロサイトの代謝活性の評価を行い、同時に高次脳機能との相関も検証し た。【方法】抗AQP4抗体陽性NMOsd患者に対して11-C酢酸PET撮影をおこない、 高次脳機能評価としてRao's Brief Repeatable battery of neuropsychological test (BRBN) を行った。また、頭蓋内病変の有無の評価のためPET撮影にあわせて頭 部MRIの撮影も行った。結果】頭蓋内病変を有するNMO患者脳では健常者と比 ベアストロサイト代謝活性の低下を認め、一部の高次脳機能との相関も認めた 【結論】酢酸PETはNMOsdに対して直接病勢を評価するためのッールとなる可能 性がある。

\section{0-16-3 Processing Speed Testによる日本人健常者の認知 機能標準値の検討}

新野 正明 ${ }^{1}$ 、宮崎 雄生 ${ }^{1}$ 、鬼塚 康弘 ${ }^{2}$ 、神田三智弘 ${ }^{2}$

北海道医療センター 臨床研究部、2 バイオジェン・ジャパン株式会社

【目的】Processing Speed Test (以下、PST) は、多発性硬化症 (以下、MS) 患者の 認知機能を評価するためにデザインされたiPad®専用の評価ツールである。本研 究では日本人MS患者評価の基礎データにするため、日本人健常者におけるPST デー夕を収集し、日本人健常者標準值の作成を目的とした。【方法】本PST研究は 日本人健常者を対象とした単群横断研究で、2019年 8 月に参加の同意を得られた 20歲以上65歲以下の健常者で実施した。主要評価項目は全体のPSTスコアの分布、 副次評価項目は年齢、学歴、性別ごとのPSTスコア分布とした【結果】登録され た254名のうち、ミニメンタルステート (MMSE) 検査のスコアが27点以上の 242 名 で解析を行った。平均年齢 44.2 歳、男性 $51.2 \%$ で、修業年数 13 年以上（大学、専門 学校、またはそれ以上) は60.7\%であった。全体の平均PSTスコア $( \pm \mathrm{SD})$ は $61.8 \pm$ 10.0 、中央值は 62.0 (最小 37 、最大 88 ) であった。年齢毎の平均PSTスコア $( \pm \mathrm{SD})$

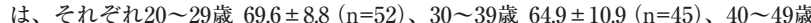
$63.5 \pm 6.1(n=46) 、 50 \sim 59$ 歳 $57.1 \pm 8.7(n=44) 、 60$ ６5歳 $54.3 \pm 6.7(n=55)$ であった。

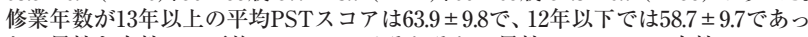
た。男性と女性での平均PSTスコアはそれぞれ、男性 $61.6 \pm 10.9$ 、女性 $62.0 \pm 9.1$ であった。【結論】日本人MS患者評価の基礎データにするため、日本人健常者 242

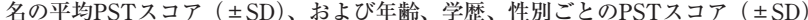
を算出した。当日は、年齢、学歴、性別によるPSTスコア分布の統計学的考察を 発表する予定である。 
0-16-4 䯣液IL-6 にBAFF、GFAPを加えた測定による視神経 脊髄炎の診断と疾患活動性の評価

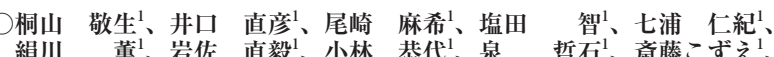

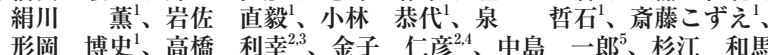
${ }^{1}$ 奈良県立医科大学 脳神経内科学、 ${ }^{2}$ 東北大学 脳神経内科学、

国立病院機構米沢病院 脳神経内科、 ${ }^{4}$ 国立病院機構宮城病院 脳神経内科、 ${ }^{5}$ 東北医科菂科大学医学部 老年脳神経科学

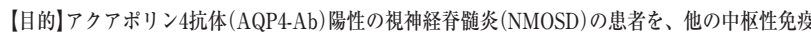
疾患と素早く鑑別でき、疾患活動性を語佂できるバイオマーカーがMRI所見や抗体以外にあれ ば臨床上有用である。㞃液中のIL-6、BAFF (B-cell activating factor),GFAP (glial fibrillary acidic protein）を同時に測定することが、NMOSDと他疾患との鑑别や疾患活動性語価に役立 つか検討した。【方法対象は疾患活動期のAQP4-Ab陽性NMOSDI4例とした。視神経炎 (ON) の みは2例、初回発症時6例。急性期ステロイド加療前の䯣液8例、ステロイドパルス開始後もしく は内服中路液例。対照として非炎症性疾患12例、McDonald criteriaを满たす典型的Multiple sclerosis (MS) 18例、MOG抗体陽件関連疾患（MOG-Ab associated disease:MOGAD） 8例、导 の他atypical MS合志中枢性免疫疾患 (atypical MS群:tumefactive lesionあり 4例、AQP4-Ab㓌

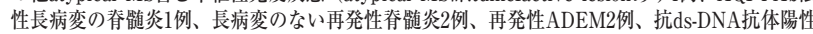

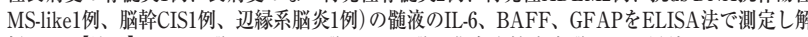
析した。[結果]NMOSD群、MOGAD群ではMS群、非炎症性疾患群に比べ喵液IL-6、BAFFか 優位に上昇していた。GFAPはNMOSD 9/14例とAQP4-Ab除性長病変の脊践炎、辺縁系媨炎患

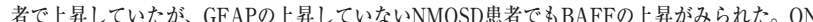

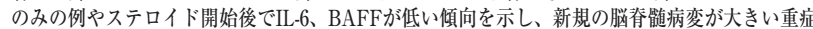
例でAFFが高值を示していた。atypical MS群ではTDLのある1例でもIL-6、BAFFの上昇がぬ られた。[結諭「アストロサイト障害のマーカーとなるGFAPはAQP4-Ab陽性NMOSDの疾患活 動期の卻液で上昇するが、再発時に低い例もあり、自己反応性B cellの活性化纪関倸するIL-6、 BAFFを同時に測定することで免疫の病態䛦断の補助や疾患活動性の指标になると考兄られた。

\section{0-16-6 抗MOG抗体関連疾患, 視神経脊檤炎, 多発性硬化症に} おける血清, 脳脊䚙液HMGB1 の検討

田中 覚、山元 正臣、橋本 ばく、山鹿 哲郎、杉本 恒平、 古谷真由美、宮内 敦生、石塚 慶太、鈴木 理人、田島 孝士、 成川真也、原涉、伊崎 祥子、吉田 典史、王子 聡 傳法 倫久、樑浦 颜彰、野村 恭-

埼玉医科大学総合医療センター 神経内科

【背景・目的】high-mobility group box 1 (HMGBI) は活性化されたモノサイト/マ クロファージ系細胞, 神経細胞, 血管内皮細胞などからの分泌, 塤死細胞からの受 動的な遊離によって, 様々な生体現象に関与することが知られてきている. 近年 HMGB1は多発性硬化症や視神経脊䯣炎で上昇することが報告されているが, 抗 MOG抗体関連神経疾患での報告はない. 今回我々は抗MOG抗体関連神経疾患, 視

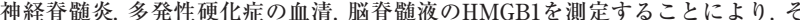
の関与を検討した. [方法]対象は, 抗MOG抗体関連神経疾患 (MOG群) 12例, 抗 AQP4抗体視神経脊随炎関連疾患18例 (AQP4群), 多発性硬化症 12例 (MS群) と した. 採取した血清, 脳脊咆液のHMGB1をELISA kit II で測定した（Shino-Test Corporation, Tokyo, Japan ). 疾患対照として非炎症性神経疾患（control群）15例 を設定して統計学的检討を行った【結果】血清のHMGBIはMOG群が11.4 14.9

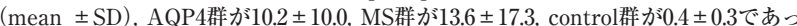
た. 各群間に明らかな有意差は認めなかった。脳春娟液中のHMGB1はMOG群が $1.8 \pm 2.5, \mathrm{AQP} 4$ 群が $2.6 \pm 3.1$, MS群が $0.9 \pm 0.9$, control群が $0.5 \pm 0.3$ であり, AQP4群

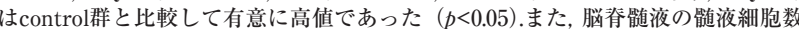
$(\mathrm{r}=0.889 ; \mathrm{p}<0.001)$, Qalb $(\mathrm{r}=: 0.483, \mathrm{p}=0.001)$ に相関を認めた.[結語] 血清のHMGB はいずれも明らかな上昇は認めなかった, 脳春噵液のHMGB1はAQP4群では有意 に上昇していたが,他の疾患では認めなかった。

\section{O-16-8Ｂ細胞の表現型解析は抗AQP4 抗体陽性視神経脊鹃道炎 関連疾患と他疾患の鑑別に有用である}

\section{○赤谷律、千原 典夫、古東 秀介、松本 理器 \\ 神戸大学大学院医学研究科 脳神経内科学}

【目的】視神経䅦䯑道炎関連疾患（NMOSD）の病態においては抗アクアポリン4 (AQP4)抗体の関与が知られるが, 抗AQP4抗体産生細胞であるplasmablasts (PB) を含むB細胞の類縁疾患における動態は十分解明されていない. 今回我々は抗 AQP4抗体陽性NMOSD と, 抗AQP4抗体陰性の他の神経免疫疾患におけるB細胞 の表現型を明らかにすることを目的とした。【方法12018年6月から2019年11月まて の期間に当院を受診した25名の免疫性神経疾患患者（抗AQP4抗体陽性NMOSD患 者13名，多発性硬化症 $(M S)$ 患者 8 名，抗MOG抗体関連疾患患者4名) から末梢血単 核細胞 (PBMCs) および脳脊䯣液 (CSF) を採取し，健常人8名のPBMCsを対照群と して採取した。蛍光抗体を用いてリンパ球に多重染色を行い, リンパ球全体に対 する $\mathrm{CD} 19^{+} \mathrm{B}$ 細胞の割合, B細胞中のCD27のナイーブ細胞㧍よびCD $27^{+}$のメモリー 細胞の割合, $\mathrm{CD} 19^{\text {dim }} \mathrm{CD} 27^{\text {high }} \mathrm{CD} 180 \mathrm{CD} 38^{+}$のPBの割合をフローサイトメトリーで 解析した【結果】抗AQP4抗体陽性NMOSD患者では，健常人およびMS患者と比 較して, リンパ球全体に対するCD $19^{+} \mathrm{B}$ 細胞の割合およびメモリー/ナイーブ分画 には有意な差を認めなかったが, PBMCsにおけるB細胞中のPBの割合が有意に増 加していた $(\mathrm{p}<0.05)$ 。また，CSFにおいてもNMOSD患者ではMS患者と比較して 有意にB細胞中のPBの割合が上昇していた $(\mathrm{p}<0.05)$ 。一方，抗MOG抗体関連疾患 ではこの傾向はみられなかった.【結論】抗AQP4抗体陽性NMOSD と抗MOG抗体 関連疾患では疾患活動期の末梢血と脳脊䯑道液のB細胞の表現型が異なり，PBの割 合は臨床的に類似する両者の鑑別に有用と考えられた。

\section{0-16-5 Processing Speed Testによる多発性硬化症患者の 高次脳機能障害の検討}

○宮崎 雄生、新野 正明 ${ }^{2} 、$ 高橋 恵理、網野 格、中野 史人、 秋本 幸子 ${ }^{1}$ 南尚哉、菊地 誠志

北海道医療センター 脳神経内科、 ${ }^{2}$ 北海道医療センター 臨床研究部

【目的】Multiple sclerosis（MS）患者は少なからず高次脳機能障害をきたし，生活 の質の低下に関与する。 また, 高次脳機能障害はその後の身体機能障害増悪と 相関するため, 治療薬選択にあたって重要な要素の一つである. MS患者の高次 脳機能を評価する方法として様々な検査が提唱されているが，時間的，人員的 制約のある一般臨床においてこれらを施行することは容易ではない. Processing Speed Test (PST) はMS患者の高次脳機能を評価するためにデザインされたタブ レット端末のアプリケーションであり，本方法を用いることで従来の検查法と比 べて簡便にMS患者の高次脳機能を評価可能である. 本研究ではMS患者において PSTの結果が身体機能障害, 脳容積と相関するか検討した.【方法】30名のMS患 者 (平均年齢40.4歳)において，PSTを施行した，身体機能障害の評価はexpanded disability status scale（EDSS）を，脳容積の推定にはmagnetic resonance imagingの3DT1強調画像データを元にSIENAXソフトを用いこれらとPSTの点 数との相関をスピアマンの順位相関係数を用いて解析した.【結果】MS患者におけ るPSTの点数の平均 \pm 標準偏差は $51.3 \pm 18.0$, 中央值 50.0 (最小 11 , 最高78) であっ た.PSTの点数とEDSSの間に有意な負の相関を認めた $(\mathrm{p}=0.0003)$. 一方, PSTの 点数と総脳容積 $(\mathrm{p}=0.0001)$, 総灰白質容積 $(\mathrm{p}=0.0002)$, 皮質灰白質容積 $(\mathrm{p}<0.0001)$ の間に有意な正の相関を認めた【結論】MS患者においてPSTの点数は身体機能障 害, 脳容積と相関する。

\section{0-16-7 多発性硬化症および視神経脊髄炎における情報処理速 度の検討-CogEval $囚$ を用いた評価}

出口 一志、高田 忠幸、土居 智和 ${ }^{1}$ 、紀乃 正志 ${ }^{1}$ 喜多 誠、 高場 啓太 ${ }^{1}$ 、城 妃咲、峠 哲男 ${ }^{2}$ 、正木 勉 ${ }^{3}$

${ }^{1}$ 香川大学病院 脳神経内科、 ${ }^{2}$ 香川大学 健康科学、 ${ }^{3}$ 香川大学病院 消化器内科

【目的】多発性硬化症（MS）における認知機能障害の特徵として、注意・集中・情 報処理の障害が知られている。これらの評価には符号数字モダリティー検査 (SDMT) が有用だが、近年、より簡便に施行可能なCogEval『が開発された。本 研究では、CogEval@を用いて、1) MSの情報処理速度と臨床情報との関連、2) 類縁疾患である視神経脊㕼炎（NMOSD）との違いについて検討を行った。【方法】 対象は、寛解期にあり、視力および上肢機能が保たれているMS19例、NMOSD7 例。カルテから発症年齢、罹病期間、発症から2年以内の再発回数、EDSS、MRI 上の大脳・脳幹・小脳および㝓髄病変数に関する情報を抽出した。外来受診時に CogEval ${ }^{\circledR}$ 施行し、調整後Zスコアを記録した。同日に日常活動（performance status: PS)、疲労 (Chalder fatigue scale: ChFS)、意欲 (やる気スコア)、うつ (self-reported quick inventory of depressive symptomatology: QIDS-SR) の評柾 を行った。【結果】MSとNMOSDのプロフィールは、大脳・脳幹・小脳の病巣数（MS で有意に多い）以外は同等であった。Zスコア-1.65以下を異常とした場合、MS では3例（16\%）で情報処理速度が低下していた。MSではZスコアと意欲の間に有 意な負の相関 $(\mathrm{p}<0.01)$ がみられたが、他の要因との間に有意な関連はなかった。 NMOSDではZスコアの異常やZスコアと各種の要因との間に有意な関連はなかっ た。【結論】少数例の検討ではあるが、情報処理速度の低下はMSのみで認められ、 既報 (SDMTで評価) と同様に意欲低下との関連が示された。大脳・脳幹・小脳病 変の数が多いにも関わらず、Zスコアが正常な例がMS/NMOSDの両群にみられた ことから、CogEval $\mathbb{R} の$ 結果はMRIで可視化できないニューロンネットワークの 変化を反映している可能性がある。今後の検証が必要だが、CogEval $®$ 簡便か つ非侵襲的な疾患修飾療法のモニタリング法として利用できるかもしれない。

\section{0-16-9 第 5 回全国疫学調査が示す多発性硬化症・視神経脊 髄炎総患者数の顕著な増加傾向の持続}

\section{磯部 紀子 ${ }^{1,2}$ 、新野 正明 ${ }^{3}$ 、松下 拓也 ${ }^{1}$ 、中村 優理 4,5}

中島 一郎 ${ }^{6}$ 、渡邊 充 ${ }^{1}$ 酒井 康成 ${ }^{7}$ 迫田 礼子 ${ }^{1}$ 中原 仁、

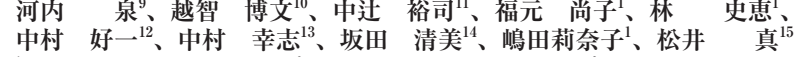
${ }^{1}$ 九州大学大学院医学研究院神経内科学、 ${ }^{2}$ 九州大学大学院医学研究院脳神経治療学、 ${ }^{3}$ 北海道医療セン夕ー

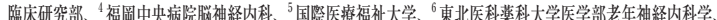

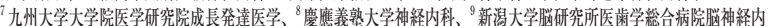
科・新渴大学大学院医歯学総合研究科総合医学教育センター、10 爱媛大学大学院医学系研究科脱神経内科・老年医学、 富山大学蓠神経内科、 ${ }^{12}$ 自治医科大学公衆筩生学、 ${ }^{13}$ 琉球大学大学院医学研究科衛生学公衆衛生学

年岩手医科大学医学部衙生学公衆衙生学、 ${ }^{15}$ 金沢医科大学医学部神経内科学

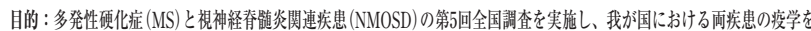
明ら加する。方法：2017年1月1日加 12 月 31 日までの1年間に調查刘象施設科 (内科・脱神経内科、小児科、眼科) を受

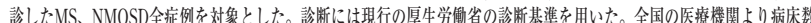
に応した抽出率でランダムに買定した施設に加兄、全国の大学病院、日本神経学会代議員が勤務する病院、日本小览神経 学会専門医が勤務する医療機関も抽出した。さらに、特别階層病院として、第4回全国調查の二次調查で 10 例以上の回答 があった施設、ならびにUS、NMOSDの診療に特化した施設を今回の対象に含めた。2018年11月より一次調查票を発送 し、一次調查で症例ありと回答があった施設科に対し、2019年1月より二次調查票を送付した。結果：一次調查では、送

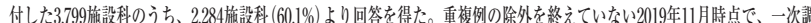
查より推定した患者数は24,813名であり、粗有病率は人口10万人あたり19.6人であった。一次調相で症例有りの回答があっ た645施設科の13,067症例について、二次調查票を送付し、6,840例 (52.3\%) の回答を得た。診断、性别についての記載が あった6,741例のうち、MSは4,795例、NMOSDは1,838例、Bal $\dot{b}$ 病は9例、MScNMOSDの比は、72.3\%:27.7\%、それそ

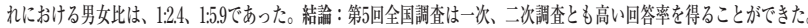
MS/NMOSDの総患者数は、14年前の第4回調查時の2.5倍、45年前の第 1 回調査時の11倍に増加していた。今後、MSと

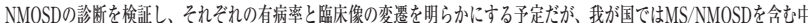

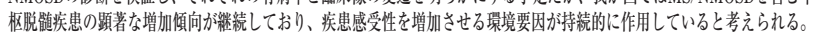




\section{0-16-10 多発性硬化症における変形性脊椎症は脊䯣病変と関連する}

○古東 秀介 ${ }^{1,2}$ 、千原 典夫 ${ }^{2} 、$ 小田 哲也 ${ }^{1} 、$ 中野 孝宏 ${ }^{1}$ 、下村 雅浩、 紐身 雅史 ${ }^{3}$ 、松本 理器 2 、濱口 浩敏

北播磨総合医療センター脳神経内科、

北播磨総合医療センターリハビリテーション科

【目的】多発性硬化症（MS）は中枢神経系における慢性炎症性脱䯠性疾患であり， 脳血液循環の関連が注目されている，障害部位としてしばしば㞣䯣病変を合併し， 分節性の運動障害や感覚障害・疼痛, 腱反射低下, 丞性, 膀胱直腸障害などを引 き起こし，臨床上問題となる。一方，変形性脊椎症は稀な疾患ではなく，50歳 以上ではしばしば見られる変性疾患であり，脊柱管狭窄症や神経根症，脊䯣症を

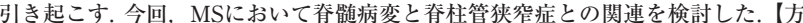

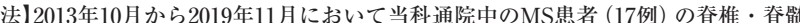
MRIを後方視的に評価し，脊檤病変ならびに臨床像との関連を検討した．なお， 視神経脊䯣炎症例は本検討から除外した.【結果】MS患者17例の平均年齡は40.2歳 (27-54歳) であり，全ての症例で何らかの変形性脊椎症を有した，MSの金髄病変 は12例でみられ，36病変を同定した。その内 10 病変 (9例) はC 3 以上の上位頸䯣に 12 病変 $(7$ 例) はC4以下の下位頸蹃に、14病変 (5例) は胸噵に見られた 上位頚䯣を 除いた 13 病変で変形性脊椎症の高位と一致し, 下位頸䯣では7例に, 胸髄で 6 例に 認めた。【結論】MS患者では比較的若年であるにも関わらず全例で変形性脊椎症

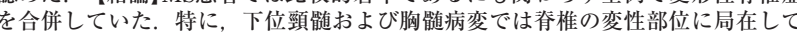
液循環障害の関与が推察された。
神戸大学大学院医学研究科 脳神経内科学、 いることが多く，脱䯑道病変の発症に脊柱管狭窄による脊随静脈路のうっ滞など血

\section{0-17-1小児科から移行した脳性麻痺患者の臨床的検討}

大迫 美穂、竹内 千仙、湊川みつ子、望月 葉子 東京都立北療育医療センター 神経内科

【目的】脳性麻痷は胎生期から生後4週間までに生じた脳の非進行性病変にもとづ く、永続的かつ変化しうる運動抢よび姿勢の異常と定義される。脳性麻痺のある 患者における小児期の臨床的問題点の報告は多いが、成人期の診療経験の報告は 少ない。当院は小児期発症の神経系疾患患者の小児科から神経内科への計画的な 移行を行っており、脳性麻疩移行例について、基礎疾患、合併症、移行後の診癔 等を検討したので報告する。【方法】2018年8月から2019年10月の間に、当院の移行 カンファレンスを経て、小児科から内科へ移行した18例の脳性麻痺患者について、 診療録と移行カンファレンス議事録を後方視的に調査した。【結果】患者は18例 (男 性 9 例、女性 9 例) 、移行時の年齢は33歳から55歳で平均 46.0 歳、脳性麻疩の分類は、 アテトーゼ型11例、症直型3例、混合型4例であった。出生時に仮死を認められた ものが10例あり、仮死なく出生した 5 例のうち 2 例に滑脳症を認めた。その他の 3 例 は周産期・新生児仮死の病歴が不明であった。移行時の合併症は、てんかんが11 例にあり4例は難治で投薬調整をした。変形性䅡椎症が 3 例にあり頝椎装具を 1 例 に作製、 1 例は手術適応の検討が必要であった。運動能力はgross motor function classification systemで2度が1例、3度が1例、4度が4例、5度が 12 例で、全員に生 活上の介助が必要であった。12例が経口摄取を行っており、そのうち7例に攝食 與下評価を行い食形態の変更を行った。6例は既に胃瘦造設術を受けており、そ のうち1例が喉頭閉鎖術・気管孔造設術を受けていた。結論】今回の検討では脳性 麻瘏患者にはてんかんの合併、嬩下障害の進行や変形性脊椎症がみられることが 多い。成人診療科への移行を機にした神経内科医による診療上の見直しは有用で ある。

\section{0-17-3 脳卒中、神経難病を含めた疾患統合型の地域連携手帳 (あらお健康手帳) の開発と課題}

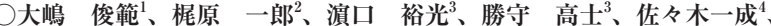
安楽 和也 ${ }^{5}$ 石川 智久 ${ }^{6}$ 、笨 ${\text { 久美 } 7^{7} \text { 中村 光成 }{ }^{8} \text { 藤瀬 隆司 }}^{8}$ 荒尾市民病院 脳神経内科、 ${ }^{2}$ 荒尾市民病院 循環器内科、 ${ }^{3}$ 荒尾市民病院 外科、 荒尾市民病院 糖尿病内分泌内科、5 荒尾市民病院 リハビリテーション技術科、 熊本大学神経精神医学講座、 ${ }^{7}$ 荒尾こころの郷病院、 ${ }^{8}$ 荒尾市医師会

【目的】地域の中核病院である当院では、医師会との連携のもと、急性期および専門的医療 を提供している。地域包括ケアシステムの構築の必要性が国を挙げて推奨されているが、 当地域でも、2018年10月より在宅医療サポートセンター事業が開始され、その準備とし て、2017年より行政、医師会、当院の専門医を中心に、既存の連携パスや手帳の統合の検 討を重ねた。2018年に基本部分と認知症、脳卒中、心不全、癌、糖尿病の疾患別部分とか らなる地域連携手帳を開発し、2019年1月より当院から仮運用を開始し、4月から医師会全 体で本運用を開始したささらに、10月からはパーキンソン病の症状日誌も疾患別部分とし て追加し、当科独自の工夫として運用を開始した。運用開始にあたっての方法と状況、課 題について報告する。【方法と結果】手帳作成: 全国規模の「健康長寿社会を目指した大規模 認知症コホート研究」において、当地域では、火の国あんしん受診手帳（通称:〈まモン手 帳）によるフォローアップを行っており、基本情報はこの手帳を活かして作成した。疾患 别の冊子については、当院の専門医が中心となり作成し、精神科領域と脳卒中領域を「頭 とこころの記録」として統合した。実績: 2019年1月～10月において、当院では全体で50例 (脳卒中 15 名、心不全 24 名、癌 3 名、糖尿病 2 名、その他 6 名)、各医療機関では 103 例の 登録を行った。手帳の配布と記載: 看護師から患者もしくは患者家族へ 1 対 1 対応で説明し、 手帳利用への同意を得、記載の介助を行った。当院では、基本情報に加え、各疾患別情報 を加えることが多かった。結論】本手帳は患者や家族が管理する紙媒体の情報共有ツール であり、災害時も含め、医療、介護、福祉、行政などの多職種協同体制の実践を支えるこ とが期待される。また、当地域で唯一の脳神経内科の標榜科である当院と、近隣の医療機 関との間で包括的な地域連携の構築が可能になると考えられる。

\section{0-17-5ＲNA-Seq解析によるパーキンソン病に対するゾニサ ミドの治療効果を規定する因子の検討}

\section{おだやかな看取りを明日に活かする
域と共有する新度戸モデルの展開-}

○内原 俊記 ${ }^{1,2}$ 、融 衆太 ${ }^{2} 、$ 山根 道雄 ${ }^{3} 、$ 廣川 勝昱 ${ }^{4}$ 北川 昌伸 ${ }^{5}$ 入江 徹也

新渡戸記含中野総合病院 脳神経研究室

新渡戸記念中野総合病院 脳神経内科、 ${ }^{3}$ 新渡戸記念中野総合病院 内科、

新渡戸記念中野総合病院 病理診断科、 ${ }^{5}$ 東京医科歯科大学医学部包括病理

背景 : 神経変性疾患の経過は長く、療養中に在宅や施設で最期を迎える患者が今 後増加する。しかし「在宅からの病理解剖」の体制がない在宅医療の現場では、解 剖を通じて診療を振り返るという臨床医学の原点に戻る機会はなかった。方法： 「新渡戸モデル」は外部資金を確保して「在宅からの病理解剖」に要する費用を支援 する新たな試みである。こうして神経疾患の病態や全身の病態をとらえて、地域 と共有することで、診療の質を検証し、教育や研究にも反映させる。進捗と展開 (1) 在宅・施設療養を経て病理解剖に至った神経疾患は66例 (2010年9月 -2019年3月) で費用を支援したのは 21例。うち55例 (88.3\%) が神経変性疾患であった。(2)臨床 診断が病理と異なる例は認知症 $3 / 20$ パーキンソン症候群 $4 / 15$ バ、予想外の合併 病変が8例でみいだされた。(3)看取りを病理解剖につなげた在宅医自身がCPCて 臨床提示まで担当した 2 例があった。(4)生前同意7例の内 4 例を解剖できた。屍を 明日に活かそうとする死生観が芽生えている。(5)臨床医の到着が遅れ、解剖開始 が遅延した2例があり、御遗体確認手続の定式化を要する。(6)臨床、病理所見を 司会担当の研修医に事前開示する体制を確立した。他の研修医や参加者もCPCて 積極的に発言するようになり理解は深まった。(7)その司会研修医は公式なまとめ を作製する。それを在宅医、遺族へフィードバックする体制を今後確立し、地域 との連携をさらに深めたい。8本事業継続のための安定的な財源確保が不可欠て ある。
内藤 龍彦 ${ }^{1}$ 佐竹 涉 ${ }^{1,2} 、$ Pei-Chieng Cha ${ }^{2}$ 村田 美穂 ${ }^{3}$ 、

戸田達史 ${ }^{1,2}$

${ }^{1}$ 東京大学大学院医学系研究科神経内科、

神戸大学大学院医学研究科脳神経内科、 ${ }^{3}$ 国立精神・神経医療研究センター

【目的】パーキンソン病のwearing-off症状に対してゾニサミドが有効であるが, 治 療効果には個人差を認める。治療効果の指標となる血中バイオマーカーの特定や 個人差を規定する機序の解明を目的として, 全トランスクリプトーム解析を行っ た【方法】過去に行われたパーキンソン病に対するゾニサミドの臨床試験に参加 した患者から、ゾニサミド投与によるwearing-off時間の短縮量やUPDRSの改善 量に従い, ゾニサミドが著効した群 23 例と無効であった群 25 例を選定した. 各例 についてゾニサミド投与開始前, 投与開始 12 週間後の血液検体に対して, RNA 解析を行った【結果】発現差異解析では，発現量に有意な差のある遗伝子は特定 できなかった。さらなる解析のため, 遗伝子発現量の相関関係から遺伝子を複数 の共発現群に分けて解析を行う weighted gene co-expression network analysis （WGCNA）も行った．投与後検体のWGCNAでは，1つの遗伝子群について治療 反応性との相関が伺われ $\left(\mathrm{r}=-0.39, \mathrm{P}=6.6 \times 10^{-3}, \mathrm{P}_{\mathrm{adj}}=0.32\right)$, それらの遺伝子群の gene ontology enrichment解析では炭水化物代謝の制御のontology と有意に相関 していた $\left(\mathrm{P}=38 \times 10^{-2}\right)$ また著効群のWGCNAでは1つの遗伝子群において治 療前後で有意な変化を示し $\left(\mathrm{P}=1.1 \times 10^{3}, \mathrm{P}_{\mathrm{adj}}=4.6 \times 10^{2}\right)$, それらの変化量の群間 での差異は全遺伝子の中で有意に上位であった $\left(\mathrm{P}=5.4 \times 10^{-17}\right)$.【結論】ゾニサミ ド投与前に治療効果の指標となる単一のバイオマーカーの特定には至らなかった が, 投与前後の発現量変化や投与後の発現量において群間で差のある共発現遗伝 子群を認めた。 それらの機能的な意義の解明やバイオマーカーの特定にはさらな る検討が必要である。 Seqにより全トランスクリプトーム解析を行い, 投与前後・群間の発現量の比較 


\section{0-17-6 CANVASの臨床・分子遺伝学的検討}

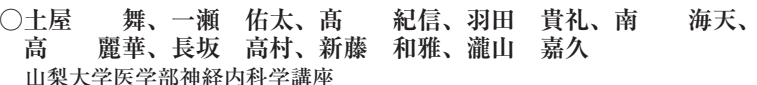
高麗華、長坂 高村、新称経内科学講座

【目的】CANVAS (cerebellar ataxia with neuropathy and vestibular areflexia syndrome）は小脑性運動失調, 感覚神経障害, 前庭機能障害を三徵とする症候群 である，2019年にCANVASはRFC1 (replication factor C subunit 1) のイントロ ン反復配列伸長が原因であること, 欧米では遲発性小脳性運動失調症の原因とし てRFC1遗伝子変異例の頻度が高いことが報告された。我々は, 当科のCANVAS 症例の臨床・分子遗伝学的検討を行った。【方法】当科の皮質性小脳萎縮症と診 断されていた 12 例と主なりピート病が否定された未診断遗伝性小脳運動失調症 23 家系25例（臨床的にCANVASを疑った症例を含む）について, RFC1イントロン のAAGGGリピート配列伸長の有無をRT-PCR, Long range PCR, Sanger法, サザ ンブロッティングを用いて解析した.【結果と考察】上記症例のうち2例にAAGGG リピート配列伸長をへテロ接合体で有することが判明した。遗伝形式は孤発性 と常染色体劣性遗伝性であった。臨床像は 2 例とも小脳性運動失調, 前庭機能障 害を呈し，感覚神経伝導検查は導出不良であった。2例とも慢性咳濑を伴ってお りCANVASの診断基準を満たしていた，さらに1例では睡眠時無呼吸を認め，別 の1例では病的反射が陽性であった. 頭部MRIでは 2 例とも小脳萎縮を認めた.【結 論】本邦ではじめてRFC1遗伝子変異をもつCANVAS症例を同定した。未診断の 劣性遗伝性小腷運動失調症に加えて皮質性小脳萎縮症と診断されていた症例につ いてもRFC1イントロン反復配列伸長を検討すべきであると考えられた。ささらに， CANVASではこれまでに報告のない睡眠時無呼吸などを呈する可能性があり，本 邦でのCANVASの頻度や臨床像について今後のさらなる検討が必要である。

\section{0-17-7ラクナ梗塞患者におけるNOTCH3 変異保有率と臨床的特徵}

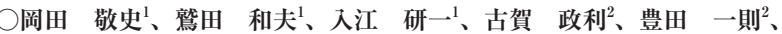
阔崎 周平 ${ }^{3}$ 小泉 崇、水田依久子、水野 敏樹、猪原 匡史 ${ }^{1}$ '国立循環器病研究センター脳神経内科、

国立循環器病研究センター 脳血管内科

大阪大学大学院医学系研究科 神経内科学、 ${ }^{4}$ 京都府立医科大学 胹神経内科

【目的】CADASILは最も多い遺伝性脳小血管病で, その有病率は2-5人/100,000とさ れている。近年, 非典型的な臨床症状を呈するCADASIL症例が多く存在すること が明らかとなっており, 潜在的なNOTCH 3 遺伝子変異は予想以上に多いとする報 告が散見される. 本研究では, ラクナ梗塞で入院となった症例におけるNOTCH3 遺伝子変異の頻度や変異例の臨床的特徵を解析した.【方法】2011年1月から2018年 4月までの間に当院に入院した穿通枝領域の脳梗塞症例1094例を対象とし, そのう ち高血压がないにも関わらず白質病変（Fazekasスコア2または3）を有する症例 31 例（コホート1）と60歳以下の症例 54 例（コホート2）に扔けるNOTCH3遺伝子変 異を調べた. 末梢血から抽出したゲノムDNAのNOTCH3のエクソン2-24における EGF-like repeatの変異をダイレクトシークエンス法で解析した.【結果】コホート 1 のうち 2 例, コホート 2 のうち 1 例, 計 3 例にR75P変異を認め, コホート 1 とコホート 2内における頻度は $35 \%$ （3/85) であった 3例はいずれも脸卒中の家族歴があり 中等度以上の白質病変を有していたが, 片頭痛や偽性球麻瘏, 側頭極病変など典型 的なCADASILの所見は有していなかった. R75P変異3例のCADASILスケールJ值 (25点満点, カットオフ值 16点) は14.3 55.1 (range 10-20) と比較的低值であった 【結論】若年発症, 脳卒中の家族歴を有し, 中等度の白質病変を有する症例の中にシ ステイン置換を伴わないNOTCH3変異を有する潜在的なCADASIL症例が多い可 能性がある.

\section{0-18-1＼cjkstart神経磁界計測による腓腹神経活動の評価}

○三谷 悠貴 ${ }^{1}$ 、赤座 実穂 ${ }^{2}$ 、川端 茂德 ${ }^{3}$ 、星野 優子 ${ }^{3}$ 、佐々木 亨 $^{4}$ 橋本 淳、渡部 泰士 ${ }^{1,4}$ 、宮野 由貴 ${ }^{\mathrm{i}}$ 、佐藤 慎司 ${ }^{\mathrm{i}}$ 、金 碩燦 ${ }^{\mathrm{N}}$ 高橋陽一郎 1 、足立 善昭、関原 謙介 $介^{3}$ 、大川 淳 ${ }^{4}$ 株式会社リコー、 ${ }^{2}$ 東京医科歯科大学大学院 呼吸器・神経系解析学分野、 ${ }^{3}$ 東京医科歯科大学大学院 先端技術医療応用学講座、 ${ }^{4}$ 東京医科歯科大学大学

院 整形外科学分野、 ${ }^{5}$ 金沢工業大学 先端電子技術応用研究所

【目的】神経磁界計測法は、周辺の体組織の影響を受けにくく、電位計測法に比べ高 い究間分解能を有し、神経の走行に沿って連続的に神経電気活動を可視化できる。 今回、神経磁界計測法により、感覚神経の詳細な機能評価を目的とし、腓腹神経の 活動を評価した。【方法】対象は健常者 5 人(平均年齢 33.8 歳) とした。測定には我々が 共同開発した132チャンネルのSQUIDセンサアレイを持つ神経磁界計測装置を用い た。下腿部をセンサアレイ上に当て、外果後方で腓腹神経を経皮的に最大上刺激し (duration $0.05 \mathrm{~ms}, 5 \mathrm{~Hz}, 2000$ 回加算)、誘発された神経磁界を体表より測定した。同 刺激部位、刺激条件で神経直上の体表面上に等間隔に設置された表面電極により 感覚神経活動電位も測定し比較した。測定された磁場データに対して電流分布推定 法を適用し、計算された電流分布を形態画像上に重权合わせて可視化した。結果】 全例で下腿部における神経誘発磁界が測定された。磁界データから計算された電流 分布図では、近位に向かって伝搬する軸索内電流、脱分極部の内向き電流が形態画 像上に重ね合わせ表示された。伝道経路上の仮相電極での電流波形の頂点潜時から 計算した伝導速度は平均 $46.8 \mathrm{~m} / \mathrm{s}$ であり、感觉神経活動電位波形より算出された伝 導速度の平均 $47.0 \mathrm{~m} / \mathrm{s}$ とほほ一致した。【結論]本研究の結果は解剖学的、生理学的 にも妥当であり、神経磁界計測により腓腹神経の神経電気活動を可視化できたと考 えられる。本法により、神経活動電流を構成する軸索内電流と脱分極内向き電流を 別々に評価することが可能である。また、仮想電極によって任意の占での神経の活 動を連続的に評価できる。神経磁界計測は感覚神経の機能を詳紼に評価できる新た な神経機能評価法として、末梢神経障害の診断への応用が期待される。

\section{0-18-3＼cjkstart神経磁界計測による肘部管の神経活動の可視化}

渡部 泰士 ${ }^{1,2}$ 、川端 茂德 ${ }^{3} 、$ 関原 謙介 ${ }^{3}$ 、佐々木 亨 ${ }^{1}$ 宮野 由貴 ${ }^{2} 、$ 佐藤 慎司 ${ }^{2}$ 、三谷 悠貴 ${ }^{2}$ 、山賀 匠 ${ }^{2}$ 、足立 善眧 ${ }^{4}$ 大大川 淳 ${ }^{1}$ ${ }^{1}$ 東京医科歯科大学大学院 整形外科学分野、 ${ }^{2}$ 株式会社リコー HC 事業本部、 ${ }^{3}$ 東京医科歯科大学大学院 先端技術医療応用学講座、

金沢工業大学 先端電子技術応用研究所

【背景】时部管の周辺部では尺骨神経走行の深さや向きが急激に変化するため、従 来の電気生理学的検査による精密な障害部位診断は技術的に難しい。一方、神経 の電気活動により生じる磁界を計測する神経磁界計測は、周囲組織の影響をほと んど受けないため、従来の電位計測よりも高い空間分解能を有する。今回我々は、 神経磁界計測による时部管周囲の神経活動の可視化に成功したので報告する。【 法】対象は健常人5名とした（26 29歳男女、平均 27.3 歳)。測定は我々が共同開発 した132チャンネルのSQUIDセンサアレイを持つ神経磁界計測装置を用いた。时 部管をセンサアレイ上に当て、尺骨神経を手関節部にて電気刺激（最大上刺激, 刺 激頻度 $5 \mathrm{~Hz}$ ) し、誘発された磁界を測定した (加算平均2000回)。測定された磁場 データに対して電流分布推定法を適用し、計算された電流分布を単純X線像上に 重ね合わせて可視化した。神経走行に沿って仮想電極を設定し、各点における電 流波形を求めた。比較のために、时部管を中心とした 3 か所において、複合神経 活動電位を測定した。【結果】全例で肘部管周辺における神経誘発磁界が測定され た。磁界デー夕から計算された電流分布図では、神経走行に沿って时部管を通過 し、近位に向かって伝搬する電流が単純X線画像上に重ね合わせ表示された。伝 道経路上の仮想電極での電流波形の頂点潜時から計算した伝導速度は平均 $54.4 \mathrm{~m} /$ S、複合神経活動電位波形の頂点潜時から計算した伝導速度は平均 $56.4 \mathrm{~m} / \mathrm{s}$ と、ほ ほ一致した。【考察】本研究の結果は解剖学的、生理学的にも妥当であり、神経磁 界計測により肘部管周辺における神経電気活動を可視化できたと考えられる。神 経磁界計測は形態画像と神経機能情報を融合して評価することが可能であり、神 経活動を詳細に評価できる神経機能評価法として、末梢神経障害の診断への応用 が大いに期待される。 


\section{0-18-4 胸骨切開術後腕神経叢障害はT1 前枝も障害し得る}

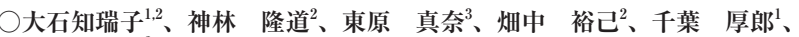
園生 雅弘

杏林大学病院 脳神経内科、常京大学病院 脳神経内科、

東京都健康長寿医療センター

【目的】胸骨正中切開術後に腕神経叢障害が起こることが知られており、C8前枝の 障害であるとされる。閏胸時の腕神経對の伸展や第一助骨に上る損䅞などが原团 として想定されている。我々は、その障害レベルがT1主体となる症例を経験した。 本研究では、胸骨正中切開術後神経叢障害の障害レベルについて检討することを 目的とした。【方法】2005年〜2018年の筋電図データベースより胸骨正中切開術後 神経叢障害の患者を抽出し、臨床症状と電気生理学検查の結果を後乃向きに検討 した。【結果]7例が抽出された。年齢は52 83歳、全例男性であった。うち5例では、 徒手箅力テスト (MMT) で主としてC8支配筋の筋力低下を認め、電気生理学検查 では全例尺骨神経の感覚神経活動電位 (SNAP) 振幅が低下していた。さらに、5例 中3例では環指記録正中神経SNAP振幅の低下があり、これが正常の残り2例では 針筋電龱でC8/後骨間神経支配である短母指伸筇の障害を認めた。一方内側前腕皮 神経 (MAC) SNAPは全例正常で、腕神経叢でのC8前枝障害と診断できた。7例中1 例では、MMTでC8・T1筋とも筋力低下を認め、MAC SNAP消失、短母指外転筋 (APB)の複合筋活動電位 (CMAP) 振幅が高度低下していたが、尺骨神経・環指記 録正中神経SNAPの振幅も低下し、C8/T1合併障害と診断した。もう1例はT1支 配筋の優位な筋力低下であり、MAC SNAP消失、APBのCMAP振幅が高度低下 していたが、尺骨神経SNAPは正常であることから T1前枝障害と診断した。【結論】 詾骨正中切開術後腕神経丵障害において、C8前枝のみならず、 T 1 前枝も障害さ れることがある。胸骨正中切開術後に上肢の運動感営障害を来した例では、顠椎 症や尺骨神経の圧迫性ニューロパチーを原因としてまず考える場合が多く、腕神 経丵障害は見逃されている例が多いと考える。電気生理学的検查以外での診断は しばしば困難であり、容易に局在ができる電気診断を積極的に行うべきである。

\section{0-18-6 免疫チェックポイント阻害薬投与後に発症した感覚性 ニューロパチーの臨床像}

丸山 健二 ${ }^{1,2}$ 、曽根 源基 ${ }^{1,2}$ 、樋口 瑛子 ${ }^{1,2}$ 、安達有多子 ${ }^{1,2}$

戸田中央総合病院 脳神経内科、 ${ }^{2}$ 東京女子医科大学 脳神経内科

【目的】免疫チェックポイント阻害薬は，癌細胞とT細胞が結合している免疫宽容

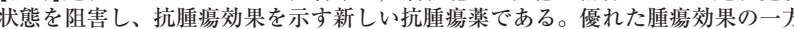
で免疫状態を変化させるため重篤な副作用も報告されている。特に自己免疫疾㭧 が重篤になることが多く、注意が必要であると思われる。今回、我々は免疫チエッ クポイント阳害薬投与中に発症した感営性ニューロパチー（SN）経験したのて 報告する。【方法】2018年〜2019年に免疫チェックポイント阻害薬投与後にSNを発 症し当科へ入院した 3 例について臨床像を検討した。[結果】 1 例目は肺扁平上皮癌 に対してペムブロリズマブを21クール使用後にSNを発症。2例目は膀洊癌に対し てペムブロリズマブを 2 クルル施行にSNを発症。3例目は、肺腺癌に対してアテソ リズマブを2クール施行後にSNを発症。いずれも立位保持することが困蜼でベッ ド卧床状態であった。随液榆查では、蛋白細胞解離を認めた。末梢神経伝導検查 では、感覚神経のびまん性の振幅低下がみられた。ステロイドパルス療法を施行 したが、症状改善しないため免疫グロブリン大量療法 (IVIg)を施行し、いずれも 2クールのIVIgを必要した。症状は、改善したが独歩は困難な状態であった。】考 察及び結論1免疫チェックポイント阻害薬はいろいろな悪性腫㿠に適応拡大が搪 がってきている。薬剤の特性上副作用として自己免疫疾患の増加が予想される。 今回、病巣が後根神経節と思われ、日常生活が制限されるため重篤な副作用と思 われる。原因薬凨を中止し、IVIgを主体とした免疫治療が必要である。

\section{0-18-8＼cjkstart全身性エリテマトーデスと関節リウマチの末梢神経障 害における補体活性の病理学的相違}

\author{
深見 祐樹 ${ }^{1}$ 、飯島 正博 ${ }^{1,2}$ 、仁紫 了爾 ${ }^{1}$ 、小池 春樹、祖父江 元 $^{3}$ \\ 勝野 雅央 ${ }^{1}$ \\ 名古屋大学 神経内科、2 名古屋大学 先端医療開発部、 \\ 名古屋大学 大学院医学系研究科
}

【目的】全身性エリテマトーデス（SLE)や関節リウマチ (RA)の病態において補体の 関連は以前より報告されているが、疾患に関連した末梢神経障害での補体の関与 については十分わかっていない。今回SLEとRAの末梢神経生検検体での補体の関 与について検討した。【方法】2017年までに腓腹神経生検を施行したSLE関連ニュー ロパチー 12 例、RA関連ニューロパチー 12 例を対象とし、コントロールとして 非炎症性のニューロパチーおよび剖検検体を使用した。パラフィン切片において 補体成分である $\mathrm{Clq}<$ 古典経路〉、 $\mathrm{Bb}$ <副経路>、マンノース結合レクチン $(\mathrm{MBL})$ およびFicollin-3<レクチン経路>、それらより下流の経路であるC3d、C4d、C9 neoantigen (C9neo) の免疫染色を行い、比較検討した。【結果】患者背景として SLEとRAで年齢、性別、血清補体価に有意な差は認めなかったが、SLEはRAと 比較し白血球数、CRP值が有意に低值であった。病理学的にはSLE㧍よびRAで 神経上膜の小血管において補体成分であるClq、MBL、Ficollin-3、C3d、C4d、 C9neoの沈着を認めたが、コントロールではほとんど認めなかった。フィブリノ イド壊死部ではC3d、C4d、C9neoの沈着を認めた。C4d、C9neoの沈着と有顝線 維密度低下に関連を認めた。すべての検体でBbの沈着は確認できなった。SLEは RAと比較してClq、Ficollin-3の沈着が有意に多く、RAはSLEと比較しMBLが有 意に多かった。結論】SLEとRAに関連したニューロパチーでの神経障害において 補体の重要性、特に古典経路およびレクチン経路の関与が示唆された。またSLE とRAにおいて補体沈着の差異を認め、病態の違いを反映している可能性がある。

\section{0-18-5 Sjögren症候群 (SS) に伴う末梢神経障害の長期予後 と運動神経障害を伴うsubtypeの特徵}

\author{
玉木 香菜、三條 伸夫、叶内 匡、横田 隆徳
}

東京医科歯科大学 脳神経病態学分野

【目的】SSに伴う末梢神経障害は病型が多彩で, 治療抵抗性であるが, 長期予後を検 討した報告は少ない，長期に追跡できた症例において剖検例を含めて経過を検討 する.【方法】1999年4月〜2019年11月に当科でフォローし, SS厚生労働省改訂診断 基準（1999年）を満たした症例において, 臨床経過・検查結果・治療を後方視的に 追跡した. 神経伝導速度検查 (NCS) は右正中神経の運動神経伝導速度 (MCV), 複 合筋活動電位振幅の推移を解析した.【結果】症例は4例で, 全例女性, 観察期間4-15 (中央值13) 年, 年齢22-54（中央值40.5）歳であった. 全例下肢の痺れで発症し, 2 例は 自律神経障害を合併し慢性緩徐進行期と数年の維持期を経て亜急性の増悪期を認 め, sensory ataxic neuropathyの経過を辿り, NCSで運動神経は正常範囲内で維持 された. 残りの2例はsensory ataxic neuropathyが主体であるが, 1例は腓腹神経生 検でvasculitis neuropathy と診断されたが, 発症6年後に四肢深部感覚障害出現し sensory ataxic neuropathyを合併し, 更に1年後に急性に右正中神経運動神経の軹 索障害が示唆された もう1例は腓腹神経生検でvasculitis neuropathyが示唆され， 四肢潹部感覚障害が強く, 死亡時病理解剖で後根神経節細胞へのT細胞浸潤を認め た. 筋力低下は明らかでなかったが, 右正中神経MCVが徐々に低下した. 2 例とも 赤沈, 䯣液 $I g G$ indexが運動神経障害を伴わない2例より高值の傾向にあった. 治療 は増悪時にステロイドパルス療法, IVIg療法, シクロホスファミド静注療法のいず れかが実施され, 1例のみリツキシマブが投与されていた【結論】いずれも sensory ataxic neuropathy主体だが, 運動神経障害を伴わない群，伴う群に分かれた，後者 は後根神経節細胞への炎症細胞浸潤がある一方血管炎の存在もあり, SSによる末 梢神経障害の長期罹患者における, 運動神経障害の合併にはシステミックな炎症 や䯣液中のIgG産生が関連していることが示唆された.

\section{O-18-7 NSVNとEGPAによる末梢神経障害の臨床・神経生理 学的比較研究}

渡部 俊介 ${ }^{1}$ 関口 兼司 ${ }^{1}$ 、森本 ${\text { 耕平 }{ }^{1} \text { 、野田 佳克 }{ }^{1,2} \text { 、松本 理器 }}^{1}$ 神戸大学大学院医学研究科 脳神経内科学、 ${ }^{2}$ 中田医院

【目的】血管炎症候群は全身臟器を障害することが多いが、末梢神経障害のみ呈す るNon-systemic vasculitic neuropathy (NSVN) も存在する。NSVNはCHCC 2012 分類でSingle-organ vasculitis of the peripheral nervous systemに位置づけられ、 $40 \mu \mathrm{m}$ 以下の微小血管の障害が主体と報告されるが，詳細な病態は明らかでな い。同サイズの血管が障害されるEosinophilic granulomatosis with polyangiitis (EGPA) の末梢神経障害との臨床・神経生理的比較から病態の特徵を明らかにす る。【方法】2016年1月から2019年11月までに当院を受診しNSVN及び末梢神経障 害を伴うEGPAと診断された症例を後方視的に抽出し神経伝導検查、神経超音波 検查、臨床病型を比較検討した。臨床病型はCollinsらにより2017年提唱された Multifocal neuropathy (MN.2つ以上の解剖学的に連緢しない神経の多発単神経 障害)、Overlapping multifocal neuropathy (OMN;解剖学的に連続した神経の多 発単神経障害)、Distal symmetric polyneuropathy (DSP;遠位優位で左右対称の 神経障害）の3病型を用いた。【結果】NSVN8例、EGPA6例が抽出された。神経伝 導検査は全例軸索障害を認め、NSVNで尺骨神経の障害が多かったが (障害頻度 : 運動及び感覚神経 $\mathrm{p}<0.05$ )、他の神経は有意差を認めなかった。神経超音波検查 はNSVN5例のみ施行され、著明な腫大はなく、正中・尺骨神経の前腕部優位に 軽度の局所的神経腫大を認めた。臨床病型はMNがNSVN0例、EGPA2例、OMN がNSVN8例、EGPA4例、DSPがNSVN1例、EGPA0例であった。診断までの期

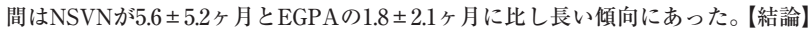
$\mathrm{NSVN}$ の進展様式はMN $\rightarrow \mathrm{OMN} \rightarrow \mathrm{DSP}$ 順と考えられている。本研究のNSVN、 EGPAの臨床病型は診断までの期間を反映し多様であり、同一病期ならば同様の 臨床病型を呈している可能性がある。神経伝導検査でも尺骨神経以外に大きな差 異はなく、NSVNはEGPAと類似した病態の可能性が示唆された。

\section{O-18-9＼cjkstart神経伝導検査による 2 型糖尿病患者の神経障害につ いての検討}

飯泉 玩矢

荻寉病院 内科・神経内科

【目的】進行した糖尿病性神経障害diabetic neuropathy（DN）は生命予後を短縮し 生活の質を著しく損なうため、DNの客観的重症度判定法の確立が求められてい る。馬場らによる下肢 2 神経 (脛骨神経と腓腹神経)の神経伝導検査によるDNの客 観的重症度判定法 (Severity criteria of Baba`s diabetic neuropathy classification (BDC)）が発表され、糖尿病診療におけるDN重症度把握の重要性が提唱された。 BDCを用いて当院に扔ける2型糖尿病患者のDNについて把握検討を行った。方 法】当院にて神経伝導検査を行った 26 例の 2 型糖尿病患者について後ろ向き観察的 横断研究を行い、神経伝導検查の結果からBDC-0 4に分類し、各群における患 者背景、検查データについて比較検討した。結果】26例中、BDC-0 4例 BDC-1 6 例 BDC-2 14例 BDC-3 2例 BDC-4 0例であった。感覚神経活動電位（SNAP mean \pm SD $\mu V)$ ）(BDC-0 12.8 $\pm 3.8 ，$ BDC-1 9.3 $\pm 3.8 ，$ BDC-2 2.4 \pm 1.3 ）、感覚神経伝導速

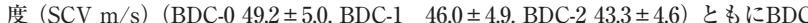
との相関がみられたが、進行例ではSNAPの低下がより顕著であり、複合筋活動 電位 (CMAP mV) (BDC-0 27.9 \pm 5.6 , BDC-1 21.1 \pm 7.0 , BDC-2 16.6 \pm 7.1 , BDC-3 3.4 $\pm 0.5)$ 、運動神経伝導速度 (MCV m/s) (BDC-0 48.3 \pm 4.5 , BDC-1 42.6 \pm 3.2 , BDC-2

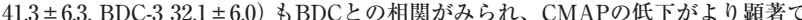
あった。SNAP、CMAPによる分類に妥当性がみられ、DNは活動電位がより障害 されると考えられた。尿中CペプチドとBDCに相関がみられたが、HbAlc、年齢、 BMIとBDCに明らかな相関はなかった。全例でしびれや筋力低下などの訴えはな かった。【結論】BDCはDNの重症度を反映し、その分類にはSNAP、CMAPが役立 つ。尿中CペプチドはBDCを補助する可能性がある。自覚症状がみられない段階 でもDNは進行しており、神経伝導検査は早期に神経障害を評価・把握でき、2型 糖尿病患者管理の精度向上に寄与する。 


\section{0-18-10 先天性白内障を伴ったCMT2A2A家系の臨床・遺伝 学的検討}

\author{
○羽田 貴礼、南 海天、深尾 統子、長坂 高村、瀧山 嘉久
} 山梨大学医学部神経内科学講座

【目的】Charcot-Marie-Tooth (CMT) 病は四肢遠位優位の筋力低下と感営障害を主 な症状とする遗伝性の未梢神経疾患であるが、様々な臨床症状を呈し、複数の遗 伝子変異が報告されている。今回我々は白内障を合併したCMT病の1家系 (4世代 患者4名、健常者14名）について臨床・遗伝学的検討を行った。【方法】発端者は40 歳男性、小児期より足が遲く 30 歳頃から階段昇降が困難となった。既往歴に先天 性白内障と糖尿病があった。神経学的には四肢遠位筋優位の筋力低下・筋萎縮、 滕蓋腱反射の元進・アキレス腱反射の消失、Babinski反射陽性を認め、神経伝導 検查では下肢優位にCMAP・SNAPの低下と伝導速度の低下を認めた。発端者の 母・三女には同様に小坚期からの歩行障害があり、母・母方祖父には白内障と糖 尿病の既往があった。発端者を含む家系内の 6 名に対し遺伝子解析を実施した。!結 果I発端者のexome解析とSanger法により、既知のへテロ接合性 $M F N 2$ 遗伝子変 異 (c.314C>T, p.Thr105Met) CMT2A2A と診断した。また、発症者である母・ 女子同変異を有し、家系内共分離が示唆された。年れ以外のCMT病、遗伝性症性 対麻瘦、白内障の原因遗伝子変異は認めなかった。[結論] MFN2遗伝子変異は帱 索型CMT病の原因遗伝子としては本邦で最多のものであり、本家系と同様に錐体 路症状を伴う例や糖尿病をはじめとした代謝疾患の合併例が報告されている。一 方、本家系で見られた先天性白内障については合併の報告は見出されなかったも

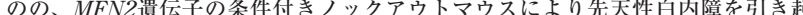
こすことが報告されている。発端者はMFN2遗伝子による先天性白内障の可能性 があり、CMT病の多粎性を考える上で示唆に富む例と考えられた。

\section{0-19-2 withdrawn}

\section{0-19-4 Serum zinc, vitamin B1 and folate decrease in Parkinson's disease with sleep attack}

\section{OShuro Kogawa, Jiro Oi, Makiko Hashi}

Kohka public hospital, Department of Nuerology, Japan

Purpose To evaluate the risk factors of sleep attack (SA) in Parkinson's disease (PD). Methods Subjects were 51 PD patients aged from 40 to 90 year-old (mean age was 72.7 ). We asked every PD patients whether they experienced SA or not. Intellectual activity was evaluated by MMSE. Severity of motor symptoms of PD was evaluated by UPDRS part 3. Atrophy of white matter and gray matter were evaluated byT1WI MRI using Voxel-Based Specific Regional Analysis System for Alzheimer's disease. We measured the serum zinc, copper vitamin B1, B12, 1, 25 vitaminD2 and folate. We compared these factors and age and PD duration between the SA groups and no SA group using student's t-test. Results SA were experienced by 5 patients. SA group had lower vitamin $\mathrm{B} 1(30.0 \mathrm{vs} 49.8 \mathrm{ng} / \mathrm{ml}, \mathrm{p}=0.02)$, folate $(3.7 \mathrm{vs} 13.2 \mathrm{ng} / \mathrm{ml}, \mathrm{p}=0.03)$ and zinc $(66.4$ vs $78.8 \mathrm{ug} / \mathrm{dl}, \mathrm{p}=0.01$ ) significantly than no SA group. On the other hand, age PD duration, MMSE, volume of white matter nor gray matter were not differnt significantly between the two groups. Conclusion Results of this study suggest that nutritional back ground in PD patients may influence the onset of SA. Intervention to butritional state may prevent SA of PD patients.

\section{0-19-1 withdrawn}

0-19-3 Fatty acid-binding protein 3 is critical for alphasynuclein uptake in cultured dopamine neurons

Kohji Fukunaga, Ichiro Kawahata

Tohoku University Graduate School of Pharmaceutical Sciences, Japan

[Objective] Fatty acids partially regulate $\alpha$-Synuclein accumulation, and mesencephalic dopaminergic neurons highly express fatty acid-binding protein 3 (FABP3). We previously demonstrated that FABP3 knockout mice show decreased $\alpha$-Synuclein oligomerization and neuronal degeneration of tyrosine hydroxylase (TH)-positive neurons in vivo. [Methods]We investigated the importance of FABP3 in $a$-Synuclein uptake, 1-methyl-4-phenylpyridinium $\left(\mathrm{MPP}^{+}\right)$-induced axodendritic retraction, and mitochondrial dysfunction. To address the questions, we employed cultured mesencephalic neurons derived from wild type or FABP3 ${ }^{2}$ C57BL6 mice and performed immunocytochemical analysis. [Results] We demonstrated that $\mathrm{TH}^{+}$neurons from $\mathrm{FABP}^{+/+}$mice take up $\alpha$-Synuclein monomers while $\mathrm{FABP} 3 \% \mathrm{TH}^{+}$neurons do not. The formation of filamentous $a$-Synuclein inclusions following treatment with $\mathrm{MPP}^{+}$was observed only in $\mathrm{FABP}^{++}$, and not in $\mathrm{FABP}^{-/}$, neurons. Moreover, FABP3 was also critical for $\mathrm{MPP}^{+}$-induced reduction of mitochondrial activity. [Conclusions]These data indicate that FABP3 is critical for $\alpha$-Synuclein uptake in dopaminergic neurons, thereby preventing synucleinopathies, including Parkinson's disease.

\section{0-19-5 withdrawn}




\section{0-19-6 Novel Drosophila model for Parkinson's disease by targeting phosphoglycerate kinase}

OTakashi Kasai', Shimizu Joº ${ }^{2}$ Hideki Yoshida',

Yumiko Nakao- Azuma $a^{1,3}$, Makiko Shinomoto ${ }^{1}$, Takahiko Tokuda ${ }^{1,4}$,

Toshiki Mizuno ${ }^{1}$, Masamitsu Yamaguchi ${ }^{2}$

${ }^{1}$ Department of Neurology, Kyoto Prefectural University of Medicine,

Japan, ${ }^{2}$ Department of Applied Biology, Kyoto Institute of Technology,

${ }^{3}$ Department of Rehabilitation Medicine, Gunma University Graduate School

f Medicine, ${ }^{4}$ Department of Molecular Pathobiology pf Brain Diseases,

Kyoto Prefectural University of Medicine

[Background] Phosphoglycerate kinase 1 (PGK-1) is a glycolytic enzyme encoded by PGK-1, which maps to the X chromosome. PGK-1 deficiency, which was classically recognized as glycogen disease type 9 , causes X-linked recessive hereditary chronic hemolytic anemia, myopathy, and neurological disorders due to insufficient ATP regeneration. Parkinsonism has occasionally been reported as a neurological complication of this condition. We have reported a boy with PGK-1 deficiency presenting earlyonset parkinsonism and his mother with early-onset Parkinson's disease (PD) who is a heterozygous carrier of the mutation. [Objectives] To investigate phenotypes of Drosophila models with Pgk (a single Drosophila ortholog for human PGK-1) knock-down and validate whether degeneration in dopaminergic $(\mathrm{DA})$ neurons is present under the loss of PGK function. [Resultl DA neuron-specific Pgk knockdown lead to locomotive defects in both young and aged adult flies and was accompanied by progressive DA neuron loss with aging. Pgk knockdown in DA neurons decreased dopamine levels in the centra nervous system (CNS) of both young and aged adult flies. Furthermore, pan-neuronspecific Pgk knockdown induced low ATP levels and the accumulation of reactive oxygen species (ROS) in the CNS of third instar larvae. [Conclusionl These results indicate that a failure in the energy production system of Pgk knockdown flies causes locomotive defects accompanied by neuronal dysfunction and degeneration in DA neurons.

\section{0-19-8 Intranigral inoculation of mutant alpha-synuclein} fibrils induces Lewy-like pathology in mice

OKousuke Baba ${ }^{1}$, Hideki Hayakawa ${ }^{1}$, Kensuke Ikenaka ${ }^{1}$,

Choong Chi-jing ${ }^{1}$, Cesar Aguirre', Masato Koike ${ }^{2}$, Takeshi Ikeuchi ${ }^{3}$, Masato Hasegawa', Seiichi Nagano ${ }^{1}$, Yoshitaka Nagai ${ }^{5}$, Hideki Mochizuki ${ }^{1}$

${ }^{1}$ Department of Neurology, Osaka University Graduate School of Medicine Japan, ${ }^{2}$ Department of Cell Biology and Neuroscience, Juntendo University Graduate School of Medicine, ${ }^{3}$ Department of Molecular Genetics, Bioresource Science Branch, Center for Bioresources, Brain Research Bioresource Science Branch, Center for Bioresources, Brain Research
Institute, Niigata University, ${ }^{4}$ Department of Neuropathology and Cell Biology, Tokyo Metropolitan Institute of Medical Science, ${ }^{5}$ Department of Neurotherapeutics, Osaka University Graduate School of Medicine

Alpha-synuclein $(a$-syn) is a major component of Lewy bodies, which are the pathological hallmark in Parkinson's disease, and its genetic mutations cause familial forms of Parkinson's disease (PD). Patients with $a$-syn G51D mutation exhibit severe clinical symptoms. However, in vitro studies showed low propensity for $a$-syn with the G51D mutation. We studied the mechanisms associated with severe neurotoxicity of G51D mutation using a murine model generated by G51D $a$-syn fibril injection into the brain. [Methods] We analyzed the structure of G51D a -syn fibrils using Fourier transform infrared spectrometer (FT-IR). We next performed pathological analysis of G51D mutation using in vivo inoculation model of $a$-syn fibrils into mouse SN. [Results] FT-IR analysis revealed that G51D $a$-syn fibrils have higher $\beta$-sheet contents than wildtype (WT) $a$-syn fibrils. G51D $a$-syn fibrils induced robust phosphorylated $a$-syn inclusions in inoculation side at 12 weeks, which further spread to the contralateral side at 24 weeks. Moreover, mice inoculated with G51D $a$-syn fibrils showed nigral neuronal loss and motor impairment at 24 weeks. [Conclusions]0ur studies showed that G51D $a$-syn fibrils cause very severe pathology including neuronal cell death compared to W' $a$-syn fibrils. The only difference between G51D $a$-syn fibrils and WT $a$-syn fibrils is the $\beta$-sheet rich content. Our findings indicate that the structural difference of G51D $a$-syn fibrils plays an important role in its accelerated neurotoxicity in the pathogenesis of G51D mutation-linked PD.

\section{0-20-1 Phenotypic skew of circulating follicular helper T cells in Double Seronegative Myasthenia gravis}

OShinji Ashida ${ }^{1},{ }_{2}$ Chihiro Fujiii ${ }^{1}$, Hamatani Mio ${ }^{2}$, Ryusei Nishigori ${ }^{2}$,

Masaki Takata ${ }^{2}$, Kimitoshi Kimura ${ }^{2}$, Kazuyuki Kawamura ${ }^{3}$

Hirofumi Ochi', Ryosuke Takahashi', Toshiki Mizuno ${ }^{1}$,

Takayuki Kondo ${ }^{5}$

'Department of Neurology, Kyoto Prefectural University of Medicine,

Japan, ${ }^{2}$ Department of Neurology Kyoto University Graduate School o

Medicine, ${ }^{3}$ Department of Neurology, National Hospital Organization Minami Kyoto Hospital, ${ }^{4}$ Department of Geriatric Medicine and Neurology, Ehime University Graduate School of Medicine, Toon, Japan, ${ }^{5}$ Department of Neurology, Kansai Medical University Medical Center, Osaka, Japan

[Introduction] 0ver 10\% of patients with MG are negative for detectable antibodies to nicotinic acetylcholine receptor (AChR) and for muscle-specific tyrosine kinase (MuSK). In case with such doubleseronegative MG (dSNMG), diagnosis is sometimes challenging. Since we previously revealed that C-XChemokine Receptor 5 (CXCR5)-expressing follicular helper T cells (Tfh) in peripheral blood (circulating Tfh: cTfh) were phenotypically skewed in anti-AchR antibodies-positive MG (seropositive MG: SPMG) we studied whether these skews were applied to dSNMG. [Methods] Six patients with dSNMG were enrolled. We analyzed peripheral blood T cells from dSNMG by flow cytometry and compared with 24 SPMG and 18 healthy subjects (HS). We analyzed the frequency of cTfh within CD4 T cells and the expression of Inducible T-cell co-stimulator (ICOS) on cTfh. [Results] The frequency of cTfh within CD4 T cells was higher in dSNMG than HS (8.8\% in dSNMG vs. 9\% in SPMG vs. $5.8 \%$ in HS), but not significantly. The frequency of ICOS highly expressing (ICOS ${ }^{\text {high }}$ ) cells within cTfh were significantly higher in dSNMG compared with HS (26\% in dSNMG vs. $39.6 \%$ in SPMG vs. $11.6 \%$ in HS, p= 0.008 [dSNMG vs. HSI). In addition, the frequency of ICOS ${ }^{\text {high }} \mathrm{cTfh}$ within CD4 T cells were higher in ASNMG than HS (2.3\% in $\mathrm{dSNMG}$ vs. $4 \%$ in SPMG vs. $0.9 \%$ in HS, p= 0.02 [dSNMG vs. HS]). [Conclusion] dSNMG showed cTfh phenotypic change like SPMG. Although it is necessary to obtain statistic significance by increasing number of subjects in analysis, ICOS ${ }^{\text {high }} \mathrm{cTfh}$ can be useful as the diagnostic biomarker in dSNMG.

\section{0-19-7 ATP13A2/PARK9 protects brains from a-synuclein propagation}

Taiji Tsunemi', Yuta Ishiguro ${ }^{1}$, Asako Yoroisaka ${ }^{1}$, Ayaka Okuzumi ${ }^{1,2}$, Nobuyuki Nukina ${ }^{2}$, Nobutaka Hattori

${ }^{1}$ Department of Neurology, Juntendo University School of Medicine, Japan, Laboratory of Structural Neuropathology, Doshisha University Graduate School of Brain Science

[Objectivel Parkinson's disease (PD) is pathologically defined as the deposition of $a$-synuclein $(\alpha$-syn) containing Lewy bodies (LBs) and Lewy neurites (LNs). Accumulating evidence suggest that $\alpha$-syn may spread within the nervous system in a prion-like manner. We and others reported that ATP13A2 PARK9-deficiency resulted in decreased secretion of $a$-syn, whereas PARK9 overexpression increased secretion of $\alpha$-syn, leading to the attenuation $\alpha$ -syn accumulation from host neurons in cell culture models. To analyze the effect of the enhanced secretion in neighboring neurons, we plan to examine the alternations of Atp13a2 levels on $\alpha$-syn spreading in vivo. [Methods] At three months after inoculating mouse $\alpha$-syn fibrils into the striatum of three Atp13a2 null and three wild-type mice, we stained the brain sections with anti-phosphorylated $\alpha$-syn antibodies, and then quantified LBs/LNs in each brain regions. We also injected the lentivirus carrying human ATP13A2 at two weeks before the inoculation to examine the effect of increased levels of ATP13A2. [Results] While LBs/LNs were formed in the entire brains, no significant difference was observed in terms of LB/LN formation between Atp13a2-deficient and wild-type mice. Interestingly, overexpression of ATP13A2 lead to decreased LB/LN formation in entire brains. [Conclusion] These results combined with our previous studies suggest that enhanced secretory pathways by increased ATP13A2 levels attenuate spreading of $a$ -syn in brains, suggesting a protective role of ATP13A2 in $\alpha$-synucleinopathies.

\section{0-19-9 Loss of CHCHD2 affects mitochondrial structure and dopaminergic neuronal loss in aged mice}

OShigeto Sato ${ }^{1}$, Sachiko Noda ${ }^{1}$, Manabu Funayama ${ }^{2}$, Nobutaka Hattori ${ }^{1}$ ${ }^{1}$ Department of Neurology, Juntendo University Graduate School of Medicine, Japan, ${ }^{2}$ Research Institute for Diseases of Old Age, Juntendo University

[Objective] Mutations in the CHCHD2 gene cause an autosomal dominant late onset Parkinson's disease (PD). The gene product CHCHD2 contains mitochondria targeting sequence in the N-terminus and coild-coil domain at the $\mathrm{C}$-terminus and has been localized to the intermembrane space of mitochondria. Although little is known regarding the physiological and pathological roles of CHCHD2, the close homologue CHCHD10 is believed to regulate crista structure, maintaining the integrity of the mitochondrial respiratory complexes at the crista junction of the intermembrane space. These studies are preceded by in vitro studies, but there is no evidence of the function in vivo. To understand the physiological and pathological roles of CHCHD2 in vivo, we established CHCHD2 deficient mice. [Methods] We generated and examined the CHCHD2 knockout mice to clarify the phenotype (behavioral analysis, mitochondria structure, dopaminergic neuron) with aging. [Results] Dopaminergic neuronal loss and motor dysfunction were observed in aged mice. In general, PD associated gene deficient mice demonstrated rare phenotype. We would like to discuss the characteristic phenotypes of CHCHD2 knockout mice.

\section{0-20-2 Suitable indications of eculizumab for patients with refractory generalized myasthenia gravis}

Munenori Oyama ${ }^{1}$, Kensuke Okada ${ }^{1}$, Masayuki Masudai ${ }^{2}$, Yuko Shimizu ${ }^{3}$, Kazumasa Yokoyama ${ }^{4}$, Akiyuki Uzawa ${ }^{6}$, Naoki Kawaguchi, ${ }^{5}$, Ryotaro Ikeguchi ${ }^{1}$, Yukiko Ozawa ${ }^{7}$, Jin Nakahara ${ }^{1}$, Hitoshi Aizawa ${ }^{2}$, Kitagawa Kazuo ${ }^{3}$

Nobutaka Hattori ${ }^{4}$, Satoshi Kuwabara ${ }^{6}$, Murai Hiroyuki ${ }^{7}$, Shigeaki Suzuki ${ }^{1}$ Department of Neurology, Keio University School of Medicine, Japan, Department of Neurology, Tokyo Medical University Hospital, ${ }^{3}$ Department of Neurology, Tokyo Women's Medical University School of Medicine, ${ }^{4}$ Department of Neurology, Jntendo University School of Medicine, Department of Neurology, Neurology Chiba Clinic, ${ }^{6}$ Department of Neurology, Graduate School of Medicine, Chiba University, ${ }^{7}$ Department of Neurology, School of Medicine, International University of Health and Welfare

[Objective]Eculizumab is a humanized monoclonal antibody that targets complement protein C5 and inhibits terminal complement-mediated damage at the neuromuscular junction. Eculizumab is effective and well tolerated in patients with anti-acetylcholine receptor antibody-positive $(\mathrm{AChR}+)$ refractory generalized myasthenia gravi $(\mathrm{gMG})$. The purpose of the present study is to determine the suitable indications for treatment with eculizumab for refractory gMG. [MethodslBetween January and December 2018, we followed 1,388 patients with MG a seven hospitals located in Tokyo and Chiba. We evaluated the clinical features of MG and the patients' quality of life (Q0L). ResultslOf 1,388 MG patients, $12(0.9 \%)$ patients received eculizumab. Eleven AChR+ refractory gMG patients ( $\mathrm{M} \cdot \mathrm{F}=3.8)$ completed the 26 -week treatment with eculizumab. The disease subtypes represented included six cases of early-onset MG, one of late-onset MG, and four of thymoma-associated MG. Seven patient had experienced myasthenic crisis. The mean quantitative MG score ranged from 18.6 at baseline to 9.1 at week $26(\mathrm{p}=0.008)$. Similarly, the mean $\mathrm{MG}$ activities of daily living score ranged from 10.8 at baseline to 4.2 at week 26 $(\mathrm{p}=0.002)$. There were marked improvements in all patients' Q0L. Seven patients were able to reduce the dose of prednisolone at week 26 . All but one patient required rescue treatment. [Conclusion]Refractory gMG patients with myasthenic crisis, thymoma-associated MG, and pregnancy are suitable for eculizumab administration. 


\section{0-20-3 The Clinical Features of Myasthenia Gravis in Japan from the National Epidemiological Survey 2018}

OHiroaki Yoshikawa ${ }^{1}$, Yoshikazu Nakamura ${ }^{2}$, Nagato Kuriyama ${ }^{3}$, Hiroyuki Murai ${ }^{4}$, Yasunari Sakai $^{5}$, Yoshiko Nomura ${ }^{6}$, Kazuo Iwasa $^{8}$, Makoto Matsui

${ }^{1}$ Kanazawa University, Health Service Center, Japan, ${ }^{2}$ Jichi Medical

University, Center for Community Medicine, Public Health, Kyoto Prefectural University of Medicine, Department of Epidemiology for Welfare, School of Medicine, Department of Neurology ${ }^{5}$ Kyushu University, Welfare, School of Medicine, Department of Neurology, Kyushu University, School of Medicine, Department of Neurology, 'Nomura Yoshiko Pediatric Neurology Clinic, Kanazawa Medical University Department of Neurology,
${ }^{8}$ Kanazawa University, Graduate School of Medical Sciences, Department of Neurology and Neurobiology of Aging

[Objective] To understand the clinical features of myasthenia gravis (MG) in Japan. [Methods] We conducted the national epidemiological study of $M G$ in 2018. We report the result of the secondary study, including patients diagnosed from Jan 1, 2015, to Dec 31, 2017. [Results] We collected 1452 clinical records from medical institutes. Age of onset (median linterquatile rangel) of total was 58 [41-69], male: 60 [47-69] and female: 54 [37-70]. The ratio of male: female was 1:1.17. The percentage of MGFA I was 36.9. Patients with anti-acetylcholine antibody (AChR $\mathrm{Ab}$ ) was $85.1 \%$, anti-muscle specific tyrosine kinase antibody (MuSK Ab): $2.7 \%$, double positive; $0.3 \%$, double negative: $12 \%$. Thymus image study revealed normal thymus in $58.5 \%$, tumor: $28.6 \%$, hyperplasia: $5.8 \% .36 .5 \%$ of patients received thymectomy. As far as surgery techniques, simple thymectomy was $2.5 \%$, extended thymectomy: $60.8 \%$, endoscopic thymectomy: $32.6 \%$, others: $1.5 \%$, unknown: $2.7 \%$. Regarding the thymic pathology, thymoma was 23.1\%, hyperplasia; $2.7 \%$, involuted thymus; 6.2 , others; $1.1 \%$, and unknown; $66.9 \%$. For complications, Hashimoto disease was 4.6\%, Basedow disease: 4.1 , rheumatoid arthritis; $1.5 \%$, systemic erythematosus: $0.4 \%$, multiple sclerosis $0.1 \%$. As therapies, $77.8 \%$ received choline esterase inhibitor, $68.4 \%$ : steroid, $87.8 \%$; tacrolimus. $1.9 \%$ had a postoperational crisis, and $1.4 \%$ had a post-infectious crisis. Only $1 \%$ of patients had a family onset. [Conclusions] The modern features of MG patients in Japan are informative to consider the diagnosis and therapeutic approaches.

\section{0-20-5 withdrawn}

\section{0-20-4 Diagnosis of LEMS and MG overlap or borderline cases}

Yuki Hatanaka, Yudai Uchida, Kiyoshi Matsukura, Junpei Yamamoto, Midori Kuwabara, Keiichi Hokkoku, Masahiro Sonoo

Department of Neurology, Teikyo Medical University Hospital, Japan

[Objective] MG LEMS overlap syndrome (MLOS) exists between myasthenia gravis (MG) and Lambert Eaton myasthenic syndrome (LEMS), there are double seropositive cases of AChR and VGCC antibodies, and electrophysiological overlap cases. To clarify the existence of borderline cases between MG and LEMS that do not meet serological and electrophysiological diagnostic criteria. [Methods] Retrospectively review clinical features and electrophysiological findings of follow-up LEMS cases. Classify and organize the three parameters of electrophysiology examination: Post Exercise Facilitation (PEF), RNS decremental responses, and decrease of CMAP. [Results]11 cases with clinical symptoms and fulfilling either a PEF $>60 \%$ increase or VGCC antibody positive were defined as LEMS or borderline of LEMS. There were 8 typical LEMS cases, 6 of which were VGCC positive. There were 2 normal CMAP cases (1 VGCC positive) and 1 VGCC positive case with no RNS decrement as the borderline of LEMS. Two cases with normal CMAP amplitude were classified as borderline of LEMS because they did not meet the MLOS criteria proposed by $\mathrm{Oh}$ in 2016. [Conclusions] It should be reconfirmed that CMAP normal and PEF positive cases exist as the borderline of LEMS. Post exercise facilitation examination should be considered for cases that can be diagnosed with usual MG.

\section{0-20-6 withdrawn}

\section{0-20-7 Unique pathomechanisms of nuclear envelope myopathy}

Yukiko Hayashi, Kaori Yamashita, Megumi Kato, Eiji Wada

Department of Pathophysiology, Tokyo Medical University, Japan

[Objective] Mutations in the genes encoding nuclear envelope proteins such as emerin and A-type lamins cause several human diseases including EmeryDreifuss muscular dystrophy (EDMD). EDMD is characterized as slowly progressive muscular dystrophy, early joint contractures, and cardiomyopathy with conduction defects. We recently produced a double mutant mouse named EH, by crossing emerin knock-out (Emd) and Lmna H222P knockin (H222P) mice. [Methods] We used Emd, H222P, EH and wild type (WT) mice. Growth curve and survival rate were examined. Muscle functions were analyzed in vivo and ex vivo. Histological analyses were done using skeletal and cardiac muscles. Gene and protein expression were also compared. [Results] EH mice show dystrophic changes of skeletal muscles before appearance of cardiomyopathy. Abnormal nuclear shape and altered localization of nuclear membrane proteins are seen which are similarly observed in EDMD patients. Some candidate molecules have been identified which may have important roles for nuclear envelope myopathy. [Conclusions] Lack of emerin enhances skeletal muscle symptoms which is different from cardiac muscle. $\mathrm{EH}$ mouse is a good animal model to elucidate pathomechanisms of EDMD.

\section{0-20-8 Cricopharyngeal bar in inclusion body myositis: A red flag}

$\bigcirc$ Kenichiro Taira ${ }^{1}$, Toshiyuki Yamamoto ${ }^{1}$, Madoka Mori-yoshimura ${ }^{1}$, Satoru Fujita ${ }^{2}$, Yasushi Oya ${ }^{1}$, Ichizo Nishino ${ }^{3}$, Yuji Takahashi ${ }^{1}$ ${ }_{1}^{1}$ Department of Neurology, National Center Hospital, National Center of Neurology and Psychiatry, Japan, ${ }^{2}$ Department of Neurology, Gunma University Graduate School of Medicine, ${ }^{3}$ Department of Neuromuscular Research, National Institute of Health, National Center of Neurology and Psychiatry

Objective: To show the predictive risk factors for aspiration pneumonia and prognostic importance of a cricopharyngeal bar (CPB) on videofluoroscopic examination of swallowing (VFS) in inclusion body myositis (IBM). Methods: In this longitudinal study, we examined a consecutive series of 37 patients with clinicopathologically defined IBM based on the European Neuromuscular Center diagnostic criteria for IBM from 2013. A standard VFS was performed at diagnosis. The primary outcome was aspiration pneumonia. Secondary outcomes included IBM Functional Rating Scale score, forced vital capacity (FVC), and body mass index (BMI). Results: Aspiration pneumonia occurred in 10 of 37 IBM patients (27\%). Based on univariate analysis, 4 factors increased aspiration pneumonia risk: BMI < $18.5(\mathrm{n}=5$; hazard ratio [HR], 10.7; 95\% CI, 2.50-46.0; $\mathrm{p}=0.001)$; aspiration $(\mathrm{n}=7$; HR, 7.57; 95\% CI, 1.82-31.6; $\mathrm{p}=0.005$ ); insufficient opening of the upper esophageal sphincter $(\mathrm{n}=11$; HR, $4.53 ; 95 \% \mathrm{CI}, 1.12-18.3 ; \mathrm{p}=0.03)$; and CPB presence $(\mathrm{n}=15 ; \mathrm{HR}$, $11.6 ; 95 \%$ CI, 1.46-91.8; $\mathrm{p}=0.02$ ). Clinical features of IBM-CPB $(+)$ were elderly onset, obstruction-related dysphagia, and mild decreases in $\mathrm{FVC}$, resulting in aspiration pneumonia in 1.3 years (interquartile range, $0.9-5.2) ; 67 \%$ of IBM-CPB $(+)$ patients underwent interventional procedures for dysphagia. IBM-CPB $(+)$ patients had a lower FVC than IBM-CPB (-). Conclusions: A CPB in IBM is a risk factor that predicts aspiration pneumonia and refractory dysphagia requiring aggressive therapy. 


\section{0-20-9 Clinical features of inclusion body myositis associated with Sjögren's syndrome}

Satoshi Yamashita ${ }^{1}$, Akihiro Mukaino ${ }^{1}$, Yoshimune Yamasaki ${ }^{1}$, Kentaro Hara', Nozomu Tawara', Asako Kakimoto',

Hidetsugu Ueyama ${ }^{2}$

${ }^{1}$ Department of Neurology, Graduate School of Medical Sciences, Kumamoto University, Japan, ${ }^{2}$ Department of Neurology, National Hospital Organization, Kumamoto Saishun Medical Center

[Objective] Inclusion body myositis (IBM) is a refractory muscle disease characterized by inflammatory and degenerative features in myofibers. While immunotherapy is typically less effective for IBM patients, many cases present patients with Sjögren's syndrome $(\mathrm{SjS})$, for whom immunotherapy has been reported to be effective. The aim of this study is to determine whether IBM patients with and without SjS are clinically different. [Methods] We investigated the clinical differences between the IBM patients with and without SjS, in terms of the following parameters: age, gender, disease duration, body mass index, initial symptoms, presence of dysphagia, distribution of muscle weakness, grip strength serum levels of creatine kinase, anti-NT5C1A autoantibodies, respiratory and cardiac function, IBMFRS scores, and responsiveness to immunotherapies. [Results] Among 248 patients enrolled into the study, 165 patients fulfilled the ENMC2011 criteria for diagnoses of IBM. We compared the clinical differences between the patients with $\operatorname{SjS}(n=10)$ and without $\operatorname{SjS}(n=155)$. The patients with $\operatorname{SjS}$ exhibited a significant female predominance, and decreased vital capacity and forced vital capacity. However, other parameters were not significantly different between the both groups, including responsiveness to immunotherapies. [Conclusions] While IBM with SjS shares histological similarities with IBM, it differs from IBM in female predominance, and decreased respiratory function. Based on the observation, we speculate a possible pathogenic relationship between IBM and SjS.

\section{0-21-1 A novel vaccine against S100A9 prevented} thrombus formation in cynomolgus monkey

\footnotetext{
Munehisa Shimamura ${ }^{1,2}$, Koichi Kaikita ${ }^{3}$, Tsutomu Sasaki ${ }^{1}$

Tomohiro Kawano ${ }^{1}$, Kenichi Tsujita ${ }^{3}$, Hideki Mochizuki ${ }^{1}$

${ }^{1}$ Department of Neurology, Osaka University Graduate School of Medicine,

Japan, ${ }^{2}$ Department of Health Development and Medicine, Osaka University Graduate School of Medicine, Japan, ${ }^{3}$ Department of Cardiovascular

Medicine, Graduate School of Medical Sciences, Kumamoto University
}

Objective To solve the low medicine adherence in secondary prevention in stroke, we recently developed an antithrombotic vaccine against S100A9 in mice. One of problems in clinical application is that the amino acid sequences in B-cell epitope is quite different between mice and human. To solve the problem, we examined the effects of vaccine against human S100A9, whose sequence is common to that in monkeys, using cynomolgus monkey. Methods An epitope in human S100A9 was conjugated to KLH. The mixture of the epitope and Alum was subcutaneously injected for three times every two weeks. Production of antibody for human S100A9 was examined in ELISA or Western blotting analysis. To check the antithrombotic effects, the mixture of vaccinated serum and fresh whole blood from another monkey was examined in an automated microchip flow-chamber system. Result Successful production against human S100A9 was shown in ELISA and Western blotting analysis. Although addition of pre-vaccinated serum into fresh whole blood did not affect the thrombus formation, post-vaccinated serum prevented the thrombus formation in 2 monkeys. The antithrombotic effects were partially reversed with the epitope peptide. This indicated that epitope could neutralize the antithrombotic effects. Prolongation of bleeding time was not observed. Conclusion Newly desinged vaccine against human S100A9 could successfully showed antithrombotic effects in some monkeys. This vaccine might be a novel strategy in antithrombotic therapy although further studies in safety aspects are necessary.

\section{0-21-3 CRP: strong exacerbation predictor in acute ICA/ M1O patients who underwent recanalization}

\section{Junichi Uemura ${ }^{1,2}$, Takeshi Inoue ${ }^{1,2}$, Masahiro Ohta ${ }^{1}$, \\ Shinji Yamashita ${ }^{1,2}$, Yoshiki Yagita ${ }^{2}$ \\ ${ }^{1}$ Department of Stroke Medicine,Kawasaki Medical School General Medical Center, Japan, ${ }^{2}$ Department of Stroke Medicine, Kawasaki Medical School,} Japan

(Objective) Intravenou recombinant tissue plasminogen activator (rt-PA) and mechanical thrombectomy (MT) have become standard therapy for acute internal carotid artery and middle cerebral artery M1 segment occlusion (ICA M1O).However, in some cases, the prognosis is one of exacerbation.We aimed to predict patient factors associated with this prognosis of exacerbation. (Methods) This was a single-center, retrospective study of 35 consecutive patients with acute ICO/M1O who underwent rt-PA/rt-PA and MT at our hospital between January 2016 and September 2019. We divided patients into two groups based on their modified Rankin Scale (mRS) score at discharge;improvement (mRS score 0-2) and exacerbation (mRS 3-6) and compared clinical characteristics, laboratory data, and MRI findings between the groups. (Results) Improvement group had $13(37 \%)$ and exacerbation group had $22(63 \%)$ patients.Improvement group had lower mean values of age ( 70 vs. 81 years, $p=0.02)$,National Institutes of Health Stroke Scale score (13 vs.19,p=0.02), and C-reactive protein (CRP) levels $(0.24$ vs. $0.92 \mathrm{mg} / \mathrm{dl}, \mathrm{p}<0.01)$ than exacerbation group.ROC curve showed that cut-off of age was 79 (sensitivity $76.9 \%$, specificity $72.7 \%$,area under the curve 0.745$)$,NIHSS was $20(92.3 \%, 63.6 \%, 0.741)$, and CRP was $0.14 \mathrm{mg} / \mathrm{dl}(69.2 \%$ $81.8 \%, 0.774)$. Multivariate analysis comfirmed that CRP $(>0.14 \mathrm{mg} / \mathrm{dl}) \quad(\mathrm{OR}$ $10.16 ; 95 \%$ CI $1.38-75.13, \mathrm{p}=0.01$ ) was independently associated with exacerbation group. (Conclusions) $\mathrm{CRP}(>0.14 \mathrm{mg} / \mathrm{dl})$ is a strong predictor of exacerbation at dischage in patients with acute ICA/M1O who underwent recanalization therapy.
0-20-10 Relationship between verbal IQ and gene mutation in patients with Duchenne muscular dystrophy

Hajime Arahata, Akihiro Watanabe, Nobutaka Sakae, Yuji Kawano, Akifumi Yamamoto, Naokazu Sasagasako

National Hospital Organization Omuta National Hospital, Japan

[Objective] The clinical features in patients with DMD are progressive muscle weakness, cardiomyopathy and intellectual disability. The former two progressively decline in the course of the disease and are involved in life span, but are unclear in the intelligence. Here, we examined the relationship between VIQ and DMD isoforms. [Methods] Among patients with confirmed DMD clinical and genetic diagnosis, we performed verification in patients who had consent and received multiple Wechsler Intelligence Scale (WAIS-R or WAIS-III and WISC-III) tests. [Results] In 31 patients (13.0 yo \pm 5.5 yo), there was no decline in VIQ (first time $77.7 \pm 20.5$ ) over time (final VIQ value 81.3 \pm 20.0 ) (test interval 6.5 years \pm 3.0 ). As biopsy of brains are not possible, we used information of mutations in $31 D M D$ genes, patients were classified into theoretical disturbed/non-disturbed isoforms groups. Among them, the Dp140 non-disturbed group and disturbed group did not change VIQ over the time, but each groups' VIQ was $86.8 \pm 19.1$ and $73.3 \pm 20.2(\mathrm{p}<0.05)$. [Conclusions] In DMD patients, dystrophin-induced dysfunction in neurons decline in intelligence at birth. But it may not change after the birth. Also, significant difference was observed in the grouping based on the presence or absence of Dp140. There are some cases in which correct psychological examination is difficult due to psychological problems, but genetic information may be helpful in these cases. In addition, isoforms such as Dp140 were speculative to affect in the early stage of the disease.

\section{0-21-2 Wnt signaling is associated with hemorrhagic transformation after intravenous thrombolysis}

Junlei Chang ${ }^{1}$, Song $\mathrm{Ta}^{2}$, Zhen-ni Guo ${ }^{2}$, Hang Jin², Peng Zhang ${ }^{2}$,

Fenge $\mathrm{Li}^{2}$, Chenqing Zeng, Qingquan $\mathrm{Gu}^{3}$, Yuan Zhang ${ }^{4}$,

Wenlan $\mathrm{Liu}^{4}$, Yi Yang ${ }^{2}$, Xian-fang Rong

${ }^{1}$ Shenzhen Institutes of Advanced Technology, Chinese Academy of

Sciences, China, ${ }^{2}$ Dept of Neurology, The First Hospital of Jilin University,

${ }^{3}$ Shenzhen RealOmics Biotech Co., Ltd., ${ }^{4}$ Shenzhen Second People's Hospital

Objective The Wnt signaling is essential to blood-brain barrier function in animals. Here we explored the implication of the Wnt signaling in hemorrhagic transformation (HT) after intravenous thrombolysis in acute ischemic stroke (AIS) patients. Methods Blood samples are collected at admission prior to thrombolysis and HT is detected with CT scans 24 hours later. Serum Wnt signaling biomarkers were measured, and SNPs or exon sequences for 28 Wnt signaling genes were determined with a customized sequencing chip. Gene mutations were further studied in vitro in cellular models. Results 124 patients including HT patients $(n=54$, consecutively enrolled) and Non-HT patients ( $\mathrm{n}=70$, age- and sex-matched) were enrolled. Serum DKK3 was decreased in HT patients $(p=0.001)$, whereas serum DKK2 was selectively increased in HT patients with parenchymal hematoma $(\mathrm{PH})(p=0.015)$. WNT7A SNP rs2163910 and rs1124480, and $W N T 7 B$ SNP rs67604162 were increased in HT patients $(p<0.05)$. GPR124 SNP rs75336000 (missense variant, c.3587G>A) was selectively enriched in $\mathrm{PH}$ patients $(p=0.0088)$. A higher portion of $\mathrm{PH}$ patients than Non-HT patients had multiple copies of these HT risk SNPs ( $>4$ copies/patient, $18.2 \%$ vs. $7.6 \%)$. Furthermore, the c.3587G $>$ A mutation of GPR 124 substantially reduced Wnt signaling by dissociating DVL1 from GPR124 intracellular domain in cell culture Conclusions Wnt signaling serum biomarkers and genetic variations are associated with increased risk of HT following thrombolysis in AIS patients, suggesting a key role of Wnt signaling in thrombolysis induced intracerebral hemorrhage.

\section{0-21-4 Stroke incidence in super elderly patients taking direct oral anticoagulants}

Taizen Nakase ${ }^{1}$, Hiroaki Shimizu ${ }^{1}$, Junta Moroi ${ }^{2}$, Tatsuya Ishikawa ${ }^{2}$

Stroke Comprehensive Medical Center, Akita University Hospital, Japan,

Akita Cerebrospinal Cardiovascular Center

[Objective] The effectiveness and safety of direct oral anticoagulants (DOACs) in super elderly patients are still under debate. However, the older the population becomes, the higher the prevalence rate of atrial fibrillation and the needs of anticoagulation therapy become. Therefore, this study aimed to investigate the stroke incidence in super elderly patients who had been prescribed any DOAC as preventing embolic events. [Methodsl Acute ischemic stroke patients were screened between April 2015 and March 2019, and patients taking any kind of DOAC prior to the index stroke were included in this study $(n=64)$. Super elderly were defined as aged over 85 yearsold. Clinical data were compered between patients over 85 yo $(n=14)$ and younger than 85 yo $(n=50)$. [Results] The prevalence rate of stroke risk factors was not different between two groups. Inappropriate prescription rate was significantly lower in over 85 group compared with younger group $(p=0.047$ : $7 \%$ and $38 \%$, respectively). The ischemic lesion size was significantly smaller in over 85 group compared with younger group ( $\mathrm{p}=0.042: 2.3 \mathrm{ml}$ and $23.5 \mathrm{ml}$, respectively). The most frequent stroke subtype was cardioembolic stroke in both groups $(65 \%)$. The outcome was not significantly different between two groups. [Conclusions] There was no specific problem related to super elderly in regards to stroke incidence during anticoagulation therapy using DOAC. Moreover, the efficacy of DOAC could be properly functioned in super elderly patients, since lesion size was small in those patients with DOAC appropriately prescribed. 
0-21-5 Observation of maladaptive behaviors in a stroke patient with Vineland II Adaptive Behavior Scales

Masanori Nagaoka ${ }^{1}$, Sayuri Ofuji ${ }^{2}$, Kazuhiro Kanayama ${ }^{2}$,

Yuko Ozone ${ }^{2}$, Saori Kokubo ${ }^{3}$, Narumi Yasui ${ }^{3}$

${ }^{1}$ Dept of Internal Medicine, Meirinkai Nikko-Noguchi Hospital, Japan, ${ }^{2}$ Dept of Rehabilitation, Meirinkai Nikko-Noguchi Hospital, ${ }^{3}$ Nursing Department,

Meirinkai Nikko-Noguchi Hospital

We present the case of a 78-year-old male with left hemiplegia suffered from stroke. During seven years after the stroke, he insidiously became showing maladaptive behaviors to his caregivers. On admission, he had cognitive impairment, maladaptive speeches and actions, i.e. insisted only selfish desires, abusive words and spat at others, and very vigorous and rapid actions of his non-paretic right hand which sometimes hurt his caregivers. Surface EMG showed low voltage tonic activity in his neck and right arm at rest and during action, the outbreaks of EMG among arm muscles, sometimes with grouping pattern at about $1 \mathrm{~Hz}$. Brain CT revealed low density areas in internal capsule and basal ganglia and in cerebellar hemisphere, both on the right side. We thought his rapid action, i.e., a kind of hyperkinesia, is caused by cerebellar lesion on the right side. And maladaptive speeches were considered as the acquired ill manner built by overprotection during almost of seven years of institutionalization and hospitalization, based on impaired cognitive functions With the small amount of haloperidol, one of neuroleptics, his maladaptive speeches and abrupt actions were improved to some extent and he could be backed to his previous nursing home. This changes in adaptive behaviors particularly in communication, were evaluated retrospectively with Vineland II Adaptive Behavior Scales.

\section{0-21-7 CYP2C19 and PON1 polymorphisms alter on-} clopidogrel platelet reactivity in neurointervention

Koji Tanaka ${ }^{1}$, Shoji Matsumoto ${ }^{2}$, Gulibahaer Ainiding ${ }^{1}$,

Ichiro Nakahara ${ }^{2}$, Akira Ishii ${ }^{3}$, Taketo Hatano ${ }^{3}$, Kyoko Iinuma ${ }^{1}$ Takuya Matsushita ${ }^{1}$, Noriko Isobe ${ }^{4}$, Ryo Yamasaki ${ }^{3}$, Izumi Nagata, Jun-ichi Kira ${ }^{1}$

${ }^{1}$ Department of Neurology, Neurological Institutes, Graduate School of Medical Sciences, Kyushu University, Japan, ${ }^{2}$ Department of Comprehensive Strokology, Fujita Health University School of Medicine, ${ }^{3}$ Department
of Neurology, Kokura Memorial Hospital, ${ }^{4}$ Department of Neurological of Neurology, Kokura Memorial Hospital, ${ }^{4}$ Department of Neurological
Therapeutics, Graduate School of Medical Sciences, Kyushu University

[Objective] We aimed to investigate associations between CYP2C19 and paraoxonase-1 (PONI) polymorphisms and on-clopidogrel platelet reactivity in patients undergoing neurointervention. [Mehods] Between May 2010 and November 2013, consecutive patients who received elective neurointervention under the dual antiplatelet therapy were enrolled. The on-treatment platelet reactivity was measured using the VerifyNow ${ }^{\mathbb{B}}$ P2Y12 assay as P2Y12 reaction units (PRU) High platelet reactivity (HPR) was defined as PRU $\geqq 230$. Genotype testing was performed for the CYP2C19*2, *3, and *17, and PON1 Q192R. The associations between both CYP2C19 and PON1 polymorphisms and HPR were investigated. [Results] Among 350 patients (177 men, median 68 years of age), $199(56.9 \%)$ had at least one CYP2C19*2 allele, $78(22.3 \%)$ had at least one *3 allele, $3(0.9 \%)$ had one ${ }^{*} 17$ allele, and $311(88.9 \%)$ had at least one R allele in PON1 Q192R. HPR was seen in 162 patients (46.3\%). Patients with HPR more frequently had at least one CYP2C19*2 allele ( $67.3 \%$ vs. $46.8 \%, \mathrm{p}<0.001)$ and $P 0 N 1$ Q192R R allele $(92.6 \%$ vs. $85.6 \%, \mathrm{p}=0.039)$ comparing to those without. In multivariate analysis, having at least one CYP2C19*2 allele (odds ratio [OR] 5.44, 95\% confidence interval [CIl 1.06-42.03), and both at least one CYP2C19*2 and PON1 Q192R R alleles (OR $10.51,95 \%$ CI 2.58-71.44) were associated with HPR after adjustment with sex, hematocrit, platelet count, and current smoking status. [Conclusions] Both CYP2C19 and PON1 polymorphisms may be synergistically associated with HPR under clopidogrel in patients undergoing neurointervention.

\section{0-21-9 NBP reduces cerebral ischemic injury by maintaining} mitochondrial function of endothelial cells

\section{OJingjing Jia \\ Peking University First Hospital, China}

Objective:Dl-3-n-butylphthalide (NBP) is a yellow oily liquid with celery fragrance,which is a kind of anti-ischemia drug developed in China.Many studies have reported that NBP can exert neuroprotective effect against ischemic injury. However,the exact intracellular target and mechanism of NBP is still unknown.This study focused on the effect and mechanism of NBP on vascular endothelial cells after cerebral ischemia. Methods:In this study, we used male C57BL/6 mice to conducted $\mathrm{MCAO} / \mathrm{R}$ model,and used bEnd 3 cells to construct $\mathrm{OGD} / \mathrm{R}$ model.The volume of cerebral infarction and the cell survival rate were detected. The mRNA expression of IL-1b,IL-6,TNF-a,iNOS,VEGF,HIFla were detected by qPCR, WB were used to detected the protein expression of CC3,Bax,Bcl-2,AIF,cytoC. ROS production, MMP and ATP content was detected. Results:NBP can significantly inhibit the cell death rate after OGD $\mathrm{R}$ treatment, reduce the cerebral infarction volume of mice after MCAO/R treatment, inhibit the expression of IL-1b,IL-6, TNF-a,iNOS mRNA,restrain the expression of CC3 and Bax,promote Bcl-2,reduce the release of cytoC and ROS from mitochondria to cytoplasm,and improve the level of MMP and production of ATP,and promoted the expression of VEGF and HIF-la. Conclusions:This study illustrated that NBP can significantly reduce ischemia-reperfusion injury,reduce oxidative stress response,inhibit cell apoptosis and promote angiogenesis. These neuroprotective functions may be produced by maintaining mitochondrial function. Therefore,NBP may play a neuroprotective role by acting on targets in mitochondria.

\section{0-21-6 Association of unknown atrial fibrillation and stroke severity and outcome}

Kenichi Todo ${ }^{1}$, Shuhei Okazaki ${ }^{1}$, Tomoya Wadayama ${ }^{1}$, Aimi Tanaka ${ }^{1}$, Mariko Ohara ${ }^{1}$, Shintaro Sugiyama ${ }^{1}$, Takaya Kitano ${ }^{1}$, Kotaro Watanabe ${ }^{1}$, Kyoko Higashida ${ }^{1}$, Sho Murase ${ }^{1}$, Yoko Kimura ${ }^{1}$, Hiedaki Kanki ${ }^{1}$,

Tsutomu Sasaki ${ }^{1}$, Manabu Sakaguchi ${ }^{1,2}$, Hideki Mochizuki ${ }^{1}$ ${ }^{1}$ Department of Neurology, Osaka University Hospital, Japan, ${ }^{2}$ Department of Neurology, Osaka General Medical Cwenter

[Objective] We hypothesized that ischemic stroke patients with first-ever diagnosis of atrial fibrillation (AF) may have fewer risk factors for cerebrovascular diseases, and thus might be associated with less stroke outcome. However, such patients usually do not receive anticoagulant therapy, and thus might be associated with severe stroke outcome. In the current study, we analyzed the association of "unknown $\mathrm{AF}^{\text {" with stroke }}$ severity and outcome. [Methods] We retrospectively analyzed a database of 196 patients with acute ischemic stroke patients with AF between January 2010 and October 2019. We defined "unknown $\mathrm{AF}^{\text {" }}$ as first-ever AF diagnosed after index stroke, and "known $\mathrm{AF}^{\prime \prime}$ as $\mathrm{AF}$ diagnosed before index stroke. We assessed the National Institute of Health Stroke Scale (NIHSS) score on admission and modified Rankin Scale (mRS) score at discharge. [Results] The population of unknown AF was 33\% (64/196). There were no differences in age ( 76 vs 77 ), gender (male; $50 \%$ vs $67 \%$ ), hypertension ( $53 \%$ vs $62 \%$ ), diabetes mellitus ( $12 \%$ vs $20 \%)$, and past history of heart failure (3\% vs $8 \%)$, between patients with unknown and known $\mathrm{AF}$, respectively. Patients with unknown $\mathrm{AF}$ were associated with lower CHADS2 score $(1[1-2]$ vs 2 [1-4], $p<0.01)$, lower proportion of previous stroke $(12 \%$ vs $34 \%, \mathrm{p}<0.01)$, and less proportion of anticoagulant therapy $(5 \%$ vs $59 \%, p<0.01)$. There were no differences in stroke severity (NIHSS score; 12 vs 9) and outcome (mRS score; 3 vs 3). [Conclusion] Unknown AF is associated with low CHADS2 scores but not stroke severity and outcome.

\section{0-21-8 PCA laterality predicts better functional outcomes after MCA occlusion treated with thrombectomy}

Masahiko Ichijo ${ }^{1}$, Satoru Ishibashi ${ }^{2}$, Nanami Saso ${ }^{1}$, Masashi Suzuki ${ }^{1}$, Asuka Yasuura ${ }^{1}$, Tony Toshiyuki Watanabe ${ }^{1}$, Takeshi Amino', Tomoyuki Kamata ${ }^{1}$

${ }^{1}$ Department of Neurology, Musashino Red Cross Hospital, Japan,

Department of Neurology and Neurological Science,Tokyo Medical and Dental University

[Objective]Endovascular mechanical thrombectomy (MT) is a promising therapeutic approach for stroke patients with large vessel occlusion, though the clinical course is heterogeneous. Prominent PCA laterality upon MRA, indicating collateral flow from PCA to MCA territory via leptomeningeal anastomoses, has often been encountered in MCA occlusion (MCAO) patients. We hypothesized that this sign is correlated with improved functional outcomes in patients with MCAO treated with MT. [Methods]Forty-five acute ischemic stroke patients with MCAO were treated with MT from September 2015 to September 2019. All patients routinely underwent initial MR scans. We retrospectively analyzed the clinical and radiologic data of the patients with or without PCA laterality sign. [Results] Twenty-one of 45 patients had PCA laterality sign on MRA. NIHSS score on arrival did not differ between groups. NIHSS score 24 hours ( $9.5 \pm 7.2$ vs. 15.2 vs. 8.5, $P=0.020)$, and 7 days $(5.9 \pm 6.9$ vs. 10.4 vs. $7.0, P=0.035)$ after stroke onset was significantly lower in patients with PCA laterality sign compared with patients without the sign. Recanalization rate did not differ between groups (TICI3or2b; $18 / 21$ vs. $19 / 24, P=0.705)$.Multivariate logistic regression analyses showed an adjusted odds ratio of 8.50 for a favorable outcome (mRS score $0-1$ at 3 months) in patients with PCA laterality sign $(95 \% \mathrm{CI}, 1.6-65.6 ; P=0.010)$. [Conclusion]The presence of PCA laterality sign on MRA before mechanical thrombectomy can be used as a predictor of improved functional outcome in patients with MCAO.

\section{0-21-10 Involvement of Mucosal-associated invariant T cells for neuroinflammation in acute ischemic stroke}

Sho Nakajima ${ }_{3}^{1}$, Ryota Tanaka ${ }^{1,2}$, Kazuo Yamashiro ${ }^{1}$, Asako Chiba ${ }^{3}$, Daisuke Noto ${ }^{3}$, Hideki Shimura ${ }^{4}$, Naohide Kurita ${ }^{4}$, Kenichiro Hira ${ }^{1}$, Nobukazu Miyamoto ${ }^{1}$, Yuji Ueno ${ }^{1}$, Takao Urabe ${ }^{4}$, Sachiko Miyake ${ }^{3}$, Nobutaka Hattori ${ }^{1}$

${ }^{1}$ Department of Neurology, Juntendo University School of Medicine, Japan, ${ }^{2}$ Stroke Center, Jichi Medical University Hospital, Division of Neurology, Department of Medicine, Jichi Medical University, ${ }^{3}$ Department of Immunology, Juntendo University School of Medicine, ${ }^{4}$ Department of Neurology, Juntendo University Urayasu Hospital

[Objective]The purpose of this study was to elucidate the association between Mucosal-associated invariant T (MAIT) cells and acute ischemic stroke.[Methods]We used MR1 knockout C57BL/6 (MR1-/.) mice, which are deficient in MAIT cells, and wild-type littermates. We performed a 1-hour transient middle cerebral artery occlusion ( $\mathrm{tMCAO}$ ) and evaluated the cerebral infarct volume, motor function of the mice, and the activation of microglia on 24 and 72 hours after ischemiareperfusion. Meanwhile, tMCA0 models of $\mathrm{C} 57 \mathrm{BL} / 6$ mice administered with the MR1 ligand that suppresses the activation of MAIT cells were similarly analyzed. MAIT cells infiltrating the infarct hemibrain were analyzed by fluorescence-activated cell sorting (FACS). ResultslWe observed a significant reduction in infarct volume and a significant improvement of neurological dysfunction in MR1-\% mice on 72 hours. Similar results were obtained in the ligand administration group. Regarding microglia, the number of Ibal positive microglia on 24 hours and the morphological grading assessment on 72 hours was significantly reduced in MR1-/- mice. The cytokine levels of IL-1 $\beta$ and IL- 6 on 24 hours, and the levels of IL-17 on both 24 and 72 hours, were significantly lower in the MR1 -/- mice. FACS analysis showedthe number of MAIT cells infiltrating the infarct hemibrain decreased significantly on 24 hours.[Conclusion]MAIT cells may play an important role in neuroinflammation after focal cerebral ischemia, and the regulation of MAIT cells may have potential as a new neuroprotectant for the treatment of acute ischemic stroke. 


\section{0-22-1 特発性正常圧水頭症における症候と脳白質障害,} Default mode networkの障害との関連性

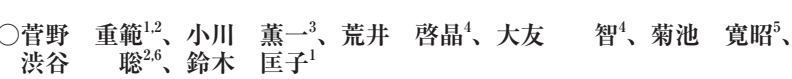
東北大学医学系研究科高次機能障害学分野、

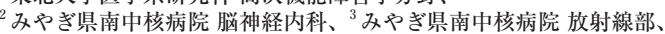

4 久やき県南中核病院 脑神経外科、5 みやぎ県南中核病院 健診センター、 森山記念病院 内科

【目的】特発性正常圧水頭症 (iNPH) における臨床症状の重症度と, 安静時でのDefault mode network (DMN)の活動, 脳白質障害との関連性について检討した. 【方法] iNPP診療ガイドライ

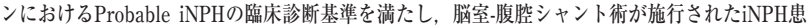
者20名が参加した。術前と術拺6ケ月の時点で，隔床症状の重症度をiNPH grading scale, $3 \mathrm{~m}$ 起立歩行試伢 (TUG), Frontal Assessment Battery (FAB), Rey Auditory Verbal Learning Test (RAVLT) を用いて評侕した。また，術前に安静时譄活動を患者每に測定し，全患者の安 静时媨活動デー夕を用いて独立成分分析を施行したところ，DMNの活動を梌出することができ た. Dual regressionによりDMNの機能的結合性（DMN-FC）を患者每に算出した。更に，全脑 の拉散テンソル画像を患者每に撮像 L、Fractional anisotropy (FA) mapを作成した。全患者 のFA mapを用いて腷白質線維束のスケルトンを作成し, 各患者の腷白質線維束平均 $\mathrm{FA}$ A值 (FBFA) を算出した. FB-FAとDMN-FCの散布図を確認したところ，FB-FAに比してDMN-FCが者 しく低下している群(DMN-FC良好群 : $\mathrm{n}=12$ ) と比較的保たれている群 (DMN-FC不良群 $\mathrm{n}=6$ ) に分けられたため，術前，術後における臨床症状の重症度を雨群間で比較した. 結果IDMNFC不良群ではDMN-FC良好群と比較して術前のRAVLT (即時再生,20分後荤延再生と再認) の

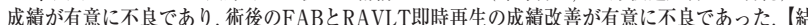
論1本検討ではiNPH患者の $30 \%$ において临白質線維束の損傷度に比してDMN-FCが著しく低下 しており，記譩障害が重度から認知機能の術後改善が不良であった。 iNPHにおけるアルッハイ マー病理の合併率は22\% 50\%とされており, 本検討の有所見率に近似していた. DMN-FCと FB-FAの測定によりiNPHにおけるアルッハイマー病理の合併を予测できるかもしれない．

\section{0-22-3アルツハイマー病におけるCAAと血中ホモシスティ ンとの関連}

○金丸 和富、仙石 錬平、仁科 裕史、村山 繁雄 東京都健康長寿医療センター 神経内科

【目的】ホモシステイン (Hcy) とアルッハイマー型認知症との関連が注目されてい る. Hcyが, 脳アミロイド血管症 (CAA) と関連しているとの報告もある.今回、ア ルッハイマー病（AD）におけるCAAと血中Hcy濃度との関連について检討した。 【方法】対象は, 臨床的に診断されたAD 136例（75.2 28.8 歳, 女性83例, 男性53例)。 頭部MRIを施行し, T2*強調MRIによって認められる大腮皮質から皮質下にかけて の脑葉型微小出血 (CMBs) をCAAの指標とした. CAAの有無で2群 (CAA- 90例, $\mathrm{CAA}+46$ 例）に分け, 血中Hcy濃度を比較検討した。また、脳脊政液バイオマー カー (CSF A $\beta 42$, tau, ptau-181) pMMSEについても検討を加えた. CSF A $\beta$ 42, tau, ptau-181は, 承諾を得た後, 腰椎穿刺によって得た脳脊䯠液を用い, ELISA (Fujirebio, Belgium)により測定した.【成績】AD全例においてHcyの上昇は MMSEの低下と有意に相関した $(\mathrm{p}<0.05)$. Hcyは, CAA-: 11.6 $\pm 4.0, \mathrm{CAA}+: 14.3 \pm$ $10.5 \mathrm{nmol} / \mathrm{ml}$ とCAA+において高值の傾向はあったが, 有意差は認めなかった。

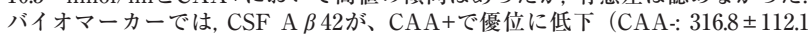
$\mathrm{CAA}+274.2 \pm 108.7 \mathrm{pg} / \mathrm{ml}, \mathrm{p}<0.05, \mathrm{t}$ 検定)、また, MMSE值が, CAA+で優位に低 下 (CAA-: 20.3 $\pm 6.3,16.5 \pm 7.0, \mathrm{p}<0.005$, t検定) していた. CSF tau, ptauは, 両群間で 有意差は認めなかった、【結諭】Hcyは認知機能低下と関連する. CAA+群において 血中Hcyは, 高値の傾向はあったが, 有意差は認めなかった. CAA+において, CSF A $\beta 42$,また, MMSEが有意に低下していた。

\section{0-22-5 視覚呈示時間による全体と部分認知の関連性 -Navon図形を用いた症例模討-}

\footnotetext{
○森原 啓介 ${ }^{1}$ 、東山 雄一 1 、浅野 史織 1 、松永 祐已 ${ }^{1}$ 、高橋 慶太 $\mathrm{N}^{1}$

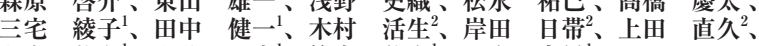
上条 英人、土井宏、竹内 英主、田中章景 1

'横浜市立大学神経内科学・腷卒中医学、

横浜市立大学附属市民総合医療センター 神経内科
}

[背景】同時失認とは，紐部の認知は良好であるにも関わらず同時に全体を把握するこ とが困難な状熊とされ，その症候や病巣，想定される障害機序により様々な分類がな されている.我々は右後大脳動脈領域梗塞により，Farahの腹側型同時失認を認めた 症例を対象に階層的複合刺激，いわゆるNavon図形を用いた視知営検查を行い，刺激 呈示時間により部分/全体認知がどのように変化するか検討を行った。【対象】症例は 62 歳右利き男性. 某日歩行時のふらつきとともに, 外の景色が扔かしいことに気づき 近医を受診。脳MRIで右後頭葉(海馬傍回・舌状回・一次視覚野)，右視床に新規脑梗 塞を認め当院緊急入院となった、入院時，意識清明で読み書きを含めた言語機能に異 常はなかったが、左半側空間無視，相貌失認，街並失認に加え，呈示された視觉刺激 に対して部分部分を逐次的に処理して認知する，腹側型同時失認を認めた【【検討】小 さな数字で大きな別の数字を構成したNavon図形12種を，それぞれランダムに0.2秒， あるいは2秒間，右視野に視覚呈示し，判読できた数字を全て回答させた。対照刺淿 としてNavon図形(全体・部分)と同サイズの数字4種を用いた課題も施行した【結果】 Navon図形の部分のみを回答した (同時失認) のは２秒，02秒条件でそれぞれ41.7\%， $20.8 \%$ ，全体を知覚できたのは各条件で $58 \%, 75 \%$ であり，0.2秒条件で有意に同時失認 が少なかった $\left(\chi^{2}\right.$ 検定, $\left.\mathrm{p}<0.01\right)$. 一方, 対照図形についてはほほ全問正答できた。 [考 察]本例では，Navon図形を短時間の久視覚呈示すると同時失認が出現しにくい， なわち全体を認知できる傾向がみられた。このことより，視覚認知の初期段階では対 象の全体知覚がなされているにも関わらず，それが早期に減衰する，あるいは後に部 分の知覚处理が過剩に行われることで同時失認が生じていると考察した。

\section{0-22-2 頭部MRIにおける脳内微小出血MBsおよび白質病変 と新規血中マーカーMR-pro ADMの関係}

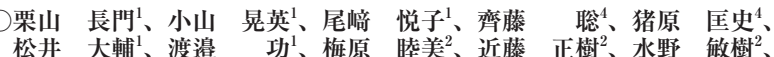
丸中 良典、高田 明浩、赤澤健太郎、山田 惠 ${ }^{3}$ 富田 仁美 ${ }^{1}$ 長光 玲央 ${ }^{1} 、$ 宮欲史太郎、至、宅 正裕 ${ }^{6}$ 、渡邊 能行 ${ }^{1,7}$ 、上原 里程 京都府立医科大学大学院医学研究科 地域保健医療疫学、 京都府立医科大学大学院医学研究科脎神経内科学

京都府立医科大学大学院医学研究科放射線診断治療学

“国立循環器病研究センター 脳神経内科、5 京都工場保健会

${ }^{6}$ 京都大学大学院医学研究科 眼科学、 7 京都先端科学大学 健康医療学部

(目的我々は、血管作動性生理ベブチドのアドレノメデュリン前取体であるMR-proADM (Midregional

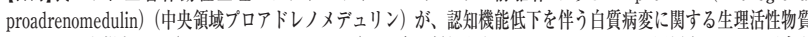

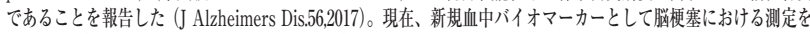

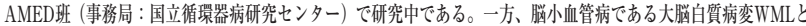

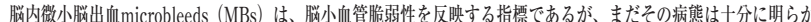

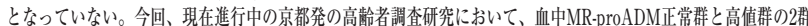

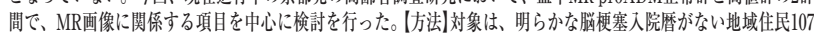

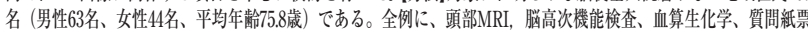

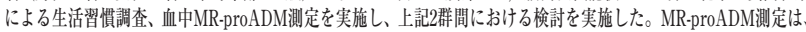

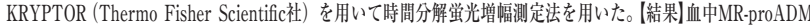

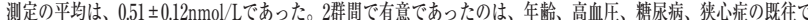

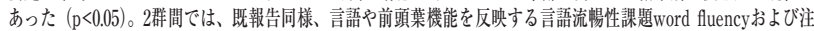

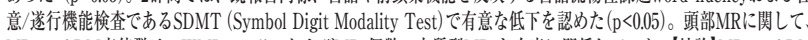

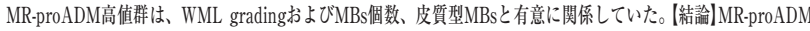

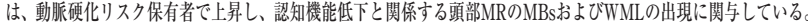

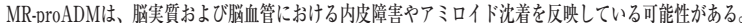

\section{O-22-4 iNPHの基盤に存在するPSPの画像所見 : FP-CIT SPECT}

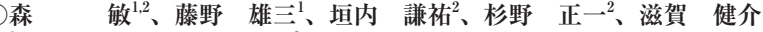
${ }^{1}$ 松下記念病院 脳神経内科、 ${ }^{2}$ 藍野病院 脑神経内科

【目的】特発性正常圧水頭症(iNPH)の症状はシャント後に一時的に改善するが, 再 び悪化する。これは, 基盤に変性疾患が存在するためで, 病理所見は大半が進行 性核上性麻瘦(PSP)である。その臨床病型は,「すくみ足を呈し緩徐に進行する軽 症型 (progressive gait freezing)」と報告されている。iNPHの基盤に存在する本 病型を診断するための着目点として，前々回に症候（pull test），前回に形態画像 所見 (concaved tegmentum) について報告した。今回は, FP-CIT SPECT所見に ついて報告する。【対象と方法】iNPHの臨床徴候（歩行障害・認知機能障害・尿失 禁), 特徵的形態画像所見(脳室拡大・円蓋部くも膜下腔狭小化・シルビウス裂開大) を呈し,タップテスト陽性の連続6症例。神経学的診察に加えて, CT/MRI, FPCIT SPECTを実施したSBR值はファントム補正および年龄補正したグラフで判 定した。【結果】神経所見としては, 口尖らし反射・固縮に加えて, pull testが陽性 であった。これらはPSPの改訂診断基準 (Movement Disorders, 2017) によりPSP と診断された。MRI/CTの正中矢状断においては，上記のiNPH所見に加えて中脳 被蓋萎縮を認めた。FP-CIT SPECTの線条体集積は, 左右差なく, SBR值は正常 下限 (3例) から軽度低下 (3例) 域に分布していた。考察】純粋無動症 (PSPの上記曲 型に該当)のSBR值は正常〜軽度低下と報告されている(織茂智之他, 臨床神経学, 55巻Suppl.S307, 2015)。本症のSBR值も同様で, たとえ正常域にあっても本亜型 を否定する根拠とはならない。【結論】iNPHのFP-CIT SPECTの判読にあたっては, SBR值が境界域に分布するため,「正常」あるいは「異常」と定性的に判定するので はなく，年齢補正したグラフで境界域に分布することを確認すべきである。

\section{0-22-6 Wason selection taskにおける、社会的交換と安全 規則の疑似論理の検討}

板東 充秋 ${ }^{1}$ 、角南 陽子 ${ }^{1}$ 、井上 里美 ${ }^{2}$ 、栗崎 博司 ${ }^{2}$

'都立神経病院 脳神経内科、 ${ }^{2}$ 石神井公園ひろクリニック

目的：Wason selection task（WST）を用い、社会的交換と安全規則の疑似論理を 検討した。対象と方法：主に頭部外傷の16例に、社会的交換、安全規則、利害な き規則のWSTを施行。各規則 8 問で、問題は 4 択、正しい選択肢は 2 つ。 2 つ も正答で問題の正解とする。結果：1)社会的交換と安全規則の成績が良い例 1 例、 2 )安全規則のみ良い例 2 例、3) どちらも低下する例 13 例、3)のうち、利害なき 嫢則の、A）一つの選択肢は正答する例 9 例、B）どの選択肢も䛊ることがある例 4 例。3 B)のうち、（1）どの規則も選択肢の正答数が低下する例 3 例、 $(2)$ 利害 なき規則より他の規則がよい例 1 例。考察と結論：日常論理と疑似論理が働くと、 社会的交換と安全規則で二つの選択肢とも選び問題を正解。日常論理が働き疑似 論理が働かないと、一つの選択肢のみ正答。問題理解や日常論理も障害されると、 成績はさらに低下。従って、1）は日常論理と両方の疑似論理が働き、2）は社会 的交換の疑似論理が障害され、3A）は、どちらの疑似論理も障害され日常論理の み働き、3B)の(1)は問題理解あるいは疑似論理も日常論理も障害され、(2)は $3 \mathrm{~B}-$ (1) と 1) や 2 ) の組み合わせと考えられる。両方の疑似論理が保たれる 1)に前頭 葉病変がなく、障害される $3 \mathrm{~A}$ ) に前頭葉病変 $(9$ 例中 8 例が両側性。眼窩面を含ま ない例もある）があり、疑似論理は前頭葉内に局在する可能性がある。2）の社会 的交換の夕障害された例は眼窝面に病変や血流低下があり、3 B- (2) の、社会的 交換と安全規則の正答数が利害なき規則より良い例は、両側前頭葉と左後頭葉に 病変があるが前頭葉眼窩面の変化は軽度で、眼窩面は疑似論理自体か、そのアク セスに関わる可能性がある。3 B) - (1)の日常論理も障害される例は、軽度だが失 語のある1例と、失語がなく一般知能が保たれ両側前頭葉と側頭葉あるいは視床 などの病変がある 2 例で、日常論理に様々な部位の関与が示唆される。 
0-22-7 バイオマーカーとリスク遺伝子で再考するアルツハイ マー型認知症の臨床診断

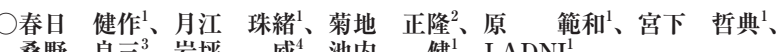
桑野 良三 3 岩坪威、池内 健、 J-ADNI

新潟大学脑研究所遗伝子機能解析学分野、

2 大阪大学大学院医学系研究科ゲノム情報学共同研究講座、

旭川荘総合研究所、 ${ }^{4}$ 東京大学大学院医学系研究科神経病理学分野

【目的】バイオマーカー研究の発展により生前にアルッハイマー病 $(\mathrm{AD})$ 病理の検 出が可能となった。これまで臨床的にAD型認知症の約 $20 \%$ は非AD病理によるこ とを示してきた。今回、臨床診断とバイオマーカー所見の乘離頻度が、生物学的 背景により異なるかを明らかにする。【方法】国内多施設共同研究J-ADNIに参加の 想知正常高齢者 53 例、軽度認知障害 89 例、AD型認知症56例を、APOE $\varepsilon 4$ で層別 化し(非保因者: $\varepsilon 4$-、保因者: $\varepsilon 4+$ )、脳脊能液バイオマーカーにより ATN $(\mathrm{A}=$ アミロイド、 $\mathrm{T}=$ 病的夕ウ、 $\mathrm{N}=$ 神経変性を、陽性+、陰性一で表記) 分類を行った。 【結果】認知正常高龄者において、 $\varepsilon 4-て ゙ は \mathrm{~A}-\mathrm{T}-\mathrm{N}-$ が78\%を占める一方、 $\varepsilon 4$

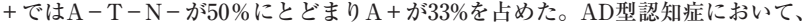

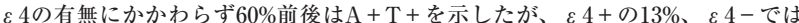
29\%がAーであった。結諭】 $\varepsilon 4+$ では認知正常であってもすでにAD病理を伴って いると考えられる症例が約 $20 \%$ 存在する。一方、 $\varepsilon 4$-ではAD型認知症と臨床診 断されても、脳内に $\mathrm{A} \beta$ 沈着を伴わないと考えられる症例が約 $30 \%$ 存在する。生 前のAD病理検出のためには、臨床表現型に加え生物学的背景を考虑する必要が ある。

\section{0-22-9 喊液バイオマーカー診断された軽症アルツハイマー病 患者における漢字能力の臨床的意義}

葛谷 聡、宮本 将和 ${ }^{1}$ 、山本 洋介 ${ }^{2}$ 、打田 倫子 ${ }^{1}$ 、國立 淳子 $^{1}$ 、 江川 斉宏、杢下 彩栄、福原 俊一 2 、高橋 良輔 ${ }^{1}$

${ }^{1}$ 京都大学大学院医学研究科 踇床神経学、

京都大学大学院医学研究科 社会健康医学系医療疫学分野、

京都大学大学院医学研究科 人間健康科学系在宅医療看護

(目的1日本漢字能力検定協会 (以下、漢検) との共同研究にて、䯚液バイオマーカー診断 された軽症アルッハイマー病(以下、AD)患者の漢字能力を評俇し、病態との関連を検証 する。【方法】対象はもの忘れを主訴とする当院患者で臨床的に軽症 $\mathrm{AD}$ (年齢55歳以上) か 疑われ、路液中のADバイオマーカーを测定した疾患群 44 名と質問票により物忘れを認 めない健常群56名。疢患群は䯣液 $\mathrm{AD}$ ハイイオマーカー陽性 23 症例を $\mathrm{AD}$ 群、陰性 21 例を非 $\mathrm{AD}$ 群に分類。各種認知機能検查、画像検查に加光、漠検の、漢字検定問題 $(5$ 級から準 2 級 よりランダム抽出し作成した漢字読及書き問題を実施し、ADにおける漢字能力を統計学 的に検証した。[結果]漢字書字テストの正答率 (mean [SD]) は、健常群73.2 (20.7) \%、非 $\mathrm{AD}$ 群 48.1 (19.5)\%、AD群44.1 (24.0) \% と疾患群で有意に低下した。誤答パターンを無反応、 錯書に分類し、誤答に㧍ける無反応の割合(以下、無反応率) (mean [SD])を比較したとこ 3、健常群 36.5 (30.9) \%、非AD群56.1\% (23.4)\%、AD群59.5\% (26.9)\%と疾患群で有意に 増加した。スピアマンの㮌位相関分析を用いた解析で、AD群での反無反応率が諭理的語 憶 $(\mathrm{r}-0.587, \mathrm{p}<0.005)$ 、MMSE $(\mathrm{r}-0.538, \mathrm{p}<0.01) 、$ カテゴリー語流啺 $(\mathrm{r}-0.507, \mathrm{p}<0.02)$ と 有意に相関した。さらにAD群を無反応率の高い群、低い群で分類したところ、両群で教

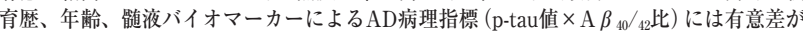
ないものの、低無反応率群で有意にMMSE高值を認めた。また統計画像解析を用いて膊 血流SPECTを両群で比較した結果、低無反応率群で左Wernicke野を中心特定の領域 で有意な血流低下を認めた。[結論] ADでは早期より漢字の想起障害を認め、論理的記憶、 語想起、MMSEと相関した。教育歴やAD病理が同程度でも、漢字の想起障害が不良な ほど認知機能障害の程度が強く、熯字書字能力とAD疾患抵抗性との関連が示唆された。

\section{0-23-2 パーキンソン病におけるアルツハイマー病の合併率と SPECT所見}

○緒方 昭彦1、中村 雅一1、西村 洋昭 1 、興水 修一1、新保 和賢1、

大柣 美香、浜上 尚也 ${ }^{2}$

北海道脑神経外科記念病院 脳神経内科、 ${ }^{2}$ 北海道医療大学 薬学部

【目的】パーキンソン病 $(\mathrm{PD})$ の患者数は高龄化とともに有病率は上昇しており進行 するにつれ、認知症の合併も推測される。認知症がどの程度併発し、どのような 認知症がみられるか画像所見と合わせ検討し、特に臨床的に明らかなアルッハイ マー病 $(\mathrm{AD})$ を合併する場合の割合と画像所見を解析する。[対象と方法]典型的な レビー小体型認知症 (DLB) は除外する。PD症状で発症し、PDの臨床経過をとっ ている症例 (60例) で検討し、MMSE、trail-making-test (TMT)、Moca Jなどて 詳しく認知症を評洒し、認知症を有する23例で、特に画像的にも $\mathrm{AD}$ の特徽を有 する症例のMRIの経時的変化と画像所見、SPECT所見の変化を評価した。結果] ほとんどの症例はMMSEの軽度の低下があり、TMTの延長、特にTMT-Bの延長 がみられ、それ程進行がなく、SPECTでは前頭葉の血流低下がみられる症例が2 例（約38.3\%）認められた。また、一部の症例に証知症の進行が早く、経珮と共に SPECTではアルッハイマー病 $(\mathrm{AD})$ 関心領域の血流低下所見を有する症例 (5例) がみられ、PDの5.8\%にみられた。ADを伴うSPECT所見では特に下前頭回の血流 低下も認められた。【考察】あまり進行しない認知症を有するParkinson's disease with dementia（PDD）と診断できる症例を多く認めたが、PDにADが合併した特 微を有する症例がある程度高率に認められたPDの $a$-synucleinがAD病理の促 進因子となっている可能性も考えられる。神経病理学的脚報告されている特殊な 進行を示したDLBは完全に否定できない可能性がある。結論】一般的に認知症を 伴うPDは高次脳機能梌查では前頭葉の機能低下例が多く、SPECTでも前頭葉の 血流低下を示す場合が多いが、PDで認知症の進行の早い症例では比較的高率にみ られる $\mathrm{AD}$ 合併を考虑して検查を進める必要があり、それに応じた治療が必要 になると考えれる。

\section{O-22-8＼cjkstart進行性核上性麻痺における前部帯状回の乳酸高値は前 頭葉機能障害と関連する}

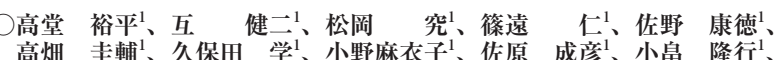
河村 和紀 ${ }^{2}$ 、張 明栄 ${ }^{2}$ 須原 哲也 ${ }^{1}$ 、島田 斉、樋口真人 ${ }^{1}$ 1 量子科学技術研究開発機構·放射線医学総合研究所・脳機能イメージング研究部、

2 量子科学技術研究開発機構・放射線医学総合研究所・先端核医学基盤研究部

[背景・目的] 進行性核上性麻痺（PSP）では前頭葉機能障害およびFDG-PETでの前頭葉の 糖代謝低下が知られている。正常脑ではグルコースはアストロサイトで乳酸に代謝され たのちに神経細胞で利用される，アストロサイト・ニューロン・乳酸シャトルモデルが提 唱されている，本研究では，PSPのアストロサイト機能障害に着目し，PSPの前頭葉の乳 酸が前頭葉機能障害の指標となるとの仮説をたて, 磁気共鳴スペクトロスコピー (MRS) を用いて検証を試みた。 [方法] 臨床症状で診断しタウPET $\left({ }^{18} \mathrm{~F}-\mathrm{PM}\right.$-PBB3) で診断を検証 しえたPSP患者 16 名, 軽度認知機能障害/アルツハイマー病 $(\mathrm{MCI} / \mathrm{AD})$ 患者11名, 健常者 13名を対象に，MRSにて前部帯状回および後部帯状回におけるグルコースおよび乳酸量 の評価を行った.またFrontal assessment battery (FAB) で前頭葉機能を, Mini-mental state examination (MMSE) で全般的な認知機能を評価した. [結果]夕ウPETの評価にて, 前部带状回では健常者群に比しPSPおよびMCI/AD群で夕ウ蓄積を示唆する有意な集積を 認めなかったが, 後部带状回ではMCI/AD群で有意な集積を認めた $(\mathrm{p}<0.05)$. MRSで測 定した乳酸は全群において前部帯状回で後部帯状回よりも高值を示した $(\mathrm{p}<0.05)$ 。また グルコースおよび乳酸は，健常者群に比しPSP群の前部带状回において高值であった $(\mathrm{p}<$ $0.05)$ ，健常者とPSP全体のFABは乳酸と目の相関を示したが $(\mathrm{r}=-0.60 ; \mathrm{p}<0.05)$ ，MMSE とは有意な相関は認めなかった．健常者とPSP全体のグルコースはFABと相関を示さな かった. [考察] 前部帯状回は後部帯状回に比して正常脳でも乳酸濃度が高く, 疾患におけ る乳酸濃度上昇も後部带状回より顕著である. PSPで夕ウ沈着が顕著でない段階でもFAB の低下と相関して前部帯状回の乳酸濃度は増加することから, PSPを含めた前頭側頭葉変 性症で前部帯状回の乳酸濃度は前頭葉機能障害を反映する鋭敏な指標となりうる。

\section{O-23-1＼cjkstart電気生理学的手法を用いたパーキンソン病患者におけ る運動症状を定量的に評価する試み}

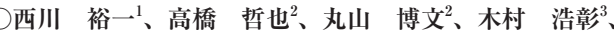

Allison Hyngstrom

1 広島大学病院 リハビリテーション部門、

広島大学大学院 医系科学研究科 脳神経内科学、

広島大学病院 リハビリテーション科、 ${ }^{4}$ Department of Physical Therapy, Marquette University

【目的】Unified Parkinson's Disease Rating Scale (UPDRS) Part IIIはパーキンソン病(PD)患者 の運動機能障害の評価に有用であるが、半定量的でありながら評洒に検者間のばらつきがある ことが課題の一つである。PDの運動症状は中枢神経の機能異常に由来するものの、症状は末梢 の効果器である筋活動の異常として観察されることから、本研究では多チャンネル表面筋電図 法を用いて運動単位の発火動態を解析することにより、PD患者における運動症状の定量的な評 価を試みたので報告する。(方法JPD患者8名（女性、年齢： $75.3 \pm 8.3$ 歳、罪病期間 : $16 \pm 2.2$ 年、 UPDRS Part III : $18.0 \pm 7.7$ ) および健常者 9 名 (女性、年齢 : $73.2 \pm 9.2$ 歳) を対象とした。最大随 意筋力の $30 \%$ を 20 秒間保持する課題 (等尺収縮) 中の筋電図信号を、64チャンネル表面筋電図を 用いて、PD患者は両側の外側広筋、健常者は利き足の外側広筋から取得した。CKC methodに より個々の運動単位每に筋電図信号を分離し、運動単位の発火頻度、発火頻度の変動倸数 $(\mathrm{CV})$ および運動単位の発火闌値を算出した。結果】PD患者の影響側（症状が強い側）では計127個、 非影響側は120個、健常者では88個の運動単位を検出した。PD患者の影響側は、健常者と比較 して運動単位の発火頻度およびCVが有意に高值を示し ( $13.8 \pm 2.5$ vs. $9.63 \pm 2.2 \mathrm{pps}, p=0.0237$ 抒 よび $26.8 \pm 2.8$ vs. $19.8 \pm 2.6 、 p=0.0006) 、$ UPDRS part IIIと運動単位の発火頻度およびCVには 有意な正の相関を示した $(\mathrm{r}=0.8361, p=0.0191, \mathrm{r}=0.899, p=0.002)$ 。さらにPD患者の非影響側に おいても健常者と比較してCVが有意に高値を示した $(22.5 \pm 4.1$ vs. $19.8 \pm 2.6 、 p=0.036)$ 。結論】 PD患者は、健常者とは異なる運動単位の発火動態を示し、重症度に応じて運動単位の発火頻度 およびCVが高值を示すことが明らかになった。本手法は、PD患者の筋活動異常を定量的に評 価することができ、新たな運動機能評価ツールとしての応用可能性が示された。

\section{0-23-3 Alzheimer病が合併したと考えられるParkinson病患 者の臨床的特徵の検討}

○古寺 紘人、藤澤 洋輔、村賀香名子、永山 寛、木村 和美 日本医科大学付属病院 脳神経内科

【目的】Parkinson病 (PD) では様々な要因で認知機能障害を呈することが知られて いる。その一つにAlzheimer病 $(\mathrm{AD})$ の合併が関与することが知られているが、ま だ不明な部分も多い。今回、PDでの脳血流シンチグラフィーの相対的血流低下 部位からAD合併が示唆される症例の臨床的特徴を検討した。【方法】2015年4月か ら2019年8月に当科を受診し、British Brain Bank またはMDSの診断基準を満た 于PD 27例（男性16例、女性11例、発症年齢 $66.5 \pm 9.8$ 歳、検查時年齢71.3 \pm 9.3 歳、罹病期間 $45.2 \pm 37.7$ 个月）を対象とした。これらの患者に神経心理学的検查 (MMSE、MoCA-J) および脳血流シンチグラフィー ( ${ }^{123}$ I-IMP SPECT) を施行し、 脳血流シンチグラフィーでAD関連局在部位(後部帯状回、楔前部、頭頂葉皮質)の 相対的血流低下をきたした群の発症年齢、検查時年齢、罹病期間、神経心理学的 検查との関連性について検討した。脳血流の評価は、3-Dimensional Stereotactic Surface Projection (3D-SSP) で血流低下の程度が正常群の1.64 SD以上の場合を 相対的血流低下ありとした。結果】後部帯状回での相対的血流低下を認めた6例で

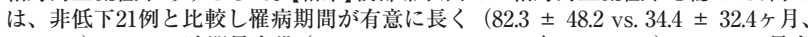
$\mathrm{p}=0.036) 、 M M S E$ 時間見当識 $(4.3 \pm 0.5$ vs. $4.8 \pm 0.5$ 点、 $\mathrm{p}=0.017) 、$ MoCA-J見当 識 $(4.8 \pm 1.2$ vs. $5.7 \pm 0.7$ 点、 $\mathrm{p}=0.031)$ が低下していた。楔前部での相対的血流低

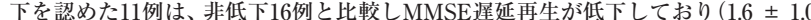
vs. $2.7 \pm 0.5$ 点、 $\mathrm{p}=0.0087$ )、頭頂葉皮質での相対的血流低下を認めた 11 例では、 非低下 16 例と比較しMMSEの遅延再生 $(1.6 \pm 1.0$ 点vs. $2.7 \pm 0.5$ 点、 $\mathrm{p}=0.0087)$ か 低下していた。【結論】PDへのAD合併が示唆される患者は、䍜病期間の長さが関 連する可能性が示された。その臨床的特徵は、ADでの中核症状となる遅延再生 や見当識との関連が認められた。 
0-23-4 パーキンソニズムの患者では内因性フロックは遅くなるか

○寺尾 安生 ${ }^{1}$ 宮崎 泰 ${ }^{2} 、$ 本間 元康 ${ }^{1} 、$ 德重 真一 ${ }^{2}$ 、寺田さとみ ${ }^{1}$ 、

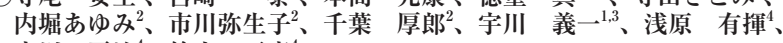
宮川 晋治、鈴木 正彦

杏林大学医学部 病態生理学教室、

杏林大学神経内科、 ${ }^{3}$ 福島県立医科大学 ヒ下神経生理学、

"慈恵会医科大学䓪飾医療センター神経内科

[背景)パーキンソン $(\mathrm{PD})$ 病では時間情報处理諜題の際、心の中で時間の長さを計る内因性 クロックのスピードが渥くなり、L-dopa投与により改善するとされる。他方、課题によっ てはクロックが速まるとの報告もある。[万法対象はPD患者27人（男性16人、女性11人、 $72.6 \pm 5.7$ 歳)、進行性核上性麻㷧 (PSP) 患者5人 (男性 4 人、女性 1 人、75.8 5 5.5歳)、年齢を

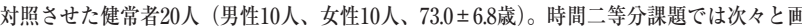

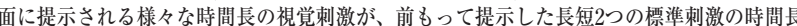
( $400 \mathrm{~ms}$ と 1600ms、または2秒と8秒) のいずれに近いかを回答させ、その成績から被験者か $50 \%$ の確率で長いと答光る時間長を"時間二分点"として推定し内因性クロックの速さの指橴 とした。時間再生課題では被験者は画面に提示された視觉刺激の時間長（1８秒）をボタン 押しにより再生した。再生された時間長からクロックの速さを推定した。これらとUPDRS motor score、DATスキャンのspecific binding rate (SBR) との相関を久た。[結果]PD患者 では2秒、8秒の標淮刺激を対比した時間二分理題では、時間二分占が延長し内因性ク口ッ

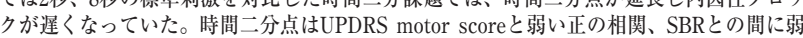
い負の相関を示した。 $400 \mathrm{~ms} 、 1600 \mathrm{~ms}$ を対比した時間二分課題ではPDと健常者で時間二分 点に有意差はなかった。時間再生は健常者に比較して軽度不正確だったが、抒抒む称た れていた。他方、PSP患者では時間二分、時間再生課題とも正常被験者、PD患者と此較し て有意に成績が悪かった。[考察]PD患者では時間二分課題で秒の範囲で内因性クロックか 遅くなっていた。他方、より記憶の要素の強い時間再生課題の不正碓さは複数の時間長の 刺激を記憶する際、それらの記憶が平均の時間長に向けて収束する䫀向を反映すると考え られた。PSP患者の時間課題の不正確さは、PDより病変分布が広いことによると考えられた。

\section{O-23-6 健康診断の結果を用いたParkinson病の発症前バイオ マーカーの検索}

横井 克典 ${ }^{1}$ 、服部 誠、佐竹 勇紀 ${ }^{1} 、$ 平川 晃弘 ${ }^{2} 、$ 勝野 雅央 ${ }^{1}$

名古屋大学大学院医学系研究科 脳神経内科

東京大学大学院医学系研究科生物統計情報学

【目的】多くの神経変性疾患で、神経症状の発症前から分子病態が進行しているこ とが明らかになっている。パーキンソン病 (PD) では $\alpha$-synucleinの蓄皘は運動症 状の出現より以前に始まっていると考えられており、発症前の症候としてレム贁 眠行動㜔害や嗅緹低下、自律神経症状などが知られている。本研究の目的はPD思 者の健康診断のデー夕を用いて発症前の血清学的マーカーの変化を解析し、発症 前バイオマーカーを特定することである。【方法]発症前後での健診デー夕を有す 万男性 24 名、女性 27 名のPD患者、健常者男性60名、女性60名のデー夕を収集し、 線形混合モデルにより解析、比較検討をすることで、バイオマーカーの特定を試 みた。またZ-scoreを用いることでより適したバイオマーカーを検索した。結果】 PD患者では、健診項目のうち、身長、体重、総コレステロール、LDL-コレステロー ルといった複数の項目で発症前からの低下を認めた。これらのうち、発症時に低 下が認められたBMIと総コレステロールをZ-scoreに変換し、それらの和を評価し たところ、男性で発症前の低下が明らかになった。女性については今回の解析で は発症前に明確な差のある項目は特定できなかった。これまでに指摘されている ヘモグロビン、尿酸値は今回の解析では発症前の有意な低下は認められなかった。 【結論】BMIと総コレステロールのZ-scoreの和が男性PD患者の発症前バイオマー カーの侯補として考兄られた。少なくとも男性ではPDの発症前に代謝異常が生し ている可能性が示唆された。

\section{0-23-5 パーキンソン病における運動および知的学習の転移効果}

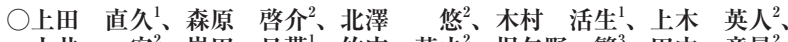
土井耾 2 岸田 日带1、竹内 英之 2 、児矢野 繁、田中 章影 '横浜市立大学附属市民総合医療センター神経内科、

横浜市立大学大学院医学研究科神経内科学・脳卒中医学、

横浜南共済病院神経内科

【背景】パーキンソン病 $(\mathrm{PD})$ における運動・知的学習に閔する報告は多数あるが それらを別の夕スクに応用する運動・知的学習の転移効果についての報告はほと んどなく，関与する神経機構を含めメカニズムも未解明である.【目的】PDの運動 および知的学習転移について, 健常者 $(\mathrm{HC})$ との比較を行い, さらに各種臨床パラ メーターとの関連性を検討した.【方法】対象はPD患者 30 名とHC25名. (1) 運動学 習として時計回り $30^{\circ}, 75^{\circ},-60^{\circ} の 3$ 種のvisuomotor rotation perturbation task （VRPT）をずれが無くなるまで学習させた その前後に-45゚でのVRPTを行い， ずれ角度の改善度を運動学習転移度とした。 (2)知的学習として，4つの絵から特

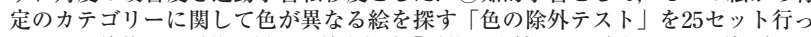
た. その前後に，形状が異なる絵を探す「形状の除外テスト」を 4 セットずつ行い， 正答までの時間の改善度を知的学習転移度とした，それぞれの学習転移度に関し てPDとHCで比較した PDにおいて, 運動学習転移度と知的学習転移度との相閣 や，学習転移度とMDS-UPDRS III, 各種高次機能検查，脳血流分布との相関を解 析した.【結果】PDではHCに比して運動学習転移度が低下していたが, 知的学習 転移度は低下の傾向のみであった.PDにおいて運動学習転移度と知的学習転移度 の間には軽度の相関傾向を認めた，両者に共通する関連脑部位として，脳血流分 布の解析から視営や関節位置情報に関連する頭頂連合野が推測された。学習転移 度とUPDRSや高次機能梌查結果との相関は認めなかった. [考察】PDでは運動学 習転移能力が障害されており一旦運動を獲得しても継続的なりハビリテーショシ が必要である. 学習転移についての研究は, PDの日常生活における様々な運動. 知的活動の改善を図る上で重要である。

\section{0-23-7 血中ニューロフィラメント軽鎖のパーキンソン病鑑別 における有用性 : メタアナリシス}

○士師正太郎、佐光 亘、村上 永尚、大崎 裕亮、和泉 唯信 徳島大学病院 神経内科

【目的】パーキンソン病 $(\mathrm{PD})$ とパーキンソン症候群 $(\mathrm{APD})$ を鑑別する客観的バイ オマーカーの確立が必要とされている。今回我々はPDとAPDの鑑別における血 中ニューロフィラメント軽鎖（NfL）の有用性について、メタアナリシスを用いて 評価した。【方法】2019年10月31日にPubMedとScopusを用いて文献検索を行った。 PDはUK brain bank criteria、Gelb criteria、多系統萎縮症はGilman criteria、 進行性核上性麻盘はNINDS-SPSP、大脳皮質基底核症㬋群はBoeve、NINDS、 Langの診断基準に従って診断しているものを組み入れた。統計学的解析では各 研究の統合にBivariate modelを用い、異質性は感度・特異度の相関倸数と Forest plot、Summary Receiver Operating Characteristic (SROC) 曲線を用いて解析し た。異啠性が示唆されたためにMeta-regressionを囲いて原因梌索も行った。 版バイアスはDeeks' funnel plotを用いて視鸴的に評偋した。【結果】文献検索の結 果、5研究（PD 415人、APD 232人）をメタアナリシスに組み込んだ。2研究は検 体に血清を、2研究は血槳を、1 1 研究は血清と血槳両方を使用していた。メタアナ リシスより、血中NfLはPD群より APD群で高く、PDとAPDの鑑別診断において 感度 $78.0 \%$ 、特異度 $85.4 \% 、$ SROC曲線の area under the curve 0.87 であった。感 度と特異度の相関係数は 0.55 と0より大きく、異啠性が示唆された。Forest plot と SROC曲線でも各研究間のばらつきが見られ、研究間の異質性があると判断した。 Meta-regressionにより APD群のUPDRS III score $\left(\mathrm{R}^{2}=92.6 \%, p=0.03\right)$ を有意な 変数として検出した。Deeks' funnel potの視觉的評価では出版バイアスは示唆さ れなかった。結論】本研究により血中NfLはPDとAPDの鑑別に有用である可能性 がメタアナリシスによって示唆された。APD群のUPDRS IIIの值を考虑すると血 中NfLの有用性はさらに向上する可能性がある。

\section{0-23-9 パーキンソン病患者の視床下核脳深部刺激療法前後で の立位・歩行時の足底圧変化}

○伊澤 奈々 ${ }^{1,3}$ 、岩室 宏一 ${ }^{2}$ 、谷 真美 1 、羽鳥 浩三 ${ }^{1}$ 、大山 彦光 ${ }^{3}$ 、 波田野 㙇 $^{3}$ 、梅村 淳、下 泰司 ${ }^{4}$ 、服部 信孝、藤原 俊之 ${ }^{1}$ 1 順天堂大学医学部リハビリテーション科、

順天堂大学医学部運動障害疾患病態研究・治療講座、

順天堂大学医学部脳神経内科、 ${ }^{4}$ 順天堂大学医学部附属練馬病院 脳神経内科、 順天堂大学医学部脳神経外科

【目的】近年増加しているパーキンソン病（PD）に対する視床下核脳深部刺激療法（STN DBS）は、術後の運動症状の改善は明らかであるが、ときに術後に一過性の姿勢バラン スの増悪を経験する。そこで、PD患者のSTN-DBS前後での立位・歩行時の足底圧の変 化を検討した。【方法】当院においてSTN-DBSを施行したPD16名について、手術前後の足 底圧を、以下の 3 条件において足圧測定機能付きトレッドミルを用いて計測した；1) 開眼 静止立位 30 秒、2) 䦥眼静止立位30秒、3) トレッドミル歩行時 (歩行周期10サイクル)。静 止立位では足底の後ろ半分にかかる压比率、足底圧中心 (COP) の移動距離 (pathlength) お上び2次元的な分布状態を示す $95 \%$ 範囲円を求めた。歩行時は足底を前部・中部・後部

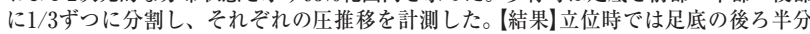
にかかる圧比率は開眼、閉眼共に術前後での変化はみられなかった。Pathlengthは開閉 眼ともに術前・術直後・退院時のいずれも有意差はみられなかった。95\%範囲円は開眼 時には有意な変化は見られなかったものの、閉眼時には術前、術直後、術後3-4週の3群 間に有意差を訒め $(\mathrm{p}=0039)$ 、らに多重比較にて術前 $6332 \pm 4199 \mathrm{~mm}^{2}$ と比較して術直 後1162.8 $\pm 953.1 \mathrm{~mm}^{2}$ で有意に拡大していた。歩行解析では術前は全足底接地で足底全面 で荷重していたが、術後では初期接地時の踵への荷重傾向が増加し、正常歩行に近づい ていた。結論】PD患者において、STN-DBSにより歩行時の荷重移動に改善がみられた。 また、立位時の足底圧分布は影響を受けなかったが、閉眼立位時の動摇性が術後早期に 増悪した。STN-DBSにより傍春柱筋の筋緊張が低下することが報告されており（2008， Visser et al)、これが術後早期の立位動摇性の増悪の一因である可能性が考えられた。 


\section{0-24-1 Variants in saposin D domain of prosaposin gene linked to Parkinson's disease}

OYutaka $0 \mathrm{ji}^{1}$, Taku Hatano ${ }^{1}$, Shin-ichi Ueno ${ }^{1}$, Manabu Funayama ${ }^{2}$, Kei-ichi Ishikawa ${ }^{1,3}$, Ayami Okuzumi ${ }^{1}$, Shigeto Sato ${ }^{1}$, Wataru Satake, Tatsushi Toda ${ }^{4}$, Yuanzhe $\mathrm{Li}^{1}$,

Taiji Tsunemi ${ }^{1}$, Kenya Nishioka ${ }^{1}$, Tatsuro Mutoh ${ }^{5}$, Yoshihisa Takiyama ${ }^{6}$, Masahito Yamada, Matthew Farrer ${ }^{8,9}$, Yasuo Uchiyama ${ }^{2}$, Wado Akamatsu ${ }^{3}$, Junko Matsuda, ${ }^{4,10}$, Nobutaka Hattori ${ }^{1,4}$ ${ }^{1}$ Department of Neurology, Juntendo University School of Medicine, Japan, ${ }^{2}$ Research Institute for Diseases of Old Age, Graduate School of Medicine, Juntendo University, ${ }^{3}$ Center for Genomic and Regenerative Medicine, Juntendo University, ${ }^{4}$ Department of Neurology, University of Tokyo, ${ }^{5}$ Department of Neurology, Fujita Health University, ${ }^{6}$ Department of Neurology, University of Yamanashi, ${ }^{7}$ Department of Neurology, Kanazawa University, ${ }^{8}$ Department of Neurology, University of Florida, ${ }^{9}$ Department of Medical Genetics, University of British Columbia, ${ }^{1}$ Department of Pathophysiology and Metabolism, Kawasaki Medical School

[Background] The genetic variability in lysosomal storage disorders (LSDs) has been implicated in Parkinson's disease (PD). However, it has been unknown whether mutations in $P S A P$, which is a rare causative gene for sphingolipidoses, are involved in PD. [Methods] We performed a genetic mutation screening study of PSAP mutations in 290 patients of familial PD. We did an additional whole-exome sequencing (WES) study. We screened PSAP mutations in 440 patients with sporadic PD (sPD) for a case-control association study. We analyzed patient-derived skin fibroblasts and induced pluripotent stem cells (iPSC)-derived dopaminergic neurons. We generated mice with a mutation in the saposin D domain (SapD) of Psap for behavioral and histopathological test. [Results] Three pathogenic mutations in the SapD of PSAP (c.1235G $>\mathrm{A}, \mathrm{c} .1358 \mathrm{~A}>\mathrm{C}$, and c.1431G $>$ A) were identified in three families of autosomal dominant PD. WES revealed no other mutations in genes known as causing PD or LSD. Allele frequencies of six intronic variants (rs3747860, rsl1000016, rs4747203, rs142614739, rs749823, and rs885828) in SPD were significantly different compared with controls ( $p=5.0 \times 10$ , $5.0 \times 10^{5}, 2.6 \times 10^{9}, 2.0 \times 10^{3}, 2.2 \times 10^{3}$, and $7.7 \times 10^{10}$, respectively, chi-squared test). Abnormal accumulation of autophagic vacuoles, alteration of intracellular localization of prosaposin, and aggregation of alpha-synuclein were seen in patient-derived cells. Knock-in mice with a mouse PSAP SapD mutation developed a progressive motor decline and dopaminergic neurodegeneration. [Conclusion] PSAP SapD can be involved in PD.

\section{0-24-3 Praja 1 E3 ubiquitin ligase suppresses adenovirus-} induced neuronal TDP-43 aggregate formation

Kazuhiko Watabe ${ }^{1,2}$, Yoichiro Kato ${ }^{2}$, Miho Sakuma ${ }^{3}$, Makiko Murata ${ }^{1}$, Motoko Niida ${ }^{2}$, Taro Takemura ${ }^{4}$, Nobutaka Hanagata ${ }^{4}$, Mari Tada ${ }^{5}$, Akiyoshi Kakita ${ }^{5}$, Noriyuki Shibata ${ }^{2}$

${ }^{1}$ Department of Medical Technology (Neuropathology), Faculty of Health Sciences, Kyorin University, Japan, ${ }^{2}$ Department of Pathology, Division of Pathological Neuroscience, Tokyo Woman's Medical University, Japan, ${ }^{3}$ School of Medicine, Tokyo Woman's Medical University, ${ }^{4}$ Research Network

and Facility Services Division, National Institute for Materials Science,
${ }_{5}$ Department of Pathology, Brain Research Institute, Niigata University

Objective: Transactive response DNA-binding protein-43 (TDP-43) is a main constituent of cytoplasmic agregates in neuronal and glial cells in cases of amyotrophic lateral sclerosis (ALS). We have previously demonstrated neuronal cytoplasmic aggregate formation induced by recombinant adenoviruses expressing human wild type (WT) and C-terminal fragment (CTF) TDP43 under the condition of proteasome inhibition. The formation of the adenoviral TDP-43 aggregates was markedly suppressed by co-infection of an adenovirus expressing heat shock transcription factor 1 (HSFl), a master regulator of heat shock response. In the present study, we performed DNA microarray analysis to identify candidate molecules locating downstream of HSFl that counteract TDP-43 aggregate formation. Methods: The 1464R rat neural stem cells were differentiated into neurons in the presence of retinoic acid, and co-infected with adenoviruses expressing WT and CTF TDP-43, and HSF1 in the presence of proteasome inhibitor MG-132. Total RNAs were then isolated and DNA microarray analysis was performed, and candidate genes were cloned and examined. Results: We found 64 genes that are upregulated more than 2-fold by HSF1 transduction, and 393 genes that are upregulated more than 2-fold in association with aggregate inhibition by HSF1 transduction. In these, Praja 1 RING-finger E3 ubiquitin ligase (PJA1) suppressed phosphorylation and aggregate formation of TDP-43. Conclusion: PJAl upregulated by HSF1 has a capability of TDP-43 phosphorylation and aggregation, which may have therapeutic potential in ALS.

\section{0-24-5 Caveolin 3 suppresses activation of sarcolemmal} nNOS: implications in the pathogenesis of LGMD1C

\author{
OYutaka Ohsawa ${ }^{1}$, Yoshihide Sunada ${ }^{1}$, Shunichi Shirakawa ${ }^{1}$, \\ Hiroki Hagiwara \\ ${ }^{1}$ Neurology, Kawasaki Medical School, Japan, ${ }^{2}$ Medical Science, Teikyo \\ University of Science
}

[Background] Caveolin 3, a structural protein in the sarcolemmal caveolae regulates several signaling molecules. We previously generated a mouse model of caveolin 3-deficient limb-girdle muscular dystrophy 1C (LGMD1C) by transgenic overexpression of a dominant-negative mutant of caveolin 3 (CAV$\left.3^{\mathrm{P} 104 \mathrm{~L}}\right)$ in mouse muscle. The deficiency of caveolin- 3 caused atrophic myopathy accompanied with the activation of sarcolemma neuronal nitric oxide synthase (nNOS) in the mice. [Objective] To uncover the potential role of the nNOS activation in the mechanisms leading to muscle atrophy in the mice. [Methods By crossing the caveolin 3-deficient mice $\left(\mathrm{CAV}-3^{\text {P104L }}+/+\right)$ with nNOS-deficient mice (nNOS- $/-$ ), we generated the double-deficient mice $\left(\mathrm{CAV}-3^{\mathrm{P} 104 \mathrm{~L}}+/+\right.$, nNOS$\left.\iota_{-;} \mathrm{n}=10\right)$. [Results] The double-deficient mice exhibited a significant $(\mathrm{p}<0.05)$ reduction in the muscle mass and the single myofiber area when compared with the caveolin 3 -deficient mice. The mice were significantly $(\mathrm{p}<0.05)$ weaker than the caveolin 3-deficient mice both in grip strength and muscle tension. No compensatory upregulation of other NOS isoforms was observed in the doubledeficient mouse muscle. [Conclusions] These data indicate that the activation of sarcolemmal nNOS by caveolin 3-deficiency could prevent muscle atrophy in the LGMD1C. Underlying molecular mechanisms by which caveolin-3 inhibits activation of nNOS will be presented.

\section{0-24-2 Aberrant cytoplasmic aggregation of TDP-43 is prevented by interaction with G3BP1 and USP10}

$\bigcirc$ Masahiro Fujii ${ }^{1}$, Masahiko Takahashi ${ }^{1}$, Hiroki Kitaura ${ }^{2}$, Akiyoshi Kakita ${ }^{2}$, Taichi Kakihana ${ }^{1}$, Yoshinori Katsuragi, Yuriko Iwakura, Hiroyuki Nawa ${ }^{3}$, Akihide Koyama, Osamu Onodera

${ }^{1}$ Division of Virology, Niigata Graduate School of Medical and Dental Sciences, Japan, ${ }^{2}$ Department of Pathology, Brain Research Institute, University of Niigata, ${ }^{3}$ Department of Molecular Neurobiology, Brain Research Institute, University of Niigata, ${ }^{4}$ Department of Neurology, Brain Research Institute, University of Niigata

[Objective] Amyotrophic lateral sclerosis (ALS) is a progressive fatal neurodegenerative disease characterized by loss of lower and upper motor neurons, muscle atrophy and death from respiratory failure. TDP-43 is a causative factor of the familial and sporadic ALS. Aberrant cytoplasmic TDP-43 inclusions in motor neurons are a causative factor of ALS. In this study, we examined how stress granules and aggresomes play a role in TDP-43 pathology in ALS. Stress granules (SGs) are stress-inducible protein aggregates containing RNA-binding proteins and RNA. Aggresomes are stress-inducible ubiquitinated protein aggregates. [Results] While TDP-43 protein in cultured cells at steady-state was localized predominantly in the nucleus, a proteasome inhibitor treatment induced sequential localization of TDP-43 in SGs and aggresomes. We found that the formations of SGs and aggresomes as well as TDP-43 localizations in SGs and aggresomes were regulated by G3BP1 and USP10, and the depletion of G3BP1 and USP10 protein reduces the formation of TDP-43-positive SG and TDP-43-positive aggresome, respectively. TDP-43 interacted with G3BP1 and USP10, and the impaired interactions by TDP-43 mutations reduced the localizations of TDP-43 in SGs and aggresomes, and induced G3BP1/USP10-negative TDP-43 aggregates. Immunohistochemistry detected that cytoplasmic TDP-43 inclusions in motor neurons of ALS patients are USP10-negative. [Conclusions] The present study suggests that interaction of TDP-43 with G3BP1 and USP10 prevents pathogenic cytoplasmic TDP-43 aggregations in ALS.

\section{0-24-4 Exploring lipophilic compounds which induce BDNF secretion from astrocytes beyond the BBB}

Yukio Takeshita ${ }^{1}$, Susumu Fujikawa ${ }^{1}$, Tomotaka Okino ${ }^{2}$,

Miwako Fujisawa ${ }^{1}$, Fumitaka Shimizu ${ }^{1}$, Toshihiko Maeda ${ }^{1}$,

Yasuteru Sano ${ }^{1}$, Michiaki Koga ${ }^{1}$, Takashi Kanda

${ }^{1}$ Department of Neurology and Clinical Neuroscience, Yamaguchi University

Graduate School of Medicine, Japan, ${ }^{2}$ Ono Pharmaceutical co., LTD

Background Brain-derived neurotrophic factor (BDNF), which is a member of neurotrophic factors, is a potential therapeutic agent for neurological diseases. However, peripheral administration of BDNF were insufficient because BDNF is unable to pass though the blood-brain barrier (BBB). It is shown that pericytes and astrocytes, are the main components of the BBB, have the ability to secrete BDNF. Hence, the compound which can be transported beyond the BBB and react on astrocytes or pericytes directly to facilitate secretion of BDNF are expected as therapeutic agents. Aim We find the lipophilic compounds which induce BDNF secretion from pericytes or astrocytes across endothelium with a new BBB model incorporating tri-culture of conditionally immortalized human endothelium (EC), pericyte (PCT) and astrocyte cell line (AST). Method PCT were co-cultured on luminal side of insert with AST on abluminal side. EC were cultured on Upcell dish, which can achieve sheet-like detachment of confluent cells by temperature-shifting. Then sheet-like detachment of EC and were transferred onto the PCT, which were co-cultured with AST on the insert. Each 20 compound was added in cultured inserts to vascular (EC) side, and BDNF secreted in brain parenchymal (AST) side were quantitated by ELISA. Result Two compounds facilitated secretion of BDNF. These didn't induce secretion of BDNF in PCT or EC mono-culture supernatant and did in AST mono-culturing. Conclusion We found two compounds that induce BDNF secretion from astrocytes beyond the BBB. These could be therapeutic agents for neurological diseases.

\section{0-24-6 C9orf72-derived PR poly-dipeptides compromise} phase separation of low-complexity protein sequences

$\bigcirc$ Eiichiro Mori ${ }^{1}$, Hitoki Nanaura ${ }^{2}$, Tomo Shiota ${ }^{2}$, Kazuma Sugie ${ }^{2}$

Department of Future Basic Medicine, Nara Medical University, Japan,

Department of Neurology, Nara Medical University

[Objective] Repeat expansion in the first intron of a gene designated C9orf72 is the most prevalent form of familial amyotrophic lateral sclerosis (ALS) and produces toxic arginine-rich poly-dipeptides, proline:arginine (PR) and glycine:arginine (GR). However, the detailed molecular mechanism is still unknown. [Methods] Interactors of PR poly-dipeptides were determined by proteomic approaches, and identified molecules were characterized by $\mathrm{X}$-ray diffraction, systemic mutagenesis, thioflavin- $\mathrm{T}$ assay, semi-denaturing detergent agarose gel electrophoresis (SDD-AGE), transmission electron microscope (TEM), hydrogel binding assay, isothermal titration calorimetry (ITC), and solution nuclear magnetic resonance (NMR). [Results] PR polydipeptides targeted proteins with low sequence complexity/intrinsic disorder (LC-domains) and stabilized labile cross- $B$ polymers (LC polymers). Interestingly, PR poly-dipeptides bound and stabilized polymeric form of phenylalanine:glycine (FG)-rich domains of nuclear pore proteins and disrupted nucleocytoplasmic transport. Moreover, PR poly-dipeptides inhibited nuclear import receptor karyopherin- $B 2$ (Kapß2) to capture monomeric state of LCdomains. [Conclusion] C9orf72-derived PR poly-dipeptides compromise phase separation of LC-domains and nucleocytoplasmic transport. 
0-24-7

Changes of striatal serotonin transporter expressions in a rat model of levodopa-induced dyskinesia

$\bigcirc$ Rie Tohge, Satoshi Kaneko, Satoshi Morise, Mitsuaki Oki, Masataka Nakamura, Norihiro Takenouchi, Hirofumi Kusaka

Department of Neurology, Kansai medical university, Japan

[Objective] Non-dopaminergic neurotransmitters have been emphasized on the pathophysiology of levodopa-induced dyskinesia (LID). We previously reported that levodopa intermittent treatment developed LID and zonisamide (ZNS) ameliorated LID via down-regulation of adenosine A2A and endocannabinoid $\mathrm{CB} 1$ receptor expressions (Oki et al, 2017). To investigate the changes of striatal serotonergic transmission in LID, we analyzed striatal serotonin transporter (SERT) expressions after five different treatments. [Methods] PD model rats made by 6 -OHDA injection into the unilateral medial forebrain bundle were subdivided into five groups; 1) no medication (N), 2) intermittent levodopa injection (I), 3) continuous levodopa infusion (C), 4) intermittent levodopa and ZNS injections (IZ) and 5) intermittent ZNS injection (Z). After two weeks of treatments, rats were perfused with $4 \%$ PFA. The brain sections were immunostained for SERT by fluorescent immunohistochemistry. SERT expressions were evaluated in the dorsolateral portion of the striatum using the Image J software and compared between groups. [Results] SERT optical density (\% respect to control side) were reduced in Group I $(67.2 \%, p=0.0020)$ and $Z(69.8 \%, p=0.0031)$ compared with Group N (108.8\%). SERT expressions were further down-regulated in Group IZ $(48.0 \%, p=0.0006)$ and C $(49.0 \%, p$ $=0.0010)$. [Conclusion] SERT expression was down-regulated by ZNS. One of the mechanisms for LID amelioration by ZNS may be down-regulation of SERT expression. Targeting SERT expression can be a potential new strategy for LID treatment.

\section{0-24-9 Neurodegeneration of TTR E61K amyloid neuropathy}

Tatsufumi Murakami ${ }^{1}$, Shigenobu Toné ${ }^{2}$, Kazunori Sango ${ }^{3}$, Mineykuki Mizuguchi ${ }^{4}$, Kazuhiko Watabe ${ }^{5}$, Yoshihide Sunada ${ }^{1}$ Department of Neurology, Kawasaki Medical School, Japan, ${ }^{2}$ Graduate School of Science and Engineering, Tokyo Denki University, ${ }^{3}$ Department of Sensory and Motor Systems, Tokyo Metropolitan Institute of Medical Science, ${ }^{4}$ Faculty of Pharmaceutical Sciences, University of Toyama,

Faculty of Health Sciences, Kyorin University

【目的】TTR E61K アミロイドニューロパチーはこれまで 6 例報告されており、5 例は岡山県出身で、このうち最近報告されている4例はいずれも孤発例である。高 齢発症 (平均64.3歳) で、感覚優位の多発神経炎、自律神経障害、心アミロイドー シスを特徴としている。4例に腓腹神経生検が施行され、いずれも神経内膜にアミ ロイド沈着は認められない。私どもは昨年度の本学会で、チオフラビンT結合測 定でE61K TTRのアミロイド凝集能を検討し、V30MTTRより弱く、正常TTRと 同程度であることを報告した。今回はE61K TTRの神経細胞障害機序を検討した。 【方法】正常TTR、E61K TTR,V30M TTRの各組み換え蛋白を、ラット初代後根 神経節培養細胞に加え神経突起成長抑制効果を調べる。また腓腹神経 $(n=1$,自验 例）のTTR沈着を抗TTR抗体による免疫組織化学染色で調べる。さらに同組織で TUNEL染色を用いアポトーシスの有無を調べ、透過型電顕で細胞の種類を同定 する。【結果】V30M TTRを添加した培養上清では神経突起成長が有意に抑制され たが、E61K TTRでは抑制効果はなく、正常TTRと同程度であった。腓腹神経で は一部の神経内膜細胞がTTR陽性であった。また神経内膜ではTUNEL陽性細胞 が多数認められ、電顕でシュワン細胞であることが明らかとなった。結諭】E61K TTRの神経細胞毒性は弱いと考えられた。腓腹神経の細胞外には非線維性TTR凝 集は認められなかった。TTRアミロイド沈着は血液神経関門の欠如している後根 神経節で生じていると考えられる。またシュワン細胞アポトーシスが多数認めら れ神経変性に関与しているかもしれない。

\section{0-25-2 A yearly effect of zonisamide on neuroinflammation and dopamine terminals in early PD: a PET study}

YYasuomi Ouchi ${ }^{1}$, Tatsuhiro Terada ${ }^{1,2}$, Tomoyasu Bunai ${ }^{1}$,

Takafumi Matsudaira ${ }^{1,2}$, Takashi Konishi ${ }^{3}$, Tomokazu Obi ${ }^{2}$

${ }^{1}$ Dept of Biofunctional Imaging, Hamamatsu University School of Medicine,

Japan, ${ }^{2}$ Dept of Neurology, Shizuoka Institute of Epilepsy and Neurological

Disorders, ${ }^{3}$ Dept of Neurology, Japanese Red Cross Shizuoka Hospital

Objective: Neuroinflammation is among the important pathophysiology of Parkinson's disease (PD). Previous animal studies suggested a possible capacity of zonisamide, an anti-PD drug, on neuroprotection. but no direct evidence still exists in the human setting. Here we investigated the neuroprotective effect of zonisamide by measuring microglial activation and dopamine transporter in early PD patients using PET. Methods: Seventeen PD patients at Hoehn and Yahr stage 1-2 were recruited. The PD patients were randomly classified into two groups: one with and the other without zonisamide administration under sustained L-dopa treatment. PET scans with [11ClDPA713 and [11ClCFT were performed before and one-year after the zonisamide treatment. The binding potentials $\left(\mathrm{BP}_{\mathrm{N}}\right)$ of the tracer uptake were estimated using the simplified reference tissue model (SRTM) with supervised cluster analysis. Betweengroup analysis and paired t-test were performed using statistical parametric mapping (SPM). Results: SPM showed a significant increase in [11C]DPA713 $\mathrm{BP}_{\mathrm{ND}}$ in the entire brain in the whole $\mathrm{PD}$ group. Further increase in the [11C] DPA713 $\mathrm{BP}_{\mathrm{ND}}$ was found one year later in the $\mathrm{PD}$ group in general compared with the control group. In contrast, the degree of [11C]DPA713 $\mathrm{BP}_{\mathrm{ND}}$ change and the regional extent of elevated [11ClDPA713 $\mathrm{BP}_{\mathrm{ND}}$ areas were significantly lower in one year in the zonisamide-plus group which showed also less decrease in [11C CFT binding in the striatum. Conclusions: Zonisamide can exert a long-time, neuroprotective effect on the dopaminergic neurons in the living PD brain.
$0-24-8$ withdrawn

\section{0-25-1 Preoperative impulsivity leads to better QOL after deep brain stimulation in Parkinson's disease}

$\bigcirc$ Tatsuya Yamamoto ${ }^{1,2}$, Weibing Liu², Yoshitaka Yamanaka ${ }^{2}$, Masato Asahina, Tomoyuki Uchiyama, ${ }^{2,}$, Shigeki Hirano ${ }^{2}$ Keisuke Shimizu', Yoshinori Higuchi ${ }^{3}$, Satoshi Kuwabara ${ }^{1}$ Department of Rehabilitation, Chiba Prefectural University of Health Sciences, Japan, ${ }^{2}$ Department of Neurology, Graduate School of Medicine, Chiba University, Japan, ${ }^{3}$ Department of Neurological Surgery, Graduate School of Medicine, Chiba University, ${ }^{4}$ Department of Neurology, International University of Health and Welfare, Ichikawa, ${ }^{5}$ Neurology Clinic, Tsudanuma

[Objectivel Indications for deep brain stimulation (DBS) surgery are determined basically by preoperative motor function; however, postoperative quality of life (QOL) is not necessarily correlated with the improvement in motor symptoms, suggesting that cognitive and psychiatric symptoms might affect QOL after surgery in patients with Parkinson's disease. We aimed to explore which cognitive functions and neuropsychiatric symptoms affect QOL and are therefore predictive of changes in QOL, before and after DBS surgery. [Methods] A total of 59 patients with Parkinson's disease were enrolled in this study (mean age, $64.3 \pm$ 1.0 years; mean disease duration, $12.1 \pm 0.5$ years). Motor function, cognitive function, and neuropsychiatric symptoms were evaluated before and after DBS surgery. Postoperative evaluation was performed 3 months, 1 year, and 3 years after surgery. [Results] Of the 59 participants, 43 completed the postoperative clinical evaluation after 3 months, 40 after 1 year, and 23 after 3 years. Higher impulsivity scores and higher frontal lobe function led to significantly worse QOL before and 1 year after surgery. Preoperative higher impulsivity scores and greater reductions in the scores on Unified Parkinson's Disease Rating Scale Part III during the "off" phase between before and 3 months after surgery led to significant improvement in QOL 3 months after surgery. [Conclusions] Preoperative higher impulsivity scores and improvement in motor functions led to better QOL 3 months after surgery.

\section{0-25-3 Pharmacological remodeling of glycolytic energy homeostasis in Parkinson's disease}

$\bigcirc$ Naomi Kanzato, Kou Nakachi, Hiroyuki Akamine,

Kensuke Tanikawa

Okilanawa Prefectural Southern Medical Center \& Children's Medical Center, Japan

(Objective) To evaluate the effect of Parkinson's disease (PD) pharmacological agents to the glycolytic energy homeostasis. (Background) Neuronal energy supply is highly dependent to hexokinase (HK-1) to ATP production. PD agenets such as L-DOPA induce HK-2 transcroption via Akt kinase to higher energy demand (catabolism). A2AR antagonist/istradefyllin (Ist) induce AMPK-lysosome to reactivate autophagy with energy conservation (anabolism). (Methods) The cohort recuited 185 PD patients for six years from 2013 to 2019 (age,70 \pm 11 ; female/male, 103/82; duration, $9.8 \pm 7$; modified $\mathrm{H} \& \mathrm{Y}$ (on) $3.0 \pm$ 1.0 , (off) $4.0 \pm 0.9$; LEDD $729 \pm 255$ ). The body weight changes after L-DOPA replacenebt therapy (derta loss or gain) and other disabilities were evaluated. Biological marker; serum HK-2 (colorimetric enzyme activity assay; ab136957), insulin-like growth factor type 1 (IGF-1,immune-radiometric assay; daiichi, Japan) were measured. Adjunctive agents (Ist, zonisamide, dopamine agonist, MAO-B inhibitor) and DBS (STN,GPi) were evaluated with multivariate logistic analysis. (Results) Overall prevalence of insulin resistance were $19.4 \%$ loss of weight (derta loss) were $56.8 \%$, dyskinesia were $17.1 \%$, and depression $6.3 \%$. L-DOPA correlated with derta loss and lower circulating IGF-1 bioactivity $(\mathrm{p}<0.01)$, Ist and DBS were protective for dyskinesia. L-DOPA naïve patient revealed lower serum HK-2 activity $(\mathrm{p}<0.01)$. (Conclusions) Glycolytic energy homeostasis and cell protection with autophagy are dynamically coordinated by PD pharmacotherapies. 
0-25-4 Long-term outcome of STN-DBS patients changed from a conventional to independent current control IPG

$\bigcirc$ Katsuo Kimura ${ }^{1}$, Hitaru Kishida, ${ }^{1}$ Y u Kitazawa ${ }^{1}$,

Takefumi Higashijima ${ }^{2}$, Takashi Kawasaki ${ }^{2}$, Keisuke Morihara ${ }^{3}$,

Yuichi Higashiyama ${ }^{3}$, Yosuke Miyaji ${ }^{3}$, Hideto Joki ${ }^{3}$, Hiroshi Doi ${ }^{3}$

Hideyuki Takeuchi ${ }^{3}$, Naohisa Ueda ${ }^{1}$, Fumiaki Tanaka ${ }^{3}$

${ }^{1}$ Department of Neurology, Yokohama City University Medical Center,

Japan, ${ }^{2}$ Department of Neurosurgery, Yokohama City University Medical

Center, ${ }^{3}$ Department of Neurology and Stroke Medicine, Graduate School of Medicine, Yokohama City University

Objective: To investigate the safety and efficacy of the Multiple Independent Current Control (MICC)-compatible implantable pulse generator (IPG) in patients with Parkinson's Disease (PD) who previously underwent subthalamic nucleus deep brain stimulation (STN DBS) with conventional IPG. Methods: Seventeen cases of PD were included. All patients previously underwent STN-DBS with the conventional quad polar electrode and primary cell type IPG. The average age at IPG exchange was $66.9 \pm 7.3$ years old, and the mean period from implantation was $7.0 \pm 2.1$ years. We surveyed the safety of the IPG exchange. setting parameters, and clinical outcomes at 3 and 12 months after the exchange. Results: No patients experienced perioperative and long-term complications for 12 months. The number of stimulating contacts per lead was $1.40 \pm 0.80$, the current was $5.6 \pm 26 \mathrm{~mA}$ per lead, the pulse width was $69.0 \pm 30.0$ microseconds, and the frequency was $148.0 \pm 34.0 \mathrm{~Hz}$ before the exchange. The stimulation parameters 3 months after IPG exchange were as follows: $1.40 \pm 0.8$ stimulating contacts per lead, $5.8 \pm 3.2 \mathrm{~mA}$ current per lead, $32.0 \pm 24.6$ microseconds pulse width, and 113.5 $\pm 36.5 \mathrm{~Hz}$ frequency. After 12 months, four patients experienced motor improvements such as in akinesia or walking. Speech and posture improved in three and two patients, respectively. Constant and precise control of the current by MICC-IPG may have improved symptoms and prevented stimulation-evoked complications. Conclusions: MICC-IPG may be beneficial as an alternative to a conventional IPG for patients with PD undergoing STN-DBS.

\section{0-25-6 Relationship between gait and cognition in Parkinson's disease}

Akira Nishida, Daiske Kanbe, Nobukatsu Sawamoto,

\section{Ryosuke Takahash}

Department of Neurology, Kyoto University Graduate School of Medicine, Japan

Objectives: Gait disturbance and cognitive dysfunction often coexist in patients with Parkinson's disease (PD). Emerging evidence indicates increased gait variability and slow step velocity are associated with cognitive deterioration in PD. Here, we evaluated interaction between gait and cognition by using dual- and single-task in patients with PD. Methods: We recruited $48 \mathrm{PD}$ patients and 11 healthy controls. Gait performance under dual- and singletask was measured using an electronic walkway system. During dual-tasking the subjects perform forward digit span while walking. They also underwent cognitive tests. Results: Using principal component analysis and K-means clustering, we divided PD patients into 3 subgroups. Groupl is characterized by worsening of gait variability during dual- compared to single-task. Group 2 is characterized by low gait variability and fast step velocity both during dual-and single-task. Group 3 is characterized by high gait variability and slow step velocity both during dual- and single-task. Consistent with previous reports, group 2 showed preserved gait and cognitive function while group 3 demonstrated gait and cognitive deficits. There was no statistically significant cognitive deterioration in groups 1 compared to group 2. Conclusion: Our study confirmed the relationship between gait disturbance and cognitive dysfunction in PD. In addition, we found that worsening of gait variability in dual-task was not necessarily related to cognitive dysfunction.

\section{0-25-8 High-levodopa plasma concentration predicts} levodopa induced dyskinesia in Parkinson's disease

Tomotaka Shiraishi ${ }^{1}$, Noriko Nishikawa ${ }^{1}$, Junko Takei ${ }^{2}$,

Yohei Aoshima ${ }^{1}$, Yuka Hama ${ }^{1}$, Yohei Mukai ${ }^{1}$, Yuji Tkahashi ${ }^{1}$

${ }^{1}$ Department of Neurology, National Center of Neurology and Psychiatry,

Japan, ${ }^{2}$ Department of Mental Retardation and Birth Defect Research,

Psychiatry

Introduction: In Parkinson's disease (PD) patients, pulsatile dopaminergic stimulation may be a prime cause of levodopa induced dyskinesia (LID). Our aim is to investigate correlation between levodopa pharmacokinetics and LID in PD. Methods: We retrospectively reviewed the consecutive series of PD patients from 2015 to 2017. The levodopa/benserazide $100 / 25 \mathrm{mg}$ was administered under fasting conditions. Plasma levodopa concentration was calculated before and 15, 30, 60, 120, 180 and 240 minutes after the administration (The levodopa test). The patients with LID in the levodopa test and with missing follow-up data were excluded from this study. Follow-up was obtained in an outpatient clinic. Results: In 226 PD patients who underwent the levodopa test, LID was present in 66 patients $(29 \%)$ A total of 135 patients were included in the cohort (age $69 \pm 10$, men 72 [52\%] disease duration $6.3 \pm 5.2$ years, levodopa equivalent dose [LEDD] $385 \pm 290 \mathrm{mg}$ ). During a median follow-up of 33 months (interquartile range 16.5 to 43 ), 41 patients (30\%) developed LID. In ROC-analysis, maximum plasma concentration of levodopa $(\mathrm{C} \max )>12.9 \mu \mathrm{mol} / \mathrm{L}$ predicted LID with sensitivity $26 \%$ and specificity $94 \%$ (AUC 0.60). In patients with $C \max >12.9 \mu \mathrm{mol} / \mathrm{L}$ LID survival rate was significantly decreased $(\mathrm{p}<0.01)$. In the multivariable Cox regression analysis, $\mathrm{Cmax}>12.9 \mu$ $\mathrm{mol} / \mathrm{L}$ and LEDD were associated with incident LID (hazard ratio [HR] 4.54 confidence interval [CI] $95 \% 1.95$ to 10.5 , HR 1.001 , CI 1.000 to 1.002 , respectively). Conclusion: High-levodopa plasma concentration is associated with incident LID.

\section{0-25-5 Characteristics of amnestic cognitive impairment in Parkinson disease}

OIkko Wada ${ }^{1}$, Nobukatsu Sawamoto ${ }^{2}$, Yusuke Sakato ${ }^{1}$, Yuta Terada, Haruhi Sakamaki ${ }^{1}$, Akira Nishida ${ }^{1}$, Kennji Yoshimura ${ }^{1}$,

Daisuke Kannbe ${ }^{1}$, Koji Furukawa ${ }^{1}$, Atsushi Shima ${ }^{2}$, Yasutaka Fushimi ${ }^{3}$, Tomohisa Okada ${ }^{3}$, Kaori Togashi ${ }^{3}$, Ryosuke Takahashi ${ }^{1}$ Department of Neurology, Kyoto University, Japan, ${ }^{2}$ Department of Human Health Sciences, ${ }^{3}$ Department of Diagnostic Imaging and Nuclear Medicine

[Introduction] Cognitive deficits in Parkinson disease (PD) is not rare even at the earliest stage of motor symptom onset. The underlying pathology of the cognitive deficits is presumed to include cortical and limbic Lewy body deposition though neurofibrillary tangles and senile plaques may also play a role. Here, we describe the data from our cohort on their cognitive profiles and neurogenerative biomarkers involving atrophy on structural MRI and hypoperfusion on 123I-IMP SPECT. [Methods] We recruited 136 patients with PD at our hospital. We conducted neuropsychological examinations using each 2 tests in five domains, specifically, attention, executive, language, visuospatial function and memory. 3 tesla MRI and 123I-IMP SPECT were obtained. The images were analyzed using SPM12. [Results\&Discussion] 82 patients $(60 \%)$ were judged to be PD with normal cognition (PD-NC) while 25 patients (19\%) were impaired in 2 memory tests and categorized to PD with cognitive impairment (PD-CI) amnestic. PD-CI amnestic group demonstrated local reductions in gray matter in anterior temporal area including hippocampus compared to PDNC ( $<<0.05$ FDR corrected). PD-CI amnestic group also showed decreased blood flow in bilateral association parietal areas, temporal areas, posterior cingulate and precuneus compared to $\mathrm{PD}-\mathrm{NC}$ ( $\mathrm{P}<0.05$ FDR corrected). The patterns of reductions in gray matter and decreases in blood flow were similar to those observed in patients with Alzheimer disease. Neurofibrillary tangles and senile plaques is likely to be related to pathology in PD-CI amnestic.

\section{0-25-7 Cerebrospinal fluid proteomic profiling of PSP:} Chromogranin B as a diagnostic potential biomarker

Hiroshi Takigawa ${ }^{1}$, Ryoichi Sakata ${ }^{1}$, Toshiaki Inoue-nishida ${ }^{2}$,

Hisanori Kowa ${ }^{3}$, Kenji Nakashima ${ }^{3}$, Ritsuko Hanajima ${ }^{1}$

${ }^{1}$ Division of Neurology, Department of Brain and Neurosciences, Faculty of Medicine, Tottori University, Japan, ${ }^{2}$ Division of Human Genome Science, School of Life Sciences, Faculty of Medicine, Tottori University, ${ }^{3}$ Department of Neurology, National Hospital Organization, Matsue Medical Center

[Objective] Progressive supranuclear palsy (PSP) is a distinct neurodegenerative disorder and various clinical subtypes have been reported. The aim is to identify the biomarker associated with PSP for better understanding of a pathophysiology and clinical diagnosis. [Methods] Cerebrospinal fluid (CSF) samples were analyzed by SELDI-TOF MS method as a discovery study in order to identify a biomarker for PSP. In the validation study, CFS samples from a different cohort of 53 PSP patients (mean age; $73.6 \mathrm{ys}$ ), 24 Parkinson' disease (PD) patients (73.0 ys), 15 corticabasal syndrome (CBS) patients $(73.5 \mathrm{ys})$ and 20 healthy control (CTL) (69.2 ys) were analyzed by ELISA. [Results] One putative protein peak $(\mathrm{m} / \mathrm{z} 6255)$ was differentially expressed in PSP compared to PD and CTL subjects andwas identified as the partial fragment of chromogranin B (CHGB) byLC-MS/MS method. The mean level of CHGB in CSF were $76.8 \mu \mathrm{g} / \mathrm{mL}$ in PSP patients, $61.5 \mu$ $\mathrm{g} / \mathrm{mL}$ in PD patients. $61.2 \mu \mathrm{g} / \mathrm{mL}$ in CBS patients and $59.0 \mu \mathrm{g} / \mathrm{mL}$ in CTL subjects. CHGB levels in PSP patients were significantly higher than it in PD, CBS and CTL subjects $(\mathrm{p}<0.05)$. A multivariate logistic model of $\mathrm{CHGB}$ revealed a ROC AUC of 0.671 , a sensitivity of $62.3 \%$, a specificity of $66.1 \%$, a positive predictive value of $57.9 \%$ and a negative predict value of $62.7 \%$. The cutoff of CFS CHGB level offering more than $90 \%$ sensitivity was $120 \mu \mathrm{g} / \mathrm{mL}$. [Conclusion] CHGB is an acidic soluble molecule widely distributed in nerve cells and one of the neurosecretory proteins and is expected to be a candidate molecule for elucidating the pathogenesis of PSP

\section{0-25-9 withdrawn}


0-25-10 Profile \& Quality of Life of Filipino Patients with Focal Dystonia treated with Botulinum toxin A

Meleza Mea B. Cambalon, Jarungchai Anton S. Vatanagul

Perpetual Succour Hospital, Philippines

Objectives: To determine the profile and compare the quality of life of Filipino patients with focal dystonia treated with Botulinum toxin A. Method: The sample consisted of 22 patients who had Botulinum toxin Injection for focal dystonia. Data were collected using Craniocervical Dystonia Questionnaire developed by Muller, J. et. al. Results: Patients with cervical dystonia were younger with a mean age of 52.4 years than hemifacial spasm with a mean age of 55.67 years. Majority of the patients were married, college graduates and had a full-time employment. Hypertension was the most common comorbidity with an overall prevalence of $63.64 \%$ in both cervical dystonia and hemifacial spasm group. Most patients had family history of hypertension (77\%) and diabetes mellitus (36.36\%). All patients with cervical dystonia had symptoms of neck tilt and twist in an unusual fashion and neck pain radiating to shoulders while all patients with hemifacial spasm had symptoms of involuntary muscle twitching of the facial area and uncontrollable eye blinking of either or both eyes. Conclusion: Cervical dystonia (CD) had greater negative impact to the patients' quality of life compared to hemifacial spasm ((HFS). Patients with HFS generally had better emotional well-being, lesser pain symptoms, more effective in carrying out activities of daily living and had more positive social/ family life relationships compared to CD patients. In HFS, smaller muscle groups were involved, lesser dose of botulinum toxin required and thus lower cost needed for repeated sessions compared to cervical dystonia.

\section{O-26-2 無菌性髄膜炎に対する髄液ヘルペス属real time PCR の結果と臨床像の検討}

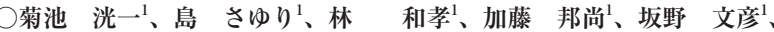
東 篤宏 ${ }^{1}$ 、長尾龍之介、前田 利樹 ${ }^{1}$ 、村手健一郎 ${ }^{1} 、$ 廣田 政古 ${ }^{1}$ 、 石川 等真 ${ }^{1}$ 、水谷 泰彰 1 、新美 芳樹 ${ }^{1}$ 、植田 晃広 1 、石丸聡一郎 ${ }^{2} 、$ 河村 吉紀 2 伊藤 信二 ${ }^{1}$ 、武藤多津郎 ${ }^{1} 、$ 吉川 哲史 ${ }^{2}$ 渡辺 宏久 ${ }^{1}$ 藤田医科大学 脳神経内科学、 ${ }^{2}$ 藤田医科大学 小児科学

【目的】無菌性㟘道膜炎は一般的に多くの場合経過良好であることが多いがへルペス ウイルスが起因の場合、脳炎を合併あるいは何らかの後遺症が残存し、予後不良 となることがしばしばある。一般には血中あるいは䯣液中へルペスウイルス抗体 価測定検查が普及しているが、多数例でreal time PCR法を用いてウイルス量・型 を測定し、その陽性率を検討するとともに、臨床経過や予後を照合した報告は少 ない。【方法】頭痛・意識障害・発熱などで無菌性䯣膜炎あるいは脳炎を疑った2013 年4月から2019年10月までに当院を受診した連続657例を対象として揈液のreal time PCR法を用いてヘルペスウイルスの測定を行った。また、陽性例の臨床経過 を検討した。【結果】ヘルペスウイルス属が陽性となった例は 46 例 $(7.0 \%)$ で、内 訳はHSV-1 : 6例、HSV-2 : 4 例、VZV : 28例、EBV : 3例、CMV $: 0$ 例、HHV6 $: 5$ 例、HHV7：0例であった。HSV-1 陽性の6例は全例が脳炎で、うち4例は中等度 以上の認知機能障害が残存し、救命しえたものの日常生活の予後は不良であった。 HSV-2陽性例は全例経過良好で後遗症はなかった。VZV陽性の28例は2例に軽度 認知機能障害が残存した。EBVは全例経過良好であった。HHV- 6 陽性の5例に抒 いて脳炎は1例であり、㕼膜炎の 4 例も含めて全例経過良好であった。染色体に組 及込まれた HHV- 6 (CIHHV6) を疑う症例が2例あった。【結論】無菌性䯣膜炎・脳 火の7.0\%でヘルペスウイルス属が陽性であった。髄液のreal time PCRの測定結果 と臨床所見を照合することは、治療方針の決定のみならず、その後の経過や予後 を推定するうえで有用であることが示唆された。

\section{O-26-4 アシクロビル抵抗性単純ヘルペス脳咨に対するビダラ ビンの有用性}

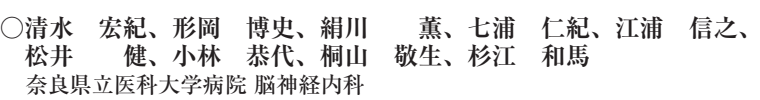

【目的】単純ヘルペスウイルス (HSV) の薬剤耐性は遗伝子変異により生じるが、楽 剤感受性を調べるのは困難である。アシクロビル (Acy) を十分量投与しても檤液 や脳画像で悪化した場合は、作用機序の異なるビダラビン併用療法が推奨されて いる。【方法】ビダラビン (Vid)への切り替えで、あるいはVidの併用が有効であっ たHSV脳炎を報告する。【結果】症例 1 ：30歳女性。5日間の発熱と頭痛に続き異常 言動が出現し意識障害で搬送。GCS7点であり、頻回な全身性症攣と低換気のため 人工呼吸器管理となった。頭部MRIは両側の側頭葉内側に異常高信号を示し、蛕 液細胞数は $321 / \mathrm{mm}^{3}$ と上昇し、 real-time HSV PCRは38000 copies $/ \mathrm{ml} ゙$ あった。 Acy $(10 \mathrm{mg} / \mathrm{kg} /$ day, 10日間) とdexamethasone (16mg/day, 5日間)、抗痓攣剤を 開始した。意識状態に改善なく、第11病日の䯣液細胞数が再上昇し、頭部CTでク モ膜下出血を認め AcyからVid $(900 \mathrm{mg} /$ day, 14日間) に切り替えた。Vid投与7日 後に指示動作が可能となり、10日後の䚛液細胞数は $26 / \mathrm{mm}^{3}$ と低下し、13日後に は呼吸器を離脱した。経過中肺塞栓を合併しへパリン持続静注をしたが、クモ膜 下出血の増大なくJCS 3点、U字歩行で転院。症例 $2: 34$ 歳女性。発熱と記憶障害 で他院を受診。檤液細胞数増多と頭部MRIで両側の側頭葉と島に異常を認めAcy とステロイドを投与されたが、異常行動がみられるようになり転院。髄液細胞数

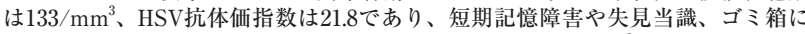
放尿する異常行動がみられた。Acyを継続し咀液細胞数 $43 / \mathrm{mm}^{3}$ と低下したが、転 院1ヶ月後に髄液細胞数が再上昇し $\left(93 / \mathrm{mm}^{3}\right)$ 、頭部MRI異常高信号の拡大を認め、 Vid $(600 \mathrm{mg} /$ day, 9日間) を追加した。短期記憶障害は持続するも異常行動はなく なり、Vid投与 6 日後の䯣液細胞数は $34 / \mathrm{mm}^{3}$ と低下した。【結論】十分量のアシク ロビル投与で効果が得られない場合は、ビダラビンを考慮すべきである。

\section{O-26-1 E200K遺伝性CJD 60 例の臨床的特徵}

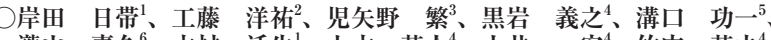

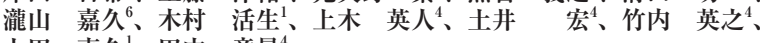
上田 直久、田中 章景 ${ }^{4}$

横浜市立大学附属市民総合医療センター 神経内科、

横浜市立脳卒中・神経脊椎センター 脳神経内科、 ${ }^{3}$ 横浜南共済病院 脳

神経内科、 ${ }^{4}$ 横浜市立大学大学院医学研究科 神経内科学・脳卒中医学、

国立病院機構静岡医療センター 脳神経内科、 ${ }^{6}$ 山梨大学医学部 神経内科学

【目的】E200K遺伝性CJD (E200KgCJD) の臨床的特徵を検討した。【方法】1999年よ り2019年までのプリオン病サーベイランス調查で、我々が調查した神奈川・静岡・ 山梨 3 県のE $200 \mathrm{KgCJD}$ 症例について、性別、発症年齢、罹病期間、臨床症状、検 查所見などについて、検討した。【結果】E200KgCJD 60症例を検討した。性別は、 男性29例、女性31例とほほ同数だった。平均発症年齢は63.6 09.3 歳で、孤発性CJD ( SCJD) の既報の発症年齡69.7歳に比し、やや若年発症であった。同一家系内の同 胞で発症が確認できた2つの家系で表現促進現象がみられた。臨床症候は、進行性 認知症 $(100 \%)$ ミオクローヌス $(76 \%)$ 、錐体路徴候 $(75 \%)$ 、錐体外路徵候 $(37 \%)$ 、 小脳失調 $(68 \%)$ 、視覚異常 $(38 \%) 、$ 精神症状 $(60 \%) 、$ 無動無言状態 $(85 \%)$ で、既 報の本邦のSCJDの症候と類似していた。脳波検查では、基礎律動の徐波化は $98 \%$ に、周期性鋭波複合は $82 \%$ で認められた。脳脊䯣液検查では、14-3-3蛋白は $97 \%$ 、 総tau蛋白は $90 \%$ 、RT-QUICは100\%の陽性率であった。脳MRI拡散強調像での高 信号は5 59 例 $(98 \%)$ でみられた。発症から無動無言に至るまでの平均期間は 3.6 月、 発症から死亡までの罹病期間は 12.0 月と、SCJDの17.3月に比べ短かった。遺伝子多 型は、129MV多型を3例、219EK多型を4例で認め、そのほかは129MM·219EEであっ た。臨床経過の確認できた $129 \mathrm{MV}$ の例と $219 \mathrm{EK}$ の例では、罹病期間が長く緩徐 な経過を示した。考察】E200KgCJDはsCJDの経過と類似しているとされてきたが、 実際にはやや発症年齢が若く、急速進行していた。ただ、129MVや219EKのよう な遗伝子多型を有する症例は、緩徐進行で、臨床症候や検査所見が異なっていた。

\section{O-26-3 臓器移植患者における進行性多巣性白質脳症につい て：症例報告と文献的レビュー}

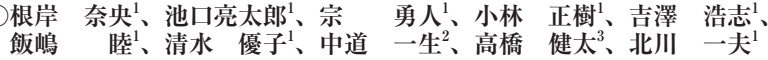

${ }^{1}$ 東京女子医科大学病院 脳神経内科、 ${ }^{2}$ 国立感染症研究所 ウイルス 第一部、

国立感染症研究所 感染病理部

【目的】進行性多巣性白質脳症（PML）は、免疫抑制患者に発症する予後不良の脱䯣 性疾患である、臓器移植患者は，拒絶反応を予防するため兔疫抑制剂を内服するの が一般的であるが, 稀に進行性多巣性白質脳症を発症する要因ともなる. 今回我々 は生体腎移植 21 年後にPMLを発症し, 免疫抑制剤中止, メフロキン・ミルタザピン 投与により進行速度が緩徐になった症例を経験した. 本研究は症例報告と文献的し ビューを行い, 移植関連PMLの特徴について明らかにすることを目的とする.【方 法】症例は59歳女性で, 生体腎移植後21年後にふらつきや複視が出現した. 頭部MRI で左小脳半球から小脳脚にかけて病変があり, 徐々に脳幹に拡大した. 䯣液中JCV PCRが陽性で, 脳病理所見からPMLと診断した.タクロリムス・ミコフェノール酸 モフェチルを漸減中止し, メフロキン・ミルタザピン投与により, 神経症状・画像 所見ともに進行が緩徐になった. 1971年から2019年までに報告された臟器移植後に PMLを発症した症例と自験例について, 移植関連PMLにおける予後因子などの特徴 について検討した【結果】検索した限り臓器移植後にPMLを発症した報告は66例あ り,うち腎移植が 33 例, 肝移植が18例, 心移植が8例, 肺移植が7例であった. 発症年齢 は10歳から87歳 (平均48.7歳), 性別は男性36例, 女性30例であった. 免疫抑制剂の内 服が明記されていたのは 52 例で, 移植からPML発症までは 1 312か月であった (平 均50か月). PMLを発症し, 死亡したと記載されているものは44例, 死亡までの期間 の平均は17.6か月であり，症例の中には少数の長期生存例もいたが,これらの多くは 免疫抑制剂を減量もしくは中止していた【結論】稀ではあるが, 臓器移植後にPML を発症する.臓器移植患者において免疫抑制剤を中止することはリスクを伴うが 移植関連PMLの予後に関連する可能性があるため, 今後の症例の蓄積が必要である.

\section{O-26-5＼cjkstart初診時に他臓器感染症合併のある細菌性䯣膜炎例の特徵}

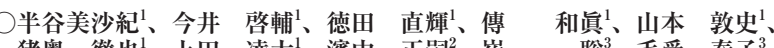
猪奥 徹也 ${ }^{1}$ 、上田 凌大 ${ }^{1}$ 、濱中 正嗣 ${ }^{2}$ 、崔 聡 $^{3}$ 、毛受 奏子 ${ }^{3}$ 、

京都第一赤十字病院 脳神経・脳卒中科、 ${ }^{2}$ 京都第二赤十字病院 脳神経内科、 京都府立医科大学 脳神経内科、 ${ }^{4}$ 済生会滋賀県病院 脳神経内科

【目的】神経内科医の初診時に他臟器感染症を合併している細菌性䯑道膜炎 (BM) 例の 特徵を明らかにする.【方法】2011年3月から2019年9月まで当施設で入院加療を受け たBM連続例を対象とした．対象を当科初診時での他臟器感染症の合併群(I群) と非 合併群 (N群)の分類し，両群間で背景因子と入院時症状，検查所見，起炎菌，治療， 全身合併症，予後を比較した、【結果】対象49例のなかで，I群13例（27\%）、N群36例 であり, 年齢中央值は $74 / 65.5$ 歳, 男性は $6 / 22$ 例, 他施設・他科からの転院・転科は $9(69 \%) / 20(51 \%)$ 例であった. I群の感染巣は肺炎 3 例, 感染性心内膜炎, 化膿性椎 体炎, 齵歯が各 2 例, 中耳炎, 副鼻腔炎, 化膿性関節炎, 腎孟腎炎が各1例であった. 初診時に意識障害は $10 / 32$ 例，発熱 $\left(>38^{\circ} \mathrm{C}\right)$ は $8 / 19$ 例，䯣膜刺激徵候は $10 / 27$ 例，頭 痛は $4 / 16$ 例でみられた, 初診時の検查所見では, CRP高值 $(>10 \mathrm{mg} / \mathrm{dl})$ は $10(77 \%) / 20$ $(56 \%)$ 例, WBC増多 $(>10,000 / \mathrm{ul})$ は $9 / 25$ 例，血小板数減少 $(<12$ 万 $/ \mu \mathrm{L})$ は $5(39 \%) / 8$ $(22 \%)$ 例，血液培養陽性は $9(70 \%) / 21(58 \%)$ 例, 葡液細胞数中央值は $1759 / 1158$ ( $\mu \mathrm{L})$ であった。起炎菌について肺炎球菌は $4 / 10$ 例, ブドウ球菌は $4(31 \%) / 4(11 \%)$ 例, 他の菌は $2 / 12$ 例，菌不明は $3 / 10$ 例であった．治療に関してCTRX+VCM+ABPCは 5/9例，MEPM+VCMは5/9例，他の抗菌薬は3/18例，ステロイド併用は5 $(39 \%) / 22$ (61\%) 例，免疫グロブリン大量静注併用は $7 / 16$ 例，抗DIC療法併用は $5 / 11$ 例であっ た。 ショックは3/9例, DICは5/13例, 急性腎障害は7 (54\%)/11 (31\%) 例で合併し, 退院時GOS中央值は $3 / 5$, 死亡数は $4(31 \%) / 4(11 \%)$ 例であった.【結論】初診時の 他臓器感染症合併のBM例では, 非合併例と比較し, 高齢で, 転院·転科とCRP高値, 血小板数減少，血液培養陽性，ブドウ球菌が起炎菌の例が多く，ステロイド併用例 が少なく，急性㹂障害合併例と予後不良例，死亡例が多かった，BM初診時の他臟 器感染症は感染源とともに，予後増悪因子ととらえるべきである。 


\section{0-26-6 再発性自己免疫性脳炎の臨床的検討}

○林 紗葵、大井 長和 ${ }^{1}$ 、佐藤 啓1 1 十川 純平 ${ }^{2}$

宇治病院 脳神経内科、 ${ }^{2}$ 京都医療センター 脳神経内科

【目的】再発性自己免疫性脳炎を疑った症例について、臨床的検討を行うこと。【対 象と方法!対象は当院で入院加療した2症例。病歴、画像と䯑液所見を解析した。 症例 $1 ： 80$ 歳代女性、右利き。主訴は見元にくい。現病歴はA年某月某日から視力 低下が急に出現し、発症5日後から複視が出現していずれも進行性。発症 12 日後 から意識障害が出現したススロイドパルス療法 (SPT) で軽快して退院し、独居 生活。1回目の脳炎発症4か月後に自宅で倒れていたために救急搬送。搬送時は神 経学的に半昏睡。脑MRIにて中脑・橋にDWIとFLAIR画像でHISA、同部位のGd 造影効果を認めた。噵液検查は異常なし。SPTにて意識障害と脳MRI所見は軽度 改善した。リハビリ目的に当院に転入院した。転院時は認知障害、频部と右上脑 のジストーニア、左上下肢の麻㾌、四肢拘縮を認めた。ADLは全介助で、中心䢂 脈より高カロリー輸液。症例 $2: 60$ 歳代男性、右利き。主訴は本人からなし。B年 某月某日からリモコン操作が難しくなり、カレンダーに話しかける異常行動が出 現し、以後持続。発症 3 月後に意識障害が出現して入院。咀液梌查で細胞数增加 と脳MRIで両側側頭葉にFLAIR/HISAを認めた。へルペスウイルスの抗体価は㓌 性。SPTにて臣床症状は改善し退院したが、性格変化々認知障害が残存。1回目の 脳炎発症 2 年後に再び意識障害が出現し入院。SPTで意践障害の改善を認めるも 垵たきりとなり胃瘦造設。当院にリハビリ目的で転入院。神経学的に失外套症候 群、四肢拘縮を認めADLは全介助。既往歴は自己免疫性ネフローゼ症候群。[結果] いずれの症例も1回目の脳炎が急性経過をとり、邻液と脳MRI検查で異常所見があ ク、ステロイドで効果を認め、自己免疫性脳炎を疑った。両症例とも脑神経の自

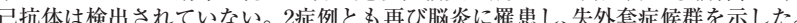
【結論】両症例とも自己抗体が未同定であるが、予後不良の再発性自己免疫性脳炎 を示唆した。

\section{0-26-8 無菌性髄膜炎における非典型的所見}

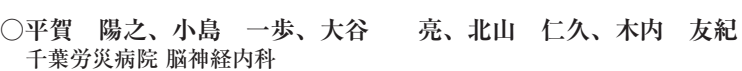

目的無菌性嗔膜炎は典型例では診断は容易であるが、時に非典型的な臨床また は㭘查所見を呈して他の感染性䟦膜炎との鑑別が困難な場合がある。回我々は 無菌性髄膜炎における非典型所見の頻度と特徵を検討した。【方法】2009年10月か ら 2019 年 9 月の 10 年間に当科に入院した無菌性艏膜炎症例を検討した。無菌性䯣膜 炎に扔ける非典型所見は、細菌性檤膜炎の診療ガイドライン2014に記載のウイル

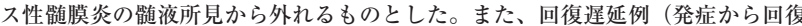
開始までが2週間以上)、政液ADA值8/U/L以上、踇膜炎-尿閉症候群も非典型所

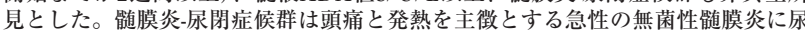
閉を伴い、尿閉と旤膜刺激徵候以外の神経症状を伴わないものと定義した。【結果】

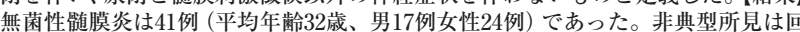

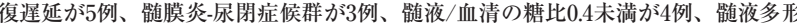
球 $50 \%$ 以上が 3 例、跹液蛋白 $100 \mathrm{mg} / \mathrm{dL}$ 以上が7例であり、政液白血球 $1000 / \mu \mathrm{L}$ 以上 は0例であった。鹃液ADA值8U/L以上は測定した20例中5例に認めた。以上の7つ の非典型所見について、41例中 18 例 $(44 \%)$ が1つ以上の非典型所見を認め、うち 1 つのものが12例であり、2つが4例 (うち 2 例が髄膜炎-尿閉症候群)、3つが1例、4つ が 1 例 (㵦膜炎-尿閉症候群症例) であった。なお、軽度の檤液/血清の糖比 0.6 未満は 34例（83\%）と高率に認めた。【結論】無菌性䯣膜炎では非典型所見は決して稀では ない。そのため、無菌性髁膜炎の診断には全身状態や採血も含めた総合的な判断 が必要である。

\section{0-26-7 クリプトコッカス髄膜炎の臨床的特徵}

○田尻 正輝、中尾 聡、池田 淳司、高曽根 健、大橋 信彦、 佐藤 充人、吉長 恒明、関島 良樹

信州大学医学部 脳神経内科、リウマチ・膠原病内科

【目的】当科で経験したクリプトコッカス喵膜炎の臨床的特徵に関して検討する 【方法】2007年11月から 2019 年9月までの12年間に当科でクリプトコッカス链膜炎 と診断した7例について 診療録から患者情報を抽出し検討した【結果】平均年齢 69.4歳（41-80歳），基碟疾患は関節りウマチ 3 例，顕微鏡的多発血管炎りウマチ

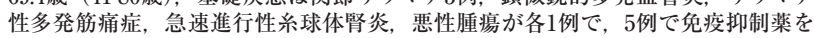
使用していた。初発症状から診断に至るまで全例で一ヶ月以上の期間を要した。

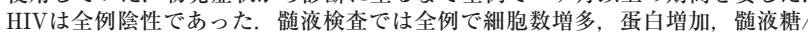
血糖比低下を示した。6例で軻液墨汁染色陽性，真菌培養検查は全例陽性で，同 定された菌種は全例C neoformansであった韨液中のクリプトコッカス抗原は 測定された5例全てで陽性であった(32-32768倍) が病势との相関は示唆されなかっ た. 頭部MRI画像で咆膜の高信号変化を5例，脳室拡大を 4 例で認めた。全例で初 期治療にAMPBを使用し，退院時JCSが1以上であったのは4例で, 1例は死亡した。 【結諭】クリプトコッカス喵膜炎は免疫抑制患者で多く発症する傾向にあるが，健 常人にも発症する。また，炎症巣の近傍である脑公からの軻液検查で初めて菌体 が検出されることもあり，起炎菌の同定されない唱膜炎では鑑別の一つとして考 虑する必要がある。

\section{0-26-9 ゲルストマン・ストロイスラー・シャインカー病 24 例の検討}

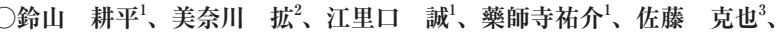

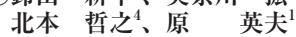

${ }^{1}$ 佐賀大学医学部、 ${ }^{2}$ 高邦会高木病院、 ${ }^{3}$ 長崎大学医菓薬学総

合研究科運動障害リハビリテーション分野 (神経内科学)、

東北大学大学院医学系研究科・病態神経学

【目的どルストマン・ストロイスラー・シャインカー病 (GSS) 恃本邦のプリオン 病の3\%程度であるが、恢賀県は集積地として知られている。本研究では当科で診 療を行ったGSSの臨床像を检討する。【方法】2002年4月から2019年10月に当科でプ リオン遺伝子変異P102Lを確認し、GSSと診断された例を対象とする。[結果]24例 (22家系, 男性11名, 平均年龄60.6 08.9$)$ がGSS と䛦断された。同様の症状の家族歴 は21例に見られたが、4例は春噵小脎変性症と診断されていた。初発の症状は歩。 行障害 (17例) 、認知機能低下 (3例) 、下肢感㥯障害 (2例)，構音障害 (2例)だった。 下肢の腱反射は12例で低下, 2 例でえ无進していた。能液NSEは $21.4 \pm 9.2 \mathrm{ng} / \mathrm{ml}$ た。頭部MRIで小脳萎縮は2例、拡散強調画像で皮質高信号は2例のみで認めた。 䏚波でPSDを認めた症例はなかった。結論】GSSの初発症状は多彩である。家族 歴のある小脳失調の症例で小脳萎縮を欠く場合GSSを考慮する必要がある。

\section{0-26-10 Carnitine palmitoyltransferase 2多型を伴った急 性壊死性脳症の成人 3 症例の検討}

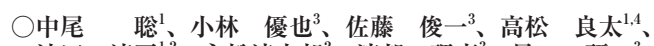

池田 淳司 ${ }^{1,2}$ 、永松清志郎 ${ }^{2}$ 、渡部 理恵 ${ }^{3}$ 、星 研一 ${ }^{3}$ 、石井 亘、 星野 愛、水口 雅 ${ }^{5}$ 、清水 雄策 2 、矢彦沢裕之 、関島 良樹 $^{1}$

${ }^{1}$ 信州大学医学部 脳神経内科・ リウマチ膠原病内科、2 伊那中央病院脳神経

内科、 ${ }^{3}$ 長野赤十字病院神経内科、 ${ }^{4}$ 長野赤十字病院膠原病リウマチ内科、

東京大学大学院医学系研究科 発達医科学教室

【背景】Carnitine palmitoyltransferase 2（CPT2）はミトコンドリア内膜に存在しカルニチ シシャトルの一部として機能し脂肪酸の $\beta$ 酸化に関与している, 急性壊死性脳症（acut necrotizing encephalopathy : ANE) はCPT2熱感受性多型との関連が指摘され，東アジア人に 多い．また小児に多く成人発症の報告は少ないとされる. 目的·方法】2017年4月から2019年7月 にANEと診断しCPT2多型を認めた成人 3 例について比較検討し報告する.【結果】症例1: 53 歳男 性 CPT2 (p F 352C heterozygous)の多型を有L，両䚋視床や脳幹主体のFLAIR高信号とい。 たANEの特徵的な画像所見を認めた，ステロイドパルス療法 (IVMP) を行ったが病変の拡大と 多臟器不全を合併し第24病日に死亡した，症例2: 77歳男性. CPT2 (p.F352C homozygous) の 多型を有し両側視床や脳幹主体にFLAIR高信号を呈した. IVMPに加え免疫グロブリン大量静 注療法を行ったところ病変の縮小を認め, 歩行訓練できる程度まで回復した，症例3: 25歳男性 CPT2 (p.F352C heterozygous) の多型を有し，大脳全体の浮腫，pseudo SAHのCT所見を呈 し両側後頭葉主体に壊死が進行した，気切行い植物状態で転院された。考察】CPT2多型では CPT2の酵素活性低下，热不安定性上昇，半隇期短縮が起こるとされる，小览では発熱により $\beta$ 酸化によるエネルギー生産が低下，感染によるサイトカインストーム，興奮練胞毒性により ANEに至るとされる，今回の3症例ではいずれもCPT2多型を有し，症例1，3では低栄養状態 と高熱を認め不幸な転帰となったが, 症例2は低栄養状態であったもののインフルエンザA陽性 にも関らず発熱をほとんど認めなかった。 インフルエンザ関連の発症例が多く報告されており。 発熱，䬣餓以外に異なる発症機序が存在するかもしれない、【結論】ANEの成人例は稀であり脑 神経内科医の間での認知度は低い。今後の症例蓄積と治療方法の構築が望まれる。 
0-27-2 Contribution of endogenous neural stem/progenitor cells to astrocyte regeneration in NMOSD

OYoshiki Takai ${ }^{1}$, Tatsuro Misu ${ }^{1}$, Chihiro Namatame ${ }^{1}$,

Yuki Matsumoto ${ }^{1}$, Shuhei Nishiyama ${ }^{1}$, Kimihiko Kaneko $^{1,2}$,

Toshiyuki Takahashi ${ }^{1,3}$, Hiroshi Kuroda ${ }^{1}$, Kazuo Fujihara ${ }^{4}$,

Masashi Aoki ${ }^{1}$

${ }^{1}$ Department of Neurology, Tohoku University Graduate School of Medicine, Japan, ${ }^{2}$ Department of Neurology, National Hospital Organization Miyag National Hospital, ${ }^{3}$ Department of Neurology, National Hospital Organization Yonezawa National Hospital, ${ }^{4}$ Department of Multiple Sclerosis Therapeutics,
Fukushima Medical University

Objective: To experimentally elucidate the effects of endogenous neural stem/progenitor cells (NSPCs) on the regeneration of astrocytes in the context of astrocytopathic lesions of aquaporin 4 (AQP4) antibody-positive neuromyelitis optica spectrum disorder (NMOSD). Methods: We created a model of NMOSD by directly injecting anti-mouse AQP4 monoclonal antibody and complement into the mouse brain. Then we immunohistochemically evaluated the temporal changes of astrocytes destruction and regeneration (1, 2, 4, 7 and 14 days after injection) and the appearance and distribution of NSPCs. Results: Following injection of AQP4 antibody and complement, astrocytes were destroyed and AQP4 was lost at the injection sites. However, the area of AQP4 loss subsequently decreased over time due to regenerated astrocytes, which was prominent between day 4 and 7 (Area of AQP4 loss: $1.28 \pm 0.46 \mathrm{~mm}^{2}$ in day 1.4 vs $0.28 \pm 0.19 \mathrm{~mm}$ in day $7-14, \mathrm{P}<0.01$ ). Although a small number of cells expressing Nestin, a NSPC marker, had already appeared in the area of AQP4 loss from day 1, the density of Nestin+cells increased significantly between day 4 and $7\left(8.5 \pm 3.6\right.$ cells $/ \mathrm{mm}^{2}$ in day $1-4$ vs $33.4 \pm 10.1$ cells $/ \mathrm{mm}^{2}$ in day $7-14, \mathrm{P}<0.01$ ). NSPCs appeared at the sites where astrocytes initially disappeared, but Nestin was no longer positive in regenerated mature astrocytes expressing glial fibrillary acidic protein Conclusion: Our experimental study suggests that endogenous NSPCs plays an important role in astrocyte regeneration in AQP4 antibody-positive NMOSD and may have therapeutic implications.

\section{0-27-4 The first patient with pathologically-definite} ATXN8OS-associated amyotrophic lateral sclerosis

Makito Hirano ${ }^{1}$, Shigeo Murayama ${ }^{2}$, Yuishin Izumi ${ }^{3}$,

Makoto Samukawa ${ }^{1}$, Tomoyasu Matsubara ${ }^{2}$, Kazumasa Saigoh ${ }^{1}$, Yusaku Nakamura ${ }^{4}$, Susumu Kusunoki

${ }^{1}$ Department of Neurology, Kindai University Faculty of Medicine, Japan, ${ }^{2}$ Department of Neurology and Neuropathology, Tokyo Metropolitan Geriatric Hospital and Institute of Gerontology, ${ }^{3}$ Department of Neurology, Tokushima University, ${ }^{4}$ Department of Neurology, Sakai City Medical Center

[Objectivel Sporadic amyotrophic lateral sclerosis (ALS) in Western countries is frequently (4-21\%) associated with non-coding repeat expansions in the C9ORF72 gene. However, such an association is rare in Japan $(<0.5 \%)$. We have very recently found that non-coding CTA/CTG repeats in the ATXN8OS gene causative for spinocerebellar ataxia type 8 (SCA8) are expanded in Japanese patients with sporadic ALS (about 3\%). This study was aimed to clarify clinical and pathological findinos of this type of ALS. [Methods] We analyzed the ATXN8OS gene in brain bank specimens of 49 patients with pathologically definite ALS. The mutation-positive patient was examined for most genes causative for ALS and clinically compared with four other patients with ATXN8OS mutations (86223 repeats; normal <51) of whom features were bulbar-onset or neck weakness. [Results] We found that one patient had 81 repeats, without other gene mutations. The mutation-positive patient was clinically characterized by bulbar-onset and relatively slow progression. Pathological findings included neuronal or glial cytoplasmic inclusions with phosphorylated TDP43 immunoreactivities in motor cortex and spinal/brainstem nuclei. [Conclusion] We identified the first patient who had pathologically definite ALS with ATXN8OS mutation. We speculate that the ATXN8OS mutation is associated with bulbar symptoms.

\section{0-27-6 A PET study of primary age-related tauopathy} in healthy volunteers

OHitoshi Shinotoh ${ }^{1,2}$, Hitoshi Shimada ${ }^{1}$, Kenji Tagai ${ }^{1}$, Manabu Kubota ${ }^{1}$, Keisuke Takahata ${ }^{1}$, Yasunori Sano ${ }^{1}$, Naoyoshi Yamamoto, Kiwamu Matsuoka , Yuhei Takado, Yoshikazu Nakano ${ }^{1,3}$

Shigeki Hirano ${ }^{1,3}$, Ming-rong Zhang ${ }^{1}$, Tetsuya Suhara ${ }^{1}$, Makoto Higuchi ${ }^{1}$ National Institute of Radiological Sciences, National Institutes for Quantum and Radiological Sciences and Technologies, Japan, ${ }^{2}$ Neurology Clinic Chiba, Japan, ${ }^{3}$ Department of Neurology, Chiba University Graduate School of Medicine

Objective: A term "primary age-related tauopathy" (PART) was recently introduced to describe a pathology that is commonly observed in the brain of aged individuals. Symptom in persons with PART usually range from normal to amnestic cognitive changes. The aim of the study is to explore the tau aggregates accumulation in the brain of healthy volunteers in tau PET studies with $\left[{ }^{18} \mathrm{~F}\right] \mathrm{PM}$-PBB3 in our institute. Methods: Fifty-two healthy individuals ( 30 men and 22 women ranging in age from 23 to 79 years with a mean of 60) without any history of psychiatric and neurological diseases participated in this study. All subjects underwent neurological examination, cognitive tests, brain MRI, $\left[{ }^{11} \mathrm{ClPiB}\right.$ PET (A $\beta$ imaging), and $\left[^{18} \mathrm{~F} \mid \mathrm{PM}-\mathrm{PBB} 3 \mathrm{PET}\right.$. $\left[{ }^{11} \mathrm{ClPiB}\right.$ PET images $(50-70 \mathrm{~min})$ was visually assessed. An automated analysis of the volumes of interest in $\left.{ }^{18} \mathrm{~F}\right] \mathrm{PM}-\mathrm{PBB} 3$ images $(90$ $110 \mathrm{~min}$ ) was performed using the PNEURO module in the PMOD software. Standardized uptake value ratio (SUVR) values were obtained using the cerebellar cortex as a reference region. Results: Neurological examination revealed no significant finding except for hand tremor in one subject. Cognitive tests were normal in all subjects. Two men were positive for ${ }^{11} \mathrm{ClPiB}$ PET and excluded from the following analysis. There was a positive correlation between age and $\left.{ }^{18}{ }^{18} \mathrm{~F}\right] \mathrm{PM}-\mathrm{PBB} 3 \mathrm{SUVR}$ in the fusiform gyrus and middle and inferio temporal cortex of 52 subjects $(\mathrm{r}=0.33, \mathrm{P}<0.02$ and $\mathrm{r}=0.32, \mathrm{P}<0.02$ without correction for multiple comparisons). Conclusion: The present result supports the concept of PART.
0-27-3 Possible role of T-bet and aryl hydrocarbon receptor on lymphocytes in neuromyelitis optica lesions

Fumihiro Yanagimura ${ }^{1,5}$, Etsuji Saji ${ }^{1}$, Takahiro Wakasugi ${ }^{1}$, Yasuko Toyoshima ${ }^{2}$, Akiyoshi Kakita ${ }^{2}$, Hitoshi Takahashi ${ }^{2}$ Masatoyo Nishizawa ${ }^{4}$, Osamu Onodera ${ }^{1}$, Izumi Kawachi,

${ }^{1}$ Department of Neurology, Brain Research Institute, Niigata University, Niigata, Japan, ${ }^{2}$ Department of Pathology, Brain Research Institute, Niigata University, Niigata, Japan, ${ }^{3}$ Comprehensive Medical Education Center,
Niigata University School of Medicine, Niigata, Japan, ${ }^{4}$ Niigata University of Health and Welfare, Niigata, Japan, ${ }^{5}$ Department of Neurology, NHO Niigata Health and Welfare, Niigata, J

Background: Neuromyelitis optica (NMO) is an autoimmune disease of the central nervous system (CNS) and the autoantigen is aquaporin-4 (AQP4). In NMO, AQP4-specific interleukin (IL)-17-producing helper $\mathrm{T}\left(\mathrm{T}_{\mathrm{H}} 17\right)$ cell in the peripheral blood and the elevation of IL-17-related cytokines on relapses have been reported. However, the dynamics of $T_{H} 17$ and $T_{H} 1$ cells in the CNS lesions is not clarified. Objective: To elucidate inflammatory axis in NMO lesions by analysis of melanoma cell adhesion molecule (MCAM) and aryl hydrocarbon receptor (AHR) which are highly expressed on $\mathrm{T}_{\mathrm{H}} 17$ cell, and T-bet highly expressed on IFN $\gamma$-producing helper $\left(\mathrm{T}_{\mathrm{H}} \mathrm{1}\right)$ cell. Methods: We investigated the autopsy specimens of 7 cases with NMO and 5 cases with control diseases by immunohistochemical studies. The lesions were classified into initial lesions (IL), early active lesions (EA), late active lesions (LA) and inactive lesions (IA). Results: Neutrophils, eosinophils, macrophages, $\mathrm{CD}^{+} \mathrm{T}$ cells, $\mathrm{MCAM}^{+}$cells, $\mathrm{AHR}^{+}$cells and T-bet ${ }^{+}$cells infiltrated into IL/EA of NMO The frequency of $\mathrm{MCAM}^{+} \mathrm{T}$ cells (IL/EA 7.7\%, LA 1.6\%, IA 0.2\%) and $\mathrm{AHR}^{+} \mathrm{T}$ cells (IL/EA 50\%, LA $38 \%$, IA 28\%) were significantly high in IL/EA. The frequency of T-bet ${ }^{+} \mathrm{T}$ cells (IL/EA $46 \%$, LA $80 \%$, IA 90\%) were significantly high in LA and IA. Conclusions: $\mathrm{T}_{\mathrm{H}} 17$-skewed inflammatory axis may contribute to the early immune responses (e.g. IL/EA) in NMO lesions, while $\mathrm{T}_{\mathrm{H}}$ 1-skewed inflammatory axis may be involved in the late or inactive immune responses (e.g. LA/IA). Each lineage of lymphocytes may be involved in each distinct phase of immune responses of NMO.

\section{0-27-5 Phosphorylation of SRRM2 leads to synaptic} pathology at ultra-early phase of Alzheimer's disease

Hikari Tanaka ${ }^{1}$, Kanoh Kondo ${ }^{1}$, Xigui Chen ${ }^{1}$, Hidenori Homma ${ }^{1}$ Kazuhiko Tagawa ${ }^{1}$, Takaomi Saido ${ }^{2}$, Shin-ichi Muramatsu ${ }^{3}$ Kyota Fujita ${ }^{1}$, Hitoshi Okazawa

Department of Neuropathology, Medical Research Institute, Tokyo Medical and Dental University, Japan, ${ }^{2}$ aboratory for Proteolytic Neuroscience, Center for Brain Science, RIKEN, ${ }^{3}$ Department of Neurology, Jichi Medical University

[Objective]Early-phase pathologies of $\mathrm{AD}$ are attracting much attention after clinical trials of drugs designed to remove beta-amyloid $(A \beta)$ agoregates failed to recover memory and cognitive function in symptomatic AD patients. The purpose of this study was to clarify the phosphorylation signal change that occurs in ultra-early phase of Alzheimer's disease.[MethodslIn previous paper, we found that the phosphorylation status of serine/arginine repetitive matrix 2 (SRRM2) changes before formation of extracellular A $\beta$ agregates.We performed behavioral, morphological and biochemical analysis to elucidate downstream of the phosphorylation.[Results]We showed that phosphorylation of SRRM2 at Ser1068 by Erk1 / 2, which is observed in the brains of early phase AD mouse models, prevents its nuclear translocation by inhibiting interaction with T-complex protein subunit $\alpha$. SRRM2 deficiency in neurons destabilize polyglutamine binding protein $1(\mathrm{PQBP} 1)$, a causative gene for intellectual disability (ID), greatly affecting the splicing patterns of synapse-related genes, as demonstrated in newly generated PQBP1-cKO model. In addition, abnormal splicing of several genes was confirmed in early phase AD mouse models. PQBP1 and SRRM2 were downregulated in cortical neurons of $\mathrm{AD}$, and the AAV-PQBP1 recovered the synapse phenotype and the cognitive decline in $\mathrm{AD}$ mouse models.[Conclusions]These results collectively revea a new aspect of AD pathology in which a phosphorylation of SRRM2 affecting RNA splicing and synapse integrity precedes the formation of extracellular $\mathrm{A} \beta$ aggregates.

\section{0-27-7 Ultrastructure of macrophage-induced demyelination in Guillain-Barré syndrome}

Haruki Koike ${ }^{1}$, Yuki Fukami ${ }^{1}$, Ryoji Nishi ${ }^{1}$, Masahiro Iijima ${ }^{1}$,

Masahisa Katsuno ${ }^{1}$, Gen Sobue

${ }^{1}$ Department of Neurology, Nagoya University Graduate School of Medicine, Japan, ${ }^{2}$ Nagoya University Graduate School of Medicine

【目的】ギラン・バレー症候群 (GBS) においては抗ガングリオシド抗体との関連で 軸索型(AMAN)の病態に関する研究が進んでいる。これに対して、脱葡型 (AIDP) の抗ガングリオシド抗体陽性率はAMANと比べて低く、その病態は十分明らかに なっていない。今回、マクロファージによる脱䯣病変の超微形態を定量的に検討 した。【方法】腓腹神経生検でマクロファージが䯣鞘を領食することによって生じ

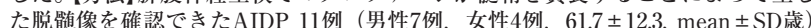
の縦断切片を電子顕微鏡にて定量的に検討した。マクロファージによる㕼䩗病変 とランビエ絞輪部および傍絞輪部との関係を明らかにするため、合計 1205 個のラ ンビエ絞輪を同定した。【結果】剈道鞘を囲む基底膜内に侵入したマクロファージを 252筒所で認めた。このうち40筒所では䯣鞘の構造が完全に消失しており、有䯣線 維における位置の同定が困難であったが、他の212筒所のうち183筒所は絞輪間部 で鹃鞘を領食中であり、1例では特に多数の病変を認めた (152箇所)。絞輪間部の 病変ではシュミット・ランターマン切痕からの䯣鞘破壊像が多くみられた。残り 29筒所ではランビエ絞輪部ないし傍絞輪部を示唆する構造を認めた。3例では傍 絞輪部の終末ループと軸索膜の間にマクロファージの突起が侵入して、傍絞輪部

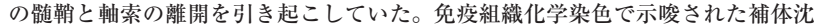
着部位はランビエ絞輪部、傍絞輪部、絞輪間部の 3 パターンがあり、症例ごとの マクロファージによる病変の偏在と概ね一致していた【結論】蹃鞘の破壊はシュ ミット・ランターマン切痕と傍絞輪部の終末ループ・軸索膜間から始まっており、 マクロファージは髄鞘の特定の成分を認識して領食を開始している可能性が示唆 された。 
0-27-8 Clinicopathological features of EGPA from the view point of IL-5 and ANCA

Ryoji Nishi ${ }^{1}$, Yuki Fukami ${ }^{1}$, Ken Ohyama ${ }^{1}$, Masahiro Iijima ${ }^{1}$, Haruki Koike ${ }^{1}$, Gen Sobue ${ }^{2}$, Masahisa Katsuno ${ }^{1}$

${ }^{1}$ Department of Neurology, Nagoya University Graduate School of Medicine, Japan, ${ }^{2}$ Research Division of Dementia and Neurodegenerative Disease,

Nagoya University Graduate School of Medicine

【目的】好酸球性多発血管炎性肉芽腫症 (EGPA ; eosinophilic granulomatosis with polyangiitis）はANCA関連血管炎に分類されているが、近年EGPAにおける抗 IL-5抗体製剂の有効性が示されている。今回、EGPAにおけるIL-5とANCAの意 義を病理学的観点から検討した。【方法】腓腹神経生検を施行し血清IL-5及びMPO ANCA (myeloperoxidase-antineutrophil cytoplasmic antibody)を測定したEGPA 45例（男性25例、女性20例。年齢63.2 \pm 14.7 (mean $\pm \mathrm{SD}$ ) 歳）の臨床病理所見 を検討した【結果】IL-5陽性26例 (58\%)、陰性19例（42\%）、MPO-ANCA陽性14例 (31\%)、陰性31例 $(69 \%)$ であった。IL-5陰性例では陽性例と比較し、MPO-ANCA 陽性の割合が高い傾向を認めた (27\% vs. 37\%)。IL-5陽性例ではIL-5陰性例と比較 して、神経上膜へ浸潤した好酸球 $\left(56.0 \pm 125.1\right.$ vs. $2.0 \pm 2.8$, 個 $\left./ \mathrm{mm}^{2}, \mathrm{p}<0.01\right)$ 、 血管内腔の好酸球 $(0.74 \pm 0.90$ vs. $0.11 \pm 0.19$, 個/総血管数, $\mathrm{p}<0.001)$ 、血管内 皮に接着した好酸球 $(\mathrm{p}<0.01)$ 、血管内腔の好酸球による閉塞 $(\mathrm{p}<0.05)$ を多く認 めた。MPO-ANCA陽性例ではMPO-ANCA陰性例と比較し、血管のフィブリノイ ド壊死 $(\mathrm{p}<0.01)$ 、その他の血管炎を示唆する構造破壊の所見 $(\mathrm{p}<0.05)$ を多く認 めた。【結論】EGPAにおいて血管炎所見はANCAで規定され、好酸球の血管内胿 貯留と神経上膜への浸潤はIL-5で規定されていた。

\section{0-27-10 Clinical features in pathologically confirmed CBD and PSP presenting CBS}

Ikuko Aiba ${ }^{1}$, Mari Yoshida ${ }^{2}$, Takayoshi Shimohata ${ }^{3}$, Yuichi Hayashi ${ }^{3}$ Terunori Sano ${ }^{4}, Y_{\text {uko Saito }}{ }^{\text {, Shigeo Murayama }}{ }^{5}$, Kazuko Hasegawa ${ }^{6}$, Yasushi Iwasaki ${ }^{2}$, Motoko Sakai ${ }^{7}$, Koichi Wakabayashi ${ }^{8}$,

Takashi Komori, Kenji Nakashima ${ }^{10}$

${ }^{1}$ Department of Neurology, National Hospital Organization Higashinagoya National Hospital, Japan, ${ }^{2}$ Institute for Medical Science of Aging, Aichi Medical University, ${ }^{3}$ Department of Neurology, Gifu University

Graduate School of Medicine, "Department of Pathology and Laboratory Medicine, National Center Hospital Graduate School of Nedicine, ${ }^{5}$ epartment Reurology and Psychat . Department on Research), Tokyo Metropolitan Geriatric Hospital and Institute of Gerontology, 'Department of Neurology, National Hospital Organization Sagamilhara National Hospital, Department of Neurology, National Hosp Organization Suzuka National Sospita, Depalo Hospital, ${ }^{10}$ Department of Neurology, National Hospital Organization Matsue Medical Center

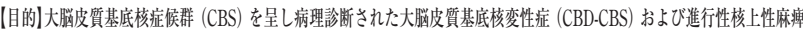

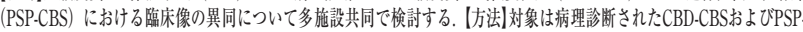

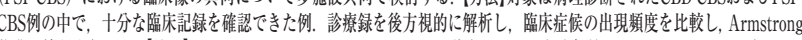

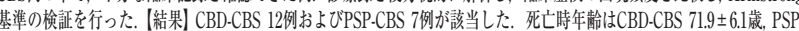

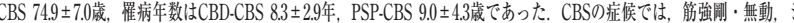

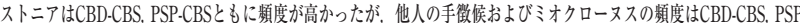
CBSをも低頻度であった．失行，皮質性感覚障害はPSP-CBSの方が頻度が高い順向であった．CBS以外の症候では遂 行機能障害, 全般性認知機能障害, 姿勢保持障害・転倒はCBD-CBS, PSP-CBSともに頻度が高かった。一方尿失禁は CBD-CBSの方が, 垂直性注視麻痺・衝動性眼球運動の速度低下はPSP-CBSの方が高頻度の愐向であった。最終的に Armstrong基潐のprobable sporadic CBDに該当したのはCBD-CBS 50\%,PSP.CBS25\%, possible CBDに該当したのは

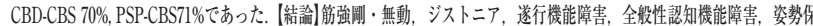

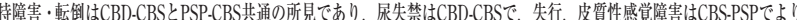

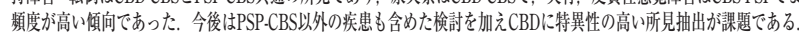

\section{O-28-2 慢性炎症性脱䯣性多発神経炎診断における神経超音波 の有用性}

\footnotetext{
○関口 縁、三澤 園子 ${ }^{2}$ 、狩野 裕樹 ${ }^{2}$ 、中村 圭吾 ${ }^{2}$ 常山 篤子 ${ }^{2}$

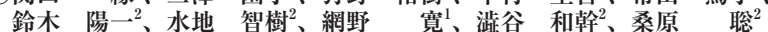
${ }^{1} \mathrm{~J} R$ 東京総合病院 脳神経内科、采葉大学大学院医学研究院
}

【目的】慢性炎症性脱㕼性多発神経炎(CIDP)では、超音波検查で神経腫大が報告さ れている。CIDPの病型診断に超音波検査が有用かを検証する。【方法】当科を2012 年から 2018 年12月までに受診し、神経伝導検査 (NCS) と神経超音波検査を行っ た42名を対象とした。超音波検査は伝導検查と同側の正中神経で手首・前腕・肘 部・上腕部の断面皘を超音波診断装置（使用機器：Logiq E9 GE Healthcare、プ ローブ：6-12MHリニア型）を用いて計測した。【結果】臨床病型はTypical群32例、 MADSAM群10例で、罹病期間はMADSAM群で有意に長かった（中央值；0.3 VS 11年)。MADSAM群のUS断面積 $\left(\mathrm{mm}^{2}\right)$ は、Typical群に較べて、正中神経前腕 および上腕部に有意に腫大していた（平均值；前腕部9.4 VS 16.9、上腕部13.4 VS 43.8）が、手首执よび肘部では両群に差は認めかった。尺骨神経でも、MADSAM 群で前腕㧍よび肘部の腫大が強い傾向がみられ、上腕部では有意に腫大していた (平均值；10.3 VS 24.5)。またMADSAM群の上腕/手首部断面積の比は、Typical 群に較べて有意に大きかった (平均值；1.3 VS 5.8)。MADSAM群で神経腫大を認 めた 13 神経全例で、NCS上伝導速度遲延を認めたが、伝導ブロックの定義を満た したのは5神経のみであった。[SM1]【結論】MADSAM型CIDPの神経超音波所見 は、Typical群と較べて前腕部から上腕部にかけての肥厚[SM2] が目立ち、かつ手 首部との差が際立っていた。両病型での神経腫大の分布の相違は、病態の差異に 由来する可能性がある。上腕部までの神経超音波は、近位部の脱髄病変検出に有 用であり、MADSAMの診断の一助になる可能性がある。
0-27-9 Brain pathological study in tumefactive MOG antibody-associated disease: the role of $B$ cells

Ryotaro Ikeguchi ${ }^{1}$, Natsuki Kanda ${ }^{1}$, Masaki Kobayashi ${ }^{1}$,

Kenta Masui ${ }^{2}$, Toshiyuki Takahashi ${ }^{3}$, Takakazu Kawamata ${ }^{4}$,

Noriyuki Shibata ${ }^{2}$, Tatsuro Misu ${ }^{3}$, Yuko Shimizu ${ }^{1}$, Kazuo Kitagawa

${ }^{1}$ Department of Neurology, Tokyo Women's Medical University, Japan,

Department of Pathology, Tokyo Women's Medical University, ${ }^{3}$ Department

of Neurology, Tohoku University School of Medicine, ${ }^{4}$ Department of

Neurosurgery, Tokyo Women's Medical University

【目的】抗MOG抗体は視神経脊噵炎、急性散在性脳春䯣炎、視神経炎などで陽性となる自己 抗体である。腫瘍梯脑病変の一部でも陽性となることがあるが、脎病理を検討した研究は少 なく、病態についても明らかではない。本研究は腫瘍様脳病変を呈し抗MOG抗体が陽性で あった3例において脳病理学的検討を行い、抗MOG抗体関連疾患の病態を明らかにすること を目的とする。(方法12015年1月から2019年10月の間に、当院に入院もしくは外来通院し腫瘍 様脳病変を呈した患者のうち、抗MOG抗体陽性かつ脳生検を行った患者について臨床的・病 理学的特徵について検討した。CD3、CD4、CD8、CD20、CD68、CD79a、CD138、C9neo、 GFAP、SM131などの染色を行った。結果】2015年1月から2019年10月の間に、腫場様腷病変 を呈した患者は24例であり、そのうち6例 $(25 \%)$ で抗MOG抗体が陽性だった。うち3例で脑 生検を施行した。3例の発症年齢中央值は18歳（15２2歳）、男性が2例であった。いずれも春

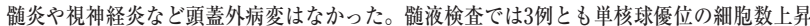
があり、中央值は 45.9 個 $/ \mu \mathrm{L}(18.7 \sim 77.7$ 個 $/ \mu \mathrm{L})$ だった。MBPは1例で上昇、OCBは1例で陽 性だった。頭部MRIでは3例とも基底核から側頭葉にかけて、長径 $4 \mathrm{~cm}$ 以上の不均一なGd増 強効果を伴う病変が認められた。いずれもステロイド治療を行い治療反応性は良好であった が、再発は2例でみられた (それぞれ1回)。脳病理では、2例で血管周囲にB細胞優位のリン パ球集簇、1例でT細胞を主体とする血管周囲の小型リンパ球集簇を認めた。1例で境界明暸 な脱䯙が認められた。結論]抗MOG抗体陽性脳病変には、自験例のようにB細胞主体の集簇 を認める一群があり、液性免疫が病態に強く関与していることが示唆された。また腫愓様脎 病変を呈する患者、特に若年者においては、抗MOG抗体関連疾患を鑑別に挙げる必要がある。

\section{O-28-1 一次運動野へのQuadripulse stimulation (QPS) に よる可塑性誘導}

冨樫 尚彦、代田悠一郎 ${ }^{2}$ 、濱田 雅 ${ }^{2} 、$ 長谷川一子 ${ }^{1}$

国立病院機構相模原病院 神経内科、帛東京大学医学部附属病院 脳神経内科

【目的】一次運動野 (M1)へのQuadripulse stimulation (QPS)により、運動野の皮質 興奮性を短期的に変化させることができ、シナプス可塑性に基づいた変化である ことが推測されている。今回、M1-QPSが運動学習に与える影響を検討した。また、 刺激時間を変更可能であるcontrollable pulse parameter TMS (cTMS) 用いて 同様の運動学習を検討した。【方法】対象は健常者 14 人。左M1にQPSを 30 分間施行 した。刺激間隔は長期増強 (LTP) 効果をもつ5 ms (QPS 5)、長期抑制 (LTD) 効 果をもつ50 ms (QPS 50)、可塑性を誘導しない $1250 \mathrm{~ms}$ (QPS 1250) の3条件とし た。cTMSでは対象は13人。QPS1250と刺激間隔の長い刺激（Positive phase 100 $\mu \mathrm{s} 、$ Negative phase $170 \mu \mathrm{s}$ )、短い刺激 (Positive phase $30 \mu \mathrm{s} 、$ Negative phase 81 us）のそれぞれでQPS5、QPS50を行う5条件としたQPSの後に反復母指外転 運動学習を行い、10回ごとの最大加速度の平均值の変化を評価した。【結果】QPS 1250 と比較し、QPS 5では変化はなかったが、QPS 50 では加速度の増加が優位に 増強されていた。cTMSではいずれの条件でも優位な変化は認めなかった。結論】 QPSを用いた運動野へのLTD誘導は運動学習を促進する可能性が示唆された。

\section{0-28-3 痙性斜頸に合併する頭頸部不随意運動の頻度とボツリ ヌス治療効果}

\section{大澤美貴雄 ${ }^{1}$ 、飯嶋 睦 ${ }^{2}$}

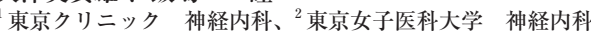

【目的】丞性斜頸に合併する頭頸部不随意運動（AIM）として、緩徐反復性運動 (SRI)、振戦やミオクローヌスが知られているが、詳細は明らかではない。本研 究では、これらの合併頻度、頭頸部筋の針筋電図検査 $(\mathrm{nEMG})$ 所見やボツリヌス 毒素 (BTX) 治療に対する治療効果について報告する。【対象】痤性斜頚251名 (年齢 25 92歳、男109名、女142名)。【方法】AIMは、臨床症状とnEMG所見により診断 した。246名でA型またはB型BTX治療を、頭頸部筋のnEMG所見を参考にして約 3力月毎に施行した。BTXを効果と副作用をみながら漸増し、その効果は自覚症 状とTsui評価スケール (変法) を指標として評価した。【結果】AIMの合併は107名

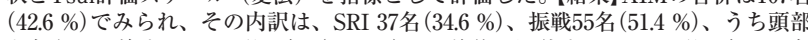
を左右に回旋するno-no型 42 名 $(76.4 \%)$ 、同前後に屈伸するyes-yes型10名、同左 右に屈伸する metronome型3例、ミオクローヌス7名、振戦とSRIの合併 2 名、振戦 とミオクローヌスの合併 3 名、ミオクローヌスとSRI 3名であった。nEMG上、振 戦は、no-no型で左、右回旋筋に、yes-yes型で前、後頸部筋で、metronome型で は左、右側屈筋で群化放電が、それぞれ律動性に出現した。ミオクローヌスは、 持続の短い（200msec以内）電位陽性、すなわち陽性ミオクローヌスのみならず、 持続放電の短い $(100 \mathrm{msec}$ 以下) 中断、すなわち陰性ミオクローヌスが単独または 高振幅電位に引き続き認められた。最大効果に達しえたBTX治療でのやや改善以 上の症例は、SRI 17名 $(63.0 \%) 、$ 振戦 24 名 $(47.1 \%)$ 、うちno-no型14名 $(42.4 \%)$ 、 yes-yes型8名 $(80.0 \%)$ metronome型2名であった。治療によりAIM型の変化が7名 でみられた。【結論】痤性斜頸に合併するAIMの合併はno-no型振戦が最も多かった が、BTX治療効果は、yes-yes型振戦が最もよかった。痤性斜頸のBTX治療効果 向上のため、異常頭位のみならず、合併するAIMも詳細に検討すべきである。 


\section{O-28-4 脛骨神経SEP N17 電位で局在診断し得た蓨髄上部円 錐部病変の 3 例}

此枝 史恵 ${ }^{1,2}$ 、高橋 和沙 2 、大石知瑞子 ${ }^{2,3}$ 、上田 優樹 ${ }^{2,4}$ 、

松倉 清司 ${ }^{2} 、$ 溝井 令一 2 , 酒井 健雄、園生 雅弘

ささんたま市立病院 神経内科、2 帝京大学 脳神経内科、

${ }^{3}$ 杏林大学 㸺神経内科、 ${ }^{4}$ 東京医科大学入王子医療センター 脳神経内科、

埼玉医科大学 脳神経内科・脳卒中センター、 ${ }^{6}$ 千里リハビリテーション病院 リハビリテーション科

目的IN17電位は下肢SEPに执いて馬尾を上行する小さな近接電場電位（NFP）である。 今回下肢SEPでN17を記録することにより局在診断し得た金跹上部円錐部病変の 3 例 を経験したので報告する。【方法】2017年から2019年までの当院筋電図データベースか ら、下肢SEP測定時にL5S-L4S、L4S-L3S、L3S-L2S誘道を加えることでN17が同定で き春鲐円錐部病変と診断された症例を後方視的に抽出した。結果] 3 例が抽出された 66 歳男性、56歳女性、50葴男性)。主訴は運動感覚障害で、運動障害では 3 例とも下垂足 による步行障害、感営障害では下肢しびれ感 2 例、感覚鈍麻 1 例であった。筇力低下 は両側性にL5>S1に分布していたが若干の左右差があり、また、同欲笽内でも障害に はばらつきを認めた。感覚障害はしびれ感や感覚鈍麻がL5ないしはS1以下でみられた がこれも多くは左右差を認めた。錐体路微候を 1 例、膀胱直腸障害を 2 例で認めた。神 経伝導検查では1例で脛骨神経複合筋活動電位振幅低下、腓腹神経は 1 例で軽度の振幅 低下を認めた他は正常であった。腰椎MRIは全例で施行されていたが、塞栓術後の発 症で脊面血管障害が疑われた1例では画像変化なし。残りの2例では上部円錐部に圧通 があったが、見逃されるか、あるいは整形外科医も局在診断に迷っていた。脛骨神経 SEPでは全例でP15電位までは正常であったが、N21電位が消失、または低振幅、ないし、 P15-N21潜時の延長を認めたことから、馬尾一腰似欲病変部と局在され、さらに全例 で尾例から頭側に潜時が伸びなから上行するN17電位が同定出来たことから、馬尾て はなく上部脊面円錐部の障害であると結論できた。結論】画像で病変が特定できない 例に执いて下肢SEPにおける馬尾由来のN17電位の記録は局在診断に有用である。

\section{0-28-6 パーキンソン病における認知障害の基盤としての睡眠 障害に関する検討}

○宮下 真信、公文 彩 ${ }^{1}$ 、佐川美土里 ${ }^{1}$ 、川上 正裕 $^{2}$ 、長谷川一子 ${ }^{1}$ '独立行政法人 国立病院機構 相模原病院 神経内科、

独立行政法人 国立病院機構 相模原病院 臨床検查科

【目的】パーキンソン病 (PD) では経過に伴って認知機能低下を認める頻度が高く なるが，認知障害発症の基盤となる病態に対する検討は少ない，PDに於ける睡眠 障害としては急速眼球運動期 (REM) 睡眠行動異常REM sleep behavior disorder: RBDが知られているが，睡眠構築の異常や睡眠時無呼吸と認知機能とに関する 検討は少ない. 今回, 我々は認知機能と睡眠構築との関連について検討を加え, 認知障害の発症基监に睡眠障害があるかを検討したので報告する。【方法】対 象は当院通院中のPD患者40名（男性18名，女性22名）とし，PDの診断は臨床像， L-dopaへの良好な反応性，FP-CIT検查でのイオフルパンの取り込及低下，MIBG 検查での榜種取り込み低下を認めたことによった, PD症例の平均羅病期間は 9

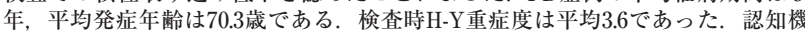
能はMMSE, FAB, RBMTを行い, 可能な症例についてはWAIS-IVを行った。睡 眠障害については終夜䏚波検查を polymateにより施行した。なお，本検討では終 夜脑波検查と認知機能検查をほほ同時期に施行した症例のみを解析対象とした。 【結果】睡眠脑波の結果は, stagel-2の浅睡眠の夕：21人, 浅睡眠と睡眠の断片化 2人, 深睡眠+：3 人, REM+：21人，うちRWA+:4人，REM-19人だった。認知 機能との関連では浅睡眠のみ，あるいは睡眠の断片化を示した症例では認知機能 低下がみられた(平均23.6)。 REM睡眼が碓認できない症例ではREM睡眠を認める 症例に比較して認知機能の低下を認めた。一方，RBD症例では認知機能低下が認 められなかった (平均27)。【結論】 PD患者の認知機能を終夜脳波結果で解析する と，深睡眠とREM睡眠は認知機能維持に必要であることが推定できた。睡眠の質 の改善, 維持することがPDの認知機能の維持に有用である可能性を示すことがで きた。

\section{0-28-8 神経筋疾患における電気診断と組織診断の一致度の検討 \\ ○薮内 健一 ${ }^{1}$ 、麻生 泰弘 ${ }^{1}$ 、石橋 正人 ${ }^{1}$ 、軸丸 美香 ${ }^{1}$ 、小村 成志 ${ }^{1}$ 西野 - 三”松原 悦朗 \\ 大分大学医学部神経内科学講座、 \\ 国立精神・神経医療研究センター神経研究所疾病研究第一部}

【目的】針筋電㘠による電気診断所見を，筋生検による組織骖断所見と対比させ ることで針筋電国换查の正確性と pit fall を検証する. 【方法】 当院神経内科にて 2017 年 4 月から 2019 年 9 月までに針筋電龱検查と筋生検の両者を施行した33例（男 性19名, 女性14名）について, 筋生検前の電気診断と, 生検による組織効断を対 比し，一致度を検証した。電気診断は日本臨床神経生理学会の専門医 1 名が行なっ た，組織診断は国立精神・神経医療研究センターに検体を送付し依頼した。両者 の所見が不一致であった症例についてはその原因について個別に検討を加えた。 【結果】針筋電図に上る電気診断と, 筋生検での診断が一致したものは33例中 30 例 (91\%) であった．筋生検による組織診断で筋原性であった症例は22例 $(67 \%)$, 神経 原性は 4 例 $(12 \%)$. 筋原性と神経原性の並存が1例 $(3 \%)$, 正常筋組織は 6 例 $(18 \%)$ であった，結果が一致しなかった 3 症例のうち 2 例は，いずれも筋電図で長潜時 MUPのみならず，有意な動員低下と干涉低下を浔めており，神経原性変化と䛦断 されたが、組織診断では1例がネマリンミオパチー。もう1例が筋原線維性ミオ パチー(疑い) であった. 不一致であった 3 例目は, 針筋電龱で下肢の能の強い 脱力にも関わらず動員が正常であったため筋原性変化と電気診断されたが, 組織 診断では神経原性変化のみであった。この症例は最終的にはHTLV-1関連脊噵症 (HAM) と診断された【結諭】不一致例では，筋電㘠の施行筋が少なかったこと が詋診につながった可能性がある。また生检部位の選択も電気診断との不一致の 原因となる。また，ネマリンミオパチーや筋原線維性ミオパチーは神経原性変化 が針筋電図上前景に立つことがあり, 電気診断の際には注意を要する。

\section{0-28-5 視床以外の病変で失立症を呈した 3 例}

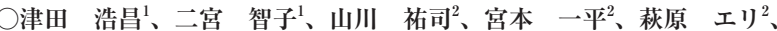
伊藝 孔明 $2^{2}$ 岡本 直樹 ${ }^{2}$

東京都保健医療公社豊島病院 神経内科

東京都保健医療公社豊島病院 呼吸器内科

【緒言】失立症とは、中枢性病変により、四肢・体幹の筋力低下や四肢の失調がない にも関わらず立位保持機能が障害される稀な症候である。Masdeuは失立症15例(脸 出血 7例、腷梗塞 6 例、神経膠芽腫 2例) の頭部CT所見に基づき、責任病巢を視 床後外㑡と述心、「視床性失立症」という概念を提唱した (Ann Neurol 1988;23:596603)。我々は、視床以外の病変により失立症を呈した3例を経験し、責任病巣、基 碳疾患について新知見が得られたので報告する。[症例提示] 症例 $1 ： 82$ 藏、男性。 肺腺癌に対し、化学療法が施行されていた。失立症が突然発症した。頭部MRIで左） 補足運動野に急性期梗塞が梌出された。抗凝固痘法が開始され、2日後には無症状 となった。症例 $2: 72$ 歳、男性。肺腺癌に対し、化学療法が施行されていた。失立 症が突然発症した。頭部MRIで、右）補足連動野に及ぶ浮腫を伴う大脎皮質の転移 性脳腫場が検出された。抗浮腫療法が開始され、翌日には無症状となった。症例 3 : 72 歳、女性。既往歴に高血圧症·糖尿病があり、某日起床時に失立症が発症していた。 副部MRIで右) 僋脳室近傍の大脳深部白啠に直径8 $\mathrm{mm}$ の急性期梗寒が梌出された。 抗血小板療法により、二日後には無症状となった。[考察]視床以外の病変により失 立症を呈した既報告として、後部帯状回梗塞 (Stroke 2006;37:e3、Case Rep Neurol 2014;6:14)、補足運動野梗塞 (BMJ Case Rep 2010;2010:bcr0120102618)、前部腮梁. 带状回梗塞 (J Clin Neurosci 2015;22:763) がある。症例1、2は補足運動野の病変に 起因する失立症であった。症例2のように脳腫場による補足運動野の障害に起因す る失立症の既却告はなく、きわめて貴重な症例である。また、症例了では視床後外 側から後部带状回または補足運動野へ連絡する線維が障害され、失立症が起きた と推定された（J Gen Fam Med 2017:18:275)。[結語]失立症は、補足運動野または 大脳樑部白質の片側性病変でも起こりうる。

\section{0-28-7 取り下げ演題}

\section{O-28-9 健常者における安静時脳磁図ネットワーワの加齢性変化}

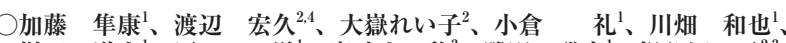
桝田 道人、原一洋、寶珠山稳、勝野 雅央、祖父江 元 $^{2,3}$ '名古屋大学神経内科、2名古屋大学脳とこころの研究センター、

名古屋大学大学院医学系研究科、 ${ }^{4}$ 藤田医科大学脳神経内科

【目的】加龄は神経変性疾患の最重要りスクである。また、近年、脳内神経回路か らみた神経変性疾患の病態理解が急速に進んでいる。神経回路は、主に安静時機 能的MRI (fMRI) を用いて行われてきたが、媨磁図 (MEG)は、 FMRIより直接的な 神経活動を評洒することが出来ると考えられている。今回、MEGを用いた脳内神 経回路の加齢性変化を多数例で検討した。【方法!健常者 157 例を対象として、安静 時MEGデー夕を收集した。安静時fMRIの独立成分分析により同定したデフォル トモードネットワークのハブにあたる楔前部と感覚運動ネットワークのハブにあ たる内側前頭皮質を関心領域とし、Amplitude Envelope Correlation (AEC) 法を 用いて、周波数带域每 $(\delta, \theta, \alpha, \beta$, low $\gamma$, high $\gamma)$ にそれぞれの関心領域と全 脳とのネットワークを作成、検討した。統計学的に有意な領域を算出し、この結 果をfMRI所見と比較するとともに、40歳台から70歳台まで各年代30名の平均相閶 図を作成し、加龄性変化を検討した【結果】いずれの関心領域でも $\beta$ 周波数帯域 の脑磁図ネットワークの形状が安静時fMRIネットワークの形状と類似していた。 加龄性変化の梌討では、有意な結合を認めた領域数は、 $a$ 周波数帯域と $\beta$ 周波数 帯域で異なる変動を呈していた。[結論】脑磁図を用いた譛前部と感覚運動ネット ワークの加龄性変化を検討した。 $0.1 \mathrm{~Hz}$ 程度と非常にゆっくりとしたfMRIの波か ら䆃き出されたネットワークと、MEGの15-30 Hzと早い $\beta$ 波数带域から導き出さ れたネットワークの形状で類似性を認めた。加齢によるネットワークの変化は、 周波数带域每に異なり、単純な線形変動ではない可能性が示唆された。 


\section{O-28-10 ALSの早期診断のための神経エコーの応用“腕神経 叢の観点から"}

○山㠃 博輝、高松 直子 ${ }^{1}$ 、沖 良祐 ${ }^{1}$ 、福島 功士 ${ }^{2} 、$ 吉田 剛 ${ }^{3}$ 、

大崎 裕亮、和泉 唯信

德島大学病院 神経内科、黑滝村診療所、 ${ }^{3}$ 近森病院 神経内科

【目的】筋菱縮性側索硬化症(ALS) は発症早期であるほど診断は難しい。神経エコー を用いた頚神経根の形態学的評佂、すなわち同部位の萎縮の検出がALSの診断の一 助になることは既に報告されている。一方で第5頳神経根 (C5) 〜第1胸神経根 (Th1) からなる腕神経丵もまた神経エコーで観察でき、腕神経丵の断面皘（plexus-CSA） 值も計測が可能である。ALS患者においては䭘神経根と同様にplexus-CSA値も減 少することが推察されるが、これに関する研究はない。さらに䅡神経根の萎縮にお いても発症早期のALS患者のみを対象とした研究もまだない。今回我々は発症早 期のALS患者を対象に行った神経エコーを用いた顏神経根の断面積とplexus-CSA 值につき報告する。【方法】2017年4月から2019年7月の間に当院当科において、発症 加 1 年以内に診断したALS患者18例のうち下肢発症者2例を除く 16 例（12例は上脑 筋力低下、4例は構音障害で発症)を対象とし後方視的に評価した。䅡神経根の断面 皘和は"C5-7の3本の神経根の断面皘の和"で求め、plexus-CSAは"銷骨窝から導出可 能なC5-Th1由来のすべての神経根の集合で形成されるarea"の值とし、それぞれ両 側で計測し健常者から得た施設内基準值と比較した。神経の描出には䅡動脈用の $12 \mathrm{MHz}$ のリニアプローブを使用し、ALSの診断にはUpdated Awaji基準を用いた。 【結果】施設内基準値との比較で、16例のALS患者のplexus-CSAの平均値は両側と もに有意に小さく、䅡神経根の断面皘和においては有意差は認めなかった。また 肢筋力低下発症のうち3例ではplexus-CSA值の左右差が大きく(20\%程度の差を認 めた)、患㑡とplexus-CSA低值側の一致を認めたが、残り 9例と構音障害で発症し た4例では左右差は小さかった。よって健㑡、患側問わずplexus-CSA值の減少は早 期から生じると推察された。[結諭]発症1年未満の早期ALSにおいても、神経エコー を用いたplexus-CSA值の計測が診断の一助になる可能性がある。

\section{0-29-2 Cytokine profiles in cerebrospinal fluid from} patients with neurosarcoidosis and CNS lymphoma

Hiroshi Kuroda ${ }^{1,2}$, Kimihiko Kaneko ${ }^{1}$, Takaaki Nakamura ${ }^{1}$

Yoshiki Takai ${ }^{1}$, Shuhei Nishiyama ${ }^{1}$, Tatsuro Misu ${ }^{1}$

Kazuo Fujihara ${ }^{1,3,4}$, Masashi Aoki

Department of Neurology, Tohoku University Graduate School of Medicine, Japan, ${ }^{2}$ Department of Neurology, South Miyagi Medical Center. Japan, ${ }^{3}$ Department of Multiple Sclerosis Therapeutics, Fukushima Medical University School of Medicine, ${ }^{4}$ Department of Multiple Sclerosis Therapeutics, Southern TOHOKU Research Institute for Neuroscience

[Objective] To clarify cytokine profiles in cerebrospinal fluid from patients with neurosarcoidosis and CNS lymphoma. Methodsl We performed CSF examinations in patients with neurosarcoidosis (NS) and CNS lymphoma (CNSL); measured cytokines in the CSF using a bead-based suspension array method. The measured cytokines included IL-1b, IL-1ra, IL-2, IL-4, IL-5 IL-6, IL-7, IL-8, IL-9, IL-10, IL-12p70, IL-13, IL-15, IL-17A, eotaxin, FGF basic, G-CSF, GM-CSF, IFN-g, IP-10, MCP-1, MIP-1a, PDGF-bb, MIP-1b, RANTES, TNF-a, VEGF. We compared CSF data with those in patients with non-inflammatory/nonneoplastic CNS diseases as control. [Results] Patient numbers were NS $(n=5)$, CNSL ( $n=$ $9)$, and control $(n=16)$. Median age and male percentage were NS [58 years, $40 \%$ ], CNSL [68, 67], and control [55, 56]. Median values of CSF data in 3 groups [NS, CNSL, control were cell count $\left[3,2,0\left(/ \mathrm{mm}^{3}\right)\right]$, protein $[85,97,40(\mathrm{mg} / \mathrm{dL})]$, glucose $[49,52,60(\mathrm{mg} / \mathrm{dL})]$ Of CSF cytokines in 3 groups [NS, CNSL, controll, following concentrations were highe in NS and CNSL than those in control: IL-8 [79, 59, $8.9(\mathrm{pg} / \mathrm{mL})](\mathrm{P}<0.0001)$, IP-10 [16.6, 2.8, $0.9(\mathrm{ng} / \mathrm{mL})$ ] $(\mathrm{P}<0.0001)$; following were higher in NS than control: IL-6 [8.1, 3.1, 0.0 $(\mathrm{pg} / \mathrm{mL})](\mathrm{P}<0.01)$ and IL-17A [1.5, $0,0(\mathrm{pg} / \mathrm{mL})](\mathrm{P}<0.05)$; following were higher in CNSL than control: IL-10 [1.2, 7.3, $0.0(\mathrm{pg} / \mathrm{mL})](\mathrm{P}<0.001)$; following were higher in CNSL than those in NS and control: MCP-1 [97, 257, $102(\mathrm{pg} / \mathrm{mL})](\mathrm{P}<0.05)$. [Conclusion] The combination of CSF cytokines may discriminate NS and CNSL from other CNS diseases.

\section{0-29-4 Common Features Are Shared by Clinically Heterogeneous} Patients with MOG Antibody-related Disorder

OToshi Sai ${ }^{1}$, Daiki Takewaki ${ }^{1}$, Chihiro Fujiii ${ }^{1}$, Shinji Ashida ${ }^{1}$,

Rei Yasuda', Yukiko Tsuji ${ }^{1}$, Jun Fujinami ${ }^{1}$, Atsushi Yamamoto ${ }^{2}$, Takuma Katou ${ }^{2}$, Keisuke Imai ${ }^{2}$, Toshiki Mizuno

${ }^{1}$ Department of Neurology Treatment, Kyoto prefecture university of medicine, Japan, ${ }^{2}$ Department of Neurology and Stroke Treatment, Acute Stroke Center of Kyoto First Red Cross Hospital

[Objective]To clarify the clinical characteristics of patients with anti-myelin oligodendrocyte glycoprotein antibodies (MOG-Ab)-related disorder. [Methods Consecutive ten patients in independent two facilities who were positive for anti-MOG-Ab were included. Comprehensive clinical, magnetic resonance imaging (MRI), and laboratory data were retrospectively analyzed. [Results]Ten patients (age: $32.7 \pm 16.6$ years, 5 women and 5 men) with anti-MOG-Ab-related disorder were included. The distribution of clinical phenotypes was as follows: three acute demyelinating encephalomyelitis, three relapsing optic neuritis, one isolated myelitis, one unilateral cerebral cortical encephalitis with epilepsy, one tumefactive demyelinating lesion, and one unclassified central nervous system (CNS) demyelinating disease. Cerebrospinal fluid oligoclonal bands (OB) were negative in all cases except one. Intravenous methylprednisolone (IVMP) alone not followed by plasmapheresis brought remarkable improvement in thei clinical and MRI abnormalities in all cases. [Conclusions/Patients with antiMOG-Ab-related disorder represented various clinical phenotypes, suggesting the need for anti-MOG-Ab measurement in a wide range of patients with CNS demyelinating diseases. The absence of OB highlights a distinction from multiple sclerosis, whereas the great recoveries after IVMP alone are rarely observed in neuromyelitis optica spectrum disorder. These two characteristics might be helpful for finding anti-MOG-Ab-related disorder.
0-29-1 Status epilepticus suspected autoimmune: antibody frequency and its main clinical features OHiroki Suga' ${ }^{1}$ Takahiro Iizuka ${ }^{1}$, Juntaro Kaneko', Atsuko Yanagida ${ }^{1}$,
Atsushi Kaneko ${ }^{1,2}$, Eiji Kitamura ${ }^{1}$, Naomi Kanazawa ${ }^{1}$,

Tsugio Akutsu ${ }^{1}$, Kazutoshi Nishiyama ${ }^{1}$

${ }^{1}$ Department of Neurology, Kitasato University School of Medicine, Japan,

2Department of Neurology, Kitasato University School of Medicine

[Objective] To characterize the frequency of neuronal surface antibodies (NS-Abs) and accompanying clinical features in patients who presented with status epilepticus (SE) suspected to be autoimmune. [Methods] We retrospectively reviewed the clinical information of 102 patients (median age, 27 years [5-93 years]; 67 [65.7\%] female) who presented with clinical features of SE suspected to be autoimmune. NS-Abs were examined in both serum and CSF (except 4 in either serum or CSF) obtained at symptom onset with previously reported rat brain immunohistochemistry and cell-based assays. We compared the clinical features of antibody-positive and negative patients. [Results] 34 patients $(33.3 \%)$ had NS-Abs, including 29 NMDAR ( 1 of them with concurrent GABAbR and AMPAR, and another case with MOG); 2 GABAaR : 1 GABAbR; 1 LGIl, and 1 against unknown antigens. Compared with NS Ab-negative patients, NS-Ab-positive patients were more likely to be female (29/34 vs $38 / 68$ ), had more frequent accompanying psycho-behavioral or memory alterations before onset of SE (22/34 vs $10 / 68)$, dyskinesias (29/34 vs $12 / 68)$, CSF pleocytosis $(29 / 34$ vs $42 / 68)$, CSF oligoclonal bands (OCBs) $(12 / 25$ vs $3 / 56)$, and an underlying tumor $(15 / 34$ vs $6 / 68)$, and were less likely to have brain MRI abnormalities (12/34 vs $41 / 68)$. [Conclusion] In the current series, NS-Abs were identified in $1 / 3$ of patients with SE suspected to be autoimmune. Several clinical features such as psycho-behavioral or memory alterations, dyskinesias, CSF pleocytosis, CSF OCBs, or tumor are important clues that suggest the presence of NS-Abs.

\section{0-29-3 Role of serum IL-6 in neuropsychiatric systemic lupus erythematosus}

OShinsei Hirohata ${ }^{1,2}$, Hirotoshi Kikuchi ${ }^{2}$, Tamiko Yanagida ${ }^{2}$

${ }^{1}$ Nobuhira Hospital \& Institute of Biomechanics, Japan, ${ }^{2}$ Teikyo University School of medicine, Japan

[Objective] Although cerebrospinal fluid (CSF) IL-6 was found to be elevated in neuropsychiatric systemic lupus erythematosus (NPSLE), little is known as to serum IL-6 in NPSLE. The present study was designed in order to elucidate the roles of serum IL-6 in the pathogenesis in NPSLE.IMethods] Paired serum and CSF samples were obtained from 101 SLE patients when they presented active neuropsychiatric manifestations (69 patients with diffuse psychiatric/ neuropsychological syndromes [diffuse NPSLE] and 32 patients with neurologic syndromes or peripheral nervous system involvement [focal NPSLE]) and from 22 non-SLE control patients with non-inflammatory neurological diseases.The levels of albumin and IL-6 in CSF and sera were measured by ELISA.Results Serum IL-6 and CSF IL- 6 were elevated in NPSLE compared with non-SLE control.Among NPSLE, serum IL-6 and CSF IL- 6 were significantly elevated in acute confusional state (ACS) compared with non-ACS diffuse NPSLE (anxiety disorder, cognitive dysfunction, mood disorder and psychosis) or focal NPSLE. $\mathrm{Q}$ albumin (CSF/serum albumin quotient) was also significantly higher in ACS than in the two other groups of NPSLE.Of note, serum IL-6 $(r=0.2801$, $\mathrm{p}=0.0207)$, but not CSF IL-6 $(\mathrm{r}=0.1602, \mathrm{p}=0.1918)$, was significantly correlated with Q albumin in patients with diffuse NPSLE, including ACS and non-ACS [Conclusion] These results indicate that serum IL-6 as well as CSF IL-6 is involved in the pathogenesis of NPSLE. Moreover,it is suggested that serum IL-6 might play a most important role in blood-brain barrier breakdown in NPSLE.

\section{0-29-5 Effects of sera in NMO and MOG on IgG translocation to central nervous system}

Miwako Fujisawa, Yukio Takeshita, Susumu Fujikawa,

Fumitaka Shimizu, Toshihiko Maeda, Yasuteru Sano, Michiaki Koga, Takashi Kanda

Department of Neurology and Clinical Neuroscience, Yamaguchi University Graduate School of Medicine, Japan

[Background] Autoimmune neurological diseases such as Neuromyelitis optica (NMO) and MOG antibody-related disease (MOG) are characterized by autoantibodies to targets in CNS. One central event is blood-brain barrier (BBB) dysfunction where autoantibodies cross the BBB and engage the targets. As it is thought that IgG-translocation to CNS is independent on the BBB function, it remains uncertain how autoantibodies access intrathecal antigen because of lack of the adequate models to evaluate the microvolume IgG translocation.[Aim] Our aims are 1) to construct the new measurement of microvolume IgG in vitro BBB model, and 2) to evaluate the effects of sera on $\operatorname{IgG}$ translocation through human brain microvascular endothelial cells (hBMECs). Methods] We prepared the individual sera (NMO; N=6, MOG; N=3, multiple sclerosis[MSl; N=7) and healthy control $(\mathrm{N}=3)$. Conditionally immortalized hBMECs were cultured on the membrane of the inserts. After exposing each serum to hBMECs, human IgGs, which were labeled with IRDye $\mathbb{R} 800 \mathrm{CW}$ protein, were added. Then translocated IgG to lower chamber was detected by the Odyssey ${ }^{\circledR}$ Infrared Imaging System. 10K-dextran permeability was also measured. [Results] The sera of NMO and MOG significantly increased translocated IgG as compared with those of MS and healthy control. However, total amounts of translocated-IgG were not correlated with 10K-dextran permeability.[Conclusion] We developed the new evaluation model of microvolume IgG translocation. These results indicated that the sera in NMO and MOG promote IgG translocation without the dysfunction of BBB. 
0-29-6 Anti-ganglionic acetylcholine receptor antibody in irritable bowel syndrome and functional dyspepsia

Akihiro Mukaino ${ }^{1,2}$, Shunya Nakane ${ }^{1,2}$, Osamu Higuchi ${ }^{3}$,

Yasuhiro Maeda ${ }^{3}$, Makoto Yamakawa ${ }^{2}$, Kotaro Takamatsu ${ }^{2}$, Hidenori Matsuo

${ }^{1}$ Department of Molecular Neurology and Therapeutics, Kumamoto University Hospital, Japan, ${ }^{2}$ Department of Neurology, Kumamoto University, Japan, ${ }^{3}$ Department of Clinical Research and Neurology, Nagasaki Kawatana

Background: Autoimmune gastrointestinal dysmotility (AGID) is the disease entity caused by autoantibody including achalasia, gastroparesis and chronic pseudo-obstruction AGID is also reported to be limited form of autoimmune autonomic ganglionopathy (AAG) and anti-ganglionic acetylcholine receptor (gAChR) antibody is one of the pathogenic autoantibodies. Functional gastrointestinal disorders (FGID) including irritable bowel syndrome (IBS) and functional dyspepsia (FD) are characterized by chronic and recurrent abnormal defecation. Although IBS and FD are similar as AAG clinically, the relationship between the pathogenicity and anti-gAChR antibodies remained resolved. Objective: To elucidate the seropositivity of anti-gAChR antibodies and clinical features of seropositive IBS and FD. Material and Method: Serum samples obtained from all hospitals between January 2012 and August 2018 (1,787 cases and 1,381 samples). We measured $a$ and $\beta$ subunit of anti-gAChR antibodies by Luciferase immunoprecipitation systems. We abstracted IBS and FD cases, and compared the clinical data and the prevalence of autonomic symptoms between seropositive and seronegative IBS and FD. Results: Nine cases of IBS and 2 cases of FD (1 case comorbid with IBS) were found. Seropositivity was 4 out of 11 cases $(36.4 \%)$. Sicca symptoms were observed in 3 out of 4 cases $(75 \%)$ of seropositive FGID compared with 0 out 7 cases $(0 \%)$ of seronegative FGID. Conclusion: We found the seropositive cases of IBS and FD. Neurologists and gastroenterologists should cooperate with each other to decide the treatment strategy.

\section{0-29-8 Pooled safety analysis from Phase 3 trials of} satralizumab in neuromyelitis optica spectrum disorder

Kazuo Fujihara ${ }^{1}$, Benjamin Greenberg ${ }^{2}$, Jerome De Seze ${ }^{3}$

Edward Fox ${ }^{4}$, Albert Saiz ${ }^{5}$, Takashi Yamamura ${ }^{6}$, Carole Marcillat ${ }^{7}$, Xiujing Kou ${ }^{7}$, Kristina Weber ${ }^{7}$, Brian G. Weinshenker

${ }^{1}$ Multiple Sclerosis and Neuromyelitis Optica Center, Southern Tohoku

Research Institute for Neuroscience, Japan, ${ }^{2}$ University of Texas

Southwestern Medical Center, ${ }^{3}$ Department of Neurology, Hôpital de

Hautepierre INSERM, ${ }^{4}$ Central Texas Neurology Consultants, ${ }^{5}$ Service of Neurology, University of Barcelona, ${ }^{6}$ National Institute of Neuroscience, National Center of Neurology and Psychiatry, ${ }^{7}$ F. Hoffmann-La Roche Ltd,

${ }^{8}$ Department of Neurology, Mayo Clinic

Objective To evaluate the safety of satralizumab in neuromyelitis optica spectrum disorder (NMOSD) using pooled data from the SAkura studies. Methods SAkuraSky (NCT02028884) and SAkuraStar (NCT02073279) were randomized, double-blind, placebo-controlled studies of satralizumab in patients with NMOSD. Safety was evaluated in the pooled safety analysis population throughout the doubleblind period using adverse event (AE) rates per 100 patient-years (PY). Results The pooled population included 178 patients (satralizumab, $\mathrm{n}=104$; placebo, $\mathrm{n}=74$ ). The mean (standard deviation) duration of the double-blind period for safety analysis was longer with satralizumab vs placebo (97.2 [61.2] vs 70.6 [55.8] weeks). Rates of AEs and serious AEs were comparable between satralizumab and placebo groups (AEs: 478.49 vs 506.51 events/100PY, respectively; serious AEs: 14.97 vs 17.98 events/100PY, respectively). Infection rates were lower with satralizumab vs placebo (113.04 vs 154.85 events/100PY), with no increased risk of opportunistic infections. The most common AEs in both groups were urinary tract infection and upper respiratory tract infection. The injection-related reaction (IRR) rate was higher with satralizumab vs placebo (18.58 vs 8.99 events/100PY); IRRs were mostly mild-to-moderate and did not lead to treatment discontinuation. Four patients $(3.8 \%)$ in the satralizumab group and six $(8.1 \%)$ in the placebo group withdrew from the study due to an AE. No deaths or anaphylactic reaction were reported. Conclusions Satralizumab shows a favourable safety profile in patients with NMOSD.

\section{0-29-10 Gene expression profile of multiple system atrophy/ primary progressive multiple sclerosis mice model}

\footnotetext{
Hiroo Yamaguchi ${ }^{1}$, Tatsunori Tanaka ${ }^{1}$, Dai Matsuse ${ }^{1}$,

Yuji Nishimura ${ }^{1}$, Katsuhisa Masaki ${ }^{1}$, Toru Saiga ${ }^{1}$,

Mitsuru Watanabe ${ }^{1}$, Ryo Yamasaki ${ }^{1}$, Kenji Tanaka ${ }^{2}$, Jun-ichi Kira ${ }^{1}$

${ }^{1}$ Department of Neurology, Neurological Institute, Graduate School

of Medical Sciences, Kyushu University, Japan, ${ }^{2}$ Department of

Neuropsychiatry, School of Medicine, Keio University
}

Aim: We developed a novel mouse model of multiple system atrophy-cerebellar type (MSA-C) and primary progressive multiple sclerosis (PPMS) by over-expression of mutant $a$-synuclein ( $a$-syn) in oligodendroglia in a temporarily restrictive manner using Tet-off system. By this aminal model, we aimed to characterize gene expression profiles of MSA-C/PPMS. Methods: We generated TetO- $\alpha$-SynA53T Tg/+; PLPtTA $\mathrm{Tg} /+$ double transgenic mice (A53T $a$-syn mice), which express mutant human A53T $a$-syn in oligodendroglia starting at 8 weeks of age when doxycycline was removed from the feed. Results: Western blot analysis showed age-dependent and central nervous system region-specific phosphorylated $a$-syn accumulation, loss of connexin (Cx) 43/Cx30 and myelin basic protein, and marked up-regulation of Ibal, arginase-1, CSF1R and TLR2 consistent with histological findings. DNA microarray analysis indicated the change of these molecules and glial inflammation including marked up-regulation of pro-inflammatory cytokines/chemokines. Re-inhibition of A53T $\alpha$-syn starting at 23 weeks and a CSF1R inhibitor administration for 14 days starting at 23 weeks eliminated microglial activation and down-regulated the elevated pro-inflammatory cytokines/chemokines, coninsided with partial recovery of the neurological symptoms and pathological abnormalities. Conclusion: Mutant human A53T $\alpha$-syn expression in oligodendroglia induces marked up-regualtion of proinflammatory cytokines/chemokines and glial activation molecules in this MSA-C/ PPMS model, which contributes to glial activation and inflammatory demyelination.

\section{0-29-7 Probenecid suppresses dural inflammation and fibrosis in mice model of hypertrophic pachymeningitis}

OUlfa C. Indiasari, Katsuhisa Masaki, Ryo Yamasaki,

Hiroo Yamaguchi, Yuko Nakamuta, Kyoko Iinuma, Jun-ichi Kira

Department of Neurology, Kyushu University, Japan

Objective: Pannexin 1 (Panx1) forms ATP-permeable hemichannels, which are expressed in most tissues and immune cells. Hypertrophic pachymeningitis (HP) is characterized by chronic inflammation and fibrosis in dura, and two major causes of HP are ANCA- and IgG4-related diseases. We recently reported a novel animal model of IgG4-related HP. As Panxl has never been studied in HP, we aimed to clarify Panxl expression and therapeutic efficacy of Panxl inhibitor, Probenecid (PBN), an anti-gout remedy, in IgG4-related HP mice model. Methods: Dura and peripheral organs of IgG4-related HP mice with a mutation $(\mathrm{Y} 136 \mathrm{~F})$ in the linker for activation of $\mathrm{T}$ cells (LAT) and wild-type (WT) mice at aged 3,6 and 13 weeks $(n=5$, respectively) were evaluated by immunohistochemical, immunoblotting, and quantitative PCR (qPCR) analyses. PBN of 50 or $150 \mathrm{mg} / \mathrm{kg}$ were intraperitoneally administered 3 times per week from 3 to 6 weeks of age. Results: Panxl-positive cells were abundantly infiltrated in both inflamed dura and peripheral organs of LAT mice but not in WT mice at aged 6 weeks. Double immunofluorescence showed Panx1 was partially co-localized to CD3-positive T cells and F4/80-positive macrophages. Immunoblot analysis revealed the expression level of Panxl was significantly increased in dural tissue of LAT mice. The mRNA level of Panxl by qPCR had a tendency to increase in dura of LAT mice. PBN of $150 \mathrm{mg} / \mathrm{kg}$ pathologically suppressed both dural inflammation and fibrosis in LAT mice. Conclusion: Panxl could be a novel therapeutic target for IgG4-related HP.

\section{0-29-9 Retrieval of therapeutic target molecules for HAM by microarray analysis of HTLV-1-infected cells}

Ryuji Kubota ${ }^{1}$, Masakazu Tanaka ${ }^{1}$, Eiji Matsuura ${ }^{2}$,

Hiroshi Takashima ${ }^{2}$

${ }^{1}$ Joint Research Center for Human Retrovirus Infection, Kagoshima

University, Japan, ${ }^{2}$ Department of Neurology and Geriatrics, Kagoshima

University

[Objective] We explored molecules that are specifically expressed in HTLV 1-infected cells from HAM patients, and examined whether a compound against these molecules would reduce infected cells. [Methods] Peripheral blood mononuclear cells (PBMC) were isolated from 4 HAM patients, and CD4+CADM1+ cells were enriched as fresh HTLV-1-infected cells. As a control, CD3+ CD4+ cells were enriched from PBMC of 4 non-infected persons. RNA from both cells were subjected to Agilent microarray. We selected genes that were rarely expressed in normal lymphocytes but highly expressed in infected cells as target candidate ones. We examined whether a compound against these molecules would reduce the number of infected cells when added to PBMC of HAM patients by XTT assay and flow cytometry. [Results] Among 17 genes showing over 20 fold expression in infected cells than in normal cells, the ADCY1 gene was over 150 times highly expressed. Three inhibitors for ADCY1 were added to infected and non-infected cell lines to evaluate viable cells. The inhibitor ST034307 showed a 20\% reduction of HTLV-1-infected MT-2 cells at $1 \mu \mathrm{M}$. Survival curves of PBMC from HAM patients and normal individuals, which were cultured with ST034307, showed little difference. In one HAM patient PBMC, $5 \mu \mathrm{M}$ of ST034307 reduced the frequency of HTLV1-infected CADM1+ cells from $9.2 \%$ to $2.6 \%$. [Conclusions] ADCY1 inhibitor ST034307 may reduce HTLV-1-infected cells in vitro.

\section{0-30-1 当院における慢性群発頭痛の検討}

菊井 祥二、宮原 淳一、杉山 華子、孝橋 睦生、山川健太郎、 團野 大介、柏谷 嘉宏、竹島多賀夫 富永病院 脳神経内科

【目的】アジア諸国の慢性群発頭痛（chronic cluster headache·CCH）の群発頭痛に 占める割合は約5\%であり, 欧米の約 $20 \%$ と比較して少ない $\mathrm{CCH} \mathrm{OOL}$ 低下 させる難治性頭痛であるが, 本邦でCCHの臨床的特徴を検討した報告はなく， 次頭痛センターにおけるCCHの特徴を検討した.【対象と方法】2011年2月1日から 2019 年 8 月 31 日の間に当院脳神経内科・頭痛外来を受診し，国際頭痛分類第3版に

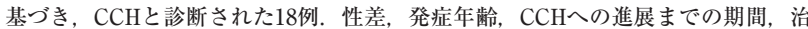
療法, 転帰について, 後方視的に検討した、【結果】CCHは群発頭痛の $4.2 \%(18 / 420)$ を占め, 発症年齢は $30.1 \pm 11.6$ 歳 $(9-49$ 歳, $\mathrm{M}: \mathrm{F}=16: 2)$ と男性優位で, 来院時年齢は $37.7 \pm 12.6$ 歳 (10-50歳)であった. 初発時からのCCHは9例で, 反復性からの進展例 も 9 例で，その期間は $11.7 \pm 10.8$ 年 (2-30年) であった。急性期治療として, スマト リプタン自己注射は湢吐のため使用できなかった1例を除いて有効で，2018年4月 に保険適応になった在宅酸素療法 (HOT) は6例中5例で有効であった。予防療法は 全例でベラパミルが導入され，必要に応じて短期間プレドニゾロンが使用されて いた. 1 例は発作が消失し，2例は反復性に移行した．7例はCCHで継続通院中で あるが, 発作頻度は減少している. 継続例の5例はHOT導入例でスマトリプタン 自己注射と併用されていた，2例は転居のため転医し，6例は外来通院を自己中断 している. 自己中断例は全例, HOTが保険適応される以前の症例であった.【結論】 全例で予防療法には大差はみられないが，HOTを導入することでマトリプタン自 己注射の副作用や注射回数の減少，発作回数が 2 回/日以上でも制限なく使用でき ることなどから, 急性期治療の恩恵が得られ, 自己中断例が減少してきていると 推察された. 本邦のCCH患者のQOLが改善してきていると考えられた 


\section{0-30-2 片頭痛に対する抑肝散の効果についての検討}

秋山 久尚、伊佐早健司、長谷川泰弘

聖マリアンナ医科大学 脳神経内科

【目的】本邦では現在、片頭痛を適応とした予防薬は僅かであり、利用できる選択 肢は不十分である。また、有効性の久如や有害事象により予防薬の使用率が低い ことも報告されている。漢方薬は頭痛に対し、その効果・安全性の両面から有用 と評価され、予防薬、急性期治療薬として長年にわたり使用されている。慢性頭 痛のガイドラインでは呂葉草湯、桂枝人参湯、釣藤散、葛根湯が推奨可能とLて 挙げているが、近年、抑佣散の有效性も報告されている。本研究では、片頭痛に 対する抑肝散の効果について後方視的に検討した。【方法】2018年11月以降、当院 頭痛外来で国際頭痛分類第3版にて片頭痛と䛦断し、抑肝散を処方した 16 (女性 15）例のうち、胘量、ふらつき、失神、下痢などの有害事象により1か月以上の内 服継続が不可能であった5例を除いた11（女性10）例を対象として、その頭痛の背 景や抑肝散の効果を診療録から調查した。[結果]全対象11例の平均年齡は14 74 (平均44.4 415.7 ) 歳であった。抑肝散開始までの片頭痛䍜患歴は 1 ４5 (平均 $25.7 \pm$ $12.6)$ 年で、粲張型頭痛が5例 $(45.5 \%$ ) 亿混在し、前兆のある片頭痛は1例 $(9.1 \%)$ て あった。抑肝散の投与前には予防薬が $1212($ 平均 $4.7 \pm 3.6)$ 種類使用され、漢方䔉

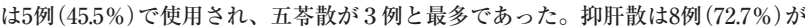
単独投与で、1日あたり $5 \sim 7.5$ (平均 $6.6 \pm 1.3) \mathrm{g} 、 2 \sim 12$ (平均 $6.1 \pm 3.4$ ) か月投与さ れていた。有効性は頭痛日数の開始時から $50 \%$ および $70 \%$ 減少率で評洒し、投与 開始後2か月、3か月時点で、各々、 $50 \%$ が6例 $(54.5 \%)$ と7 例 $(63.6 \%) 、 70 \%$ が6例 (54.5\%) と6 例 (54.5\%)であった。また 6 か月以上の長期使用5例は、頭痛日数の減 少は経時的に持続していた。結論】少数例での検討であるが、継続困難でなけれ ば、抑肝散の有効率 (頭痛日数の減少率) は内服 $2 \sim 3$ 只で 50 ～ $60 \%$ 程度に達して いた。今後、更なる多数例での大規模研究が必要である。

\section{0-30-4 典型的前兆のみで頭痛を伴わない例の検討}

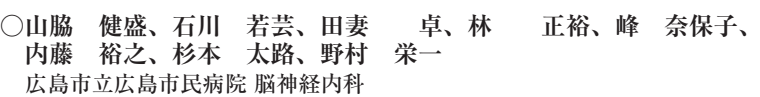

【背景と目的】典型的前兆を呈しながら頭痛を伴わない例を時々経験する。てんか んや，高齢者においては胋血管障害をはじめ頭蓋内病変の鑑別がきわめて重要て あるとの指摘がある。しかし一方で，一般人口に扔いて一過性の視覚症状を呈す ることは稀ではないとの報告もある。今回，典型的前兆を呈しながら頭痛を伴わ 大かった例の臨床的特徵を明らかにする。方法2013年4月から2019年11月の期 間に当院を受診し典型的前兆のみを呈し頭痛を伴わなかった連続28例のうち、国 際頭痛分類第3版(ICHD-3)「1.2.1.2典型的前兆の久で頭痛を伴わないもの」の診断基 準を満たす23例について, 性別，年齢，回数，持続時間，頭蓋内病変の有無等に ついて後方視的に検討する。【結果】典型的前兆は，全例間輝暗点であった。男性 9 例，女性 14 例で，年齢は $59 \pm 16$ 歳（男性 $63 \pm 19$ 歳，女性 $56 \pm 12$ 歳）と，男性で年 龄が高かった，回数は，2回が4例，3回が6例で，一方で10回以上が10例であった。 持続時間は，5 15分が3例，20〜30分が15例，40〜60分が4例と，20〜30分が $2 / 3$ を占めた．視覚症状の表現は，「ギザギザ」が11例，次いで「キラキラ」が4例であっ た. 既往としてICHD-3「1.2前兆のある片頭痛」がある例が5例あった。頭部MRIは，

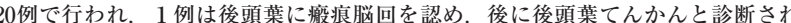
たが，他の例では問題となる異常は認めなかった，治療希望があったのは4例で， いずれもロメリジンがある程度有効であった。1例は，多発性硬化症と診断され， インターフェロン投与が行われていた。 全般に転帰は良好であり，現在通院中は 3例のみで, うち2例で投薬中である。【結論]頭痛を伴わず益型的前兆のみを呈す る例では, それほど稀でないと考元られる。前兆のある頭痛と比べ, 高龄者に多い ただ，高齢であっても頭蓋内器質性病変見つかる可能性は低いものと考元られる が、後頭葉てんかんとの鑑別は重要と考えられる。

\section{0-30-6 日本における片頭痛患者の社会的負担の評価 : population-based 調查の解析}

$$
\begin{aligned}
& \text { 五十嵐久佳 }{ }^{1} \text {. Sungeun Jung }{ }^{2} \text { 植田 要 }{ }^{3} 、 \text { 蔡 志紅 }{ }^{3} 、 \\
& \text { 中村 智実 }{ }^{3} \\
& { }^{1} \text { 富士通クリニック 内科 (頭痛外来)、 }{ }^{2} \text { カンター, 韓国、 } \\
& { }^{3} \text { 日本イーライリリー株式会社 }
\end{aligned}
$$

Objective To investigate the social burden of patients with migraine vs non migraine controls and compare patients currently receiving prescribed medication $(\mathrm{Rx})$ for migraine vs patients not receiving $\mathrm{Rx}$ (non- $\mathrm{Rx}$ ) in Japan. Methods Data from the online National Health \& Wellness Survey 2017 Japan $(\mathrm{N}=30,001)$ was analysed. Respondents with self-reported physician diagnosis of migraine and without migraine were 1:1 propensity score matched. Bivariate analysis was performed to compare outcomes: Quality of Life (QoL: EQ-5D), Work productivity and Activity Impairment (WPAI), and Healthcare Resource Utilization. Bivariate analysis was also conducted to compare outcomes in Rx vs non-Rx patients. Results 1,265 migraine patients were analysed. Migraine patients had lower QoL (EQ-5D: 0.77 vs $0.86, \mathrm{p}<0.001$ ) than matched controls $(\mathrm{n}=1,265)$. Migraine patients reported higher impairment to work productivity absenteeism: $7.0 \%$ vs $3.1 \%$; presenteeism: $32.7 \%$ vs $18.9 \%$; total work productivity impairment: $34.8 \%$ vs $20.0 \%, \mathrm{p}<0.001)$ and more visits to physicians in the past 6 months ( 8.4 vs $4.6, \mathrm{p}<0.001)$ compared to controls. Non- $\mathrm{Rx}(\mathrm{N}=678)$ had fewer migraine episodes in the past 30 days $(3.6$ vs $6.0, \mathrm{p}<0.001)$ and outpatient visits in the past 6 months (7.5 vs $9.4, \mathrm{p}=0.013)$ than $\mathrm{Rx}(\mathrm{N}=587)$. However, non-Rx showed similar QoL (EQ-5D: 0.77 vs 0.76 ) and work productivity impairmen with Rx. Conclusion Migraine patients in Japan experience a significant socia burden. The patients not receiving prescribed medication for migraine suffer similar QoL and WPAI as patients receiving prescribed medication.

\section{0-30-3 当院頭痛外来に通院中の片頭痛患者の特徵 (HIT-6 を 含めて)}

潼沢翼、中原仁、柴田謢
慶應義塾大医学部 神経内科

【目的】当院頭痛外来に通院中の片頭痛患者の特徵について，日常生活支障度の指 栖であるHIT-6を含めて梌討した【方法嘼痛外来に通院している200例の一次性 頭痛患者のうち片頭痛患者 160 名について梌討した. HIT-6についても回答が得ら れた139症例では検討した.【結果】片頭痛患者の平均年齢は $47 \pm 13$ 歳, $85 \%$ が女性, 1か月あたりの頭痛日数は7.6 6 6.7日，頭痛の持続時間（鎮痛薬未使用時）は $17 \pm 18$ 時間であった. 約1/3が前兆のある片頭痛であった. HIT-6の平均值は $59.6 \pm 7.9$ 点 であった，HIT-6は頭痛日数と正の相関関係がみられた $(\mathrm{r}=0.41 ， \mathrm{p}<0.01)$ が，頭痛

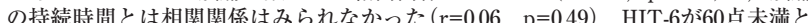
60 点以上の患者で比較したところ, 年㱓は $48 \pm 13$ 歳 vs $47 \pm 13$ 歳 $(p=0.59)$, 女性 の比率は $76 \%$ vs $88 \%(\mathrm{p}=0.07)$, 頭痛日数は $4.7 \pm 3.6$ 日 vs $9.6 \pm 7.6$ 日 $(\mathrm{p}<0.01)$, 頭 痛の持続時間は $14 \pm 14$ 時間 vs $20 \pm 20$ 時間（ $\mathrm{p}=0.09 ）$, 前兆のある片頭痛の割合は $42 \%$ vs $23 \%(\mathrm{p}<0.05)$ ， トリプタンの使用率は $78 \%$ vs $85 \%(\mathrm{p}=0.34)$ ，予防薬の使 用率は $31 \%$ vs $57 \%(\mathrm{p}<0.01)$ ，予防薬を2唷使用している割合は $9 \%$ vs $17 \%(\mathrm{p}=0.17)$ であった. [結論】当院頭痛外来に通院している片頭痛患者について, HIT-6は頭 痛日数と相関していた. HIT-6の高い患者では，頭痛日数が多く，前兆のある片 頭痛の割合は少なく，予防薬を使用している割合が高かった．既存の予防薬を使 用していてもADL障害が高い患者が認められることから，現況としてはunmet medical needsが存在することが推察された.

\section{O-30-5 特発性レム睡眠行動異常における認知機能と転帰}

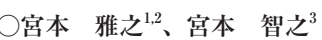

獨協医科大学看護学部看護医科学 (病態治療)

“獨協医科大学病院 脳神経内科、獨協医科大学埼玉医療センター 脳神経内科

【目的】中高齢者の特発性レム睡眠行動異常(IRBD) は、レビー小体関連疾患 (LBD) との関連が報告されている。我々は先の本学会の第53回学術大会において、IRBD 36例を対象に、IRBDの認知機能についての横断的研究の結果を報告した。今 回、これらのIRBD症例における認知機能と転㴆との関連を明らかにすることを 目的に転帰調查を行った。方法】対象は、2011年5 10月の期間（ベースライン： BL) そMMSE (Mini-Mental State Examination) とMoCA-J (日本語版 Montreal Cognitive Assessment) を施行したIRBD 36例（平均68.4歳、男性30例、女性6例) である。MMSEとMoCA-Jの総得点のカットオフ值をそれぞれ 24 点、26点に設 定した。これらの対象者の転滞について、2019年11月に診療録より調查した。本 研究は本施設の生命倫理委員会の承認のもとで行われた。結果】BLの時点で、 MMSE 総得点は平均28.2点 (全例 24占以上)、MoCA-J 総得点は平均 24.9 点 (同 26 点以上が17例、同 26点未満が19例) であった。転帰調查時点までにフォローアッ プできた症例は36例中29例 (80.6\%) であり、このうちBLでMoCA-J 26点以上が12 例 $(41.4 \%) 、 M o C A-J$ 26点未満が17例 (58.6\%)であった。パーキンソン病 $(\mathrm{PD})$ また はレビー小体型認知症 (DLB) を発症した例は、MoCA-J 26点以上で2例 (PD 1例、 DLB 1例)、MoCA-J 26点未満で10例（PD 4例、DLB 6例）であった【結論】BL時 占での認知機能の評価において、MoCA-Jの方がMMSEより主低得占の傾向にあっ た。今回の調查で、MMSEが高得点であっても、特にMoCA-Jが低得点の例では、 PDまたはDLBをのちに発症する例が多い傾向にあった。IRBDにおいて、BLでの MoCA-Jの低得点は、LBDの病態が背景に存在することを予測する上で役立つ可 能性がある。

\section{0-30-7 SPECT/CTを用いた脳槽シンチブラフィーによる临

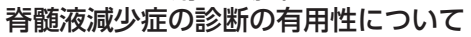

○光藤 尚 ${ }^{1} 、$ 田村 直俊、大田 一路 ${ }^{1} 、 川$ 崎 一史 ${ }^{1} 、$ 池田 桂 ${ }^{1}$

松成 一朗 ${ }^{2}$ 、山元 敏正 ${ }^{1}$ 、荒木 信夫 ${ }^{1}$

${ }^{1}$ 埼玉医科大学病院 脳神経内科、 ${ }^{2}$ 埼玉医科大学 核医学診療科

はじめに脳脊髄液減少症の診断は, ミエロCTによる䯣液漏出の評価が最も有用 とされる。我々は, SPECT/CTを用いた脳槽シンチグラフィーを14例15件に行い fusion画像を用いた評価を行ったので報告する. 対象と方法 2017年9月1日より 2019年10月30日の期間にSPECT/CTを用いた脳槽シンチグラフィーで䯣液漏出を 検討した14例の15件の検查を後方視的に検討した，結果 14例（男性10例，女性 4例) の症例に対して15件の脳槽シンチグラフィーが施行されていた。脳脊䯣液減 減少症の診断基準を満たした症例は 10 例 (男性7例, 女性 3 例) だった. うち6例 (男 性5例，女性1例）で直接漏出所見を認めた。頝䯣レベルで䯣液漏出を認めた1例と

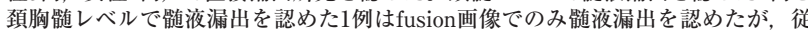
来の撮像方法では髄液漏出を確認できなかった。 2 回脳槽シンチグラフィーを撮

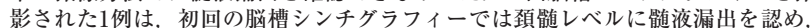
ブラッドパッチ施行後も頭痛が継続していたことから、脳槽シンチグラフィーを 再検されて脳脊髄液減少症が否定されていた．髄液鼻漏を認めた 1 例は従来の撮 像方法でもfusion画像でも䯣液漏出を確認できず，患者のマスクからRIを検出し て䯣液鼻漏が確認された。直接漏出所見を認めなかった 4 例はいずれもRIクリア ランスの元進を認めたことから脳脊葡液減少症の診断を得た。結論 SPECT/CT を用いたfusion画像を撮影することで䅡胸䯣の佮道液漏出の直接所見を確認できた ことからSPECT/CTを用いたfusion画像を組み合わせることが診断に有用である と考えられた。謝辞 本検討はAMED委託研究「脳脊喊液減少症の病態と治療法 の開発」の一環として行った。 


\section{0-30-8 片頭痛症例における頭部自律神経症状と中枢神経感作 の関係性について}

\author{
團野 大介 ${ }^{1} 、$ 宮原 淳一 ${ }^{1}$ 、菊井 祥二 1 、石崎公郁子 ${ }^{1} 、$ \\ Johanna WOLF 2 、平田 幸一 3 、竹島多賀夫 \\ 富永病院 脳神経内科・頭痛センター、兵庫医科大学脳神経内科、 \\ 獨協医科大学脳神経内科
}

【目的】頭痛に伴う眼球充血や流涙などの頭部自律神経症状 (CAS) は群発頭痛を はじめとする三叉神経・自律神経性頭痛 (TACs) で認められ, その診断根拠と なっている。一方CASは片頭痛の診断基準には含まれないが近年片頭痛症例でも CASを有するという報告が増加している，当院頭痛センターで片頭痛と診断した 373 例を検討したところ $42.4 \%$ でCASを有していた. CASを有する群は有 さない群に比して音過敏、臭い過敏、アロディニアが有意に高率であった，アロ ディニアは中枢感作を反映するとされ、臭い過解および音過敏はアロディニアと 関連が示唆されていることから, CASの発症に中枢神経感作が関与している可能 性が示唆された。このため、今回CASの有無により中枢感作の程度に差があるか どうかを検討した【【方法】当センターに通院中の片頭痛患者 156 例に妥当性の 検証された中枢感作問診票 (CSI) を用いて中枢感作の定量化を行ったこのうち CASデータが利用可能であった 116 例について解析を行った. [結果慢性片頭 痛が 80 例（薬物乱用あり 46 例, 薬物乱用なし 34 例), 反復性片頭痛が 36 例であった，男性 27 例，女性 89 例で平均年齢は 41.3 歳 $( \pm 12.3 \mathrm{SD})$ て あった．CSIスコアは慢性片頭痛で 34.6 , 反復性片頭痛で 31.8 と慢性片顽 痛で高値であったが有意差は認めなかった。 116 例中 59 例でCASを有してお り, 41 例が $1-2$ 個のCASを有するのみで 3 個以上は 18 例であった. CSI万 コアはCASを有する群では 37.5 で、有さない群の 29.8 に比して有意に高湖 であった $(\mathrm{p}=0.002)$.[結論] 頭部自律神経症状を有する片頭痛患者はより高度な中 枢感作が起こっている可能性がある。本研究は, 厚生労働科学研究費補助金 治性疾患等政策研究事業の助成によって行われた。

\section{0-30-10 東日本大震災被害地域の岩手県沿岸における頭痛リス 刀因子研究-2012-2018 年の变遷}

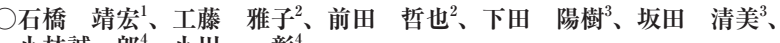
小林誠一郎、 4 小川 彰

“北上済生会病院 脳神経内科、2 岩手医科大学 脳神経内科・老年科、

岩手医科大学衛生学公臬衛生学、 ${ }^{4}$ 岩手医科大学

【目的】東日本大震㷋後に拈ける頭痛合併頻度と頭痛との関連因子の変化を検討す

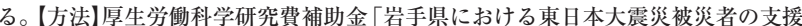
を目的とした大規模コホート研究」の一環として、頭痛に関する問診を 2012 年から 2018年まで行った。対象者は2012年から2018年までの期間それぞれ5906名、5578 名、5386名、5309名、5063名、4884名、4733名であった。(1)年齢、(2)性别、(3)精 神的因子（ストレス、K6、睡眠障害）、(4)メタボリック症候群、(5喫煙習惯、6 拎酒習慣、(7)運動習慣、8 住居（仮設住宅居住経験など)、99震災による心的外䅞 後ストレス障害 (PTSD) 関連因子、10ソーシャルネットワーク因子(友人の有無な ぞ) と、頭痛の有無との関連を調查した。【結果]頭痛の頻度は2012年から2017年に かけて $25.5 \%$ から $15.7 \%$ ○有意に減少してきた。頭痛を持つ群は調查期間を通し て若年で、女性に多く、精神的因子、PTSD関連因子を持つ頻度が高く、メタボリッ ク症候群、飲酒習慣を持つ頻度が低かった。運動習慣を持つ頻度は頭痛を持つ群 で低くかった。仮設住宅居住経駼を持つ頻度は頭痛を持つ群で2012年から2016年 まで高かったが、2017年以降差がなくなった。友人を持つ頻度は2012年には両群 で差を認めなかったが、2013年から頭痛を持つ群で低くなった。[結諭]仮設住宅 居住経䮦は頭痛を持つ群で頻度が高かったが、震災から6年を経て影響が低下し てきた。震災に関連するPTSD、ソーシャルネットワークは震災後7年を経過して も頭痛との関連因子である。

0-31-2 Japan-Plasmapheresis Outcome and Practice Patterns Study for Neurological diseases: real world survey

OYouwei Lin ${ }^{1}$, Narita Tomoko ${ }^{2}$, Satoru $\mathrm{Oji}^{3}$, Katsuichi Miyamoto ${ }^{4}$, Hiroshi Takashima ${ }^{5}$, Kimiaki Utsugisawa ${ }^{6}$, Masaaki Niino, Kazumasa Yokoyama, Osamu Watanabe, Shugo Suwazono ${ }^{10}$ Masahiro Mori ${ }^{11}$, Hiroo Yoshikawa ${ }^{12}$, Hidenori Matsuo ${ }^{10}$ ${ }^{1}$ Dep.Neurology, National Center Hospital, National Center of Neurology and Psychiatry, Japan, ${ }^{2}$ Dep.Neurology, Nagasaki Kawatana Medical Center, ${ }^{3}$ Dep.Neurology, Saitama Medical Center, ${ }^{4}$ Dep.Neurology, Kindai University Hospital, ${ }^{5}$ Dep.Neurology and Geriatrics, Kagoshima University Hospital, Dep.Neurology, General Hanamaki Hospital, ${ }^{7}$ Dep.Neurology, Hokkaido Medical Center, ${ }^{8}$ Dep.Neurology, Juntendo University Hospita, ${ }^{9}$ Dep Neurology, Kagoshima City Hospital, ${ }^{10}$ Dep.Neurology, Okinawa National Hospital, ${ }^{11}$ Dep.Neurology, Chiba University Hospital, ${ }^{12}$ Dep. Neurology, Hyogo College of Medicine Hospital, ${ }^{13}$ Nagasaki National Hospital

[Background/Objective] Disease-modifying drugs have widened therapeutic options in some neuroimmunological diseases. Plasmapheresis has been an approved therapy for acute relapse or progression of selected cases. However, realworld studies regarding whom to administer plasmapheresis and how to manage the patients are lacking. We searcher recent data of plasmapheresis for neurological diseases for efficacy and safety to obtain useful information to optimize management. [Materials and Methods] We recruited 210 patients among individuals subjected to plasmapheresis from June 2017 to March 2019 from 12 representative hospitals. We analyzed disease type and procedure approaches, and evaluated their efficacy. We adopted the modified Rankin Scale (mRS) and Barthel Index (BI) as a universal scale longside each disease-specific scale. [Results] 82 cases of myasthenia gravis ( $\mathrm{MG}$ ), 30 cases of multiple sclerosis (MS), 4 cases of neuromyelitis optica (NMOsd), 4 cases of Guillain-Barre syndrome (GBS), 11 cases of chronic inflammator demyelinating polyradiculoneuropathy (CIDP) and 59 cases of other diseases including 40 cases of autoimmune encephalitis were enrolled. Overall, mRS and BI were significantly reduced ( $\mathrm{p}<0.0001$ ), especially in MG and othe diseases. Comparison of efficacy before, during, and after the procedure, there was some tendency to relieve the symptoms after the procedure for MG, NMOsd and other diseases, whereas during the procedure for MS. IConclusions Plasmapheresis may be an efficient in additional neurological diseases besides the four currently approved diseases.

\section{0-30-9 片頭痛患者の腹痛発作は中年以降も持続する}

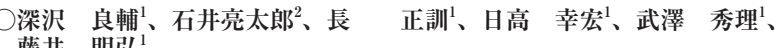
藤井 明弘

済生会滋賀県病院 脳神経内科、

京都府立医科大学附属北部医療センター救急災害医療システム科

【目的】腹部片頭痛は小児の $4 \%$ 程度が罹患している，腹痛発作や湢吐・嘔気を繰 り返す疾患である。統計的には将来片頭痛になりやすいことが知られるが，症状 が消失する時期については不明である。我々は, 医療過疎地の救急病院にて, 片 頭痛患者の $42 \%$ 過去 10 年間に腹痛を主訴に救急外来を受診していることを報告 した. 今回は，その受診患者の特徵について検討する.【方法】2017年4月から 2018年3月までの1年間に頭痛を主訴に頭痛外来を受診し，片頭痛と診断された患 者71例を対象とし，過去10年間に腹痛による救急受診の有無を後ろ向きに検討し た。副次評価項目は, 性別, 頭痛初発年齢・前兆の有無, MOH (薬剤の使用過多 による頭痛）の有無, 頭痛の頻度, 外来受診時の頭痛の強度, 外来受診時の年齢, 腹痛発作発症時の年齢, 救急外来での暫定診断, 検查内容, 救急受診後の経過, 投 薬内容, 発症時間, 下痢の有無, 嘔吐の有無とした。【結果】片頭痛患者71例中, 腹 痛発作での受診があったのは30例だった. 女性 22 例, 男性8例で平均年齢は31.5歳 であった。前兆のある片頭痛は12例で，MOHは9例であった。 2008年1月6日と 2017年8月 2 日には異なる居住地の異なる患者 2 ペアが同日に受診していた. 年齢と ともに減少傾向にあるものの，腹痛発作は2-62歳でみられた.【考察】既報告では, 108 人の小览腹部片頭痛追跡結果では、 37 人 $(34 \%)$ が10歳までに寛解を得たが, 残 りの症例に関しては18歳を過ぎても寛解を得られなかった。一方で成人における 腹部片頭痛につての詳細な検討はない，今回，片頭痛患者において，治療が必要 なかった腹痛により救急受診が高齢まで持続する症例が存在することがわかっ た.【結論】片頭痛患者は, 高齢になっても腹部片頭痛を発症している可能性が考 えられた。

\section{0-31-1 Long-term Safety and Efficacy of Patisiran in the} Global Open-label Extension Study: 24-Month Data

Mitsuharu Ueda ${ }^{1}$, David Adams ${ }^{2}$, Alejandra González-duarte ${ }^{3}$

Elizabeth A Mauricio ${ }^{4}$, Thomas H Brannagan ${ }^{5}$, Teresa Coelho ${ }^{6}$,

Jonas Wixner ${ }^{7}$, Hartmut Schmidt ${ }^{8}$, Erhan Berber', Marianne Sweetser ${ }^{9}$, Matthew T White, Jing Jing Wang, Michael Polydefkis ${ }^{10}$

Department of Neurology, Kumamoto University Hospital, Japan, ${ }^{2}$ National Reference Center for FAP (NNERF) / APHP/ INSERM U 1195/ CHU Bicêtre, Le Kremlin Bicêtre, France, ${ }^{3}$ Instituto Nacional de Ciencias Médicas y Nutrición, Salvador Zubirán, Mexico City, Mexico, ${ }^{4}$ Mayo Clinic, Jacksonville, FL, USA, ${ }^{5}$ Department of Neurology, Columbia University, New York City, NY, USA, Centro Hospitalar Universitário do Porto, Portugal, ' Department of Public Health and Clinical

${ }_{9}^{9}$ Alnylam Pharmaceuticals, Cambridge, USA, ${ }^{10}$ Johns Hopkins University, Baltimore, USA

Introduction: Patisiran's efficacy/safety were demonstrated in Phase 2 and 3 (APOLLO) studies in hATTR amyloidosis with polyneuropathy. Objective: To potentially present 24 -month results from the ongoing Global OLE study. Methods: International, safety/efficacy study (NCT02510261) in eligible patients from parent studies; APOLLO patients randomized to placebo (APOLLO/placebo, $n=49$ ) or patisiran (APOLLO/patisiran, $n=137$ ) and Phase 2 OLE patients (n=25). Results: 189/211 patients had 12-month assessments by 09/24/18. Safety was consistent with previous studies. After 12 months in OLE, durable improvement was seen for mNIS+7 (mean change [SEMI) in APOLLO/patisiran (-4.01.9]) and Phase 2 OLE (-4.7[3.5]) groups $v$ s parent study baselines Norfolk QOL-DN showed durable improvement in APOLLO/patisiran patients (-3.9[2.1) following 12 months in OLE. APOLL0/placebo patients experienced improvement after 12 months of patisiran (mNIS+7: -1.4[2.4], Norfolk Q0L-DN: -4.5[2.5]), but progressed vs AP0LL0 baseline (mNIS+7: +24.0[4.2], Norfolk Q0L-DN: +15.0[3.4]) due to progression while on placebo. Conclusions: Patients with long-term exposure to patisiran demonstrated durability of efficacy. Previously untreated patients exhibited halting of disease progression and QOL improvement after 12 months of patisiran. However, delayed treatment resulted in greater disease burden $v$ s those who started patisiran earlier, demonstrating need for early treatment. It is anticipated the 24-month Global OLE safety/efficacy data will continue to demonstrate a positive benefitrisk profile for patisiran.

\section{0-31-3 Higher risk for recurrent stroke in NVAF-related} ischemic stroke patients with prior anticoagulation

Kanta Tanaka ${ }^{1,2}$, Masatoshi Koga ${ }^{1}$, Keon-joo Lee ${ }^{3}$, Beom Joon Kim ${ }^{3}$, Eun Lyeong Park ${ }^{4}$, Juneyoung Lee ${ }^{4}$, Tadataka Mizoguchi ${ }^{1}$,

Sohei Yoshimura ${ }^{1}$, Jae-kwan Cha ${ }^{5}$, Byung-chul Lee ${ }^{6}$, Jin Nakahara ${ }^{2}$, Norihiro Suzuki ${ }^{2}$, Kazunori Toyoda ${ }^{1,2}$

National Cerebral and Cardiovascular Center, Japan, ${ }^{2}$ Keio University, Japan, Seoul National University Bundang Hospital, ${ }^{4}$ Korea University,

Dong-A University Hospital, ${ }^{6}$ Hallym University Sacred Heart Hospital

Objective: Nonvalvular atrial fibrillation (NVAF)-associated ischemic stroke despite prior anticoagulation may indicate underlying problems that nullify the strokepreventing effects of oral anticoagulants. We aimed to evaluate the risk for recurrent stroke in NVAF patients with prior anticoagulation, compared with that in patients without prior anticoagulation. Methods: This study comprised pooled individual patient data on NVAF-associated acute ischemic stroke from 2011 to 2014 arising from 2 prospective cohort studies. Data on 4841 eligible patients from the CRCS-K registry (15 South Korean stroke centers) were pooled with data on all patients $(n=1192)$ in the SAMURAI-NVAF registry (18 Japanese stroke centers). The primary outcome was recurrent ischemic stroke. The secondary outcomes were hemorrhagic stroke and death The outcome events were captured up to 1 year after the index event. Results: Among the 6033 patients in the full cohort, 5645 patients ( 2649 women, median 75 [interquartile range, 69-81] years of age) were analyzed, of whom 1129 patients $(20.0 \%)$ had received prior anticoagulation. The risk for recurrent ischemic stroke was higher in patients with prior anticoagulation than in those without (multivariable Cox shared-frailty model, hazard ratio $1.50,95 \%$ confidence interval 1.02-2.21). No significant differences in the risks for hemorrhagic stroke and mortality were seen between the 2 groups. Conclusions: The risk for recurrent ischemic stroke was higher in NVAF-associated stroke patients with prior anticoagulation than in those without prior anticoagulation. 


\section{0-31-4 Satralizumab monotherapy for relapse prevention} in neuromyelitis optica spectrum disorder

OAnthony Traboulsee ${ }^{1}$, Benjamin Greenberg ${ }^{2}$, Jeffrey L. Bennett ${ }^{3}$, Lech Szczechowski ${ }^{4}$, Edward Fox ${ }^{5}$, Svitlana Shkrobot ${ }^{6}$, Takashi Yamamura ${ }^{7}$ Yusuke Terada ${ }^{8}$, Yuichi Kawata ${ }^{8}$, Pádraig Wright ${ }^{9}$, H.-christian Von Büdingen ${ }^{10}$, Gaelle Klingelschmitt ${ }^{10}$, Athos Gianella-borradori ${ }^{11^{1}}$, Brian G. Weinshenker ${ }^{12}$ ${ }^{1}$ University of British Columbia, Canada, ${ }^{2}$ University of Texas Southwestern Medical Center, ${ }^{3}$ University of Colorado School of Medicine, ${ }^{4}$ Silesian Centre of Neurology, ${ }^{5}$ Central Texas Neurology Consultants, ${ }^{6}$ Ternopil State Medical University, ${ }^{8}$ National Center of Neurology and Psychiatry, Chugai Pharmaceutical Co., Ltd, Tokyo, ${ }^{9}$ Chugai Pharma Europe Ltd. London, ${ }^{10} \mathrm{~F}$. Hoffmann-La Roche Ltd, ${ }^{11}$ Chugai Pharma USA LLC, ${ }^{12}$ Mayo Clinic

Objective To compare the efficacy and safety of satralizumab monotherapy with placebo for relapse prevention in patients with neuromyelitis optica spectrum disorder (NMOSD), as part of the Phase 3 SAkuraStar study (NCT02073279). Methods SAkuraStar was a double-blind, placebo-controlled study. A total of 95 patients were randomized 2:1 to satralizumab monotherapy (120 mg s.c.) or placebo, administered at Weeks 0, 2,4 and Q4W thereafter. Concomitant immunosuppressants were prohibited. Patients had to have a diagnosis of NMO by 2006 criteria, or AQP4-IgG seropositive NMOSD by 2007 criteria, with either longitudinally extensive myelitis or optic neuritis. All patients had at least documented relapse, including first attack, in the year prior to screening. The primary endpoint was time to first protocol defined relapse (PDR), as adjudicated by a Clinical Endpoint Committee. Results Satralizumab monotherapy significantly reduced risk of PDR by $55 \%$ compared with placebo (hazar ratio $0.45 ; 95 \%$ confidence interval $0.23-0.89 ; \mathrm{p}=0.018$ ). The proportion of relapse-free patients at Week 48 was $76.1 \%$ in the satralizumab group and $61.9 \%$ in the placebo group. At Week 96 , these values were $72.1 \%$ and $51.2 \%$, respectively. Satralizumab was well tolerated, with similar rates of advers events and serious infections between groups. No deaths or anaphylactic reactions were observed. Conclusions In this first Phase 3 study of satralizumab monotherapy in patients with NMOSD, satralizumab significantly reduced the risk of relapse compared with placebo, and was well tolerated.

\section{0-31-6 A phase I clinical trial of intrathecal injection of} recombinant human HGF in subjects with ALS

Hitoshi Warita ${ }^{1}$, Masaaki Kato ${ }^{1}$, Ryuta Asada ${ }^{2}$, Atsuko Yamashita ${ }^{3}$ Hayata Hayata, Kiichi Adachi ${ }^{3}$, Masashi Aoki

Department of Neurology, Tohoku University Hospital, Japan, ${ }^{2}$ Innovative

and Clinical Research Promotion Center, Gifu University Hospital,

Kringle Pharma

[Objective] Hepatocyte growth factor (HGF) is an endogenous pleiotropic factor and a potent neuroprotectant against disease progression in amyotrophic lateral sclerosis (ALS) that is an adult-onset motor neuron disease. To evaluate safety, tolerability, and pharmacokinetics of recombinant 5-residue-deleted human HGF (KP-100) injected intrathecally through an implantable catheter with a subcutaneous port, we conducted a first-in-human phase I trial. [Methods The investigational product KP-100 was administered intrathecally to subjects with early-stage ALS as a single dose $(0.2 \mathrm{mg}, 0.6 \mathrm{mg}, 2.0 \mathrm{mg} /$ body, $\mathrm{n}=3$ group) or repeatedly $(0.6 \mathrm{mg}, 2.0 \mathrm{mg}, 5$ times at 1 -week intervals, $\mathrm{n}=3$ /group $)$ [Results] With single-dose administration, the mean half-life of KP-100 in the cerebrospinal fluid (CSF) was 1.2 to 1.4 days, with its maximum concentration increasing in a dose-dependent manner. With multiple-dose administration, the trough KP-100 concentrations in the CSF generally remained constan despite multiple dosing. There were no deaths, serious adverse events, or device malfunctions leading to discontinuation. In all subjects, plasma KP-100 concentrations were $<1 \mathrm{ng} / \mathrm{mL}$ at all time points. Anti-KP-100 antibody was not detected in the CSF or plasma specimens throughout the dosing period. [Conclusions] These results suggest that KP-100, as well as the device used to administer it, is safe and tolerable. Further testing of the intrathecal KP-100 in an exploratory clinical trial is warranted in patients with various central nervous system diseases such as ALS and spinal cord injury.

\section{0-31-8 Efficacy and safety of ofatumumab versus} teriflunomide in relapsing multiple sclerosis

OKrishnan Ramanathan ${ }^{1}$, Stephen L. Hauser ${ }^{2}$, Amit Bar-or ${ }^{3}$,

Jeffrey Cohen ${ }^{4}$, Giancarlo Comi ${ }^{5}$, Jorge Correale ${ }^{6}$, Patricia K. Coyle ${ }^{7}$, Anne H. Cross ${ }^{8}$, Jérôme De. Seze, Xavier Montalban Et Al. ${ }^{10}$ ${ }^{1}$ Novartis Pharma AG, Switzerland, ${ }^{2}$ Department of Neurology, UCSF Weill Institute for Neurosciences, University of California, ${ }^{3}$ Center for Neuroinflammation and Experimental Therapeutics and Department of Neurology, Perelman School of Medicine, University of Pennsylvania, Neurological Institute, Cleveland Clinic, ${ }^{5}$ University Vita-Salute San Raffaele, ${ }^{6}$ Institute for Neurological Research Dr. Raul Carrea, Stony Brook University, ${ }^{8}$ Washington University School of Medicine, ${ }^{9}$ University Hospital of Strasbourg, ${ }^{10}$ St Michael's Hospital, University of Toronto

Objective: To investigate the efficacy and safety of ofatumumab (the first fully human anti-CD20 monoclonal antibody) versus teriflunomide in relapsing multiple sclerosis (RMS) patients. Methods: ASCLEPIOS I and II are identical, double-blind, double-dummy, active comparator-controlled, parallelgroup, multicenter trials. Patients were randomized (1:1) to receive either ofatumumab $20 \mathrm{mg} \mathrm{sc}$ injections every 4 weeks or teriflunomide $14 \mathrm{mg}$ orally once daily, for up to 30 months. The primary endpoint was annualized relapse rate (ARR). Results: Overall, 1881 patients were randomized in 37 countries (ASCLEPIOS I, N=927; ASCLEPIOS II, N=954). Baseline characteristics of ASCLEPIOS and II were consistent and poolable. Ofatumumab demonstrated significant reduction in ARR (-50.5\% and $-58.5 \%$ in ASCLEPIOS I and II). In prespecified pooled analyses, ofatumumab showed significan reductions in 3 - and 6 -month confirmed disability worsening $(-34.4 \%,-32.5 \%) .97 .5 \%$ and $93.8 \%$ reductions of $\mathrm{Gd}+$ lesions were observed in ASCLEPIOS I and II. Overall, a favorable safety profile with $\mathrm{n}$ unexpected safety signals was confirmed in ofatumumab. There was no imbalance between ofatumumab and teriflunomide in the rates of infections or malignancies. The most common adverse event was injection-related reaction (20.6\% in ofatumumab vs $153 \%$ in teriflunomide). Conclusion: Ofatumumab with monthly $20 \mathrm{mg}$ sc dosing regimen, demonstrated high efficacy and a favorable safety profile.
0-31-5 Benefit of eculizumab for a broad range of patients with NMOSD: findings from the PREVENT study

OIchiro Nakashima ${ }^{1}$, Kazuo Fujihara ${ }^{2.3}$, Achim Berthele ${ }^{4}$, Ho Jin Kim ${ }^{5}$, Michael Levy ${ }^{6,7}$ Celia Oreja-gueva, Jacqueline Palace, Sean J. Pittock ${ }^{10}$, Murat Terzi ${ }^{11}$, Natalia Totolyan ${ }^{12}$, Shanthi Viswanathan ${ }^{13}$, Kai-chen Wang ${ }^{14,15}$, Amy Pace ${ }^{16}$, Marcus Yountz ${ }^{16}$, Larisa Miller ${ }^{16}$, Imran Tanvir ${ }^{16}$, Róisín Armstrong ${ }^{16}$, Dean M. Wingerchuk ${ }^{10}$

${ }^{1}$ Tohoku Medical and Pharmaceutical University, Japan, ${ }^{2}$ Tohoku University, Fukushima Medical University, ${ }^{4}$ Technical University of Munich, ${ }^{5}$ Research Institute and Hospital, Goyang, ${ }^{6}$ Johns Hopkins University, ${ }^{7}$ Massachusetts General Hospital, ${ }^{3}$ Hospital Universitario Clínico San Carlos, ${ }^{9}$ John Radcliffe Hospital, ${ }^{10}$ Mayo Clinic,

${ }^{11}$ Ondokuz Mayis University, ${ }^{12}$ First Pavlov State Medical University of

St Petersburg, ${ }^{13}$ Kuala Lumpur Hospital, ${ }^{14}$ Cheng-Hsin General Hospital,

${ }^{5}$ National Yang Ming University, ${ }^{16}$ Alexion Pharmaceuticals

OBJECTIVE To determine whether the beneficial effect of eculizumab (ECU) in reducing relapse risk in patients with aquaporin-4 immunoglobulin G-positive neuromyelitis optica spectrum disorder (NMOSD) in the phase 3 PREVENT trial (NCT01892345) was observed across subgroups defined post hoc by baseline disease characteristics. METHODS Patients received ECU (maintenance dose $1200 \mathrm{~m} / 2$ weeks) or placebo, with stabledose concomitant immunosuppressive therapy (IST) permitted (except rituximab and mitoxantrone). A post hoc descriptive analysis was performed on subgroups defined by time since diagnosis, total number of historical relapses, baseline expanded disability status scale (EDSS) score and prior IST use. RESULTS The proportion of patients experiencing an adjudicated relapse were lower with ECU than with placebo in all subgroups. Proportions for ECU and placebo, respectively, were: $2 / 31$ versus $6 / 12$ for $<1$ year since diagnosis and $1 / 6$ versus $14 / 35$ for $\geqq 1$ vear since diagnosis; $1 / 39$ versus $10 / 24$ for 24 historical relapses and $2 / 57$ versus $10 / 23$ for $\geqq 5$ historical relapses; $0 / 14$ versus $3 / 6$ for baseline EDSS scores $\leqq 2.0$ and $3 / 82$ versus $17 / 41$ for baseline EDSS scores 2.57.0; and 0/15 versus $2 / 5$ for no prior IST use (except corticosteroids alone) and $3 / 81$ versus 18/42 for prior IST use. Relapse-risk reductions were consistent and statistically significant in all subgroups. CONCLUSIONS This post hoc analysis suggests that ECU reduced relapse risk in PREVENT compared with placebo, regardless of time since NMOSD diagnosis, relapse history, disability burden or prior IST use.

\section{0-31-7 ROPALS trial based on the iPSC drug repositioning for ALS: baseline profiles of trial participants}

Shinichi Takahashi ${ }^{1,2}$, Satoru Morimoto ${ }^{2}$, Kensuke Okada ${ }^{3}$,

Yugaku Daté, $e^{3}$ Daisuke Ito ${ }^{3}$, Jin Nakahara ${ }^{3}$, Hideyuki Okano ${ }^{2}$

${ }^{1}$ Department of Neurology and Stroke, Saitama Medical University

International Medical Center, Japan, ${ }^{2}$ Department of Physiology, Keio

University School of Medicine, Japan, ${ }^{3}$ Department of Neurology, Keio

University School of Medicine

Objectives In December 2018, we started an investigator-initiated clinica trial testing ropinirole hydrochloride in ALS patients. This is a phase I/IIa randomized, double-blind placebo-controlled, open-label continuation clinical trial (UMIN000034954). The primary aim is to assess the safety and tolerability of ropinirole hydrochloride in patients with ALS. Secondary aims include evaluations of effectiveness: ALSFRS-R, quantitative muscle strength, muscle volume, survival, and ALSAQ40 scale. We will also perform an efficacy evaluation using subjectsderived iPSCs/motor neurons. Methods The major inclusion criteria were: 1 ) "clinically possible and laboratory-supported ALS", "clinically probable ALS" or "clinically definite ALS" according to the criteria for the diagnosis of ALS (El Escorial revised) and within 60 months after disease onset; 2) Grade 1 or 2 according to the ALS Severity Classification; 3) Japanese patients between 20 and 80 years of age; 4) ALSFRS-R score $\geqq 2$ points for all items; 5$) \% \mathrm{FVC} \geqq 70 \%$; and 6) change in ALSFRS-R score of -2 to -5 points during the 12 -week run-in period. Results A total of 29 patients have been recruited; 21 of these patients (13 men) are enrolled in the 24 -week double-blind phase. At enrollment, the mean $+/-\mathrm{SD}$ disease duration was $20+/-11$ months. ALSFRS-R score was $40+/-3$, with a mean reduction of -3 points. Finally, 15 patients were assigned to the active drug and 5 patients to the placebo. The results will be known in March 2021. Conclusions Our trial will be a touchstone trial for iPSC-based drug development strategies.

\section{0-31-9 Pooled analysis from the SAkura trials with} satralizumab in neuromyelitis optica spectrum disorder

Jerome De Seze ${ }^{1}$, Brian G. Weinshenker ${ }^{2}$, Yusuke Terada ${ }^{3}$,

Yuichi Kawata ${ }^{3}$, Athos Gianella-borradori ${ }^{4}$

H.-christian Von Büdingen ${ }^{5}$, Gaelle Klingelschmitt ${ }^{5}$,

Anthony Traboulsee ${ }^{6}$, OTakashi Yamamura ${ }^{7}$

${ }^{1}$ Hôpital de Hautepierre, France, ${ }^{2}$ Mayo Clinic, ${ }^{3}$ Chugai Pharmaceutical Co., Ltd, Tokyo, ${ }^{4}$ Chugai Pharma USA LLC, ${ }^{5} \mathrm{~F}$. Hoffmann-La Roche Ltd, ${ }^{6}$ University of British Columbia, ${ }^{7}$ National Center of Neurology and Psychiatry

Objective To evaluate satralizumab for neuromyelitis optica spectrum disorder (NMOSD) using pooled data from the SAkuraSky (NCT02028884) and SAkuraStar (NCT02073279) Phase 3 studies, which combined provide a large data set for analysis. Methods Patients were randomized 1:1 (SAkuraSky) or 2:1 (SAkuraStar) to satralizumab $(120 \mathrm{mg}$ ) or placebo administered at Weeks 0, 2, 4, and Q4W thereafter. Study drugs were given as monotherapy (SAkuraStar) or add-on to baseline immunosuppressants (SAkuraSky). The primary endpoint of both studies and the pooled analysis was time to first protocol-defined relapse (PDR). Efficacy analyses were performed on the pooled intention-to-treat population. Between-group HRs for time to PDR were calculated based on Cox proportional hazards models, stratified by study. Results Satralizumab significantly reduced risk of PDR in both trials. The pooled analysis included 104 patients on satralizumab and 74 on placebo. HR for time to first PDR was $0.42(95 \%$ CI $0.25-0.71 ; 58 \%$ risk reduction vs placebo). For AQP4-IgG seropositive patients, the $\mathrm{HR}$ was 0.25 ( $95 \% \mathrm{CI} 0.12-0.50 ; 75 \%$ risk reduction); in the seronegative group, the $\mathrm{HR}$ was 0.97 (95\% CI 0.41-223). No interaction was observed between the individual studies and treatment effect, confirming the validity of pooling the data. Incidence of adverse events was similar across groups; no deaths or anaphylactic reactions were reported. Conclusions This pooled analysis from the SAkura studies demonstrates the efficacy and favourable safety profile of satralizumab in reducing relapse risk in patients with NMOSD. 


\section{0-32-1 軽症脳梗塞・TIA患者における包括的脳小血管障害と 認知機能低下: HAGAKURE study}

○星野 有紀 ${ }^{1} 、$ 藥師寺祐介 ${ }^{1} 、$ 田中 淳、西原 正志 ${ }^{2}$ 江里口 誠 ${ }^{1} 、$ 吉川 正章 ${ }^{1}$ 、飯田絋太郎 1 、香月 美子 ${ }^{1}$ 、原 英夫

'佐賀大学医学部内科学講座脑神経内科、 ${ }^{2}$ 佐賀大学医学部 放射線科

【目的】近年, 脳小血管障害を包括的に捉える指標としてラクナ有無, 脳微小出血 するtotal SVD scoreが提唱されているが，本スコアと認知機能評価との関連の 報告は少ない，今回我々は，軽症虚血性脳卒中患者におけるtotal SVD score と 涊知機能の関連を調べた【方法JHAGAKURE研究（UMIN000037894）のサブコ ホート研究として行った．エントリー基準は1）2012年9月から2015年9月までの 期間に脳卒中患者の中で研究に同意の得られた虚血性璃卒中 (TIA含む),2) 初発脳 卒中,3) 入院時NIHSS $<5$ とした. 除外基準は入院から 90 日以内にMRI と認知機能 評価が遂行不能だったもの, MRI評侕が完全にできないものとした，認知機能検 查はMMSE,MOCA-Jを 1 名の専門看護師が行った, Total SVD score評洒は, ト レーニングを受けた 3 名の医師により行われ, score 0-4群に分けられた. 各群間 のMMSE・MOCA-J值の差について,ANOVA,順序回㷌分析で梌証した.I結果I対 MOCA-Jの平均值は, score0群 (23名) 28.4/25.8, score1群（28名）28.0/24.4, score2 群（29名）25.3/20,8, score3群（21名）24.3/20.0, score4群（23名）23.7/19.9で, 各群 間に差が見られ（ANOVA, $\mathrm{p}<0.001)$ 多重比較梌定（Dunnett T test）では各々の 点数は共にscore 0群に比し, score2,3,4群で有意に低かった。多変量順序回帰分 析では total SVD score上昇はMMSE低下に関連し（ $\beta=-0.11,95 \% \mathrm{CI}-0.19 \sim-0.02)$ MOCA-Jでは関連の傾向が見られた $(\beta=-0.06,95 \%$ CI $-0.12 \sim 0.01)$.[結論]軽症脑卒 中患者において, total SVDスコア上昇は認知機能低下に関連した。特にscore2以 上では有意な低下が見られ，潜在するSVD関連認知機能障害の関与が疑われる。

\section{0-32-3 取り下げ演題} 鈴山 耕平、溝口 恵、七條千佳、永石友公子! 井手 俊宏、 有無, 白質病変重症度, 基底核领域血管周囲腿拡大重症度の 4 項目により定性化 象は124例（年齢:中央值70歳，男性70\%) であった. Total SVD score別のMMSEと

\section{0-32-2 骨髄増殖性腫瘍におけるJAK2 遺伝子変異と脳血管障 害の関係についての検討}

$\bigcirc$ 大山 直紀 ${ }^{1}$ 岩本 高典 ${ }^{1}$ 谷本 慧太 ${ }^{1}$ 合田 敏章、山田 聖子、 近藤 敏範 2 和田 秀穂 ${ }^{2} 、$ 八九田佳樹 ${ }^{1}$

'川崎医科大学病院脳卒中医学、 ${ }^{2}$ 川崎医科大学病院 血液内科学

【目的】近年遗伝子解析技術の飛躍的な進歩に伴い、血液腫揚と関連のある遗伝子 変異と動脈硬化性疾患との関連性が指摘されてきている。中でも骨野增殖性腫惶 でしばしば認められるJAK2遗伝子変異と冠動脈疾患との関係が指摘されており、 本研究では、JAK2遗伝子変異と脳血管障害との関係について検討することを目 的とした。【方法] 2000 年 4 月から 2019 年 6 月までに当院血液内科において骨㖪增殖

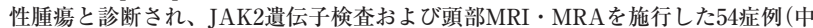
央値69藏、男性34例) を対象とし、患者背景や採血デー夕、脳血管障害の有無（有 りの場合は臨床病型)、血管病変の有無について後方視的に换討した。[結果】骨链 增殖性腫嚎はそれぞれ、本態性血小板血症36例、真性赤血球增加症13例、原発性 骨颗線維症5例であり、JAK2遗伝子変異は38例に認められた。JAK2遗伝子変異 陽性群では、18例（47\%）に脳血管障害を認め、うちアテローム血栓性腷梗塞が最 多で7例、心原性脳塞栓症1例、ラクナ梗塞2例、その他の脳梗塞5例、TIA1例、脳 出血2例であった。一方、JAK2遺伝子変異陰性群では、3例 (19\%) に脳血管障害を 認め、アテローム血栓性脑梗塞、その他の腷梗塞、TIAが各1例ずつ認められた。 また、JAK2遗伝子変異陽性群では、頭蓋内脳動脈狭窄を 18 例 (47\%) 認め、同遗伝 子変異除性群では3例（19\%）であった。JAK2遗伝子変異陽性群では陰性群に比し 有意に白血球数が高值であったが、血小板数に有意差はなく、年踚や動脈硬化危 険因子の頻度にも有意差は認められなった。結論IJAK2 遗伝子変異と頭蓋内脳動 脈狭窄や脑梗塞 (特にアテローム血栓性脳梗塞) との関連性が示唆された。

\section{0-32-4 悪性腫瘍合併脳梗塞患者に対する長期ヘパリンカルシ ウム自己注射の有効性と安全性}

岩永 健 ${ }^{1,2}$ 、岡田 博 1 、八木田佳樹 ${ }^{2}$

阙山赤十字病院 脳卒中科、 ${ }^{2}$ 川崎医科大学 脳卒中医学教空

【はじめに】進行期の悪性腄湯に合併した䏚梗塞では非細菌性心内膜炎（nonbacterial thrombotic endocarditis: NBTE) を含め塞栓症を繰り返す症例が存在す る。こうした患者では、以前は生命予後が非常に鱿かったが、近年の免疫チエッ クポイント阻害薬など新規の癌治療薬の登場で、治瘉はしないものの長期間生存 できるようになってきた。一方で䏚梗塞を再発すると癌治療が困難となることが 多く腷梗塞再発予防はこれまで以上に重要となっている。目的/方法】当院におい て鱼性腫愓に脳梗塞を合併しへパリンカルシウムを用いて脳梗塞再発予防を行っ た患者を対象として、有効性としての䐉梗塞再発予防ならびに安全性として出血 性合併症を後乃向きに調查した。【結果17名の患者（女性4名、平均年龄 22 歳）にへ パリンカルシウムを導入した。導入理由は3名でNBTEを診断（経食道心エコーで 疮贅同定）し、3名で治療中に再発（1名は抗血小板薬、2名は抗凝固薬）したため であった。経過中へパリンカルシウムを中止したのは腫愓切除による治瘾（1名）、 原疾患による死亡 (1名)、消化管出血 (1名)だった。ペリンカルシウム治療中に 1名が網膜虚血を起こし、同患者では自己注射部位に2度の皮下出血をきたした。 ヘパリンカルシウム治療中は前記の網膜虚血以外には腷梗塞をはじめ虚血性イベ ントなく癌治療を継続している。(平均治療期間404日) いずれの患者でもへパリン カルシウム導人前はDダイマーが高く (平均11.9) Dダイマーの正常化を目指してへ パリンを調整した。癌がコントロール困難な時期に出血しAPTTは延長 (平均 90.1 秒)していた。【結論】へパリンカルシウムによる抗㠜固療法は、脳梗塞を再発しゃ すいと考元られる患者に扔いて、虚血性イベントを防ぐことで、癌治療の継続が 可能であった。一方で出血性合併症をきたしやすいことを念頭に执き定期的な採 血による調整が重要である。

\section{0-32-6 急性期脳出血患者におけるcerebral microbleedsの特徵}

\section{O-32-5 急性期脳梗塞患者における尿中lgGは微小脳出血数の 関連因子である}

\author{
○小松 鉄平、幕 昂大、茂木 晴彦、高橋 麻葵、秋山 志穂、 \\ 佐藤 健朗、高津 宏樹、坂井健一郎、梅原 淳、大本 周作、 \\ 村上 秀友、豆村 秀毅、宑口 保之 \\ 東京慈恵会医科大学病院 神経内科
}

【目的】微小脳出血と慢性腎胹病 (CKD) や微量アルブミン尿との関連は知られてい るが，高分子量蛋白であり糸球体障害の指標になる尿中 $\operatorname{IgG} と の$ 関連は不明であ る. 尿中IgGと微小脑出血との関連を检討する。【方法】2018年10月から2019年10 月まで当科に入院し、来院時頭部MRIで梗塞宩を認めた発症7 日以内の急性期脸 梗塞連続162例を後乃向きに調查した。 e GFR $45 \mathrm{ml} / \mathrm{min} / 1.73 \mathrm{~m}^{2}$ 以上 (CKD重症度 分類G1〜3a) の早期腎症を抽出し，入院時MRI-SWIにより微小脳出血なし，1-2個 (少数), 3 個以上 (多数) の3群に分け, 微小腷出血数に関連する因子を検討した.【結 果] 126例（女性35例, 年齢中央值68藏, 入院時NIHSS中央値2, eGFR中央值 $71 \mathrm{ml}$

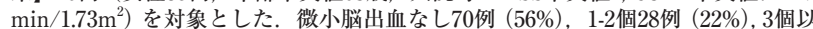
上 28 例 $(22 \%$ であった．微小脳出血数と eGFR ( 75 vs 73 vs $67, \mathrm{p}=0.24)$ に関連はな かったが，尿中IgG陽性に関連を認めた ( $4 \%$ vs $7 \%$ vs $25 \%$, p $=0.01)$. 【結論急性 期脳梗塞患者に拄ける尿中IgG陽性は微小脳出血数の関連因子である.

【目的】Cerebral microbleeds (CMBs) は、脳出血リスクのマーカーであることが

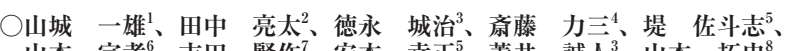

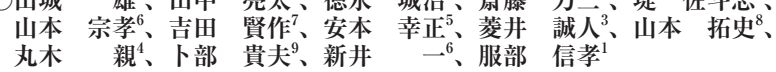

${ }^{1}$ 順天堂大学医学部附属順天堂医院脳神経内科、

2 自治医科大学内科学講座神経内科部門、 ${ }^{3}$ 順天堂大学練馬病院脳神経 外科、 ${ }^{4}$ 越谷市立病院脳神経外科、5 順天堂大学浦安病院脑神経外科、 ${ }^{6}$ 順天堂大学医学部附属順天堂医院媨神経外科、7 都立広尾病院脳神経外科、

順天堂大学静岡病院脳神経外科、䫚天堂大学浦安病院脑神経内科 知られている。本研究の目的は、急性期脳出血患者におけるCMBsの特徽を明ら かにすることである。【方法】2016年10月から2019年6月までに多施設共同の登録 研究であるJ-ICH研究に登録され、頭部MRI T2*画像によりCMBsについて評価し た連続例354名の急性期脳出血患者を対象に解析を行った。【結果】CMBsは204名 (57.6\%) に認め、部位別では樑部型24.0\%、脳葉型19.2\%、混合型14.4\%であった。 皮質出血 (92名) と深部出血 (262名) におけるCMBsの頻度 (64.1\% vs 55.3\%) に差は 認めなかったが、部位別では脳葉型（38.0\% vs $12.6 \%, \mathrm{p}<0.01 ）$ と深部型（6.5\% vs $30.2 \%, \mathrm{p}<0.01)$ で有意差を認め、混合型（19.6\% vs $12.6 \%)$ には差を認めなかった。 CMBsあり群とCMBsなし群の比較では、腎機能障害 $\left(\mathrm{eGFR} 60 \mathrm{~mL} / \mathrm{min} / 1.73 \mathrm{~m}^{2}\right.$ 未満)の頻度に有意差を認めたが ( $27.5 \%$ vs $17.3 \%, \mathrm{p}<0.05)$ 、年齢や性別、高血圧、 脳卒中の既往、発症前抗血小板薬および抗凝固薬使用の頻度には有意差を認めな かった CMBs部位別における㹂機能障害の頻度は、混合型33.3\%、脑葉型27.9\%、 深部型23.5\%であった。多変量解析では腎機能障害が独立してCMBsと関連した (オッズ比1.77、95\%信頼区間1.03 - 3.09、 $\mathrm{p}<0.05$ )。【結論】腎機能障害は急性期脳出 血患者におけるCMBsと関連していた。これらの結果より、腎機能障害を伴う患 者では脳出血リスクを考虑した治療の必要性が示唆された。腎保護によるCMBs 出現、さらには脳出血発症の抑制効果についてさらなる研究が必要である。 


\section{0-32-7 脳卒中患者の脳小血管病変と歯周病菌量の関連}

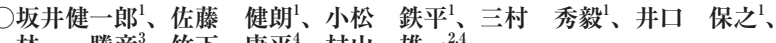

東京慈恵会医科大学病院 神経内科、

東京慈恵会医科大学病院 脳神経外科、 ${ }^{3}$ 東京慈恵会医科大学病院 歯科、

“東京慈恵会医科大学 総合医科学研究センター 先端医療情報技術部

【背景と目的】歯周病は動脈硬化や血栓傾向の進展と関連がある。歯周病菌の中で も、P.g.菌、T.d.菌、T.f菌の 3 種類（Red complex）は、歯周病原因菌として重要 である。本研究の目的は、䐉卒中患者のRed complex菌数と脳小血管病の関連性 について検討した。【方法】対象は2018年11月から2019年3月までに当院へ入院し た発症7日以内の脳卒中患者のうち、歯周病の検查を受けたものを対象とした。 歯周病菌数はサリバチェック®を使用し、唾液からリアルタイムPCR法でRed complex菌数を測定した。対象患者のRed complex総菌量に応じて3分位に分け (T1,T2,T3)、頭部MRI画像での脑小血管病変 (深部白質病変; Fazekas分類 2 以上 脳室周囲病変; Fazekas分類 2 以上, 微小出血の有無、ラクナ病変の有無）を各群て 比較した。【結果】 対象患者は26例（男性65\% , 年龄中央値56歳) で、脳梗塞 18 例、

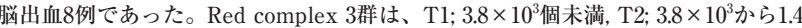
$\times 10^{5}$ 個, T3: $1.4 \times 10^{5}$ 個以上であった。脳小血管病の中で深部白質病変は3群間で 有意差を認めた（T1; $11 \%, \mathrm{~T} 2 ; 12 \%, \mathrm{~T} 3 ; 38 \%, \mathrm{p}=0.027)$ 。脳室周囲病変 $(11 \%, 12 \%$ $13 \%, \mathrm{p}=0.397)$ 、微小出血 $(44 \%, 44 \%, 25 \%, \mathrm{p}=0.643)$ 、ラクナ病変 $(0 \%, 22 \%, 25 \%$, $\mathrm{p}=0.283$ ) は3群間で有意差を認めなかった。[結語】 Red complex総菌数が多い急性 期脳卒中例は、高度の深部白質病変を認める。 林 勝彦、竹下 康平、村山 雄- 2.4

\section{0-32-8 担癌患者における脳梗塞の臨床的特徵と抗凝固療法お よび予後の検討}

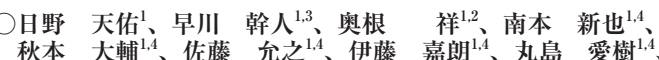
秋本 大輔1,4佐藤 允之 ${ }^{1,4}$ 、伊藤 嘉朗 1,4 、丸島 愛樹1,4 松丸 祐司 ${ }^{1,3}$

${ }^{1}$ 筑波大学病院 脳卒中科、 ${ }^{2}$ 筑波大学 医学医療系 脳神経内科、 ${ }^{3}$ 筑波大学 医学医療系 脳卒中予防・治療学講座、 ${ }^{4}$ 筑波大学 医学医療系 脳神経外科

【目的】癌を合併した脳梗塞の臨床的特徵および抗凝固療法と予後の関連を明らか にすること.【方法】2017年4月〜2019年8月の間，当院に入院した 403 例の脳梗塞 患者のうち併存疾患に癌がある 22 例を対象に臨床的背景, 発症前抗凝固療法, 急 性期治療，二次予防に関して後方視的に調查し３力月以内の脳梗塞再発または 死亡を予後不良，それ以外を良好と定義し，2群間比較した.【結果】年齢は70（5278) 歳;中央值 (四分位点), 初診時NIHSS 5 (2-12) で病前 mRS 0 が15例 (68\%), 卵 巣癌・子宮体癌など婦人科癌が10例 $(45 \%)$, TOAST分類では心原性 $4 /$ アテロー ム血栓性1/ラクナ1/Cryptogenic stroke16例で, Large vessel occlusion (LVO) が8例 (36\%) でみられた。10例 (45\%) でDVTが先行または併発し，9例 (41\%) が直 接抗凝固療薬 (DOAC) 内服中の発症であった。 tPA / 血栓回収は $1 / 3$ 例で施行, 16 例 $(73 \%)$ が急性期にヘパリン持続点滴で加療され，二次予防はヘパリンCa皮下注 と/DOACが共に6例 (27\%) ずつ選択された。予後不良群 $(\mathrm{n}=9)$ は全例Cryptogenic strokeで，良好群 $(\mathrm{n}=12)$ と比較してD-dimerが18 (7-21) vs2 (1-6) $\mu \mathrm{g} / \mathrm{ml}$ と有意に 高く $(\mathrm{P}=0.015)$ ，先行/併発DVT $7(70 \%) \mathrm{vs} 3(25 \%) \quad \mathrm{P}=0.083$ と，LVO $6(67 \%)$ vs2 (17\%) P=0.087が多い傾向にあった二一次予防(ヘパリンCa皮下注/DOAC) は 両群間で有意差がなかった. ( 3 カ月月後デー夕無 $\mathrm{n}=1)$ 【結論】担癌患者の脳梗塞は高 率にDVTが先行/併存し，DOAC内服中でも発症する可能性があり，D-dimerが 予後不良群で高値であった。

\section{O-32-10 当院におけるTrousseau症候群に伴う脳梗塞患者 14 例の臨床像の検討}

\section{0-32-9 新しく考案した脳梗塞患者でのAF予測スコアの臨床 的検討および既報告スコアとの比較}

今中 翔平、山本 真義、松本 禎之、里井斉

(公財) 田附興風会 医学研究所 北野病院

【目的】最近幾つかのAF予測スコアが報告されているが,より臨床的に使いやすい AF予測スコアが望まれる.【方法]2010年6月２019年1月までの当院脳神経内科の脑 梗塞入院患者を対象とした.信頼できる検査者による心エコーの施行例を対象とし, 最終的に1488例が該当した.AFの有無は退院時点の臨床情報で判断した.既報告の STAFscoreに着目しょり精度の高いAFの予測スコアの作成を試みたSTAFscor のvascular etiologyの有無の部分を心エコーにおけるE/e'比の8.04と11.0を cut off (Araiらの報告による) とした因子およびred cell distribution width (RDW)\%の 13と14と14.6を cut off (Malavasiらの報告による) とした因子に置き換えることで 5種類の新たなスコアを作成した. 既報告のLADSスコアについても検討した.【結 果】NINDS-CVD3分類に基づき心原性242例（AF+218,AF-24）、アテローム血检性 862例 $(\mathrm{AF}+52, \mathrm{AF}-810)$,ラクナ340例 $(\mathrm{AF}+16, \mathrm{AF}-324)$,その他44例 $(\mathrm{AF}-44)$ に分類 した.E/e'を用いた新たなスコアは,症例全体でSTAFscoreに比してAFの予測因子 として劣っていたが (AUC $=0.710$ of 8.04 cut off value,AUC $=0.686$ of 11.0 cut off value,AUC $=0.770$ of the original),RDW\%を用いた新たなスコアとLADSスコアは, AFの予測因子としてSTAFscoreに非劣性を示した（AUC $=0.783$ of $13.0 \%$ cut off value,AUC $=0.749$ of 14.0 cut off value,AUC $=0.757$ of 14.6 cut off value) 一方でア テローム血栓性脳梗塞とラクナ梗塞 1202 例においてE/e'を用いた新たなスコアと LADSスコアは,元のSTAFscoreおよびRDW\%を用いた新たなスコアに対して非劣 性あるいは優位性を認めた.!結論]RDWやE/e'などの定量的なパラメー夕を用い たスコアが臨床的に有用である可能性が示唆された.また脳梗塞患者において,特に アテローム硬化性機序が推定される相対的にNIHSSが低值の脳梗塞においては, e'およびE/e'を用いたスコアが良いAF予測因子となる可能性がある。

\section{O-33-1ＤPAA暴露は脳老化を促進する可能性がある}

○石井 一弘 ${ }^{1}$ 、根本 清貴 ${ }^{2}$ 、岩崎 信明 ${ }^{3}$ 、中山 智博 ${ }^{3}$ 柴田 康行 ${ }^{4}$ 、 增田 知之, 1,5 根本 広文、增本 智彦 7 、王岡 晃 ${ }^{1}$ ${ }^{1}$ 筑波大学病院 神経内科、 ${ }^{2}$ 筑波大学病院 精神科、 ${ }^{3}$ 茨城県立医療大学病 院 小児科、 ${ }^{4}$ 国立環境研究所 化学環境研究領域、 ${ }^{5}$ 筑波大学 解剖学、

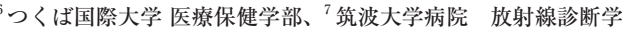

【目的】2003年茨城県神栖市で毒ガス原材料であるDPAAの不法投裹による飲用地 下水污染が発覚し, 地域住民157名が経口からDPAA暴露を受けた。症候は小脑 脳幹症状 (振戦, 失調性歩行, 眼振など) と側頭・後頭葉症状 (記憶障害, 視覚異常など) である. 昨年度, DPAA暴露中止から 1 年以内の脳血流変化を統計画像解析により 明らかにしたが DPAA暴露による䈪血流に及ぼす長期影響については調べられて いない. 本研究は健常加龄変化を考慮しながらDPAA暴露後11年経過した脳血流変 化を統計画像解析して, DPAA暴露による長期間経過後の脳血流変化を明らかに することを目的とした、【方法】暴露中止から 13 年間以上に亘り脳血流SPECTを追 跡し得たDPAA暴露者51名を対象にし，同じく11年前に健常対照者として研究参加 し，再同意を得た 20 名を長期観察健常対象者とした。DPAA暴露群は急性期の影響 が無くなった 3 年目以降の ${ }^{123} \mathrm{I}$-IMP脳血流SPECTの画像デー夕を用いた. DPAA暴 露群と健常対照群間の年齢·性別·教育歴等を比較した. 統計画像解析はSPECTデー 夕処理をSPM1 2 と 3D-SSP処理の異なる方法で実施し、健常群で見られた加齢変化 を考慮して, DPAA暴露群の約11年後の血流変化部位をFlexible factorital design を用いて縦断解析した.【結果】SPM12および3D-SSP処理による統計画像解析でほ ほ同様の結果が得られた。すなわち, DPAAによる初期に傷害が認められた後頭葉, 小脳部位である小脳虫部，右上後頭回，右紡鍾状回に血流低下が見られた．さらに 右楔前部, 左楔部の有意な血流低下も認めた。この血流低下脑部位はアルッハイマー 型認知症 $(\mathrm{AD})$ で血流低下する部位に一致しており, 脳内でAD様の病理変化が生 じている可能性が示唆された.【結論】DPAA曝露中止後13-14年後に脳血流SPECT の統計画像解析から，DPAA暴露による脳の加齢促進が考えられた．本研究は単一 の環境污染物質による老化促進現象が証明された初めての報告である。
末廣 大知 ${ }^{1} 、$ 上田 健博 ${ }^{1}$ 立花 久嗣 $^{1}$ 荒末 健 $^{1}$ 的場 健人 ${ }^{1}$

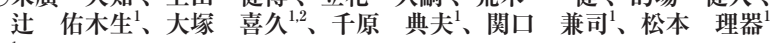
${ }^{1}$ 神戸大学大学院医学研究科 脳神経内科学、

兵庫県立尼崎総合医療センター 脳神経内科

【目的】Trousseau症候群を発症した担癌患者の予後は一般的に不良であり，診断時点 からの適切な終末期医療が望まれる，適切な診断・治療方針・予後の推定を行うこ とが必要であるが, 本邦においてTrousseau症候群を多数例で検討した報告は少な く, ガイドラインも提唱されていない. 今回, 我々はTrousseau 症候群に伴う脳梗 塞患者の臨床像について, 報告の少ない治療内容を含め検討した.【方法】2015年4月 ～2019年9月の間，当科で入院精查加療を受けた14例の臨床像を後方視的に調査した Trousseau症候群は, 「悪性腫陽に伴う㠜固能立進状態求よび非細菌性血栓性心内膜炎 などに起因する塞栓症」と定義した【結果】患者の平均年齢は71.4 (51～87) 歳, 性別 は男性10例であった。頭部MRIで脳梗塞巣は大脳(前大脳動脈領域6例，中大脳動脈領 域11例, 後大脳動脈領域8例) と小脳領域 (8例) に散在した. D-dimer值は平均值15.0 (0.9 〜 53) $\mu \mathrm{g} / \mathrm{mL}$ 高值であった。悪性腫瘍の種類は肺癌が9例，胃癌が 1 例，子宮頚癌 が 1 例，中咽頭癌が 1 例，膵癌が 1 例，胆囊癌が 1 例，分類は I 期 2 例，III 期 3 例，IV期 6 例, 不明が3例であった，悪性腫演骖断から脳梗塞発症までの期間は，I 期の平均 30 ケ月 に対し，III期では，1〜36ヶ月，IV期では，0〜36ヶ月であり，進行期では短期間で脳 梗塞を発症する例もあった。 入院時NIHSSの中央值は $4.5(0 \sim 20)$ であった。脳梗塞の 二次予防にヘパリン皮下注射，DOAC，ワルファリンを用いた。 IIIまたはIN期の患 者における使用例はそれぞれ $6,5,1$ 例であり，二次予防開始後 1 ケ月以上再発を予防で きた例はそれぞれ2,2,1例であった，脳梗塞発症後の生在期間は最長で10ケ月，最短例 は17日と予後不良だった.【結論】2015年以降の解析であり既報告よりもDOAC使用の 頻度が高かったが, 進行期の担癌患者においては治療薬の選択による脳梗塞再発に明 らかな差はみられず，患者ごとに適切な薬剤を選択する必要があると考えられた。

\section{0-33-2 正常圧水頭症 (iNPH) の鑑別診断におけるDaT- SPECTの有用性の検討}

森本 展年、高橋 義秋、森本みずき、高宮 資宜

香川県立中央病院 脳神経内科

【目的】特発性正常圧水頭症 (iNPH) は高齢者における認知機能障害、歩行障害の鑑 キンソン病などの変性疾患が合併している場合は外科的治療の効果がそしく、術 ンソン症候群の診断における重要な脳機能画像検査として広く普及し、パーキン ソニズムを示す様々な疾患の診断に応用されている。今回我々はiNPHとパーキン ソン病の鑑別診断におけるDaT-SPECTの有用性について検討した。【方法】当院に てタップテストによる改善もしくはドレナージ手術による改善をみとめ診断が碓 定したiNPHの患者13名のDaT-SPECTについて、線条体専用解析ソフトを用いて 線条体Specific Binding Ratio (SBR) とDistribution Volume Ratio (DVR) を算出 した。本態性振戦 (ET) 21名、パーキンソン病 (PD) 71名を比較対照群として検討 した。検查の有用性についてはROC解析を行った。結果】iNPH群における線条体 SBRおよびDVRはPD群に比して有意に高值であり $(\mathrm{p}<0.01) 、$ 線条体への集積が 保たれる傾向が示された。ETとの比較ではiNPH群で集積低下を認めた $(\mathrm{p}<0.01)$ 。 DVRのROC解析では、iNPHとPD間のカットオフを 2.77 以上とした場合は感度 100\%、特異度86\%であった。iNPHとET間ではカットオフを 3.31 以下とした場合 は感度 $69 \%$ 、特異度 $86 \%$ あ゙った。結論】DaT-SPECTはiNPHの診断、とくにパー キンソン病との鑑別診断において有用である可能性が示された。 別において重要な疾患である。画像的にはiNPHの特徵を呈していても、背景にパー 前に治療効果を予測するための精查が重要である。近年、DaT-SPECTはパーキ 


\section{0-33-3 筋萎縮性側索硬化症 (ALS) の治療研究 : wobbler ウスを用いた実験と治験との対比検証}

○池田 憲 ${ }^{1} 、$ 岩崎 泰雄、三本 博 ${ }^{2}$

東邦大学医療センター大森病院 神経内科、 ${ }^{2}$ 米国コロンビア大学 神経内科

【目的】運動ニューロンの変性が生じるwobblerマウスを用いた治療研究を1992年 から行ってきた、ALS患者に対する二重盲検試験を米国や本邦で実施に至った神 経栄養因子のCNTFとBDNF, edaravone, methylcobalaminのマウス実験結果を 後ろ向きに検討し, 実際にALS患者の治験の方法や結果との差異を検証した.【方 法】体幹ふるえで発病した直後の3-4週齢から4週間後まで以下の薬物を投与した. 治療効果は前肢の変形と筋力低下, 病理学的にC5-6の春䯣運動神経と末梢神経, 上腕二頭筋を定量的に評価した。治療薬は1) CNTF (1 mg/ kg), BDNF (5 mg/ $\mathrm{kg}$ ）を単独で3回/週，両者を交互に3回/週，皮下投与. 2) Edaravone (1 mg/ kg と $10 \mathrm{mg} / \mathrm{kg})$ の連日腹热内投与. 3) Methylcobalamin $(3 \mathrm{mg} / \mathrm{kg}$ と $30 \mathrm{mg} / \mathrm{kg})$, 連日 腹柼内投与した。【結果】実験結果：CNTF，BDNF，高用量のedaravone，高用 量のmethylcobalaminは前肢の運動機能障害と春䯣神経筋の病理学的所見を軽減 した。特にCNTF/BDNF併用療法が最も著効した。臨床試験と差異：ALS患者の 治験はCNTF $(0.5,2,5 \mu \mathrm{g} / \mathrm{kg}), \operatorname{BDNF}(25,100 \mu \mathrm{g} / \mathrm{kg})$ の連日皮下注は無効であっ

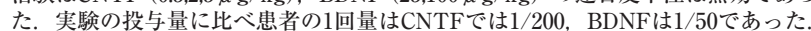
併用療法は実施されなかった。本邦と米国で承認されたedaravone治療は $30 \mathrm{mg}$ 2 回/日 (約 $1 \mathrm{mg} / \mathrm{kg} /$ 日), 14 日間/月で, wobblerマウス実験の有効量の $1 / 10$, 月 間投与量は1/2であった。現在治験中であるJETALSのmethylcobalaminは $50 \mathrm{mg}$

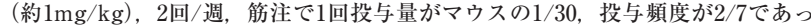
た。【結語】今回, ALS患者の臨床試験の結果とwobblerマウスを用いた同薬剤の 用量, 投与法を後ろ向きに検証した. 1990年代に行った神経栄養因子の動物実験 ではALS患者に実際に投与できない容量であった。本邦で行われたedaravoneと methylcobalaminのALS治験は動物実験の1回投与量と大差はなかった。 JETALS の有効な結果が切望される。

\section{0-33-5＼cjkstart新規急性期脳梗塞治療としての再生アソシエイト細胞 の可能性}

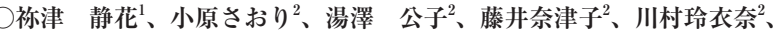
中山 平 ${ }^{2}$ 水間 敦士 2 増田 治史、浅原 孝之、永田栄一郎 ${ }^{2}$ 、 瀧澤 俊也 $^{2}$

東海大学大磯病院 神経内科、2 東海大学医学部付属病院 神経内科、 ${ }^{3}$ 東海大学医学部 生体構造機能学、 ${ }^{4}$ 東海大学医学部 再生医療科学

【目的】新規急性期脳梗塞治療として、我々が独自に開発した抗炎症・血管再生を 促進する培養系 (Quality and quantity $(\mathrm{QQ})$ culture) で培養した血管内皮前駆細 胞 (endothelial progenitor cell (EPC)) を含む単核球群 (再生アソシエイト細胞 : (regenerative associate cells (RACs)) を開発した。QQ培養では血管再生能の高 い質的・量的に優れたEPCを得られ、再生・抗炎症型マクロファージと制御性 $\mathrm{T}$ 細胞の増加による血管再生・抗炎症・免疫寛容効果の相互作用を生み出す"極めて 良好な血管再生環境をを形成できる。今回は急性期脳梗塞患者でのEPCを含む末梢 血単核球細胞群並びにRACsに関してのプロファイリングを検討した。【方法】当院 に入院した脳梗塞患者 39 名に対し、発症 24 時間以内・ $24 \sim 48$ 時間・ $48 \sim 72$ 時間・ 約10日後に末梢血を採取・QQ培養し、コロニー定量化・フローサイトメトリー (CD206、CD34、CD133)・サイトカインアッセイ (IL-10、TNF- $\alpha$ )でRACsの分化 動態を解析した。コントロール25名に対しても同様の解析を行った。【結果】脳梗 塞(Ischemic Stroke (IS)) 群とコントロール群で平均年齢、高血圧・糖尿病・脂質 異常症の既往に差はなかった。血管再生に寄与するLコロニーはIS群でコントロー ル群と同様に増加した。CD34・CD133陽性細胞の割合はQQ培養後で各群間に有 意差はなかった。CD206陽性細胞は、QQ培養後にIS群で有意に増加した。発症48 〜 72時間後のIS群で有意にIL-10上昇が見られたが、QQ培養後はIS群とコントロー ル群で差はなかった。【結論】急性期脳梗塞患者において、QQ培養により血管再生 能の高いRACsを得ることができたと考える。今後、RACsの自家移植へと慗げて 行きたい。

\section{0-33-7 Acute Stroke Team導入とシステム改善による血栓 回収療法例の搬入-再開通の時短効果}

\footnotetext{
○山崎 英一 ${ }^{1}$ 、森本 将史 2 、正田ちよ恵 ${ }^{2} 、$ 岩崎 充宏 ${ }^{2} 、$ 前田 昌宏 ${ }^{2}$ 、 井中 康史 ${ }^{2}$ 長澤 潤平 ${ }^{1}$ 、炎名 章仁、福田 慎也 ${ }^{2}$ 、佐藤 浩明 $^{2}$ 1 横浜新都市脳神経外科病院 脳神経内科・血管内治療科、 横浜新都市脳神経外科病院 脳神経外科
}

【目的】超急性期脳梗塞に対する血栓回収療法は迅速な再開通が重要である. 当院 では病院到着から再開通までの時間 (D2R) 短縮を目指して2016年1月からAcute Stroke Team (以下AST) を立ち上げた。多職種による院内協力体制を構築しシ ミュレーション研修や各症例で生じた問題点のフィードバックによるチーム力強 化とシステム改善を行ってきた。 システム改善として2018年11月にMRI撮像時間 の短縮と検查前にあらかじめ治療同意を取得することとしたＡST導入とシステ ム改善による時間短縮効果を検討する.【方法】2013年1月から2019年10月まで当院 で血栓回収療法を施行した院内発症例を除いた連続 332 例を対象とし, AST発足前 のpre AST群, AST発足後のpost AST群，システム改善後のpost system群の三 群に分類し, 各群において搬入から穿刺までの時間 (D2P), 穿刺から再開通ま での時間 (P2R), 搬入から再開通までの時間(D2R)を比較した.【結果】pre AST群 79例, post AST群166例, post system群87例であった. pre AST群/post AST 群/post system群においてD2Pの中央值は88/50/36分, P2Rの中央值は 63/42/41 分, D2R中央值は158/93/78分であった. AST導入, システム変更によりD2Pは52 分, D2Rが80分短縮できた【結語】ASTによるチーム力強化, システム改善は病院到 着から再開通までの時間短縮に有効であった.多職種が連携しアイディアを出し合 い実行することが重要である

\section{0-33-4 FIREFISH試験：脊髄性筋萎縮症 (SMA) I型患者にお けるリスジプラムの有効性及び安全性}

O竹島 泰弘、 Laurent Servais ${ }^{2}$ 、Giovanni Baranello ${ }^{3}$ 、

Maria Mazurkiewicz-Beldzinska ${ }^{4}$ Kristy Rose ${ }^{5} 、$ Dmitry Vlodavets ${ }^{6}$, Hui Xiong ${ }^{7}$.

Muna El-Khairi ${ }^{8}$,Sabine Fuerst-Recktenwald ${ }^{8}$, Marianne Gerber ${ }^{8}$, Ksenija Gorni ${ }^{8}$. Heidemarie Kletzl ${ }^{8}$ 、Renata Scalco ${ }^{8}$ 、八木下知子 ${ }^{9}$ 、Basil T. Darras ${ }^{10}$

${ }^{1}$ 兵庫医科大学小児科、 ${ }^{2}$ Reference Center for Neuromuscular Disease, Centre Hospitalier Régional de La Citadelle、 ${ }^{3}$ Carlo Besta Neurological Research Institute Foundation, Developmental Neurology Unit, ${ }^{4}$ Department of Developmental Neurology, Medical University of Gdansk, ${ }^{5}$ Paediatric Gait Analysis Service of New South Wales, The Children's Hospital at Westmead Sydney, ${ }^{6}$ Russian Children Neuromuscular Center, Veltischev Clinical Pediatric Research Institute of Pirogov Russian National Research Medical University、 ${ }^{7}$ Department of Pediatrics, Peking University First Hospital,

${ }^{8}$ F. Hoffmann-La Roche Ltd. ${ }^{9}$ 中外製薬株式会社、 ${ }^{10}$ Boston Children's Hospital, Harvard Medical School

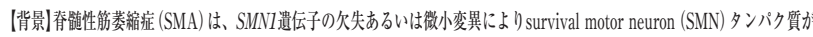

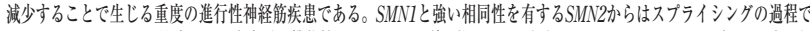
ほとんどのエクソン7が除去され、完全長の機能性SMNタンパク質は約10\%しか産生されない。リスジブラム (RG7916)経 口投与のSMN2 pre-mRNAスブライシング修飾剂であり、中枢及び末梢の機能性SMNタンパク質レベルを增加させる。目

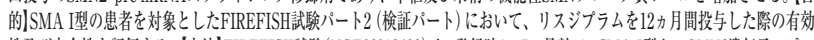

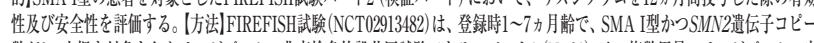
数が2の小児を対象としたりスジプラムの非盲検多施設共同陚駼である。バート1 ( N=21)は、複数用量のリスジブラムの安

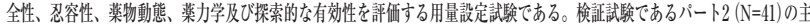

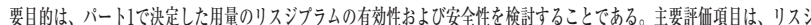

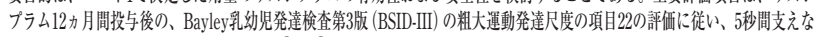
しで坐位を保持できる患者の割合である。 [結果IFIREFISH陚駼ヘヘート1では、最長30力月（中央值19力月）の投与期間中に、

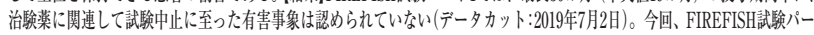
卜2で、゚ート1で決定した用量のリスジブラムを12力月間投与した患者における有効性及ひ安全性データを報告する。結論

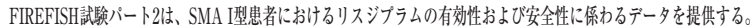

\section{0-33-6 SUNFISH試験：脊髄性筋萎縮症II型／II型患者におけ るリスジプラムの有効性及び安全性}

齋藤加代子 ${ }^{1}$ 、Eugenio Mercuri ${ }^{2} 、$ Nina Barisic ${ }^{3} 、$ Anna Kostera-pruszczyk ${ }^{4}$ 、 Riccardo Masson ${ }^{5}$, Elena Mazzone ${ }^{2}$, Andres Nascimento ${ }^{6}$.

Carole Vuillerot ${ }^{7}$ 、Sabine Fuerst-recktenwald ${ }^{8}$, Marianne Gerber ${ }^{8}$, Ksenija Gorni $^{8}$, Heidemarie Kletzl ${ }^{8}$,Wai Yin Yeung ${ }^{9}$, John W. Day ${ }^{10}$

1東京女子医科大学 臨床ゲノムセンター、 ${ }^{2}$ Paediatric Neurology and Nemo Center, Catholic University and Policlinico Gemelli, ${ }^{3}$ Clinical Medical Center Zagreb, University of Zagreb Medical School, Department of Paediatrics、 ${ }^{4}$ Katedra I Klinika Neurologii Warszawskiego Uniwersytetu、 ${ }^{5}$ Carlo Besta Neurological Research Institute Foundation, Developmental Neurology Unit, ${ }^{6}$ Neuromuscular UnLit Neuropaediatrics Department, Hospital Sant Joan de Déu, Fundacion Sant Joan de Deu, CIBERER - ISC III. ${ }^{7}$ Department of Pediatric Physical Medicine and Rehabilitation, Hôpital Mère Enfant, CHU-Lyon, ${ }^{8}$ F. Hoffmann-La Roche Ltd. ${ }^{9}$ Roche Products Ltd. ${ }^{10}$ Department of Neurology, Stanford University

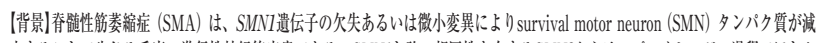
少することで生しる重度の進行性神経筋疾患である。SMN1と強い相同性を有するSWN2からはスプライシングの通程でとん

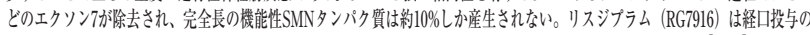

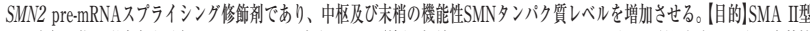

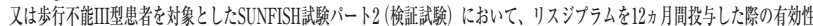

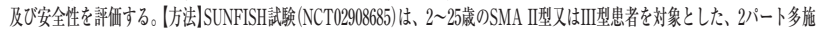

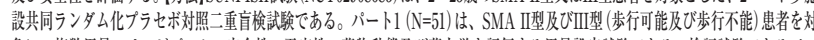

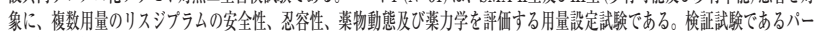
卜2 $(\mathrm{N}=180)$ の主要目的は、SMA II型及び步行不能而型患者を対象に、ハート1で決定した用量のリスジララムの有效性及び安 全性をブラセボと比較㛟討することである。主要評檤項目は、12力月間投与後の、Motor Function Measure 32項目版(MFM32 の)合計スコアのベースラインからの変化量である。[結果ISUNFISH陚駼パート1では、12个月のリス汭ラム投与期間中に，治

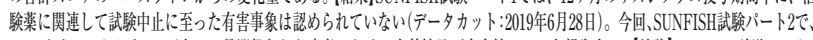

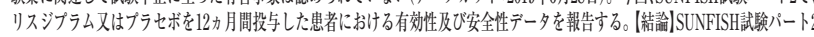

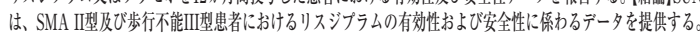

\section{0-33-8 日本人反復性片頭痛患者を対象としたガルカネズマブ の第二相臨床試験結果}

久我 敦、○尾関 暁史 ${ }^{1} 、$ Vladimir Skljarevski 、坂井 文彦 ${ }^{3}$ 日本イーライリリー株式会社、2イーライリリー・アンド・カンパニー、

埼玉精神神経センター

[Objective] Galcanezumab (GMB), a humanized monoclonal anti-CGRP antibody, was investigated to determine superiority to placebo in the prevention of migraine headache in Japanese patients. [Methods] This study was a double-blind, 6 month study in patients with episodic migraine (414 monthly migraine headache days). Patients were randomized 2:1:1 to monthly subcutaneous injections of placebo, GMB 120 or $240 \mathrm{mg}$. [Results] Both GMB doses were superior to placebo for mean change over Months 1-6 in monthly migraine headache days (primary endpoint: placebo $=-0.59$, GMB $120 \mathrm{mg}=-3.60$, GMB $240 \mathrm{mg}=-3.36$ ), percentage of patients with monthly migraine headache days reductions of $\geq 50, \geq 75$ or $100 \%$, and reduction of monthly migraine headache days with acute migraine treatment. Relative to placebo, mean change over Months 4-6 in Migraine-Specific Quality of Life Questionnaire-Role Function-Restrictive domain was greater for each GMB dose and in Patient Global Impression of Severity (PGI-S) for GMB $240 \mathrm{mg}$. There were no statistically significant differences between GMB and placebo on treatment-emergent adverse events except for a greater incidence of injection site-erythema, -pruritus, -swelling, -pain, influenza and urticaria. [Conclusion] Both doses of GMB met the primary and all key secondary endpoints except for PGI-S. Efficacy and safety outcomes were similar across GMB doses. A very low placebo effect was observed. This study demonstrated that GMB provided clinical benefit, improved function, and was safe in Japanese patients with episodic migraine. 


\section{0-33-9＼cjkstart脳梗塞におけるAlによる画像読影の可能性}

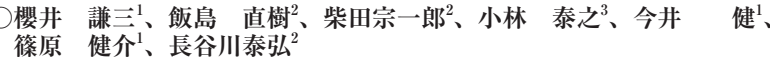

川崎市立多摩病院神経内科、聖マリアンナ医科大学 脳神経内科、 ${ }^{3}$ 聖マリ

アンナ医科大学 大学院医学研究科 / 医療情報处理技術応用研究分野

【目的】脳卒中医療の均露化を図る上で、脳卒中非専門医が初期対応せざるを得 ない地域でも安全かつ有効な腷卒中初療を可能とする方策を確立する必要があ る。一般にMRI検查により脳梗塞である事は非専門医でも容易に骖断可能である が、夜間休日带を中心にCT検查しか施行できないことも少なくなく、非専門医 が診断に苦慮することはしばしば見受けられる。IT技術の発展は著しく、これ らの問題を解決できる可能性がある。【方法】2018年8月から2019年9月までに急性 期脱梗塞で入院した 200 例のうち、急性期に頭部CT検查およびMRI検查を施行し た症例を対象とし、キャノンメディカルシステムズ株式会社の開発したCT自動 読影機器を利用し、CT-ASPECTを自動計測した。脳神経内科医の判断したCT ASPECT值及びMRI検查との整合性を評洒した。発症時間 (4.5時間以内、6時間以 内、12時間以内、24時間以内、24時間以降)、病型およびtPA投与の有無を考慮し て60例を選択して解析した。(結果)使用したCT自動読影機器の読影精度は、病巣 険出感度が高く、一部正常部位も異常所見としてとらえるものがあったが、tPA 投与症例を除き発症からの経過時間による検查に有意差はなかった。tPA静注例 に関しては、専門医の読影によるCT-ASPECTより本機器を用いたCT-ASPECT の方が低值となる傾向があった。CT-ASPECT<8では感度が高いものの、ラクナ 梗塞病巣や微小散在性病変のようなCT-ASPECT高值症例では䛊差を生じる傾向 があった。また、テント下病変を検出する機能は現段階では未開発であった。結 論|本機器の使用条件として適切に症例を選択すれば、䛦療に有用と考元られる。 出血を検出しうる機器との組及合わせで、非専門医がtPA静注療法を行う場合に おいて、十分な支援ツールとなるものと考朰れる。

\section{0-34-1 Development of antidote for therapeutic} oligonucleotides which reduces the acute toxicity

Masahiro Ohara ${ }^{1}$, Kazunori Takagi ${ }^{2}$, Kie Yoshida ${ }^{1}$, Yusuke Maeda ${ }^{2}$, Rintaro Hara ${ }^{1}$, Kazuki Sato ${ }^{2}$, Tetsuya Nagata ${ }^{1}$, Takeshi Wada ${ }^{2}$, Takanori Yokota

${ }^{1}$ Department of Neurology and Neurological Science, Graduate School of Medical and Dental Sciences, Tokyo Medical and Dental University, Japan,

Graduate School of Pharmaceutical Sciences, Tokyo University of Science

[Purpose]Antisense oligonucleotides (ASOs) have the potential to treat most neurodegenerative diseases. We previously reported that heteroduplex oligonucleotides (HDOs) have a very high gene expression inhibitory effect compared to ASOs. However, prolongation of activated Partial Thromboplastin Time (aPTT) was observed immediately after ligand-HDO administration same as ASOs. L-2,4-diaminobutanoic acid octamer (Dab8), decamer (Dab10) an dodecamer (Dab12) could bind to the major groove of an HDO and enhance its thermal stability and RNase A resistance. In this study the effect of Dab oligomers on the pharmacological activity of an HDO was evaluated. [Method] The Malatl gapmer ASO and ligand-HDO were used for aPTT evaluation and $i$ vivoexperiments. aPTT was evaluated by CA50 (Sysmex, Hyogo, Japan).[Result]E vivostudy showed that the addition of Dab12 to ligand-HDO statistically decreased aPTT $(P<0.001)$ while the addition of Dab oligomers to ASO increased aPTT. In vivostudy using $\mathrm{C} 57 \mathrm{BL} / 6 \mathrm{~J}$ mice showed that the co-injection of ligand-HDO and Dab oligomers significantly decreased aPTT (ligand-HDO: $149 \mathrm{sec}$, ligand-HDO with Dab 8: $33 \mathrm{sec})$. Dab oligomers had no effect on silencing efficacy of ligandHDO evaluated by quantitative real-time PCR assay. [Conclusion]Dab oligomers reduced the acute anticoagulant toxicity while maintaining the silencing efficacy of ligand-HDO. Co-injection of Dab oligomers can be one of the alternatives to overcome acute side effects of therapeutic oligonucleotides in clinical use.

\section{0-34-3 Satralizumab monotherapy in neuromyelitis optica} spectrum disorder: SAkuraStar subgroup analysis

Jeffrey L. Bennett ${ }^{1}$, Benjamin Greenberg ${ }^{2}$, Anthony Traboulsee ${ }^{3}$, Lech Szczechowski ${ }^{4}$ Edward Fox ${ }^{5}$, Svitlana Shkrobot ${ }^{6}$, Takashi Yamamura ${ }^{7}$ OYusuke Terada, ${ }^{8}$ Yuichi Kawata ${ }^{8}$, H.-christian Von Büdingen ${ }^{9}$, Gaelle Klingelschmitt ${ }^{9}$, Athos Gianella-borradori ${ }^{10}$, Brian G. Weinshenker ${ }^{11}$ ${ }^{1}$ University of Colorado School of Medicine, USA, ${ }^{2}$ University of Texas Southwester Medical Center, ${ }^{3}$ University of British Columbia, ${ }^{4}$ Silesian Centre of Neurology, ${ }^{5}$ Central Texas Neurology Consultants, ${ }^{6}$ Ternopil State Medical University, National Center of Neurology and Psychiatry, ${ }^{8}$ Chugai Pharmaceutical Co., Ltd, Tokyo, ${ }^{9} \mathrm{~F}$. Hoffmann-La Roche Ltd, ${ }^{10}$ Chugai Pharma USA LLC, ${ }^{11}$ Mayo Clinic

Objective To assess satralizumab monotherapy for relapse prevention in pre-defined subgroups from SAkuraStar (NCT02073279), a Phase 3, double-blind study. Methods 95 patients with neuromyelitis optica spectrum disorder (NMOSD) were randomized to satralizumab $(120 \mathrm{mg} \mathrm{s.c}$. or placebo. The primary endpoint was time to first protocol-defined relapse (PDR). Treatmen response was stratified by AQP4-IgG serostatus, prior therapy and relapse history. Betweengroup hazard ratios (HRs) were based on Cox proportional hazards models. Results In AQPIgG-seropositive patients, the PDR risk reduction was $74 \%$ with satralizumab vs placebo $(\mathrm{n}=64$ HR 0.26; 95\% CI 0.11-0.63). In seronegative patients, the HR was 1.19 ( $\mathrm{n}=31 ; 95 \%$ CI 0.30-4.78). At Week $96,76.5 \%$ of seropositive patients on satralizumab were relapse free, vs $41.1 \%$ on placebo. In seronegative patients, these values were $63.3 \%$ and $77.8 \%$. In patients previously treated with B-cell depleting therapy, the HR for PDR was $0.72(n=12 ; 95 \%$ CI $0.12-4.30)$ with satralizumab vs placebo. In patients on prior immunosuppressants or other NMO/NMOSD therapies, the HR was $0.42(\mathrm{n}=83 ; 95 \% \mathrm{CI} 0.20-0.87)$. Patients with at least 1 relapse in the year prior to screening had RR of 0.42 with satralizumab vs placebo ( $\mathrm{n}=84 \cdot 95 \% \mathrm{CI} 0.21-0.85)$; those who had their first attack in the year prior to screening had no change in PDR risk. Conclusions Satralizumab effectively reduced risk of PDR in patients with NMOSD, particularly in AQP4-IgG-seropositive patients. Results should be interpreted with caution as the study was not powered for subgroup analyses.
0-33-10 Self-assemble polydopamine nanoparticles for high-performance Parkinson's disease drug

○長崎 幸夫 ${ }^{1,2}$ 、佐藤 憂菜、 Long Vong ${ }^{1,3}$ 、

Pennapa Chonpathompikunlert ${ }^{4}$, Supita Tanasawet ${ }^{5}$ 、

Pilaiwanwadee Hutamekalin

1 筑波大学数理物質科学研究科、

筑波大学人間科学総合研究科、 ${ }^{3}$ ベトナム国家大学国際大学、

タイ科学技術研究所、 ${ }^{5}$ タイプリンスオブソングラ大学

[Objective] The major cause of Parkinson's disease (PD) is thought to be the loss of dopaminergic substantia nigra neurons and the formation of a-synucleincontaining Lewy bodies. Although dopamine supplementation is a vital therapy, it is not facile to cross the BBB. 3,4-Dihydroxyphenylalanine (L-DOPA), a dopamine precursor, is one of the main drugs to treat PD since L-DOPA can cross the BBB better than dopamine; however, there are strong demands to develop further effective drugs due to the short half-life and severa adverse effects such as dyskinesia, stomatitis, sleep disturbance, anxiety, and depression. In this study, we studied new drugs based on novel molecular selfassembling at overcoming the drawbacks of L-dopa and creating safe and effective Parkinson's disease drugs.[Method] A newly designed hydrophilichydrophobic block copolymer poly (ethylene glycol)-b-poly (L-dopa (diacetyl)) forms self-assembling nano-sized particle $\left(\mathrm{Nano}^{\mathrm{DOPA}}\right)$, which is examined to the effect on Parkinson's disease model mice. [Result] Nano is significantly prolonged the retention of L-DOPA in the blood and not only showed recovery in Parkinson's disease mice but also reduced Dyskinesia symptoms. [Conclusion] $\mathrm{Nano}^{\mathrm{DOPA}}$ is anticipated as a new high-performance Parkinson's disease drug.

\section{0-34-2 Clinical benefits of eculizumab monotherapy in} NMOSD: findings from the phase 3 PREVENT study

Larisa Miller ${ }^{1}$ Kazuo Fujihara ${ }^{2,3}$, Sean J. Pittock ${ }^{4}$, Achim Berthele ${ }^{5}$, Ho Jin Kim ${ }^{6}$ Michael Levy ${ }^{7,8}$, OIchiro Nakashima ${ }^{3,9}$, Celia Oreja-guevara ${ }^{10}$, Jacqueline Palace ${ }^{11}$ Murat Terzi ${ }^{12}$, Natalia Totolyan ${ }^{13}$, Shanthi Viswanathan ${ }^{14}$, Kai-chen Wang ${ }^{15,16}$, Amy Pace ${ }^{1}$ Marcus Yountz ${ }^{1}$, Guido Sabatella ${ }^{1}$, Róisín Armstrong', Dean M. Wingerchuk ${ }^{4}$

${ }^{1}$ Alexion Pharmaceuticals, USA, ${ }^{2}$ Fukushima Medical University, ${ }^{3}$ Tohoku University, ${ }^{4}$ Mayo Clinic, ${ }^{5}$ Technical University of Munich, ${ }^{6}$ Research Institute and Hospital, Goyang, ${ }^{7}$ Johns Hopkins University, ${ }^{8}$ Massachusetts General Hospital, ${ }^{9}$ Tohoku Medical and Pharmaceutical University, ${ }^{10}$ Hospital Universitario Clínico San Carlos, Medical and Pharmaceutical University, ${ }^{11}$ John Radcliffe Hospital, ${ }^{12}$ Ondokuz Mayis University, ${ }_{13}^{13}$ First Pavlov State Medical
John University of St Petersburg, ${ }^{14}$ Kuala Lumpur Hospital, ${ }^{15}$ Cheng-Hsin General Hospital, ${ }^{16}$ National Yang Ming University

OBJECTIVE To examine the efficacy of eculizumab (ECU) relative to placebo in patients with aquaporin-4 immunoglobulin G-positive (AQP4-IgGt) neuromyelitis optica spectrum disorder (NMOSD) not receiving concomitant immunosuppressive therapy (IST) during the phase 3 PREVENT trial (NCT01892345). METHODS Patients received ECU (maintenance dose, $1200 \mathrm{mg} / 2$ weeks) or placebo; concomitant IST was permitted (except rituximab/mitoxantrone). A post hoc descriptive analysis of clinical outcomes was performed using data from patients not receiving concomitant IST (ECU monotherapy or placebo without concomitant IST subgroup). RESULTS of 34 patients in the no-IST subgroup, 10 had never received IST for NMOSD and 14 had previously received rituximab (ECU monotherapy, $7 / 21$; placebo, $7 / 13$ ). Adjudicated relapses occurred in $0 / 21$ patients receiving ECU monotherapy and $7 / 13(53.8 \%)$ receiving placebo ( $p<0.0001$; post hoc analysis). In the placebo group, $6 / 13$ patients (46.2\%) were hospitalized for adjudicated relapses, $3(23.1 \%)$ received plasma exchange, $4(30.8 \%)$ were treated with acute intravenous methylprednisolone and $1(7.7 \%)$ received high-dose oral corticosteroids. Expanded Disability Status Scale and Hauser Ambulation Index scores each worsened in 1/2 patients $(4.8 \%)$ receiving ECU monotherapy, and in $5 / 13$ patients $(38.5 \%)$ and $4 / 13$ patients $(30.8 \%)$, respectively, receiving placebo. CONCLUSIONS These data further characterize the substantial efficacy of ECU monotherapy in patients with AQP4-IgG+ NMOSD. Long-term results from PREVENT's open-label extension will be analyzed.

\section{0-34-4 Characteristic of intracerebral hemorrhage} taking direct oral anticoagulants versus warfarin

Satoshi Suda ${ }^{1}$, Yasuyuki Iguchi ${ }^{2}$, Shigeru Fujimoto ${ }^{3}$, Yoshiki Yagita ${ }^{4}$, Masayuki Ueda ${ }^{5}$, Takao Kanzawa ${ }^{6}$, Seiji Okubo ${ }^{7}$, Kenichi Todo ${ }^{8}$. Mineo Yamazaki ${ }^{9}$, Nobuhito Nakajima ${ }^{10}$, Kazumi Kimura ${ }^{1}$

PASTA investigators ${ }^{1,2,3,4,5}$

Department of Neurology, Nippon Medical School, Japan, ${ }^{2}$ Department of Neurology, The Jikei Universit School of Medicine, ${ }^{3}$ Division of Neurology, Department of Medicine, Jichi Medical University Hospital Department of Stroke Medicine, Kawasaki Medical School, 'Department of Neurology and Stroke Medicine Tokyo Metropolitan Tama Medical Center, Department of Stroke Medicine, Institute of Brain and Blood Vessels, Mihara Memorial Hospital, ${ }^{7}$ Department of Cerebrovascular Medicine, NTT Medical Center Tokyo, Department of Neurology, Kobe City Medical Center General Hospital, ${ }^{9}$ Department of Neurology, Nippon Medical School Chiba Hokusoh Hospital, ${ }^{10}$ Department of Neurology, Kitamurayama Hospita

【目的】直接型経口抗疑固薬 (DOAC) の使用増加に伴い、DOAC服用中に発症する譄出血は日常臨床でしばしば経騟 する。しかし、単施設で小規模の報告が多く、D0AC服用中の腷出血の穾態は不明な点が多い。(方法 2016年4月よ

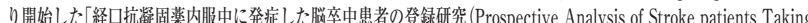

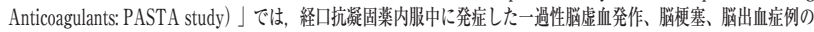
多施設共同前向き登録を行い2 2019年9月末で1045例の症例が集積された。抗凝固療法中の腷出血の特徽について

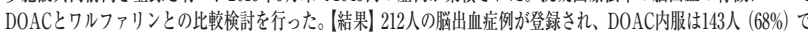
あった。年齢(中央值)はDOAC群77歳、ワルファリン群75歳 ( $\mathrm{P}=0.2452$ )、HAS-BLEDスコア(中央优)はD0AC群3 ワルファリン群3 ( $\mathrm{P}=0.8364$ )であった。抗血小板薬の併用は、D0AC群 $18 \%$ 、ワルファリン群 $22 \%(\mathrm{P}=0.5389)$ であっ た入院時の血腄体積(中央值)は DOAC群 $12.3 \mathrm{ml} 、$ ワルファリン群 $11.7 \mathrm{~mL}$ ( $\mathrm{P}=0.9080$ )であり、NIHSSスコア(中央值) はDOAC 群10、ワルフアリン群12であった $(\mathrm{P}=0.5790)$ 。血腫增大は $\mathrm{D} 0 \mathrm{AC}$ 群の $13 \%$ 、ワルファリン群は $12 \%$ に認 められ ( $\mathrm{P}=0.7571) 、$ 、質下出血の割合はD0AC群16\%、Wf群 $20 \%(\mathrm{P}=0.4497)$ であり、両群間で有意差は認めなかった。 退院時mRSの中央值は、D0AC群4、ワルファリン群4 ( $\mathrm{P}=0.4339)$ であり、mRS3-6の転㫶不良群の割合は、D0AC 群 76\%、ワルファリン群 $76 \%$ ( $\mathrm{P}=0.9341)$ であり、転帰に関しても両群間で有意差は認めなかった。抗疑固薬の再開

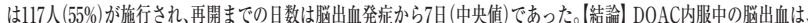
ワルファリンと比較して入院時の出血量や重症度、出血部位、退院時の転师に両群間で統計学的な差を認めなかった。 
0-34-5 Natalizumab every 7 weeks dosing in 245 multiple sclerosis patients: efficacy and loss of PML risk

Takahiko Saida ${ }^{1,2}$, Qi Hao ${ }^{1,2}$, Michiko Yamauchi ${ }^{1,2}$, Kyoko Saida ${ }^{1,2,3}$ ${ }^{1}$ Irino Clinic, Kansai Multiple Sclerosis Center, Japan, ${ }^{2}$ Institute of Multiple

【目的】多発性硬化症（MS）のNatalizumab (NAT) 治療は 4 週毎の点滴で高い有効性 が示されているが 820 人以上の進行性多巣性白質脳症（PML）が発生している。最近、 全米NAT使用全例調查の抗JCV抗体陽性でPMLリスクを有する全例が解析され、 NAT平均投与間隔 36.5 日以上 815 人の 10 年迄の観察でPML発生が無いと報告された (Neurology2019) が有効性デー夕は存在しない。本研究では平均投与間隔36.5日以上 より安全性を高める目的で、平均7週 (49日) 以上の間隔を空けた投与 (every 7 weeks dosing: Q7WD）を実施した。治療前 1 年を含めた詳細正確な全例長期評価を実施し、 治療前後での有効性比較とPML発生を評価し、PML発生の無い高効果の治療開発を 目指す。【方法】Q7WDは7 (-8) 週每点滴。体重> $80 \mathrm{~kg}$ (全体の4\%) では7 (-6) 週每点滴。 3 月每と再発時に造影MRI 診察をQ7WD開始1年前より実施。MS活動性（臨床再発 and/or MRI新病巣・造影病巣出現)、EDSS、PML、抗NAT中和抗体、抗JCV抗体户 安全性を評価。【対象】単一施設でQ7WDを開始した245人が安全性評価群。Q7WD治 療3月以上経過 LMRI評価等を実施した有効性評価群は233人。Q7WD治療期間は平均 14 (3-21) 月。学会発表時にはより長期デー夕を発表する。抗JCV抗体陽性 $83 \%$ 、開始 時の罹病期間平均 13 年、EDSS平均 $2.4(0-8.0)$ 。結果】 245 人のQ7WD治療中 240 人 $(98 \%)$ でMS活動性0が維持された。臨床再発＋造影病巣陽性 2 人はNAT-4週毎投与中にも年 1 回以上の再発が続いた超高活動例。中和抗体陽性 1 人も再発。無症候MRI造影脳病 巣のみ出現 2 人。比較するQ7WD開始前 1 年間の年間MS活動性はDimethyl Fumarate 群 (102人) 1.04回、NAT-4週毎群(65人) 0.07回 (2人、再発2回のみ)、Fingolimod群 (45

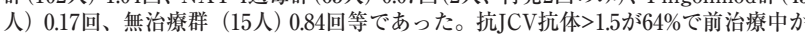
ら高PMLリスクが大半だがPML発生は無い。【結論】日本人MSでQ7WDは4週毎投与 同等の高効果を示し安全性、利便性、経済効果の高い選択肢である。

\section{0-34-7 Siponimod Delays the Time to Wheelchair in} Patients with SPMS: Results from the EXPAND study

Jin Nakahara

Department of Neurology, Keio University School of Medicine, Japan

【目的】二次性進行型多発性硬化症（SPMS）は歩行能力の低下を伴い、進行ととも に車いすに依存する患者割合が増える。シポニモドは典型的なSPMS患者集団に おいて、身体障害進行と認知機能の悪化に対する抑制効果を示した（EXPAND試 験)。本発表では、EDSS7以上（車いすが必要）に達する時間に関して、シポニモ ド群とプラセボ群を比較評価した。(方法】EXPAND試験結果を用いて、EDSS7 以上に達する時間を、2つの異なるモデル（生存時間解析と多状態モデル）により 解析した。生存時間解析ではベースラインEDSSが6.5の患者群を対象とした（シ ポニモド群293例、プラセボ群119例、以下同順)。多状態モデルでは全試験集団 を対象とした。EDSS5以下、5.5-6、6.5の3つの「状態」を規定し、各状態間の移行 確率および各状態での滞在時間を計算した。モデルは、すべての中間状態の経由 パターンを考虑することにより、各状態からEDSS7以上に達する時間を予測でき た。治療効果の持続を前提とし、推定されたパラメーターから結果を外挿するこ とにより、全試験集団においてEDSS7以上に到達する時間の中央值を計算した。 【結果】生存時間解析では、シポニモド群はプラセボ群と比較して、ベースライ ンEDSS6.5から7以上に移行するリスクが $36 \%$ 低下した（進行した患者割合 $19.8 \%$ 、 $26.1 \%$; HR [95\% CI] 0.64 [0.41; 1.0] ; $\mathrm{p}=0.0483)$ 。多状態モデルではシポニモト 群においてEDSS5以下から5.5-6に移行するリスクが21\%低下（HR [同]: 0.79 [0.63 1.00])、EDSS6.5から7以上に移行するリスクが28\%低下（HR [同]: 0.72 [0.48; 1.06]) した。モデルの仮定のもと、プラセボ群と比較してシポニモド群では全試験集団 のEDSS7以上に到達する時間の中央值が4.3年延長した (12.0年、16.3年)。【結論】シ ポニモドはSPMS患者の車いす移行を遅らせることが示唆された。これはシポニ モドのSPMS患者における身体障害進行抑制の臨床的意義を支持するものである。

\section{0-34-9 Efficacy and Safety of satralizumab add-on therapy} in a Phase 3 study in patients with NMOSD

Takashi Yamamura ${ }^{1}$, Ingo Kleiter ${ }^{2}$, Kazuo Fujihara ${ }^{3}$,

Jacqueline Palace $^{4}$, Benjamin Greenberg ${ }^{5}$, Beata Zakrzewska-pniewska ${ }^{6}$, Francesco Patti ${ }^{7}$, Albert Saiz ${ }^{8}$, Masayuki Haramura ${ }^{9}$, Yusuke Terada ${ }^{9}$, Yuichi Kawata, Jerome De Seze ${ }^{10}$

Department of Immunology, National Institute of Neuroscience, and the Multiple Sclerosis Center, National Center of Neurology and Psychiatry, Japan, ${ }^{2}$ Department of Neurology, St. Josef Hospital, Ruhr University Bochum, Bochum, and Marianne-Strauß-Klinik, Behandlungszentrum Kempfenhausen für Multiple Sklerose Kranke, ${ }^{3}$ Department of Multiple Sclerosis Therapeutics, Fukushima Medical University, and the Multiple Sclerosis and Neuromyelitis Optica Center, Southern Tohoku Research Institute for Neuroscience, Department of Clinical Neurology. John Radcliffe Hospital, ${ }^{5}$ Department of Neurology, University of Texas Southwestern Medical Center, ${ }^{6}$ Department of Neurology, Warsaw Medical University, ${ }^{7}$ Department G.F. Ingrassia, Neuroscience Section, University of Catania, ${ }^{8}$ Service of Neurology, Hospital Clinic and Institut d'Investigació Biomèdica August Pi i Sunver, University of Barcelona, ${ }^{9}$ Chugai Pharmaceutical ${ }^{10}$ Department of Neurology, Hôpital de Hautepierre, Clinical Investigation Center, INSERM

目的：ヒト化抗LL-6レセプターリサイクリング抗体サトラリズマプの視神経春镇炎スペクトラム(NMOSD) 患者における

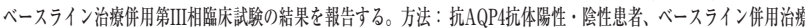

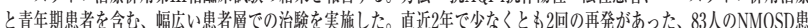
者が、0、2，4週目、その後4週ごとの皮下投与で、サトラリズマブ120mgまたはプラセボに1:1で無作為割付けされた。 主要なエンドポイントは、治験実施計画書で定義された最初の再発までの期間。また、事前に规定された追加解析項目 として、抗AQP4抗体陽性·陰性サブグループでの)有效性と年間再発率(ARR)に対する影響を检討した。ハザード比(HR)

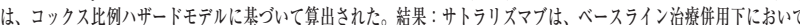
NMOSD患者の再発リスクを有意に低下した。全患者分群で、治験実施計画書で规定された再発りスクを $62 \%$ 、抗AQPA 抗体陽性群では79\%低減した。抗AQP4抗体陽性患者の91.5\% で、48もしくは96遇まで再発がなかった。全患者での ARRは、プラセホ群の0).32 (95\% CI, 0.19 to 0.51)に対し、サトラリズフブ治療群で 0.11 ( $95 \%$ CI, 0.05 to 0.21) であった。 全体を通し、有害事象、並びに重篤な感染症を含む重篤な有害事象の発生患者の割合は、サトラリズマブ投与群とプラ セボ群で同等であり、死亡例、アナフイラキシー反応は認められなかった。結諭：サトラリススマブは、NMOSD患者を 対象としたベースライン治療併用試験で有意に再発りスクを低下させ，良好な安全性ブロファイルを示した。
0-34-6 Delayed multiple cerebral lesions after endovascular aneurysmal embolization: a multicenter study

Mikito Hayakawa ${ }^{1}$, Yuji Matsumaru ${ }^{1,2}$, Shuichi Tanoue ${ }^{3}$,

Kimihiko Orito ${ }^{4}$, Yasuharu Takeuchi ${ }^{4}$, Michihiro Tanaka ${ }^{5}$,

Shigeru Miyachi ${ }^{6}$, Masaru Hirohata ${ }^{4}$

${ }^{1}$ Division of Stroke Prevention and Treatment, Faculty of Medicine, Univ.

of Tsukuba, Japan, ${ }^{2}$ Department of Neurosurgery, Faculty of Medicine.

Of Tukuba, Japan, Department of Neurosurgery, Faculty of Medicine,

Schersity of Tsukuba, Department of Radiology, Kurume University

School of Medicine, ${ }^{5}$ Department of Neurosurgery, Kurume University

${ }^{6}$ Department of Neurosurgery, Aichi Medical University

【目的】媨血管内治療後、治療対象血管域に荤発性に浮腫性変化を伴う多発病変を生じる特異な病態が報告 されている。ADEM椂反応、PRES、造影绪脑症等とした報告も散見されるが、デバイスの親水性ポリマー に対するN型アレルギーが主因と目されている。ステロイドの有効性が示唆されているが、疾患の全体像 には不明点が多い。本歈討の目的は、脳動脈瘤に対する血管内治療後に生した荤発性脳内多発病変(delayed multiple cerebral lesions: DMCL)の全体像と転帰に関連する因子を明らかにすることである。方法】2009 年 2018年の脳動脈瘤に対す万待機的血管内治療後のDMCL発症例を対象とし、背景、血管内治療内容求 よびDMCL発症時期、症状、治療内容、転㴆を後方視的に検討した。参加施設の対象期間内の待機的脑動 脈痹血管内治療件数も収集した。結果】全国32施設より58例が集積され、西像中央判定により56例（平均 59歳、女性 $80 \%$ )が対象となった。推定発症率は $0.6 \%$ で、36例 $(64 \%)$ が症候性DMCLであった。 $46 \%$ でアレ ルギー性/自己免疫疾患既往を有した。未破裂無症候瘤が79\%を占め、タブルカテーテルテクニック/ステ ント支援下塞检術は各30/20\%で行われた。血管内治瘵からDMCL診断までは中央值 41 日で、非特異的症 状は29\%に、中枢神経症状は61\% (麻瘏30\%/頭痛29\%) に認められた。ステロイドは59\%で使用（診断後中 央值4日で開始)されていた。例 (16\%) で90日以上症状が持続し、2例(3.6\%)は最終経過観察時に症状が残 存した(経過観察期間中央值 792.5 日)。症候性症例でアレルギー/自己免疫疾患既往が多く(調整 OR $5.99,95 \%$ CI 1.3-26.6)、最終経過観察時症状残存例でステロイド開始が荤延していた(診断後37/173日)。(結論]本疗 患の推定発症率は $0.6 \%$ と稀で、多くは自然に/ステロイドで症状が消失した。症状出現にはアレルギー/自 己免疫疾患既往が関連し、最終経過観察時症状残存例でステロイド開始が荤延していた。

0-34-8 Eculizumab for generalized myasthenia gravis: interim analysis of post-marketing surveillance

Hiroyuki Murai ${ }^{1}$, Shigeaki Suzuki ${ }^{2}$, Miki Hasebe ${ }^{3}$, Yuji Fukamizu ${ }^{3}$,

Ema Rodrigues ${ }^{4}$, Kimiaki Utsugisawa ${ }^{5}$

${ }^{1}$ International University of Health and Welfare, Japan,

Keio University School of Medicine, Tokyo, ${ }^{3}$ Alexion Pharma GK,

Alexion Pharmaceuticals, Inc, ${ }^{5}$ General Hanamaki Hospital

[目的]2017年12月,本邦にてエクリズマブが抗アセチルコリン受容体抗体陽性全身 型重症筋無力症 $(\mathrm{gMG})$ の治療薬として承認され,製造販売後調査（以下,本調査）が 開始された。今回,本調查より得られた中間解析デー夕を報告する. [方法]エクリ ズマブ投与の $\mathrm{gMG}$ 患者全例を本調查に登録し，2019年10月1日時点で得られたデー 夕を評価した。投与開始から 12 週あるいは26週までのMG-ADL及びQMGの変化量 を有用性の指標とした. エクリズマブによる副作用についても解析した.[結果]2019 年10月1日時点で40例の調查票を固定した。安全性解析対象例は 40 例,有効性解析 対象例は, 第3相無作為化二重盲検プラセボ対照試験 (REGAIN試験) 継続例である 6例を除いた 34 例であった，投与開始時のMG-ADL及びQMG (平均土標潐偏差) は,それぞれ $9.6 \pm 5.04(\mathrm{n}=34)$ 及び15.8 $\pm 7.21(\mathrm{n}=34)$ であり,33/40例が 12 週まで投 与を継続した. 12週のMG-ADL / QMGの変化量 (平均土標準偏差) は,それぞれ-3.7 $\pm 2.61 （ \mathrm{n}=27 ） /-5.6 \pm 3.50(\mathrm{n}=26)$ であり,26週では-4.3 $\pm 2.72(\mathrm{n}=26) /-5.6 \pm 4.02$ ( $\mathrm{n}=24)$ であった. $7 / 40$ 例で副作用が報告された．本剤を1回投与された患者 1 例が 心室細動及び急性心筋梗塞を呈し、初回投与後 10 日に死亡した（本剂との因果関 係不明)が,現時点まで䯣膜炎菌感染は報告されていない. [結論]本中間解析結果は、 REGAIN試験で得られた有効性成績と同等であり,本邦の実臨床下での g MG患者 におけるエクリズマブの忍容性及び有用性が示唆された

\section{0-34-10 Current issues of selection criteria in the} clinical trials for amyotrophic lateral sclerosis

Yuko Kobayakawa ${ }^{1,2}$, Koji Todaka ${ }^{2}$, Wataru Shiraishi ${ }^{1}$,

Ryo Yamasaki ${ }^{1}$, Jun-ichi Kira

${ }^{1}$ Department of Neurology, Neurological Institute, Graduate School of Medical Sciences, Kyushu University, Japan, ${ }^{2}$ Kyushu University Hospital, Center of Clinical and Translational Research, Japan

【目的】神経変性疾患に対する新規治療法開発を目的とした臨床試験において、対 象患者群の設定法は有効性の検出力等に大きな影響を与える。ALS患者を対象と した臨床試験について、対象患者群の設定方法の問題点を明らかにし、改善方法 を考案する。【方法】ClinicalTrials.gov㧍よびWHO Primary Registryとして認め られている臨床試験登録サイトに登録されたALSを対象とした臨床試験のうち、 2000年以降に行われALSFRS-Rスコアの変化量を評価項目に含む185試験につい て、対象患者の適格基準の設定に用いられている項目とその基準值を集計した。 また各臨床試験の適格基準の設定方法と、対象患者のベースライン特性やプラセ ボ群の経過との関連性を検討した。結果】Phase 3 抢よび症例数 100 以上のPhase 2 試験 (計52試験) について、適格基準の設定に用いられる項目は、頻度の高い順に (1)年龄の下限值 (100\%) 2 El Escorial診断基準 (90\%) 3 羅病期間の上限 (88\%) (4 \%肺活量の下限 (83\%) であり、(2) (4)の基準の組み合わせは、52試験で37パター ン存在した。ALSFRS-Rスコアに関して基準を設けた試験は、Phase2以降の134 試験中 35 試験 $(26 \%)$ で、その設定方法は 22 パターン存在した。各試験のプラセボ 群の観察期間中のALRFRS-Rの平均低下率は、適格基準の罹病期間の上限值抒 よび観察期間中の\%肺活量の平均低下率と相関する一方、ベースライン時の平均 ALSFRS-Rスコアや適格基準の\%肺活量下限值とは関連していなかった。結論】 ALSに対する臨床試験の適格基準の設定に、各試験で共通に用いられている項目 はあるものの、その設定方法は統一されておらず、多くの試験で進行速度の異な る症例が混在していると考えられる。有効性検出率を向上する適格基準の設定方 法について考察する。 
0-35-1 Increased iron deposition in CADASIL: a highresolution quantitative susceptibility mapping study

Sun Chengyue ${ }^{1}$, Wu Yue ${ }^{2}$, Ling Chen ${ }^{1}$, Fang Xiaojing ${ }^{1}$, Yang Qi ${ }^{2}$, Zhang Wei', Wang Zhaoxia', Zhang Zihao ${ }^{2}$, Yuan Yun ${ }^{1}$

${ }^{1}$ Department of Neurology, Peking University First Hospital, China, ${ }^{2}$ State Key Laboratory of Brain and Cognitive Science,XX MR Center for Brain Research, Institute of Biophysics, XXX Academy of Sciences

Objective: The distribution pattern of iron deposition in DGM of cerebral autosomal dominant arteriopathy with subcortical infarcts and leukoencephalopathy (CADASIL) have not been determined. We aimed to evaluate iron deposition of DGM in CADASIL using high-resolution quantitative susceptibility mapping (QSM). Methods: Thirty-nine patients confirmed to have CADASIL via genetic analysis and/or skin biopsy underwent extensive clinical evaluations including the Mini-Mental State Examination (MMSE) and modified Rankin Scale (mRS), and brain 7.0-T magnetic resonance imaging (MRI) examination to obtain the MRIs lesion loads, small-vessel disease (SVD) scores, and susceptibility using QSM. The regions of interest (ROIs) included caudate nucleus $(\mathrm{CN})$, putmen (PUT), globus pallidus ( $\mathrm{GPi}$ ), thalamus (THA), substantia nigra $(\mathrm{SN})$, and red nucleus $(\mathrm{RN})$. We compared the susceptibility of DGM between the CADASIL and control groups and analyzed the correlations between susceptibility of DGM and clinical characteristics. Results: The CADASIL group showed significantly increased susceptibility of CN, PUT, THA, SN, and RN compared with the control group. The susceptibility of DGM significantly increased with age or disease duration, and positively associated with the SVD scores in CADASIL. Moreover, increased susceptibility of the THA was associated with higher mRS scores in CADASIL patients after adjustment for age and disease duration. Conclusions: Excess iron deposition in the DGM might be a novel MRI feature of CADASIL.

\section{0-35-3 The impact of infarct location and size on prognosis in small vessel disease}

Takeo Sato, Kenichiro Sakai, Takahiro Maku, Haruhiko Motegi,

Maki Takahashi, Hiroki Takatsu, Teppei Komatsu, Kenichi Sakuta,

Tadashi Umehara, Shusaku Omoto, Hidetaka Mitsumura,

Hidetomo Murakami, Yasuyuki Iguchi

Department of Neurology, The Jikei University School of Medicine, Japan

Objective: To determine the impact of infarct location and size on prognosis in small vessel disease (SVD). Methods: Consecutive patients with $<24 \mathrm{~h}$ from onse to initial magnetic resonance imaging (MRI) and $\leq 14$ days from onset to second MRI with SVD were included. Infarct location and size were identified by the maximum positive region on diffusion-weighted imaging. Infarct locations wer defined as follows: caudate, putamen $(\mathrm{P})$, corona radiata $(\mathrm{CR})$, posterior limb and genu of internal capsule (IC), thalamus, and brain stem with or without involving corticospinal tract. An unfavorable outcome was defined as modified Rankin Scale score of 2 to 6 at 3 months from the onset. Factors related to an unfavorable outcome were evaluated. Results: We screened 1,558 consecutive symptomatic ischemic stroke patients, including 128 patients $(99(77 \%)$ male, median age 64 years). Of all, 29 patients $(23 \%)$ had unfavorable outcomes. The factors associated with unfavorable outcome were age (odds ratio (OR) $0.928,95 \%$ confidence interval (CI) $0.880-0.979, p=0.006$ ), infarct area (OR 0.991, 95\% CI 0.985-0.998, $p=$ 0.007 ), and infarct involving all the following areas: P, CR, and IC (OR 0.087, 95\% CI $0.013-0.571, p=0.011)$. Infarct only involving corticospinal tract did not relate to prognosis. Patients with infarct involving P, CR, and IC had higher National Institutes of Health Stroke Scale subscore of upper limb motor function on discharge (OR 3.050, 95\% CI 1.098-8.476, $p$ = 0.032). Conclusions: Infarct involving $\mathrm{P}, \mathrm{CR}$, and IC predicts unfavorable outcomes in patients with SVD.

\section{0-35-5 Blood pressure variability after reperfusion therapy and poor outcomes in acute ischemic stroke}

OSatoshi Hosoki ${ }^{1,2}$, Kaori Miwa ${ }^{1}$, Takeshi Yoshimoto ${ }^{2}$, Kanta Tanaka ${ }^{3}$,

Hajime Ikenouchi, ${ }^{1,2}$, Tadataka Mizoguchi, ${ }^{1,2}$, Kenichi Irie ${ }^{1,2}$

Shunsuke Kimura ${ }^{1,2}$, Tetsuya Chiba ${ }^{1,2}$, Tetsu Satow ${ }^{4}$, Jun C C Takahashi ${ }^{4}$, Kazunori Toyoda ${ }^{1}$, Masafumi Ihara ${ }^{2}$, Masatoshi Koga ${ }^{1}$

${ }^{1}$ Department of Neurology, National Cerebral and Cardiovascular Center Japan, ${ }^{2}$ Department of Cerebrovascular Medicine, National Cerebral and Cardiovascular Center, Japan, ${ }^{3}$ Division of Stroke Care Unit, National Cerebral and Cardiovascular Center, ${ }^{4}$ Department of Neurosurgery, National Cerebral and Cardiovascular Center

Introduction: We explored the association between blood pressure variablitiy (BPV) and outcomes after reperfusion therapy (RT): intravenous thrombolysis (IVT) and endovascular therapy (EVT). Methods: We reviewed consecutive patients with acute ischemic stroke with RT from our prospective stroke registry from 2005 to 2018 . We measured blood pressure at 7 time points within 24 hours after RT and computed the following five BPV measures: mean, standard deviation, coefficient of variation, successive variation, and average real variability (ARV). The outcomes were 1) poor outcome defined as mRS score 3-6 at 3 months and 2) symptomatic intracranial hemorrhage (sICH) as any ICH with a $\geqq 4$-point increase in NIHSS. Successful reperfusion (SR) was defined as early neurological improvements of $\geqq 4$ points in NIHSS after IVT alone and mTICI scores of $2 \mathrm{~b}-3$ after EVT. Results: Among 933 patients with premorbid mRS score 0-2 ( $73 \pm 12$ years; 348 women), 464 patients with poor outcomes and 35 with sICH were observed. In adjusted analyses, all systolic BPV (SBPV) measures were associated with poor outcomes, while all SBPV measures but mean SBP were associated with sICH. In 566 patients with SR, 256 patients with poor outcomes and 10 with sICH were observed. In adjusted analyses, all SBPV measures but mean SBP were positively associated with poor outcomes (ARV/10 mmHg increase for poor outcomes: EVT, OR=2.00 $95 \% \mathrm{CI}=1.19-3.36$; IVT, OR=1.52, 95\% CI=1.02-2.28), while no BPV measure was associated with $\mathrm{sICH}$. Conclusion: High SBPV after RT was independently associated with poor outcomes despite SR.
0-35-2 withdrawn

\section{0-35-4 withdrawn}

\section{0-35-6 CRTC1-regulated microRNA-132/212 plays a vital role in stroke mediated by vascular function}

$\bigcirc$ Haomin $\mathrm{Yan}^{1}$, Tsutomu Sasaki ${ }^{1}$, Hideaki Kanki ${ }^{1}$, Shintaro Sugiyama ${ }^{1}$, Kumiko Nishiyama ${ }^{1}$, Shigenobu Matsumura ${ }^{2}$, Hideki Mochizuki ${ }^{1}$ Department of Neurology, Osaka University Graduate School of Medicine, Japan, ${ }^{2}$ Laboratory of Nutrition Chemistry, Division of Food Science and Biotechnology, Graduate School of Agriculture, Kyoto University

[Objective] MicroRNAs (miRNAs) play critical roles in post-transcriptional regulation of gene expression. Among the miRNAs involved in central nervous system diseases, miR-132/212 cluster was demonstrated to regulate the process of synaptogenesis, neuroinflammation and brain vascular integrity. However, the mechanism of miR-132/212 in cerebral ischemia remains unrevealed. This study therefore aims to investigate the role of miR-132/212 in ischemic stroke. [Methods Neuronal cultures were prepared from the cortex of embryonic day 16 (E16) mice embryos. Oxygen glucose deprivation (OGD) was performed as in vitro ischemia. MiR-132/212 qPCR expression assay was taken. As CRTC1 was predicted to be an upstream regulator of miR-132/212 by statistics analysis, we generated $\mathrm{CRTCl}-$ - mice and subjected them to $60 \mathrm{~min}$-middle cerebral artery occlusion (MCAO). Neurological functions were examined. BBB damage was evaluated by Evans Blue injection. Moreover, miR-132/212 target proteins were assayed. [Results] The neuronal death was remarkably aggravated in neurona cultures isolated from $\mathrm{CRTC1}$-/- mice after OGD Likewise, The infarct volume and $\mathrm{BBB}$ damage in CRTCl-/- mice were significantly agravated than wildtype (WT) mice. MiR-132/212 expression was obviously decreased in CRTC1/- mice after stroke. Neurological function deficits of CRTC1-/- mice were evidently worse than WT mice. [Conclusion] These findings suggest that miR$132 / 212$ cluster is modulated by CRTC1, and it could associate with functional recovery after ischemia by enhancing neuronal survival and vascular integrity. 


\section{○吉田健太郎、德田 直希、周藤 豊、福田 弘毅 \\ 松江赤十字病院 脳神経内科}

【目的】過去の研究で急性期脳梗塞患者における左房径 (LAD) 拡大と発作性心房 細動 $(\mathrm{pAF})$ の関連が報告されているが, 左房径は一方径の評価であるためしばし ば左房の大きさを正確に反映しないことがわかっている。循環器領域ではより正 確な左房拡大の評価が可能である, 左房容積を体表面積で補正した左房容積係数 (LAVI) が広く用いられているが，本邦ではLAVIとpAFの関連を検討した報告は ない, 本研究では，日本人におけるLAVIとpAFの関連性について検討した.【方法】 2018 年10月1日から 2019 年10月31日の間に当院へ入院した急性期脳梗塞患者 321 例 のうち，LAVIを計測しえた295例を対象とした．年齢，性別，喫煙歴，高血圧 症, 糖尿病, 脂質異常症, 脳梗塞, 心筋梗塞の既往, 僧帽弁疾患の合併, 心臓超 音波検查所見，CRP值，D-dimer值，BNP值について後方視的に検討した.【結果】 解析対象を洞調律 (SR) 群 223 例, pAF群22例, 持続性心房細動 (cAF) 群50例の3群 に分け、比較を行った，LAVIはSR群，pAF群， $\mathrm{cAF}$ 群の順に大きくなり（中央 值 30.2 vs 43.7 vs $62.6, p<0.001$ ), LADも同様の傾向であった（34.8 vs 40.7 vs 44.8 $\mathrm{mm}, \mathrm{p}<0.001)$. 年齢, 入院時NIHSS, D-dimer值, BNP值も同様の傾向を呈して いた。僧帽弁疾患の合併率, CRP值はpAF群で最も高かった. SR群とpAF群を 識別する至適LAVIは 41.7 (感度 $54.5 \%$, 特異度 $88.8 \%$, AUC 0.718) であり, 至適 LADは39.9 mm（感度59.1\%, 特異度 $82.1 \%$, AUC 0.697)であった. LAVIのAUC が高い傾向にあったが，両者に統計学的な有意差はなかった，多変量解析の結果， $\mathrm{LAVI} \geqq 41.7$, 僧帽弁疾患の合併, BNP高值はpAFの独立した関連因子であった. 脱落理由で最も多かったものは仰卧位描出不良によるLAVI計測不能であり, 16 例 $(64.0 \%$ \%) であった【結論】LAVIはpAfの独立した関連因子であり，心原性脳塞 栓症を示唆する指標となりうる。 


\section{0-36-4 ラクナ梗塞とBranch atheromatous diseaseの鑑別 における、入院時血清PTX3 值の有用性}

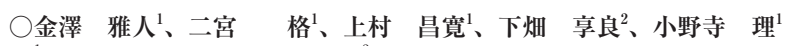
${ }^{1}$ 新潟大学脳研究所 脳神経内科、 ${ }^{2}$ 岐阜大学大学院 脳神経内科

【目的】Branch atheromatous disease（BAD）は、穿通枝動脈起始部のマイクロア テローム形成とその破綻が発症に関与するが、ラクナ梗塞は穿通枝動脈末梢のリ ポヒアリノーシス変性を基礎とし、再者の病態機序は異なる。Pentraxin 3 (PTX3) は急性期炎症性タンパク質の一つで、アテロームプラークの破綻を背景とする急 性冠症候群の炎症性マーカーとして有用性が報告されている。我々はラクナ梗塞 とBADの鑑別に入院時の血清PTX3值が有用である考え、両疾患でPTX3值を比 較検討した。【方法】当科に入院した連続80例のラクナ梗塞とBAD患者について、 後方視的な検討を実施した。両群で神経症状、退院時mRS、高感度CRP，血清 PTX3值や凝固能を含む検查データについて比較した。BADの診断はMRI画像所 見に基づいて判定した。入院時の血清を- $80^{\circ} \mathrm{C} て ゙$ 保存し、ELISA法で血清PTX3值 を測定した。退院時mRS 0-2を予後良好と定義した。【結果】80例のうち凍結血清 の保存が確認されたものは53例であった。23例がラクナ梗塞、30例がBADであっ た。予後良好はラクナ梗塞で20例、BADで11例であった。入院時PTX3值は、ラ クナ梗塞で $3397 \mathrm{pg} / \mathrm{mL}$ (IQ 1931-4336 pg/mL)、BADで4840 pg/mL (IQ 2860 $9251 \mathrm{pg} / \mathrm{mL})$ で、BADで高值であった $(\mathrm{p}=0.018)$ 。入院時OCSP分類でLACIを呈 した患者数はラクナ梗塞で16例、BADで18例で、PTX3值はそれぞれ $3287 \mathrm{pg} / \mathrm{mL}$ (IQ 1986-4145 pg/mL)、6286 pg/mL (IQ 3577-9739 pg/mL) であり、BADで約2 倍高值であった $(\mathrm{P}=0.003)$ 。血清PTX3でBADを診断するROC曲線解析では，最 適なカットオフ值は $2778 \mathrm{pg} / \mathrm{mL}$ であり, 感度, 特異度ともに $77 \%$ あったた。【結論】 ラクナ梗塞とBADの比較では、入院時血清PTX3值はBADで有意に高值であった。 特に入院時ラクナ症候群を呈する症例において、ラクナ梗塞とBADの鑑別には血 清PTX3值が有用である可能性が示唆された。

\section{0-36-6 ICTを活用して脳卒中の早期治療を目指すプログラム (タスカル/TQMプロブラム) の開発}

松本 省二 1 、安田あゆ子 ${ }^{2}$ 、中原 一郎 ${ }^{1}$ 、小山 裕司 $^{3}$ 、小池 大助 $^{2} 、$ 沖田 慎平 ${ }^{1}$ 、吉良 潤一 ${ }^{4}$

${ }^{1}$ 藤田医科大学脳卒中科、 ${ }^{2}$ 藤田医科大学 医療の質管理室、 ${ }^{3}$ 産業技術大学院

大学 情報アーキテクチャ専攻、 ${ }^{4}$ 九州大学大学院医学研究院 神経内科学

【目的】脳卒中医療では早期の治療が重要であり、予後を改善することが示され ている。早期治療実現のために脳卒中診療支援ICTシステム（タスカル）と、それ を医療機関に導入するためのプログラム（タスカル/Total Quality Management: $\mathrm{TQM}$ プログラム) を開発する。【方法】タスカルは脳卒中診療プロセス中の各部署 の準備・処理状況を横断的に可視化することで診療を支援するICTアプリケーショ ンである。タスカルの使用により電話連絡を最小限にし、部署・チーム間の多元 的同時状況認識が可能となる。本研究ではトヨタのKAIZEN手法を応用して、日 本中のどの病院でも、脸卒中診療体制を改善することを可能としたプログラムを 開発した。【結果】以下の8ステップで構成されたタスカル/TQMプログラムを開 発した。1) チーム形成、2）診療パフォーマンスの現状把握、3) 脳卒中診療の あるべき姿と目標の設定、4) 要因分析、5）対策立案、6）タスカルを用いた診 療シミュレーション、7) 効果確認、8)脳卒中診療の標準化と持続的な支援活動。 現在、国内3施設でタスカル/TQMプログラムの実証試験を開始しており、診療プ ロセス時間の短縮と医療スタッフの負担軽隇効果を検証している。【結論】夕スカ ル/TQMプログラムは日本中の医療機関で導入可能で、脳卒中患者の予後を改善 することが期待でき、広く、普及させることを目指している。

0-36-8＼cjkstart後方循環系の血行再建におけるサポートガイディング カテーテルとPenumbra ACEの有用性

\footnotetext{
姫野 隆洋 ${ }^{1}$ 、中道 淳仁 ${ }^{1}$ 、佐藤 恒太 ${ }^{1}$ 、下村 怜 ${ }^{1}$ 大田 慎三 $^{2}$

${ }^{1}$ 脳神経センター大田記念病院 脳神経内科、

2脳神経センター大田記念病院 脳神経外科
}

【目的】後方循環系の急性期血行再建において、Penumbra 5MAX ACE® (ACE) でのADAPTテクニックによる血栓回収は有用であるが、椎骨動脈 (VA) の蛇行、 大動脈弓の形状などにより、ガイディングカテーテル (GC) が留置できず、治療を 行えないことも多い。我々はGCがVAに留置困難な場合、もしくはそれが予測さ れる場合、腕頭動脈の起始部、もしくは、鎖骨下動脈の起始部にサポートガイディ ングカテーテル Medikit SELE® (SELE) を留置し、ACEでVAに直接進入し、病 変にアクセスする方法をとっている。その手技の有用性に関して検討する。【方法】 2017年1月から2019年9月までに当院で行った頭蓋内VA、脳底動脈閉塞（BA）（後 大脳動脈閉塞は除く）の急性期再灌流療法を行った 26 例のうち、ACEを用いた 22 例に関して、SELEの使用、追加治療、穿刺再開通時間 (PtoR)、有効再開通、合 併症を検討した。【結果】22例のうち、SELEは17例 $77 \%$ \%)に使用されていた。ACE によるADAPT単独での再開通群が11例、ACEでのADAPTをはじめに試み、追 加治療（Stent retriever、PTA、ウロキナーゼ動注）を行った群が11例であった。 ACE単独群11例では、心原性 (CE) 10例、アテローム血检性(AT) 1例、年齢(中央值) 79歳(IQR:72-84)、PtoR: 26分(17-31)、有効再開通(TICI 2b以上):11/11例 (100\%)、 TICI3:10例、TICI2b:1例と良好な成綪であった。ACE + 追加治療群11例ではCE6 例、AT5例、年齢78歳 (74-84)、PtoR: 68分 (57-112)、有効再開通9/11例 $(82 \%)$ 、 TICI3:5例、TICI2b:4例であった。両群とも合併症はなかった。【結論】後方循環系 の急性期血行再建においてSELEを用いることで、ACEによってVA、BAに進入し、 良好な成績を得ることができた。

\section{0-36-5 脳血栓回収療法治療後にDramatic recoveryを認め} た症例の特徵

$\bigcirc$ 片野 雄大、坂本 悠記、澤田 和貴、鈴木健太郎、金丸 拓也、 青木 淳哉、西山 康裕、木村 和美

日本医科大学付属病院 脳神経内科

【背景・目的】脳主幹動脈䦥塞における脳血栓回収療法後に急速な症状の改善 (Dramatic Recovery :DR) を経験することがある.DRを認めた症例ではその後の 転帰もよいと考えられるが,DRに関して検討した報告は少ない。今回急速に症状 の改善を認めた症例の特徴を検討した.【方法·対象】2011年 1月から2019年7月ま でに当院で急性期血行再建術を施行された内頸動脈閉塞,中大脳動脈水平部閉塞 連続症例を対象とし,急速改善を認めた症例DR群と急速改善を認めなかった症例 NDR群の2群にわけ,2群間で後ろ向きに比較検討したDR例は治療 24 時間以内に NIHSSが治療前より 10 点以上改善,または0-2であった症例と定義した.【結果】期 間内の対象症例は286例（年齢中央值76歳[67-83],女性116例[40\% ],NIHSS18[11 24]).DRを認めた症例は72例 (25\%)であった. 年齢,NIHSS,Alberta Stroke Program Early CT Score（ASPECTS）などの背景因子において2群で有意差は認められな かったPASS回数はDR群で1 [1-2] と NDR群で2 [1-3]（P=0.0022）であった.Any intracranial hemorrhage (Any ICH) はDR群で5.6\%,NDR群で28.0\% (P=0.0004) であった.3か月後の mRS0-2ではDR群で $71 \%$,NDR群で38\%（ P<0.0001）であっ た.多変量解析においてもPASS回数 $(\mathrm{P}<0.0110)$ 、Any ICH $(\mathrm{P}<0.0003)$ はヶ 月後 mRS0-2に独立して関連していた.その他,年齢,性別,血管の閉塞部位,tPAの有無,AF の有無NIHSS, 発症から再開通のまでの時間では明らかな有意差は認められなかっ た.【結論】脳血栓回収療法後にDRを認めると転㛿はよい.DRには少ないPASS回 数で,治療後の脳出血を起こさない血管内治療を行うことが重要である.

\section{0-36-9 脳神経内科で実施した未破裂脳動脈瘤に対するコイル 塞栓術の治療成績の検討}

\footnotetext{
○武澤 秀理 ${ }^{1,2}$ 、日高 幸宏 ${ }^{1,2}$ 、長 正訓 ${ }^{1,2}$ 、勝盛 哲也 ${ }^{3} 、$

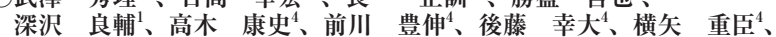
岡英輝、日野 明彦、藤井 明弘 ${ }^{1}$

済生会滋賀県病院 脳神経内科、

済生会滋賀県病院 脳神経血管内治療センター、 ${ }^{3}$ 済生会滋賀県病院 放射線科、 済生会滋賀県病院 脳神経外科
}

【はじめに急性脳主幹動脈開塞に対する経皮的脳血栓回收術のエビデンスが確立され、脳血 管内治療専門医老取得する睬神経内科医（脳内）が増加している。しかし、脳内が害施した未 破裂脳動脈瘤/破裂慢性期脎動脈瘤(AN)に対するコイル塞栓術の報告は少ない。当院ではAN に対するコイル塞栓術をすべて脳内が寒施している。目的】脳内が施行したANに対するコイ ル塞栓術の治療成績について検討する。【方 法]2016年5月から2019年10月の3年5か月間におい て、当院で治療されたANは 125 動脈瘤であった。そのうち、脳内が塞施したANに対するコイ ル塞栓術24例、25動脈瘤 (20\%) を対象とし、後方視的に解析した。結果】男性8例 (33\%)、年 齢中央值59歳であった。全例で全身麻酔下にコイル塞栓術を実施した。脑動脈瘤の位置は、 内䅡動脈が14動脈瘤、中大脳動脈が3動脈瘤、前大脎動脈または前交通動脈が4動脈瘤、椎骨 動脈または脳底動脈が動脈瘤であった。シンプルテクニックで治療したのが10動脈瘤、゙ルル ンアシストテクニックで治療したのが7動脈瘤、ダブルカテーテルテクニックで治療したのが 1動脈瘤、ステントアシストテクニックで治療したのが7動脈瘤であった。最終造影での塞检 状態の程度をRaymond塞栓スケールで評価すると、完全閒寒が16動脈瘤 $(64 \%) 、$ 動脈瘤䅡部 残存が8動脈瘤 (32\%)、動脈瘤残存が1動脈瘤 (4\%)であった。致死的合併症、永続的合併症は なく、一過性の合併症は1例（4\%）でみられた。一過性の合併症の詳細は、術翌日に歩行時の ふらつきを自覚した。明らかな神経症状は認めなかったが、頭部MRIでは複数の点状の新規 脳梗塞を認めた。2日で症状は消失し、後遗症なく退院した。術中、術後に出血性合併症を呈 した症例はなかった。術後に再治療を要したり、破裂した症例はなかった。結語】当院で脎 内が実施したANに対するコイル塞栓術の治療成績は、安全で効果的であった。 


\section{O-36-10 当院における超急性期脳梗塞の診療体制の構築一時間 短縮への取り組み一}

$\bigcirc$ 作田 健一 ${ }^{1}$ 、向井 泰司 ${ }^{1}$ 府賀 道康 ${ }^{2}$ 、奥野 憲司 $^{3}$ 、谷口 $\quad{ }^{1}{ }^{1}$ 東京慈恵会医科大学附属柏病院神経内科、

東京慈恵会医科大学附属柏病院 脳神経外科、

東京慈恵会医科大学附属柏病院 救急科

【目的】超急性期脸梗塞の診療では，血行再建療法の適応をいかに早く判断し治療 を完結させるかが転帰に直結する。時間短縮への取り組みは各施設に依存する部 分が多く，その取り組みの効果の検証は不可久である. 脳卒中基本法の成立を鑑 及，当院では超急性期脑梗塞の診療体制を 2019 年 5 月より大幅に変更した。 今回，その変更による時間短縮への効果を検証した. 【方法】 2017 年 10 月か ら 2019 年 11 月に当院に入院した急性期脑梗塞患者連続 125 例のうち, 血 栓回収術を実施した症例を対象とした。腷卒中疑い例の診療体制は以下の通りて ある. 2019 年 5 月以前は初期診療後に頭部M R I 撮影し t P A お 上び血栓 回收術の適応を判断した。 その後適応ありと判明したのちに各関係部門への連絡 と準備, 家族への説明を行った. 診療体制の変更後は各関係部門へ来院前に連絡し， 来院後に造影 C Tに上る血管評価を可及的速やかに行った，閉塞血管がある場合 は禁忌がなければ t P A を投与しつつ頭部M R I を撮影した。 それと並行して家 族への説明と血栓回收術の準備をした。診療体制が変更になった 2019 年 5 月 以前の症例 (旧体制群) と以降の症例 (新体制群)の二群にわけて比較検討した. 【結 果】 35 例 (男性 22 例, 年齢中央值 76 歳, N I H S 中 中央值 19 ) が抽出された。 新体制群は 10 例であった. 2 群間の比較では, 新体制群でN I H S S が高値 $(26$ 対 $16 . \mathrm{P}=0.008$ ) でA S P C T Sが高值 ( 9 対 $7, \mathrm{P}=0.042)$ であの た. 発症から来院までに差は無く $(68$ 分対 114 分, $\mathrm{P}=0.139)$, 来院から t P A (5 3 分対 116 分, $P=0.015)$ と来院加穿刺 $(80$ 分対 162 分, $\mathrm{P}<0.0001)$ が有意に短縮された。穿刺から再開通までは差はなかった $\left(\begin{array}{ll}6 & 0 \\ 0\end{array}\right.$ 対 69 分, $\mathrm{P}=0.306$ ).【結論】診療体制の変更で時間短縮が達成できた。

\section{0-37-2 病型別にみたリハビリテーション後の脳梗塞の機能回復}

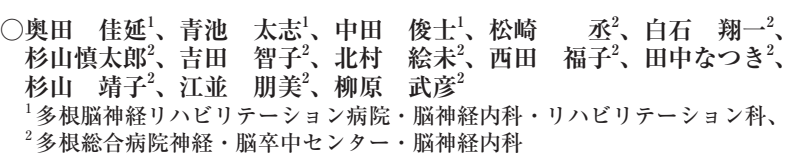

【目的】脳梗塞患者の回復期リハビリテーション後の機能回復に影響する因子 を、atherothrombotic type、cardioembolic type、 branch atheromatous disease

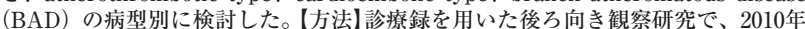
から2018年に当院を退院した腷梗塞患者688例のうち、各病型に該当した618例を 対象とした。Functional Independence Measure (FIM) を日常生活動作 (ADL) の指標とした。3病型を、(1)性別、(2)年齢、(3)病変部位（テント上下）、(4)病変 部位（左右）、(5)発症後入院までの期間、6 入院時motor FIM $(\mathrm{mFIM}) 、(7)$ 入院 時cognition FIM (cFIM)、81日あたりのリハビリテーション時間、9人院期 間、(10退院時mFIM、(11)退院時cFIM、(12)獲得FIM（退院時FIM - 入院時FIM) (13FIM effectiveness〔獲得FIM / (126一人院時FIM) 、 (14)自宅退院率、の各 因子别に比較した。また、各病型において、退院時FIM (転㷌の指整) と FIM effectiveness（機能改善の指標）を目的変数とし、説明変数を(1)〜(9)としたステッ プワイズ法による重回帰分析を行った。結果】BADでは、他の2病型と比較して FIM effectivenessが大きかった。退院時FIMは、いずれの病型でも入院晆mFIM 入院時cFIM、入院期間と年齢に影響されていたが、BADではテント下病変で有 意に低くなった。FIM effectivenessは、いずれの病型でも入院時mFIMと年齢に 影響されていたが、cardioembolic typeでは発症後入院までの期間が長いと有意 に低下した。【結論】脳梗塞患者のADL改善度は病型ごとに特徵があり、病型を考 慮したリハビリテーション実施計画が必要と考えられる。

\section{0-37-4 食道内に陰圧を形成する新しい嚾下方法 (バキューム 嚥下) は指導により習得できる}

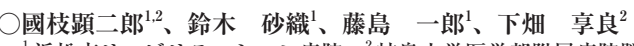

${ }^{1}$ 浜松市リハビリテーション病院、 ${ }^{2}$ 岐阜大学医学部附属病院脳神経内科
}

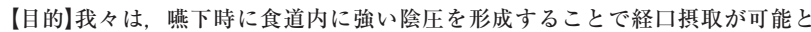
なった球麻痺 (Wallenberg症候群) の嚥下障害の1例を報告した。陰圧により食塊 が咽頭から食道内に一気に流入するため, バキューム舆下 (vacuum swallowing, VS) と命名した。本検討の目的は，VSが新規の舆下方法として健常者でも再現可 能か, 高解像度マノメトリー (high resolution manometry, HRM) を用いて検討 することである.【方法】最初にVSを担当医とSTの 2 名で習得できるか検討した HRMでは，症例と同様に嚥下時に食道内に強い陰圧が形成され，下部食道括約筋 (lower esophageal sphincter: LES) 圧が上昇していた.VSを習得した2名が，健 常者14名 (年齢 $32.7 \pm 6.8$ 歳)にVSを指導した。 HRMを用いて通常の嚥下とVS時の 食道の最小圧 $(\mathrm{P}$ min $)$ とLESの最大圧 $(\mathrm{P} \max )$ を, 水 $5 \mathrm{ml}$ で5回ずつ評価した。【結果】 14名中10名で嚥下時に食道内に陰圧が形成された。通常の嚥下と比較し，VSは Pmin $(-15.0 \pm 16.7$ vs. $-46.6 \pm 16.7 \mathrm{mmHg}: \mathrm{P}<0.001)$ と有意に低下, $\operatorname{Pmax}(25.4$ \pm 9.8 vs. $152.6 \pm 79.3 \mathrm{mmHg} ; \mathrm{P}<0.001)$ と有意に上昇していた. VSでは胸腔内 の陰圧を反映して䅡部が寉み鎖骨や胸鎖乳突筋が浮き出ていた.【考察】VS時の LES圧の上昇は横隔膜の収縮を反映しており，舆下時に横隔膜を含めた呼吸筋を 収縮させて吸気努力を行っていると推測されたＶVSでは嚥下時に吸気努力の夕イ ミングを合わせることで，嚥下時に随意的に陰圧を形成し食道内に食塊を流入さ せる，健常者でもVSを習得できることが確認できたことから，今後，が分かった． VSは新しい嶼下法として, 興下障害患者におけるでVSの有効性を確立する検討 していく必要がある。
0-37-1 脳卒中病変の局在は同期的脳活動によ゙う影響するか ? -脳波による解析-

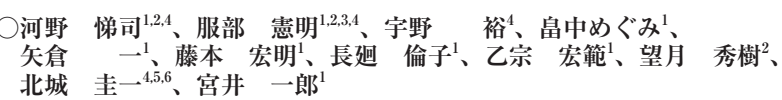
1 森之宮病院神経内科、

${ }^{2}$ 大阪大学 大学院医学系研究科 神経内科学、 ${ }^{3}$ 大阪大学 国際医工情 報センター 臨床神経医工学寄附研究部門、 ${ }^{4}$ 理化学研究所 脑神経科学 研究センター CBS-トヨタ連携センター 脳りズム情報処理連携ユニッ 卜、 ${ }^{5}$ 生理学研究所 システム脳科学研究領域 神経ダイナミクス研究部門、 6 国立大学法人 総合研究大学院大学 生命科学研究科 生理科学専攻

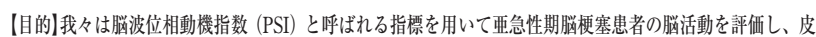
質病変を有する患者において運動野と関連したPSIが上肢Fugl-Meyerスコア(FM-UE)やリハビリテーショ ンによる回復と相関することを見出した。即ち、1.左右運動野間のPSI (C3C4-PSI; $a$ 帯) は徤常者より低 值で、入院時FM-UEと相関し、2.非病変側の半球内PSI (IntrahC-PSI; $\theta$ 带) は健常者より高值で、治療後 のFM-UE利得と相関した。本研究の目的は、梗塞巣の局在（皮質/皮質下）がPSIに及はす寸影響を評価する ことである。(方法)回復期リハビリテーション目的で入院した片麻疩を有する初発脑梗塞患者 78 名 $(66.9 \pm$ 12.6 歳、皮質群 33 名、皮質下群 45 名) を対象とし、入退院時にそれぞれ脳波計測 $(19 \mathrm{ch})$ と臨床評洒を実施し 両群間の差を評価した。(発症〜初回脎波計測までの期間 $33.1 \pm 10.8$ 日、計測間隔 $94.2 \pm 37.9$ 日)【結果】両群 において患者の年齢、初回脳波計測までの期間、脑計測間隔、入院時FM-UE、FM-UE利得の有意差はなかっ た。C3C4-PSIは初回計測時皮質群で有意に低值であったが $(P=0.015)$ 、上昇傾向を示し2回目の計測で は両群間に有意差は無加た $(P=0.052)$ 。方で非病変側IntrahC-PSIについては、初回計澌時皮質群て 有意に高值であったが $(P=0.01) 、$ 低下傾向を示し 2 回目の計測では両群で有意差は無かった $(P=0.065) 。$ 【結論】梗塞巣が同期的脳活動に与える影響は皮質群においてより㩆著であったが、回復に伴いその差は縮 小傾向を示した。興味深いことに非病変半球におけるPSI值にも有意差を認めた。この現象は梗塞巣によ る直接影響ではなく、半球間に存在する広域のnetwork活動を反映していると考えた。このように、PSIは 脳卒中に起因する媨活動の変化を評価するバイオマーカーとして有用であることが示唆された

\section{O-37-3 ALSに対するモーターアシストブローブを用いたリハ ビリテーションの有効性の検討}

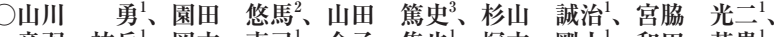

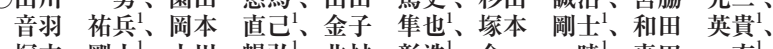
塚本 剛士 ${ }^{1}$ 、小川 暢弘、北村 彰浩、金 一暁、真田 充、

滋賀医科大学 脳神経内科、滋賀医科大学 リハビリテーション科、

滋賀医科大学 革新的医療機器・システム研究開発講座

【目的】筋萎縮性側索硬化症（ALS）に対してのリハビリテーションは過度に行うこ とで症状が進行することが指摘されており、特に手指筋力低下に対する治療は困難 である。我々は身体的な負荷が少なく適切な運動を行うリハビリテーションとし て、ロボットを用いたリハビリテーションに注目し、モーターアシストグローブ を用いたリハビリテーションの有効性と作用機序について検討した。【方法】指先へ の触知を感知して手指屈曲を補助する容易なSoft Extra Muscles Glove（以下SEM glove）を用いたリハビリテーションを行う。当院に入院したALS患者14例 (平均 年齢65歳) の片側手[漆谷1] にSEM gloveを用いたリハビリテーションを2週間行っ た。対側手では被検手を模した運動を過負荷がない範囲で実施した。SEM glove を使用した手と対側の手において、握力やSTEF簡易検查、また神経伝導検查 (Split hand index)、超音波検查(筋輝度) (全て14例)、resting state functional MRI (5例) による評価を行い、リハビリテーション前後で比較した。【結果】SEM gloveを使用 した手はリハビリテーションの前後で握力の変化はないものの、STEF簡易検査で 有意な改善を認めた。神経伝導検查・超音波検查では特に前後での差は認めなかっ た。対側の手では握力やSTEF簡易検査、神経伝導検査・超音波検査は特に変化は なかった。 resting state functional MRIは被検側が右手の症例で䒠施し、訓練によ り左扁桃体から左被殼間に有意なFunctional Connectivityがみられた。結論】2週 間のSEM gloveにおけるリハビリテーションはSTEF簡易検査で改善を認めた。ま たその改善は脳の特定部位の機能連関の獲得が関与している可能性がある。

\section{0-37-5 パーキンソン病におけるナイアシンの検討}

横山絵里子、宮田 美生

秋田県立リハビリテーション・精神医療センターリハビリテーション科

【目的】ナイアシン (NA) は, パーキンソン病や精神疾患との関連性が報告されて いる. パーキンソン病に扔けるNAと精神症状, 運動機能, 日常生活動作 (ADL), 栄美指標との関連を检討した【方法対象はパーキンソン病49例で，中央值は年 齢77歳, 䍜病期間6.0年, Yahr重症度4である。 Unified Parkinon's disease rating scale (UPDRS), HDS-R, 握力, 上肢機能検查 (MFS), 下肢運動年齢, Barthel index, functional independence measure (FIM) を評傮し，同時期に栄盖指標と して身長，体重から体格指数（BMI）を算出し，血液検查でアルブミン、へモグロ ビン，総コレステロール，総リンパ球数、ビタミン $\mathrm{B}_{1}, \mathrm{~B}_{6}, \mathrm{~B}_{12}$, 葉酸、総ホモシ スチン，1.25- $(\mathrm{OH})$,ビタミンD，カルシウム、リン，西鉛を測定した，対応のな いt検定でYahrの重症度別にNA值を比較し, Spearmanの順位相関保数を用いて, NA とUPDRS, 運動機能, ADL評価, 栄養指標との相関関係を検討した【【結果】 NAは10例で低下していた（基準値4.7〜7.9MCG/ml). NA低下群10例では，不安 を7例，アパシーを4例，抑うつを3例で認め，NA正常群39例では不安8例，アバ シー9例，抑うつを7例で認めた (重複あり). NAはY $\mathrm{ahr}$ 重症度別の比較では群間 の有意差はなかった. 相関関係の検討では, NAはMFSと有意な負の相関 $(\mathrm{p}<0.05)$, BMI, 総リンパ球数, 血清リンと有意な正の相関を認めた $(\mathrm{p}<0.05)$. UPDRS, ADLとの有意な相関はなかった.[結論]パーキンソン病において, NA低下は精神 症状，運動機能，低体重や免疫機能と関連する可能性が示唆された。 
0-37-6 パーキンソン病患者における歩行開始時の運動学的解 析:COPの左右不均等性に関する検討

\author{
○大沼 亮 ${ }^{1,2}$ 星 文彦 ${ }^{3}$ 松田 雅弘、増田 正 $^{5}$ 、 \\ ネルソン祥子 ${ }^{1}$ 、神野 哲也 ${ }^{6}$ \\ 医療法人 名圭会、 ${ }^{2}$ 東京医科歯科大学大学院、 ${ }^{3}$ 埼玉県立大学、 \\ ${ }^{4}$ 順天堂大学、 ${ }^{5}$ 福島大学、 ${ }^{6}$ 獨協医科大学埼玉医療センター
}

【目的】本研究は，左右別々に解析したCOP (Separated COP) がパーキンソン病 (PD) 患者の歩行開始に扔ける予測的姿勢調整（APAs）の機能低下の特異性を示すかを明ら かにすることを目的とした.【方法】健常高齢者10名，PD患者10名の2群を対象とし，浬 題遂行合図（光合図）に合わせて歩行させた時の歩行開始時の動作を解析した。装置 は重心動摇計（ユニメックス社製，UJK-200C)，簡易光刺激装置（イリスコ社）を使用 した，COP移動は2枚の重心動摇計を用いて，立脚側と遊脚側を独立して解析した。 Separated COPの後方移動ピーク潜時と後方移動量を健常高龄者群とPD患者群、およ び立脚側と遊脚側で比較した。さらに, PD患者のSeparated COPの移動ピーク潜時お よび移動量とUnified Parkinson's Disease Rating Scale (MDS-UPDRS), Timed up \& go test (TUG), Berg balance scale（BBS）との相関を解析した。統計処理は健常高齢 者及びPD患者のCOP移動の潜時、及び移動量をT椧定にて検証し，有意水準は5\%とし た.【結果】PD患者は健常高齢者に比して, 立脚側のSeparated COPの後方移動ピーク 潜時が延長していた $(p<0.05)$ 。また，PD患者の遊脚側より立脚側の後方移動ピーク 潜時が延長していた $(p<0.01)$. PD患者の遊脚側のSeparated COPの後方移動量が小 さかった $(p<0.01)$. PD患者の立脚側のSeparated COPの後方移動量とTUG，遊脚側 のSeparated COPの後方移動量とMDS-UPDRS，及びBBSとの間に相関を認めた $(r=$ $-46 r=-0.47 r=0.50)$.【結論】本研究上り, PD患者の歩行開始時におけるAPAs機能低 下の特徵として立脚側の独立COPの後方移動ピーク潜時の延長と遊脚側の独立COPの 後方移動量の低下が明らかとなった。 また, Separated COPと運動障害, 移動能力, 抒 よびバランス能力との関連が明らかとなったＰD患者は歩行開始時において立脚側と 遊脚側の不均等性を示し, Separated COPはAPAs機能低下の評価として有用と考える.

\section{O-37-8 中枢神経系脱髄疾患の歩行障害に対するHAL ${ }^{\circledR}$ 治療の 反復実施経験}

岡野 篤志、喜多 貴信、水井 大介、中井 良幸、岡田 弘明、 金井 雅裕、山口 啓

一宮西病院 脳神経内科

【目的】多発性硬化症をはじめとする中枢神経系脱䯣疾患では歩行障害によるADL の低下が問題となるが，それらの疾患の歩行障害に対してHybrid Assistive Limb $\left(\mathrm{HAL}^{\circledR}\right)$ の有効性を検討した報告は少ない，今回我々は中枢神経系脱䯋疾患の步 行障害に対して繰り返しHAL ${ }^{\circledR}$ 治療を行い, 歩行機能の維持・改善を得られた二 症例を経験したため報告する。【方法】症例 1 はX年1月にふらつきで発症し，両側

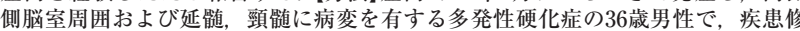
飾薬としてナタリズマブを使用している。症例 2 はY年 3 月に排尿障害で発症し, 右側脳室周囲および胸葡に病変を有する抗MOG抗体関連疾患の46歳女性で, 再発 予防のためステロイド $3 \mathrm{mg}$ 内服している、それぞれの患者は，HAL ${ }^{\circledR}$ 医療用下 肢タイプ装着下の歩行時間 40 分を 1 回とし，1クール15日間の入院期間中に計 9 回 のHAL ${ }^{\circledR}$ 治療を行い, 約6ヶ月ごとに計 3 クール実施した. 2分間歩行距離 $(\mathrm{m})$, 歩 行速度 $(\mathrm{m} / \mathrm{sec})$, Timed Up \& Go Test $(\mathrm{sec})$ を評価項目として, HAL ${ }^{\circledR}$ 初回治療

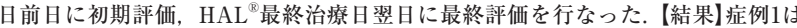
$\mathrm{X}$ 年6月，症例 2 は +1 年 4 月にそれぞれ初回 $\mathrm{HAL}^{\circledR}{ }^{\circledR}$ 治療を開始し，二症例とも開始 時のEDSSは6.0で経過中に明らかな再発は認めなかった。有害事象として二症例 とも電極部の発赤を認めたが, 軽症であり治療は要さなかった。 症例とも各クー 儿前後で評価項目の改善を認め, 症例1は3クール実施前後で2分間歩行距離は $5.8 \%$ 悪化したが，歩行速度は4.7\%，Timed Up \& Go Testは39.6\%とそれぞれ改善を認

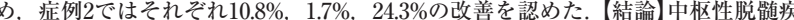
串に伴う歩行障害に対して，疾患修飾薬に加えてHAL はADLを改善し，長期にわたり歩行機能を維持できる可能性が示唆された。 より 大規模な臨床試験による今後の検証が待たれる。

\section{0-37-10 脳卒中患者における回復期リハビリテーション中に発 症した合併症の検討}

秋本 千鶴 ${ }^{1,2}$ 、近藤 総- ${ }^{1,2}$ 、鈴木 尚 ${ }^{1}$ 栗田 英治 ${ }^{1}$ 、

中澤 征人 ${ }^{1}$ 、船越 政範

栃木県立リハビリテーションセンター、 ${ }^{2}$ 自治医科大学

【目的】脳卒中 (脳梗塞, 脳出血, くも膜下出血) の患者が回復期リハビリテーショ ン (以下リハ) 中に合併する疾患について検討した.【方法】2019年度の1年間に回復 期リ八病院である当院に入院した脳卒中患者のべ318名について診療録を元に後 方視的に調查した.【結果】女性129名,男性189名（M/F=1.47）で平均年齢は72.9歳, 脳梗塞208名、脳出血 90 名くも膜下出血 20 名だった入院中に加療を必要とす るような合併症を発症したのは 87 名 $(27.4 \%)$ おりそのうち 22 名で2回以上発症し ていた。 また 32 名 $(10 \%)$ が加療目的で転院した。疾患の内訳は肺炎 16 名，尿路感 染症 15 名, 脱水 10 名, 脳梗塞再発7名をはじめ, 湢吐や下血, 㽷攣発作, 胆囊炎 などだった. 合併症を起こした群は起こさない群と比較して入院時FIM (Function Independence Measure) が平均で30点ほど低く，やや高齢 (平均76.3歳) であり 男性比率 $(\mathrm{M} / \mathrm{F}=1.72)$ が高かった脳卒中の夕イプによる合併症率は差が無く また転院している事もあり入院日数には殆ど差がなかった。肺炎を起こした 16 名 のうち経鼻胃管からの経管栄養のみの患者は2名, 経管栄養から経口摂取に移行し た患者は3名だった，尿路感染症15名のうち留置型尿道カテーテルを使用してい た患者は3名，導尿していた患者は3名だった.【結論】FIM点数が低い重度の機能 障害がある患者ほど合併症を起こしやすく、全身管理が必要だった，疾患の内訳 は急性期と似ているが，点滴加療をしていない事が多いため脱水によるBUN/Cre 比上昇や尿路感染症を起こしやすい特徵があった
0-37-7パーキンソン症候群のストレスマネジメントにおける 密教的賝想法の有用性と可能性

○村端 秀映、竹内 陽介、原靖幸

熊本労災病院 脳神経内科

【背景・目的】神経難病においてストレスマネジメントは非常に重要となる。現在、 身体的リハビリテーション、心理的サポート、音楽療法などが臨床応用されてい るが、それらを統合したメソッドは確立されていない。身体的・言語的・心理的 活動をすべて用いる伝統密教的賏想法はそのBreakthroghとなると考えられる。 伝統密教における阿字観 (阿息観) のストレスマネジメントにおける有用性を明ら かにし、その可能性について探る。【方法】健康であり同意を得られた成人 23 例お よびパーキンソン症候群患者 20 例に対し、阿息観を一日5分間、朝夕毎日実施し た。評価としては試験開始時と4週間ごとのストレッサーテスト（GHQ 28）実施 とUPDRS partI、発声継続時間で行った。24週までフォローアップを行った。【結

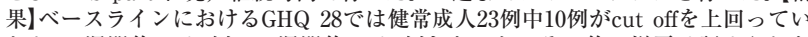
たが、4週間後には4例、12週間後には1例となった。その後の増悪は認められな かった。パーキンソン症候群患者では20例すべてでGHQ 28の改善が認められた。 GHQ 28の項目ごとの結果では、(1)身体的症状(2)社会的障害では最終的に両群の すべてでcut off以下となった。(3)身体的症状(4)うつ傾向では、cut offを上回って いた例はすべて改善し、3例は8週間でcut off以下となった。UPDRS partIは改善 傾向を示し、パーキンソン症候群患者において全例で発声時間の延長が見られた。 【結論】伝統密教的賏想法は健常成人及びパーキンソン症候群患者において非常に 有効なストレス低減効果を示した。さらに、発声時間の延長と自覚症状としての 活動性の上昇がみられた。ストレスは疾患の予後のみならず患者QOLにも直結す るものであり、密教的䀧想法は難病に打けるストレスマネジメントの臨床応用と して非常に有効である可能性がある。

\section{O-37-9 回復期リハビリテーション病棟における小脳出血のリ ハビリテーション}

横関 恵美 ${ }^{1}$ 、久保 元則 ${ }^{1} 、$ 前田 博士 ${ }^{1}$ 、沢田光思郎 ${ }^{2}$

がくさい病院 リハビリテーション科、

京都府立医科大学大学院 リハビリテーション医学

【目的】回復期リハビリテーション病棟における小脳出血の報告は多くない.当院 で経験した小脳出血の5症例のリハビリテーションについてまとめ報告する.【対 象と方法】2018年1月から 2019 年9月までに当院に入院した小脳出血の 5 症例.病巣, 血腫量, 嘔気, 嘔叶などの自覚症状, 吵下機能, 認知機能檢查の点数, 退院時の日常 生活活動, 転㷌先について検討した.【結果】血腫の部位は小脳虫部 2 例, 小脳虫部 +半球が 3 症例であった. 血腫量は $10 \mathrm{ml}$ 未満が 2 例, $10-30 \mathrm{ml}$ が 1 例, $30 \mathrm{ml}$ 以上が 2 例 であった. 経腸栄養であった1例を除き全例煰気, 嘔吐を有していた. 2 例嬿下機能 障害を認め, 1 例は嚥下機能改善術を実施した. 認知機能検査の点数は全例低下し ており,自発性の著しい低下を訒めた全例アマンタジン㕵酸塩を投与し涩知機能 の改善を認めたが, 機能的自立度評価 (FIM) の点数は低く, 日常生活が修正自立と なったのは1例であった. 転帰先は全例施設か病院であった.【結語】小脳出血の後 遺症としてはめまいや湢吐, 構音障害, 運動障害がしられているが, 嬹下障害、認 知機能障害が遷延し, リハビリテーション治療が難渋することが多い. 運動機能へ のアプローチだけでなく, 認知機能の改善をはかるリハビリテーションが重要と 考える。

\section{0-38-1＼cjkstart地域在住高齢者の認知機能と関連する生活習慣因子}

木村 成志、麻生 泰弘、藪内 健一、石橋 正人、堀 大滋、 軸丸 美香、佐々木雄基

【目的】科学的根拠の高い認知症予防法の開発がきわめて重要な課題である。今 回、我々は地域在住高龄者を対象としてリストバンドセンサで取集した生活習慣 因子と認知機能の関連を明らかにする。【対象と方法】65歳以上の曰杵市在住の高 齢者 855 例（男:女 $=317: 538$ 、平均年齢 $73.8 \pm 5.8$ 歳、教育年 $11.8 \pm 2.1$ 年）を対象と した。リストバンド型生体センサを平均 7.8 days 日間装着して生活習慣因子 (歩数、 会話時間、心拍数、睡眠時間、睡眠効率、夜間営醒時間、夜間覚醒回数、昼寝時 間）を3カ月ごとに 1 年間を収集し、一日の平均值を算出した。MMSEと生活習慣 因子の関連を年齢、性別、教育歴、血管危険因子を調整し、Random forest（RF） regression analysisを用いて解析した。さらに、partial dependence plotsを用い て危険因子と防御因子を検討した。【結果】データの収集期間は、平均 $31.3 \pm 7.1$ 日/年であった。RF regression analysisにおいてMMSEと関連する因子は、歩数、 会話時間、睡眠時間、心拍数であった。partial dependence plots では、歩数と 心拍数の増加するにともないMMSEが高值となった。会話時間は321.1分、睡眠時 間は434.1を頂点とした逆U字カーブを示した。【結論】地域在住高齢者では、運動、 睡眠、会話が認知機能と関連する。歩数は認知機能に対して防御的に作用するが、 7791歩でプラトーに達する。会話時間は $80-321$ 分、睡眠時間は $292-434$ 分で防 御的に作用し、それよりも短くても長くても危険因子となる。 
○西本 祥仁、佐々木貴史、阿部由紀子、新井 康通

慶應義熟大学医学部 百寿総合研究センター

【目的】自立した健康超高齢者の認知機能で保持される認知機能に影響する臨床因 子を検討する. [方法] 85 歳 299 藏で要支援1以下の自立した超高齢者1,026名（男性 513人，女性513人)に対して調查時時点での身体機能，認知・精神機能カテゴリー に関する質問票調查を行った. 百寿者において特徽的に保持されている認知機能 に影響する臨床的指標を一項ロジステイック多変量回㷌分析により明らかにした 【結果】MMSE ((Mini-Mental State Examination)の「知㥯運動」を示す質問項目と 関性が示された．さらに男女別にわけて検討を加えると，女性でこの傾向がより 強いことが示された。【考察我々が行ってきた543名の百寿者を対象とした大規 模調查（MMSE，一部の対象者に対してはAddenbrooke's cognitive examination (ACE)-IIIも施行) では, 加㱓に抗して健康長寿を実現している百寿者において「知 営 (視知営・言語理解)」一「運動」間の連合が保持されていることが重要であるとす でに報告した.ささらに「知覚運動」の機能がADL (バーセル指数) と有意に相関する ことも報告した (第38回日本認知症学会)。今回は85歳〜 89歳の健康な超高齢者に おいては，MMSEの「知覚運動」を問う項目に対して自己肯定的・非うつ的気分と 皘極的に他者に関わる習慣が正に相関していることを新たに見出した. 今後さら なる大規模 前向きコホート研究の中で健康長寿に関連する認知機能への影響因子 を明確にし，社会へ向けての提言につなげていくことが期待される。

\section{O-38-4 神経核内封入体病 (NIID) に見られるパーキンソン病 様症状についての検討}

○古谷 博和、宮本 由賀、古島 朋美、永松 秀一、大津留 祥、 森田ゆかり、大浐 康史

高知大学病院 脳神経内科

【目的】NIIDは認知症や精神症状を主訴として発症することが多いが、軽微なパー キンソン病様症状を合併することもあるので、当院の経験例について検討した。 【方法】対象は2013年9月から2019年8月までに当院脳神経内科を受診し、特徽的な MRI DWI と皮虚生検上り成人型NIIDと診断された男性6名 (平均69.8歳、4例が家 族例）。これらの症例に見られたパーキンソン病様症状について瀶床及び神経画像 的に検討を行った。[結果]全例主訴は認知症であったが、夜間せん妄幻視などの camptocormia 1例、静止時振戦が1例に見られたが、神経学的所見として、小刻

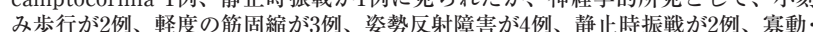
グラフィーが4例に行われたが(1例はいずれも施行されなかった)、全員正常の所 見だった。【結論】NIIDでは主訴にはならないものの、パーキンソン病様症状が潜 在的に合併している症例も多く存在し、認知症を伴うパーキンソン病として治痖 されている症例も存在する可能性が示唆された。

\section{0-38-2 健康超高齢者の認知機能保持に影響する臨床因子の検討} 「高齢者用うつ尺度 (GDS) 総点」「地域内の他者の手助けをする習慣」とは有意な相 BPSDが主訴として3例に見られた。一方、パーキンソン病様症状としての主訴は、 無動が4例に見られた。神経画像検查ではDATスキャンが3例、MIBG心筋シンチ

\section{0-38-3 ダウン症候群は早発性アルツハイマー病を合併する}

竹内 千仙 ${ }^{1}$ 、神原 容子 ${ }^{2}$ 大迫 美穂、望月 葉子 ${ }^{1}$ 東京都立北瘵育医療センター 神経内科

東京都立北療育医療センター 看護科

【目的】諸外国での先行研究にて、ダウン症候群 (Down syndrome; DS)にはアルッ ハイマー病 (Alzheimer disease; AD)の合併が多いことが知られているが、本邦に おいてはこれまでに報告がなく、その実態が不明であった。われわれは、当院外 来にて経過を钼察しえたADを合併したDSについて、その臨床経過を詳細に検討 したので、報告する。[方法]対象は、1988年1月から2018年7月に当科外来を初診 したDS患者。診療録を後方視的に検討し、認知症の発症時期、症状、経過等につ いて検討した。[結果]解析対象のDS150例のうち、認知機能の低下を主訴として 受診したものが36例 (男性17例、女性19例) あり、平均38.9藏であった。18例が $\mathrm{AD}$ 子唁断され (男性8例、女性10例、平均496歲)、その他の18例は、抑う口、甲状腺 機能低下症などの診断であった。40歳以上のDSの $46.2 \%$ 、50歳以上の $81.8 \%$ にD の合併があった。 AD 合併例では、てんかんの合併が10例あり、うち5例はてんか んが認知機能低下に先行した。パーキンソニズムが7例、ミオクローヌスが6例に 見られた。全例で認知機能低下に伴い全身状態の悪化をきたし、うち 3 例は垵た

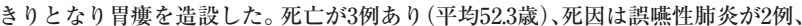
脑動脈塞栓症が1例であった。考察】21番染色体のトリソミーであるDSは、アミ ロイド $\beta$ 前駆体タンパク質遗伝子を 3 コピー有し、その量的効果により早期に老 人斑を形成し、 $\mathrm{AD}$ 々進展する。今回の検討ではDSにおける $\mathrm{AD}$ 、一般集団に 比べ明らかに頻度が高かった。DSでは40代以降にADを発症し、てんかんの合併 が多く、一般集团のADに比べ進行が早いことが特徴である。DSは遺伝性ADの最 大のリスク集団であり、認知症における皘極的な介入が必要である。さらにDSに おけるAD進展の機序の解明は、一般集団におけるADにおいても有用であると考 えられる。

\section{O-38-5 治療する認知症サポートチーム (D2ST3) の有効性と課題}

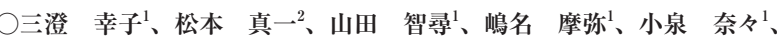

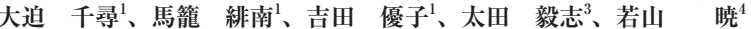

大阪脳神経外科病院看護部、 2 大阪脳神経外科病院 脳神経内科、

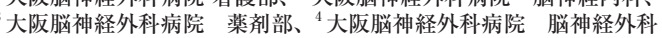

【はじめに】脳神経疾患患者は、手術、疾病、入院などで環境が変化することにで、 高次脑機能が増悪し、機能予後を增恵させることがある。また、高次朕機能障害 に伴う介護の負担が他患者のケアの障害にもなる。このため迅速から的確な対掂 が必要であるが、日常診療では主治医のみでは対応できないことが稀ならずある。 多職種による認知症サポートチームによるケアが武みられているが、看護師から 主治医への相談、主治医から認知症サポートチームへの依頼、認知症サポートチー ムの回診、認知症サポートチームから主治医への報告、主治医の判断による治療 という一連の過程では現場の声が届きにくいため、実際に介護をする看護師は艒 者の状態報告にとどまり、病熊を分析していない側面がある。【目的「治療する認 症サポートチーム」 (Dementia, delirium support team to treat: $D^{2} S T^{3}$ ) が有效 性を検討した。【方法】看護師は、介護上の問題点（主訴）、現病歴、既往歴、内服 歴、家族歴、生活歴、職歴、家族構成のチェック項目を作成した。チェック項目、 血液検查、画像検查、主治医の方針などを電子カルテ上で検討のうえ、多嬂種で 合議し、専門チームの判断で検查、治療介入する $\mathrm{D}^{2} \mathrm{ST}^{3}$ を構築した。2018年6月1 日から2019年5月31日までに脳神経外科、脳神経内科に入院した1546名中175名 (男 性71名、女性104名）に介入した。 $\mathrm{D}^{2} \mathrm{ST}^{3}$ 撙入前後の患者状態、医療者の負担の変 化などについてアンケート調查した。結論】 D ${ }^{2} \mathrm{ST}^{3}$ 導入後患者状態、医療者の負担 は改善した。 $\mathrm{D}^{2} \mathrm{ST}^{3}$ は看護師の報告を元に会議室でカルテ回診し、主治医の権限 越えて治療介入するシステムである。 $\mathrm{D}^{2} \mathrm{ST}^{3}$ は看護師の視点が生かされるが、看 護師の習熟が必要であり、治療に対する責任も伴う。 $\mathrm{D}^{2} \mathrm{ST}^{3}$ 導入 1 年間の効果と問 題点を検討し報告する。

\section{0-38-7 身体疾患で入院した認知症患者における過活動型せん 妄の検討}

高橋 若生 ${ }^{1}$ 、袮津 静花 ${ }^{1} 、$ 風張 昌司 ${ }^{1} 、$ 鷹嘴 亜里 ${ }^{2} 、$ 倉橋慎太郎 ${ }^{3} 、$ 池田 早織、大貫 陽一

東海大学付属大磯病院 神経内科

東海大学付属大磯病院 看謢部、 ${ }^{3}$ 東海大学付属大磯病院 患者支援センター、

東海大学付属大磯病院 リハビリテーション科

【目的】ドネペジルの長期間内服後の急な中止により，精神症状を生じる場合があ るが，多数例での報告は未だ認められない，今回我々は精神症状を生じた多数例 の特徵を明らかにする。【方法】対象はドネペジルを長期間 (2年以上) 内服後，急 に中止された12例（AD:Alzheimer Disease 8名, VD:Vascular Dementia 3例, FTD·Front Temporal Dementia 1例），精神症状を生じた症例の特徽を明らかに し，精神症状を生じなかった症例との比較検討を行う。【結果】精神症状を生じた のは6例 (50\%) で, AD 4例, VD 1例, FTD 1例, 平均 86.8 歳, 男性1例, 女性5例, 内服量平均 $4.6 \mathrm{mg}$. 精神症状を生じなかったのは6例 $(50 \%)$ でAD4例, VD2例，平 均 87.8 歳, 男性 2 例, 女性 4 例, 内服量平均 $5.8 \mathrm{mg}$. 中止理由は施設の理由が $10 / 12$ 例。 精神症状は易怒性，妄想，そわそわする，注意障害，日内変動のある認知機能障 害など. ドネペジル中止から精神症状出現までは平均 2.8 日。ドネペジル再開によ り $5 / 6$ 例 (83\%) が数時間から 2 日のすみやかな症状改善を認めた。 ドネペジルの緩 徐な減量中止を行った3例では精神症状の再出現を認めなかった，精神症状を生 じた例と生じなかった例とでは，疾患，年齢，性別，MMSE，ドネペジル内服量 服薬年数に差を認めなかった。他の内服薬も差を認めなかった。【考察・結論]精 神症状はせん妄と考えられた。ドネペジル中止ですみやかに出現し，内服再開て すみやかに改善したことより，抗精神病薬で生じるような離脱症状が機序として 推察された。ドネペジルは緩徐な減量で副作用なく中止できる可能性がある. 今 回は $10 / 12$ 例が同じ施設で同時期に中止され，外来患者の場合異なる介護者間で は評価が一定しないおそれがあるが，施設では介護者の評価はより一定しており， 精神症状を生じた患者と生じなかった患者の比率はより正確だと考えられた、梳え ネペジルを長期間内服している例では，急な中止を避ける必要がある。
【目的】認知症患者が入院した際に出現する過活動型せん妄 (hyperactive delirium: HD）の特徵を明らかにする目的で、入院中にHDを呈した症例におけるHDと背景 因子との関係ついて後ろ向きに検討を行った。方法】2016年8月より2017年12月の 間に何らかの身体疾患のため当院に入院した65歳以上の症例のうち、認知症高齢 者の自立度判定基準が吕以下であった 243 例を対象とした。そのうち観察期間中 にHDを呈した 97 例 (HD群 : 男性 37 例、女性60例、平均年齢 $85.8 \pm 6.2$ 歳) と HDを含 む明らかなBPSDを示さなかった73例（D群：男性28例、女性45例、平均年齢85.1 士6.6歳）の二群間で比較検討を行った。結果】認知症の病型ではHD群とD群とで それぞれの頻度に違いみられなかったが、HD群では入院前に病型診断されてい ない例が $53 \%$ を占め、control群 $(33 \%)$ に比較して有意 $(\mathrm{P}<0.01)$ に頻度が高かった。 一方、入院の契機となった身体疾患の種類については、両群間に有意差はなかっ た。また、D群は自宅からの入院が $45 \%$ 、施設からが55\%であったが、HD群は自 宅からの入院が $72 \%$ を占めた $(\mathrm{P}<0.001)$ 。また、HD群の $70 \%$ で退院までにHDの 改善を認めたが、HDが改善した例の97\%は身体疾患の経過についても良好であっ たのに対し、非改善例では $31 \%$ \%身体疾患が不変ないし悪化 (死亡含む)していた $(\mathrm{P}<0.001)$ 【結論】HDを示す症例は、身体疾患に罹患して入院する以前の段階で の認知症の精查が不十分で、から自宅から直接入院の症例が多いことから、地域 における認知症に対する医療および介護・福祉の支援体制の拡充がHDを予防する 上で役に立つ可能性がある。 
O-38-8 脳神経疾患における超音波を用いた血管内皮機能の検討

千崎 健佑、阔田 陽子、明地 雄司、武井聡子、松本 清香、 浦 史郎、越智 雅之、越智 博文、伊賀瀬道也、大八木保政 爱媛大学大学院医学系研究科 脳神経内科・老年医学講座

【目的】血管拡張反応を利用した血管内皮機能の解析は、循環器系疾患だけでなく、 認知症・神経変性疾患や自己免疫性神経疾患などでも近年報告が増加している。 今回我々は、脳神経疾患患者を対象として、超音波梌查を用いた血管内皮機能評 価を行い、疾患との関連を検討した。【方法】対象は当院に入院・外来加祭中の患 者で、研究に同意が得られた72例。TCDを用いた息こらえ陚験Breath Holding Index (BHI) と上腕動脈のFlow Mediated Dilatation (FMD) の2種類の超音波に よる血管内皮機能検査を施行した。[結果]平均年齢は58.1藏 (22-86歳)、男性34例、 女性38例であった。今回の対象全体に扔ける平均值はBHI $0.85 \pm 0.6$ 、収縮期 $\%$ FMD $4.3 \pm 2.8$ であった。年跲と BHIは有意な逆相関があり $\left(\mathrm{R}^{2}=0.08, \mathrm{p}=0.022\right)$ 、 FMDでも年齢との逆相関傾向が見られた $\left(R^{2}=0.09, p=0.051\right)$ 。過去に報告されて いる正常值を用いると、今回の検討例における血管内皮機能障害の頻度はBHI 0.7 未满；31例 $43.1 \%$ 、FMD $6 \%$ 未満；35例48.6\%であった。基磊疾患を認知症（主に アルッハイマー型認知症 $\mathrm{AD}$ )、変性疾患、炎症性疾患、その他に分類し、血管 内皮機能との関係を椧討したところ、FMD低下群では認知症が多い傾向を認め た（BHI正常群8例 $19 \%$ vs 低下群5例17\%、\% FMD正常群1例13\% vs 低下群 8 例 $23 \%$ )。[結論] ADの発症や病態進行にはNO産生低下による脑微小血管障害の関与 が報告されている。今回の我々の検討の結果から、ADにおける血管内皮障害は、 BHIよりも主にNOに対する血管昖張反応を示すFMDに反映されやすい可能性か 示唆された。腷神経疾患において両解析を比較・検討した報告はまだなく、文献 的考察を加えて報告する。

\section{O-38-10 Cingulate island sign (CIS) 指標における年辪層別 cut-off valueの㛟討}

\author{
内田 大達、木村 成志、麻生 泰弘、石橋 正人、軸丸 美香、 \\ 松原 悦朗 \\ 大分大学医学部神経内科
}

【目的】レビー小体型認知症 (DLB) のFDG-PETでは、後頭葉の糖代謝低下に加えて 後部带状回の糖代謝が保たれる。この所見は、Cingulate island sign:CISと呼ばれ、 アルッハイマー型認知症 $(\mathrm{AD})$ との鑑別䛦断に有用である。近年、脑血流 SPECT 画像を用いたCIScoreの解析法が報告され、実臨床においても活用させている。 我々は、DLBとADの鑑別における年齢層別のCIScore cut-off 值の変化を検討す る。【方法】DLBの診断基準を満たし、MIBG心筋シンチH/Mの後期像が2.1以下て ある54例 (男: 女 $=25: 29$, 平均年齢 $76.7 \pm 7.6$ 藏)、㧍上びNINCDS-ADRDA 診 断基準を満たし、腷血流SPECTでADの関心領域に血流低下を認める120例（男： 女 $=62: 58$, 平均年齢 $73.7 \pm 9.1$ 歳)を対象とした。DLBで胼血流が低下する後顽 葉を中心とした領域とADに比較してDLBで血流が保たれる後部帯状回を関心領 域に設定し、 值の比をCIS指標とした。DLBとAD症例を70歳未満、70-79歳、80 歳以上に分けROC解析により AD とDLBの鑑別診断において最適なCIS指標のcutoff值、感度、特異度、正診率を算出した。【結果】70歳未満のcut-off值は、0.250て あり、正診率80.5\%であった。70-79歲、cut-off值は、0265であり、正診率78.5\%て あった。80歳以上のcut-off值は、0.305であり、正診率73.3\%であった。結論]CIS 指標は、ADとDLBの鑑別診断に有用であるが、高齢になるほど鑑別に最適なcut off值が高値となり、正診率が低下する。この原因として合併病理の影響が考えら れる。

\section{0-39-2 Calcium-binding proteins stimulate microglia to induce proinflammatory mediators similar to ALS}

\section{OShintaro Hayashi ${ }^{1,2}$, Ryo Yamasaki ${ }^{1}$, Koichi Okamoto ${ }^{3}$, Jun-ichi Kira ${ }^{1}$ ${ }^{1}$ Department of Neurology, Neurological Institute, Graduate School of
Medical Sciences, Kyushu University, Japan, ${ }^{2}$ Department of Neurology, Gunma Rehabilitation Hospital, Japan, ${ }^{3}$ Depatment of Neurology, Geriatrics Research Institute and Hospital}

Objective:In amyotrophic lateral sclerosis (ALS) spinal cord, microglia/ macrophages in the anterolateral funiculi outside the corticospinal tracts (ALFoc), not those in the motor system, were significantly involved in TDP-43 pathology of motor neuron (Hayashi S, 2018). The present study aimed to clarify the cause of microglial activation in the ALFoc of ALS, with referring that calcium-binding protein $(\mathrm{CaBP})$-immunoreactive axons are abundantly present in the ALFoc of normal human spinal cord (Fournet N, 1984). Method:Cultured microglia (1.65 $\times 10^{4}$ cells $/$ well $/ 100 \mu \mathrm{l}$ ) were incubated by 2 kinds of CaBPs, calbindin (CB) (cytoplasmic $\mathrm{CaBP}$ ) and calreticulin (CALR) (endoplasmic reticulum $\mathrm{CaBP}$ ) both with $1 \mu \mathrm{M}, 1 \mathrm{nM}$, and $1 \mathrm{pM}$, and by culture medium (control). Cytokines chemokines concentrations (CXCL1, IFN-gamma, IL-1beta, IL-10, IL-12, IL-6, MCP1, TNF-alpha) in the supernatants were measured by Immunoassay Panel at day 0 (prior to incubation), 1, 2, and 3 . At each day, microglial cells were fix by paraformaldehyde, and crystal violet stainings were performed. Results:Among the 8 cytokines/chemokines, only TNF-alpha was elevated at day 1 and continued to increase with $\mathrm{CB}$ incubation $(1 \mu \mathrm{M}$ and $1 \mathrm{pM})$. IL-6, MCP-1, and TNF-alpha were elevated by day 1 with incubation of CALR $(1 \mu \mathrm{M}$ and $1 \mathrm{pM})$. Microglia had been alive during the day 0-3. Conclusions:This study first showed that CaBPs stimulate cultured microglia to induce proinflammatory cytokines/ chemokines. The elevated cytokine/chemokine profiles are similar to those in the cerebrospinal fluids of patients with ALS (Tateishi T, 2010).

\section{0-38-9 軽度認知機能障害 $(\mathrm{MCl})$ 患者における脳小血管病ス コアと認知機能の検討}

松田 佳奈 ${ }^{1,2}$ 、伊井裕一郎 ${ }^{1} 、$ 上田有紀人 ${ }^{2}$ 、田部井賢一 ${ }^{1,3}$ 、

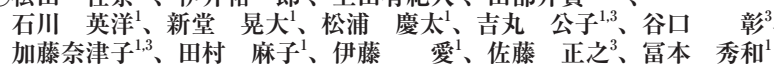
重大学大学院医学系研究科神経病態内科学

重大学医学部附属病院リハビリテーション部、

三重大学大学院医学系研究科認知症医療学

【目的】脳小血管病（SVD）の重症度を評価するスコアとして, 高血圧性SVDス コア (以下 hypertensive vasculopathy; HV-SVDスコア) と脳アミロイド血管症 （CAA）を反映するスコア（以下 CAA-SVDスコア）がある。前者は知的機能と相 関するとの報告はあるが, 後者に関する報告はない。今回, 軽度認知機能障害 (MCI) 患者においてCAA-SVDスコアと認知機能との関連について検討した。【方 法】対象は，2017年2月〜2019年7月に当院でMCIと診断され，脳MRI（3T-MRIで FLAIR, DIR, SWI, T1, T2) の撮像が可能だった42名（75.3 09.12 歳, 男性 23 名, 女性19名）で, 知的機能・記憶・前頭葉機能・構成などの認知機能を評価した。 CAA-SVDスコアは, Charidimou Aら（JAMA Neurol 2016）に基づき，脳葉型 脳微小出血, 脳表へモジデリン沈着症, 半卵円中心の血管周囲腔拡大および白質 病変の各スコアの総計を $0 \sim 6$ の 7段階で算出し, 認知機能の各指標を独立変数と して重回帰分析を行った。また，白質病変定量解析ソフトFUSIONで白質病変を 定量し後方優位に1点, CAAに起因する皮質微小梗塞 (Ishikawa H, in press)があ れば1点を加えたスコアと比較した。結果】CAA-SVDスコアと認知機能に相関を 認めた $(\mathrm{r}=0.902, \quad \mathrm{p}=0.013)$ 。CAA-SVDスコアに白質病変後方優位, CMI $(+)$ を 加えると若干回帰式の予測精度が高くなった $(\mathrm{r}=0.908, \mathrm{p}=0.010)$ 。決定係数 $\mathrm{R}^{2}$ は 0.813から 0.824 と向上した。CAA-SVDスコアは知的機能, 記憶, 構成能力と相関 した。【結論】CAA-SVDスコアはMCI患者の知的機能のみならず，記憶，構成能力 とも相関する。

0-39-1 Perampanel improves seizure via the phosphorylation of GluA1 in the DRPLA transgenic mice

Tomoko Toyota ${ }^{1}$, Zhe Huang $^{2}$, Kazumasa Okada ${ }^{1}$, Toshiya Sato ${ }^{3}$, Shoji Tsuji ${ }^{4,5}$, Hiroaki Adachi

${ }^{1}$ Department of Neurology, University of Occupational and Environmental Health School of Medicine, Japan, ${ }^{2}$ Shanghai TCM-integrated Hospital, ${ }^{3}$ Department of Laboratory Animal Science, Kitasato University School of Medicine, ${ }^{4}$ Department of Neurology, International University of Health and Welfare, ${ }^{5}$ Department of Molecular Neurology, University of Tokyo Graduate School of Medicine

Objective: The juvenile-onset dentatorubural-pallidoluysian atrophy (DRPLA) presents progressive myoclonic epilepsy (PME): ataxia, myoclonus, seizures, and progressive intellectual deterioration. DRPLA is caused by an expanded polyglutamine tract within the atrophin- 1 and an autosomal dominant fatal disease. There are no disease-modifying therapies at present. Recently, perampanel (PER), a selective competitive a-Amino-3-hydroxy-5-methyl-4 isoxazolepropionic acid (AMPA) receptor antagonist, was reported to be effective for PME. In this study, we investigated the effects of PER to the Q113 and Q129 DRPLA transgenic model mice that present PME. Methods: PER was administrated to Q113 and Q129 DRPLA transgenic mice $2.5 \mathrm{mg} / \mathrm{kg}(\mathrm{Q} 113, \mathrm{n}=6 ; \mathrm{Q} 129, \mathrm{n}=11), 5 \mathrm{mg} / \mathrm{kg}(\mathrm{Q} 113, \mathrm{n}=6, \mathrm{Q} 129, \mathrm{n}=15)$, or $10 \mathrm{mg} / \mathrm{kg}(\mathrm{Q} 113$, $\mathrm{n}=8 ; \mathrm{Q} 129, \mathrm{n}=10)$ respectively everyday via oral gavage from 6-week-old (Q113) and 4-weekold (Q129). The control DRPLA transgenic mice (Q113, $n=7 ; \mathrm{Q} 129, \mathrm{n}=17)$ were received the same volume methyl cellulose solution. We observed myoclonus and epilepsy with video. We analyzed motor function by rotarod task. Western blotting and immunohistochemical analysis of brain tissues were performed using antibodies against glutamate receptor 1 (GluAl) and phosphorylated GluA1. Results: PER was effective for myoclonus and seizure with significant difference $(\mathrm{P}<0.05)$. In immunohistochemical and biological analysis, perampanel increased the phosphorylation of GluAl. Conclusions: The phosphorylation of GluAl may contribute to improve myoclonus and seizure in the DRPLA transgenic mice.

0-39-3 HDAC $10 \mathrm{KO}$ activates chaperone-mediated autophagy and accelerates the decomposition of its substrate

Yoshito Nagano ${ }^{1,2}$, Hitomi Obayashi ${ }^{1}$, Tetsuya Takahashi ${ }^{1}$,

Takahiro Seki ${ }^{3}$, Shigeru Tanaka ${ }^{4}$, Norio Sakai ${ }^{4}$

Masayasu Matsumoto ${ }^{5}$, Hirofumi Maruyama ${ }^{1}$

${ }^{1}$ Department of Clinical Neuroscience and Therapeutics, Graduate School of Biomedical and Health Sciences, Hiroshima University, Japan, ${ }^{2}$ Mitsubishi Tanabe Pharma, Japan, ${ }^{3}$ Department of ChemicoPharmacological Sciences, Graduate School of Pharmaceutical Sciences, Kumamoto University, ${ }^{4}$ Department of Molecular and Pharmacological Neuroscience, Graduate School of Biomedical \& Health Sciences, Hiroshima University, ${ }^{5}$ Sakai City Medical Center

[Objective]Recent reports indicate that a dysregulation of chaperone-mediated autophagy (CMA) contributes to the onset or progression of Parkinson's disease (PD). a -Synuclein $(a \mathrm{~S})$, which is a major componen of Lewy bodies (LBs) in PD, has been identified as a CMA substrate. Previously, we found that histone deacetylase (HDAC) 10 is localized with a $\mathrm{S}$ in LBs. $\mathrm{HDACl0}$ is a member of class IIb HDACs, but its functions are poorly characterized. Recent study has shown that HDAC10 deacetylates HSC70 which plays an important role in CMA. Accordingly, we hypothesize that HDAC10 participates in a CMA regulation and contributes to the pathogenesis of PD. The aim of this study is to clarify whether HDACl0 is involved in CMA.[Methods]We established HDAC10 knockout HeLa cell lines using CRISPR/Cas9 system. Immunoblotting and RT.PCR were used to determine the expression levels of LAMP2A. To directly investigate the CMA activity at a single-cell level, we utilized the GAPDH-HaloTag (HT) indicator system. which could monitor the translocation of GAPDH, a well-known CMA substrate, from cytoplasm to lysosomes. Pulse chase assay using GAPDH-HT was preformed to investigate the degradation rate of GAPDH.|ResultsIIn HDAC10 knockout cells, LAMP2A protein and mRNA levels were increased and LAMP2A-positive lysosomes accumulated around the nucleus. GAPDH was delivered to LAMP2A-positive lysosomes and degraded in HDACl0 knockout cells more efficiently than in wild type cells.[Conclusions]HDAC10 participated in regulating CMA, and HDAC10 knockout activated CMA and accelerated degradation of a CMA substrate. 


\section{0-39-4 High reactivity to anti-HERV-K10 in HTLV-1- infected individuals}

Daisuke Kodama ${ }^{1,2}$, Masakazu Tanaka ${ }^{1}$, Toshio Matsuzaki ${ }^{1,2,3}$, Satoshi Nozuma ${ }^{2,4}$, Eiji Matsuura ${ }^{2}$, Hiroshi Takashima ${ }^{2}$, Shuji Izumo ${ }^{1}$ Ryuji Kubota $^{1}$ ${ }^{1}$ Division of Neuroimmunology, Joint Research Center for Human Retrovirus Infection (Kagoshima University Campus), Japan, ' Department of Neurology and Geriatrics, Graduate School of Medical and Dental Sciences, Kagoshima University, Japan, ${ }^{3}$ Department of Neurology, Medical Corporation Sanshukai Ohkatsu Hospital, ${ }^{4}$ Viral Immunology Section, Division of Neuroimmunology and Neurovirology, National Institute of Neurological Disorders and Stroke,

[Objective] Human endogenous retroviruses (HERV) are thought to have infected and integrated into human genome some hundreds of thousand years ago as well as Human T-cell leukemia virus type 1 (HTLV-1). But HERV have lost ability to multiply as virus. Recently, high reactivity to endogenous retrovirus group K member 10 (ERVK-10, HERV-K10) in sera was reported in patients with HTLV-1. associated myelopathy/tropical spastic paraparesis (HAM/TSP). Antibody to HTLV-1 is detected in hundred percent of HTLV-1-infected individuals though antibody to HTLV-1 gag or pol protein are not detected in sera or plasma of HTLV-1-infected individuals. Here, we investigated anti-HERV-K10 antibody that may affect the diagnosis of anti-HTLV-1 antibody, HTLV-1 infection, and pathogenesis of HTLV-1 related diseases. [Methods] We immunized rabbits with synthesized HERV-K10 Gag or Pol peptide to produce anti-HERV-K10 antibody. In addition, we established ELISA system to assay anti-HERV-K10 antibody in specimen from 10 patients with HAM/TSP, 5 asymptomatic HTLV-1 carriers, and 5 negative controls. [Resultsl We found that anti-HERV-K10 Gag and Pol antibody signal intensity in sera of HTLV-1infected individuals were significantly higher than those in uninfected individuals. However, there were no significant correlation between anti-HTLV-1 antibody titer or HTLV-1 PVL and anti- HERV-K10 Gag and Pol antibody signal intensity by regression analyses of sera of HTLV-1-infected subjects. [Conclusions] The high reactivity to HERV-K10 suggests that HERV-K10 may have some indirect interactions with HTLV-1.

\section{0-39-6 Clioquinol reduces oligomeric Tau}

Tadanori Hamano ${ }^{1}$, Feiyan Zhu $^{1,2}$, Gaoping Lin $^{1,3}$, Ayumu Katsuki ${ }^{1}$,

Hirohito Sasaki ${ }^{1}$, Soichi Enomoto ${ }^{1}$, Norimichi Shirafuji ${ }^{1}$, Asako Ueno ${ }^{1}$, Masamichi Ikawa ${ }^{1}$, Osamu Yamamura ${ }^{1}$, Nicholas M. Kanaan ${ }^{4}$

Shu-hui Yen ${ }^{5}$, Yasunari Nakamoto

Department of Neurology, Unviersity of Fukui, Japan, ${ }^{2}$ Department of Neurology, Tongde Hospital of Zhejiang province, ${ }^{3}$ Department of Neurology, Zhejiang Provincial People's Hospital, ${ }^{4}$ Michigan State University, ${ }_{5}^{5}$ Department of Neuroscience, Mayo Clinic Jacksonville

[Objective] The neuropathological hallmarks of Alzheimer's disease are neurofibrillary tangles (NFTs), which are composed of highly phosphorylated tau protein, and senile plaques ( $\mathrm{SPs}_{\mathrm{S}}$ consists of amyloid $\beta$ protein $(\mathrm{A} \beta$ ). As bio-metals imbalance may be involved in the formation of NFT, It was suggested that $\mathrm{Cu}^{2+}$ induces hyperphosphorylation of tau. One of metal-protein attenuating compounds clioquino (CQ) has mild chelating effect for $\mathrm{Zn}^{2+}$ and $\mathrm{Cu}^{2+}$. CQ can detach metals from SPs and reduce the $\mathrm{A} \beta$ aggradation. However, the effects of $\mathrm{CQ}$ on tau are not fully explored, yet. [Methods] To examine the effect of $\mathrm{CQ}$ on tau metabolism, we used a human neuroblastoma cell line, M1C cells which express wild type tau protein (4R0N) via tetracycline off induction. [Results] One to $10 \mu \mathrm{M}$ of $\mathrm{CQ}$ reduces the phosphorylated tau protein. The activity of c-Jun N terminal kinase (JNK), and GSk3 $\beta$, major tau kinases, was reduced by $\mathrm{CQ}$. Activation of protein phosphatase $2 \mathrm{~A}$ which acts as tau phosphatase was also observed by CQ. Fractionation study showed that reduction of oligomeric tau,detected by TOC-1, oligomer tau specific antibody, in tris insoluble, sarkosyl soluble fraction by $\mathrm{CQ}$. Ten $\mu \mathrm{M}$ of $\mathrm{CQ}$ reduced caspase cleaved tau, which accelerates aggregation of tau protein. Morphological study and ATP assay detected that 0.1 to $10 \mu \mathrm{M}$ of $\mathrm{CQ}$ had no effects on cell viability. [Conclusions] Although further examinations are needed to elucidate the mechanisms responsible for the effects of $\mathrm{CQ}$ on tau, $\mathrm{CQ}$ may shed light on the possible therapeutics of $\mathrm{AD}$.
0-39-5 Expression of thymidine kinase 2 and mitochondrial proteins in SCA31 human brains

$\bigcirc$ Hanako Aoki ${ }^{1}$, Miwa Higashi ${ }^{1}$, Michi Okita ${ }^{1}$, Takanori Yokota ${ }^{1}$, Kinya Ishikawa ${ }^{2}$

${ }^{1}$ Department of Neurology and Neurological Science, Graduate School of Medical and Dental Sciences, Tokyo Medical and Dental University, Bunkyo, Tokyo, Japan, ${ }^{2}$ The Center for Personalized Medicine for Healthy Aging, Medical School Hospital, Tokyo Medical and Dental University, Bunkyo, Tokyo, Japan

[Objective] Spinocerebellar ataxia type 31 (SCA31) is caused by a penta-nucleotide repeat in an intron of two genes, brain expressed associated with NEDD4-1 (BEAN1) and thymidine kinase 2 (TK2). While the function of BEAN1 is not known, TK2 is known as a critical protein in the mitochondrial nucleotide salvage pathway. Deficiency of TK2 leads to reduction of mitochondrial DNA-encoded proteins such as Complex IV subunit I (COX1), but not nuclear-encoded proteins such as Complex IV subunit IV (COX4). TK2 knock-out mouse exhibits cerebellar ataxia with abnormalities of Purkinje cells. It is possible to postulate that penta-nucleotide repeat causes reduced expression of TK2 and mitochondrial proteins leading to Purkinje cell degeneration. [Methods] We evaluated the expression of TK2, COX1 and COX4 on control $(n=6)$ and SCA31 $(n=2)$ human cerebellar tissues by immunohistochemistry (IHC). In western blotting (WB) TK2 as well as the ratio of $\mathrm{COX1} / \mathrm{COX} 4$ was assessed using Image J software. [Results Both in control and SCA31 cerebella, COX1- and COX4-immunoreactivity were observed more intensely in Purkinje cells than any other cells such as granule cells. In SCA31, COX1-immunoreactivity appeared preserved in areas with remarkable degeneration as well as in regions without apparent neuronal loss. In WB, the ratio of COX1/COX4 was not reduced in SCA31 compared to controls, suggesting that COX1 was not reduced. The level of TK2 in WB was not significantly different between SCA31 and control. [Conclusion] TK2 and mitochondrial-encoded COX1 were not apparently reduced in SCA31.

\section{0-39-7 Sex-specific differences in transcriptomic profiles and cellular characteristics of OPCs}

Ken Yasuda ${ }^{1}$, Takakuni Maki ${ }^{1}$, Hisanori Kinoshita ${ }^{1}$, Seiji Kaji ${ }^{1}$ Masaru Toyokawa ${ }^{2}$, Yusuke Kinoshita ${ }^{3}$, Yuichi Ono ${ }^{3}$,

Ayae Kinoshita ${ }^{2}$, Ryosuke Takahashi

Department of Neurology, Graduate School of Medicine, Kyoto University,

Japan, ${ }^{2}$ Human Health Sciences, Graduate School of Medicine, Kyoto

University, ${ }^{3}$ KAN Research Institute

[Objective] The purpose of present study was to investigate sex-specific differences in transcriptomic profiles and cellular characteristics of oligodendrocyte precursor cells (OPCs). [Methods] For in vitro experiments, we prepared primary culture of OPCs and oligodendrocytes (OLGs) obtained from neonatal rats. Sex identification was performed by PCR using Sex-determining region Y (SRY) gene. First, we evaluated the capacity of proliferation, migration, and differentiation in OPCs OLGs by performing BrdU incorporation assay, scratch experiment, and western blot analysis. Second, we examined the ischemic tolerance in OPCs by measuring cell viability after oxygen glucose deprivation for 7 hours. Third, we assessed whether sex differences in OPC-derived factors affect the integrity of blood brain barrier (BBB) by trans-endothelial electrical resistance and FITC-dextran assays. Finally, we performed RNA-seq analysis to investigate the sexual dimorphism in transcriptome profiles of OPCs. [Resultsl Female OPCs have a higher capacity for proliferation and migration. In addition, female OPCs are more resistant to ischemic stress, and can enhance the BBB integrity. Meanwhile, male OPCs have a higher capacity for differentiation and myelination. RNA-seq analysis revealed substantial transcriptomic differences in OPCs. [Conclusionsl The present study demonstrates sex-related differences in the cellular characteristics and transcriptional profiles of OPCs. Our findings may help to better understand the pathomechanisms of neurological and psychiatric diseases with sexual dimorphism.

0-39-9 withdrawn 
0-39-10 Quantum dot/nanogold colabeling for double correlative light and electron microscopy of human brain

Miho Uematsu ${ }^{1,2,3,4}$, Kyohei Mikami ${ }^{5}$, Ayako Nakamura ${ }^{1,6,7}$, Katsuiku Hirokawa ${ }^{8}$, Eijiro Adachi ${ }^{1}$, Ryosuke Takahashi ${ }^{2}$, Toshiki Uchihara ${ }^{1,6}$

${ }^{1}$ Laboratory of Structural Neuropathology, Tokyo Metropolitan Institute of Medical Science, Japan, ${ }^{2}$ Department of Neurology, Kyoto University Graduate School of Medicine, Japan, ${ }^{3}$ Department of Immunology and Genomics, Osaka City University Graduate School of Medicine, Japan, Research and Development Center for Mucosal Vaccine, Institute of Medical Science, The University of Tokyo, Japan, ${ }^{5}$ Center for basic technology research, Tokyo Metropolitan Institute of Medical Science, ${ }^{6}$ Department of neurology, Nitobe-Memorial Nakano General Hospital, 7 Department of Neurology and Neurological Science, Tokyo Medical and Dental University, ${ }^{8}$ Department of pathology, Nitobe-Memorial Nakano General Hospital

[0bjective] Cadmium selenide (CdSe) quantum dot (QD) is a nanocrystal which is detectable both as a fluorescent signal by light microscopy (LM) and as an electron-dense particle by electron microscopy (EM). It is a suitable immunolabeling probe for correlative light and electron microscopy (CLEM) of the postmortem formalin-fixed human brain section, as we have established previously. Fluoronanogold is another agent with similar dual visibility. Double CLEM by combining these probes would further expand the study of ultrastructural localization of immunolabeled proteins in the brain. [Materials and Methodsl Brain sections with neuronal inclusions and astrocytes were double-immunofluorolabeled using QDs and fluoronanogolds, respectively. The targeted structures preselected on LM were identified for EM preparation by landmarks that we placed on the sections, and subsequently subjected to EM observation to identify immunolabels on the ultrastructure. Results Ultrastructural visualization of the targeted structures which were corresponding to fluorescent images demonstrated the presence of the QDs and nanogolds on the immunolabeled filaments on EV. Specificity of both labels could be distinguished by energy dispersive X-ray spectroscopy. [Conclusions] This is the world's first research that established double CLEM of postmortem diseased brain sections using the combination of QDs and fluoronanogolds. This method would demonstrate how different molecules woven into complex three-dimensional structures are at work in situ.

\section{0-40-2 MS-related TCR recognizes CMV which protects} disability progression in patients with HLA-DRB1*04:05

OFumie Hayashi ${ }^{1}$, Noriko Isobe ${ }^{2}$, Jacob Glanville,

Guzailiayi Maimaitijiang ${ }^{1}$, Takuya Matsushita ${ }^{1}$, Jun-ichi Kira ${ }^{1}$

${ }^{1}$ Department of Neurology, Graduate School of Medical Sciences, Kyushu University, Japan, ${ }^{2}$ Department of Neurological Therapeutics, Graduate School of Medical Sciences, Kyushu University, ${ }^{3}$ Computational and Systems Immunology Program, Stanford University School of Medicine

[Aim] To identify the multiple sclerosis (MS)-related antigens by analyzing T cell receptor (TCR) repertoire. [Methods] Peripheral blood mononuclear cells were obtained from 39 MS patients and 19 HCs. Next-generation sequencing (NGS) was conducted for complementary DNA for TCR $\beta$ chain. TCR diversity and TRBV/ $\mathrm{J}$ usage were analyzed. TCR motifs enriched in MS group compared to HCs were determined with a clustering method, GLIPH. We measured cytomegalovirus (CMV) -IgG by ELISA and the percentage of $\mathrm{CD} 4^{+} \mathrm{CD} 25^{+}$regulatory $\mathrm{T}$ cells (Treg) by flow cytometry. [Results] TCR diversity was decreased by age and was higher in MS ( $p=$ 0.039). TRBV4-3 were more prevalent in MS. GLIPH consolidated 208,674 TCR clones of MS patients into 1,294 clusters. Out of the two clusters we identified, one was highly shared by $H L A-D R B 1^{*} 04: 05$ (+) MS patients $(87.5 \%)$ and was predicted to recognize CMV (CMV-TCR). The V usage of CMV-TCR was TRBV4-3. MS Severity Scores (MSSS) were lower in the patients with CMV-TCR than in those without CMV-TCR ( $p$ $=0.037)$. In patients with HLA-DRB1*04:05, the CMV-IgG (+) group demonstrated lower MSSS than the CMV-IgG $(-)$ group $(p=0.029)$. CMV-infected patients tended to have higher proportion of Treg compared to the patients without CMV infection ( $p=$ 0.059). [Conclusions] We characterized TCRs related to Japanese MS by applying NGS techniques and a TCR repertoire clustering tool. CMV is suggested to be related to HLA-DRB1*04:05 (+) MS, in a protective way partly via Treg. This is the first study in MS which refers to the association between CMV and $H L A$ class II alleles.

\section{0-40-4 Connexin 47 regulates autoimmune demyelination} in a novel mouse model of multiple sclerosis

\footnotetext{
Ryo Yamasaki, Yinan Zhao, Satoshi Nagata, Yuko Nakamuta,

Hiroo Yamaguchi, Jun-ichi Kira

Department of Neurology, Neurological Institute, Graduate School of Medical Sciences, Kyushu University, Japan
}

Objective: In multiple sclerosis plaques, oligodendroglial connexin $(\mathrm{Cx}) 47$ constituting gap junction channels with astroglial $\mathrm{Cx}_{4} 43$ is persistently lost. The roles of $\mathrm{Cx} 47$ remain undefined. We aimed to clarify the effects of $\mathrm{Cx} 47$ ablation on experimental autoimmune encephalomyelitis (EAE). Methods: We generated $P l p 1-C r e^{E R T} ; C x 47 \mathrm{fl} / \mathrm{fl}$ mice to produce tamoxifen-inducible oligodendroglia-specific conditional knockout of $\mathrm{Cx} 47$ ( $C x 47$ icKO). $C x 47$ icKO mice $(\mathrm{n}=9)$ and their control littermates $(C x 47 \mathrm{fl} / \mathrm{fl})(\mathrm{n}=8)$ were immunized with myelin oligodendrocyte glycoprotein (MOG) peptide 35-55 to induce EAE. Results: $\mathrm{Cx} 47$ icKO mice demonstrated exacerbation of acute and chronic EAE with increased relapse numbers. $C x 47$ ablation facilitated infiltration of Th17 cells into CNS lesions at acute phase, although MOG-specific proliferation of splenocytes was unaltered. Microarray analysis of isolated microglia revealed stronger activation with pro-inflammatory and injury-response phenotypes and enhanced expression of CCL2 in $C x 47$ icKO compared with $C x 47 \mathrm{fl} / \mathrm{fl}$ mice at acute phase. Immunohistochemically, NOS2 ${ }^{+} \mathrm{MHC}^{\text {class }} \mathrm{II}^{+}$microglia were more abundant in $C x 47$ icKO than $C x 47 \mathrm{fl} / \mathrm{fl}$ mice. $C x 47$ icKO mice showed upregulation of A1-specific and pan-reactive genes, and more abundant astroglia harboring $\mathrm{C} 3$, a representative Al marker, compared with $\mathrm{Cx} 47 \mathrm{fl}$ / fl mice at acute phase. Conclusion: These findings suggest that $C x 47$ deletion augments acute $\mathrm{CNS}$ inflammation, causing relapsing and progressive EAE.
0-40-1 Blood-brain barrier-activation in myelin oligodendrocyte glycoprotein antibody associated disorders

Fumitaka Shimizu1, Ryo Ogawa ${ }^{2}$, Toshiyuki Takahashi ${ }^{2}$,

Yukio Takeshita ${ }^{1}$, Tatsuro Misu', Yasuteru Sano ${ }^{1}$, Toshihiko Maeda ${ }^{1}$ Ichiro Nakashima ${ }^{3}$, Kazuo Fujihara ${ }^{4}$, Takashi Kanda

${ }^{1}$ Department of Neurology and Clinical Neuroscience, Yamaguchi University Graduate School of Medicine, Japan, ${ }^{2}$ Department of Neurology, Tohoku University Graduate School of Medicine, ${ }_{4}^{3}$ Department of Neurology, Tohoku

Therapeutics, Fukushima Medical University

Backgournd: We previously reported the effect of sera from neuromyelitis optica (NMO) patients on blood-brain barrier (BBB) dysfunction and the association between BBB dysfunction and glucose-regulated protein (GRP78) autoantibodies in NMO. Objective: To clarify the effect of IgG from anti-myelin oligodendrocyte glycoprotein antibodies (MOG-Abs) associated disorders patients on the BBB-endothelial cell activation and the positivity of GRP78 in the disease. Methods: We purified IgG from sera with MOG-Abs associated disorder patients [15 sera in the acute phase (acute MOG)], 14 sera in stable stage (stable MOG)] IgGs from 9 healthy and 27 disease controls were used as controls. IgG was exposed to the human brain microvascular endothelial cells (TY10) and the amount of nuclear NF-kB p65 positive cells as a marker of endothelial cell activation was analyzed using a high-content imaging systeme. Presence of GRP78 antibodies from patient IoGs was detected by wester blots. Results: IgG in acute MOG group significantly induced the nuclear translocation of NF-kB p65 compared to those from stable MOG group and healthy/disease control group. The rate of GRP78 antibody positivity observed in acute MOG groups $(10 / 15,66 \%)$ was significantly higher than tha in the disease control groups $(3 / 27,11 \%)$ or the healthy control groups $(0 / 9,0 \%)$. Conclusion: Endothelial cell activation induced by IgG incubtion was observed in not only NMO patients but also MOG associated disorders patients. GRP78 antibodies may be associated with BBB dysfunction in MOG-Abs associated disorders.

\section{0-40-3 Neurons promote CD4+ cells infiltration in} experimental autoimmune encephalomyelitis via CCL2

Yuki Nakazato ${ }^{1}$, Yuki Fujita ${ }^{2}$, Toshihide Yamashita $^{2}$,

Masamitsu Nakazato

${ }^{1}$ Department of Internal Medicine, Division of Neurology, Respirology, Endocrinology, and Metabolism, Department of Internal Medicine, Faculty of Medicine, University of Miyazaki, Japan, ${ }^{2}$ Department of Molecular Neuroscience, Graduate School of Medicine, Osaka University

[Objective] An animal model of viral encephalitis revealed that neurons attract inflammatory cells via C-C motif chemokine ligand 2 (CCL2). It remains unclear in multiple sclerosis (MS) whether neurons promote infiltration of inflammatory cells. We have determined neuronal effect in murine model of experimental autoimmune encephalomyelitis (EAE) by modulating neuronal activity with genetic engineering methods. [Methods] We developed inhibitory designer receptors exclusively activated by designer drugs (DREADD) under a CaMKII $\alpha$ promoter, and administered DREADD-carrying-AAV9 into the spinal cord. We applied targeted EAE, assessed daily EAE clinical scores for 28 days, and performed immunohistochemistry, in situ hybridization and quantitative PCR of cellular markers and inflammatory mediators in the spinal cord at peak of disease. We performed migration assay, and counted lymphocytes migrating toward neurons infected with AAV9. We knocked down $\mathrm{Ccl} 2$ mRNA with shRNA in targeted EAE mice and cortical neurons used in migration assay, and evaluated EAE score and histological analysis. [Results] Neuronal silencing mitigated EAE scores, reduced the expression of $\mathrm{Ccl} 2 \mathrm{mRNA}$ in the inflammatory lesions, and prevented migration of $\mathrm{CD}^{+}$cells toward neurons. Ccl2 shRNA administration to targeted EAE suppressed migration of $\mathrm{CD}^{+}$cells and alleviated the motor deficits of EAE. [Conclusions] Neuronal CCL2 produced by neuronal activation in $\mathrm{EAE}$ promotes migration of $\mathrm{CD} 4^{+}$cells and neuronal silencing by the inhibitory DREADD alleviates clinical scores and molecular markers of disease. withdrawn 


\section{0-40-6 Co-inhibitory molecule expressions on helper T cells reflect the diversity of MS and NMO}

Norio Chihara, Ritsu Akatani, Shusuke Koto, Riki Matsumoto Division of Neurology, Kobe University Graduate School of Medicine, Japan

[Objective]Multiple sclerosis (MS) and Neuromyelitis optica (NMO) are rare intractable neuroimmunological diseases that present symptoms in clinically diverse ways. For example, high-levels of endogenous interferon $\beta$ (IFN $\beta$ ) is known to exacerbate NMO, whereas IFN $\beta$ treatment is quite effective in some of MS patients. In this study, we tried to clarify IFN $\beta$ inducing coinhibitory molecule expressions on $\mathrm{CD} 4+\mathrm{T}$ cells that may reflect disease diversity. [MethodslPatients with MS, NMO and clinically isolated syndrome (CIS) were prospectively examined. T cell phenotypes in the peripheral blood and cerebrospinal fluid (CSF) including the expression of Programmed Death-1 (PD-1) were analyzed by flow cytometry. We also analyzed global gene expression of CD4+ T cells during type1 interferon treatment by RNA sequencing and performed transcriptome analysis. [Results] The frequency of PD-1 expressing (PD-1+) CD4+ T cells in peripheral blood was significantly lower in NMO patients compared to MS/CIS $(p<0.01)$ during disease relapse Whereas the frequency of PD-1+CD4+ T cells in the CSF was equivalent between NMO and MS/CIS. PD-1+CD4+ T cells induced by IFN $\beta$ treatmen obtained from MS patients showed T-cell impairment phenotypes with coinhibitory molecule expressions. [Conclusions]This study revealed the impairment of PD-1 expression on CD4+ T-cells in NMO. Co-expressed genes with PD-1 on CD4+ T cells would give us clues to elucidate differential checkpoints in the broad-spectrum pathogenesis between MS and NMO.

\section{0-40-8 Alterations of the Gut Ecological and Functional Microenvironment in Different Stages of MS}

Daiki Takewaki ${ }^{1,2,3}$, Wakiro Sato ${ }^{1,2}$, Wataru Suda ${ }^{4}$, Lena Takayasu ${ }^{4,5}$ Naveen Kumar ${ }^{4}$, Toshiki Mizuno ${ }^{3}$, Sachiko Miyake ${ }^{6}$

Masahira Hattori ${ }^{4}$, Takashi Yamamura ${ }^{1,2}$

${ }^{1}$ Department of Immunology, National Institute of Neuroscience, National Center of Neurology and Psychiatry, Japan, ${ }^{2}$ Multiple Sclerosis Center, National Center of Neurology and Psychiatry, Japan, ${ }^{3}$ Department of Neurology, Kyoto Prefectural University of Medicine, Japan, ${ }^{4}$ Laboratory for Microbiome Sciences, RIKEN Center for Integrative Medical Sciences,

Tokyo, ${ }^{6}$ Department of Immunology, Juntendo University School of Medicin

[Objective] To reveal the characteristics of the gut microbiomes in patients with different stages of multiple sclerosis (MS). [Methodsl We analyzed gut microbiomes of 62 relapsing-remitting MS (RRMS), 15 secondary progressive MS (SPMS), 21 atypical MS, 20 neuromyelitis optica spectrum disorder (NMOSD) patients and 55 healthy controls (HC) by 16S rRNA gene, shotgun metagenomic sequencing, and metabolite analysis of fecal samples. [Results] UniFrac distance analysis revealed significant dysbiosis in RRMS, SPMS, and NMOSD based on 16S data (adjusted $\mathrm{p}=0.0099,0.029,0.0099$, respectively). The analysis found a total of 30 species having significant changes in abundance and significant correlation with clinical severity in the four distinctive patient groups. Metagenomic gen and metabolite analysis revealed marked decrease in butyrate biosynthesis and level $(p=0.0007)$ concurrently with a significant reduction in Eubacterium rectale in RRMS compared to HC (adjusted $p=0.0053)$. Notably, our data also revealed an enhanced capacity for DNA mismatch repair in SPMS than in RRMS and a reduced capacity for carbohydrate metabolism in SPMS than in HC (adjusted p = 0.0009), suggesting excessive oxidative stress in the gut with SPMS, which was confirmed by increased ratio of cysteine and glutathione persulfide to their non-persulfide forms in SPMS compared to HC in sulfur metabolomic analysis $(\mathrm{p}=0.0152,0.0432$, respectively). [Conclusions] The present study revealed ecological and biological alterations of the gut microenvironment in different stages of MS.

\section{0-40-10 Association between serum amyloid $A$ and} cortical volume in patients with multiple sclerosis

$\bigcirc$ Hiroaki Yokote ${ }^{1,2}$, Shuta Toru ${ }^{1}$, Yoichiro Nishida ${ }^{2}$, Takaaki Hattori ${ }^{2}$, Nobuo Sanjo ${ }^{2}$, Takanori Yokota

${ }_{2}^{1}$ Department of Neurology, Nitobe Memorial Nakano General Hospital, Japan, ${ }^{2}$ Department of Neurology and Neurological Sciences, Tokyo Medical and Dental University, Japan

[Background]Brain atrophy is a pivotal biomarker, and closely associated with disability in patients with multiple sclerosis (MS). However, it is unclear whether brain atrophy is due to primary neurodegeneration or inflammation. [Objective]We sought to determine whether the levels of systemic inflammatory marker SAA were associated with brain volume (BV) in patients with MS. [Methods]This double-centred, cross-sectional, observational study investigated patients with MS or clinically isolated syndrome (CIS). BV was evaluated based on three-dimensional T1-weighted images using SIENAX in the FMRIB Software Library and FreeSurfer. Patients' SAA levels were determined by latex agglutination immunoassay (SRL, Japan). [ResultslWe included 40 patients with CIS or MS and 26 patients with non-inflammatory diseases as controls in the study. SAA was significantly correlated with normalized BV $(r=-0.41$, $\mathrm{p}=0.0087)$ and cerebral cortex $(\mathrm{r}=-0.36, \mathrm{p}=0.023)$ but not with subcortical gray matter volume. Further image analysis revealed that the volumes of bilatera temporal poles most strongly correlated with SAA. This correlation remained significant even after adjusting for age, sex, scanners and normalized BV $(\mathrm{p}=0.0064)$. [Conclusions]SAA is correlated with $\mathrm{BV}$, including cerebral cortex volume. Thus, systemic inflammation may be associated with brain atrophy in patients with MS. Independent correlation between SAA levels and temporal pole volumes shed light on the pathogenesis of brain atrophy in MS.

\section{0-40-7 Challenges using MRI vascular patterns to diagnose tumefactive demyelinating lesions}

Ryohei Komaki, Norio Chihara, Takehiro Ueda, Kenji Sekiguchi, Riki Matsumoto

Division of Neurology. Kobe University Graduate School of Medicine, Japan

Objectives: Central vein sign (CVS), defined as a vessel running centrally in the lesion, has been proposed as one of the discernable vascular structures of multiple sclerosis (MS) lesions. However, vascular aspects of tumefactive lesions (TL) in patients with either MS or tumefactive demyelinating diseases (TDD) remain elusive. Methods: We recruited consecutive 72 patients of MS and TDD who were hospitalized from Jan 2013 to Sep 2019. We retrospectively analyzed the radiological characteristics of 10 TLs of the 9 patients. All the imaging studies were performed using 3-T MRI including Gadolinium contrastenhanced T1-weighted imaging (GdT1). Results: Median age was 48 (18 - 55), and 8 patients were women. Five patients were diagnosed with TDD, whereas the remainder with clinically isolated syndrome. Median disease duration was 20 months (1.0 to 300 months). On brain MRI, the median lesion size was 26.9 $\mathrm{mm}(21.5$ to $46.5 \mathrm{~mm})$. One or more vessels were detected in 7 TLs with GdT1. Within them, we found a straight vessel running centrally in 4 TLs, multiple straight vessels running in one TL, and two straight vessels running periphery of boundary in one TL located at the periventricular area. We also found a vessel showing caput medusae appearance in one TL at the juxtacortical area. Conclusion: Four out of 10 TLs showed a vessel running in central. Others were different from CVS observed in typical MS patients, however they kept venous distribution. Evaluation of vascular aspects may be useful to differentiate demyelinating disorders from other etiologies.

\section{0-40-9 Role of disease activity for pregnancy outcome in a Japanese cohort of NMO, MS and MG}

Kaori Yanagawa ${ }^{1}$, Mariko Hokari ${ }^{1}$, Etsuji Saji ${ }^{1}$

Fumihiro Yanagimura ${ }^{3}$, Takahiro Wakasugi ${ }^{1}$, Masatoyo Nishizawa ${ }^{4}$, Osamu Onodera ${ }^{1}$, Izumi Kawachi

Department of Neurology, Brain Research Institute, Niigata University, Niigata, Japan, ${ }^{2}$ Comprehensive Medical Education Center, Niigata University School of Medicine, Niigata, Japan, ${ }^{3}$ Department of Neurology, NHO Niigata Hospital, Kashiwazaki, Japan, ${ }^{4}$ Niigata University of Health and Welfare

[Objective] Neuromyelitis optica spectrum disorders (NMOSD), multiple sclerosis (MS) and myasthenia gravis (MG) are predominant among women of reproductive age. The aid of this study was to identify association between disease activities and miscarriage outcomes in a Japanese cohort of these disorders. [Methods] Data on 22 Japanese women (29 pregnancies) with NMOSD, MS and MG were retrospectively collected from 2000 to 2019. [Results] 29 pregnancies (8 pregnancies with NMOSD, 11 pregnancies with MS and 10 pregnancies with MG) were confirmed during total disease courses. Among them, 22 pregnancies (7 pregnancies with NMOSD, 10 pregnancies with MS and 5 pregnancies with MG) had initia disease onset before pregnancy. In cases with initial disease onset before pregnancy, $86 \%$ $(6 / 7)$ of NMOSD, $70 \%(7 / 10)$ of MS and $80 \%(4 / 5)$ of MG had continued disease treatments including steroids or interferon-beta before pregnancy. 87\% (6/7) of NMOSD, 10\% (1/10) of MS and $60 \%(3 / 5)$ of MG had continued during pregnancy. During gestation periods, $14 \%$ $(1 / 7)$ of NMOSD, and no cases of MS $(0 / 10)$ and MG $(0 / 5)$ had miscarriage. The NMOSD patient with miscarriage had high disease activity before pregnancies even with steroid treatment (prednisolone $19 \mathrm{mg} /$ day). No cases with NMOSD, MS and MG had exacerbations during gestation periods, when disease treatments had led to low disease activities before fertilization. [Conclusions] Disease activity may be a key factor of pregnancy outcome in NMOSD, MS and MG in a Japanese cohort. Larger prospective studies will be needed.

\section{O-41-1 抗IgLON5 抗体陽性大脳皮質基底核症候群の同定}

○伏屋 公晴、木村 暁夫、吉倉 延亮、竹腰 顕、林 祐一、
下畑 主
岐皁大学大学院 医学系研究科脳神経内科学分野

岐皁大学大学院 医学系研究科 脳神経内科学分野

(目的)抗IgLON5抗体関連疾患は、睡眠時無呼吸や喉頭喘鳴を含屯睡眠障害、球 症状、歩行異常、舞踏運動、筋強剛、認知症などを呈し、一部の症例は進行性核 上性麻疩 (PSP) 様の表現型を呈する。私たちはパーキンソン病類縁疾患患者に扔 いて抗IgLON5抗体の検索を行い、免疫療法が可能な症例が含まれる可能性につ いて検討した。【方法】対象は各臨床診断基準に則って診断した多系統萎縮症 44 名、 PSP 40名、大脳皮質基底核症候群 (CBS) 18名、パーキンソン病56名とした。患者 血清を用いたcell based assay（CBA）により、抗IgLON5抗体を検索した。【結果】 CBSを呈した 1 例が陽性であった。80代女性で、約4年の経過で緩徐進行する歩行 障害を呈した。神経所見として四肢の筋強剛、左半身の失行、左下肢ジストニア、 皮質性感覚障害を認め、Armstrongの基準でprobable CBSと診断した症例であっ た。軽度の不眠と閉塞性睡眠時無呼吸を認めた。㵦液検查では㵦液細胞数を含め て異常はなかった。頭部MRIにて右半球優位の脳萎縮、脳血流シンチにて右優位 の血流低下、DATシンチにて右優位に両側線条体の集積低下を認めた。抗体陽性 判明後、抗IgLON5抗体関連疾患の既報に倣い、免疫療法を行った。ステロイド パルス療法は効果なく、大量免疫グロブリン療法を2クール行ったところ、左半 身の失行、歩行障害が軽度改善し、脳血流シンチ、DATシンチ所見の改善を認め た。【結論】抗IgLON5抗体関連疾患の新規病型として、CBSを呈することを初めて 明らかにした。本研究は（1）PSP症候群に加えCBSといった非定型パーキンソニ ズムの鑑別疾患として抗IgLON5抗体関連疾患を考虑する必要がある点、(2) CBS のうち変性疾患と考えられた症例のなかにも治療可能例が存在することを示した 点において重要な意義があると考えられた。 
0-41-2 パーキンソン病患者における睡眠障害の頻度と対応

○兼元みずき、矢野 怜、稗田宗太郎、小野賢二郎

昭和大学病院 脳神経内科

[背景]Parkinson病 (PD) において、非運動症状の一つとして、レム睡眠行動異常、 眠気、不眠などの多彩な睡眠異常の合併が知られている。その頻度はPD患者の約 90\%との報告もあり、あらゆる病期で発症する。睡眠の異常は精神症状にも影響し、 患者のQOLを左右することから、PD治療に際して、主治医が睡眠障害の合併の 有無や状態を把握し、対応することは非常に重要であると考えられる。目的IPD 患者に拈ける、特微的な睡眠障害の合併頻度や内訳、有症状者の背景や状態につ いて明らかにする。【方法】脑神経内科通院中のPD患者55名につき、問診・診察と 質問紙法による睡眠環境・睡眠状況・QOL・PD症状の評洒を行った。PDにおけ る睡眠障害のスクリーニングとして、PD Sleep Scale (PDSS)-2 日本語版、QOL の評佂としてParkinson's Disease Questionnaire-39(PDQ-39)、症状の評䛧とし てUnified Parkinson's Disease Rating Scale (UPDRS)を用いた。睡眠障害の原因 となりえる精神疾患合併や抑うつ状態の有無について評価した。睡眠障害の有無 について、調查前の主治医の認識状況と、調查によって明らかにされた睡眼障害 の有無を併せて検討した。睡眠障害が認められた患者には一般的な睡眼衛生指導 および、必要と考えられる薬剤調整を行った。[結果]睡眠障害の合併は高頻度で 認められた。その一部は、主治医によって認識されて扔らず、初めて判明したも のであった。睡眠障害の合併患者について介入を行うと、一部で睡眠障害の改善 が認められた。結論】 PD患者で多彩な睡眠障害の合併が認められた。睡眠障害は 日常䛦療では見逃されている可能性があり、積極的に有無の检索を行い、対応を 行うことが有用と考えられた。

\section{0-41-4パーキンソン病患者における起立性低血圧の特徵と意 義の検討}

○中山 博輝、水谷 真之、野田浩太郎、張 由絹、渡邊 睦房、 藤ヶ崎浩人

都立墨東病院

【目的】パーキンソン病（Parkinson's disease: PD）に扔いて起立性低血圧 (Orthostatic hypertension: $\mathrm{OH}$ ) は、患者の日常生活に関わる重要な非運動症状で あるが、OHの合併頻度については報告にばらつきがある。OHのリスクとして、 羅病期間や性別、薬剂、症状の重症度などが挙げられているが、一定の見解はな い。そこで、自施設におけるPD患者を調查し、OHを有する患者の傾向を分析す る。【方法】2017年4月1日から 2018 年3月31日までに当院神経内科に入院したPD患 者で'123 I-MIBGシンチグラフィーH/M比が2末満の31例について、年齢、性別、OH の有無、䍜病期間、UPDRS (Part III)、他の自律神経障害(便秘、嗅覚異常)の有無、 認知機能低下の有無について後方視的に梌討した。【結果】65 89藏の31例 (男性18 例、女性13例）を対象とした。OHありは14例、OHなしは17例だった。罹病期間 は初診から最大18年であった。UPDRS (PartIII) は29 88点であった。認知機能 低下をきたした例は14例であった。OHあり群とOHなし群で、年齢 UPDRS (Part III)、罹病期間、 ${ }^{123} \mathrm{I}-\mathrm{MIBG}$ シンチグラフィーH/M比について比較したが、有意な 差は認めなかった。発症早期（発症2年以内）の患者13例中OHありが7 例、認知機 能低下ありは5例だった。[考察·結論]PDでは䍜病期間が長いほど臨床症状も重症 化し、自律神経障害も同様の傾向があるとされるが、自施設例では発症早期から $\mathrm{OH}$ や認知機能低下をきたす例が目立った。 $\mathrm{OH}$ と認知機能には関連があるとされ ており、PD発症早期にOHに介入することで患者のADLや認知機能を改善させう る可能性がある。

O-41-6 精神疾患で入院加療中に進行性核上性麻痺と診断した 3 例

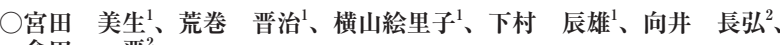
倉田 晋 2

秋田県立リハビリテーション・精神医療センターリハビリテーション科、

2秋田県立リハビリテーション・精神医療センター 精神科

【目的】PSPの典型的な症状は、核上性注視麻痻、易転倒性、筋強剛、動作緩慢な どのパーキンソニズムと言われている。しかし日常診療では多彩な臨床症状を呈 し診断に難渋する事が多い。我々は精神症状で精神科に入院中に進行性核上性麻 痻 (Progressive supranuclear palsy、以下PSP) と診断した3例を報告する。【症例】 症例1 1 71歳、男性。2年前より幻聴、妄想が出現。せん妄状態、幻聴幻視、妄想 で当センター精神科に措置入院。症例 $2: 67$ 歲,女性。20歲代よりうつ病で精神科 に通院。上肢の振戦の精查目的で入院。抑うつ気分、被害・㷋佑妄想あり。症例 3 : 61歳、男性。40歳頃よりうつ病で精神科に入退院を繰り返し、抑うつ症状が増思 乙入院。上記の精神症状以外に、3例の共通症状は程度に差はあるが認知機能低下、 核上性注視麻痺と固縮、動作緩慢、易転倒性などのパーキンソニズムであった。 また全例に頭部MRIで前頭葉優位の脑萎縮、第 3 脳室拡大あり。DAT-SCANで耐 側基底核の集皘低下あり、脑血流シンチではアルッハイマー型認知症、レビー小 体型認知症などの関心領域の血流低下なし、MIBG心筋シンチでは集積低下なし。 神経心理検查、画像検查の結果より前頭葉性認知機能低下が示唆され、また神経 学的所見より診断基準 (厚生労働省難病情報センター) の主要項目を满たし、非典 型的PSP-with frontotemporal dementia (以下 FTD) と診断した。考察]3例はう つ病や妄想などの精神症状が先行し情神科加瘵中に、神経学的検索により核上性 注視麻疩、固縮、易転倒性などのパーキンソニズムを認め、臨床的PSP-FTDの診 断に至った。3例の前景に見られた精神症状は前頭葉機能低下に起因したものと 考えられた。[結諭]非典型的PSPの症状である精神症状や認知症を主訴に精神科 を受診する症例も多く、PSP-FTDを鑑別に挙げるべきであり、臨床症状では核上 性注視麻痺とパーキンソニズム、特に固縮の有無に注目する必要がある。
0-41-3 取り下げ演題

\section{0-41-5 進行性すくみ足を伴う進行性核上性麻盘についての臨 床的検討}

橋本 里奈、佐藤 実咲、榊原 聡子、見城 昌邦、横川ゆき、 片山 泰司、齋藤由扶子、筤場 郁子、犬飼昆 国立病院機構東名古屋病院 脳神経内科

【目的】かつてすくみ足を伴った純粋無動症（pure akinesia with gait freezing, 以 下PAGF) と呼ばれた一群が，近年，進行性核上性麻瘏 (progressive supranuclear palsy, PSP) の带型のうちのprogressive gait freezing (以下PSP-PGF) として位置 付けられるようになっている. 臨床病型としてのPSP-PGFについて, その臨床的 特徵を明らかにする.【対象と方法】1999年9月から2019年7月までの間に，当院に て入院歴のある進行性核上性麻疩と診断された症例を対象とし, 臨床経過, 神経 徵候，画像検查について後方視的に検討した.【結果】上記期間中に当院に入院し た進行性核上性麻痻は 129 例であり，そのうちPSP-PGF と診断された症例は22症 例であった (平均年龄67.1 7 . 歲, 男性 12 例, 女性10例)。初期䛦断はパーキンソ ン症候群 6 例, パーキンソン病 8 例, 進行性核上性麻痺 4 例, その他 4 例であった. 当院初診時の罹病期間は5.1 \pm 3.4 年であり, 初発症状はすくみ足が 8 例, 易転倒性 が8例，動作緩慢が5例，書字障害が3例，発声障害が6例であった。2017年MDS診 断基準にてprobable PSP-PGFに該当するものは，当院初診時は13例，全経過を通 じて18例であり, possible PSP-PGFに該当するものは，当院初掺時18例，全経過 を通じて19例であった。診断基準項目のうち，すくみ足出現までの期間を限定し ない場合, 全例がpossible PSP-PGFに該当した。頭部MRIでは全例とも顕著な中 脳被蓋や上小脑脚の萎縮は認めず, 軽微な中脳被蓋萎縮は初診時6例, 経過を通 じて11例に認め, 淡蒼球の異常を14例に認めた。 ドーパミントランスポーターシ ンチグラフィーは施行した19例全例で線条体への高度集積低下を認めた.【結論】 PSP-PGFは経過が緩徐であり，すくみ足出現までに 3 年以上を要する症例があり うる。画像検查ではドーパミントランスポーターシンチグラフィーでの高度集積 低下や頭部MRIでの淡荅球異常が診断に有用であると思われた

\section{0-41-7 地方の県境医療圏における多施設医師主導のパーキン ソン病集団療養指導}

千田 圭二1、伊藤 久雄 ${ }^{2}$ 岩本 浩之 ${ }^{3} 、 川$ 守田 厚、西城 健 ${ }^{5} 、$

千田 光一

${ }^{1}$ 岩手病院 脳神経内科、 ${ }^{2}$ いとう脳神経内科、 ${ }^{3}$ 千厩ひかりクリニック、

岩手県立磐井病院 脳神経内科、5 西城病院 脳神経内科

【目的】地方の県境にある当地域では，パーキンソン病 (PD) など神経筋難病の診療 圈は 2 つの県に跨がる広域であって, 県単位の医療活動では対応しにくい点が少 なくない。ここに報告する活動は，市内の常勤脳神経内科専門医が合同で主催す る外来PD患者の集甩療美指導の会であり，2004年度から継続してきた＇19年度 の活動を紹介し，医師主導の意義について検討する。【方法】(1)当地の二次医療圈： 人口 12 万 7 千人 ('19年 4 月), 面積 $1,320 \mathrm{~km}^{2}$, 常勤脳神経内科専門医 11 人 (3病院, 2 診療所)。通院PD患者の約 $30 \%$ が隣県から通院. 22集団療盖指導 : 5 医療機関の 脳神経内科専門医 6 人が企画した。外来PD患者と家族に理解してほしい内容を年 3 回に分け，土曜日の午後に 2 時間ずつ，2回は市西部・1 回は市東部で公的施設な どを会場として開催した。脳神経内科医，外来看護師，薬剤師，理学療法士，言 語聴覚士，栄養士が分担して講演・実技指導した。対象は5医療機関に通院する患 者・家族を主体とし，ポスター，チラシ，市広報誌への掲載などで広報した。 (3) 参加者にアンケート調查した【【結果】参加した患者・家族はのべ 79 人.アンケー トに56 (患者 34 ，家族 22 ) 人が回答し，回収率 $70.9 \%$ あったた 結果は以下の通り 開催時期と場所は好評；会場に関する意見は，椅子が堅い，通路が狭いなど；講 義内容について，全て分かりやすかった [患者 $35.3 \%$ ，家族 $54.6 \%$ ，以下同順，分 かりにくい講義もあった $[64.7 \%, 40.9 \%]$, 難しかった $[0 \%, 4.6 \%]$; 希望するテー マは治療法, 治療楽, リハビリ, 便秘などであったが, これらの全てに講義また は質疑として対応できた、【結論】難病には都道府県が主導的に担当するが，県境 医療圈では医師主導の活動が効果的な場合がある。本活動は特に地域内のPD外来 診療水準の均てん化，および包括的多職種連携において意義が大きい. 
0-41-8 パーキンソン症候群とてんかん

\section{森仁、進藤 克郎 \\ 倉敷中央病院 脳神経内科}

【目的】パーキンソン症候群の患者がてんかんを合併症に持つことは稀だろう か? ?んかんは 100 人に 1 人の有病率であり、高齢者ではさらに有病率が上が る。パーキンソン症候群の中でも進行性核上性麻疩や大脳皮質基底核変性症 は大脳皮質の機能低下を生じる疾患であり、てんかんの合併は不思議ではな い。にもかかわらず文献的には、稀な病態として1例報告として取り上げられ ている現状である (臨床神経2010;50:485-8)。パーキンソン症状とてんかん症状の 合併という視点がなければ、ドラべ症候群の成人症例に適切に対処ができない (Neurology.2014;82:2250-1.)。【方法】2018年10月から2019年9月に一施設一医師の外 来に通院中のパーキンソン症候群患者のうち、てんかんを合併した 3 例を後方視 的に検討した。結果】単一施設内にパーキンソン症候群は 50 例、そのうちの 3 症例 であった $(6 \%) 。 2$ 例が進行性核上性麻疩(経過9年の81歳女性、経過2年の79歳男性) 1 例が大脳皮質基底核変性症(経過8年の65歳男性)であった。発作間欠期脳波では、 棘波や棘徐波はなく、前頭側頭部などに局在性のある間欠的な律動性徐波を認め た。発作症状は、一点凝視、言動や行動の異常、ジストニア肢位、意識消失なと であり、原疾患による症状と一見、区別がつかないのが特徴であった。丞攣は3

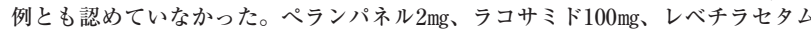
500-1000mgなどが抗てんかん薬として使用され、3症例とも速やかに発作は抑制さ れた。治療により、本人の意に沿わない行動がなくなり本人のストレスや家族の 負担が軽減され、以前に戻った（改善した）と喜んでおられた。【結論】てんかん診 療では発作症状や脳波の評価が壁となるが、パーキンソン症候群にてんかんが合 併することは稀ではないため、症状に気づき、脳波を記録し、治療介入してみる ことが重要である。患者・患者家族のQOL改善に大きく寄与する治療であること を強調する。

\section{0-41-10 パーキンソン病患者におけるレボドパ投与が血清亜鉛 值に与える影響について}

松山 裕文 ${ }^{1}$ 、松浦 慶太 ${ }^{1}$ 、石川 英洋 ${ }^{1}$ 平田 佳寛 ${ }^{1} 、$ 加藤奈津子 ${ }^{1} 、$ 丹羽篤、成田 有吾 ${ }^{1} 、$ 冨本 秀和 ${ }^{1}$

三重大学医学部附属病院 脳神経内科、

${ }^{2}$ 独立行政法人国立病院機構 三重病院 脳神経内科

【目的】レボドパの亜鉛キレート化作用が報告されており、内服したレボドパが体 内の覀鉛と結合した後その合成物は尿で排出され、亜鉛欠乏症を引き起こす場合 がある。一方、近年では初老期の亜鉛欠乏による味覚障害、皮膚疾患、性腺機能 不全との関連が示されている。パーキンソン病 (PD) 患者では、病期進行に伴う レボドパ製剤の長期服楽や投与量の増量、デバイス治療も含めた頻回投与により 低要鉛血症を来す可能性がある。今回、我々は当院で診療中のパーキンソン病患 者の血清要鉛值を測定し、レボドパ製剂の服薬期間や投与量、投与回数との関連 や味覚障害、皮膚障害などの亜鉛欠乏症の症状について検討を行った。【方法】当 科でPD ( $\mathrm{n}=26, \mathrm{M} / \mathrm{F}=11 / 15$, 平均年齢 $68.8 \pm 8.1$ 歳 $)$ と診断し、入院および外来の 血液検查で亜鉛值を測定し、亜鉛欠乏症の有無を確認した者を対象とした。各々 のPD患者におけるレボドパ製剤の内服期間、投与量、投薬回数および味覚障害や 性腺機能障害などの亜鉛欠そ症状の有無と血清亜鉛值との相関をSpearmanの順 位相関係数を用いて解析した【結果】グループ全体の平均血清覀鉛値 $67.5 \pm 11.9 \mu$ $\mathrm{g} / \mathrm{dl}$ であり、亜鉛欠乏症状の有り群はn=12であった。症状の有無の群間で血清带 鉛值の有意差は見られなかった $(\mathrm{p}=0.836)$ 。レボドパ製剤の平均投与期間 $8.7 \pm 5.9$ 年、投与回数 $3.1 \pm 0.8$ 回 $/$ day、投与用量 $386.2 \pm 273.6 \mathrm{mg} / \mathrm{day}$ であり、带鉛值とレ ボドパ投与期間 $(r s=-0.409, \mathrm{p}<0.05)$ 、投与回数 $(r s=-0.592, \mathrm{p}<0.05)$ 、投与用量 $(\mathrm{rs}=$ $0.569, \mathrm{p}<0.05)$ の項目において負の相関を認めた。【結論】レボドパ製剤は带鉛のキ レート作用を持つため、レボドパ量の増量や長期投与、頻回投与により空腸にお ける带鉛の吸収障害が生じ低带鉛血症を来すと考える。パーキンソン病診療にお いて、長期の服薬管理を行う上で亜鉛欠そ症予防は今後の注意点となり得る。

\section{O-42-2 中枢神経系リンパ腫の臨床的特徵についての検討}

本庄 智香、新出 明代、西尾有葵子、山口 聡子、中尾 寛宙、 八木田 薰、廣瀬 正和、田口 智朗、山中 治郎、柴田 益成、 末長 敏彦

天理よろづ相談所病院 脳神経内科

【目的】中枢神経系リンパ腫（central nervous system lymphoma;CNSL）の診断に は病理所見が必須である. 典型例では容易に診断可能だが，臨床経過や画像所見 が非典型な場合は生検に至らず，診断・治療までに時間を要することがあり，実 臨床の現場で有用なバイオマーカーを明らかにすることは重要である.【方法】 2014年1月1日から2019年10月31日までに病理検査でCNSLと診断された連続21症

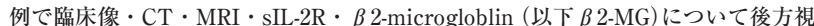
的に検討した.[結果]21例は，15歳から83歳，女性9名、男性11名だった.HIV陽性 例はなく，免疫抑制状態1名,悪性腫瘍合併例が4名だった.原発性中枢神経系リン パ腫 (primary central nervous system lymphoma;PCNSL) 17例,二次性中枢神経 系リンパ腫 (secondary central nervous system lymphoma:SCNSL) 4例であった. 病理診断ではすべてびまん性大細胞型B細胞リンパ腫だった.MRIは12例（PCNSL9 例，SCNSL3例) でCNSLに特微的な造影効果をうける腫瘤形成性病変を呈したが, PCNSL8例でびまん性の白質病変や造影効果のない病変等非典型的な所見を示し た.CTでは全症例で腫瘤性病変は等から高吸収だった.21例中13例（PCNSL11例， SCNSL2例) で血清と喵液双方で $\beta 2$-MGを測定しており,うち8例で血清 $\beta 2$-MGよ りも能茺液 $\beta 2$-MGのほうが高值であったこの8例中5例はMRIで非典型的な所見を 呈したPCNSLだった【結論】髄液 $\beta 2$-MGは中枢神経系の免疫応答活性化やリンバ 球のturnoverを反映し，CNSLで上昇することが報告されている. 今回の検討で 喵液 $\beta 2$-MGがCNSLを診断する際のよい指標となる可能性が示唆された．他の悪

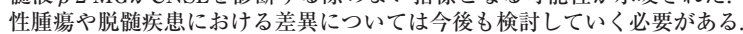

0-41-9 パーキンソン病の衝動性六進に関連した大規模ネット ワーク間の機能的結合性異常

\author{
高真守、阪田麻友美、中山 宜昭、安井 昌彰、石口宏、
}

和歌山県立医科大学病院 脳神経内科

【目的】パーキンソン病（PD）患者は衝動性が立進していること、またそれが衝動 制御障害発症時の重症度にも影響していることなどが報告されている。今回我々 は、パーキンソン病の衝動性が大規模ネットワーク間の機能的結合性異常と関 連しているかどうかについて安静時機能的MRI (rs-fMRI) を用いて検討した。【万 法】認知症を伴わないPD患者55例と健常対照者 (HC) 21 例を対象とし、Barrat Impulsiveness Scale 11th version (BIS-11) を用いて衝動性を評価し、PD群を衝 動性の高い群 (PD-HI) と衝動性の低い群 (PD-LI) に分頪 Lた Rs-fMRIの解析は、 SPM12のCONN toolboxを用いて行い、32種類の大規模ネットワークをRegion of Interest（ROI）として、ROI間の機能的結合性の違いについての群間比較、およ び衝動性との相関について検討した。結果】PD-HIはPD-LIおよびHCと比較し、 有意に衝動性が高かった。PD-HIとPD-LI間では、年齢、認知機能、教育歴、罹病 期間、抗パーキンソン病薬のlevodopa換算量、MDS-UPDRS part3に有意差を認 めず、part1のみPD-HIで有意に高かった $(\mathrm{p}=0.035)$ 。PD-HIはPD-LIと比較して、 右前頭頭頂ネットワーク (RPFN) と内側視覚ネットワーク (MVN) 間の機能的結合 性が有意に立進していることが示された（p-FDR=0.0315）。このRFPN-MVN間の 機能的結合性はBIS-11と有意な正の相関を示し、BIS-11の下位尺度である注意衝 動性および非計两衝動性とも同様に有意な正の相関を認めた。結論】PDの衝動性 充進に関連した大規模ネットワーク間の機能的結合性異常を示した。今後は他の 方法による再現性の確認や薬剤の影響などについての検討がさらに必要であると 考えられる。

\section{0-42-1 䯣液中の可溶性インターロイキン受容体が上昇する疾 患の多様性 : 自験 1023 例の検討から}

島さゆり、中野 頌子、林 和孝、坂野 文彦、加藤 邦尚、 東篤宏、菊池 洸一、長尾龍之介、前田 利樹、村手健一郎、 廣田 政古、石川 等真、新美 芳樹、水谷 泰彰、植田 晃広、 伊藤 信二、武藤多津郎、渡辺 宏久

藤田医科大学 医学部 脳神経内科

【目的】可溶性IL-2受容体 (sIL-2R) は、免疫担当細胞表面のIL-2R $a$ 鎖の一部が遊 離したもので、悪性リンパ腫の活動性と良く相関し、䯣液SIL-2Rは、神経系悪性 リンパ腫の補助診断ともなっている。しかし、sIL-2Rは、他の神経疾患などでも 上昇することが報告されている。今回、悪性リンパ腫と鑑別を要する疾患の能道液 SIL-2R值を多数例で検討し、その特徴を明らかにする。【方法】対象は、2012年4月 〜2018年12月に当院で䟦液SIL-2Rを湘定した1023例で、その臨床診断や予後を後 方視的に検討した。【結果】既報告 (Neurology 2012) に準じて50U/ml以上をカッ トオフとした場合、142例 (14.0\%) が異常値を示した。悪性腫瘍は28例 (19.7\%) のみで（びまん性大細胞型B細胞リンパ腫 (DLBCL) 14例、他のリンパ腫5例な ど）、DLBCL 20例中6例は正常であった。悪性腫瘍以外の116例中、脱䯣性疾患は 9例 (多発性硬化症 4例、視神経春䯣炎 2 例、MOG抗体陽性春䯣炎 3 例)、免疫性 疾患は25例（中枢神経系血管炎 2 例、GBS 3例、CIDP 4例など)、神経感染症は 35 例 (ヘルペス性䯣膜炎/脳炎 12 例、真菌性暍道膜炎 3 例、結核性䯑道膜炎 4 例など) であっ た。sIL-2值を経時的に測定しえた56例中、正常化もしくは低下した49例の症状 は改善したが、上昇した7例の予後は不良で、5例がDLBCLであった。【結論】䯣液 sIL-2值は脱䯣性、炎症性、感染性など様々な神経疾患で上昇していた。一方、経 時的に上昇する例は予後不良であった。

\section{O-42-3 MRIで両下肢筋に信号変化を呈した腰部脊柱管狭窄症の 3 例}

細川 隆史、小川 将司、元木三記子、吉本 幸世、増田 裕一 佐野 恵理、中村 善扸、重清 太郎、塚原 彰弘、太田 真 山根 一志、石田 志門、荒若 繁樹

大阪医科大学 脳神経内科

【目的】MRIにおける骨格筋の信号異常は筋原性変化だけでなく、神経原性変化に よって生じることが知られ、両者の鑑別が難しい場合がある。今回、私たちは MRIで両下肢筋に信号変化を呈し当初は筋原性疾患が疑われた腰部脊柱管狭窄症 例の臨床的特徴について検討した。【方法】症例は、2018年4月から2019年10月の 間にMRIで両下肢筋に信号異常が認められ、何らかのミオパチーが疑われて入院 した3例である。これらの症例の臨床経過、検查所見、画像所見を検討した。結 果]症例1は45歳男性。10力月前より歩行時に増悪する両下腿の疼痛、両下肢の異 常感覚と脱力感を自覚した。CKは533U/Lと高值を示し、針筋電図では脱神経電 位を伴う神経原性変化が認められた。ミオパチーを鑑別するため行った筋生検で は、group atrophyに加え、筋線維の大小不同と壊死再生、間質の細胞浸潤が観 察された。症例 2 は 81 歳女性。3力月前より歩行時に増悪する両下腿の疼痛、両下 肢の異常感覚と脱力感筋を自覚した。CKは $23 \mathrm{U} / \mathrm{L}$ 正常範囲内であり、針筋電図 では明らかな異常所見を認めなかった。症例 3 は79歳女性。3力月前より歩行時に 増悪する両下腿の疼痛と脱力を自覚した。CKは $18 \mathrm{U} / \mathrm{L}$ と正常範囲内であり、針筋 電図では明らかな異常所見を認めなかった。全ての症例において、骨格筋MRI脂

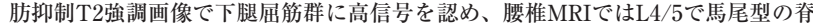
柱管狭窑を認めた。症例1は厈排所見および症状が強いため外科的治療を行った 症例 $2 \cdot 3$ は保存的療法を行い経過観察した。3症例とも自鸴症状は改善し、症例1 ではCK值の低下、両下腿屈筋群の信号異常は軽減した。【結論】馬尾型の腰部脊柱 管狭窄症では、脱神経と二次的な筋障害によりMRIで下肢筋に信号変化を呈する 例のあることが示唆された。MRIで下肢筋群に信号変化を認めるケースにおいて 間欠性跛行や感覚障害がある場合は、腰部脊柱管狭窄症の可能性を考慮する必要 があると考えられる。 


\section{0-42-4 正常圧水頭症における髄液C5a濃度の検討}

新美 芳樹 ${ }^{1}$ 、林 和孝 1 、坂野 文彦 ${ }^{1}$ 東 篤宏 ${ }^{1}$ 加藤 邦尚 ${ }^{1}$ 、 菊池 淡一 ${ }^{1}$ 、長尾龍之介 ${ }^{1}$ 、前田 利樹 ${ }^{1}$ 、村手健一郎 ${ }^{1}$ 、廣田 政古 ${ }^{1}$, 石川 等真 ${ }^{1}$ 、水谷 泰彰、島さゅり、植田 晃広、伊藤信二 渡辺 宏久 $、$ 白木 良一 2 、武藤多津郎

藤田医科大学医学部 脳神経内科、 ${ }^{2}$ 藤田医科大学医学部 腎泌尿器外科

【目的】急速に超高齢化社会をむかえる我が国に抏いて，高齢者の医療や介讙、特に認 知症は重要な社会的テーマとなっている。高齢者で認知障害, 歩行障害, 尿失禁など をきたす特発性正常圧水頭症 (iNPH) については、2004 年のiNPH 診療がイドライン の診断基準でMRI-supported possible iNPHをみたす高齢者の頻度は1.1\%という疫学 調查の結果もあり頻度の高い疾患であるが、高龄者では類似した病態も多く鑑別は必 ずしも容易ではない，またその病因は未だ解明されていない。近年神経変性疾患にお いて神経炎症の関与が注目を集めて㧍り、今回我々はiNPHに打ける炎症の関与につ いて着目し、领液中の補体C5aについて検討を行った。【方法】当病院において、2013 年から2016年の間で正常压水頭症が疑われ、probable iNPHの診断基準をみたした

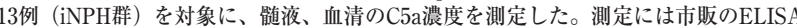
キット（abcam, Cambridge, UK）を用いた。非神経疾患コントロールとして、当院泌 尿器科にて腰椎麻酷手術を行った際に㖪夜を採取し、年龄をマッチした非神経疾患ホ ランティア10例 (NNC (neurologically normal controls) 群)、神経疾患コントロール として、UK brain bank の診断基準をみたしたパーキンソン病患者10例 (DC (disease controls) 群) との比較を行った。(結果】各群の検查時平均年齢は、 $\mathrm{iNPH}$ 群、NNC群、 DC群でそれぞれ80、73.9、76.1歳で、有意差を認めなかった。男女比は各々、12/1、5/5

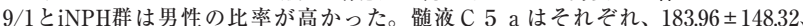
$261.71 \pm 196.29 、 127.38 \pm 73.89 \quad($ mean $\pm S D ; p g / m l)$ で、群間に有意差は認めなかっ

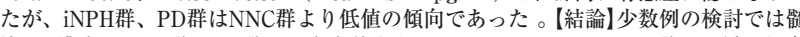
液C5莀度はNNC群、DC群との有意差を認めなかった。しかしNNC群より低い傾向 にあることから、iNPHの檤液C5aについて、今後多数例での検討が必要と考えられた。

\section{0-42-6 脳脊髄液漏出症による多髄節性筋菱縮症の 2 例}

二宮 怜子、岡田 信久、六車 彩子、小川 慈、関谷 智子、 田村 暁子、當間圭一郎、西中 和人、宇高不可思 住友病院脳神経内科

【はじめに】脳脊髄液漏出症は、脳脊䯣液減少による低髄液圧性頭痛が広く知られ ているが、近年、多彩な症候が報告されている。その中でも稀な多歫道節性筋萎組 症 (MSAM:multisegmental amyotrophy) を2例経験したので報告する。【症例1] 68 歳男性。約 20 年の経過で両上腕の筋萎縮、筋力低下が緩徐に進行した。脳神経系 に異常はなく、両伹C5-6踇節領域に筋萎縮、筋力低下を認めた。腱反射は上肢は 低下、下肢は正常で、fasciculationや病的反射、感覚障害、膀胱直腸障害は認め なかった。針筋電図ではC5-6餚節筋に限局して安静時放電および慢性の神経原性 変化がみられた。脊椎MRIでC2-3レベルにsnake eye appearanceを認め、C2-L1 レベルの硬膜外に液貯留像を認めた。CTミエログラフィーで硬膜外への髓液漏出 が示唆され、脳脊唱焲漏出症によるMSAMと診断した。症例2】65歳男性。43歳 時に激烈な頭痛、䅡部痛があり、翌年から握力が低下した。以後、約 20 年の経過 で両上肢の筋萎縮、筋力低下が進行した。両側C5-Th1踘節領域で筋萎縮、筋力低 下があり、C4-Th3領域の温痛覚の低下を認めた。腱反射は全般性に低下しており、 fasciculationや病的反射、膀胱直腸障害はなかった。針筋電図ではC5-Th1揈節筋 に安静時放電および慢性の神経原性変化がみられた。脊椎MRIではC4-7レベルで snake eye appearance、C3-Th12レベルの硬暯外に液眝留像がみられた。CTミエ ログラフィーで硬膜外への髄液漏出を確認し、MSAMと診断した。考察】MSAM の病態は、硬膜外の髄液䝪留が脊椈を圧迫して前角障害を生じたとする説や、脊 髄が後方へ圧排され、前根が挛引されたことによる伝導障害などが推測されてい る。しかし、既報告例と同様に、本例も広範な脳脊娟迹液貯留は胸椎レベルが中心 であるにもかかわらず、臨床症状は両上肢に限局し、上記の上うな単純な厈迫に 上る障害だけでは説明がつかない。頚椎症性春䯣症や平山病などの病態を交えて 検討した。

O-42-8 気象变化に伴う体調不良、自律神経失調症、頭痛、め まい、首肩こりに対しての患者統計

\section{久手堅 司 \\ せたがや内科・神経内科クリニック}

【目的】当院では、気象変化による体調変化を訴える患者数が多い。どれくらい の患者数で季節による変化があるのかを判断することを目的としている。【方法】 緊張型頭痛、片頭痛、首肩こり、めまい、気圧や温度変化による体調不良、自律 神経失調症で分類し、受診患者数を月別に統計を取った。一番強い主訴か症状に 対してのみ振り分けを行った。2018年11月〜2019年10月までの統計を月別で取っ た。(1) 月別の総患者数、(2)上記7項目での受診者数、(3)気圧変化、温度変化によ る体調不良の受診者数、(4) (3)/(1)で分類を行った。【結果】2018年11月 (1)1102名、 (2) 374 名、(3)気155名+温1名、(4) 0.1422018 年12月 (1) 938 名、(2) 304 名、(3)弎119名 +温7名、(4) 0.134 1月 (1) 973 名、(2) 266 名、(3)気109名+温3名、(4) 0.1152 月 (1) 913 名、(2) 308 名、(3)気109名+温5名、(4) 0.1253 月 (1) 1026 名、(2) 397 名、(3)気 172 名 温4名、(4) 0.172 4月 (1) 902 名、(2) 370 名、(3)気152名+温4名、(4) 0.173 5月 (1) 900 名、(2) 392 名、(3)気135名+温8名、(4) 0.159 6月 (1) 859 名、(2) 372 名、(3)気149名+温 2 名、(4) 0.176 7月 (1) 897 名、(2394名、(3)気156名+温9名、(4) 0.1848 月 (1) 638 名、 (2) 271 名、(3)気 91 名+温10名、(4) 0.158 月月 (1) 769 名、(2) 302 名、(3)気 133 名+温7名、 (4) 0.182 10月 (1) 1024 名、(2) 366 名、(3)気149名+温8名、(4) 0.153 気象変化による体 調不良は、片頭痛、緊張型頭痛、首肩こり、めまい、全身隐急感、低血圧、冷え、 不安感、うつ傾向など多岐であった。結論】月別の統計でみると、1.2月は気象変 化による体調不良を訴え受診する割合は低い。気圧差、温度差が少ないことが理 由と推測される。7.8月は、外気温と冷房の温度差で体調不良を訴えている場合が 多い。気象変化による体調不良は、片頭痛やめまい、全身供急感、低血圧、不安、 うつ状態など複合的な症状を示す場合があり、診断が困難となる場合が多い。気 象デー夕との連動することでより細かい解析が出来るのではないであろうか。

\section{0-42-5＼cjkstart薬物治療難治性のトゥレット症候群に対する脳深部刺} 激術の効果

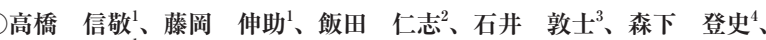
坪井 義夫

'福岡大学病院 脳神経内科、2 福岡大学病院 精神神経科、

福岡大学病院 小览科、 ${ }^{4}$ 福岡大学病院 脳神経外科

【目的】トゥレット症候群、あるいはチックは有病率が 100 人に 1 人と頻度が高 く、病態は明らかではないが楽物療法が効果を示すことが多い。また楽物療法抵 抗性の症例に対して、脳媣部刺激 (deep brain stimulation : DBS) 療法が効果を 示すことがある。今回、我々は当院でDBS療法を施行した難治性トゥレット症 候群患者の患者背景ならびに治療効果を検討した。【方法】対象は、2018年1月か ら2019年9月の期間に当院でDBS療法を行い、6力月後の評価まで終了したトゥ レット症候群患者とした。DBSのターゲットは全例視床 centromedian nucleus / parafascicular nucleus (CM/Pf) とした。術前と術後6カ月時にYale Global Tic Severity Scale (YGTSS) を用いて治療効果の判定を行った。本研究は、当院の倫 理委員会にて承認を受けている (承認番号: 2017M098)。【結果】対象患者は4名（男 性 3 名、女性 1 名、平均年齢 : $27 \pm 8.7$ 歳、平均罹患期間 : $15 \pm 5.3$ 年)であった。過 去の使用歴のある薬郕は、ハロペリドール、アリピプラゾール、クロナゼパム、 ブロマゼパム、リスペリドン、フルボキサミン、アトモキセチンであり、全例 で過去に少なくとも3凬の楽物使用歴があったが症状の改善は得られなかった。 DBSにより全例で運動チックは改善が得られ（ $\mathrm{p}=0.02 \sim<0.001 ）$ 、音声チックにつ いては、1例は改善 $(\mathrm{p}<0.001) 、 2$ 例は改善の傾向 $(\mathrm{p}=0.06 \sim 0.08)$ がみられた。結論】 CM/Pf -DBS療法は、薬剤抵抗性のトゥレット症候群患者に対して有用な治療選 択肢であり、特に運動チックに対して効果が示された。

\section{0-42-7＼cjkstart新規治療方法の進展が遺伝カウンセリングに与えた影 響 : TTR-FAPにおける後方視的解析}

中村 勝哉 ${ }^{1,2,3}$ 、石川 真澄 ${ }^{1}$ 、黄瀬恵美子 ${ }^{1}$ 、小島 朋美 ${ }^{1,3}$ 、

吉長 恒明 2 、古庄 知已真, 関島 良樹 ${ }^{2}$

${ }^{1}$ 信州大学病院 遗伝子医療研究センター

信州大学医学部 脳神経内科、リウマチ・琹原病内科、

信州大学医学部 遗伝医学教室

【目的】トランスサイレチン（TTR）型遗伝性アミロイドーシス（家族性アミロイドポリ ニューロパチー:TTR-FAP) は、TTR遺伝子の変異により、アミロイド蛋白が末梢神経 心臓、腎臓など全身に沈着し、臓器不全に至る常染色体優性遺伝性疾患である。肝移植 術が原因療法として確立しているが、手術の侵襲性、年齢、ドナー不足などの理由によ り適応外となる患者が多いことが長年の課題であった。しかし、2013年にTTR四量体安 定化薬が承認され、TTR-FAPの診療は第二の変革期を迎えている。こうした背景のも と、我々は、当院におけるTTR-FAPの遗伝カウンセリング (GC) の状況を後方視的に検 討し、その実態と、治療法の進歩がGCに及ほした影響を経時的に検討する。【方法】1998 〜2018年に当院にTTR-FAPに関連したGCを希望して来院した来談者を受診録より抽出、 後方視的に検討した。【結果】TTR-FAPに関連したGCに関する年間来談者数は $9.0 \pm 5.3$ 名 $($ mean $\pm \mathrm{SD})$ 、来談目的は発症前診断が96名、診断確定が 44 名、情報収集が 21 名、なと であった。発症前診断を目的に来談した 96 名のうち76名 $(79.2 \%)$ が、発症前診断を受検し、 変異陽性32名 $(42.6 \%)$ 、陰性44名 $(57.9 \%)$ であった。当院にて臨床研究が開始された2006 年までと、 2007 年以降での比較では、年間来談者数が $4.4 \pm 2.2$ 名、 $12.5 \pm 4.2$ 名、発症前 診断目的の来談者数、 $0.7 \pm 0.7$ 名、 $7.3 \pm 4.0$ 名といずれも増加傾向であった。結論】TTRFAPの来談者数は増加傾向にあり、他疾患の既報告と比較しても、発症前診断目的に来 談した者が多くから実際に高率に受検していた。郜床研究の開始や新規内服楽の発売が、 患者やat risk者の受診動機、特に発症前䛦断に影響を及ほしたと考えられた。他疾患の 発症前診断と同様に、特に検查陽性であった場合の予備的ガイダンスを重視しているが、 一方で、年1回のサーベイランス体制を見据えた $\mathrm{GC}$ 検討する必要があると考えられた。

\section{O-42-9＼cjkstart落語に見られる神経梅毒の高温入浴治療についての考察} 永松 秀一、古谷 博和 高知大学病院 神経内科

【はじめに】1492年にコロンブスがアメリカ新大陸を発見してから1910年にドイッ のパウル・エールリヒと日本の秦 佐八郎がサルバルサンを発見するまでほぼ 400 年の間、北米大陸の風土病であった梅毒は全世界に蒀延し、16世紀から20世紀に 至るまで世界中の文化、風俗、社会構造に大きな影響を及ほしてきた。落語は 250 年ほど前に日本で確立した話芸で、江戸時代後期、明治・大正に及ぶ庶民の 生活をユーモアを交えて描く大衆芸能である. 今回落語の中に見られる庶民の梅 毒や神経梅毒に対する対応について検討した.【対象】神経梅毒についての記載が はっきり見られる落語の演目としては「站芴問答」「明烏」「道具屋」、遊郭に行っ た後の性病感染防止のしきたりについて語られる演目として「付き馬」「突き 落とし」、「浮世風呂」などがあり、これらから当時の庶民の梅毒など性感染症に対 する予防や治療について検討した、【結果】江戸時代から明治、大正時代にかけて、 遊郭に通った翌朝には熱い風吕に入浴することがごく一般的に行われており、遊 郭周辺の銭湯の湯温は高い事、それが明治から昭和初期にかけて熱い銭湯のこと を「東京湯」と呼んで全国的に流行したこと、神経梅毒を含む後期梅毒感染症の治 療には草津の湯など源泉温度の高い温泉の長期入浴治療が好まれたことがわかっ た.【結論】梅毒スピロヘーターは高温状態に弱く、サルバルサンが開発されるま では、人工的マラリア感染による高熱治療、高温入浴治療などが行われており、 高温銭湯や温泉への入浴は当時の庶民の感染予防や治療法としてある程度理にか なっていた事がわかった キーワード：神経梅毒、落語、温泉療法、歴史神経学 Key Words: neurosyphilis, RAKUGO (traditional Japanese comical monologue), Spa therapy, Historical Neurology 